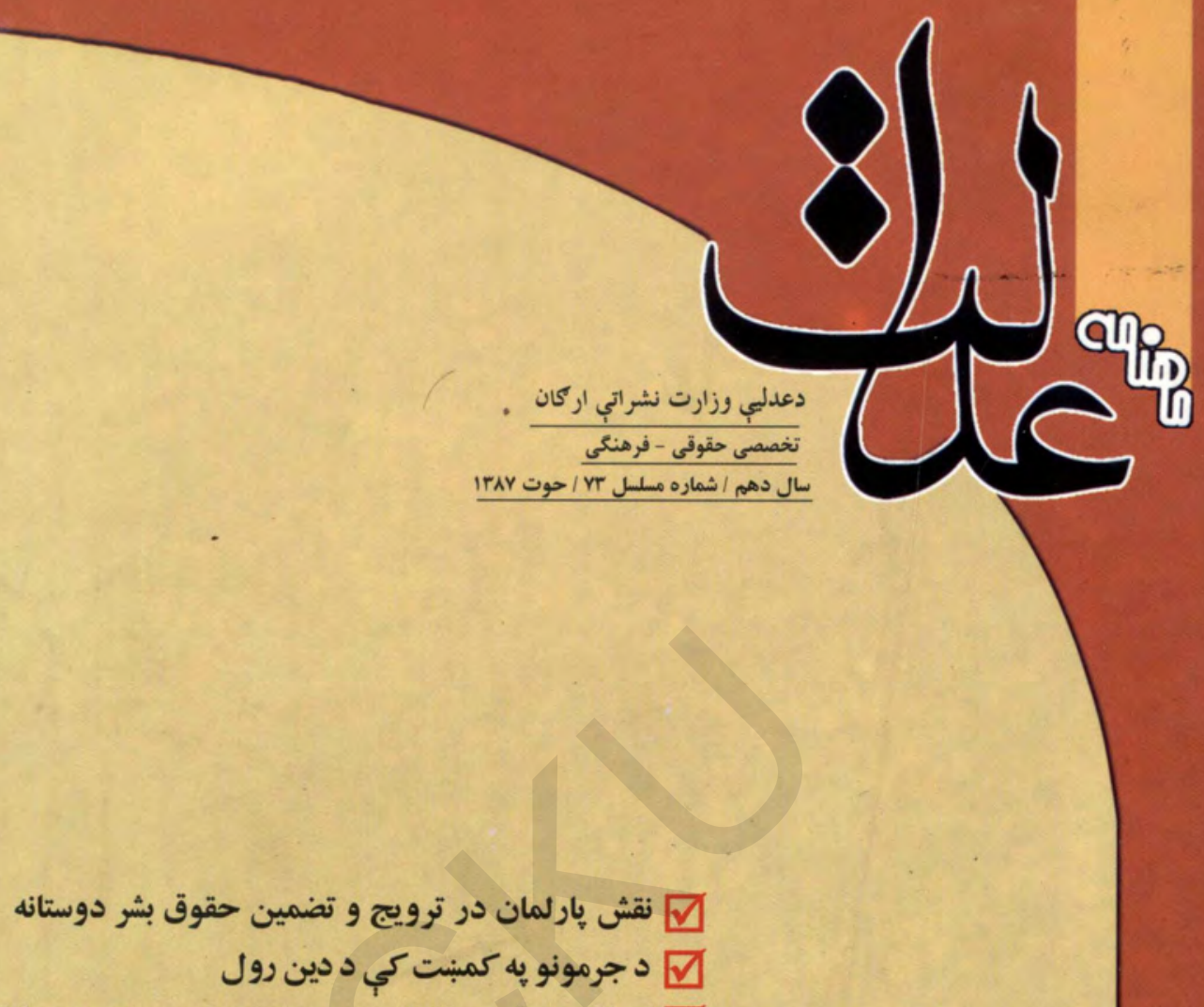

له اسناد حقوق بينالمللى مبنى بر تحريم جرايم و جنايات جنكى

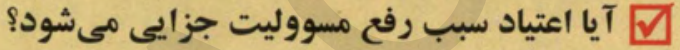

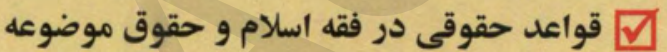

له سن رشد از نكاه شريعت و قانون

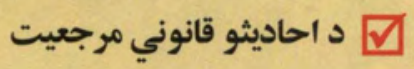

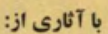

يار محمد باقرى

شاه على اصغر شهرستانى باقرى

عبدالكر يم فضلى على

عليز اده مالستانى

سيد احمد حسينى حنيف

حضرت كل حسامى احمث حسنى حنيف

على يام

على محمد ميرزايى

اسماعيل حكيمى ماحمد ميرت

قاسم قاموس حسم

سيف الرحمان ستانكزى قامون

محمد عثمان زوبل

....

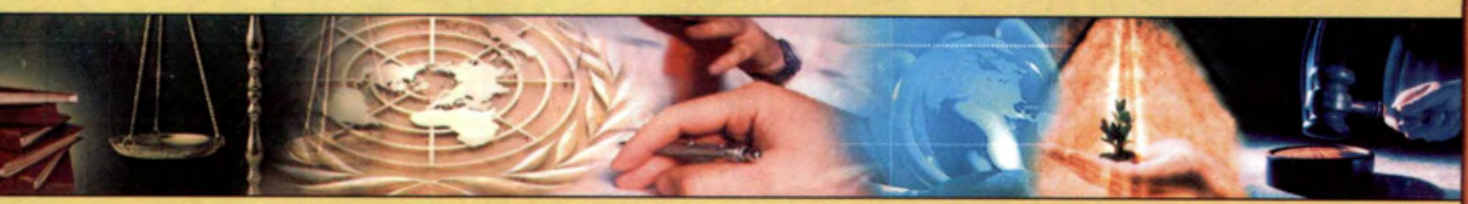




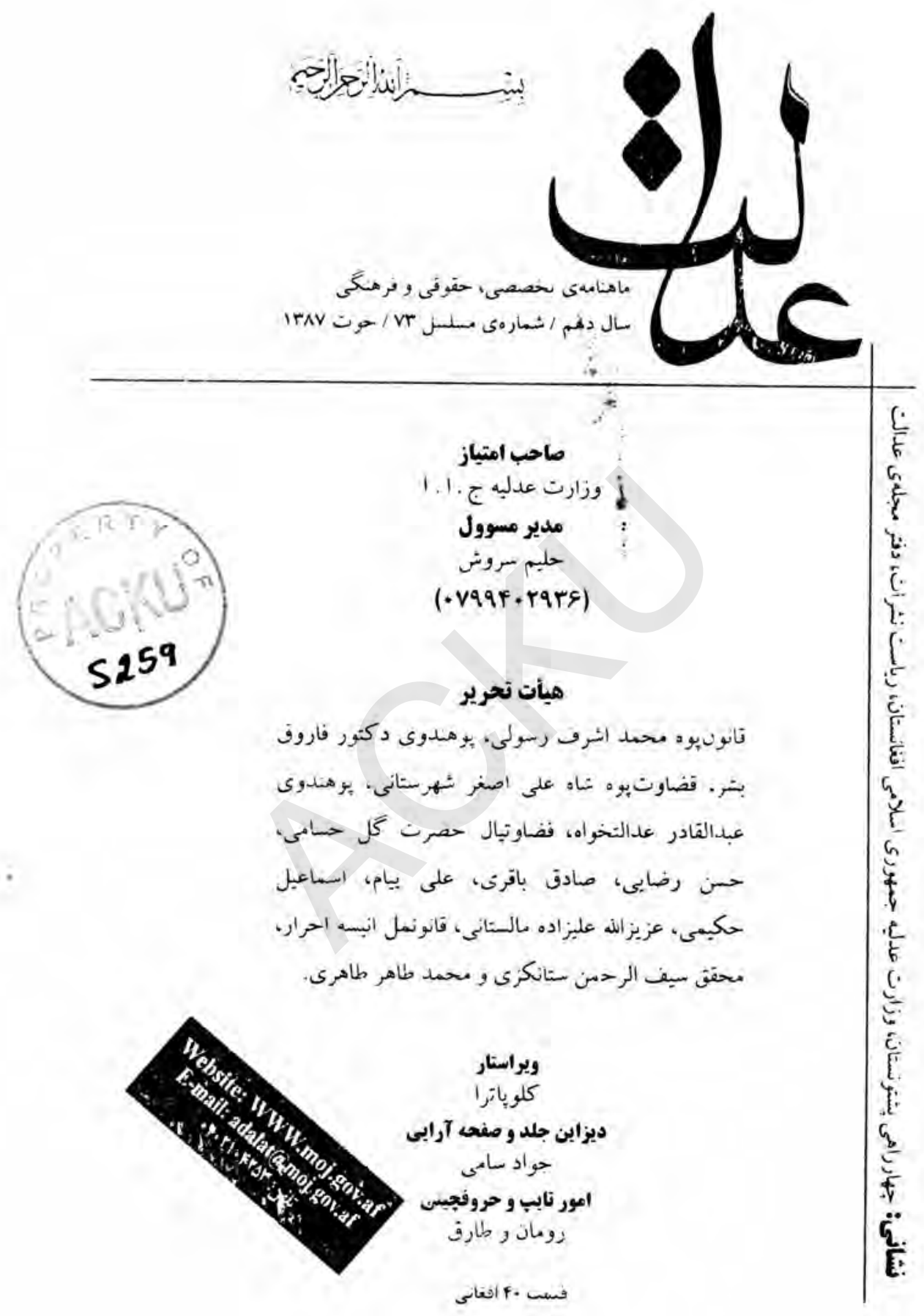




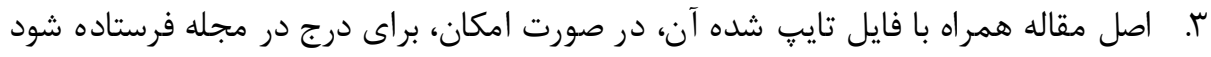
نه كيى آن.

f. . مقاله بايد داراى جكيده، وازَّان كليدى و نتيجه كيرى نهايى باشد. جكيده بايد به كونهاى نوشته شود كه محتواى مقاله را به اختصار بيان كند.

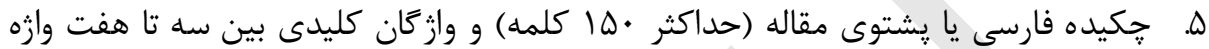

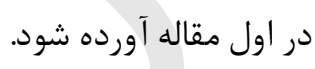
צ. توضيحات و ارجاع به منابع در برايان مقاله به قرار ذيل آورده شود:

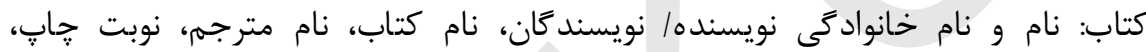
محل نشر، نام ناشر، تاريخ انتشار و شماره صام صفحه.

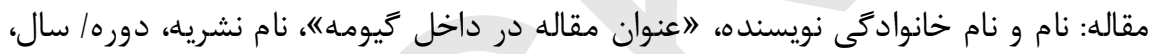
تاريخ انتشار، شماره جلد و شماره صفحه.

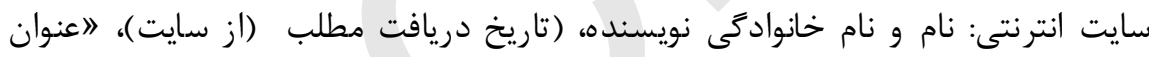

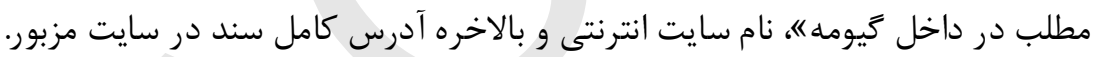

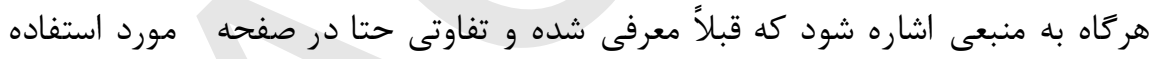

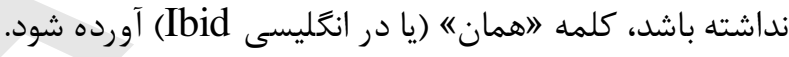

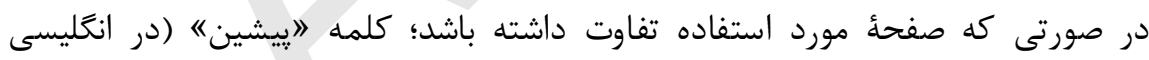
) و صفحه مورد استفاده آورده شود. (op.cet

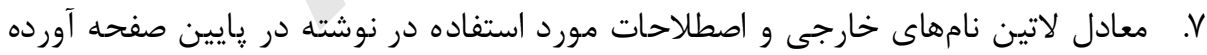

ᄉ هر كاه مقاله ارسالى ترجمه باشد، نام نويسنده و منبع مورد نظر ضرورى است.

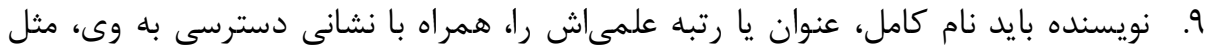

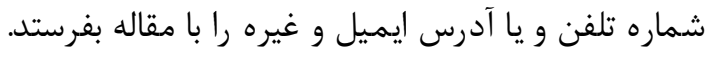
• ا. مجله در ويرايش مقاله آزاد است.

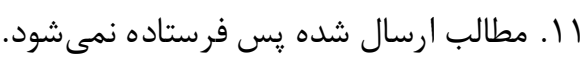

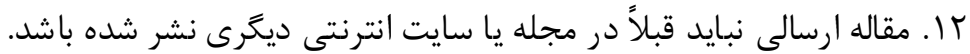




\section{فهو ست}

\section{مقالهها}

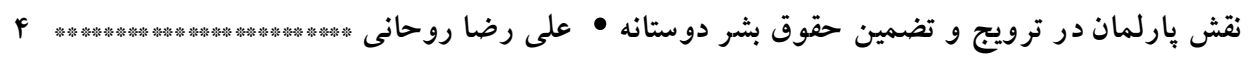

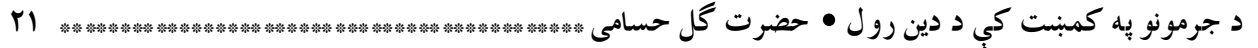

اسناد حقوق بينالمللى مبنى بر تحريم جرايم و جنايات جنكى • •

آيا اعيتاد سبب رفع مسووليت جزايى مى شود؟ •

P

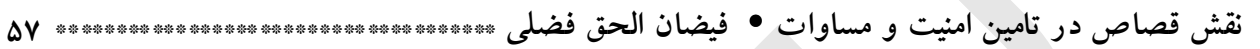

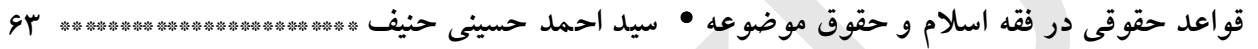

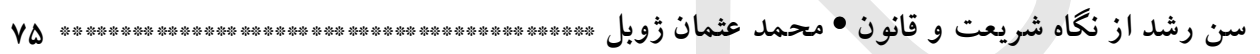

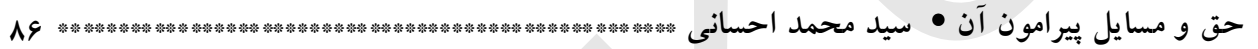

Q

كنفر انس كورميو ر(مونت بلانك) در مورد جرايم سازمان يافته در هنرهاى زيبا وآثار باستانى • محمد

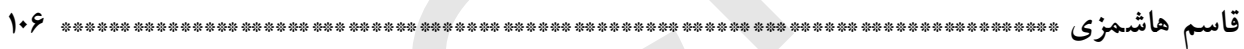

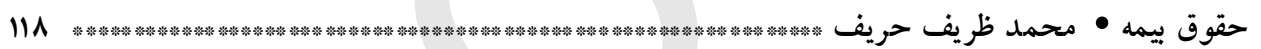

ا شتباه يا غلط در معامله • موسى فكورى

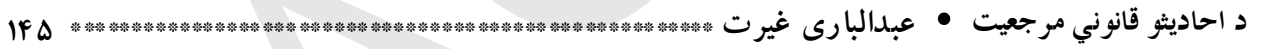




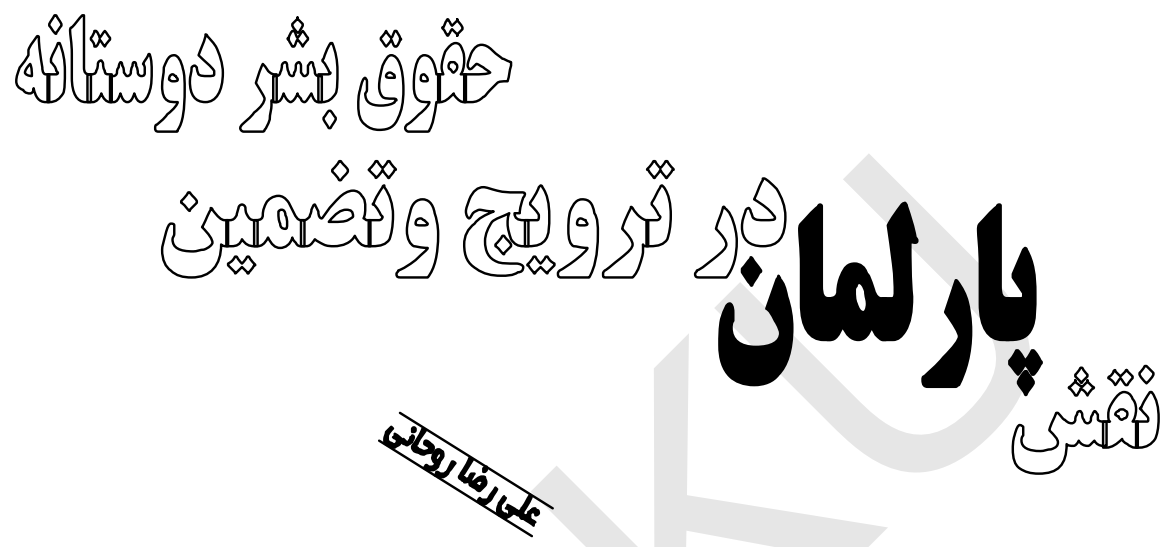

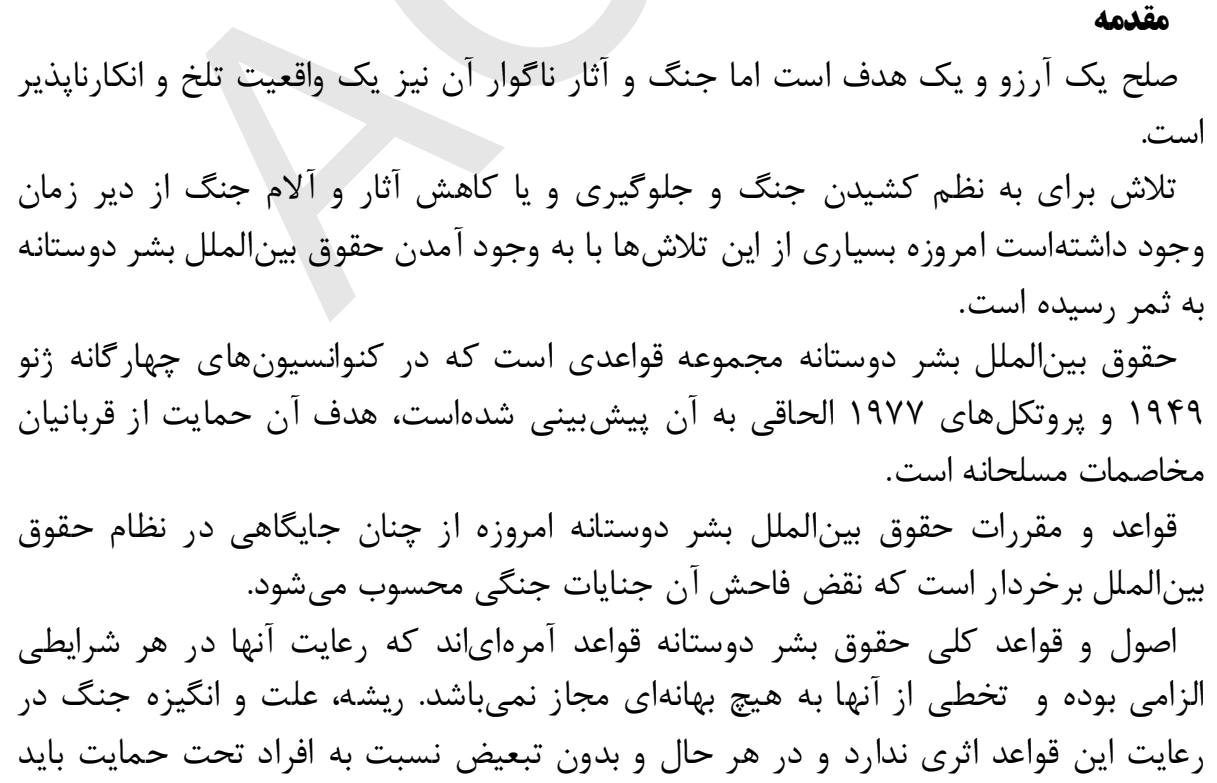


رعايت گر دد. آكاهى و شناخت دقيق اين قواعد و اطلاع از نقش و مكلفيت نهادهاى دولتى به

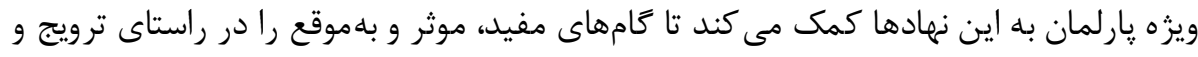

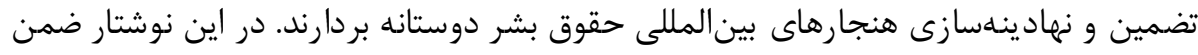

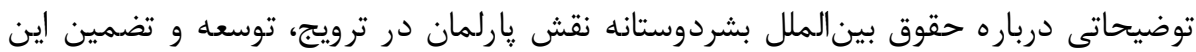
حقوق مورد بر رسى قرار مى ديرداني

\section{كفتار اول: كلياتى درباره حقوق بينالملل بشر دوستانه}

ا- تعريف

تعريف: حقوق بينالملل بشر دوستانه يكى از شاخههاى اصلى حقوق بينالملل عمومى، و و

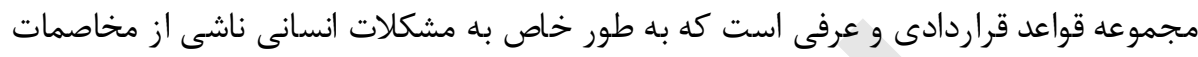

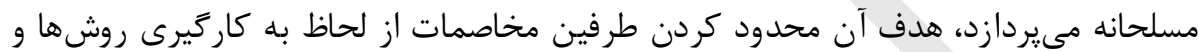

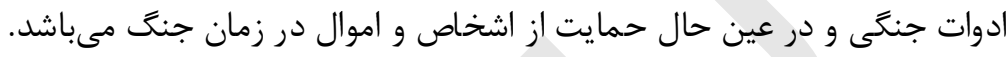

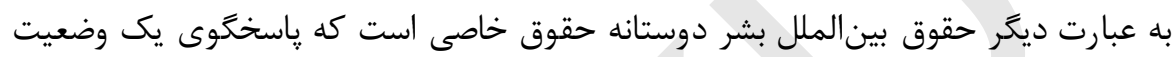

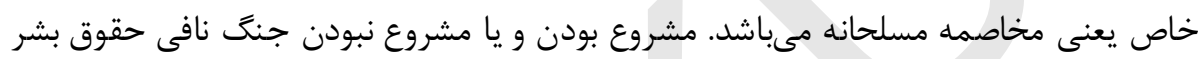

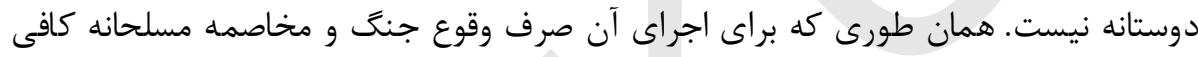

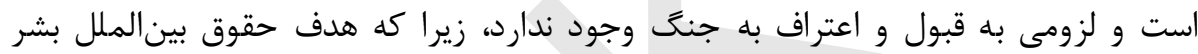

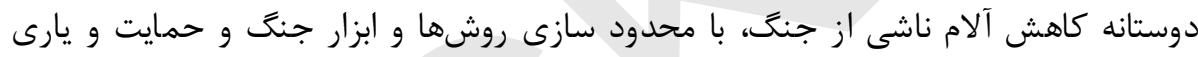

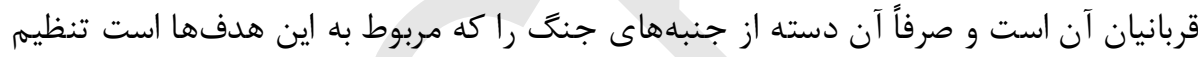
مى كند.

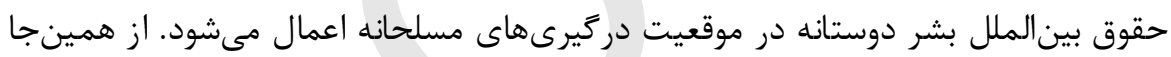

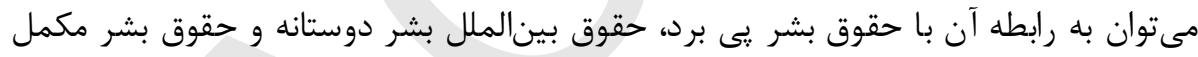

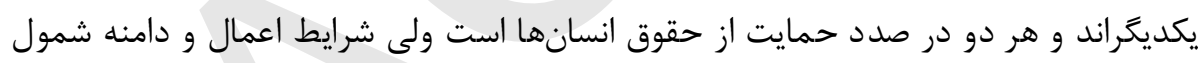

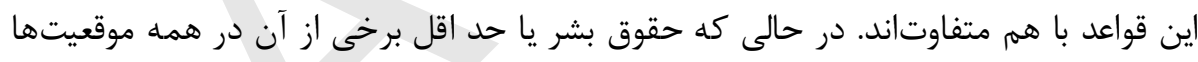

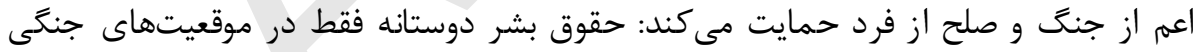

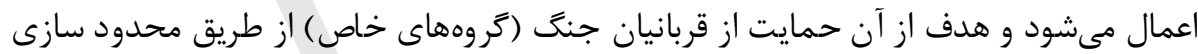

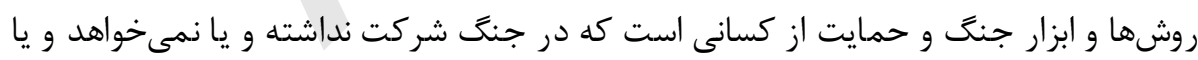
نمى نواند شركت نمايند. قواعد اساسى حقوق بينالملل بشر دوستانه جايگاه والاى در نظام ندام حقوق بينالملل دارد زيرا

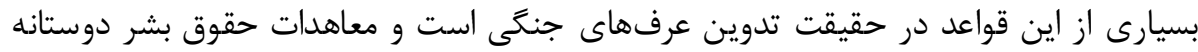

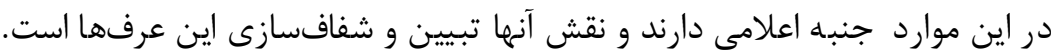

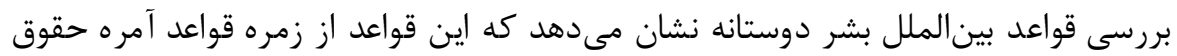

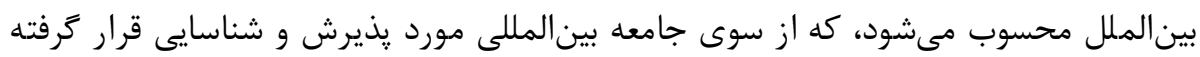

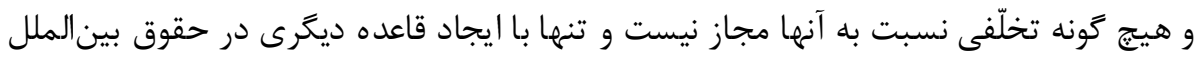

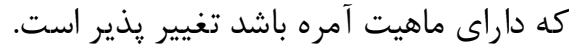




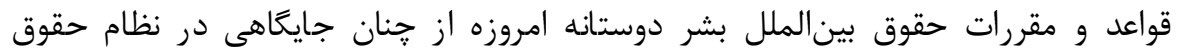

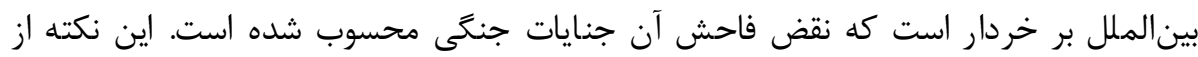

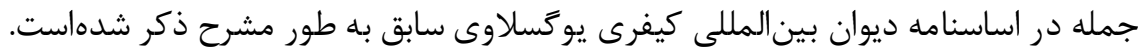

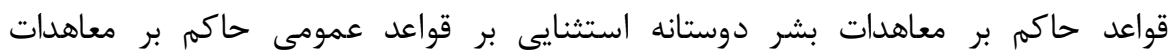

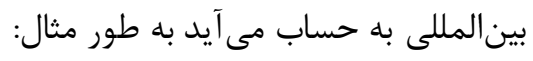

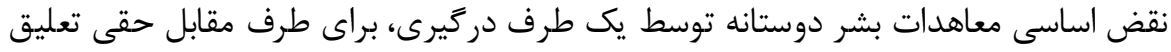

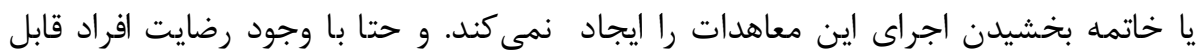

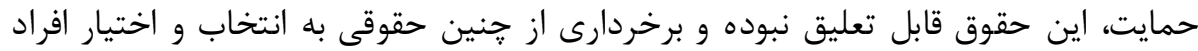

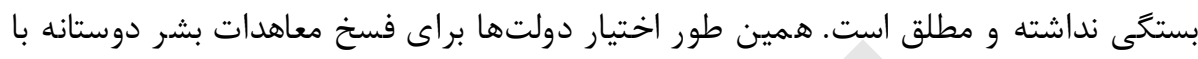

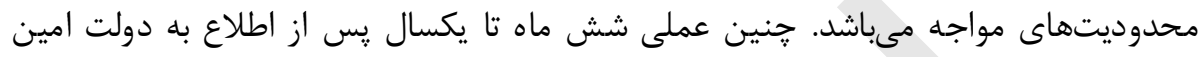

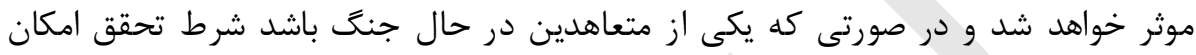

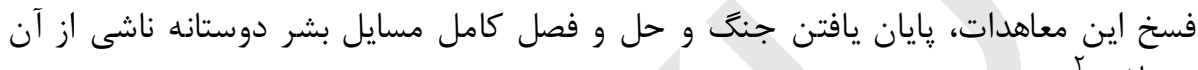

\section{r - منابع و قلمرو حقوق بينالملل بشر دو ستانه}

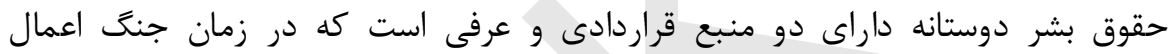
مى کردد:

\section{الف) منابع عرفى حقوق بشر دوستاذه}

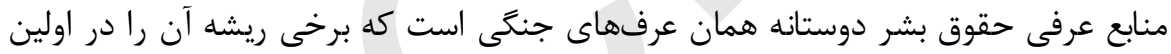

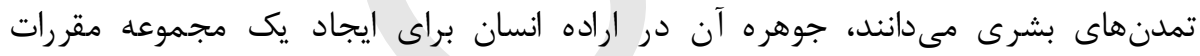

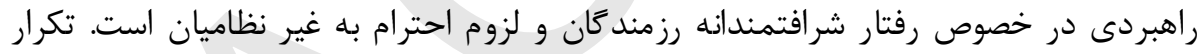
جنين رفتارهاى توام با حسن نيت از سوى همد همه كشورها

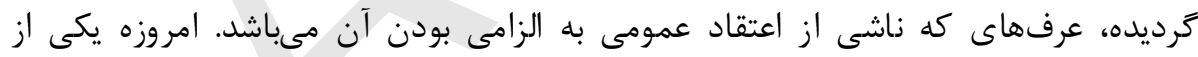

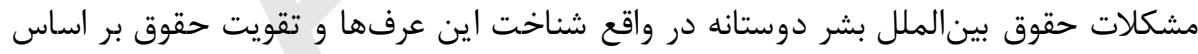

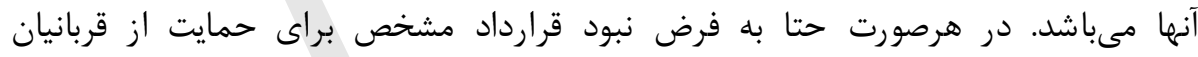

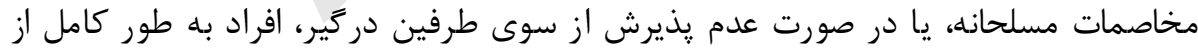

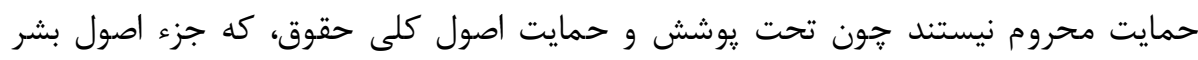

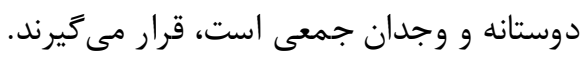

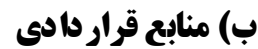

منابع قرار دادى حقوق بشر دوستانه در يك تقسيهم بندى به دو بخش قارد بابل تقسيم هستند:

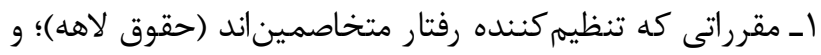
זـ مقرراتى كه حامى قربانيان مخاصمات مسلحانهاند (حقوق زنو). 
برو سى حقوق لاهـ

تدوين حقوق لاهه مديون تصويب دو قانون، يكانى داني در سطح داخلى و ديكرى اعلاميه

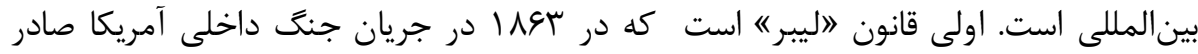

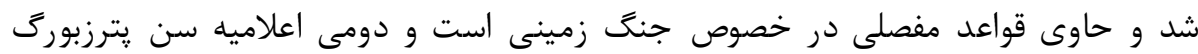

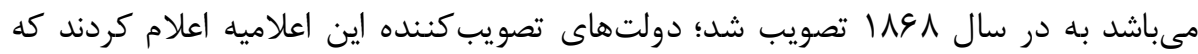

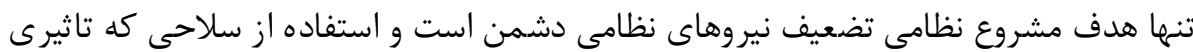

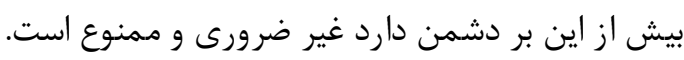

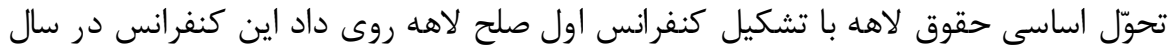

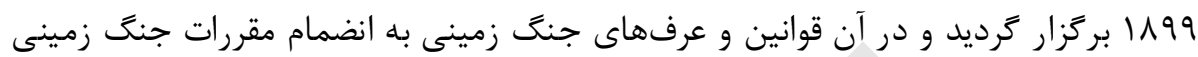

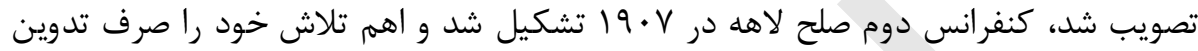

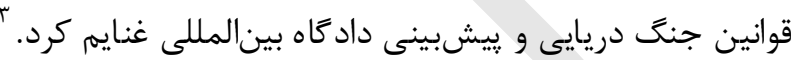

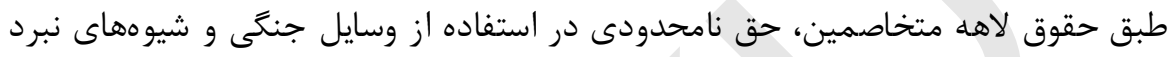

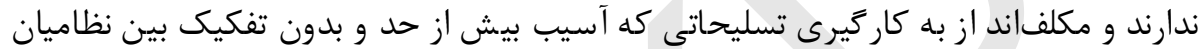
و غير نظاميان وارد مى كند اجتناب كنند.

\section{برد سى حقوق زنو}

عمدهترين بحش قواعد حقوق بشر دوستانه كه رعايت آنها در خلال درگيرىهاى مسلحانه از

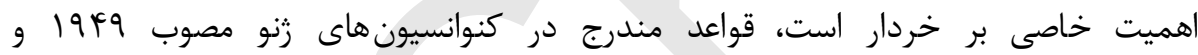

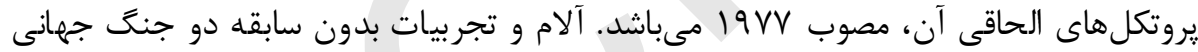

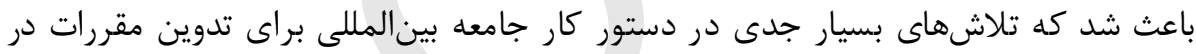

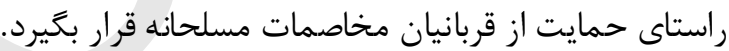

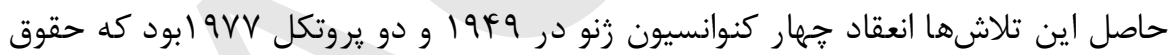

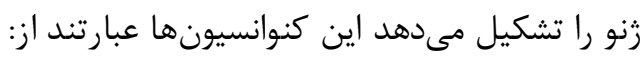

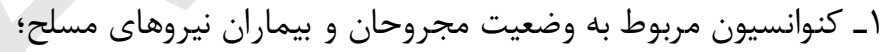

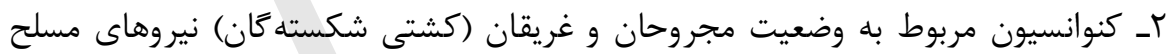

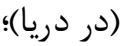

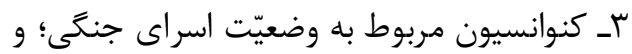
أ_ كنوانسيون مربوط به غير نظاميان.

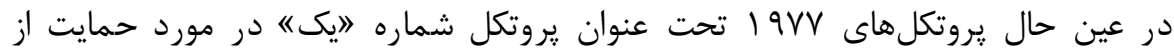

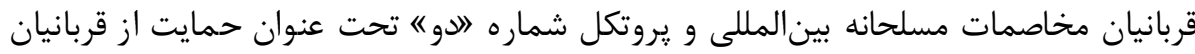

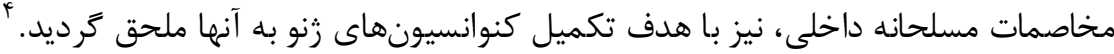

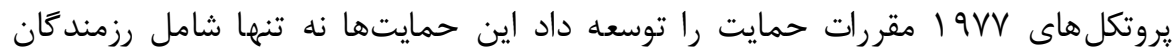

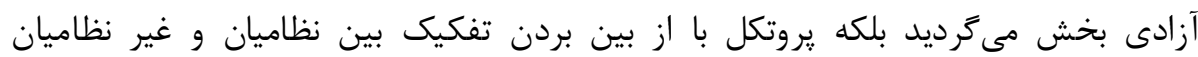

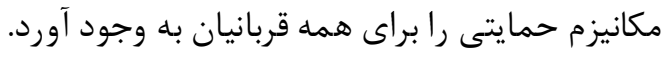


كنوانسيون هاى زنو حاوى مقررات مشترك در باره دامنه شمول، زمان اجراى موافقتنامههاى

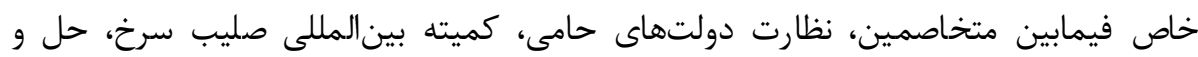

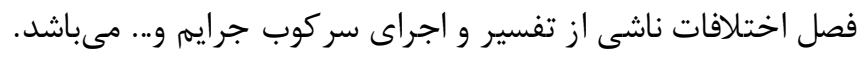

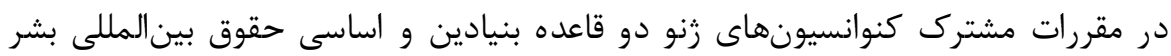

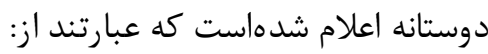

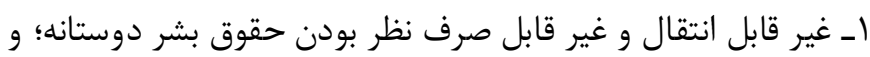
كا ـ ممنوعيت اقدامهاى تلافى جويانه.

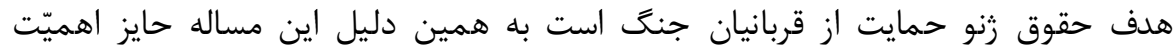

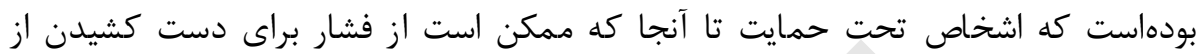

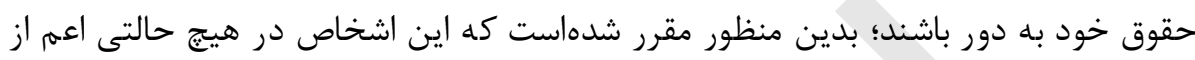

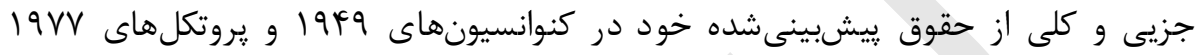

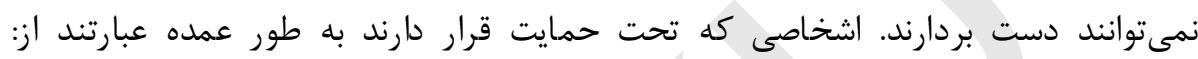

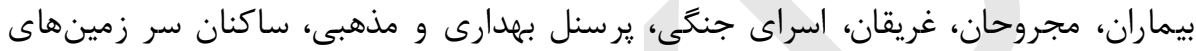

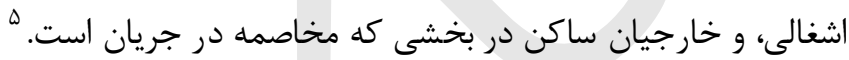

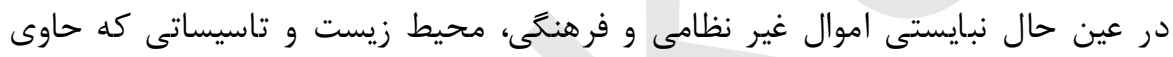

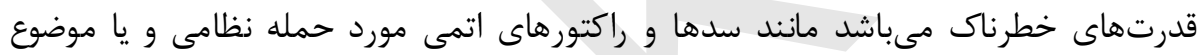
اقدامات تلافى جويانه واقع شوند.

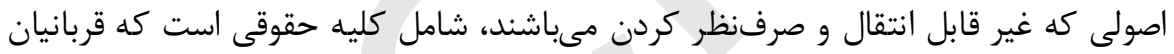

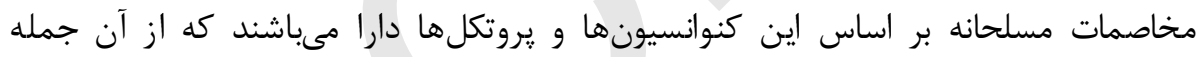

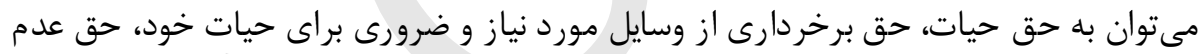

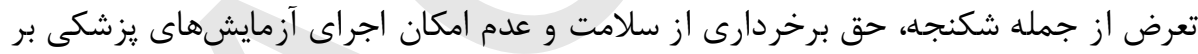

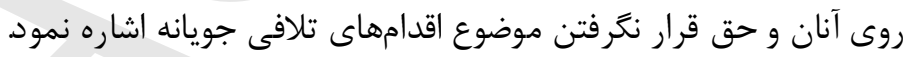

\section{r - مكانيزمهاى حمايتى و قلمرو اجراى حقوق بشر دوستانه

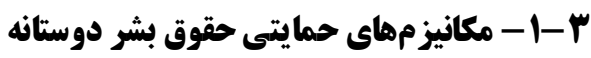

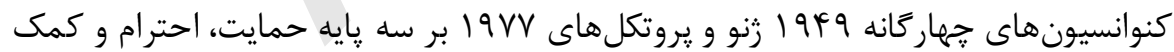

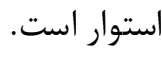

الف) حمايت: حمايت ايجاب مى كند كه امنيّت افراد تامين شود و آنها در مقابل آثار

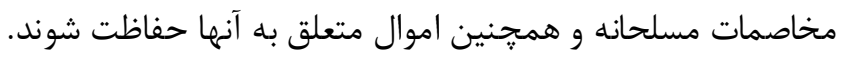

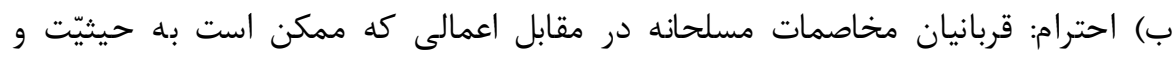

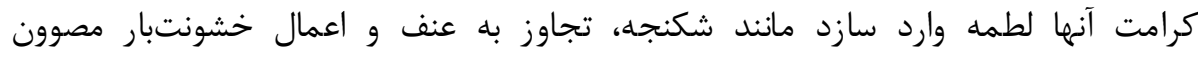


ج) كمك: كمك هم به اين معنا است كه كليه مجروحان، بيماران بدون تبعيض مورد درد دمان

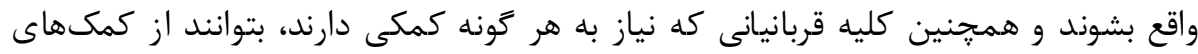
لازم بهر ممند تردند.

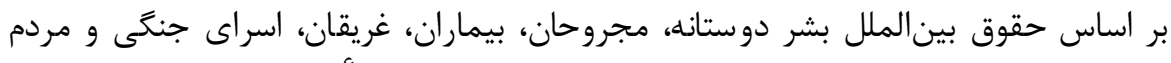

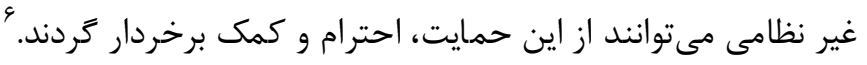

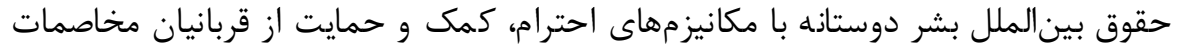

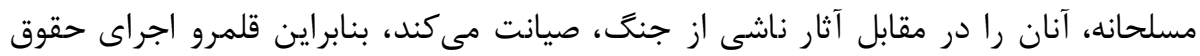

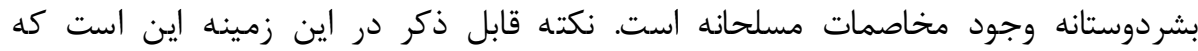

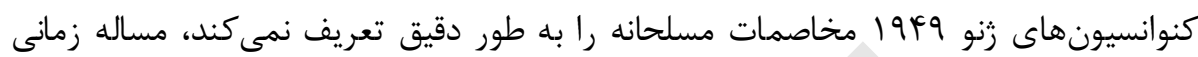

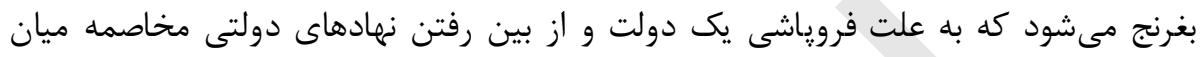

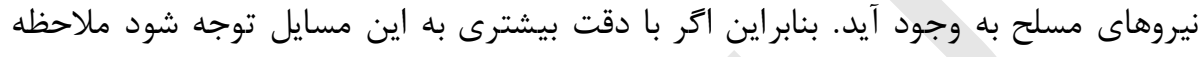

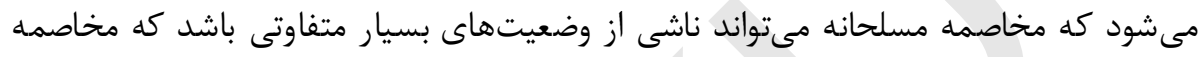

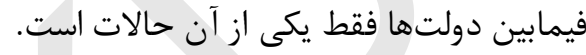

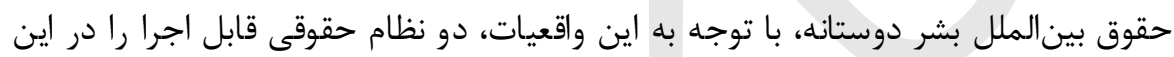

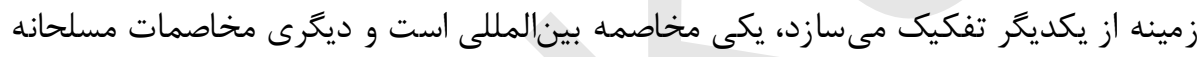

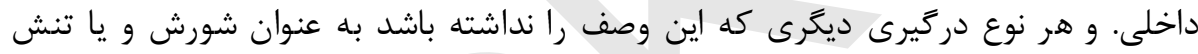
داخلى قلمداد مى كند.

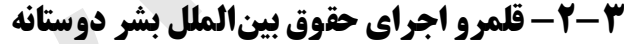 الف) مخاصمه مسلحانه بينالمللى}

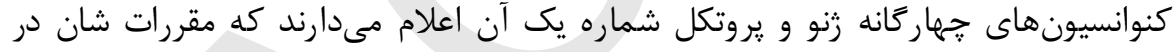

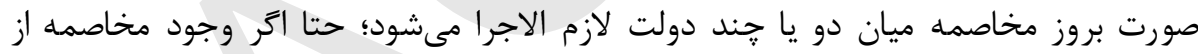

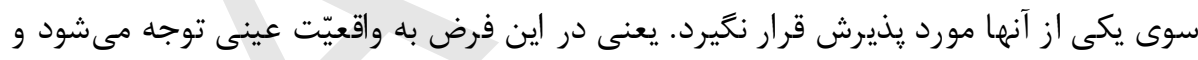

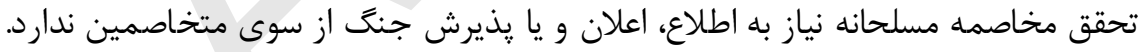

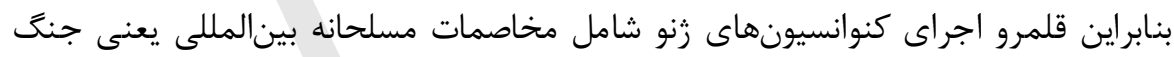

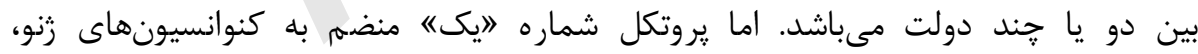

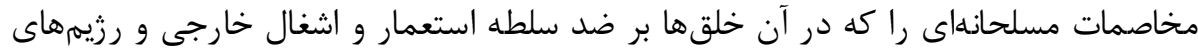

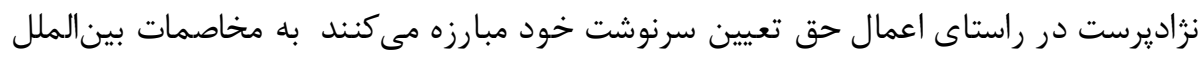
ملحق مىسازد. بدين ترتيب يروتكل شماره "ايك" مفهوم موسعى از مخاصمات مسلحانه بين المللى را مان مطرح

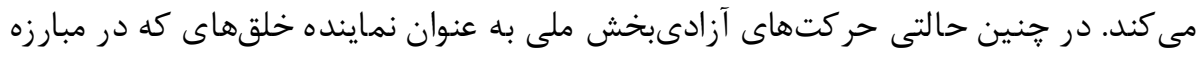

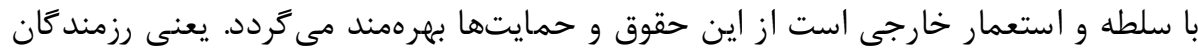

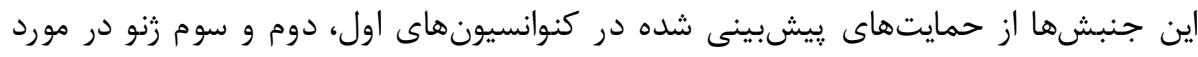


مجروحين، بيماران و غريقان و اسرا استفاده خواهد كرد. همان طورى كور كه كنوانسيون جهارم

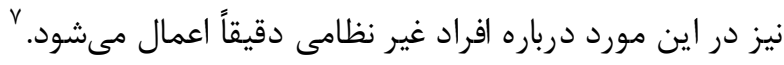

\section{ب) مخاصمه مسلحانه داخلى}

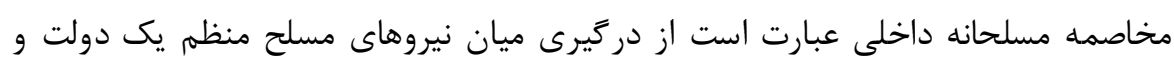

$$
\text { نيروهاى مسلح شورشى. }
$$

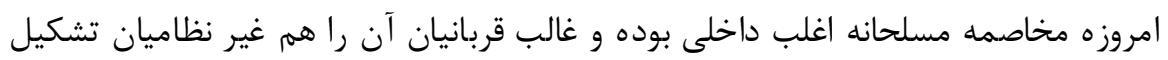

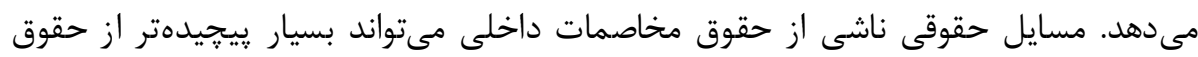

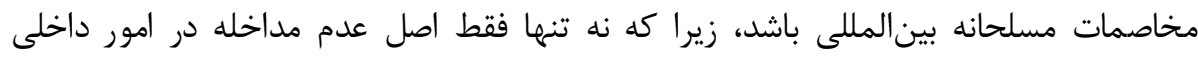

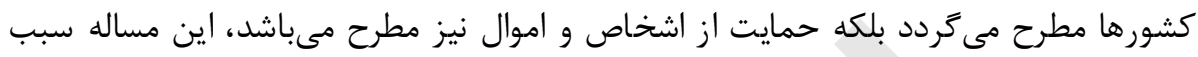

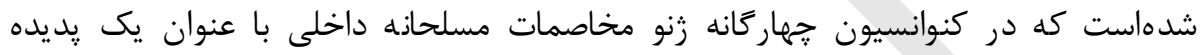

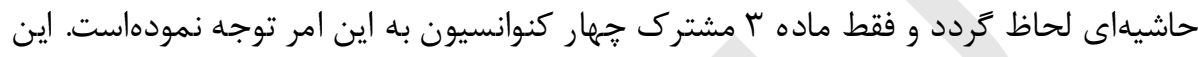

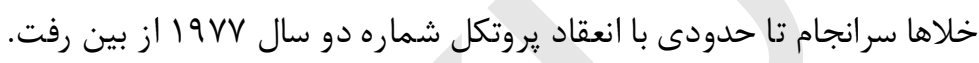

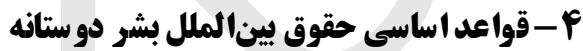

بر اساس اسناد بينالمللى حقوق بشر دواسئ دوستانه اصول اساسى حقوق بشر دوسانه دوستانه بينالمللى عبارتند از:

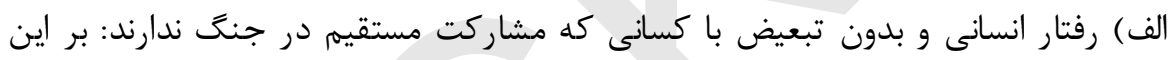

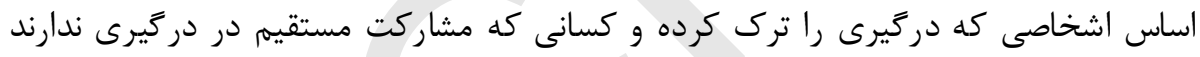

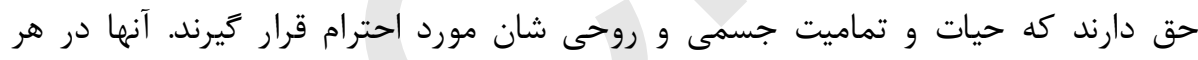

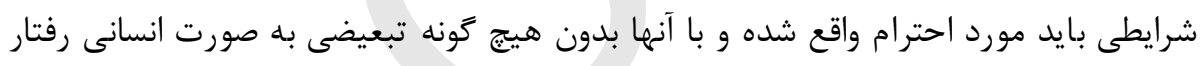

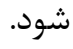

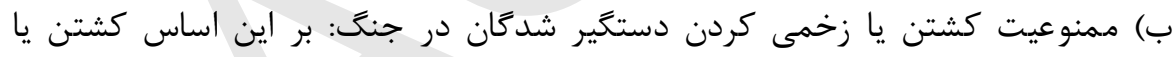

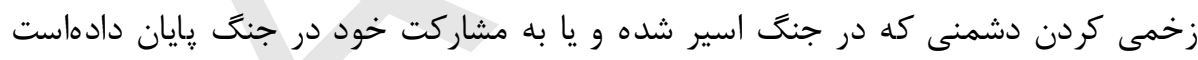

$$
\text { ممنوع مىباشد. }
$$

ج) احترام، كمك و حفاظت نظاميان و غير نظاميان دستخير شده: بنابر اين اصل، رزمند أنان

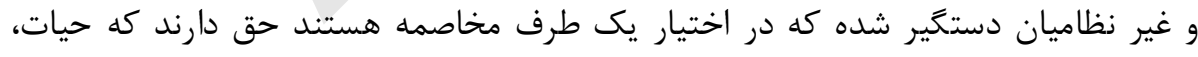

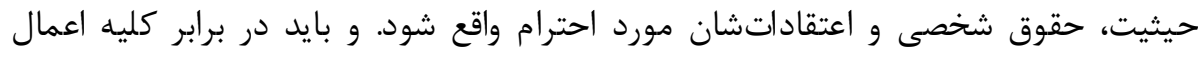

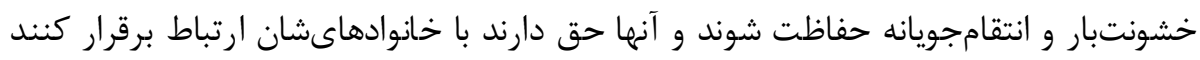

$$
\text { و كمكهاى امدادى دريافت كنند. }
$$

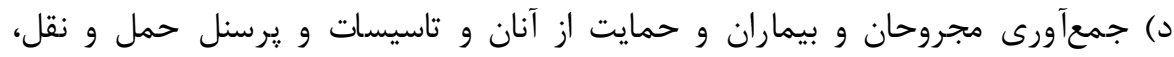

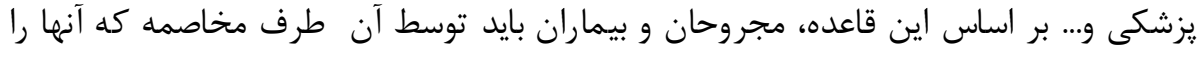

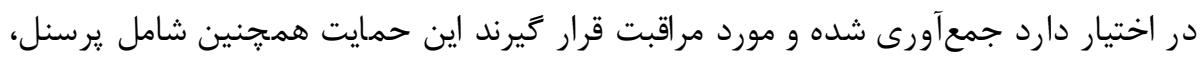

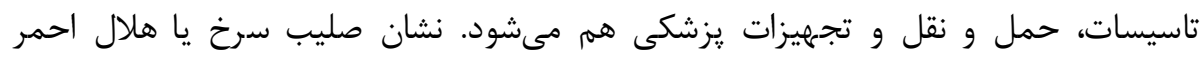


[ياكريستال سرخ كه جديدا به نشانهاى داراى احترام اضافه شدهاست] علامت جنين حمايتى است و بايد مورد احترام واقع شود.

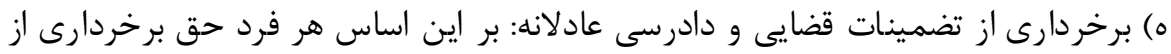

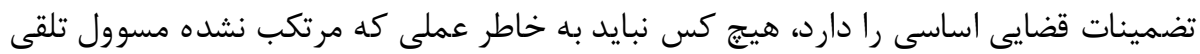

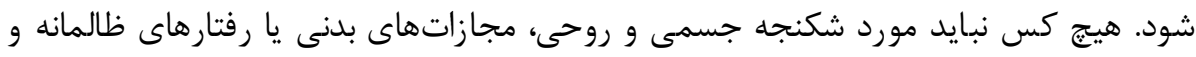
خفتبار قرار كيرد. و) محدوديت اطراف جنغ در استفاده از شيوهها و ابزارهاى جنكىى: بنابر اين اصل، طرفهاى

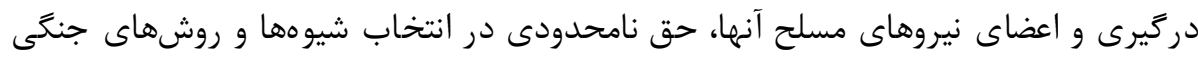

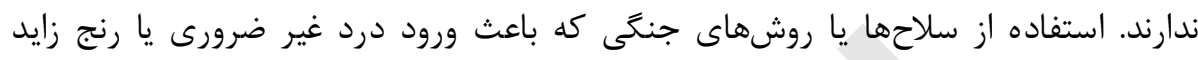
مىشود، ممنوع مىباشد.

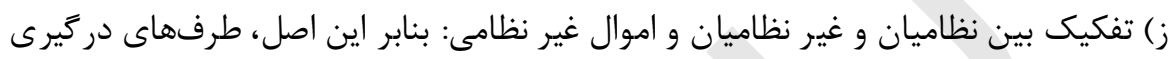

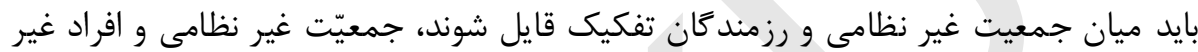
نظامى و مناطق غير نظامى و بناهاى فرهنكى و... نبايد مورد حمله واقع شود.

\section{F}

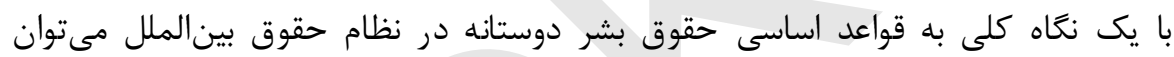

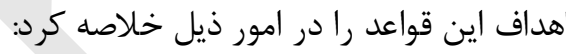

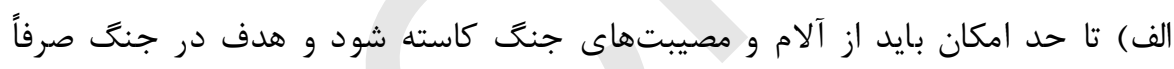
تضعيف نيروى نظامى در حال جنَ دشمن باشد.

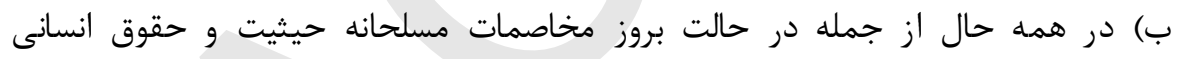

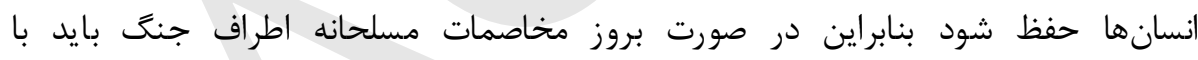

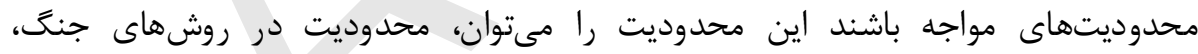
محدوديت در كاربرد ابزار جنگ، محدوديت در سلوك با دشمن و محدوديت در رفتار با كسانى إنى

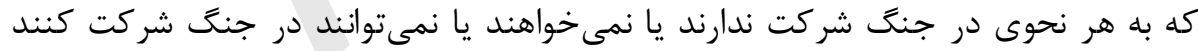

$$
\text { خلاصه كرد. }
$$

در اين مورد تذكر جند نكته ضرورى به نه نظر مى اصرسد:

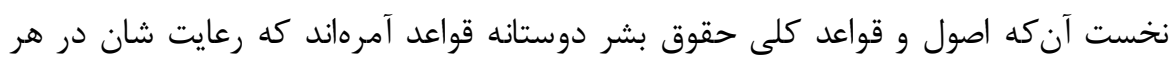

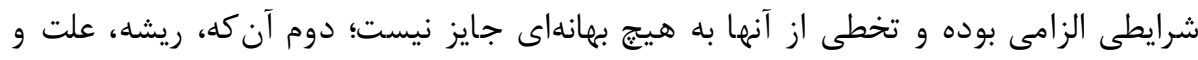

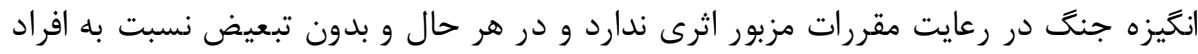

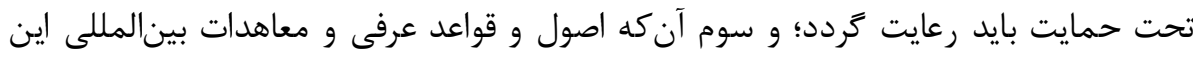
حقوق جنبههاى اعلامى دارند نه انشايى. 


\section{كفتار دوم: نقش پار لمان درترويج وتضمين حقوق بشردوستاذه}

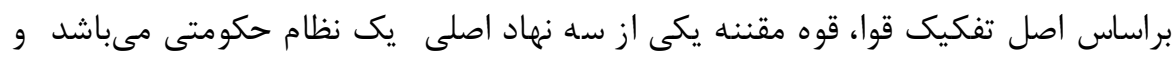

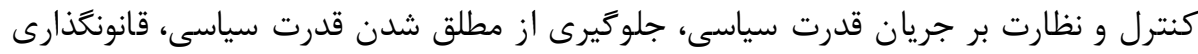

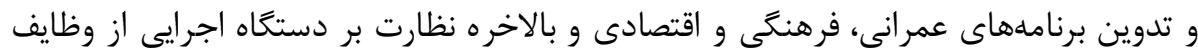

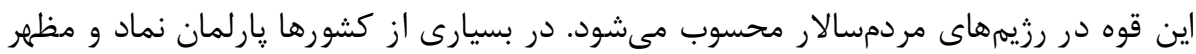

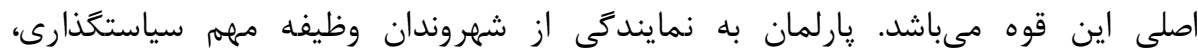

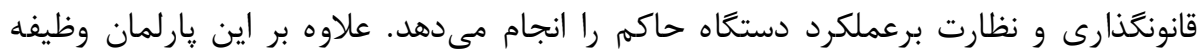

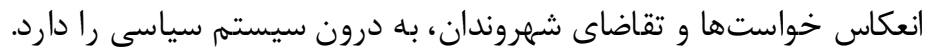

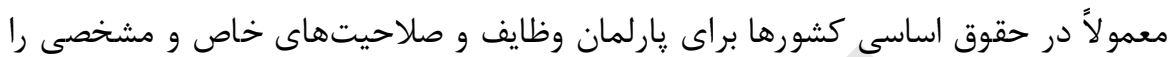

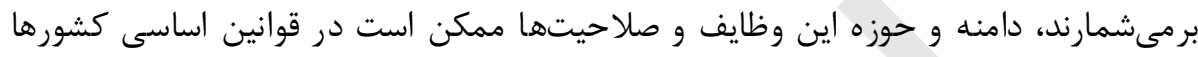

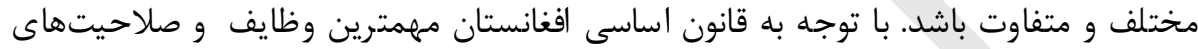

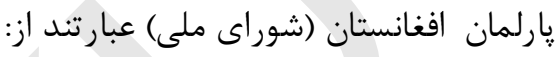

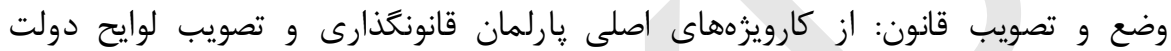

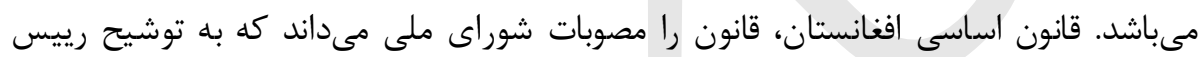

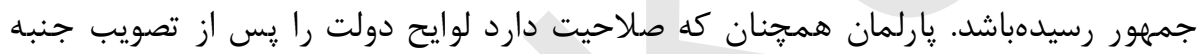

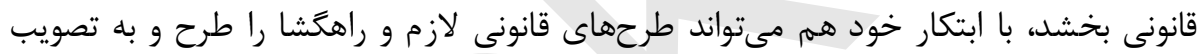

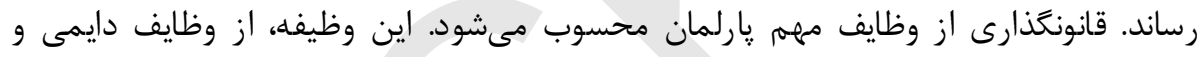

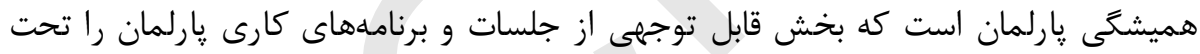

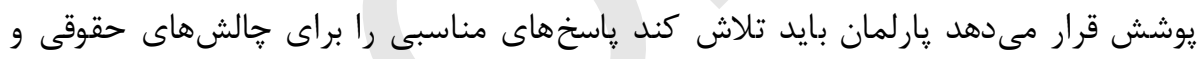

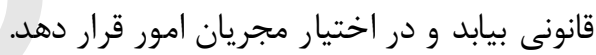

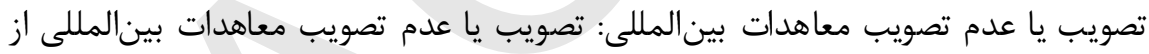

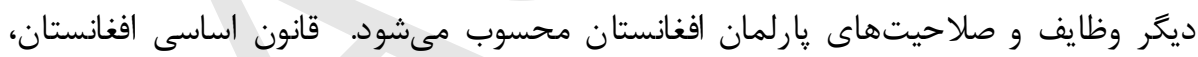

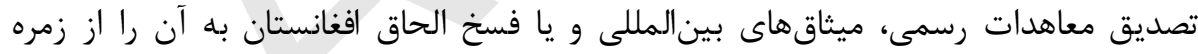

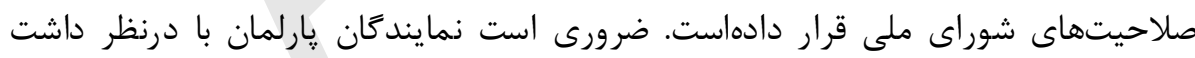

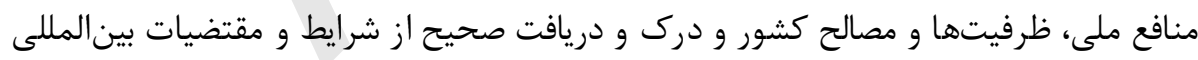

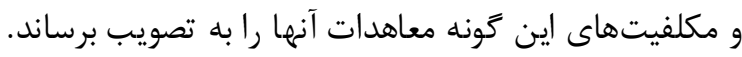

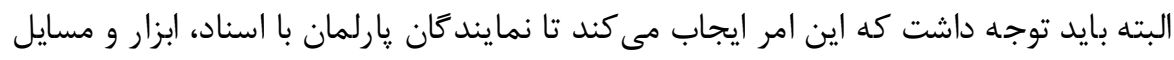

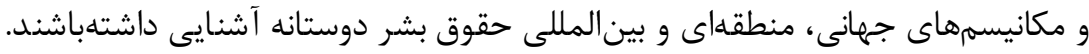

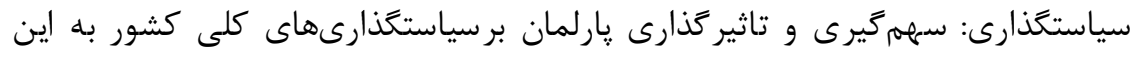

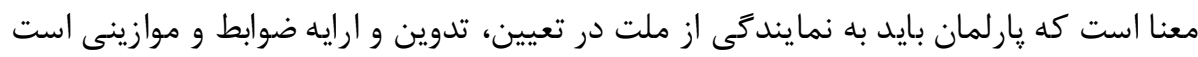

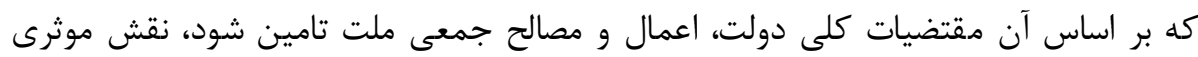


نظارت: نظارت يكى از وظايف اصلى پارلمان است اين امر از ابزارهاى اصلى كنترل قوه

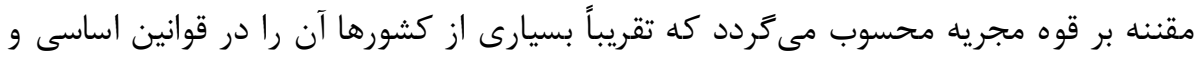

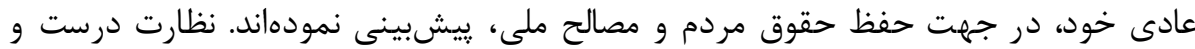

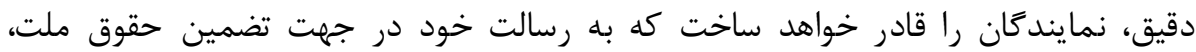

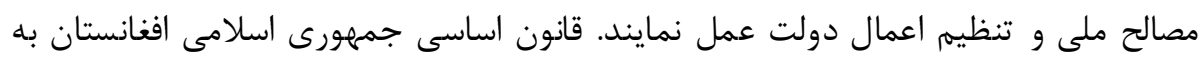

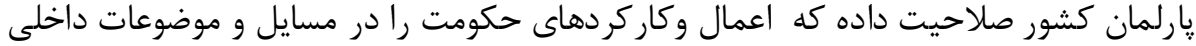

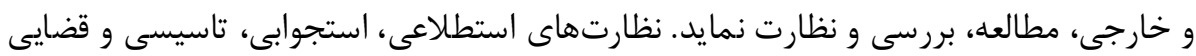

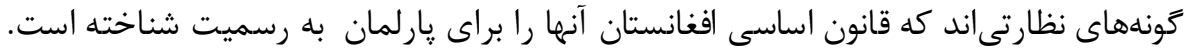

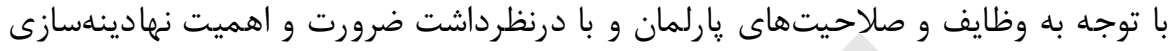

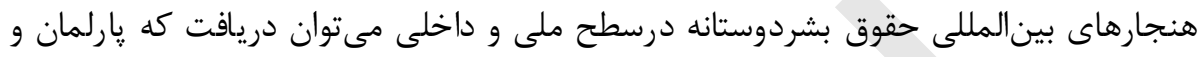

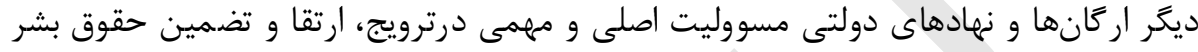

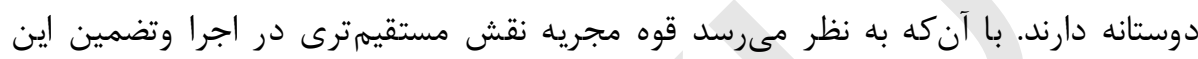

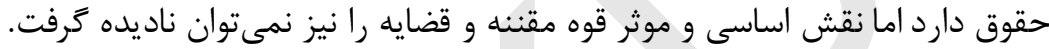

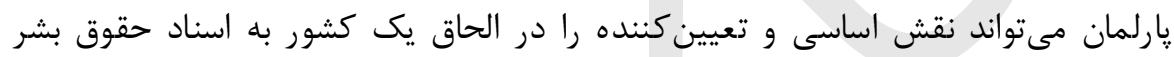

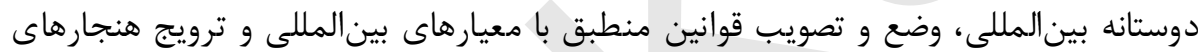

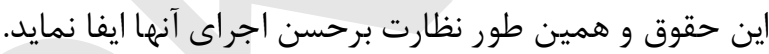

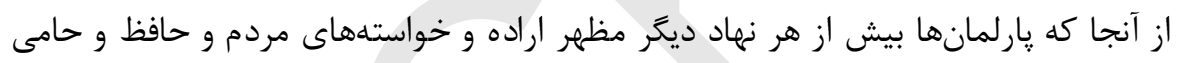

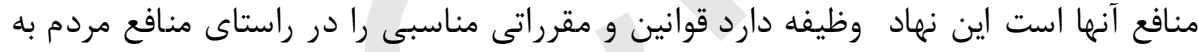

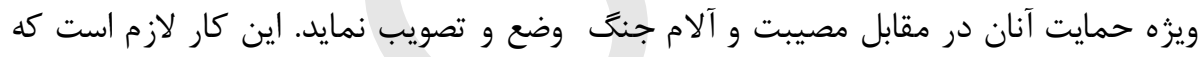

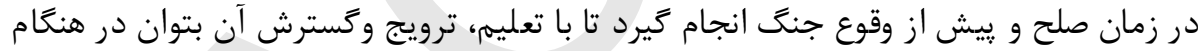

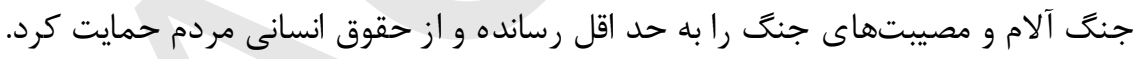

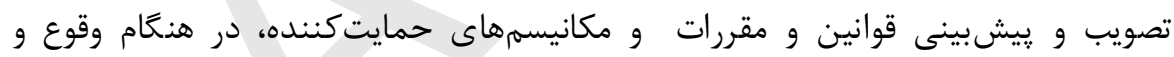

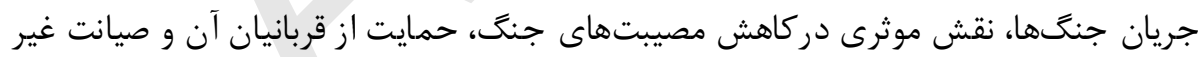
نظاميان و مناطق و مراكز غير نظامى دارد.

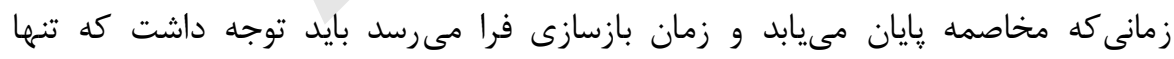

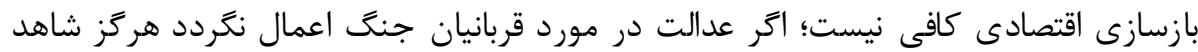

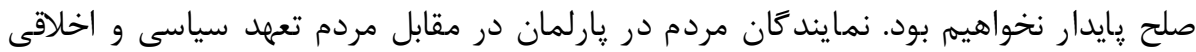

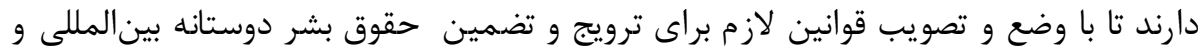

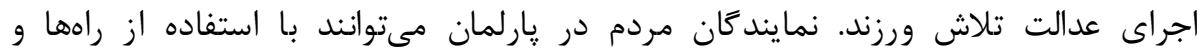

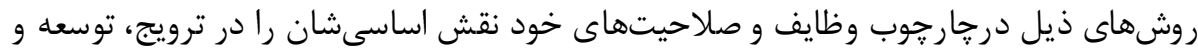
تضمين معيارهاى بينالمللى حقوق بشر دوستانه ايفا نمايد: 
1- تصويب عضويت كشور در معاهدات بينالمللى حقوق بشردوستانه

بر اساس قانون اساسى بسيارى كشورها ازجمله افغانستان تصويب عضويت و الحاق دولت به

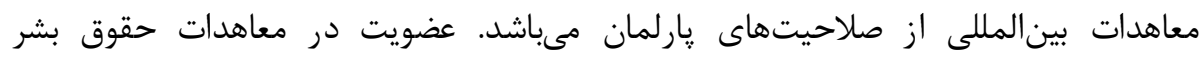

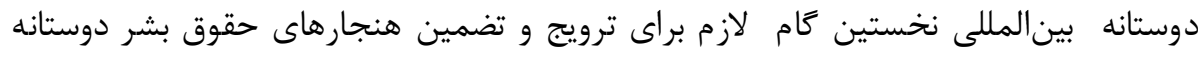

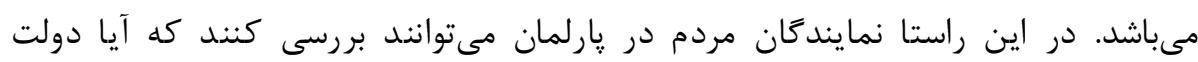

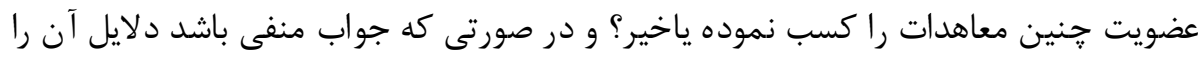

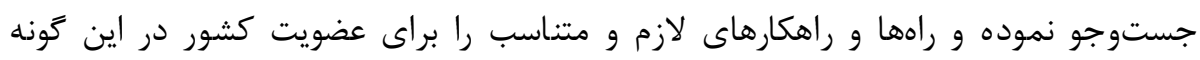

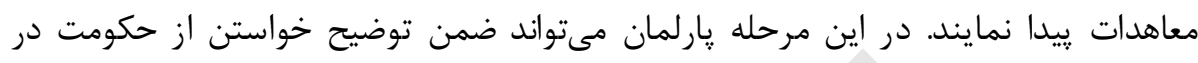

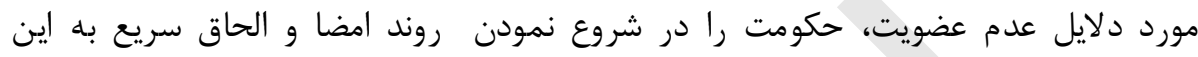

معاهدات تشويق نمايد.

در صورتى كه دولت معاهدهاى را امضا كرده ولى براى تصويب آن اقدام نكردهباشد؛ پارلمان

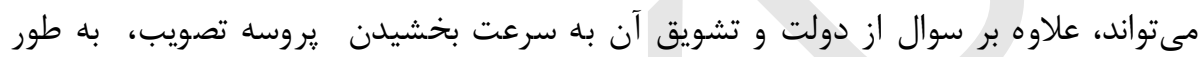

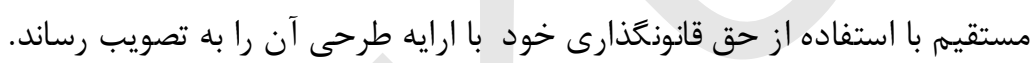

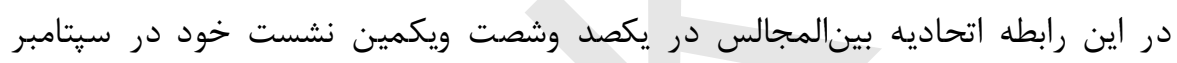
199V

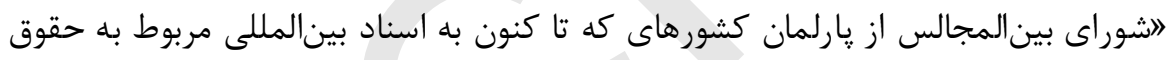

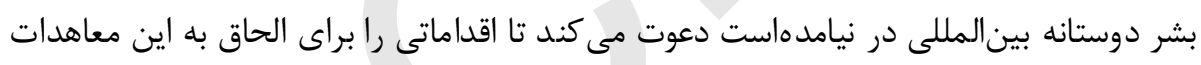

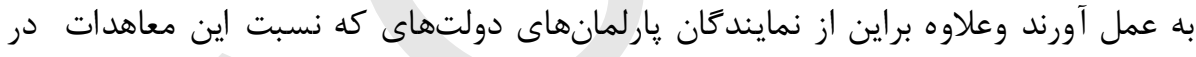

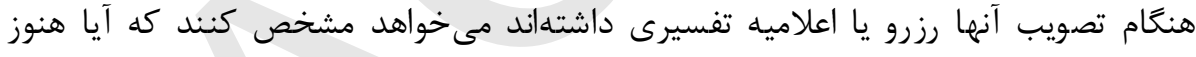

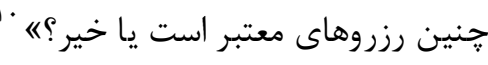

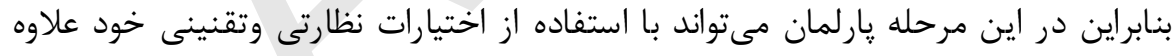

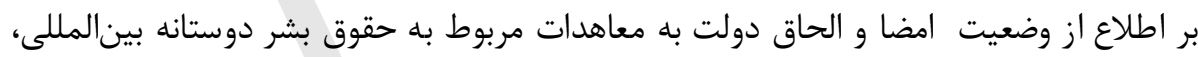

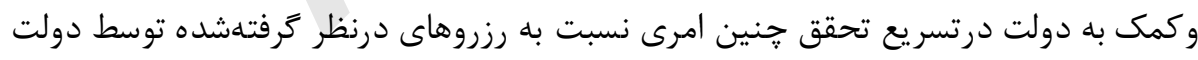

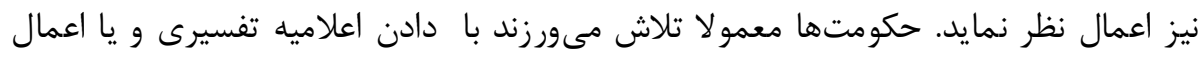

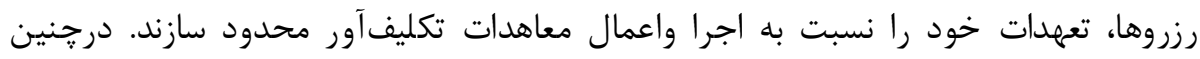

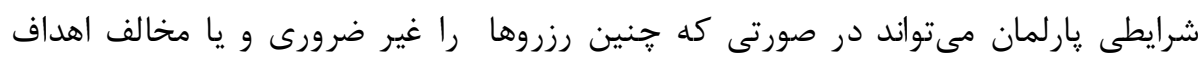

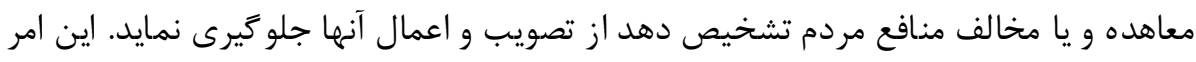

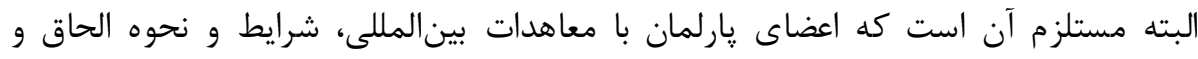

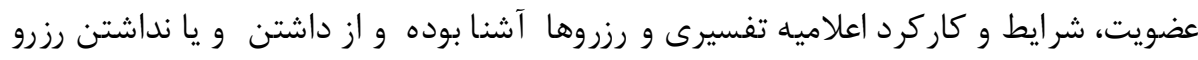
و اعلاميه تفسيرى توسط دولت نسبت اين معاهدات اطلاع داشتهباشند. 
r- تصويب قوانين داخلى منطبق با معيارهاى معاهدات بينالمللى حقوق بشر دوستانه،

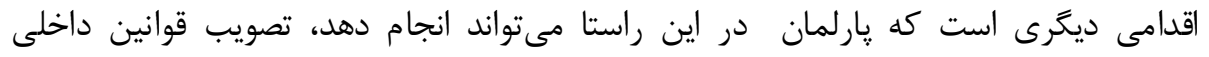

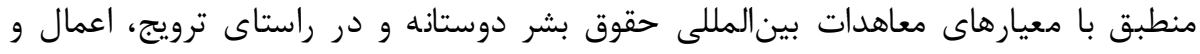

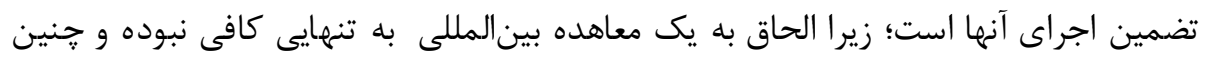

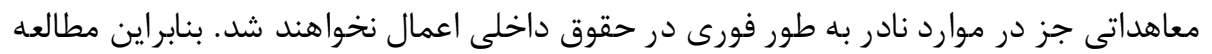

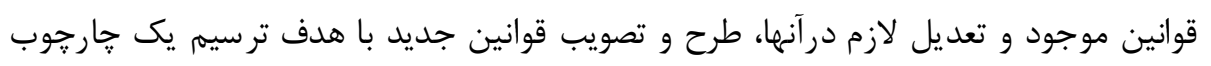

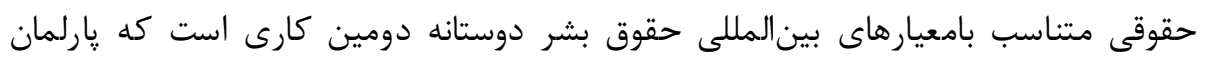

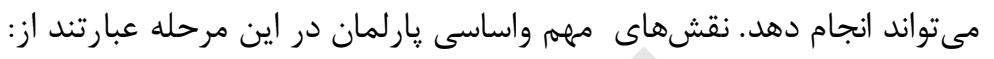

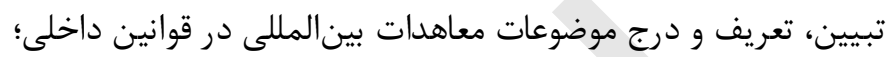

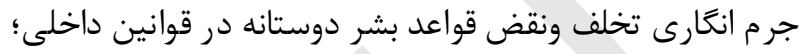

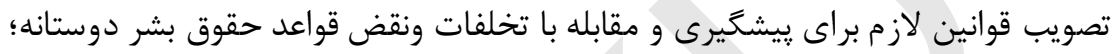

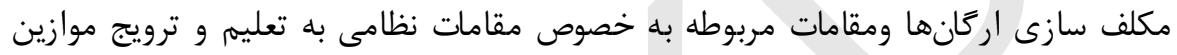

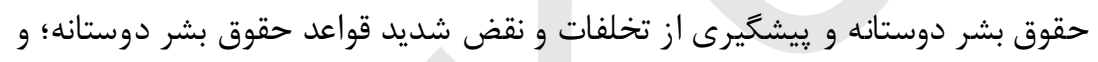

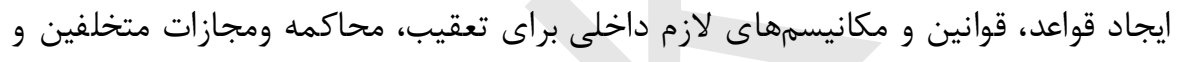

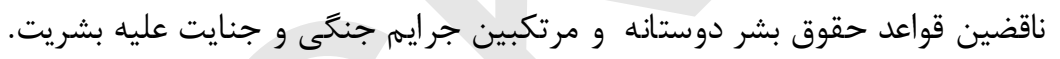

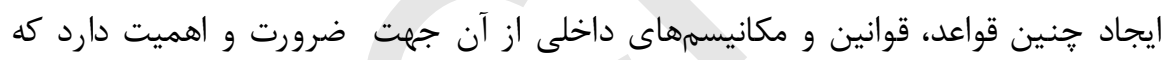

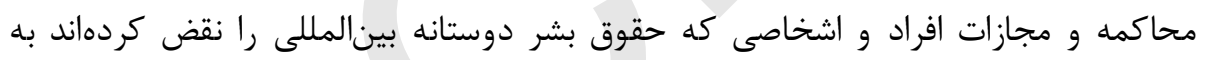

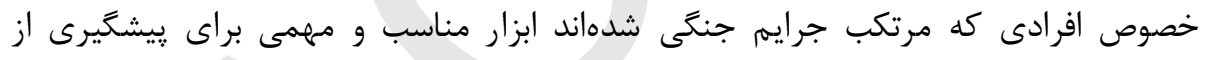
جرايم بعدى مىباشد. تشكيل ديوان بينالمللى كيفرى نشاندهنده ضرورت و اهميت محاكمه و مجازات متخلفان

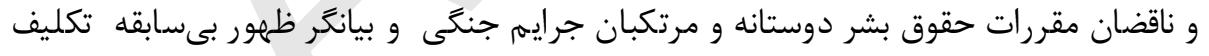

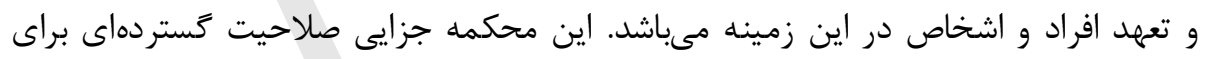

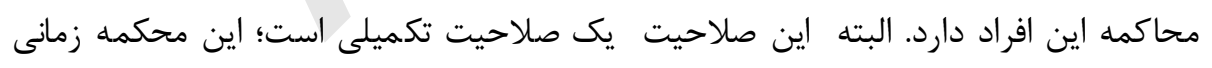

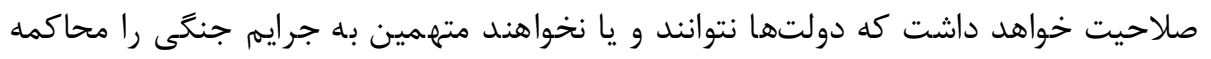
كنند. نكته مهمم و قابل توجه آن است كه محاكمه و مجازات متخلفان و ناقضان مقررات حقوق

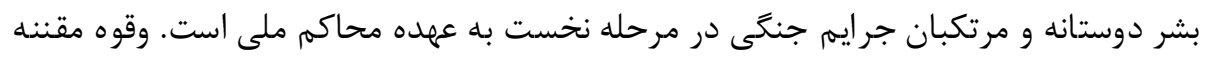

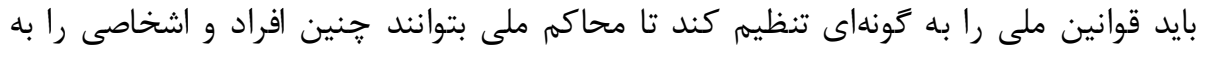

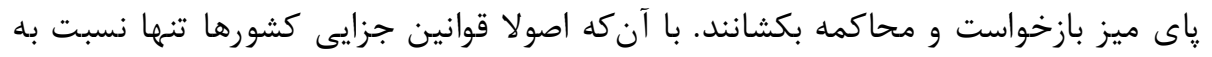

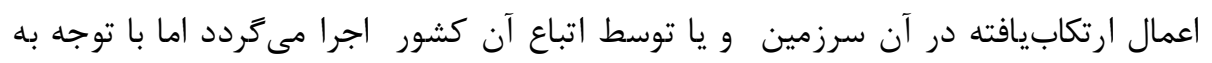


اهميت مساله و 》اصل صلاحيت جهانى" معاهدات حقوق بشر دوستانه بينالمللى دولتها را

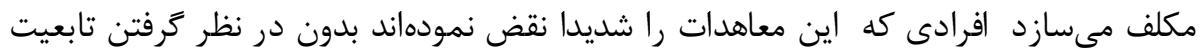

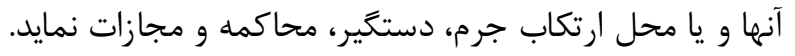

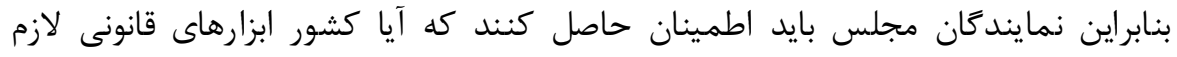

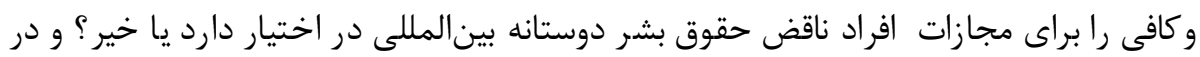

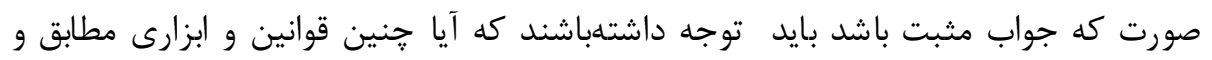

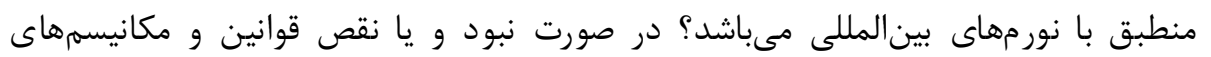

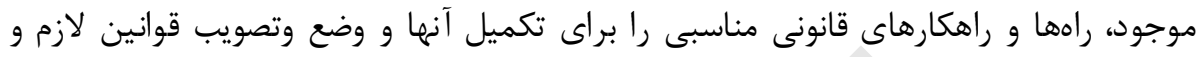

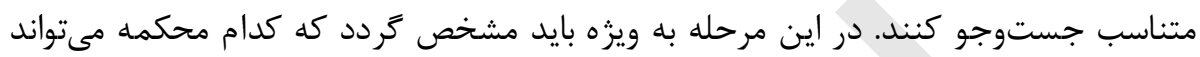

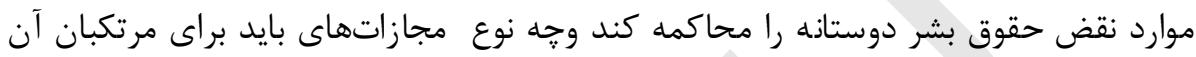
در نظر كرفته شود.

\section{r - تشكيل نهاد بار لمانى مربوط به حقوق بشر دوستاذه بينالمللى}

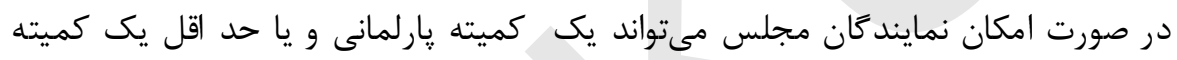

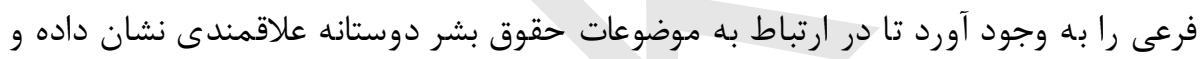

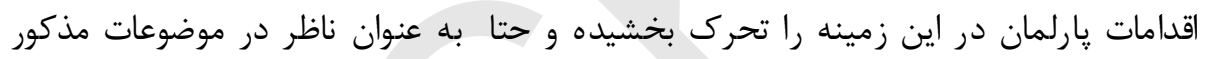

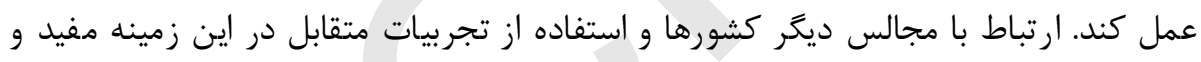

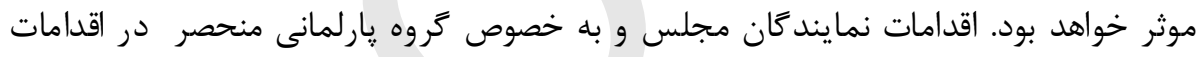

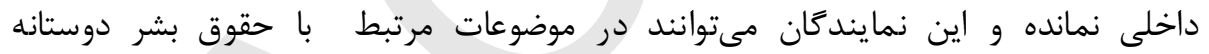

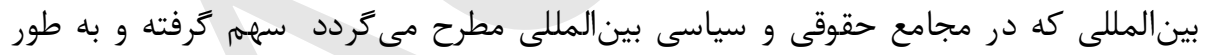

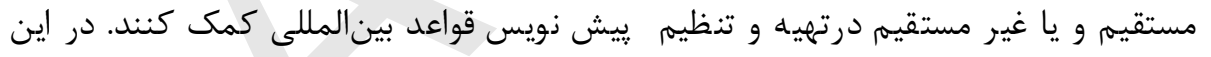

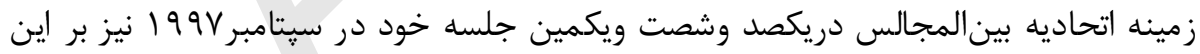

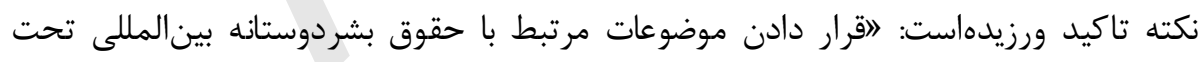

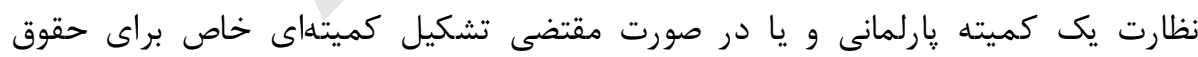

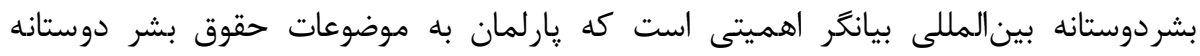

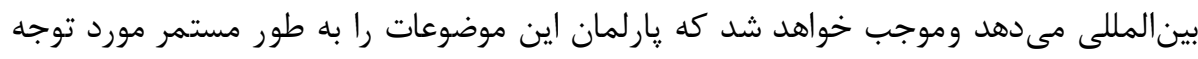
قرار دهد." يكى از مراكز مهم ترويج و توسعه حقوق بشر دوستانه بينالمللى، اتحاديه بين المجالس

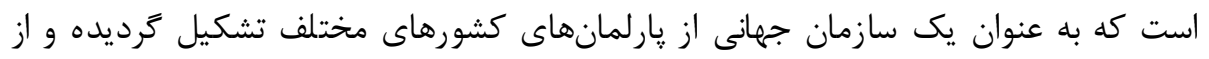


طريق كميته تخصصى خود در اين زمينه تلاش مىورزد. نمايند كان پارلمانها بايد تلاش كنند تا توصيههاى اين اتحاديه، مورد توجه قوه مقننه و مجريه قرار گيرد.

\section{F F ترويج و آموزش حقوق بشر دوستانه}

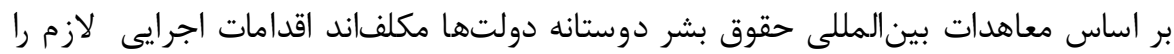

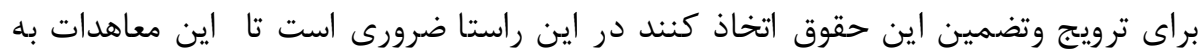

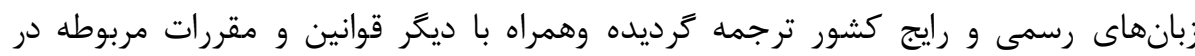

دسترس عموم مردم قرار گيرند.

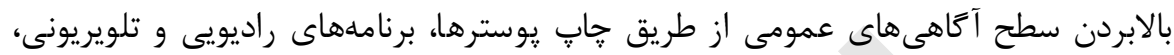

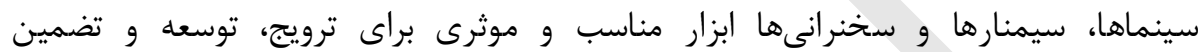

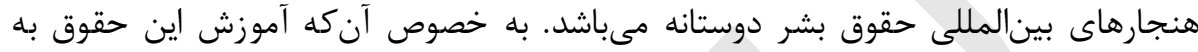
نظاميان و اشخاص مرتبط به مخاصمات مسلحانه و اصولا ورود حقوق بشر دوستانه در دكترين

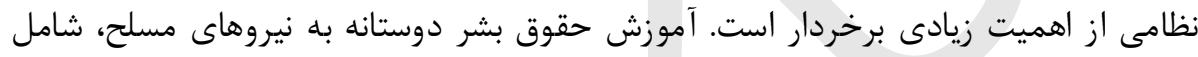

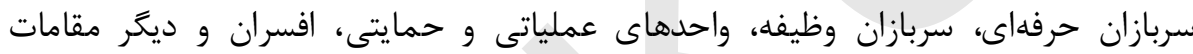

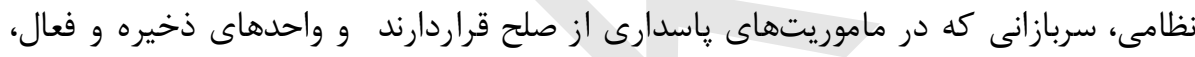
مى كردد.

حقوق بينالمللى بشر دوستانه مقرر مى دارد كه در زمان صلح بايد مشاوران حقوقى كافى

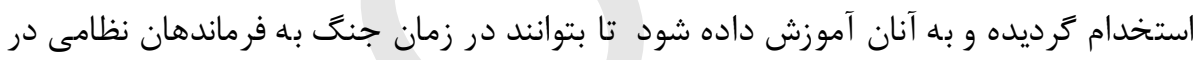

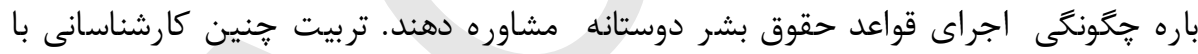

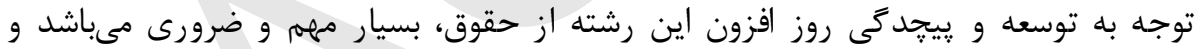

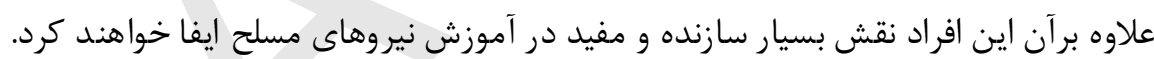

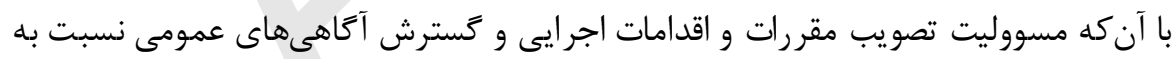

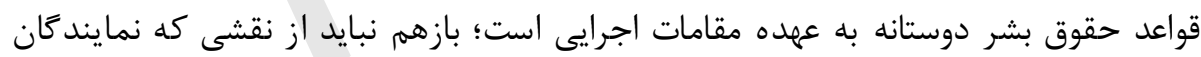

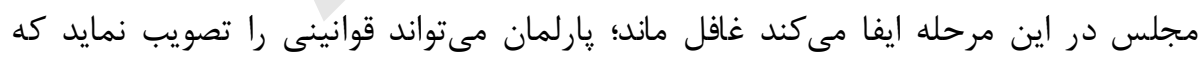

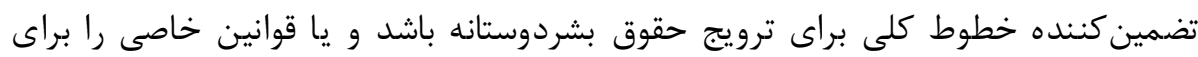

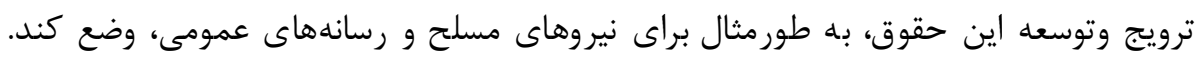

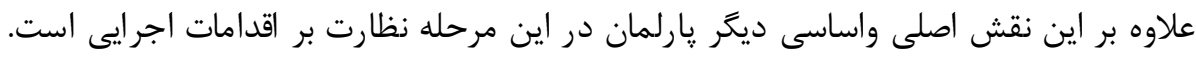

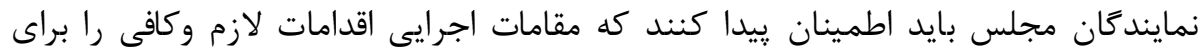

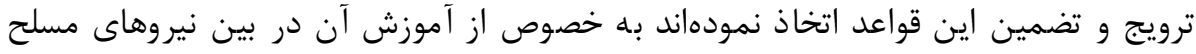

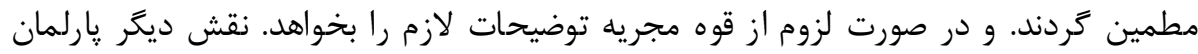


در اين مرحله تصويب بودجه لازم براى اين امر و ديكر امور مربوط به ترويج، توسعه و تضمين

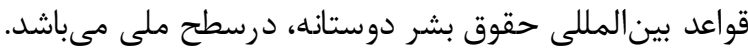

ه-ايجاد يك كميسيون و يا كميته ملى حقوق بشردوستاذه

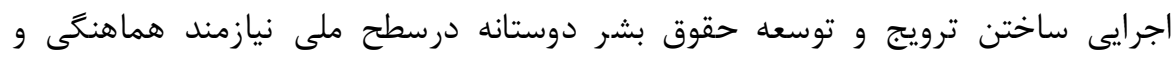

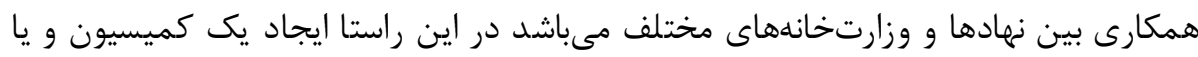

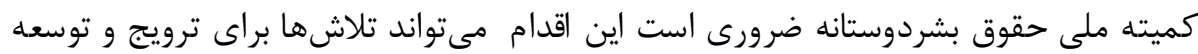
حقوق بشردوستانه را هماهنغ، مستمر و يايدار سازد. مساله معايب و نواقص مكانيسمهاى اجراى حقوق بشردوستانه، همواره ذهن اعضاى نهضان

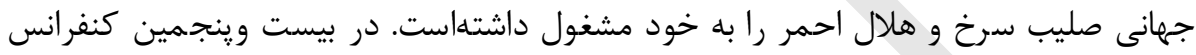
صليب سرخ و هلال احمر در 1919 زنو به تدريج زيشنهاد ايجاد نهادهاى ملى در سطح

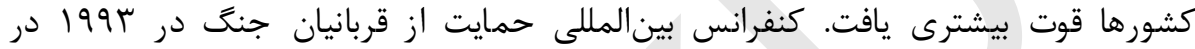

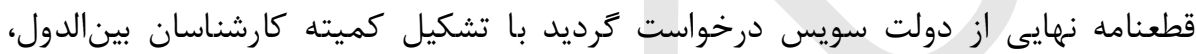
راههاى عملى اجراى مقررات بشردوستانه را مورد بررسى قرار دهند و ويشنهادهاى خود را به

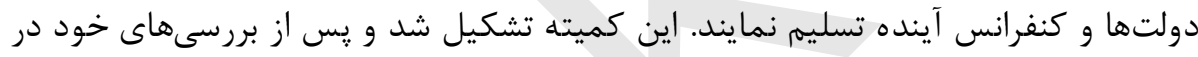

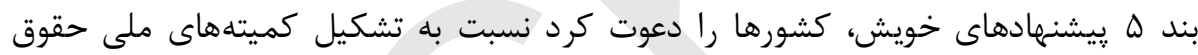

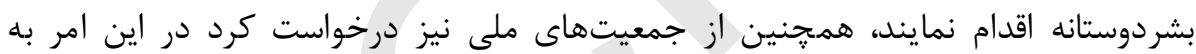
دولت هاى خود يارى رسانند.

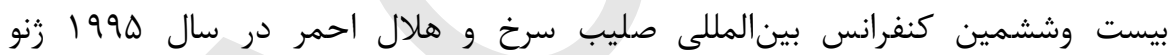
ييشنهادهاى كميته كارشناسان را مورد تصويب و تاييد قرار داد و مصرانه از كشورها درخواست

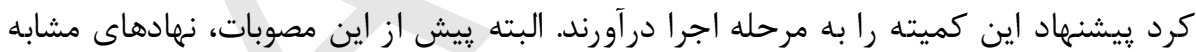

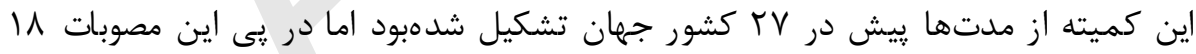

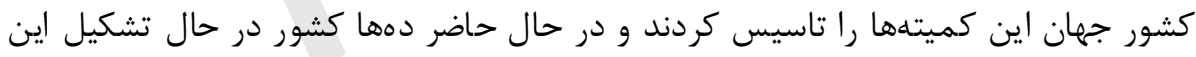
كميته هستند. كميتههاى ملى حقوق بشردوستانه عمدتاً تمام وظايفى را كه دولتها در رابطه با مقررات بشردوستانه به خصوص كنوانسيونهاى جهمار كانه زنو

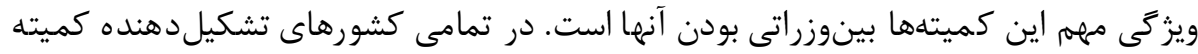

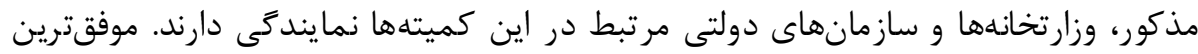

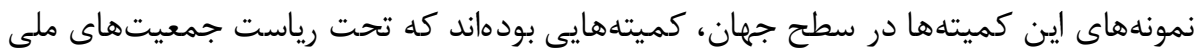
صليب سرخ ويا هلال احمر اين كشورها تشكيل شدهاند، به عنوان مثال كميته ملى حقوق بشر 
دوستانه جمهورى فدرال آلمان كه يكى از فعالترين و قوىترين كميتههاى ملى محسوب

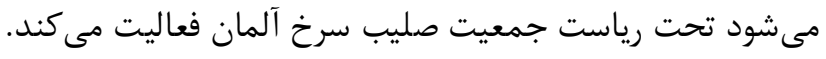

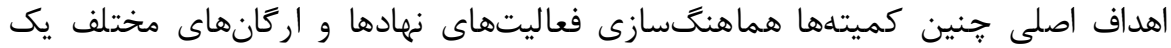

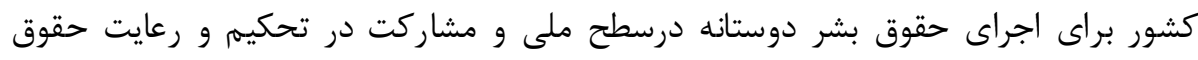
بشردوستانه در سطح بينالمللى مى باشد. موارد ذيل مىتواند از جمله وظايف واختيارات كميته ملى حقوق بشردوستانه قرار داده

تصميم كيرى در خصوص نحوه اجراى مقررات بينالمللى بشردوستانه درسطح ملى و در

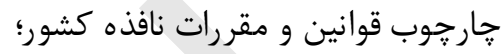

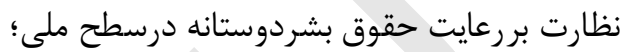

آموزش و ترويج مفاهيم حقوق بشردوستانه درميان نيروهاى مسلح، عموم مردم و درمقدئ، درداطع

مختلف تحصيلى؛

تهيه وارايه يِينههاد تصويب قوانين و مقررات لازم درجهت رعايت و و اجراى حقوق

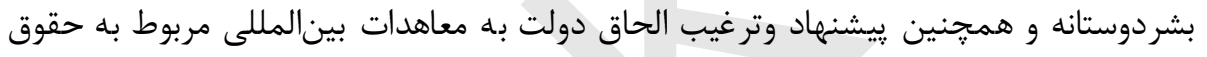

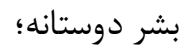
ارايه نظرات مشورتى در زمينه تبيين و تفسير مقر رات بشردوستانه؛

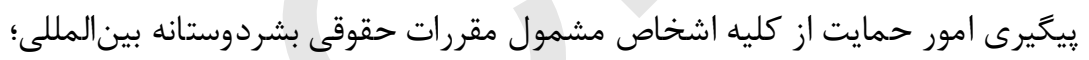

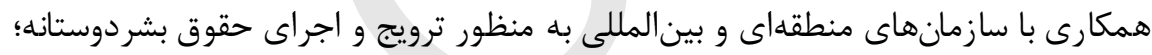

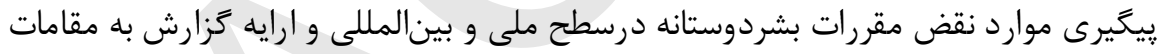

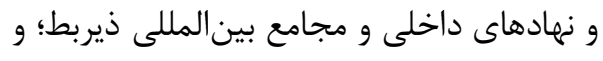

هماهنكى و تبادل اطلاعات علمى و تحقيقاتى با مراجع داخلى و وخارجى در در زمينه حقوق

\section{نتيجه كيرى}

با جمعبندى آنجه كذشت مىتوان دريافت كه رعايت اصل ضرورت، تناسب، تفكيك

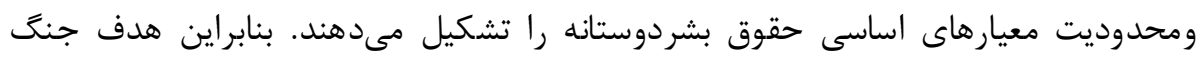

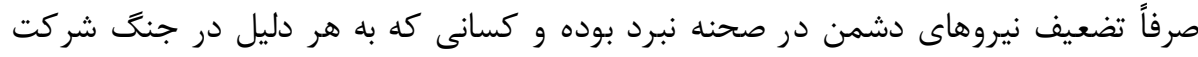

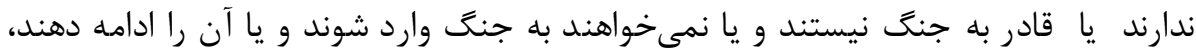

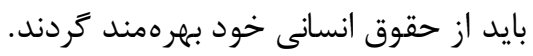

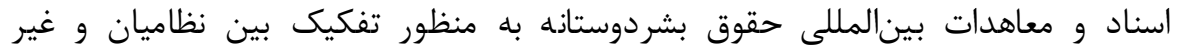

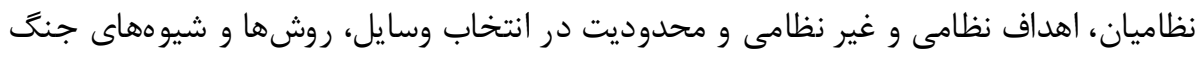




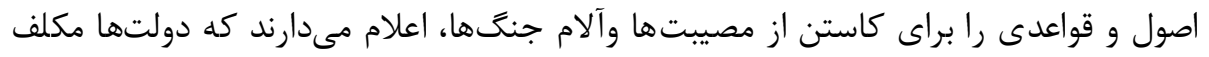

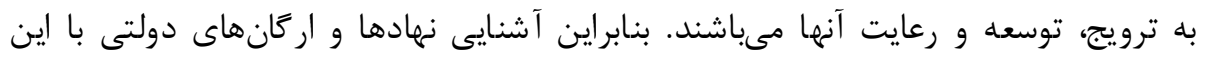

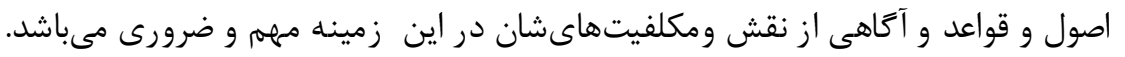

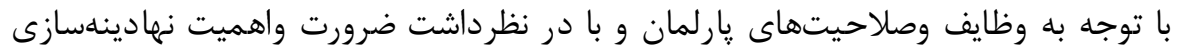

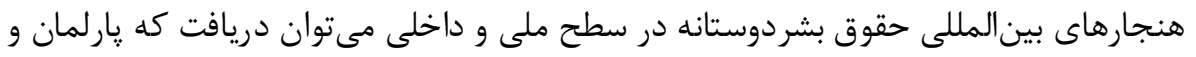

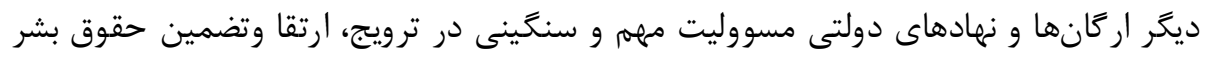

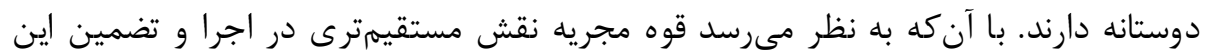

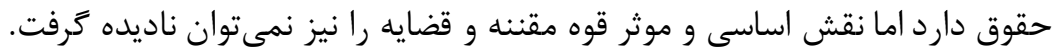

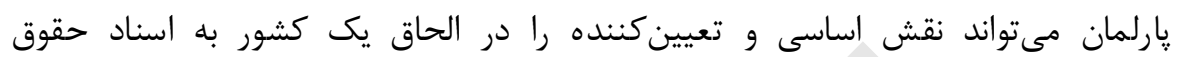

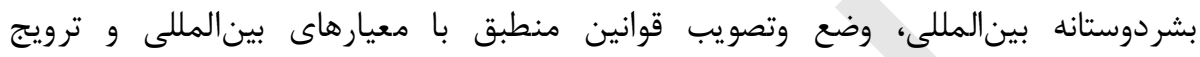

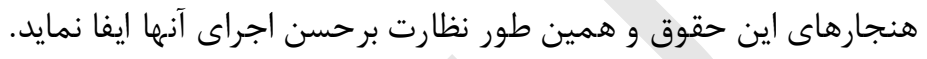

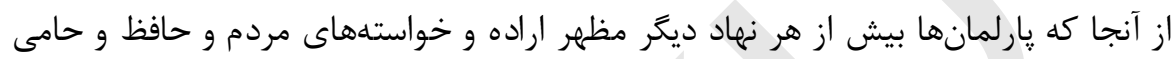

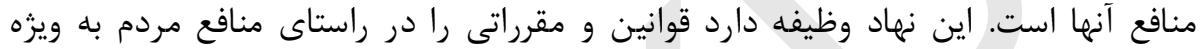

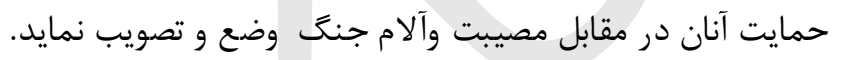

منابع:

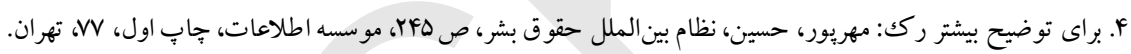

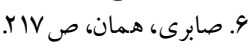

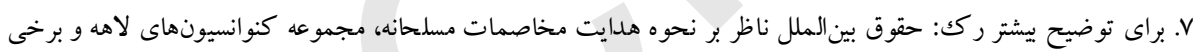

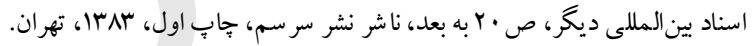

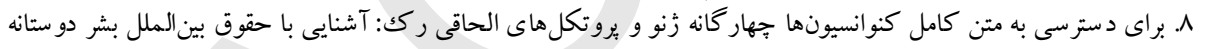

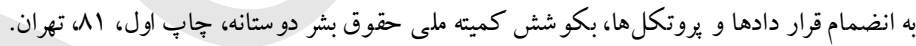

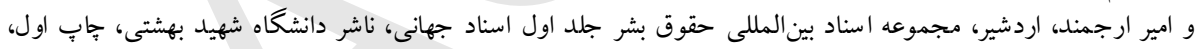

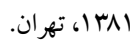

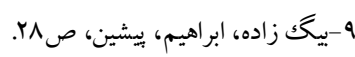

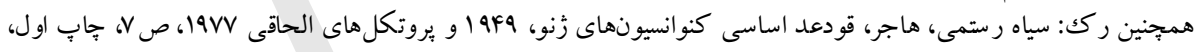
نشر مرسم، برش ا، تهران.

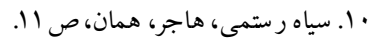

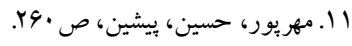

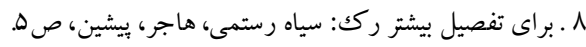

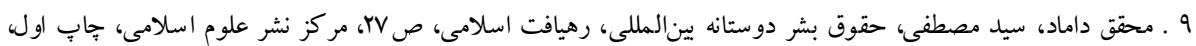


د حضرت گل حسامى زباره

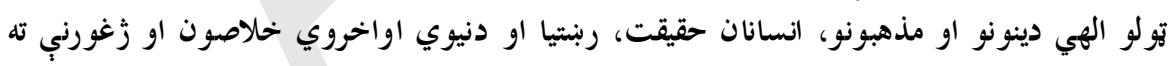
رابللي دي.

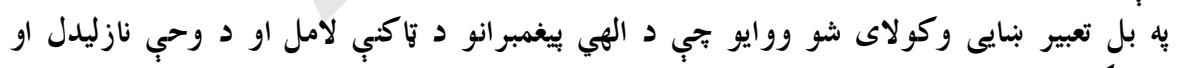

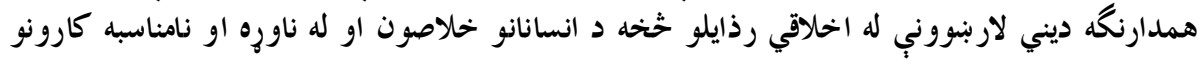

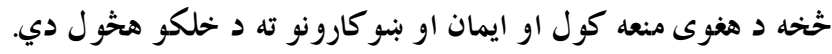

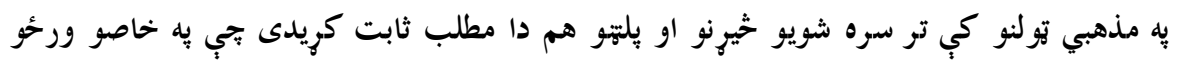

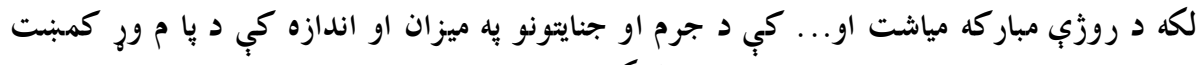

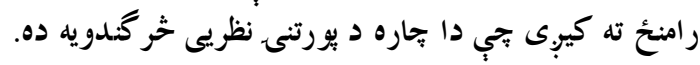

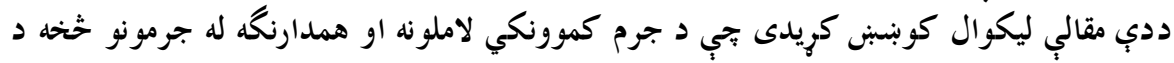

$$
\text { مخنيوى ديني تجاره وخيري. }
$$




\section{مطلب به كثه له نظره تيروو}

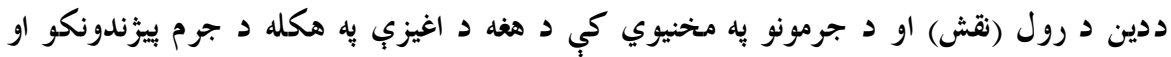

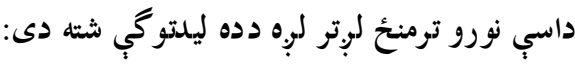

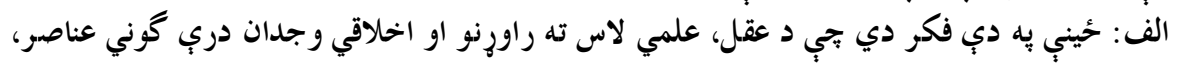

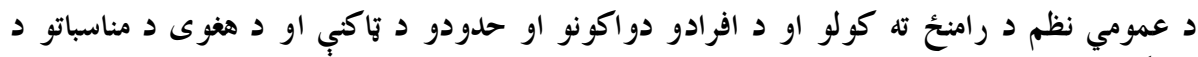

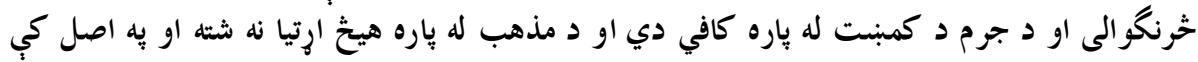

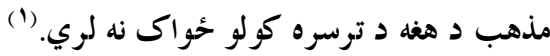

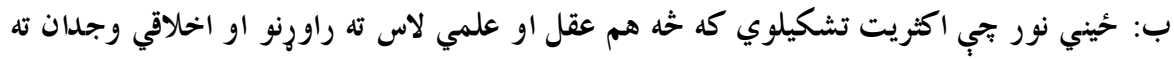

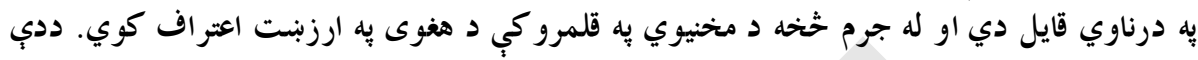

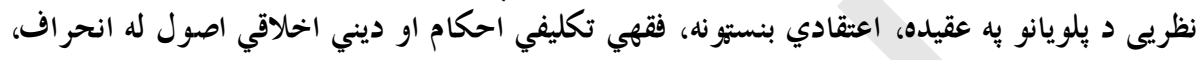

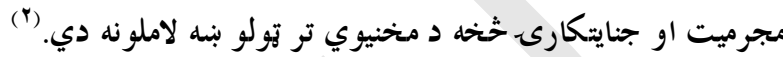

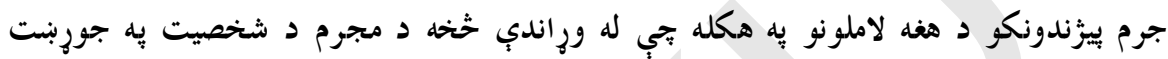

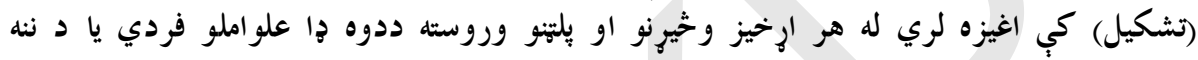

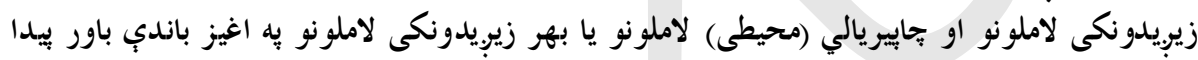

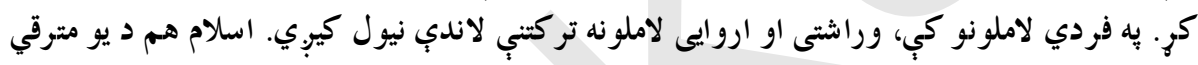

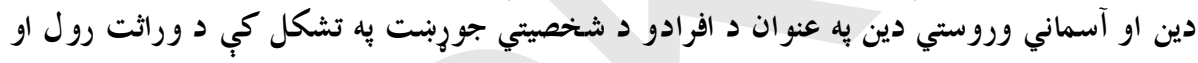

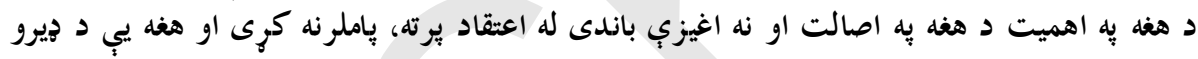

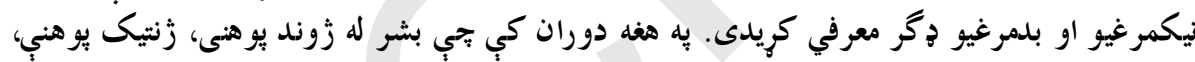

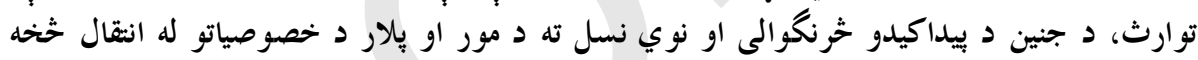

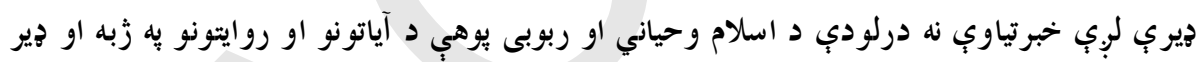

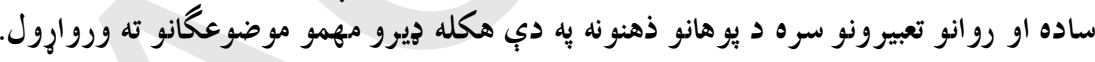

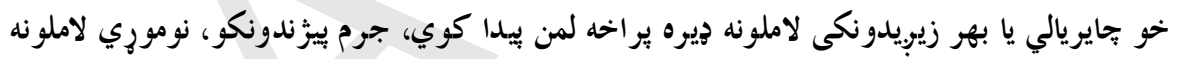

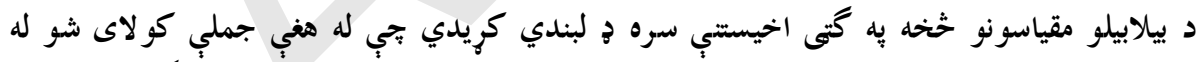

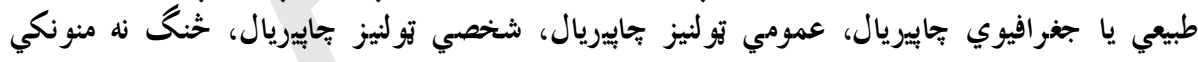

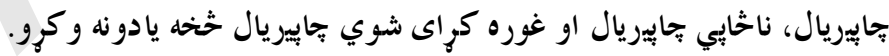

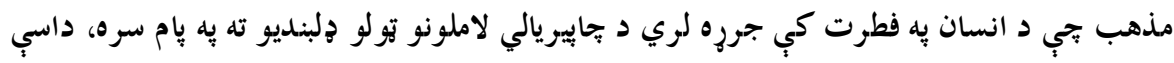

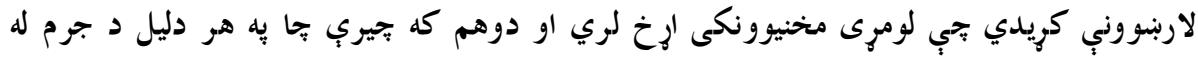

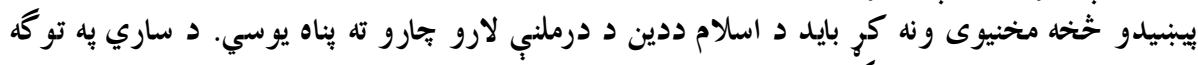

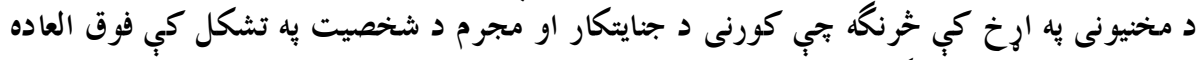

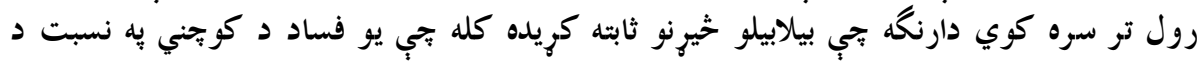

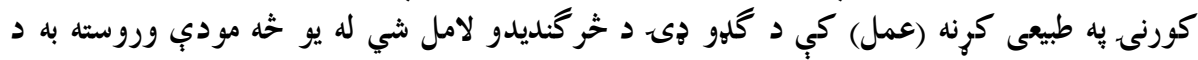

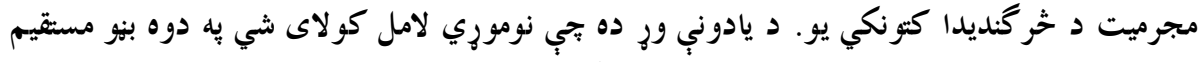

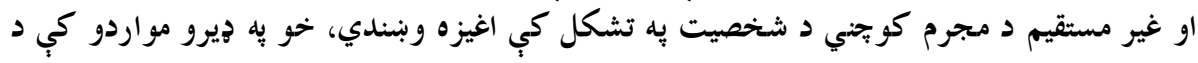




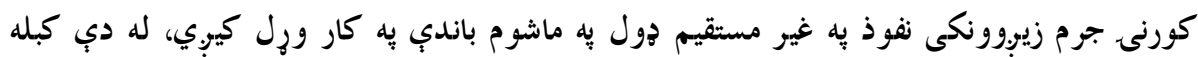

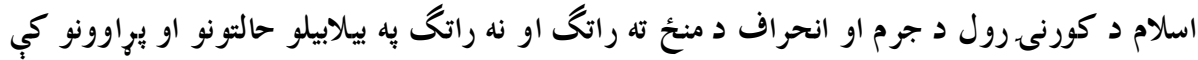

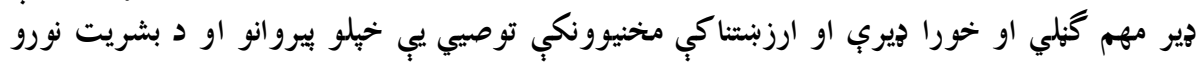

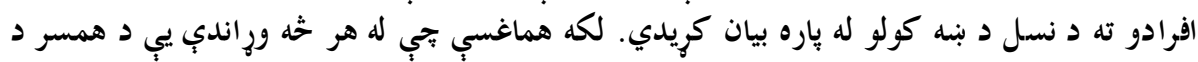

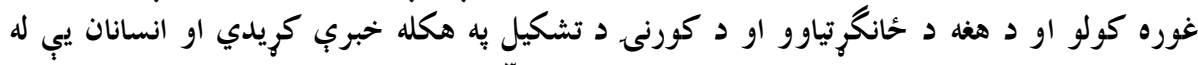

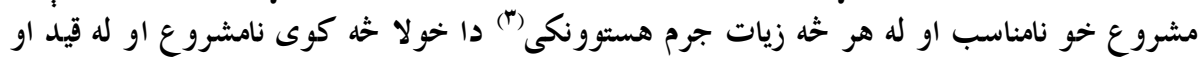

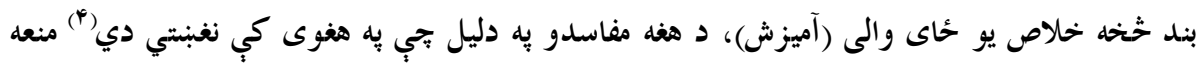

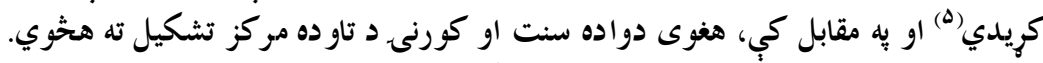

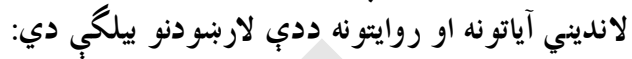

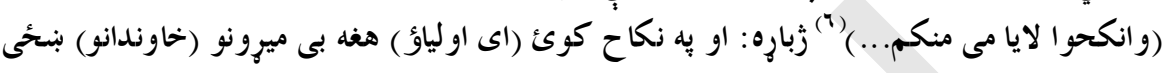
او بي بنحُخو سري له تاسب.

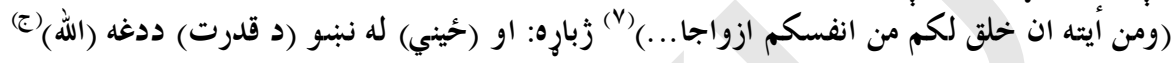

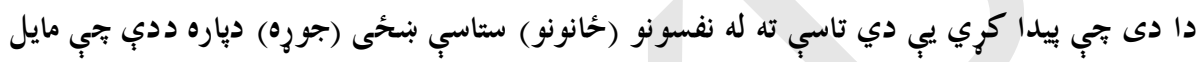
شئ دوى ته (او مطمئن اوسئ)...

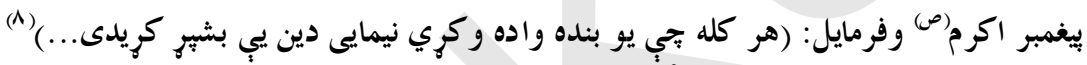

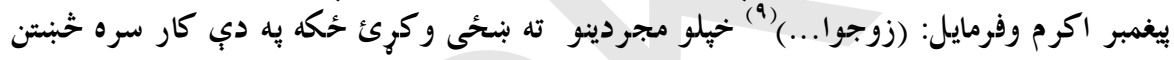

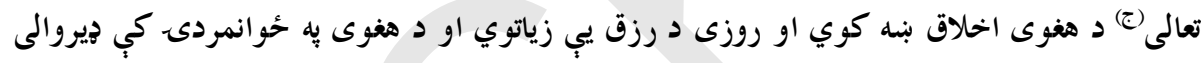
راولي.

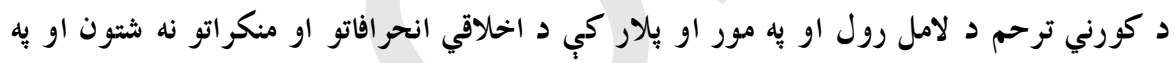

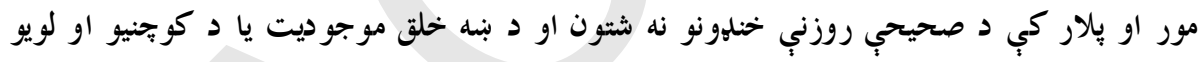

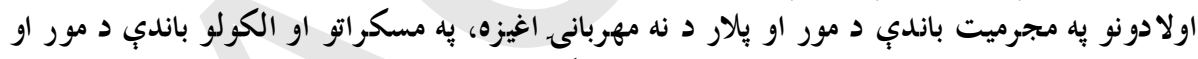

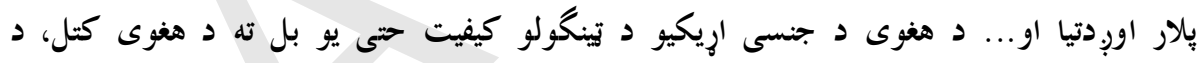

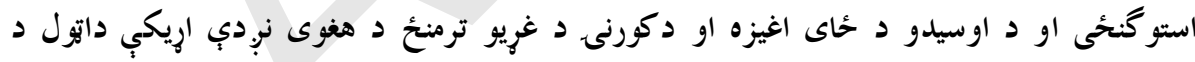

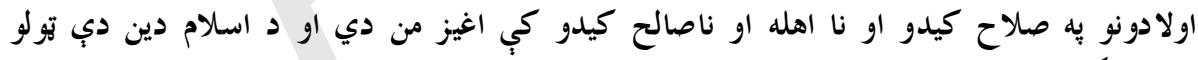

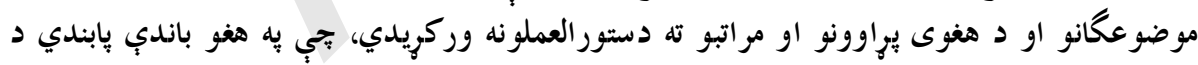

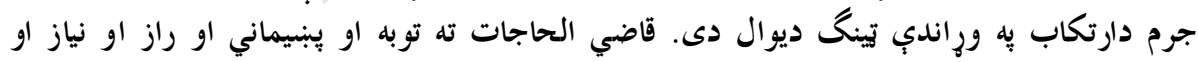

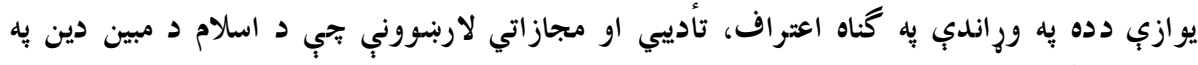

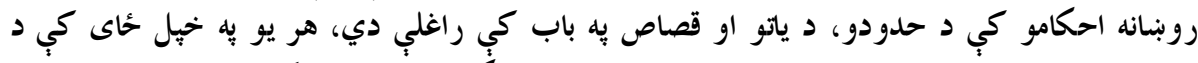

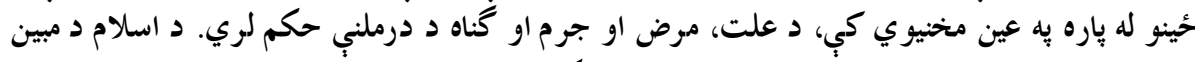

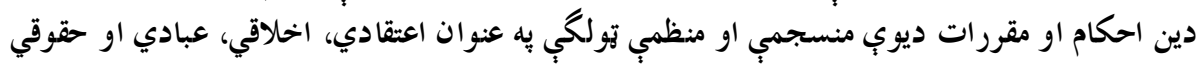

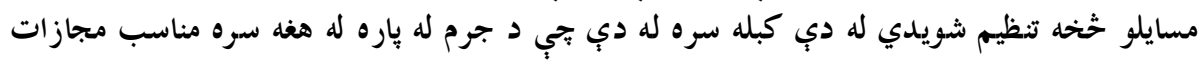

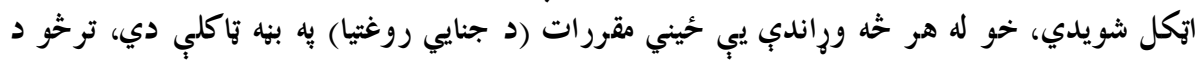


هغو به مراعاتولو سره، د جرم دارتكاب انكيزي او علثونه كمبنت ومومي او ارتكاب يب اقل حد ته ورسيبري يا له منخه ولارشي. د إم كمورنكي لاملونه

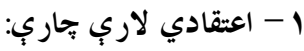
د الهي تولو بيغمبرانو آسماني مذهبونه بهانه دوو اساسي اصولو ولاري دي:

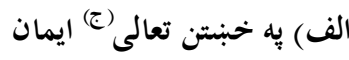

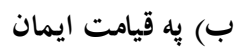

الف) به خبنتن تعالى(ج) ايمان

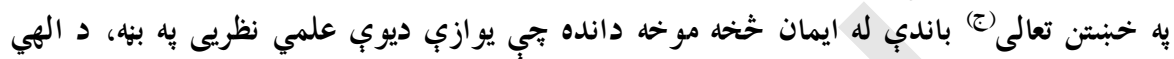

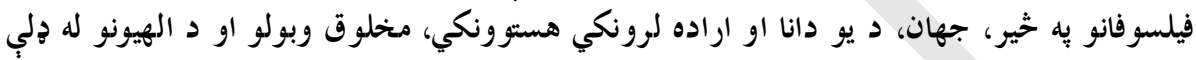

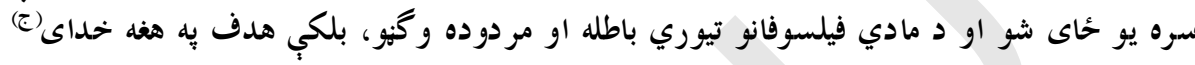

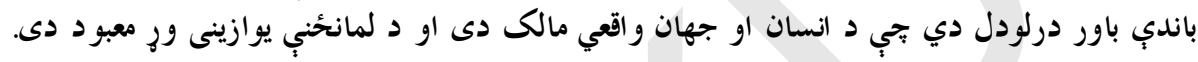

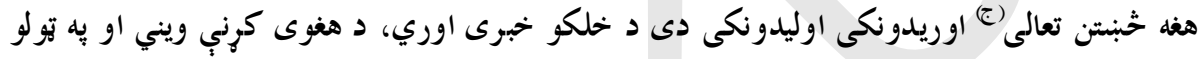

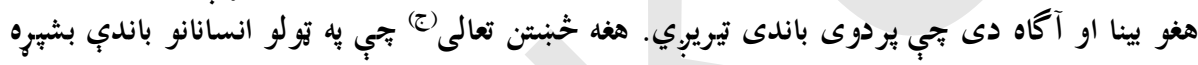

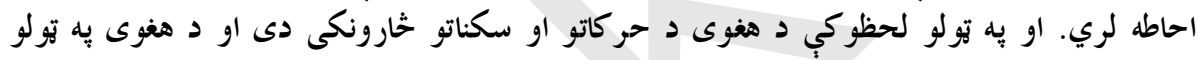

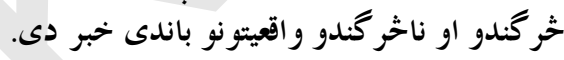

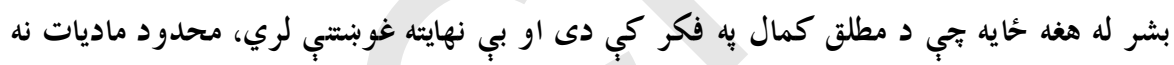

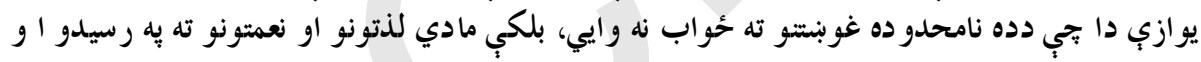

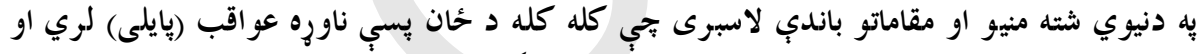

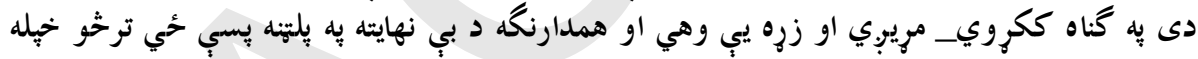

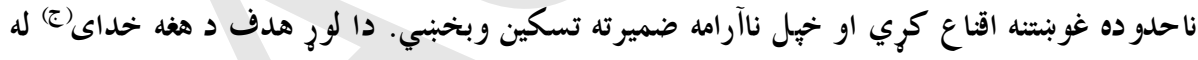

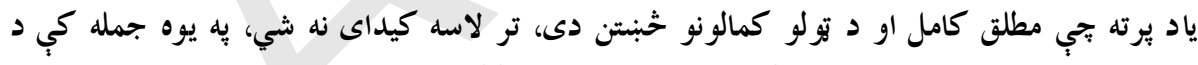

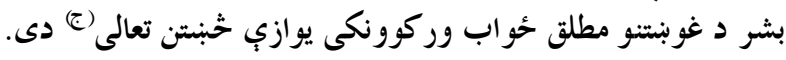

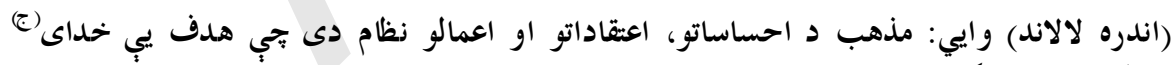

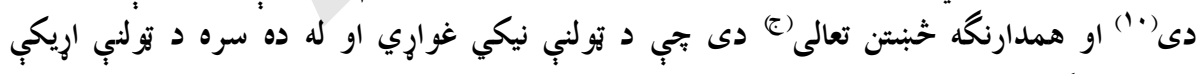

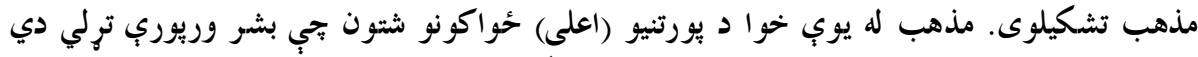

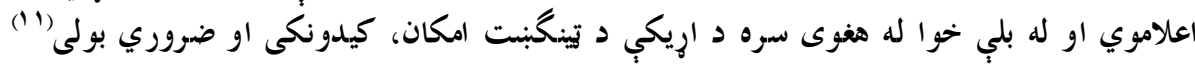

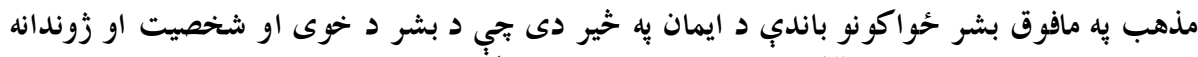

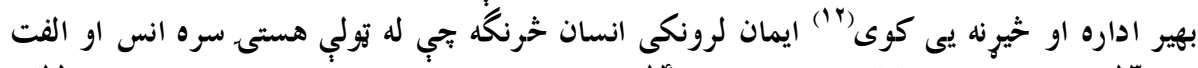

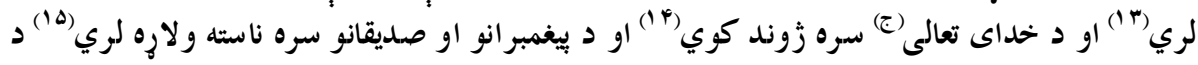

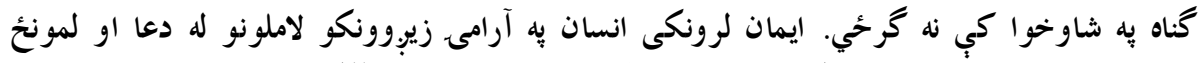

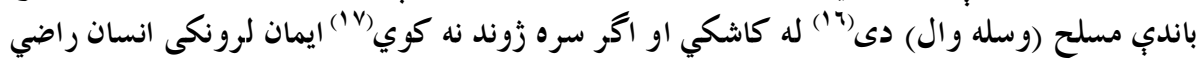




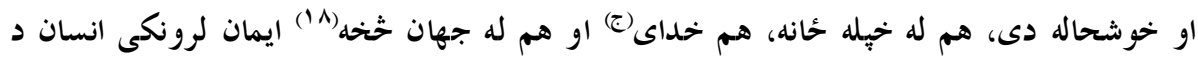

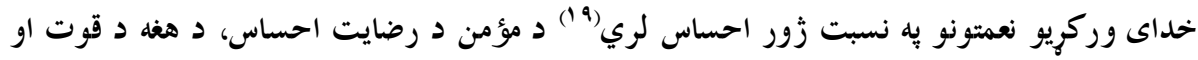

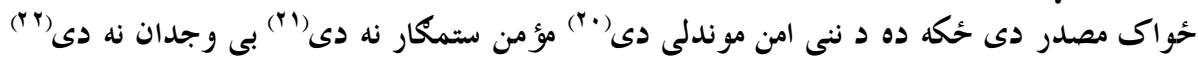

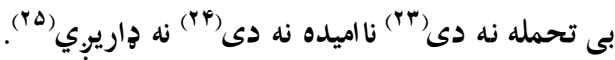

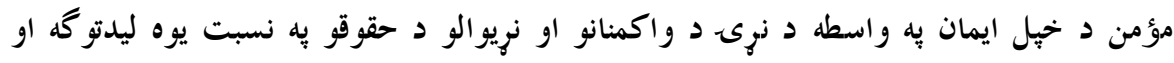

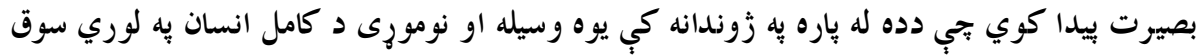

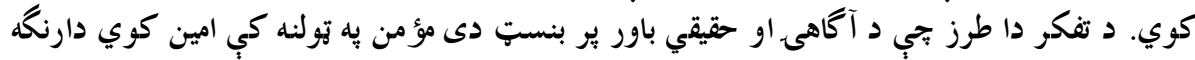

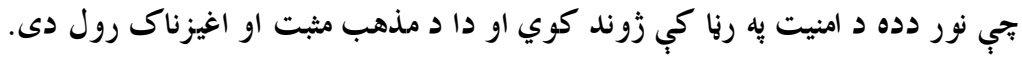

\section{ب) بِ قيامت ايمان}

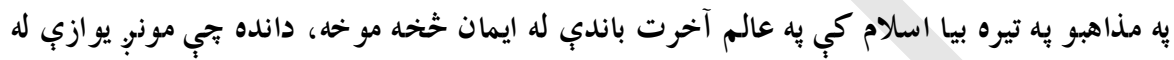

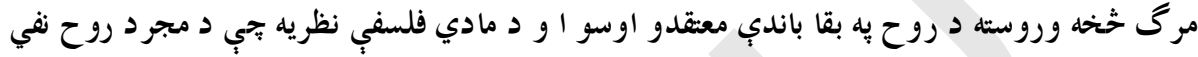

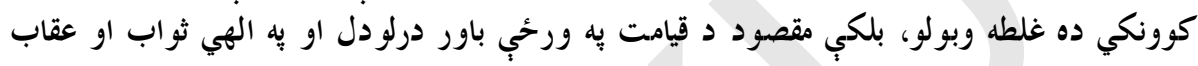

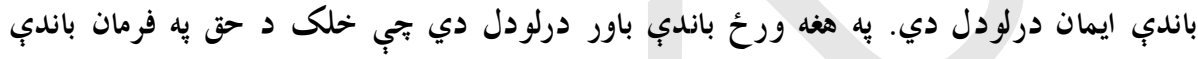

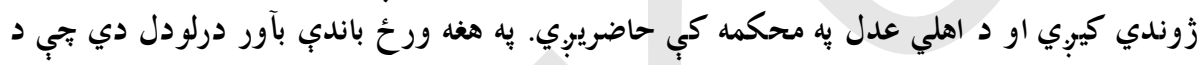

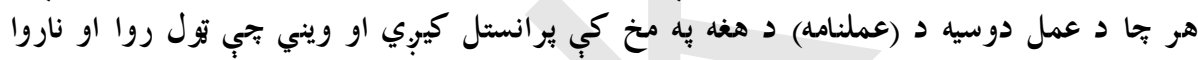

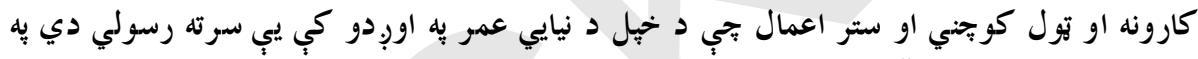

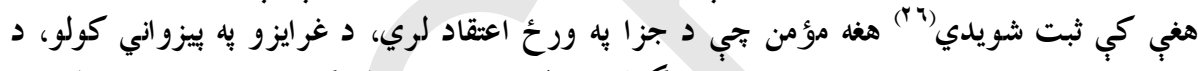

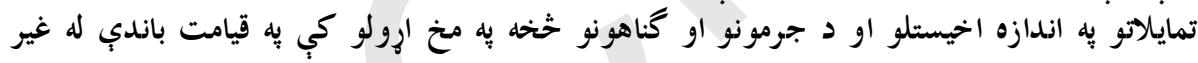

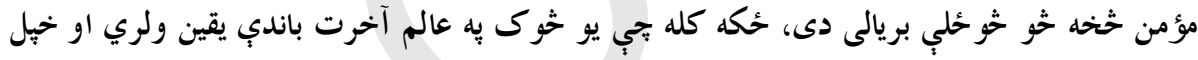

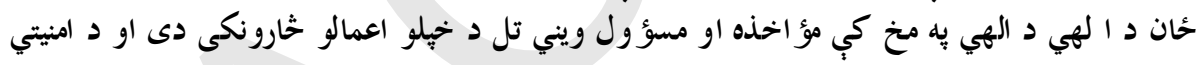

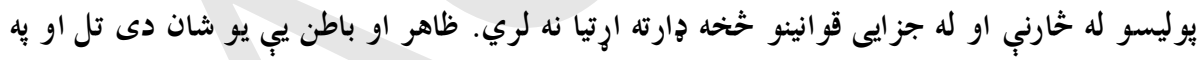

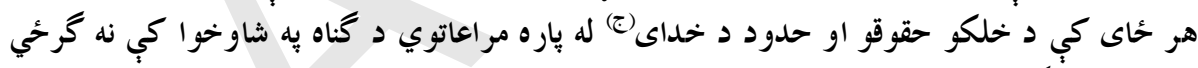

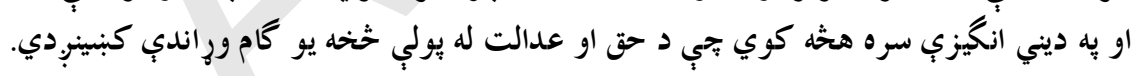

\section{r - عبادى لاري حاري}

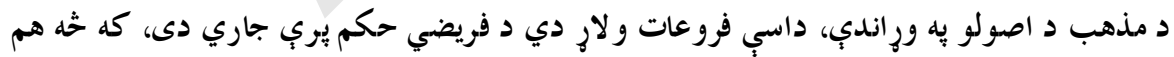

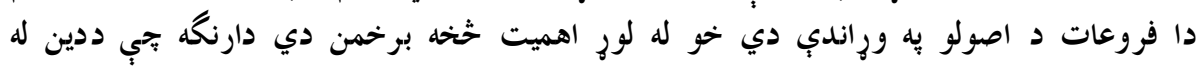
ضرورتونو خخه هم گنبل شويدي.

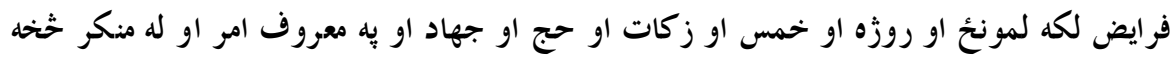

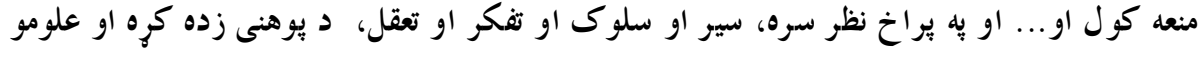

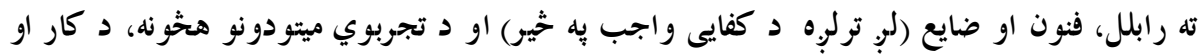

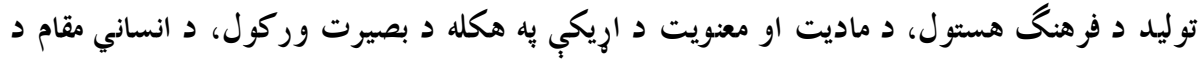




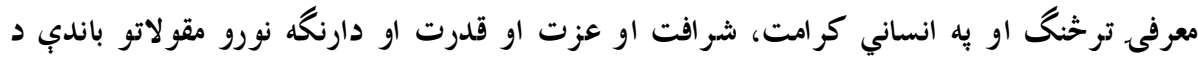

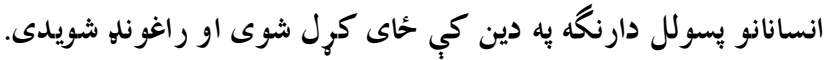

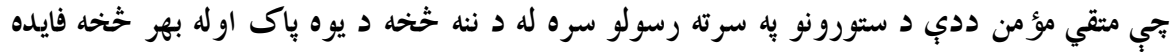

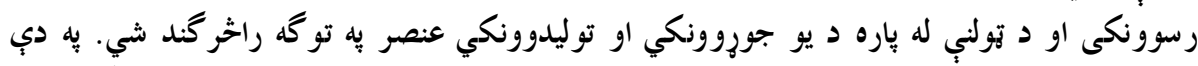

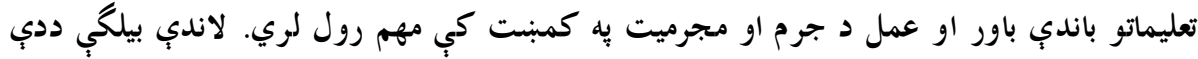

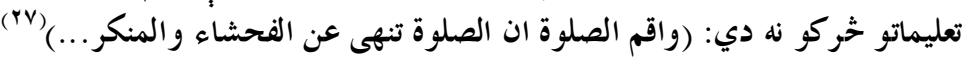

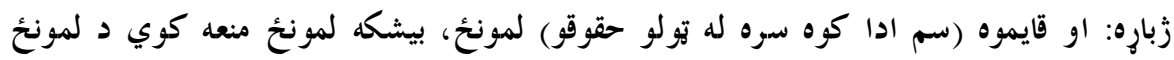

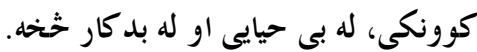

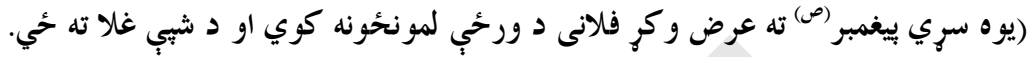

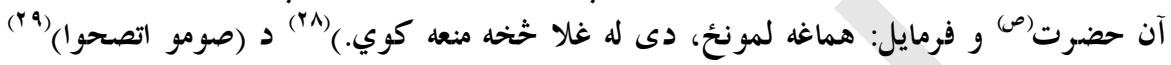

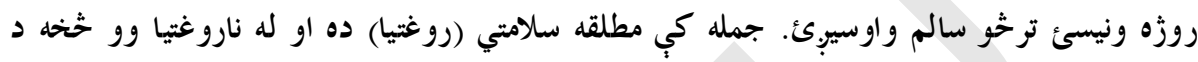

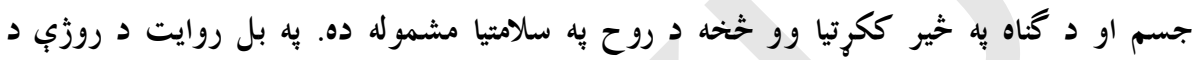

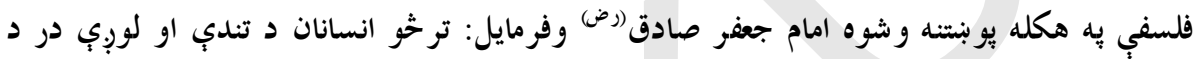

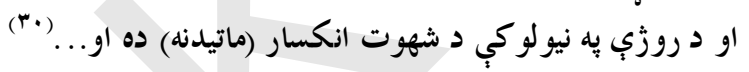

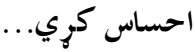

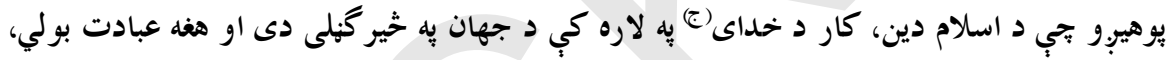

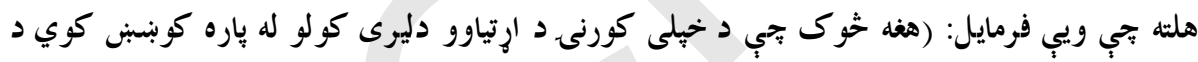

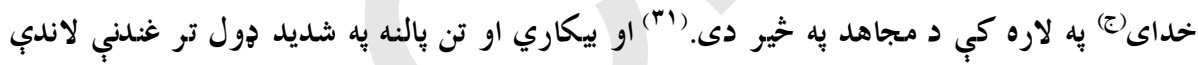

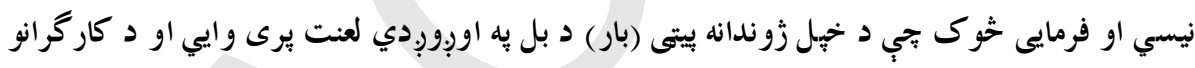

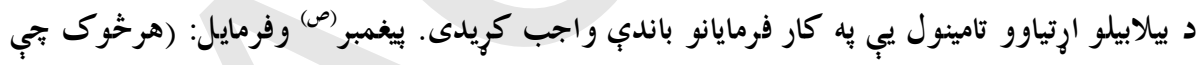

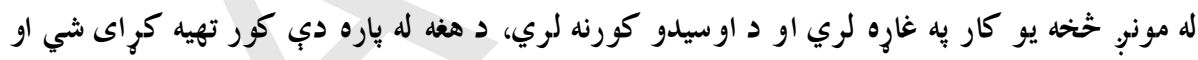

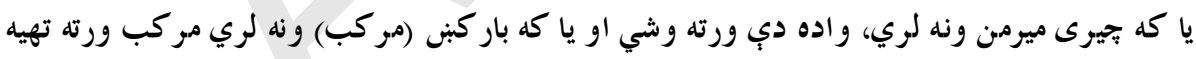

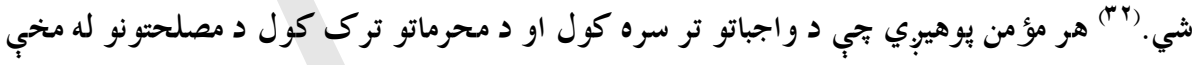

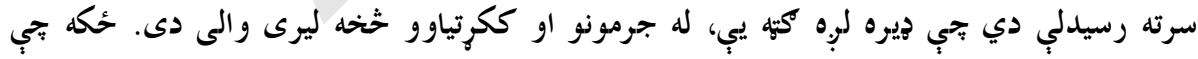

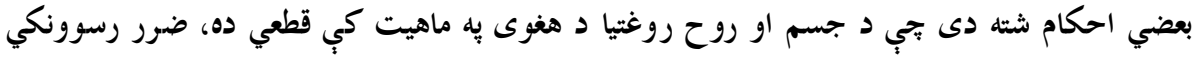

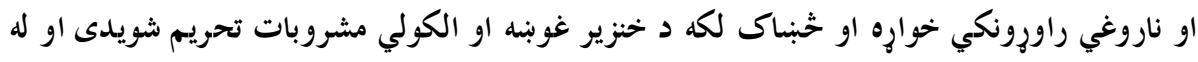

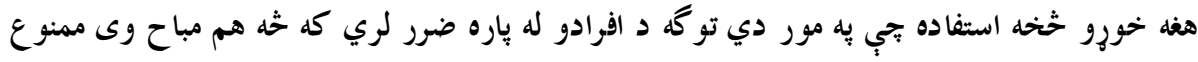

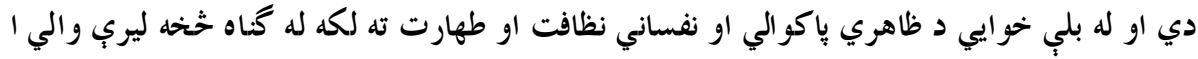

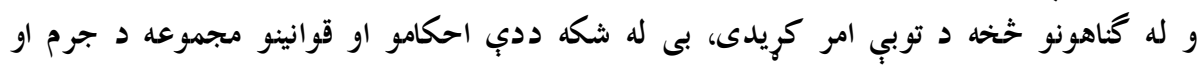
جنايتونو به كمبنت كي اغيزناكه ده. 


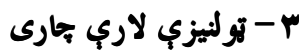 \\ الف: د تولنيزي بشهرتيا قوانين}

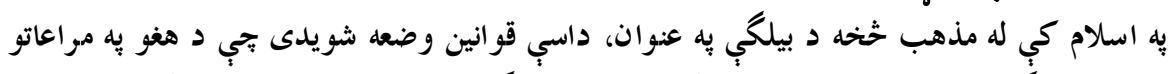

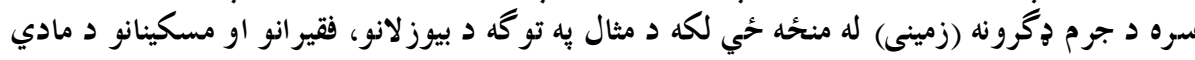

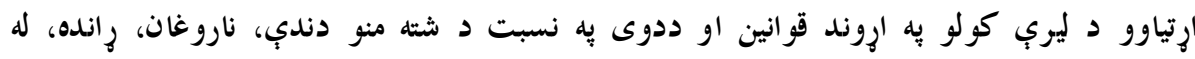

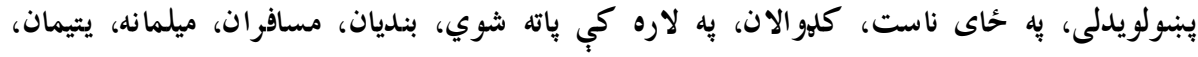

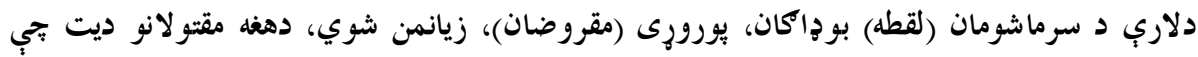

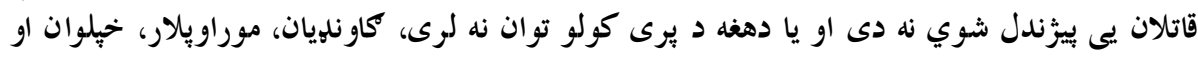

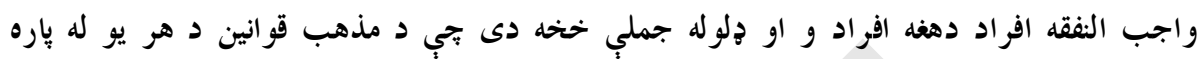

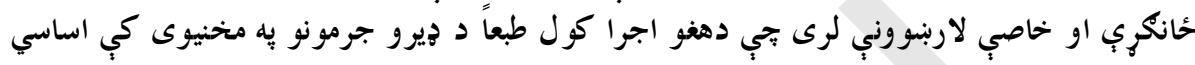

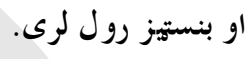

ب) التكل شوي لكبنتونه او بودجي

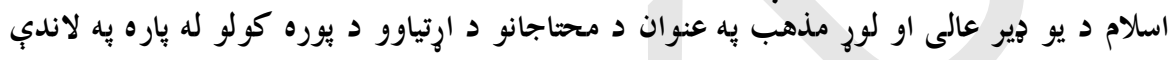

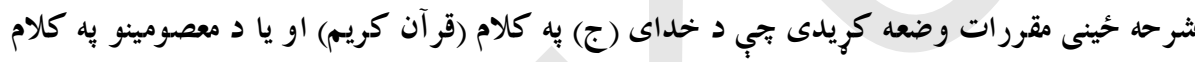

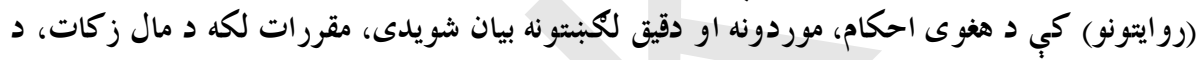

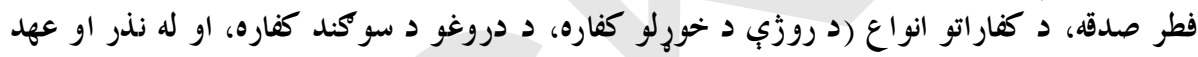

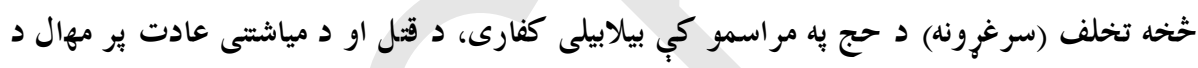

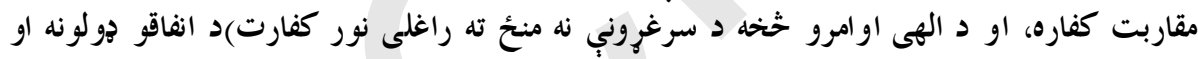

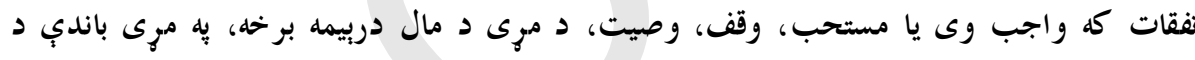

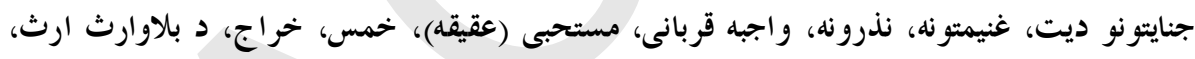

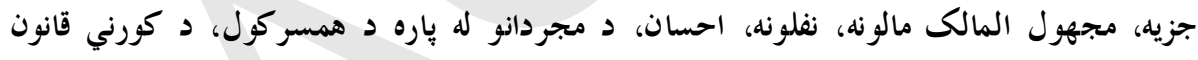

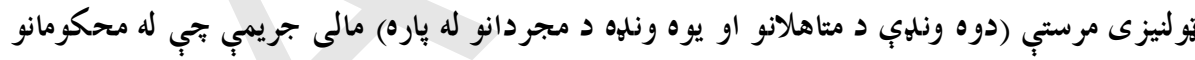

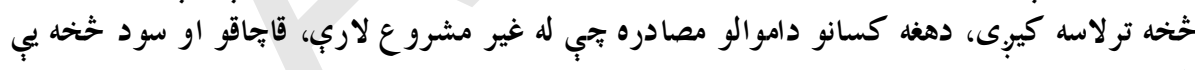

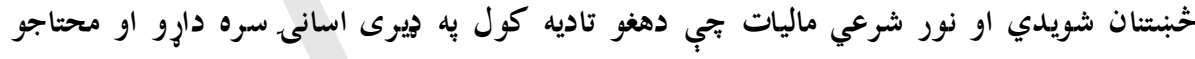

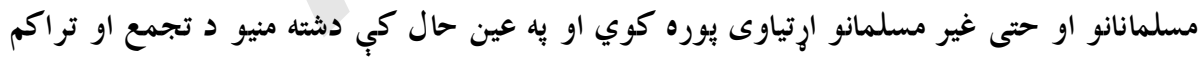

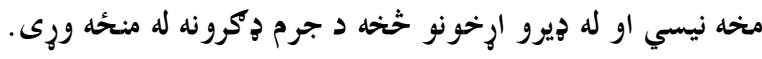

$$
\text { الف : به مذازات (وروستى درملنه) }
$$

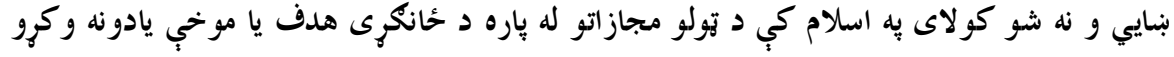

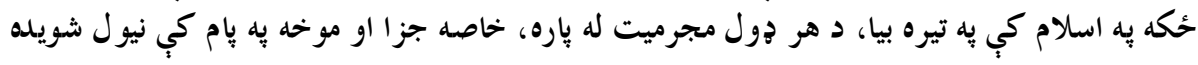

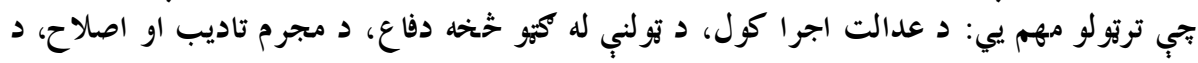

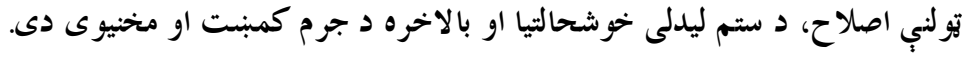




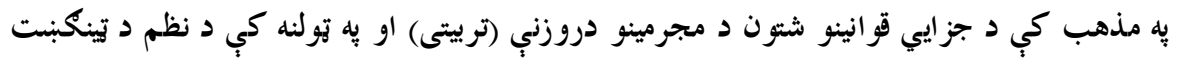

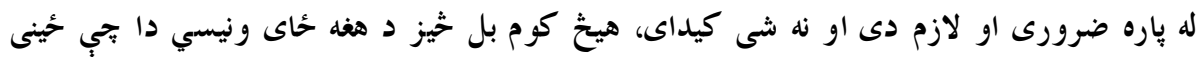

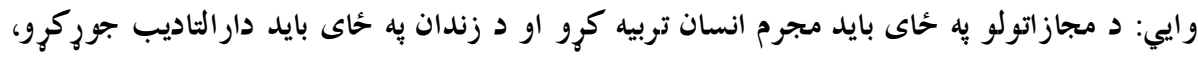

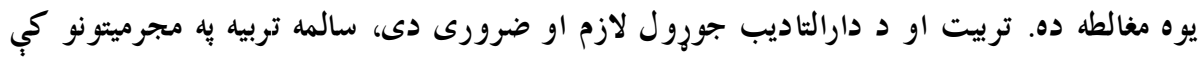

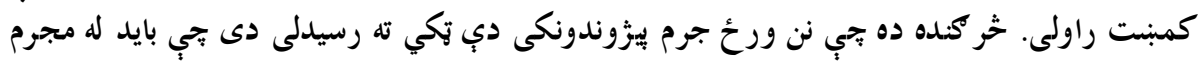

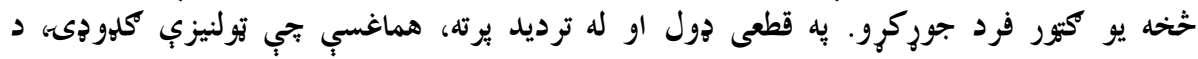

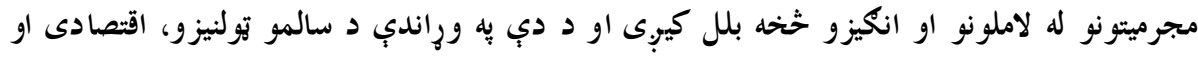

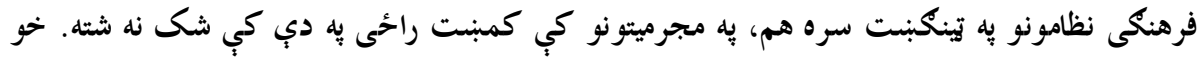

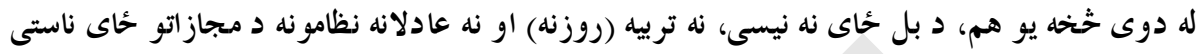

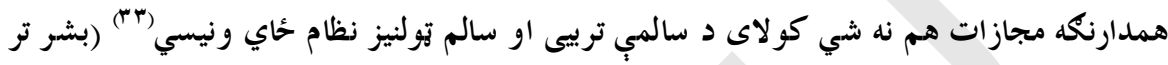

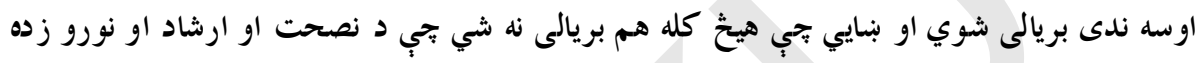

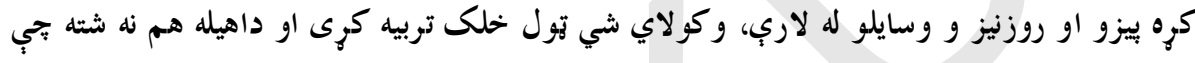

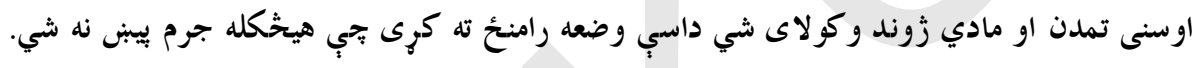

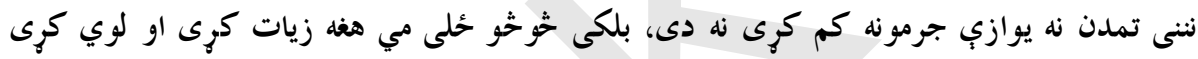

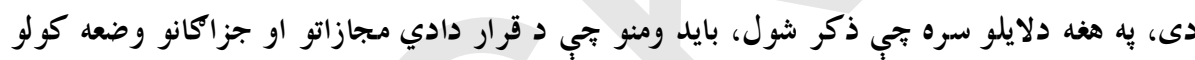

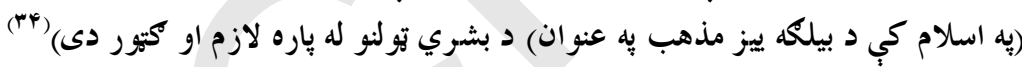

\section{ب: اسلام د جزايي احكامو حُيني بيلكى}

1

اسلام د قصاص اصل منلى دى او هغه يب به خينو حدود و بوري محدود كريدى (كتب عليكم

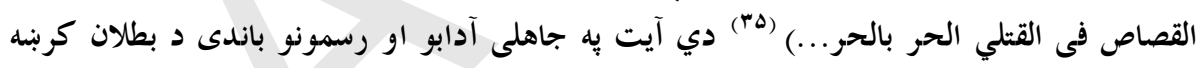

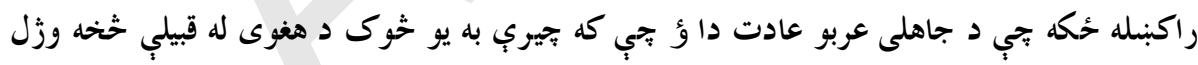

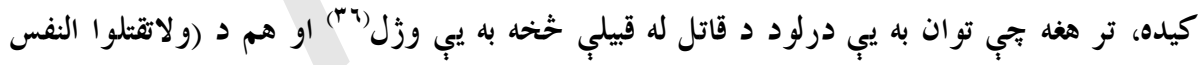

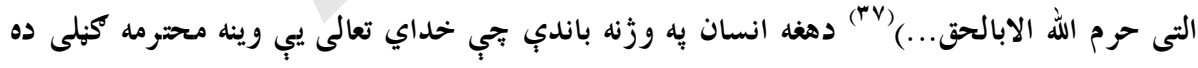

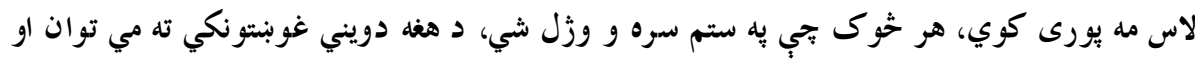

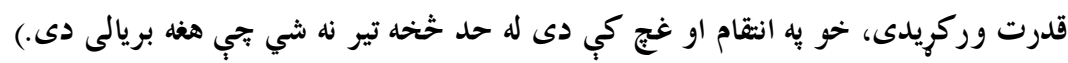

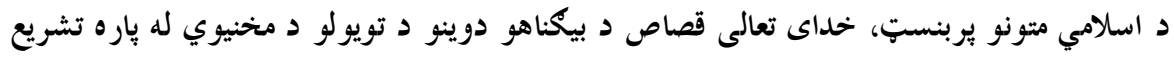

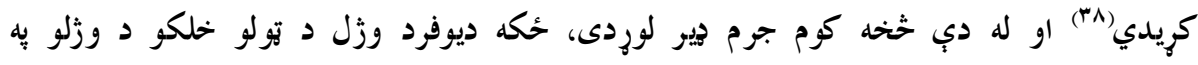

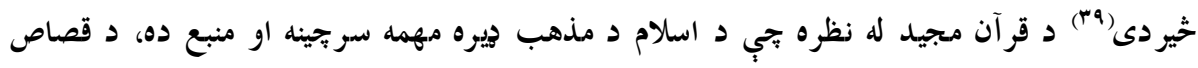

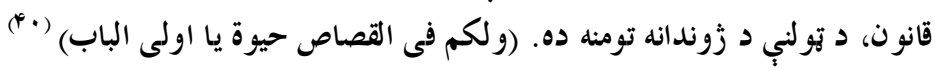




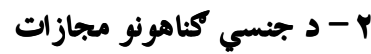

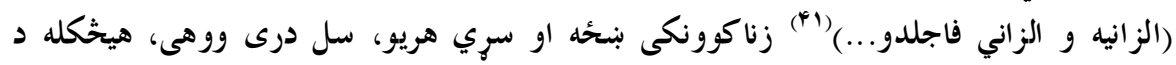

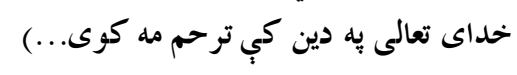

د سعدى بِه قول:

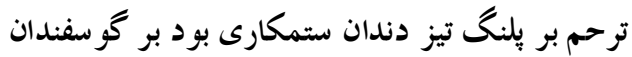

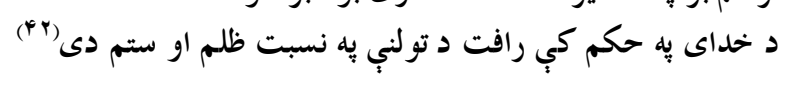

ب - د غلام مجازات

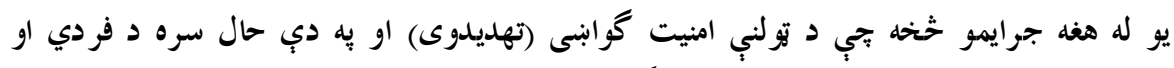

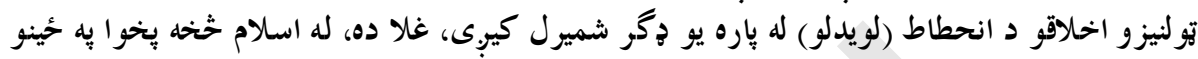

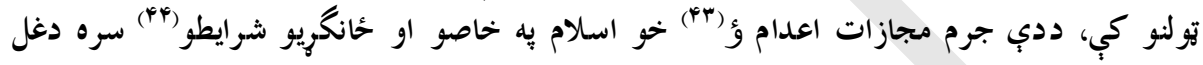

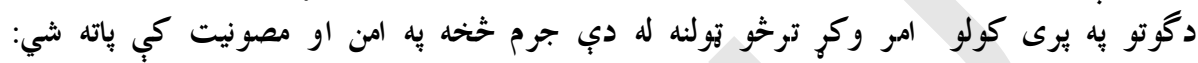

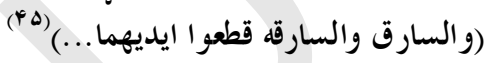

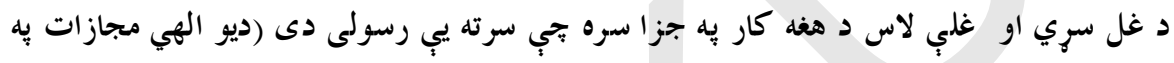

$$
\text { عنو ان) بري كرئ. }
$$

$$
\text { ه - اخلاقي مقولات (مقولي) }
$$

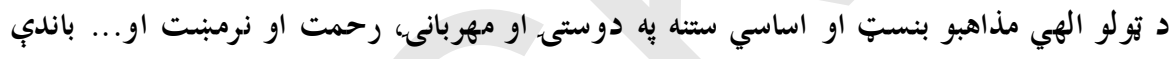

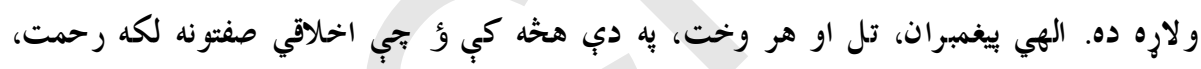

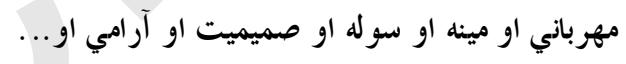

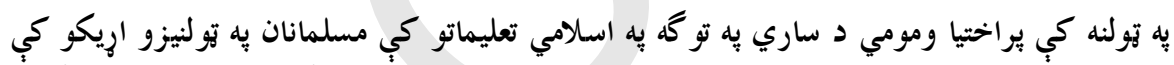

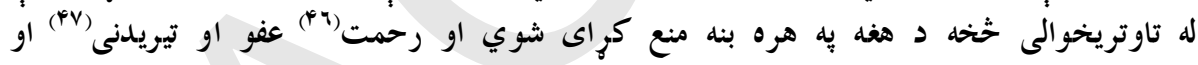

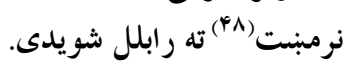

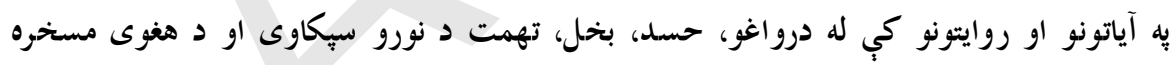

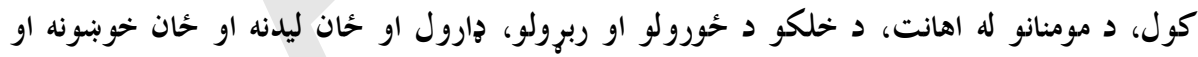

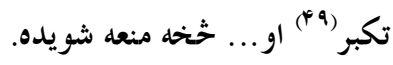

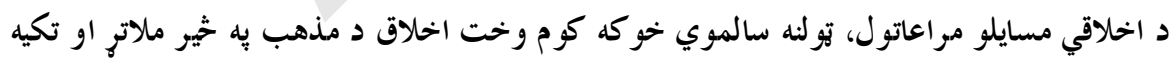

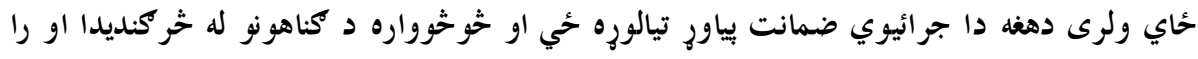

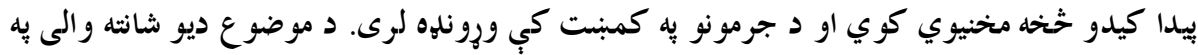

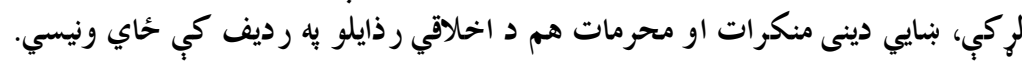

$$
\text { צ - د ديني حكومت دندي }
$$

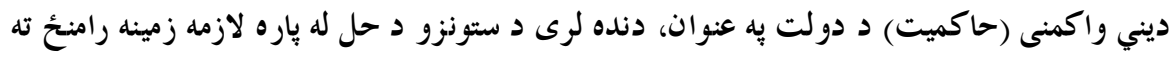

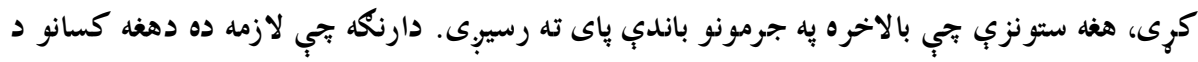

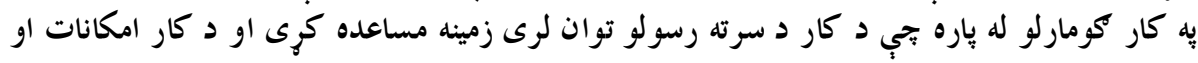




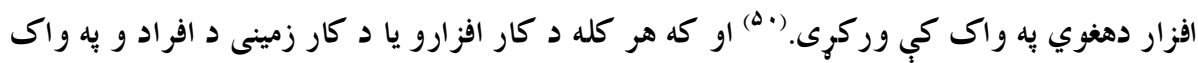

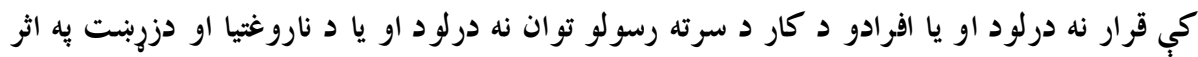

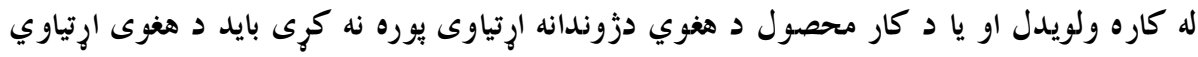

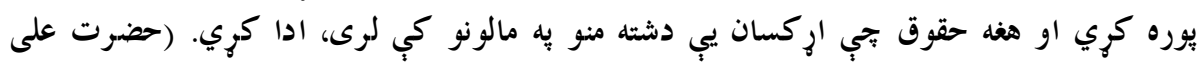

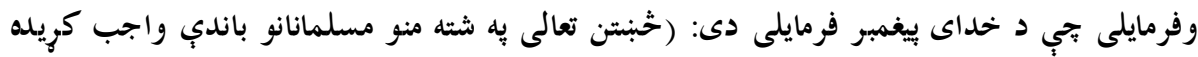

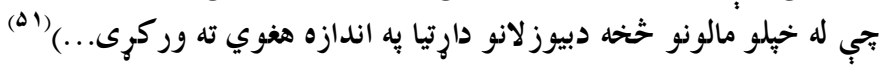

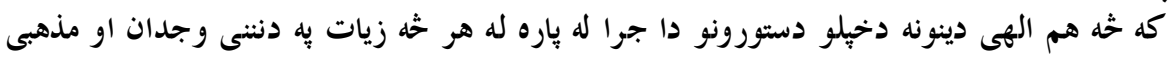

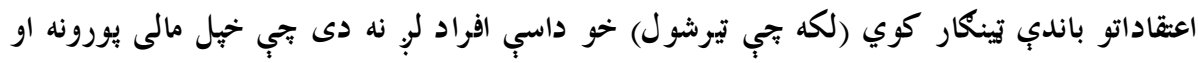

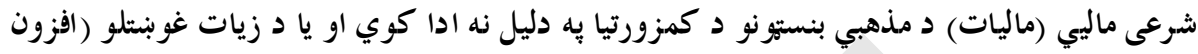

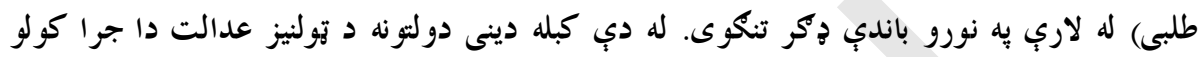

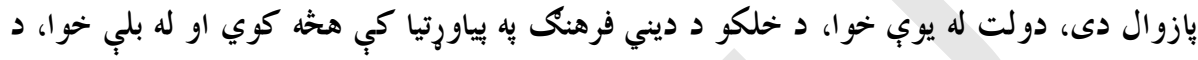

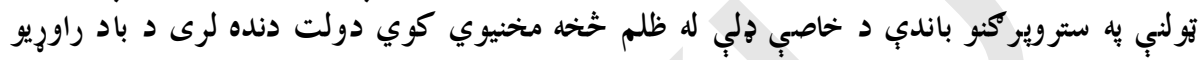

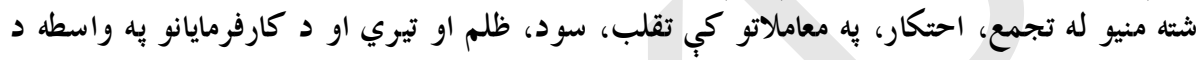

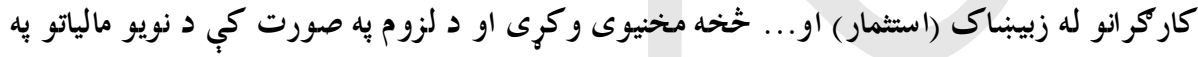

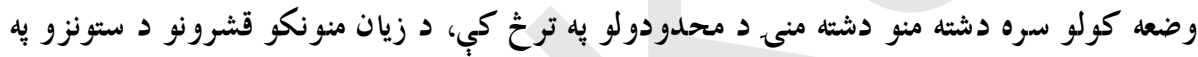

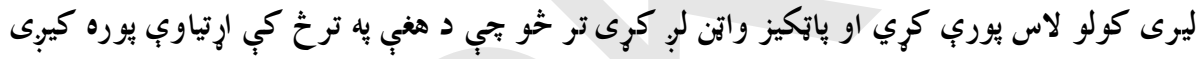

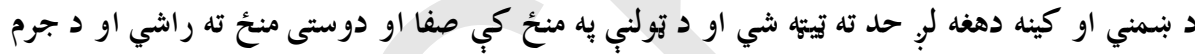

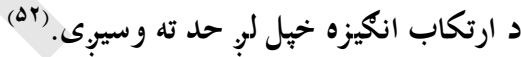

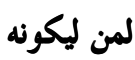

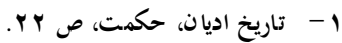

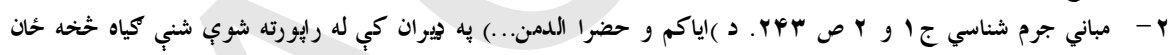

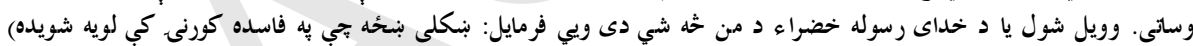

حلديث يه خيره.

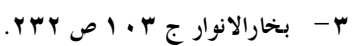

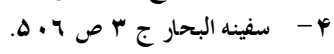

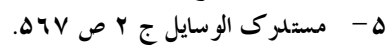

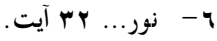

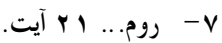

-

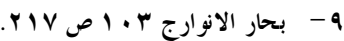

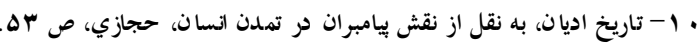
11

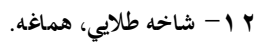

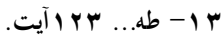

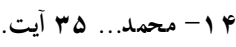

ها 1 -نسا... 9 ا 9 آيت.

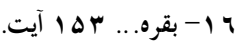




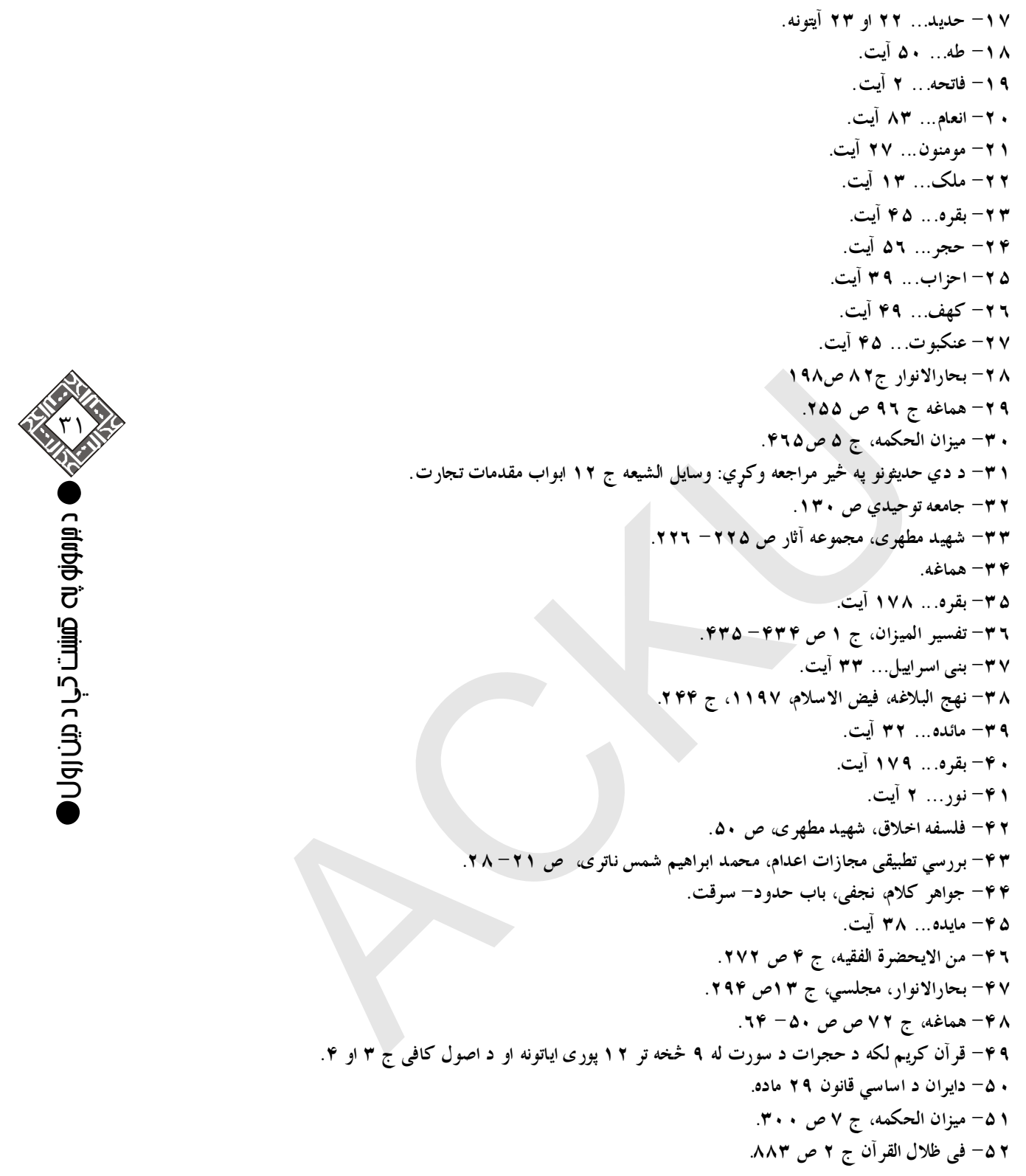




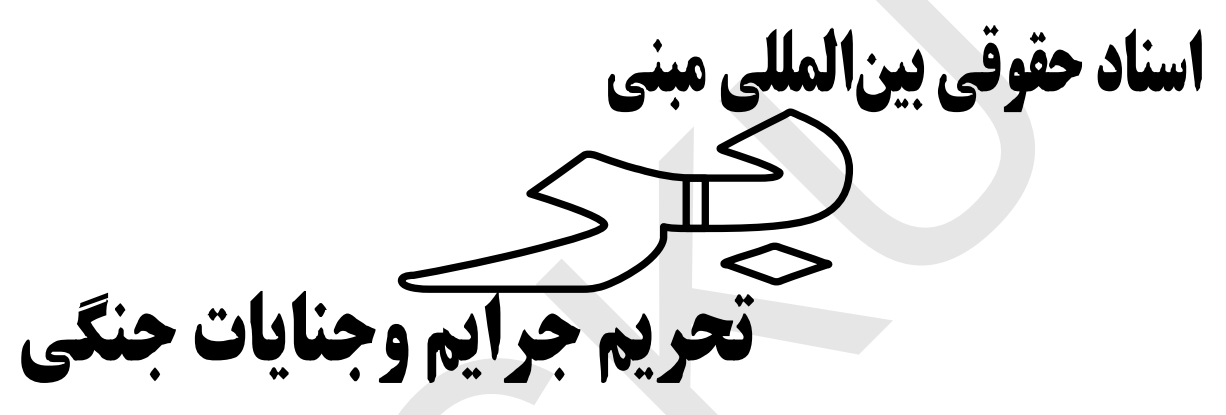

شاه على اصغر شهرستانى

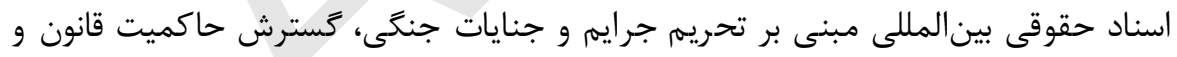

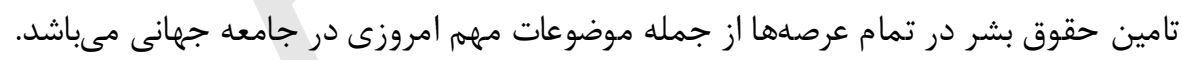

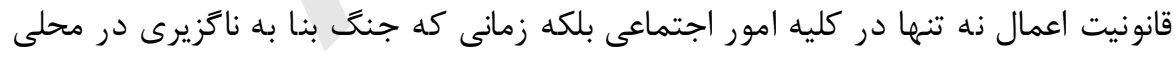

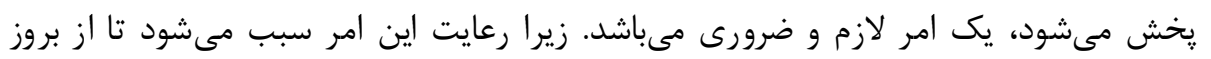

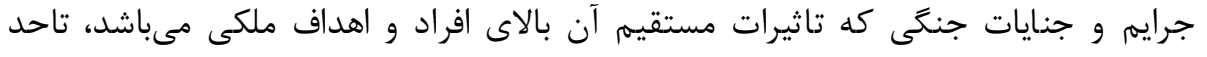
زيادى جلوكيرى شود. در اين زمينه به ارتباط موضوع مطود مالب ذيل ذيل تذكار مىيابد:

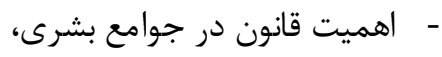

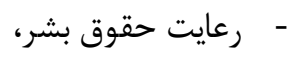

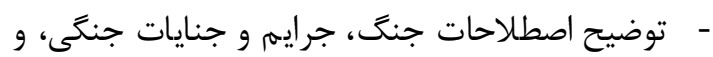
- - - اسناد حقوقى بينالمللى. 


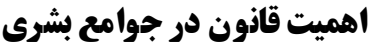

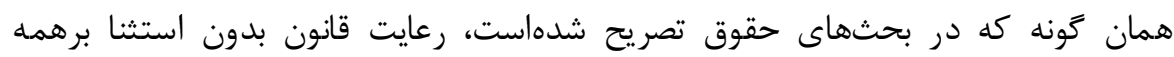

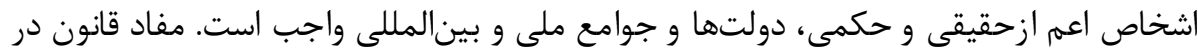

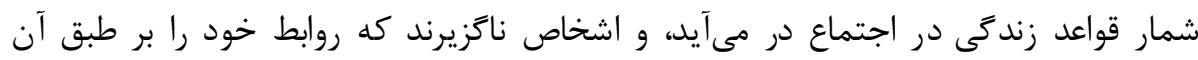

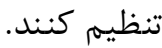

اعتبار و قدرت قانون در برابر اشخاص دو نتيجه مهم و اساسى دارد كه بايد جداكانه مطالعه

الف) رعايت قانون الزامى است و اشخاص نمى توانند به ميل خود از اجراى آن امتناع كنند.

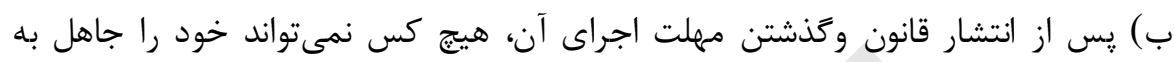

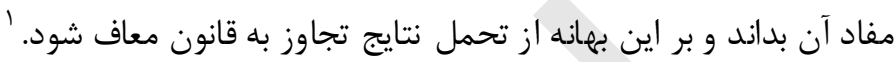

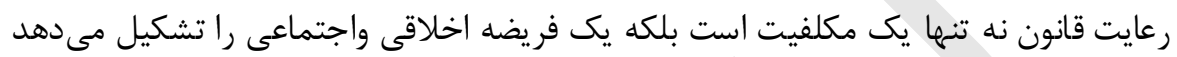

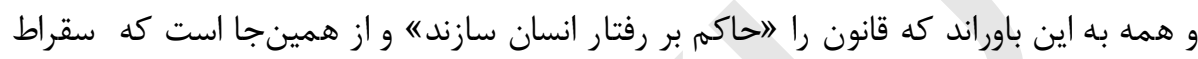

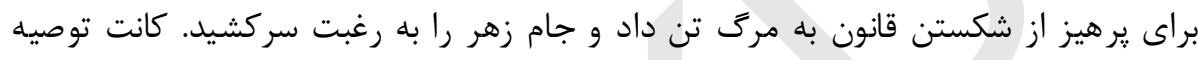

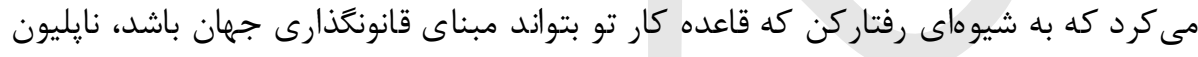

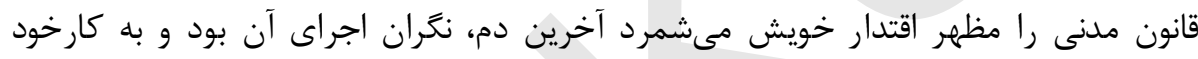

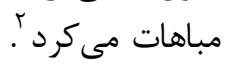

رعايت حقوق بشر در شرايط جنك مائك

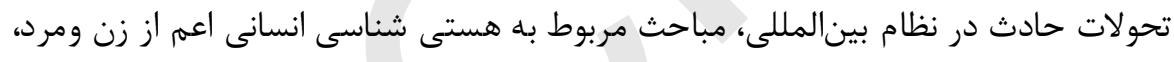

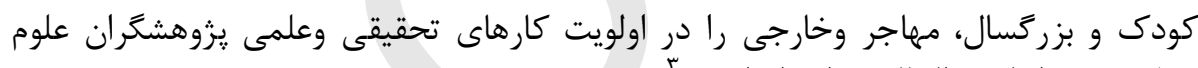
سياسى و روابط بين المللى قرار دادهاست.

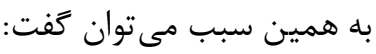

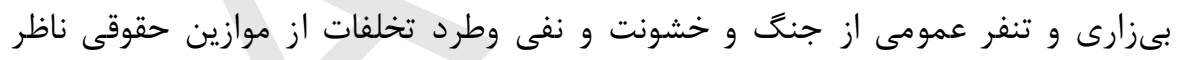

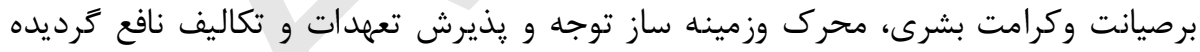
است.

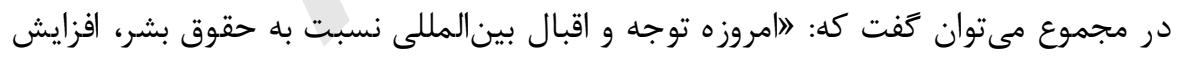

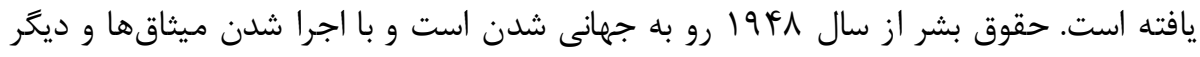

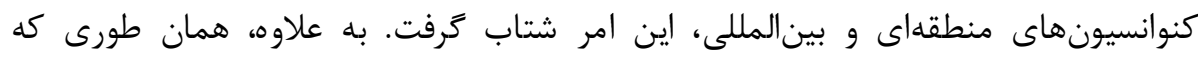
يطروس غالى، منشى عمومى سابق سازمان ملل متحد، در كنفرانس وين إنساب إنهار داشت: زبان

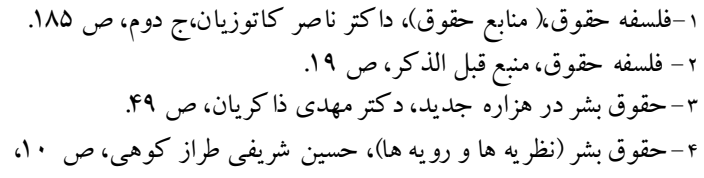


سينالمللى حقوق بشر به طور نسبى يك شكل شدهاست، ولو اين كه برخى كشورها با آن از آنجه كَفته شد، قواعده قابسل

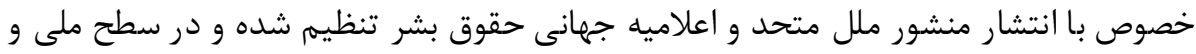

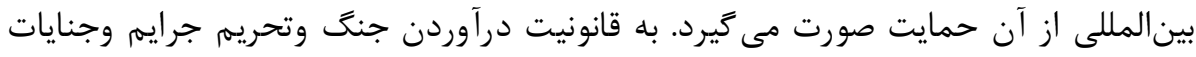

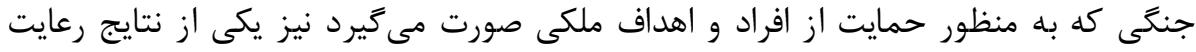
حقوق بشر را تشكيل مىدهد.

توضيح اصلاحات

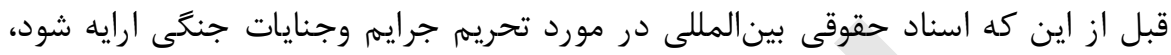

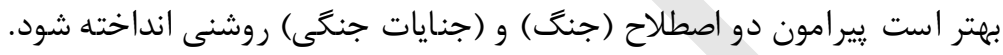

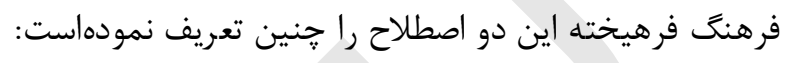

الف) جنى

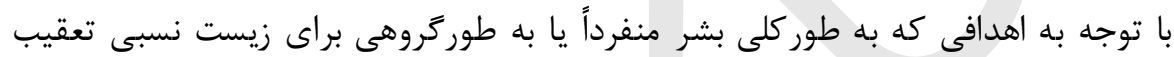

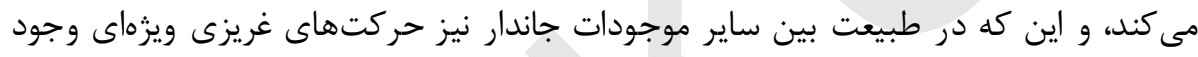

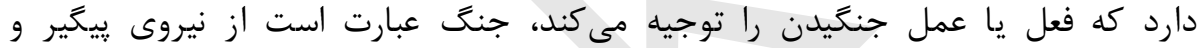

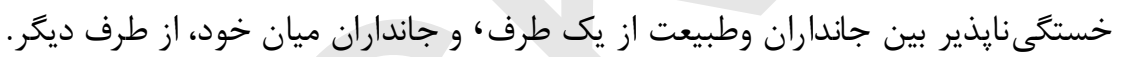

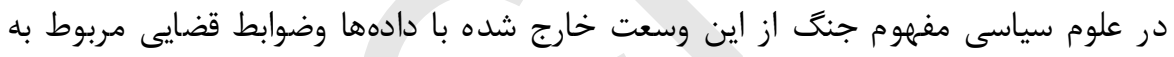

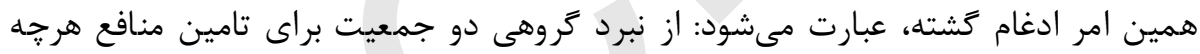

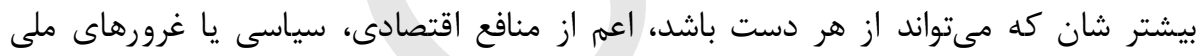

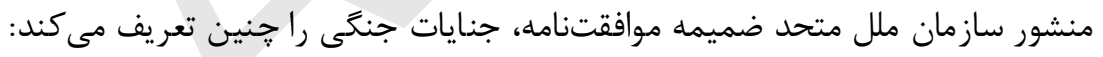

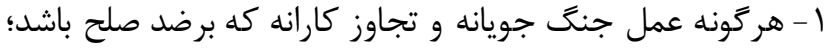

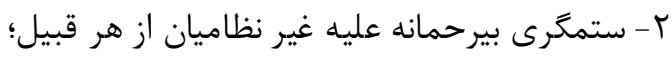

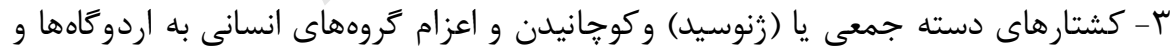
غير طورى كه محققين تحقيق نمودهاند جرايم وجنايات جنكى عبارتند از: " تخلفاتى از قانون

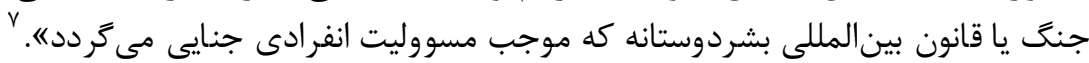

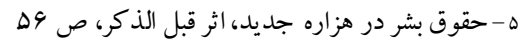

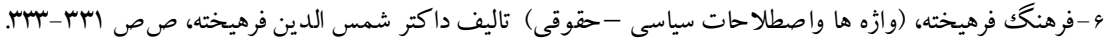

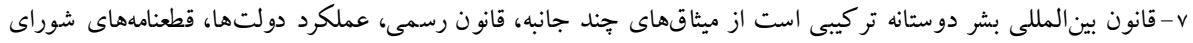

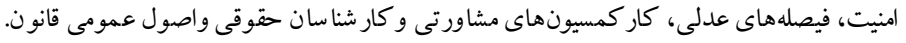




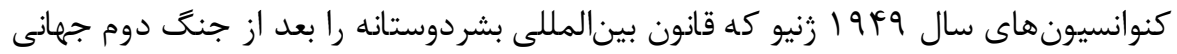

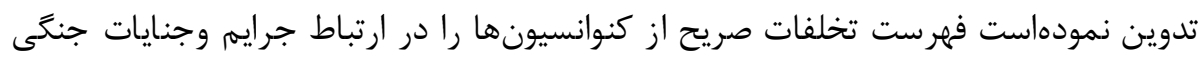

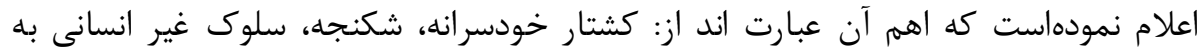

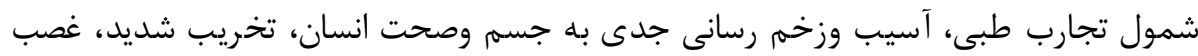

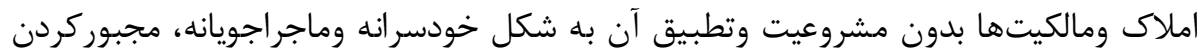

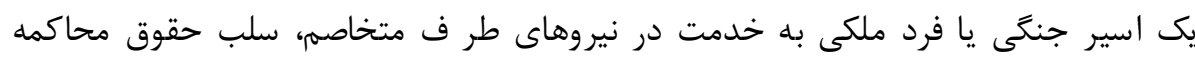

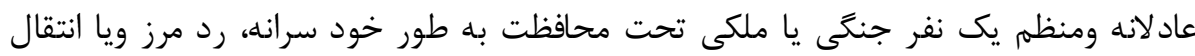

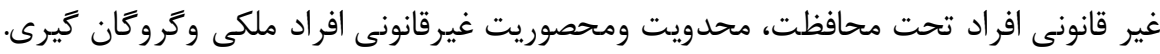

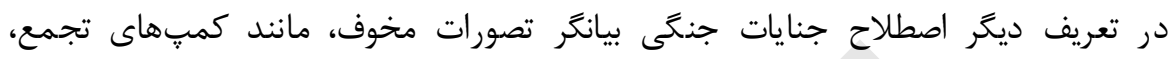

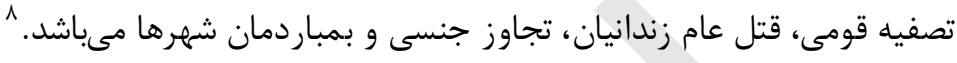

\section{اسناد حقوقى بينالمللى مبنى برتحريم جرايم وجنايات جنكى}

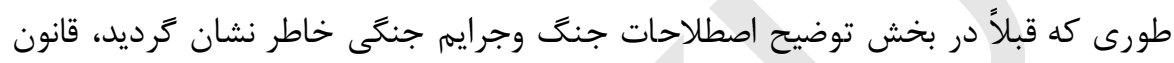

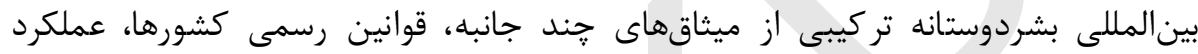

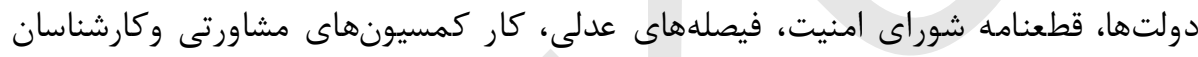
حقوقى واصول عمومى قانون مى باشد.

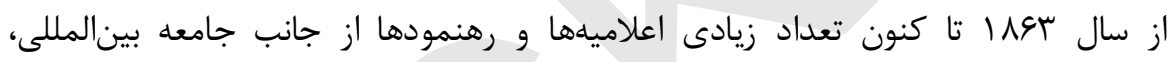

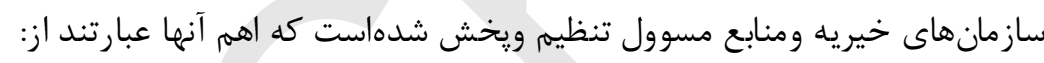

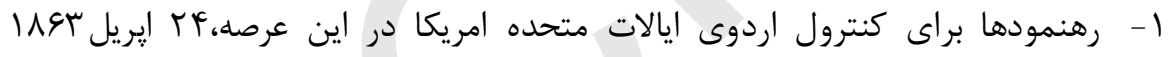

.(Lie berCode)

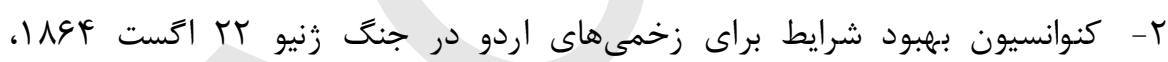
كنوانسيون سال

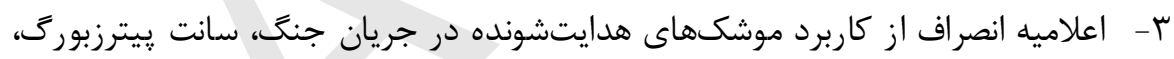

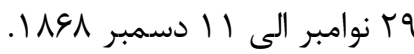

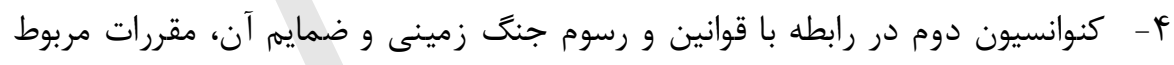

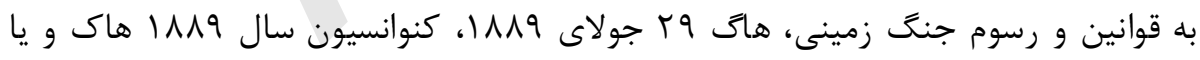

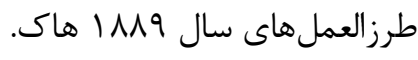

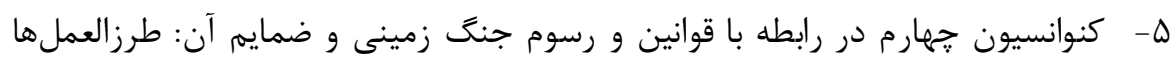

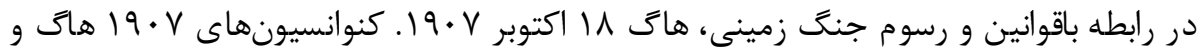

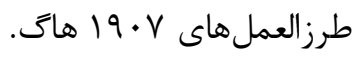

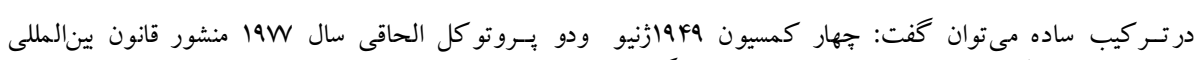

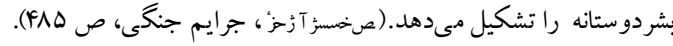

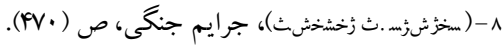




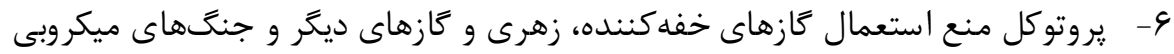

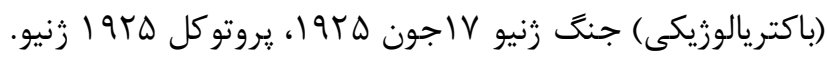

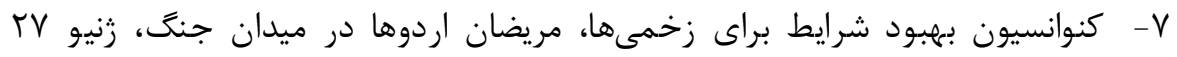

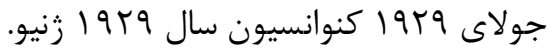

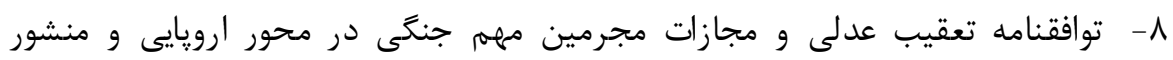

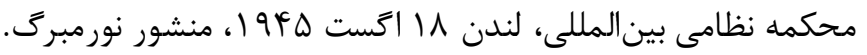

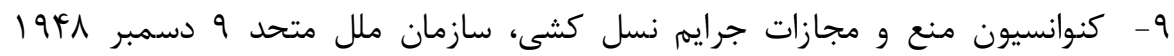

كنوانسيون نسل كشى.

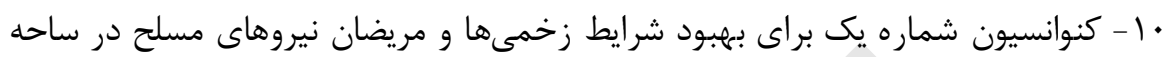

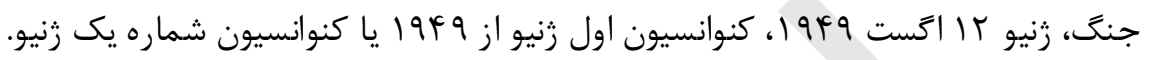

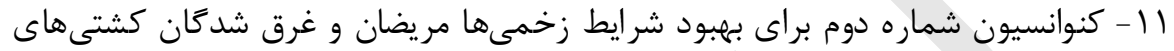

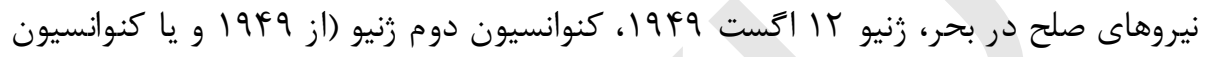

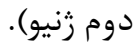

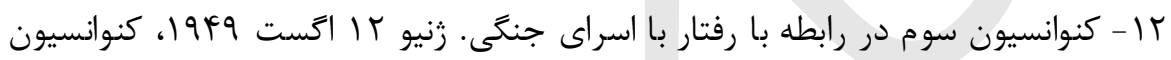

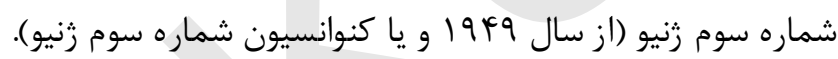

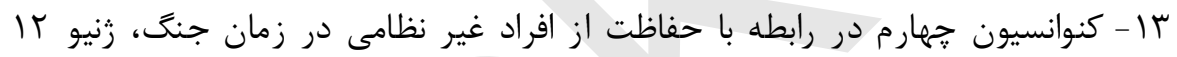

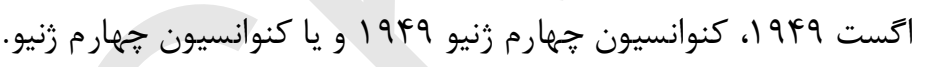

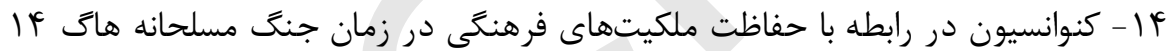

ماه مى 1904.10

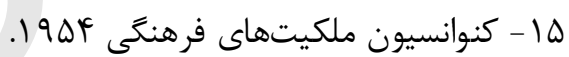

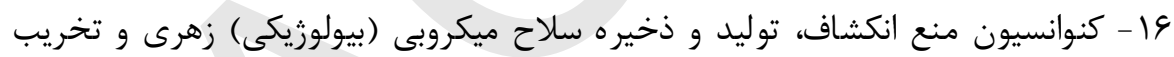

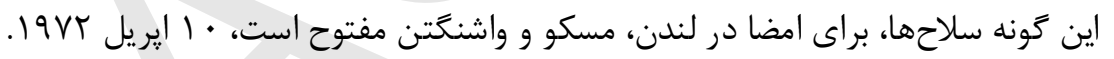

$$
\text { IV }
$$

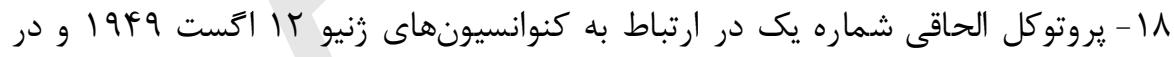

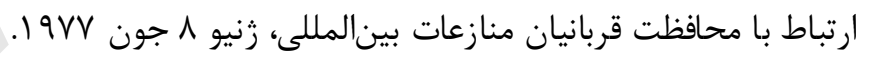

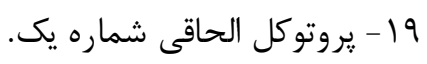

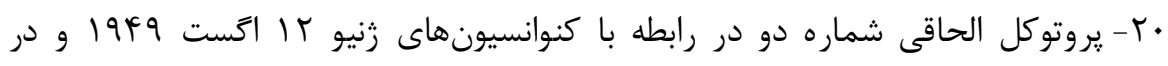

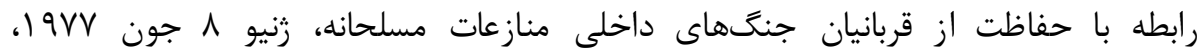

$$
\text { يروتوكول الحاقى شماره دو. }
$$

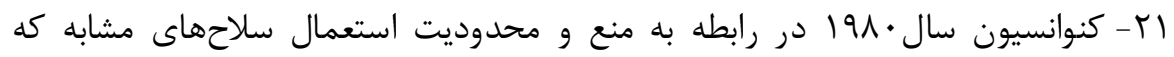

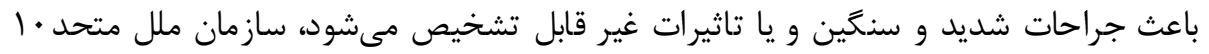

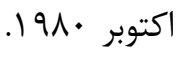

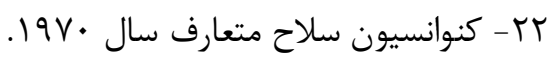


سا - كنوانسيون منع انكشاف، توليد، ذخيره و استعمال سلاح كيمياوى و تخريب اين كونه

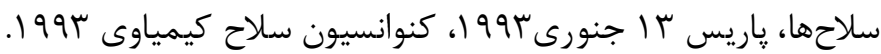

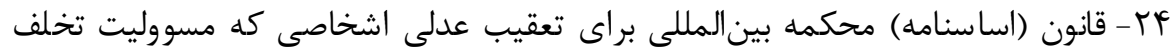

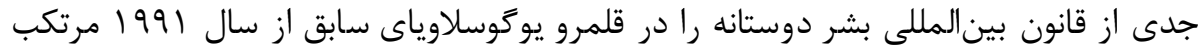

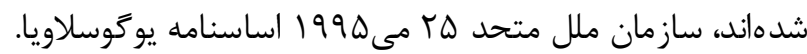

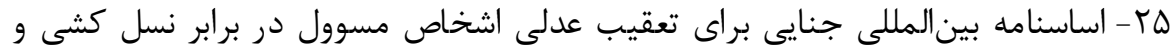

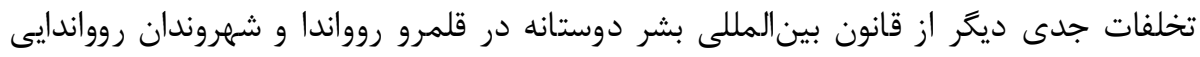

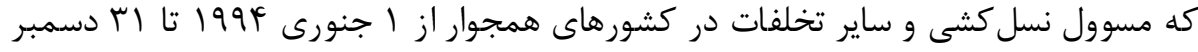

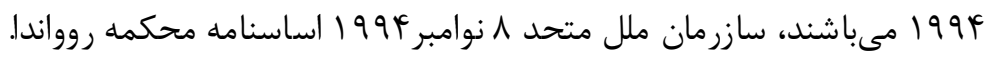

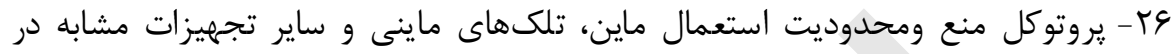

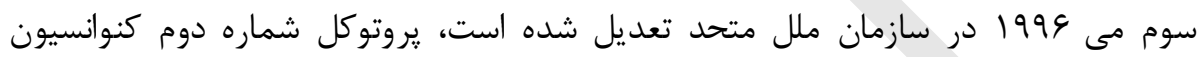

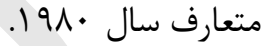
SV

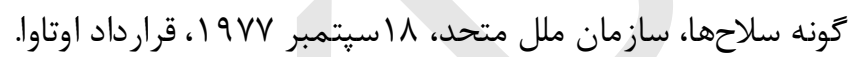

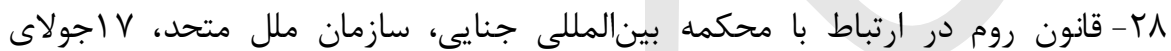

9r- اساسنامه (قانون) روم و يا اساسنامه محكمه بين المللى جنايى.

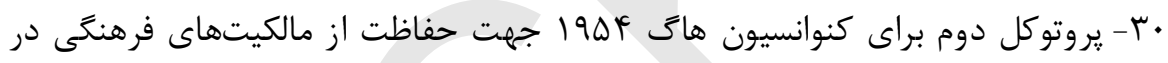

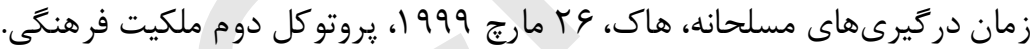

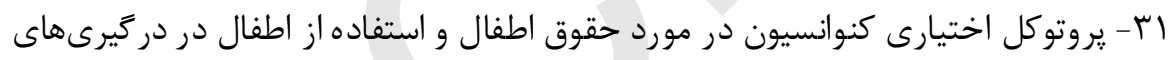

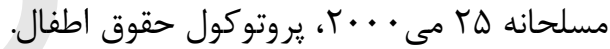

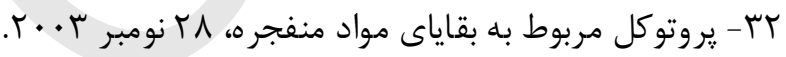

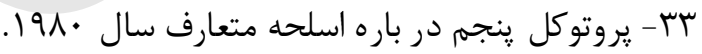

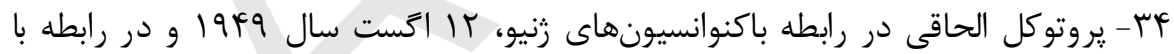

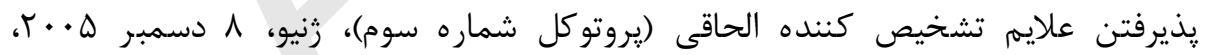

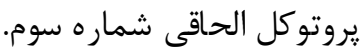

\section{منابع} ا. فرهنك فرهيخه، (وازهها و اصطلاحات سياسى -حقوقى) تاليف دكتر شمس الدين فرهيخته، جاب يكم، (تهران:

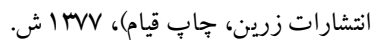

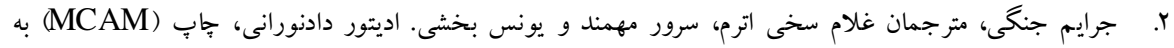

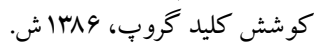

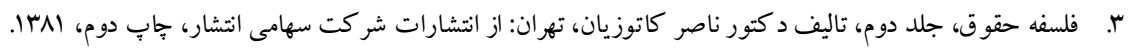

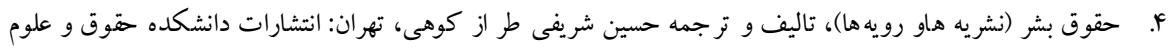

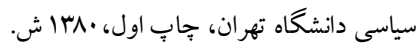

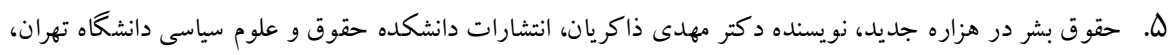




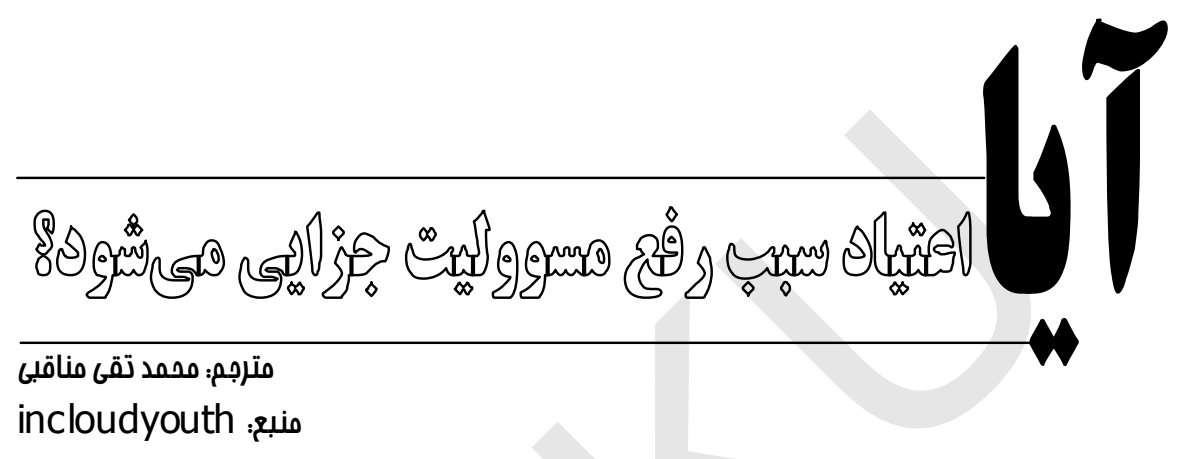

در آمد

معضل اعتياد از دير باز در جوامع انسانى وجود داشتهاست. با به بازار آمدن موان مواد نشهآ مآور

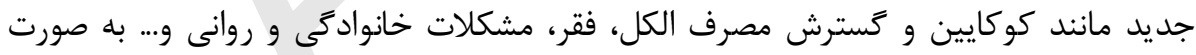

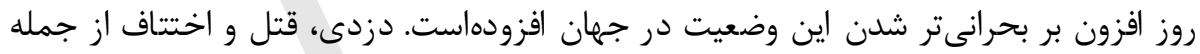

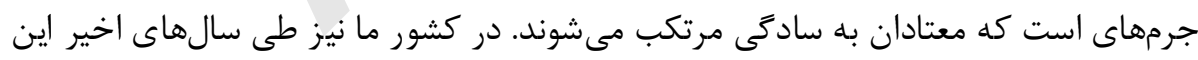

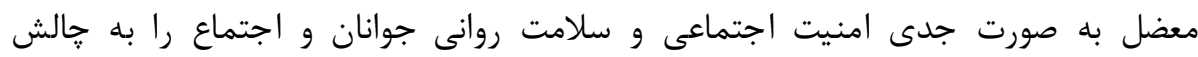
كشيدهاست. اين مقاله به بررسى آثار اعتياد در زوال اراده فرد معتاد مىيردازد و تحقيقات ميدانى و و

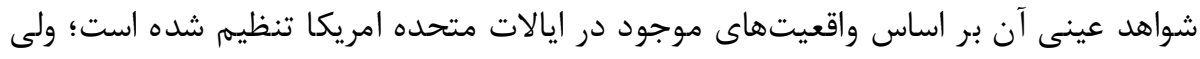

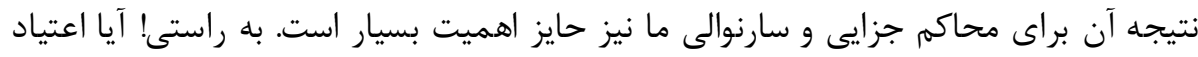

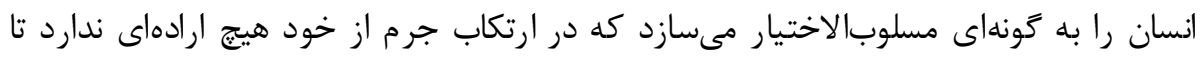

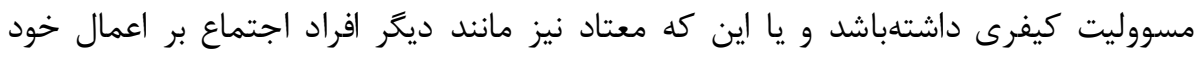

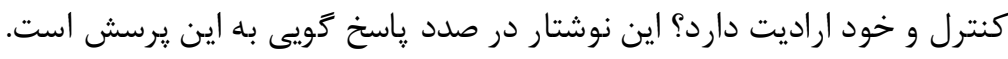


نشريه نيويورك تايمز ارزش helmsly real state empire مربوط به خانم ليونا را حدود

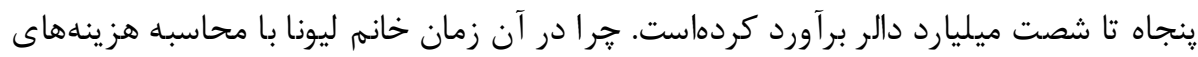

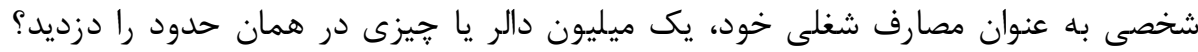

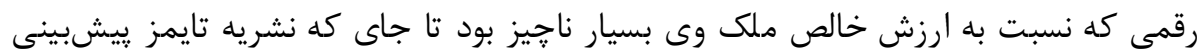

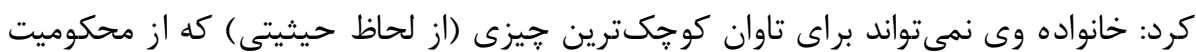

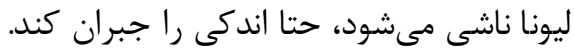

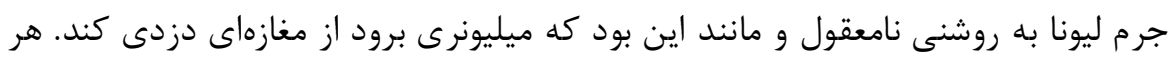

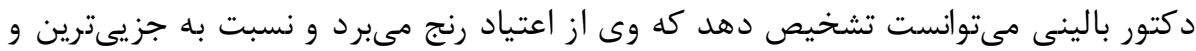

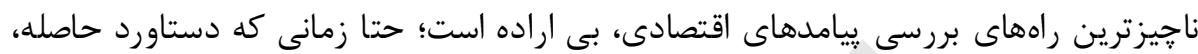

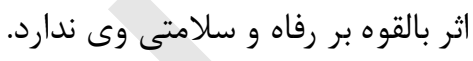

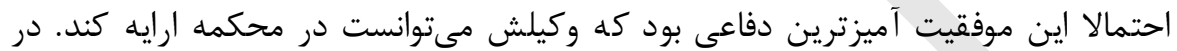

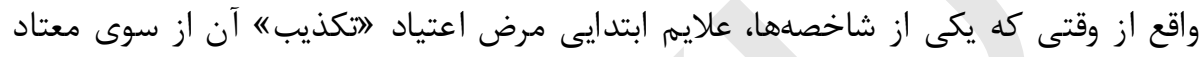

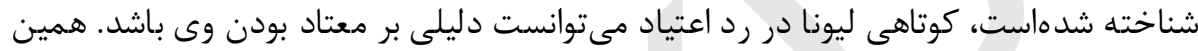

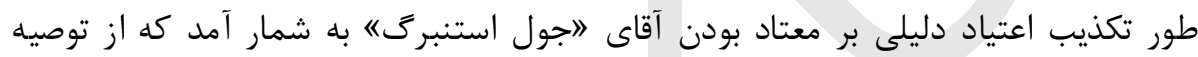

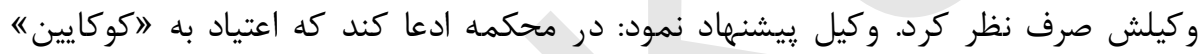

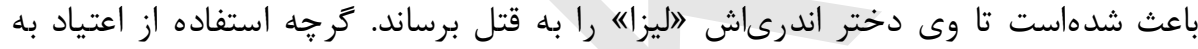

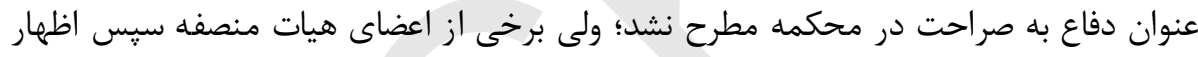

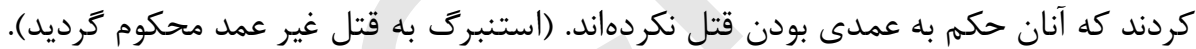

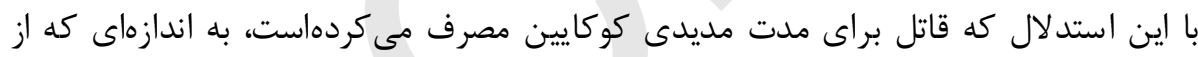

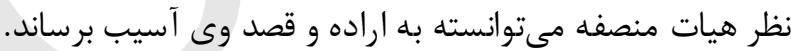

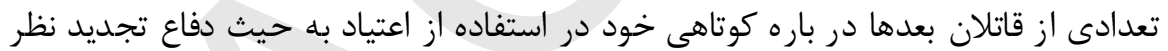

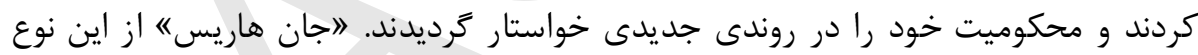

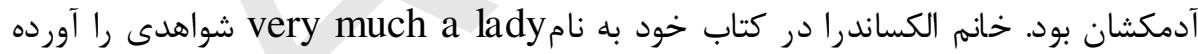

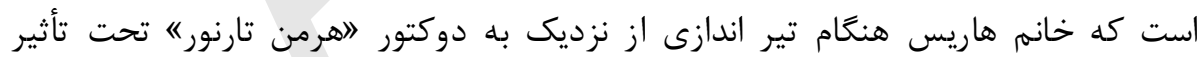

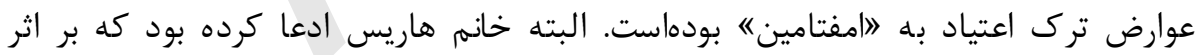

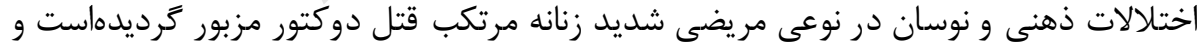

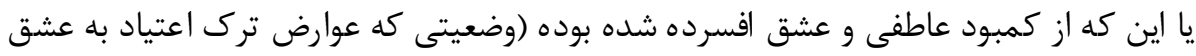

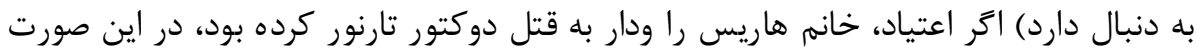

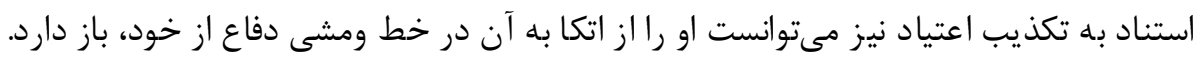

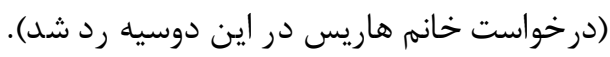

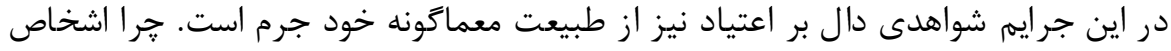

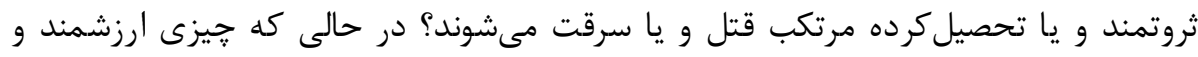

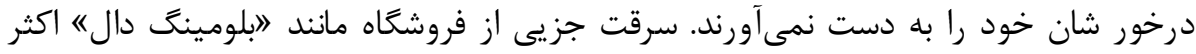




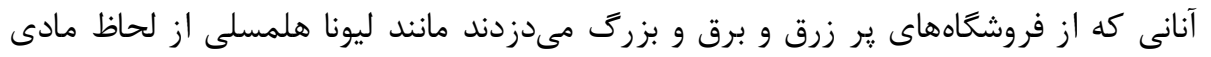

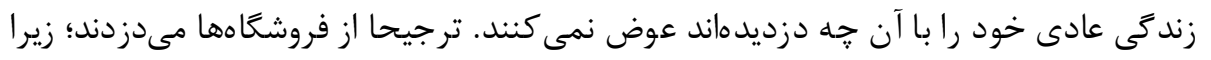

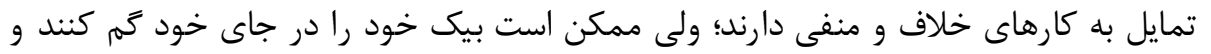

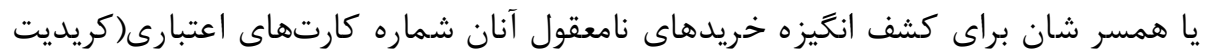

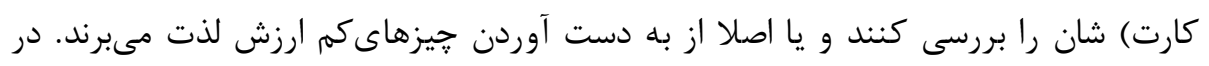

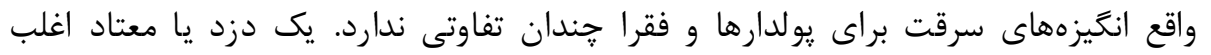

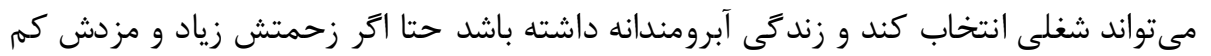

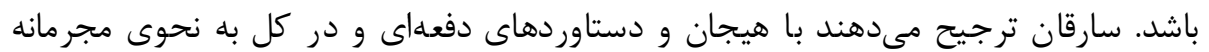
زند منى كنند.

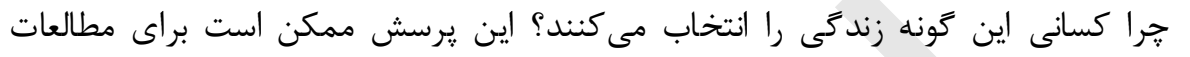

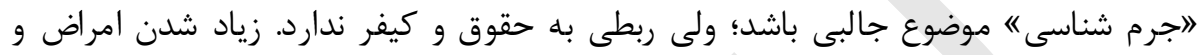

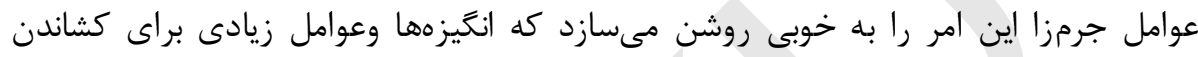

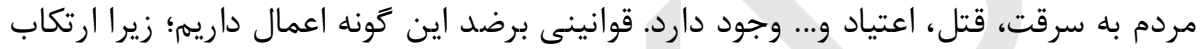

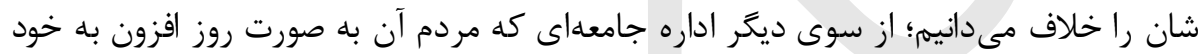

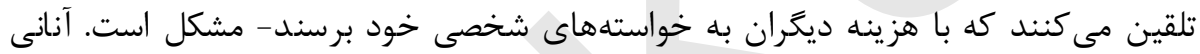

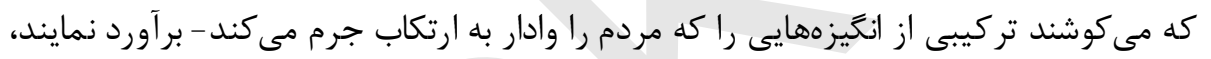

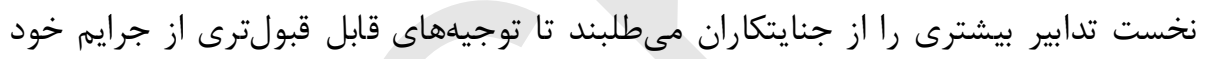
ارايه دهند.

وقيحترين جنايت كه ما را آن قدر شوكه و مبهوت ميىسازد تا با توجيه و بهانه آن را تحمل

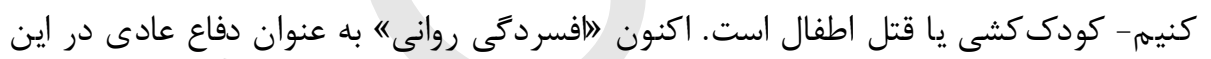

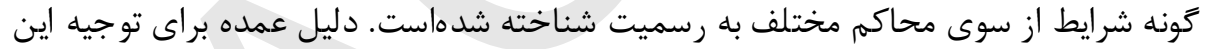

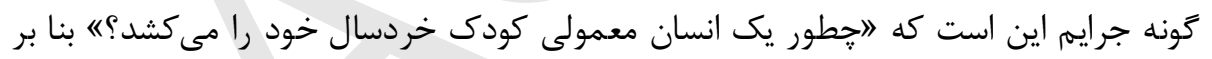

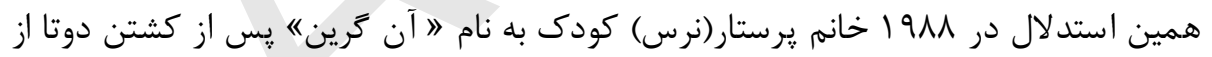

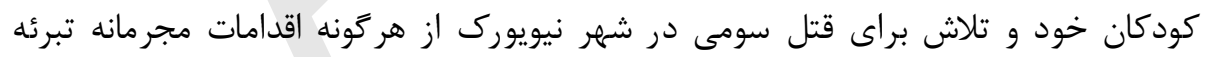

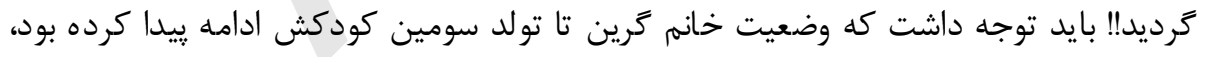

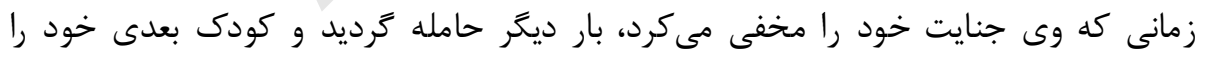

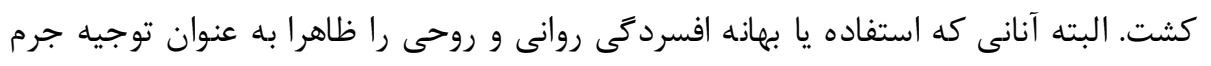

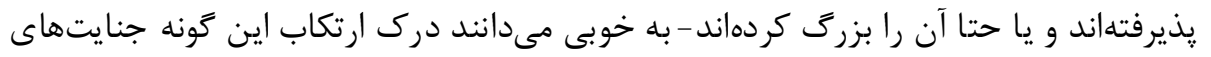

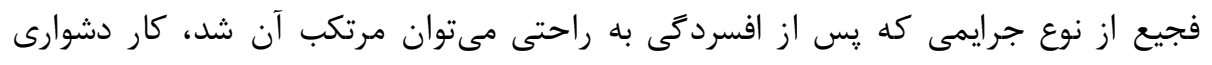
است.

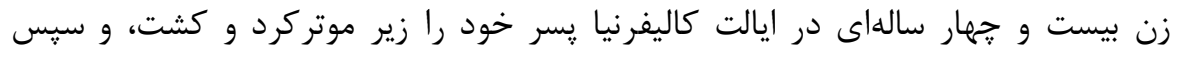

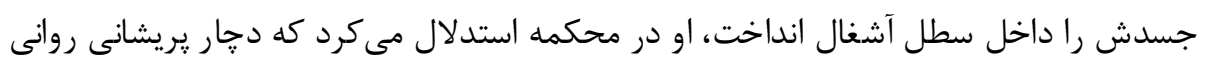


و روحى شده بودهاست. يس از آن كه محكمه وى را راتبرئه كرد، به خاطر اين استدلال از جانب

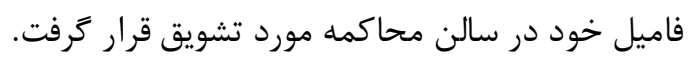

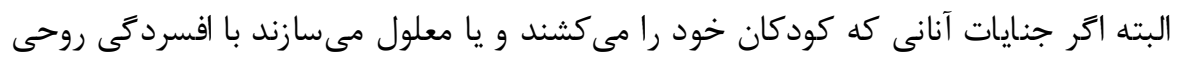

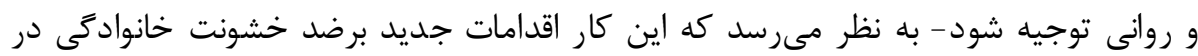

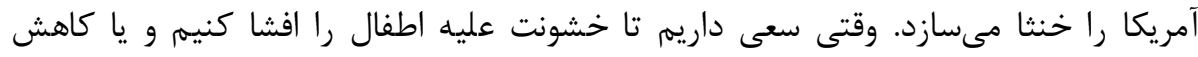

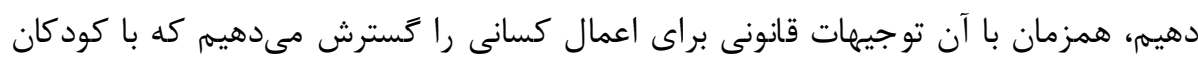

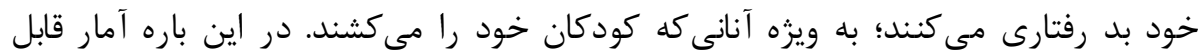

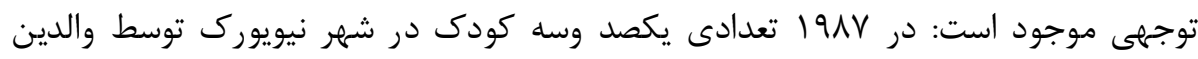

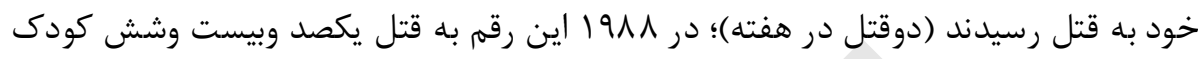
در سال رسيد (ده قتل در هرماه). در

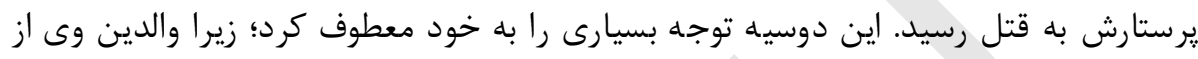

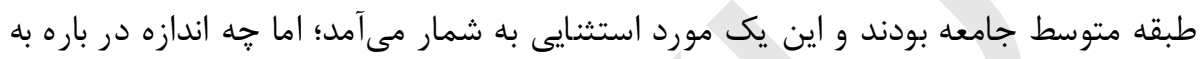

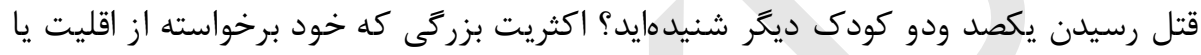

فقير بودند! قلب رسيدن

\section{يشينه مفهوماعتياد}

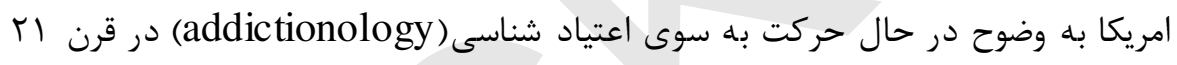

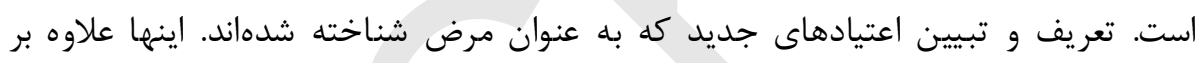

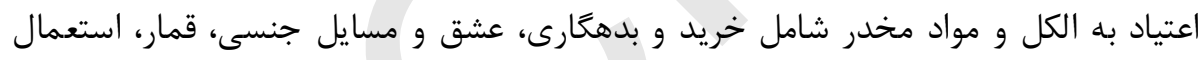

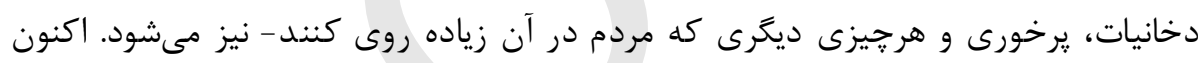

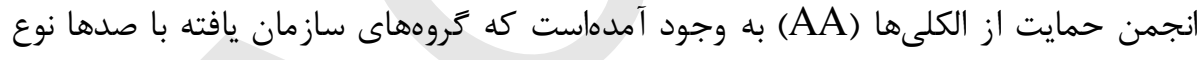

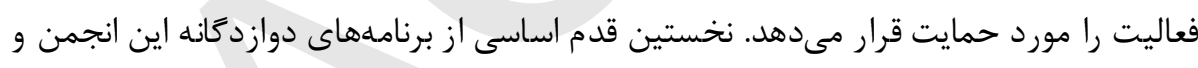

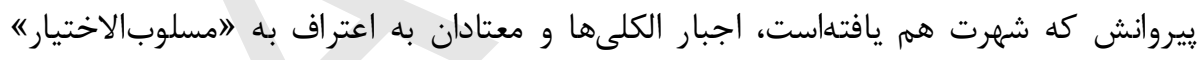

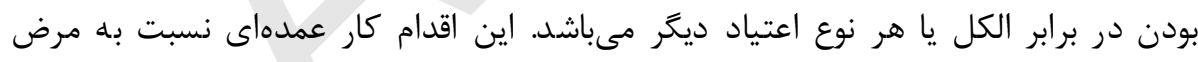

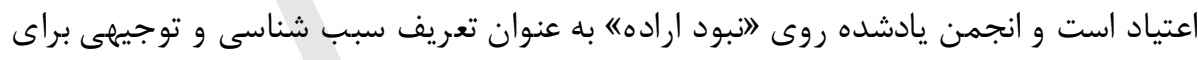

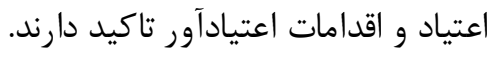

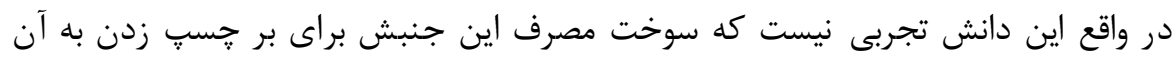

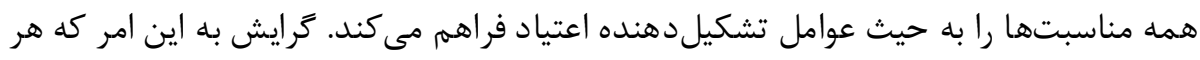

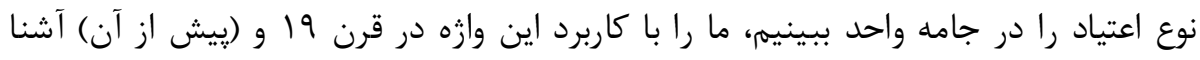

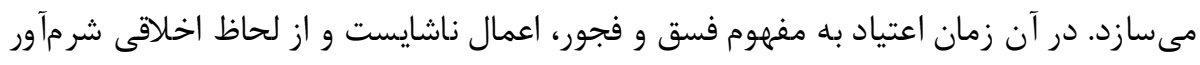

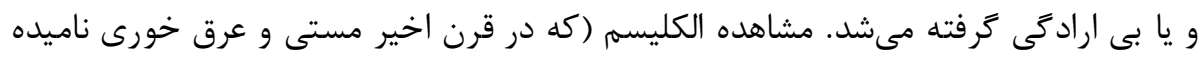

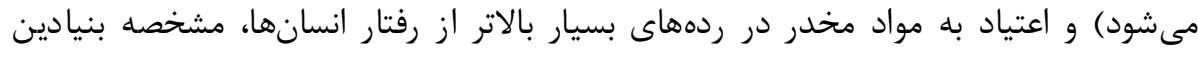

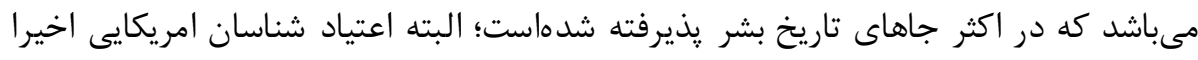

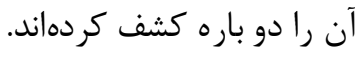




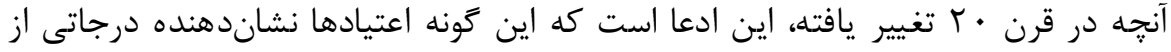

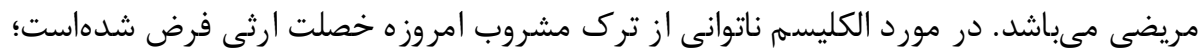

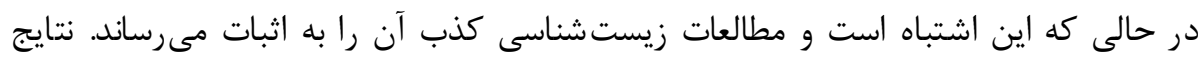

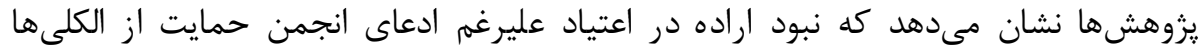

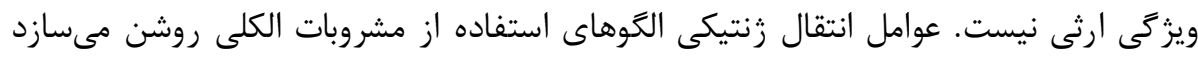

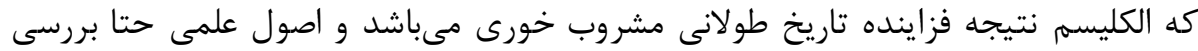

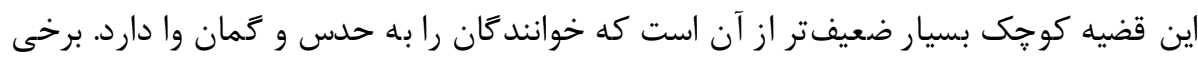

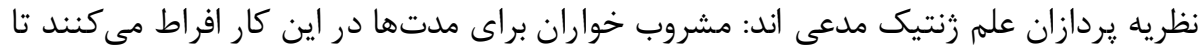

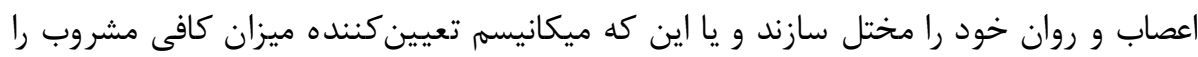

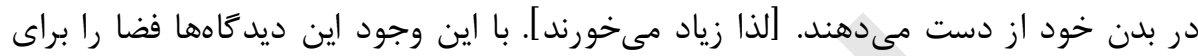

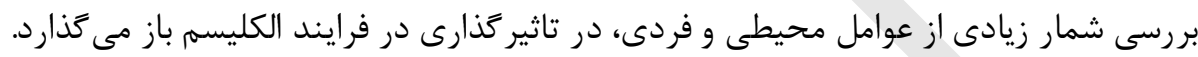

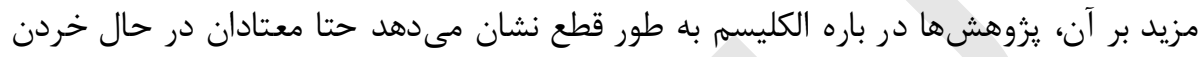

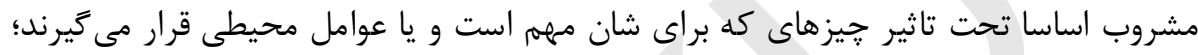

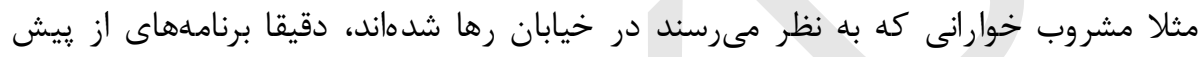

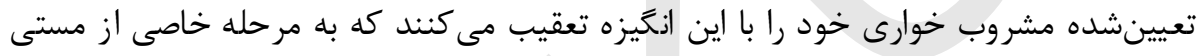

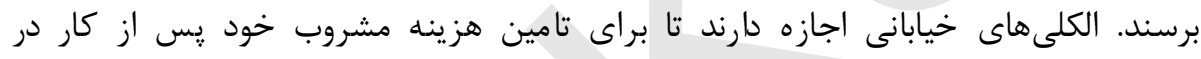

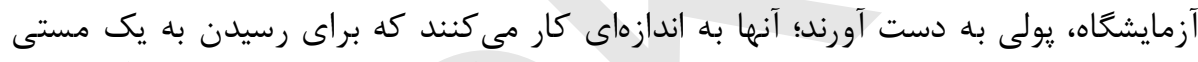

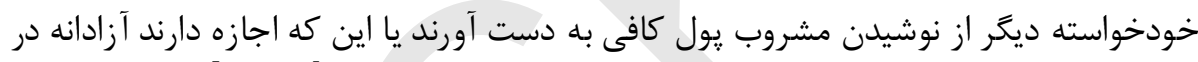

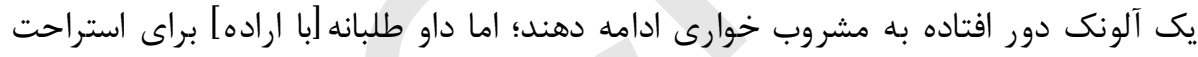

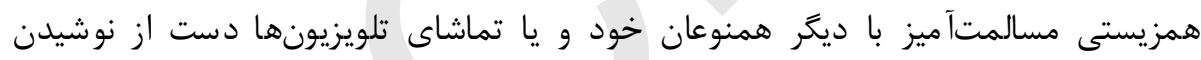

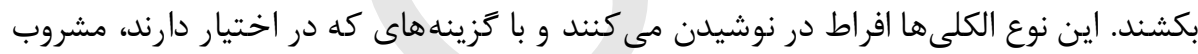

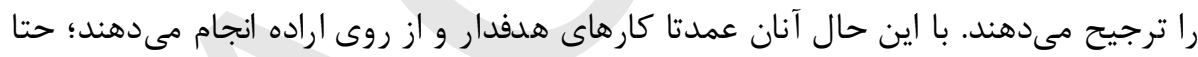

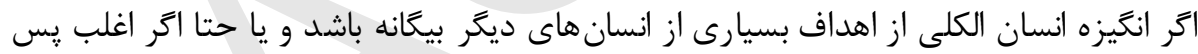

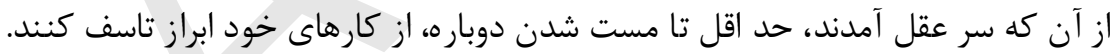

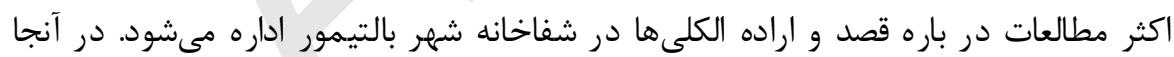

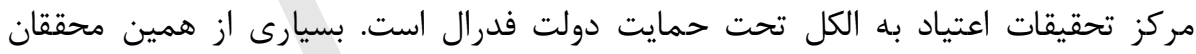

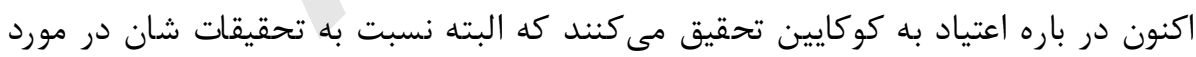

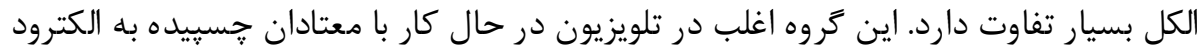

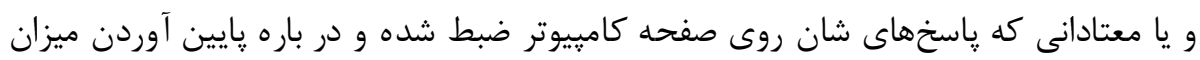

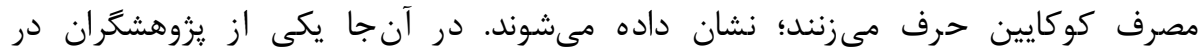

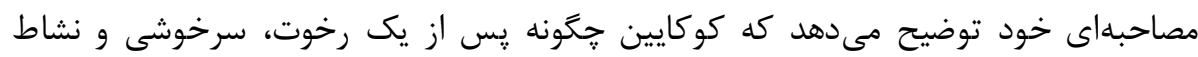

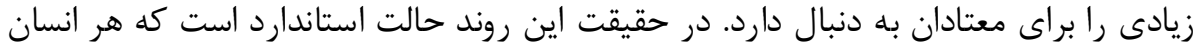

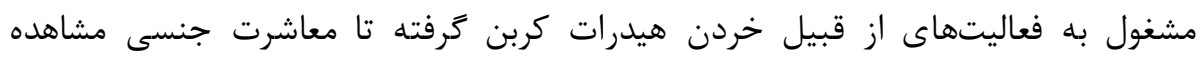

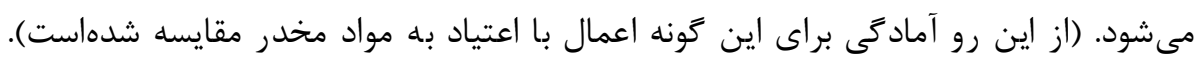

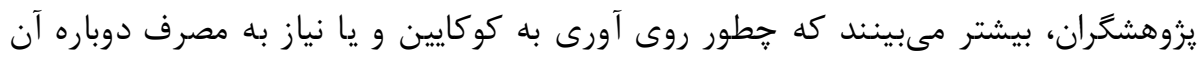




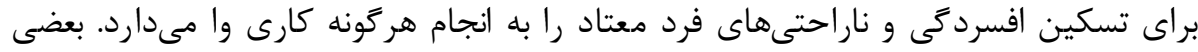

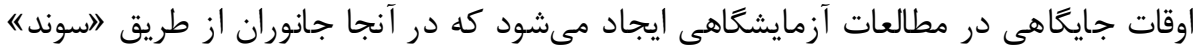

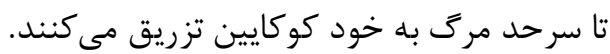

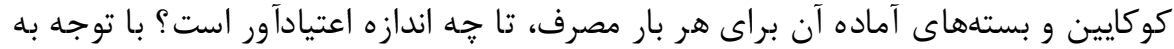

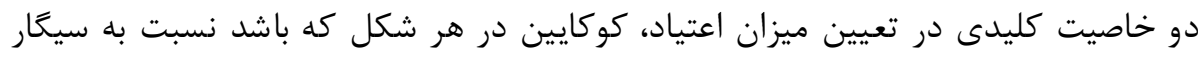

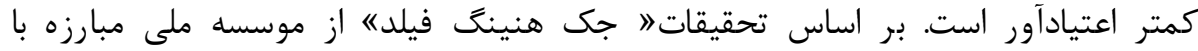

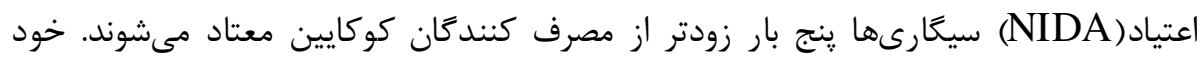

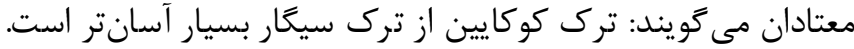

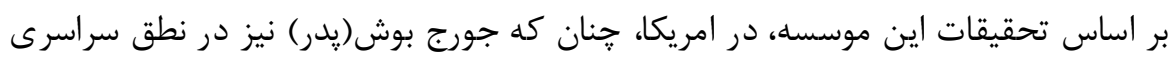

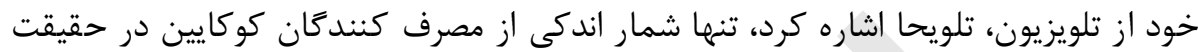

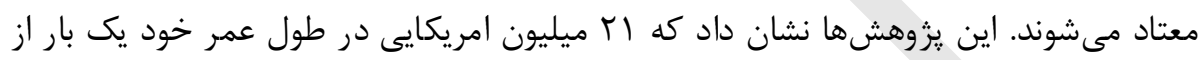

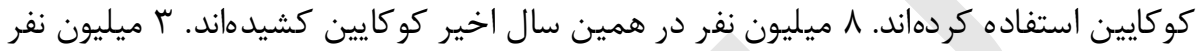

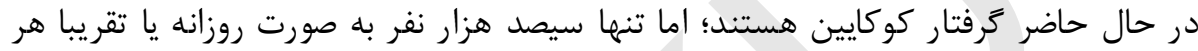

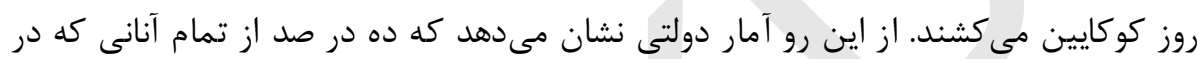

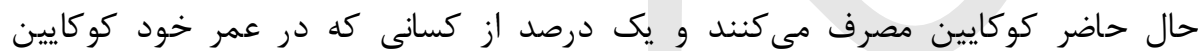

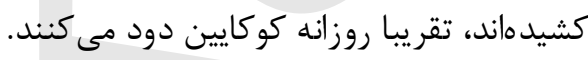

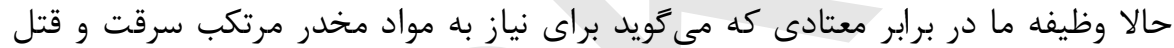

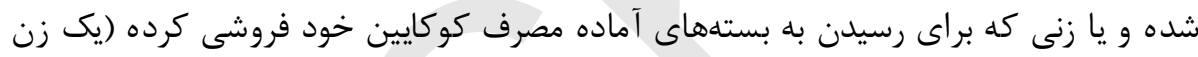

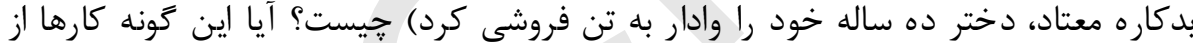
اثرات اعتياد نيست؟ دخت دخت نه خير. اين نشانكر ساده لوحى است نه دانش كه بـ بـ اراده بودن و جرايم شخص معتاد از

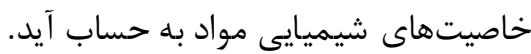

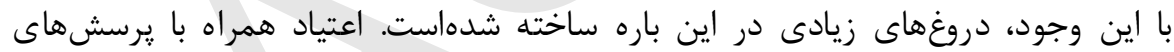

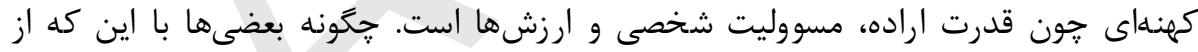

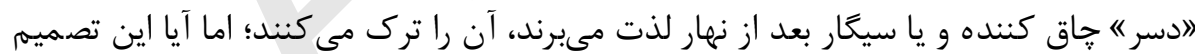

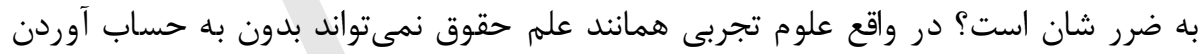

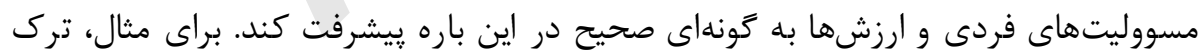

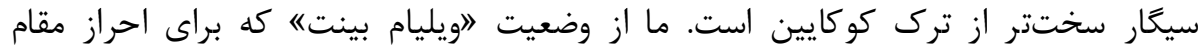

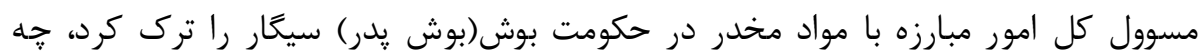

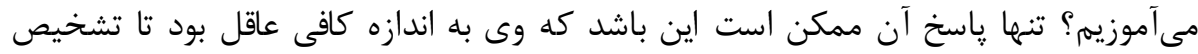

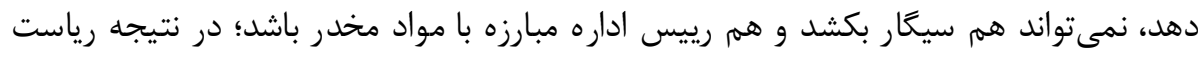
را بيشتر از سيكار مىخواست.

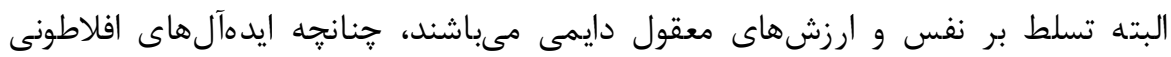

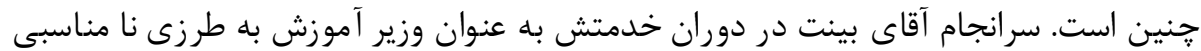
به اعتيادش ادامه داد. 


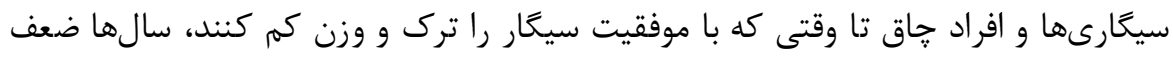

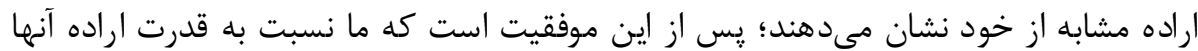

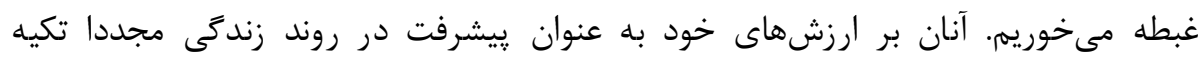

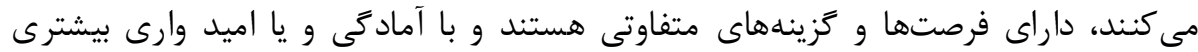

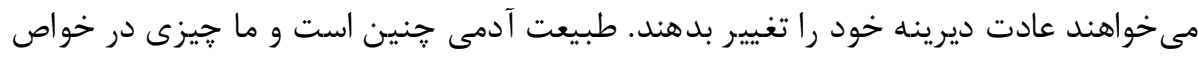

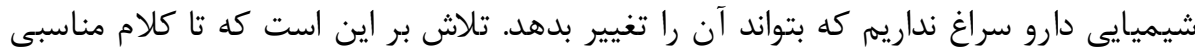

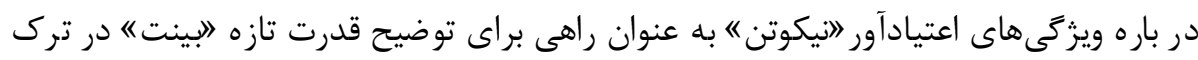
اعتياد كفته شود.

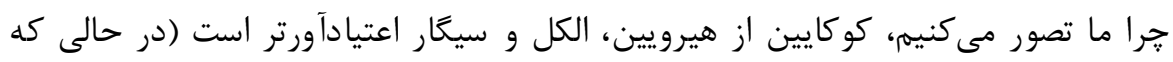

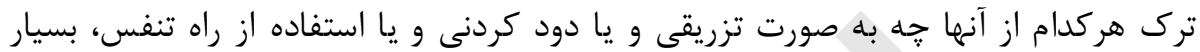

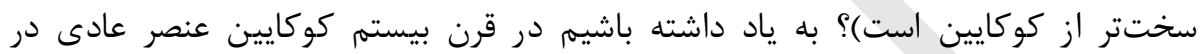

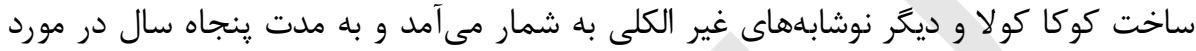

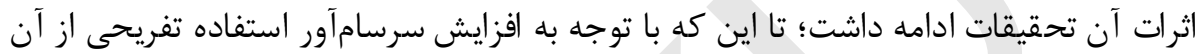

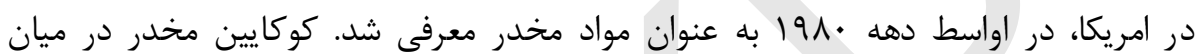

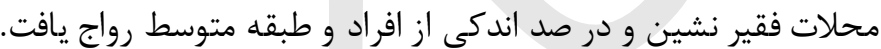

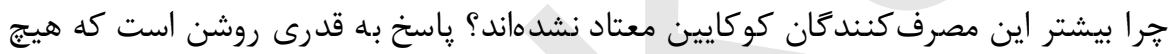

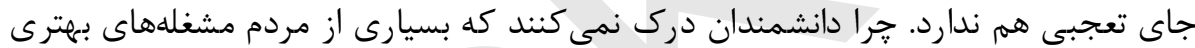

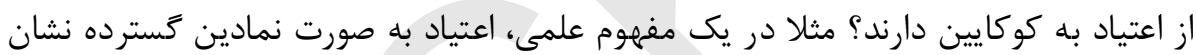
داده مىشود در حالى كه طبق اطلاعات واقعى تكذيب كر درئ ديدهاست.

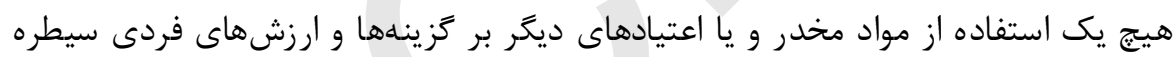

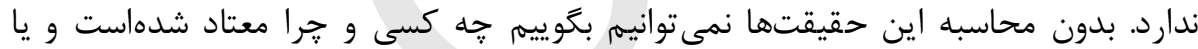

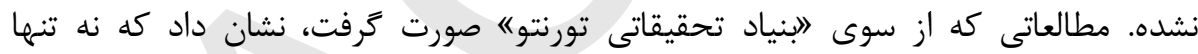

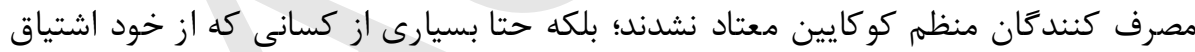

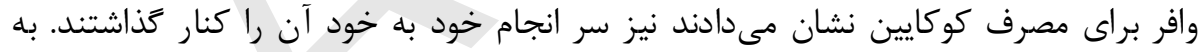

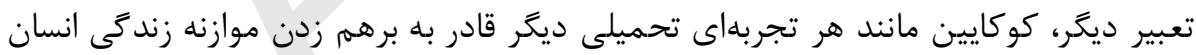

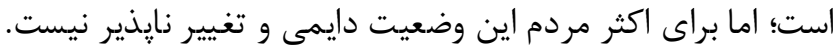

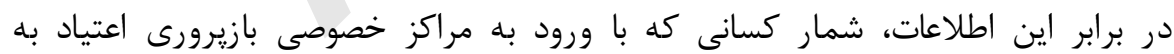

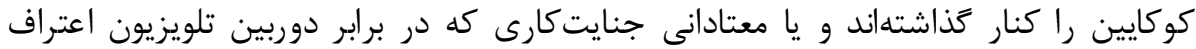

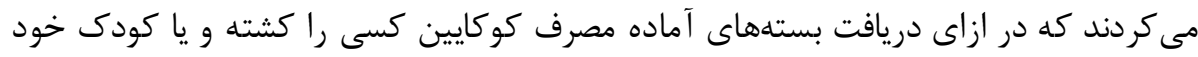

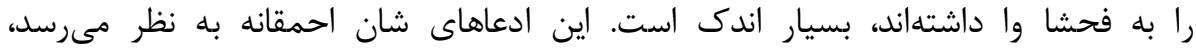

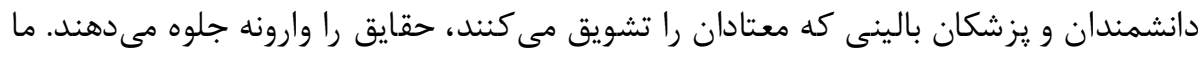

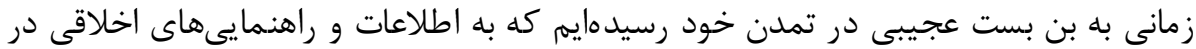

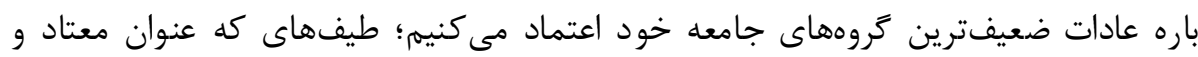

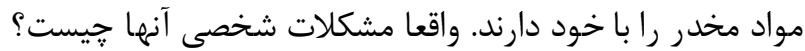


به راستى! از كسانى كه نشان دادهاند نمىتوانند از باده إدسارى دست بردارند، تمامى يول

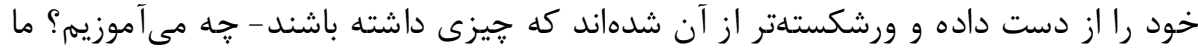

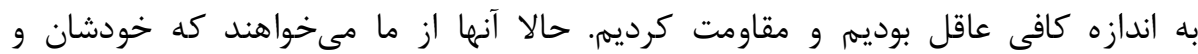
اشتباهات شان را ببخشيه.

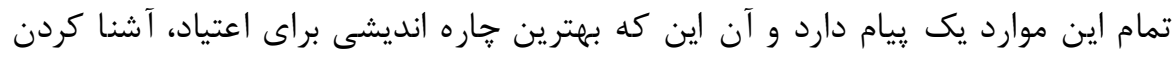

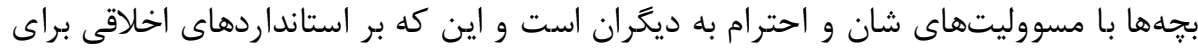

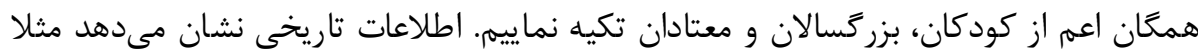

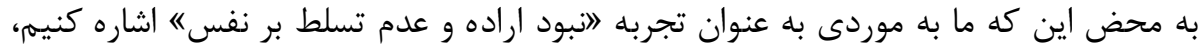

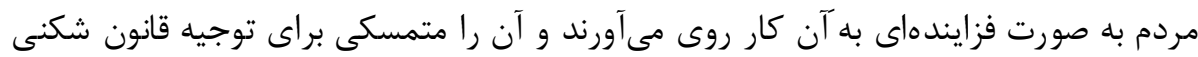

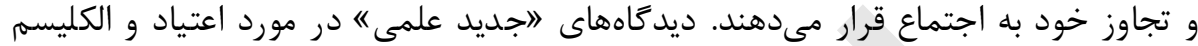

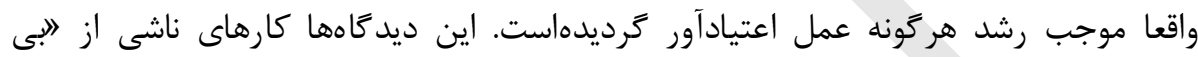

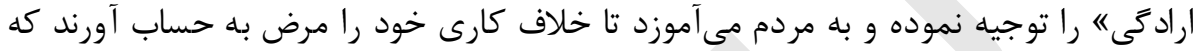

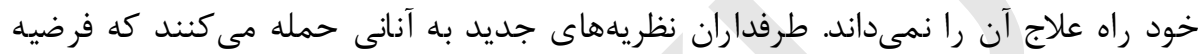

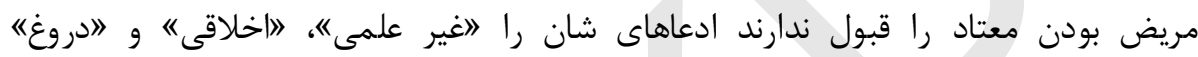

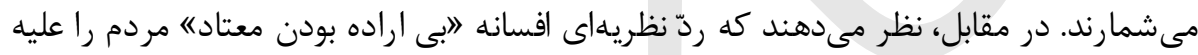
اعتياد تقويت مىنمايد.

\section{افسانه در مان اعتياد}

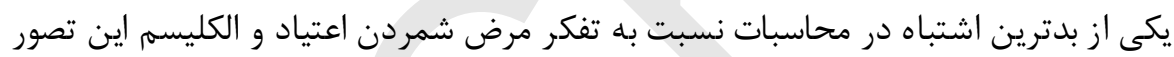

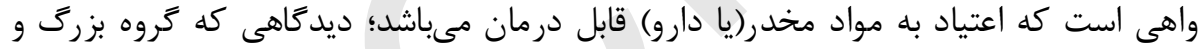

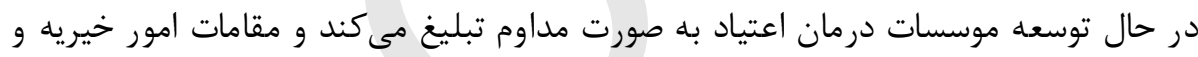

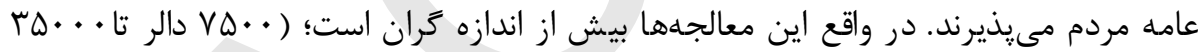

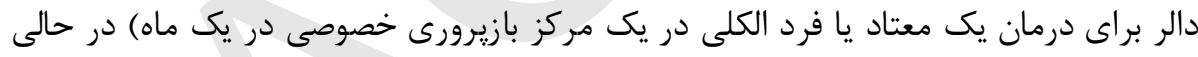
كه تاثيرى همم ندارد.

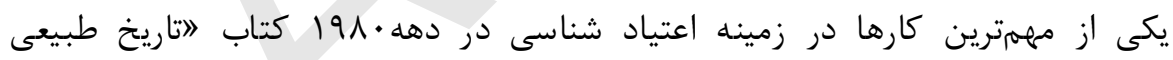

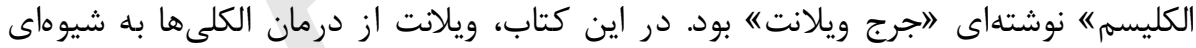

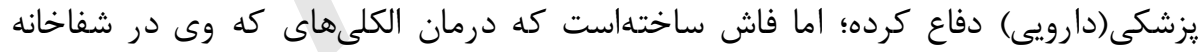

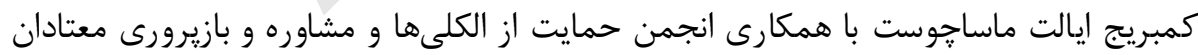

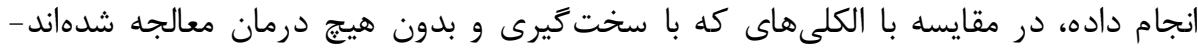

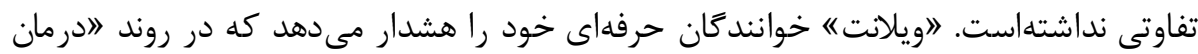

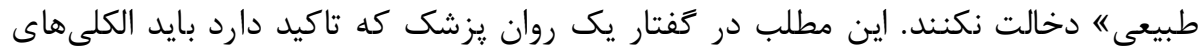

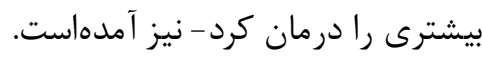

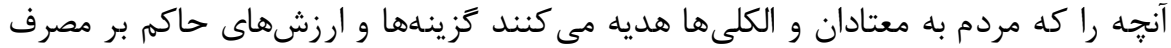

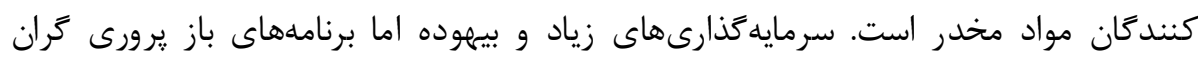

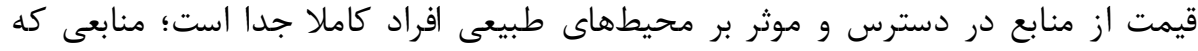

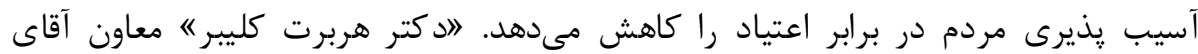




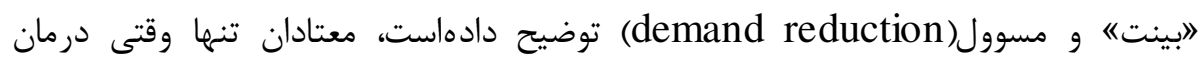

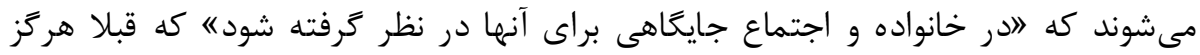

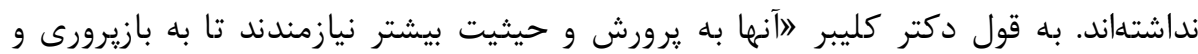

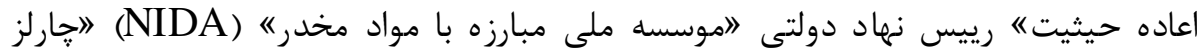

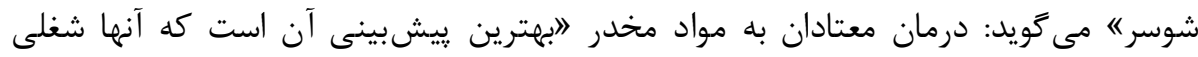

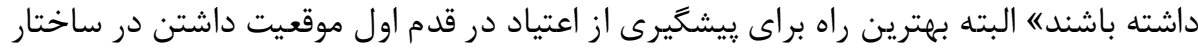

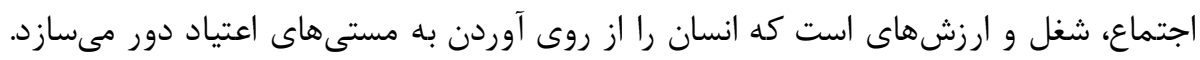

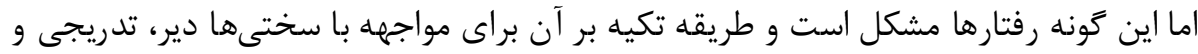

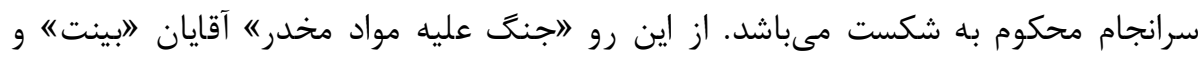

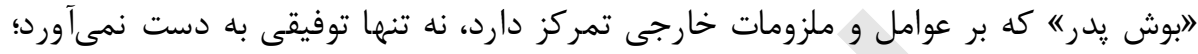

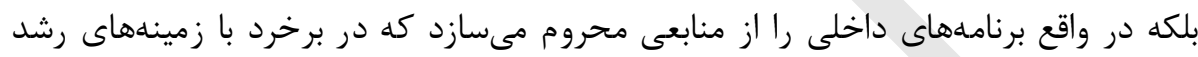

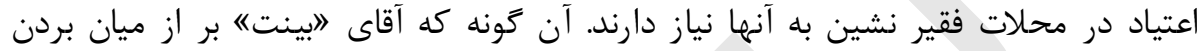

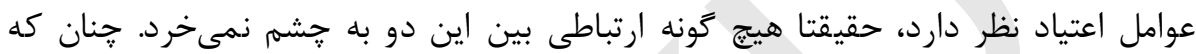

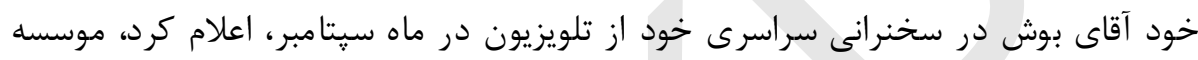

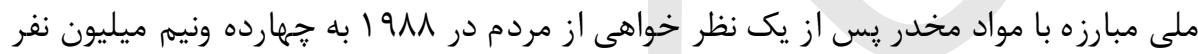

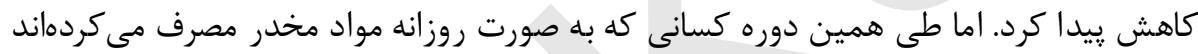

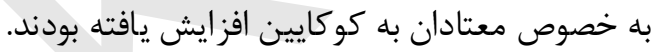

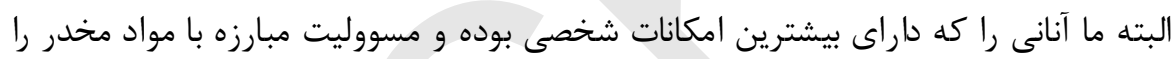

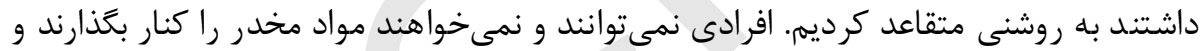

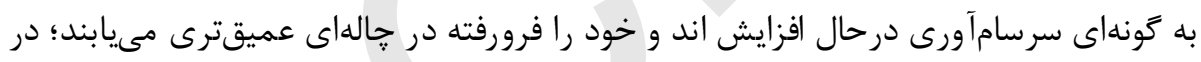

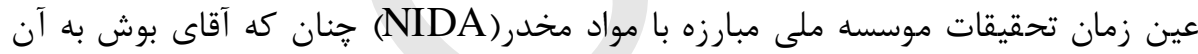

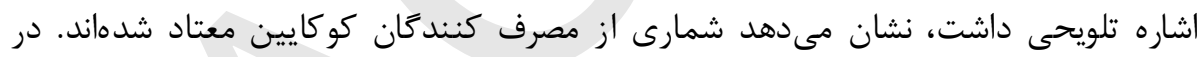

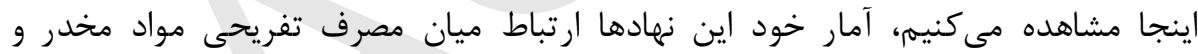

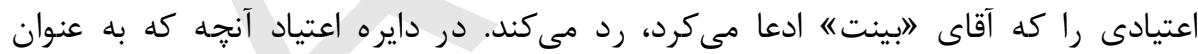

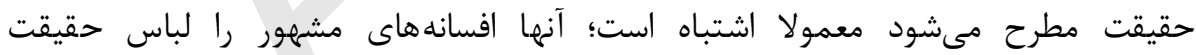

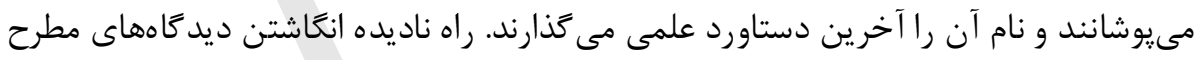

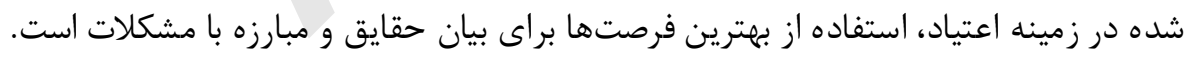




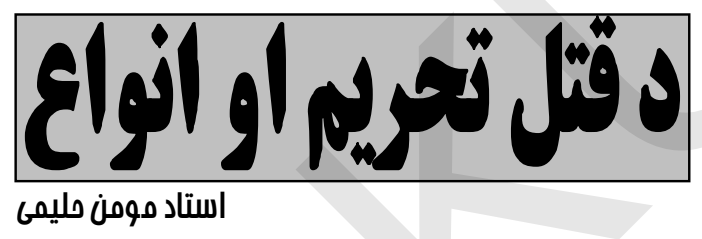

مقدمه

قتل يو ناروا عمل دى تهله وروسته له شرك خخه كبيره گناه ده. او د هغه د تحريم به باره كبنب

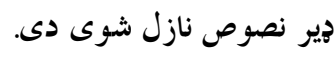

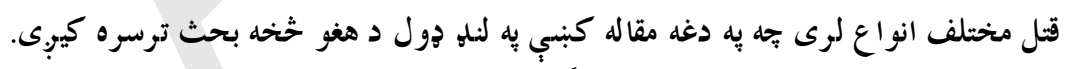

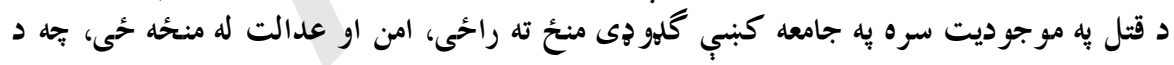

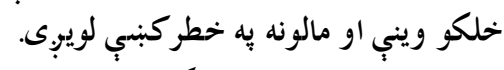

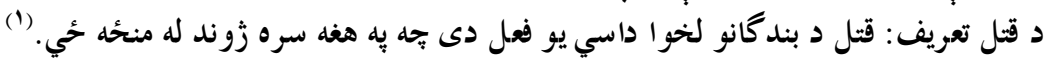

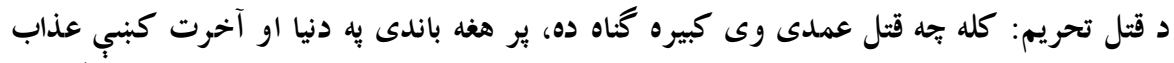

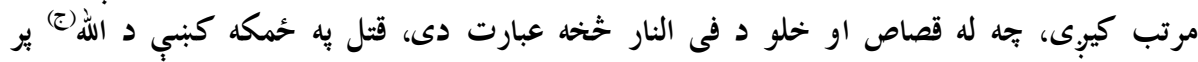

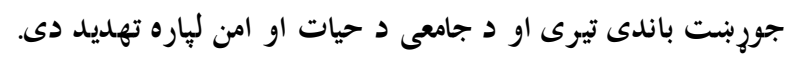

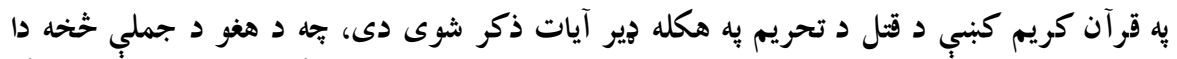

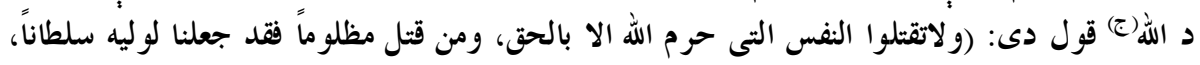

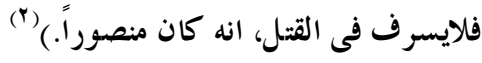




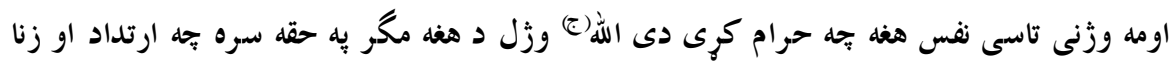

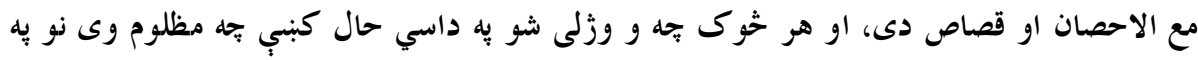

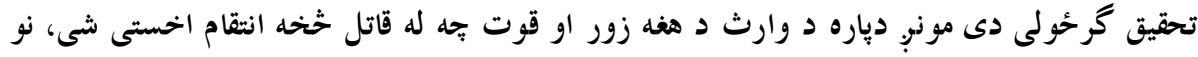

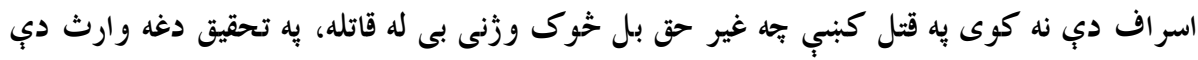

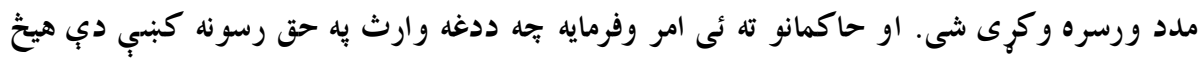

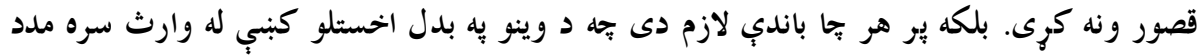

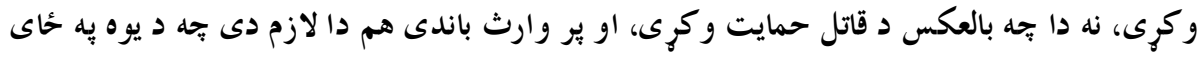

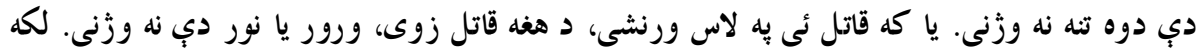

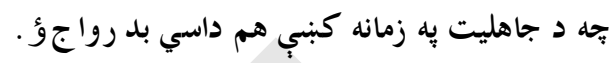

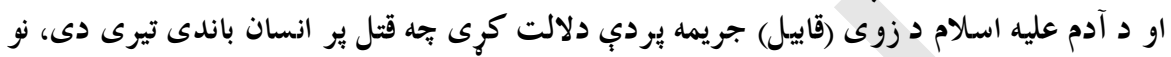

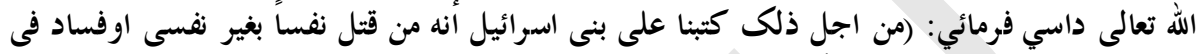

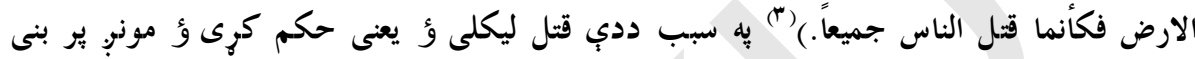

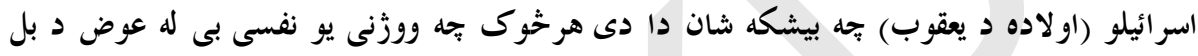

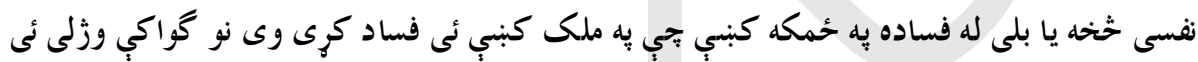

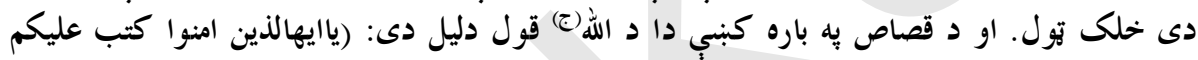

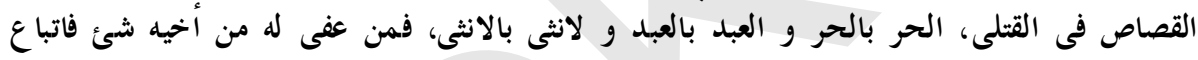

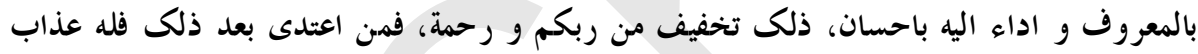

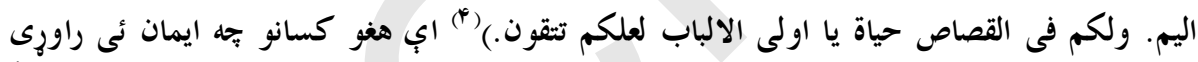

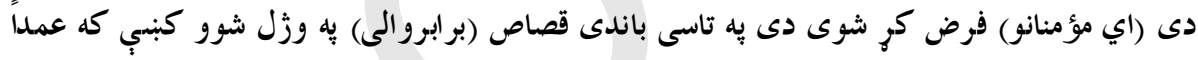

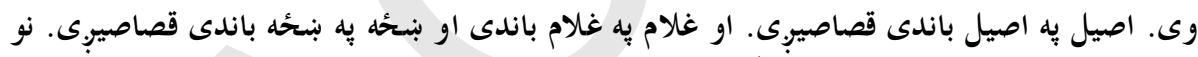

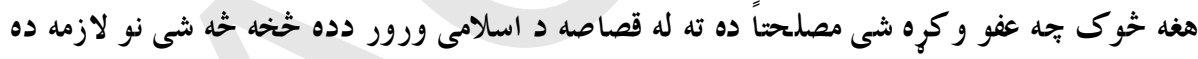

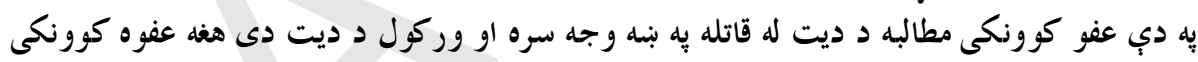

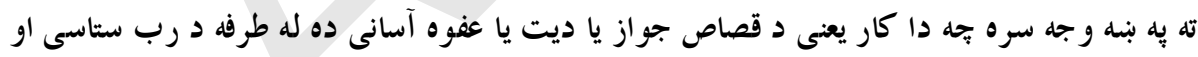

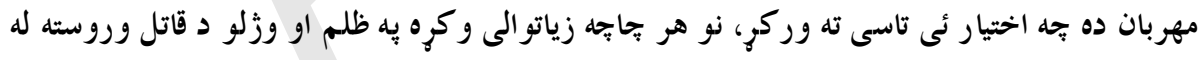

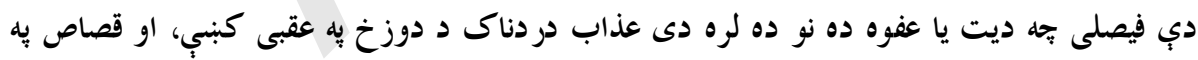

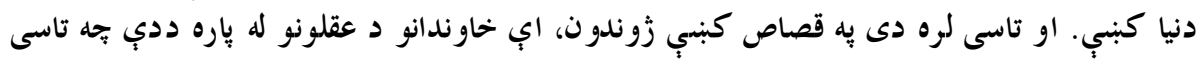
حمان وساتى له ناحقوو وينو خخه.

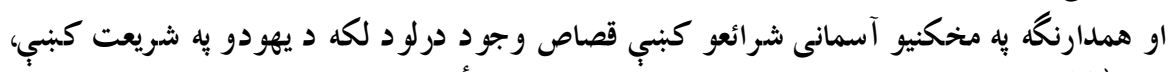

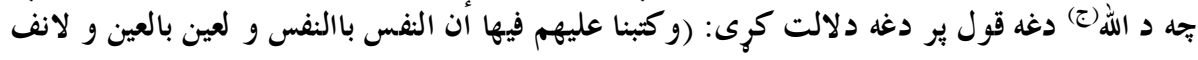

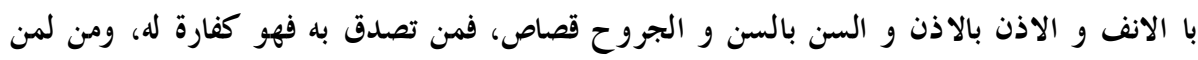

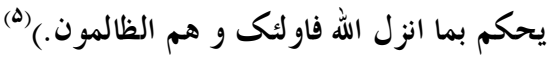

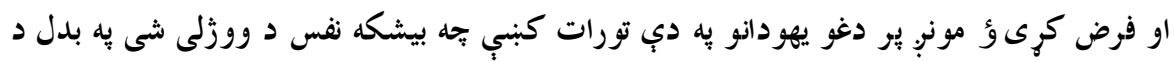

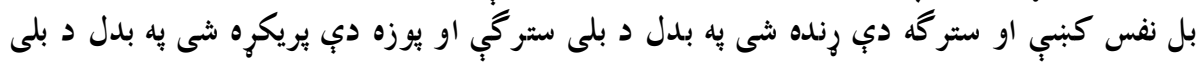




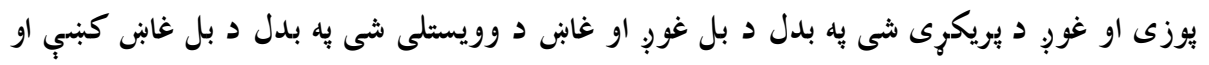

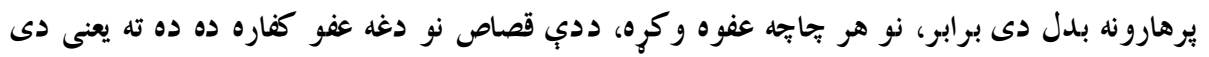

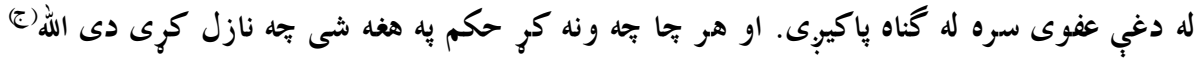
نو د هغه كسان هم دوى دى ظالمان.

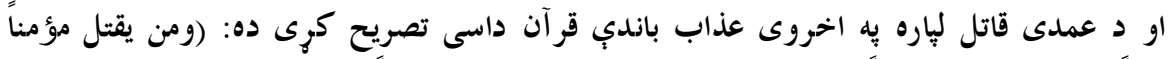

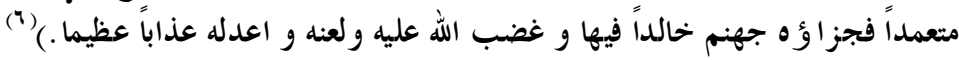

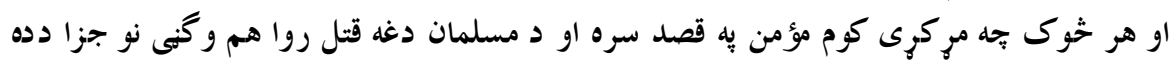

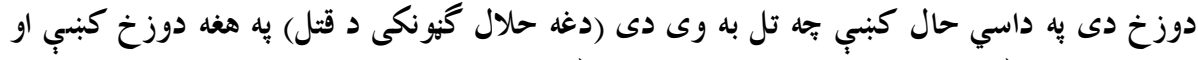

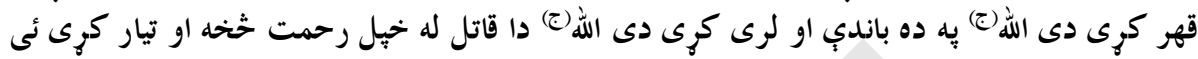

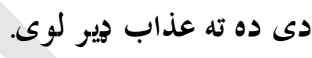

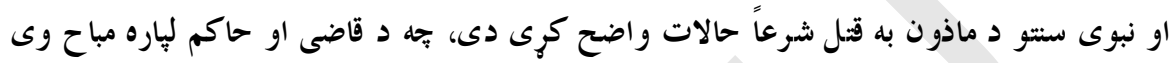

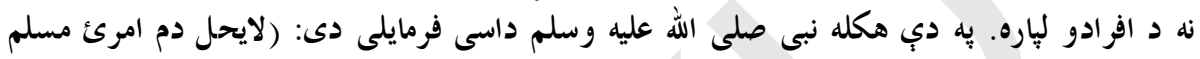

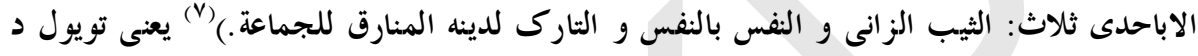

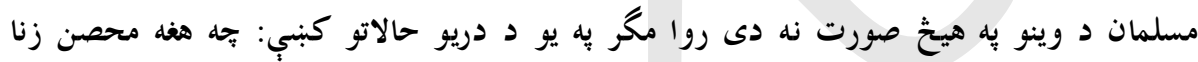

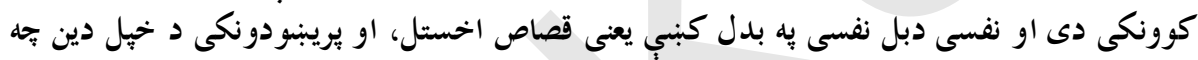

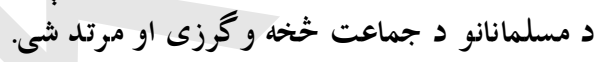

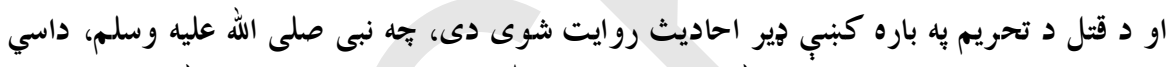

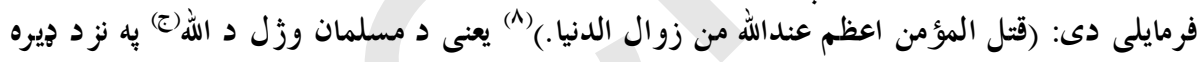

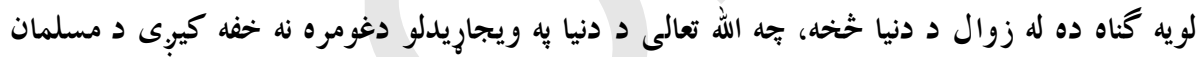

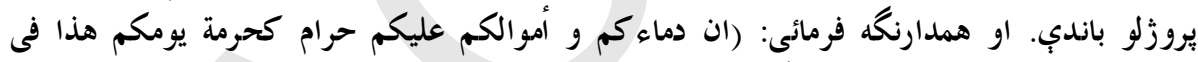

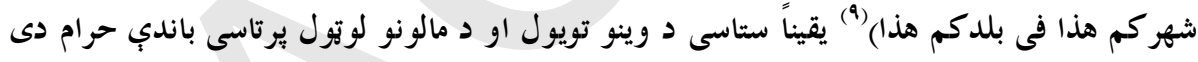

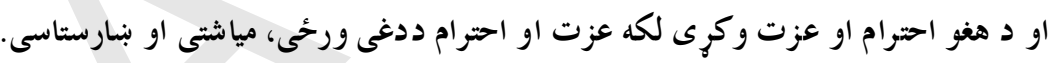

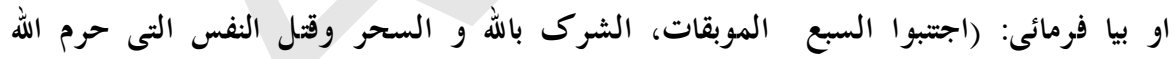

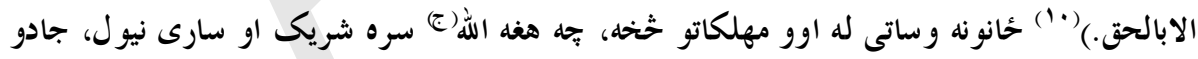

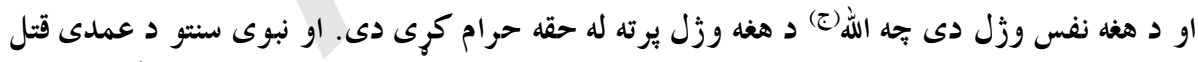

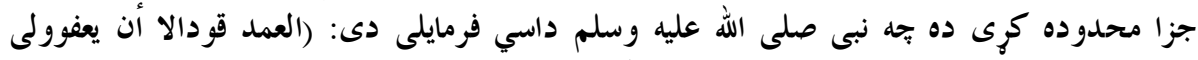

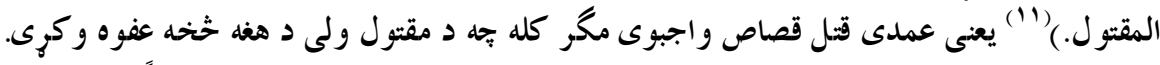

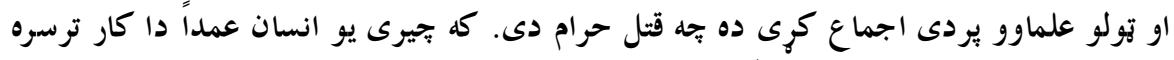

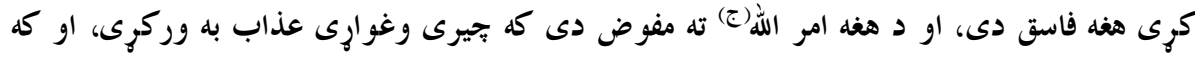

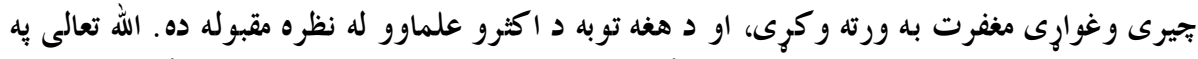

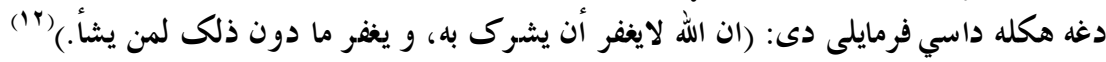

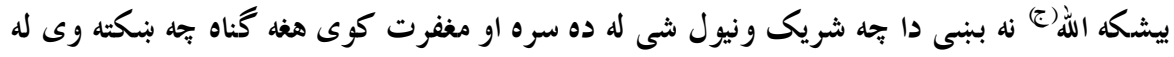

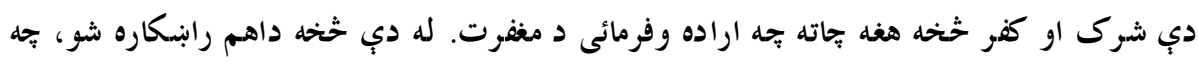




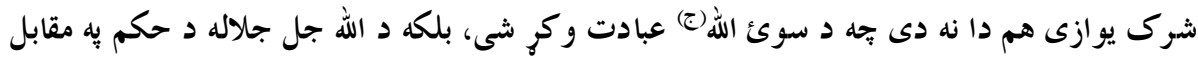

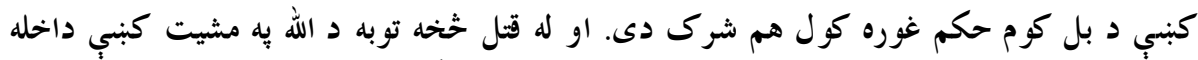

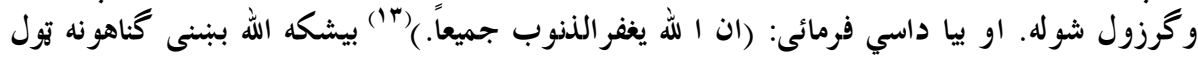

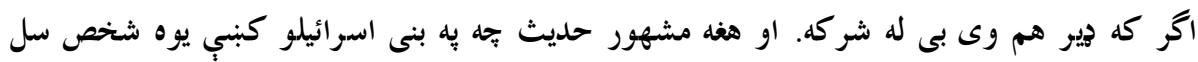

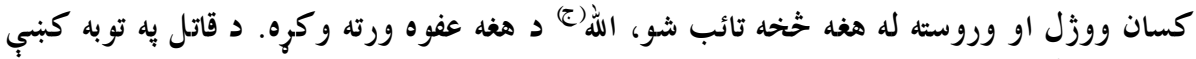

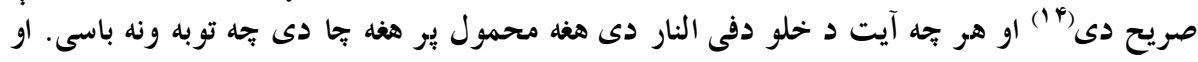

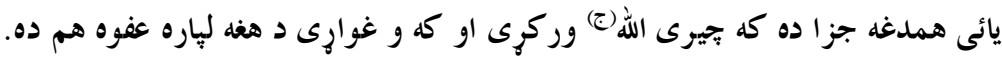

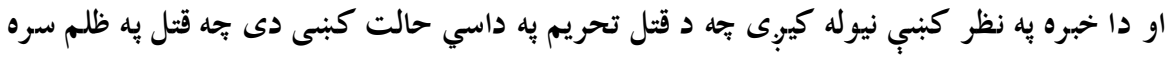

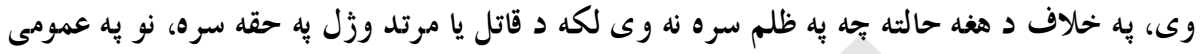

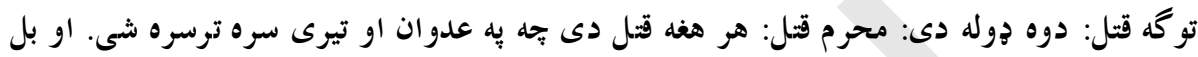

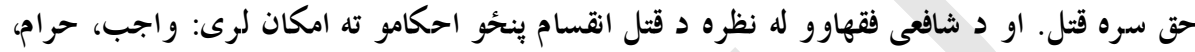

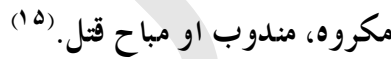

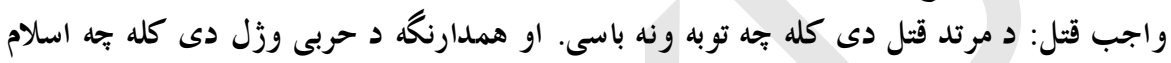

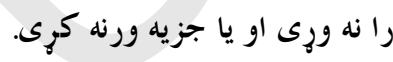

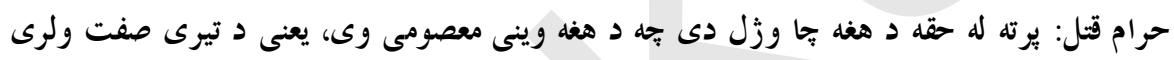

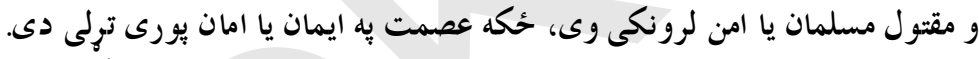

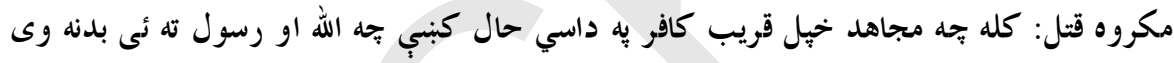
ويلى به قتل ورسوي. مندوب قتل: د مجاهد قتل دى. كله جهه خيل قريب كافر تجه الله او رسول ته ئى بد ويلى وى بِه قتل

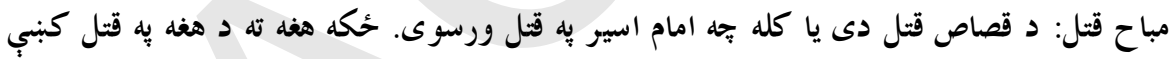

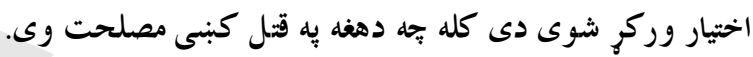

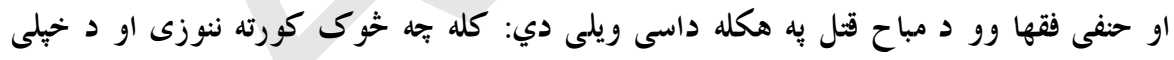

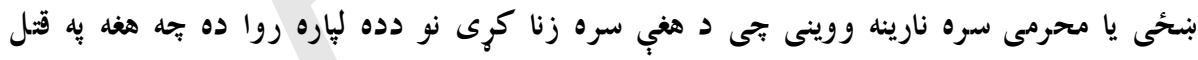

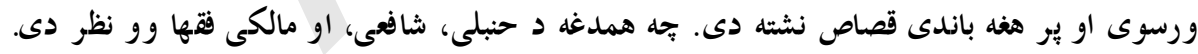

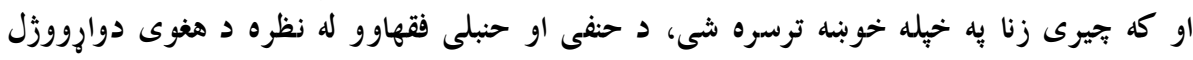

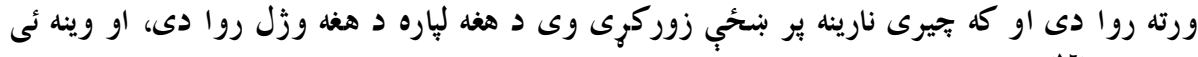
هدره ده. (14)

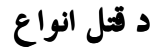

حنفى فقها وائى: قتل برينخو انواعو ويشل شوى دى: عمد، شبه، عمد، خطا، جارمجراى خطا، 


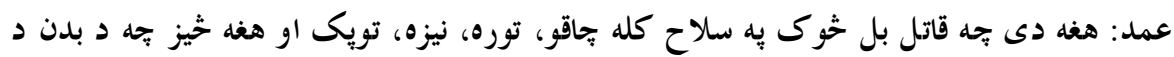

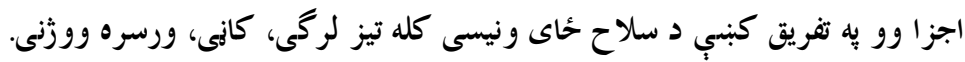

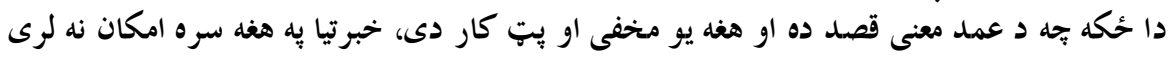

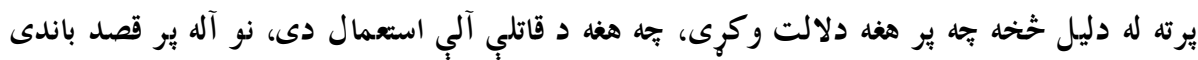

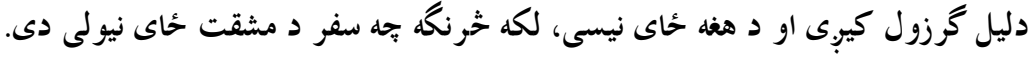

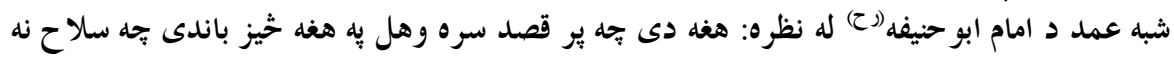

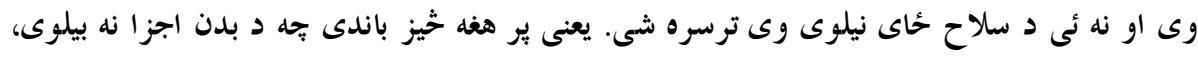

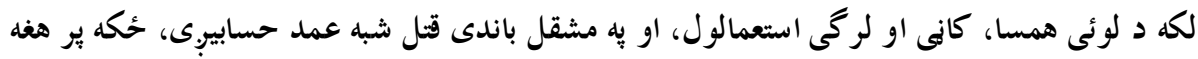

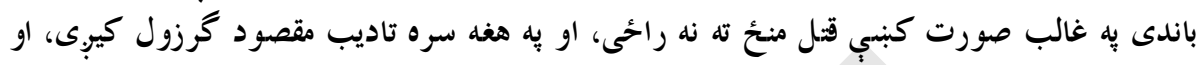

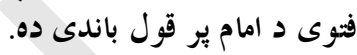

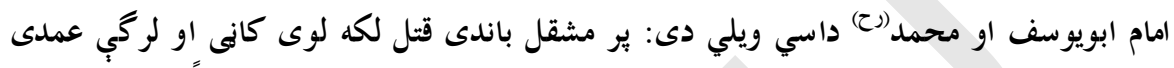

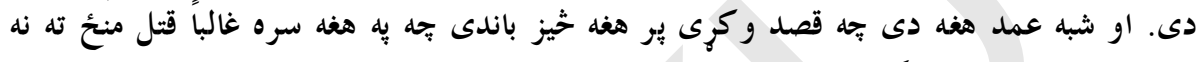

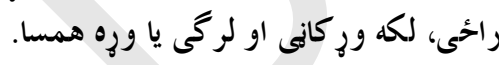

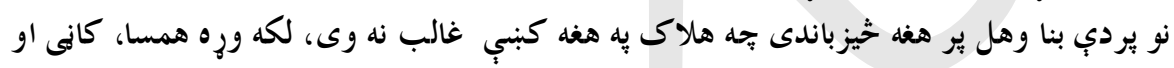

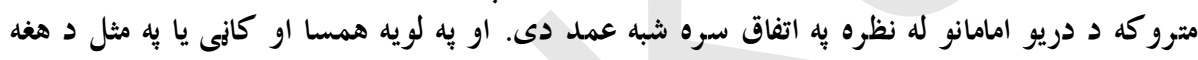

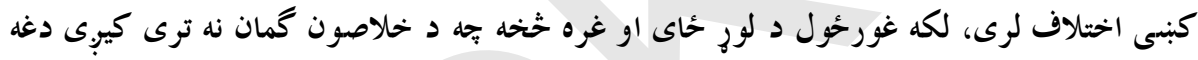

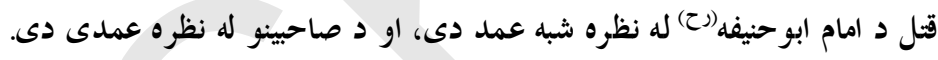

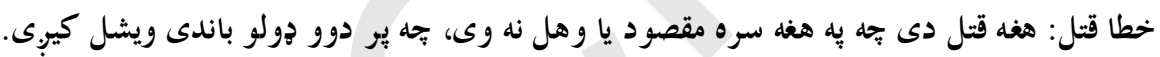

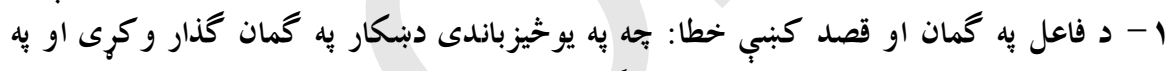

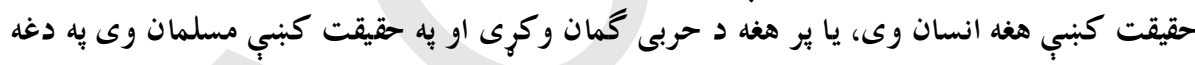

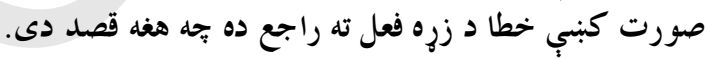

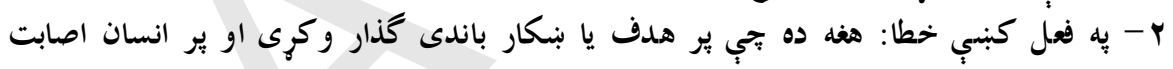

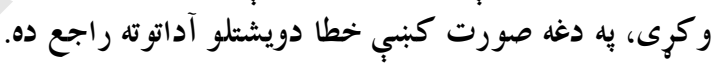

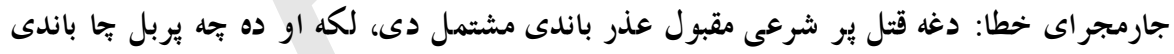

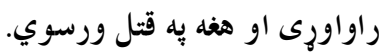

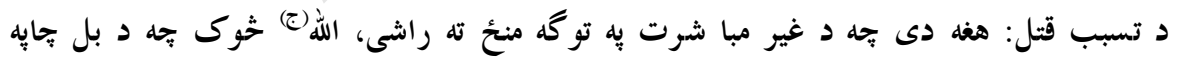

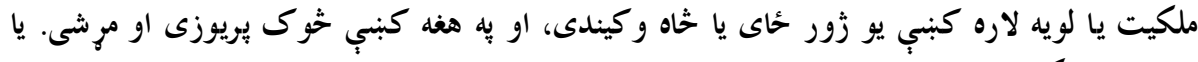

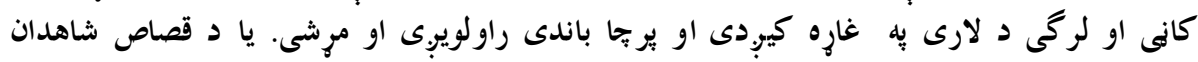

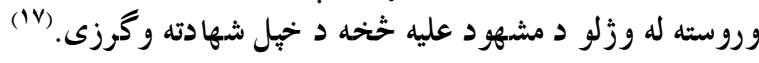

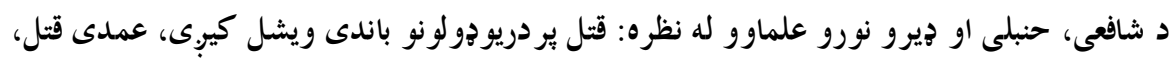
شبه عمد او خطا. 


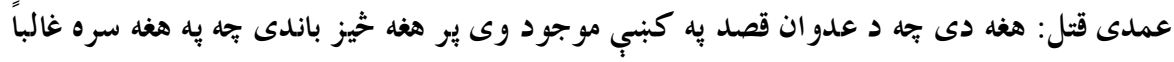

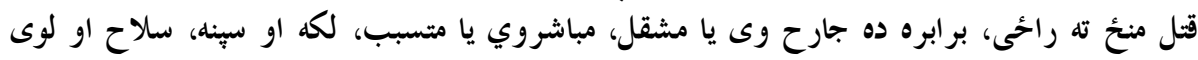

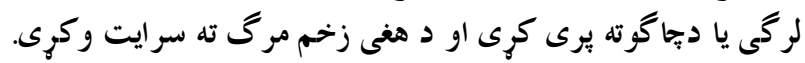

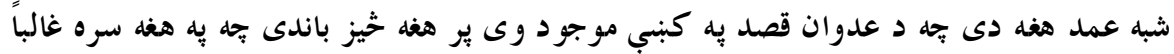

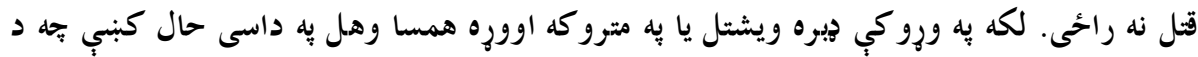

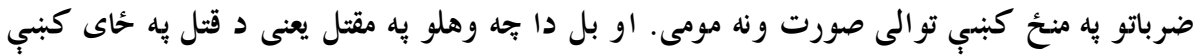

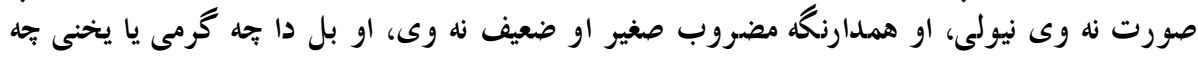

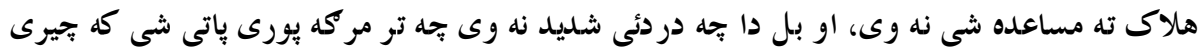

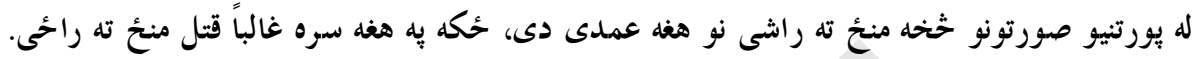

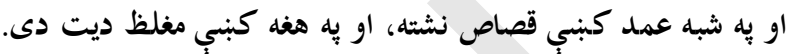

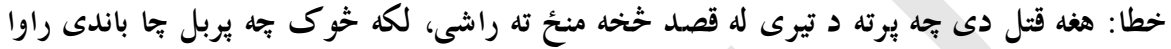

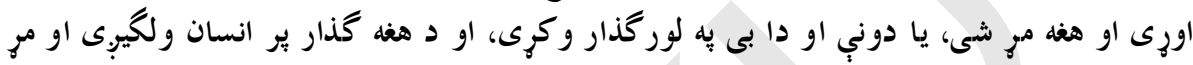

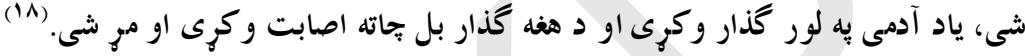

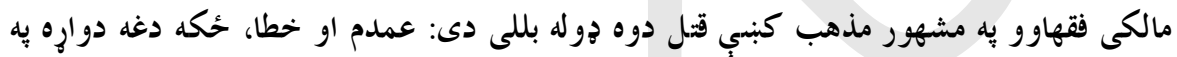

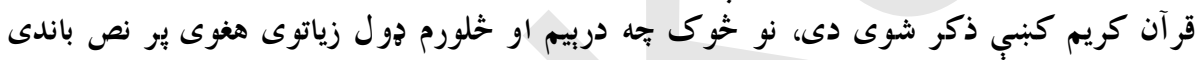

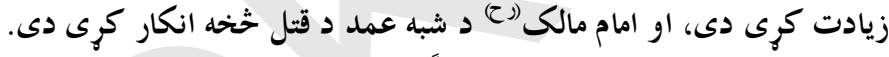

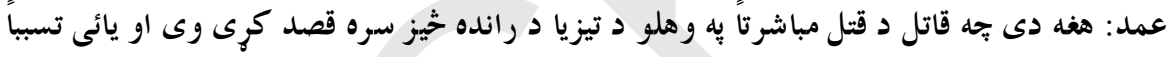

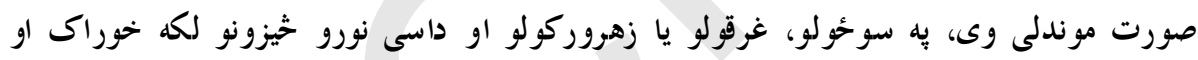

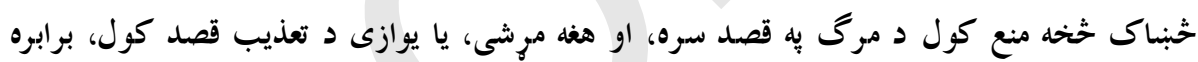

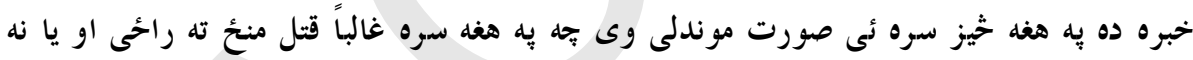

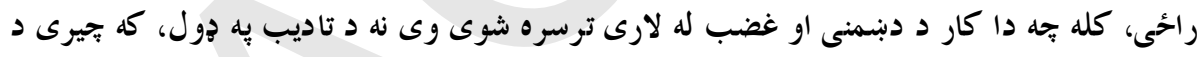

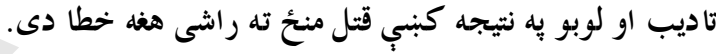

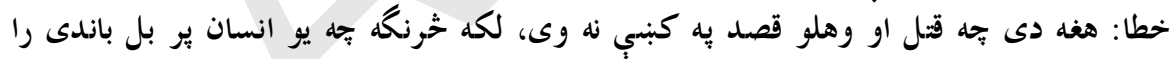

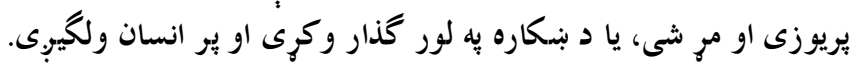

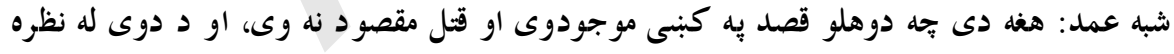

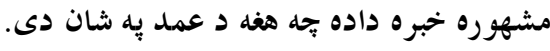

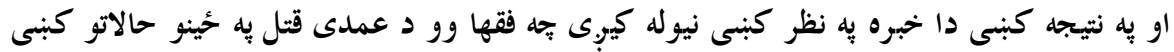

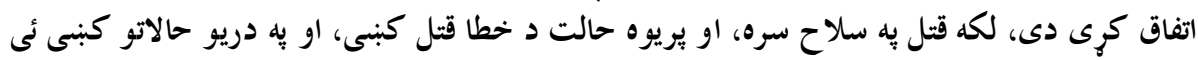

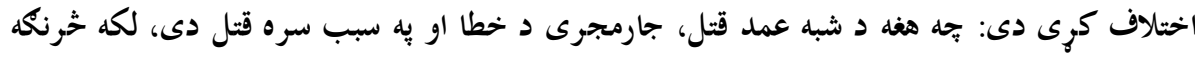

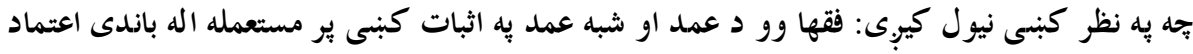

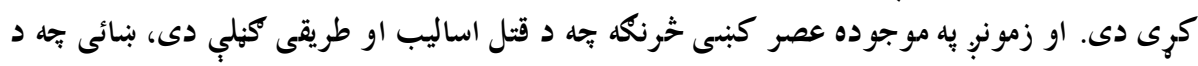

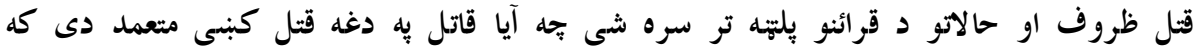




\section{د عمدى قتل اركان}

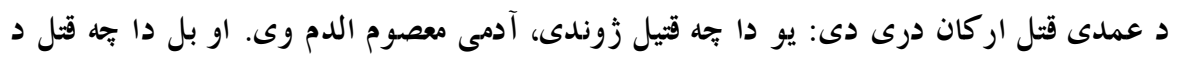

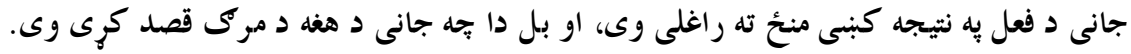

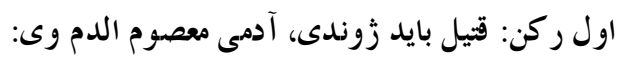

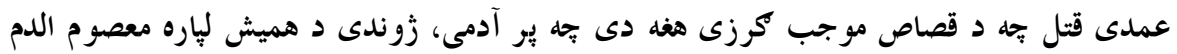

$$
\text { باندى تيرى ترسره شى. }
$$

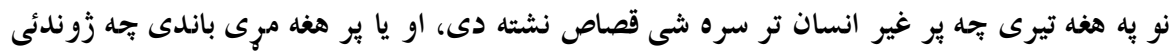

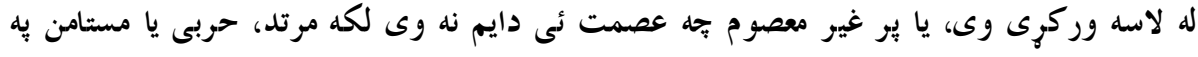

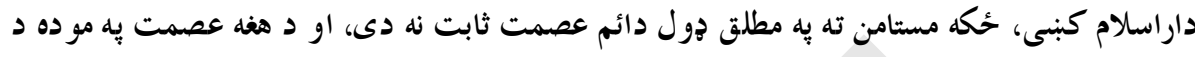

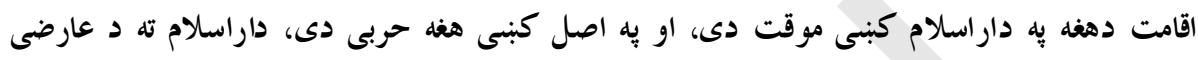

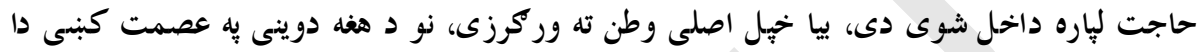

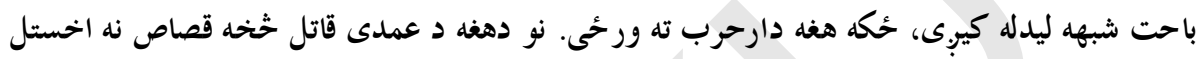

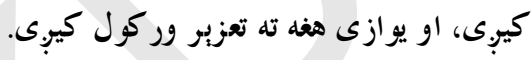

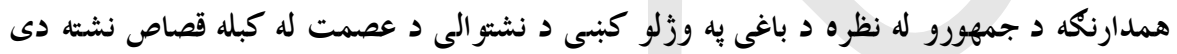

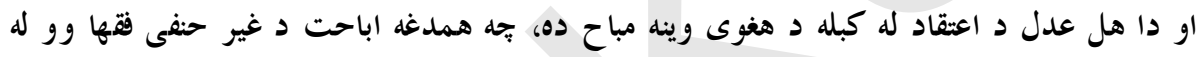

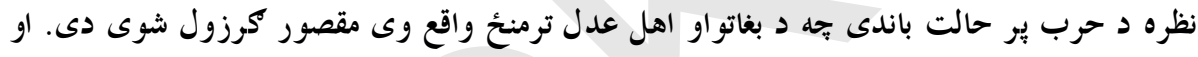

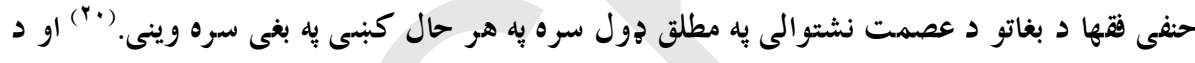

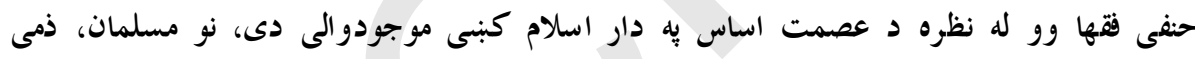

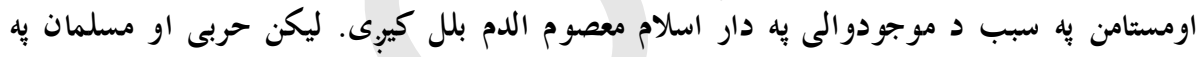

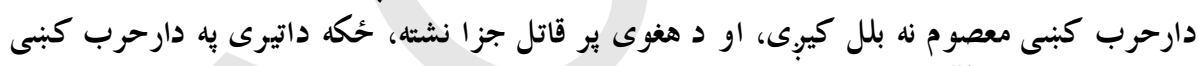
تر سره شوى دى. (1)

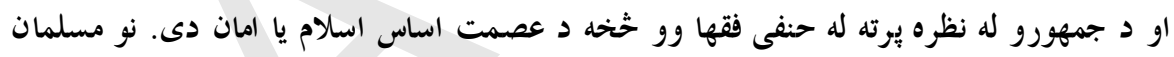

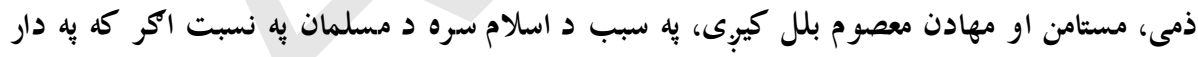

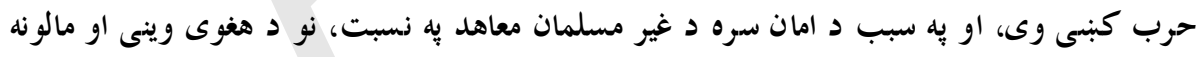

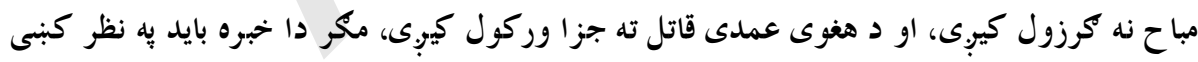

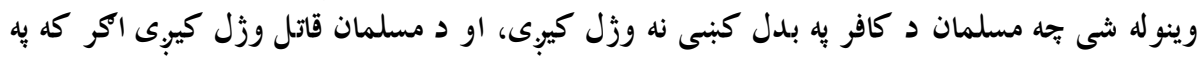

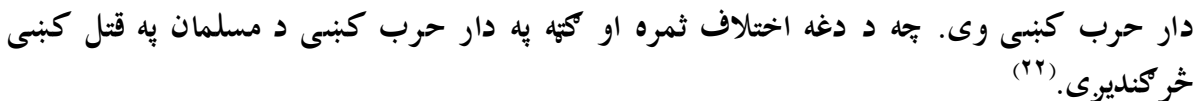

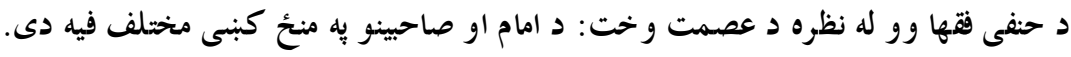

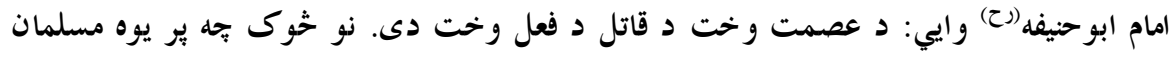

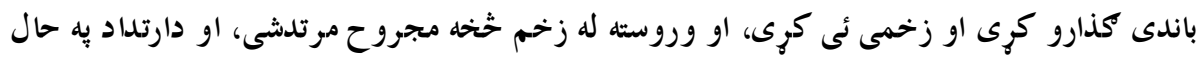

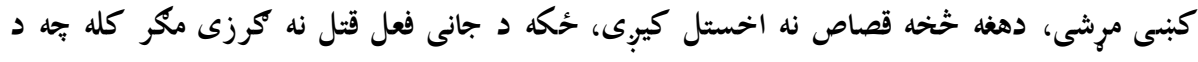

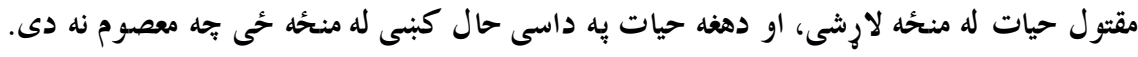




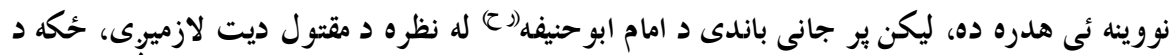

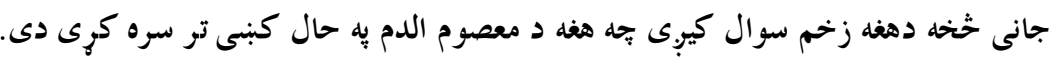

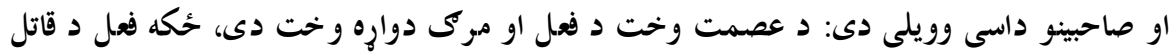

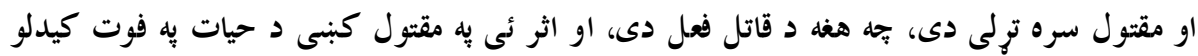

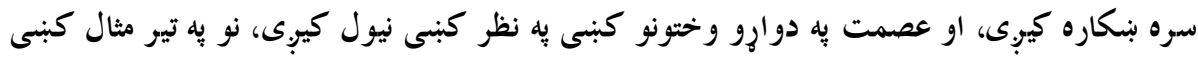

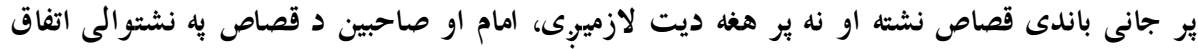

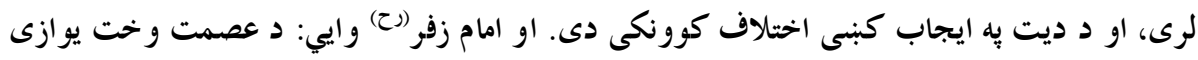

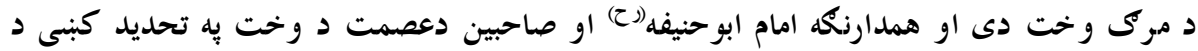

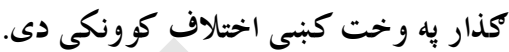

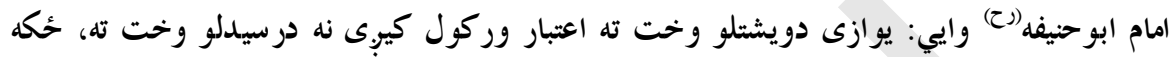

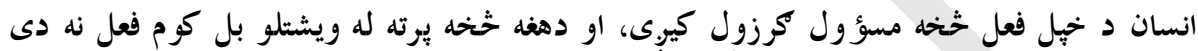

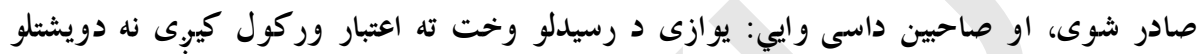

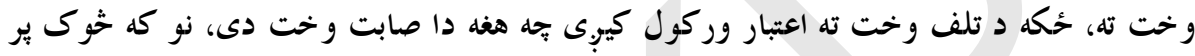

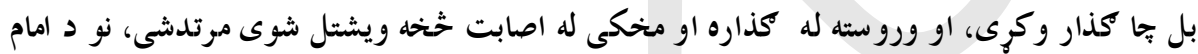

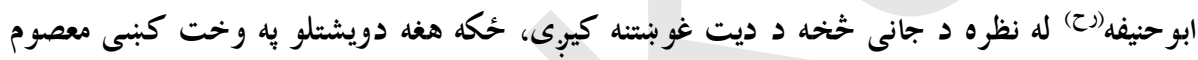

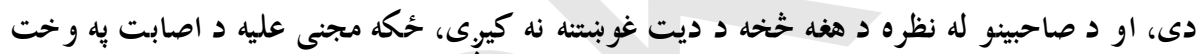
كبنسى معصوم نه دى أله.

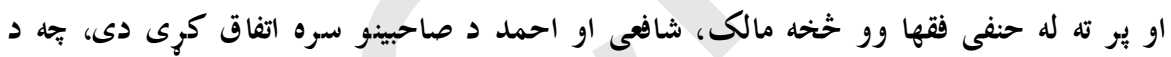

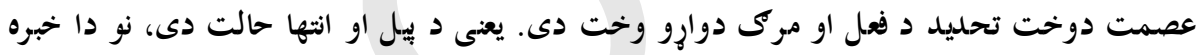

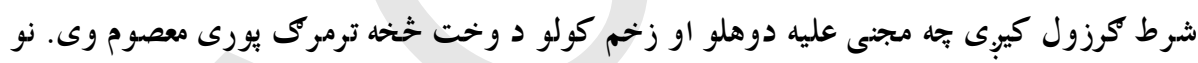

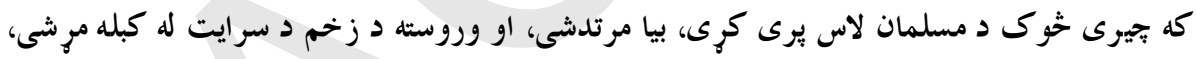

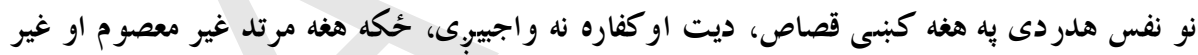

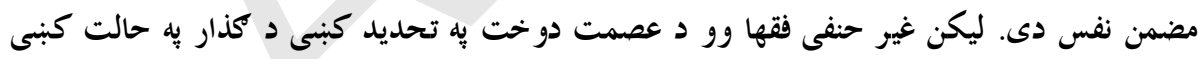

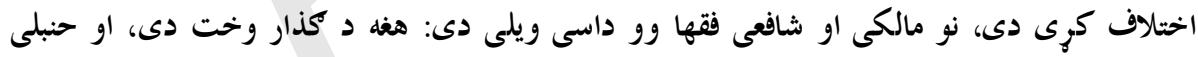

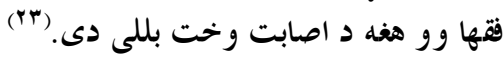

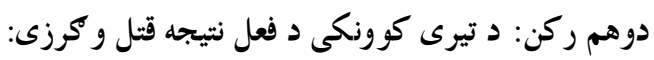

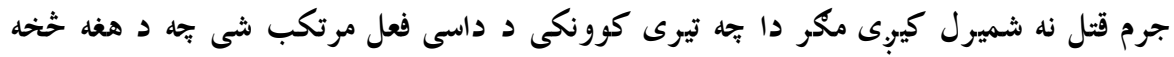

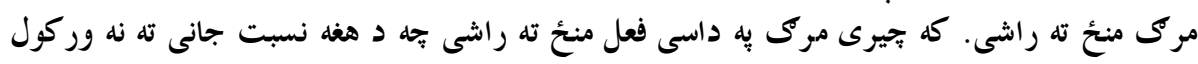

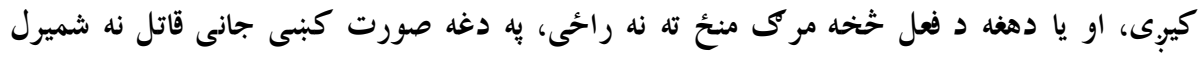

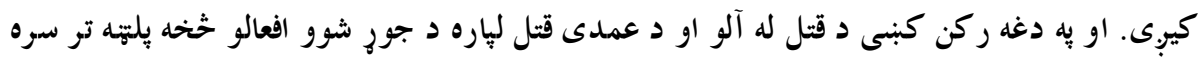
كيوىى. 
د قدل آدات

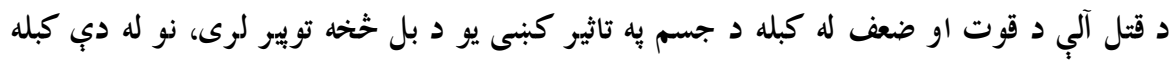

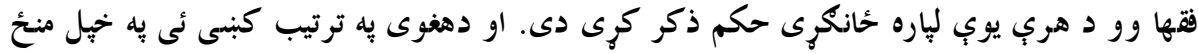

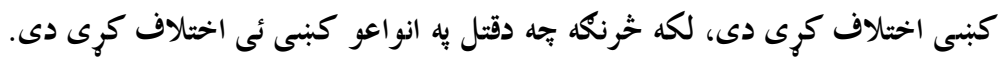

\section{اول - د حنفى فقها وو نظر او رايه}

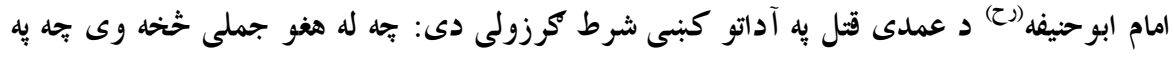

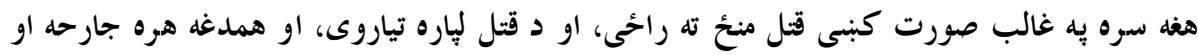

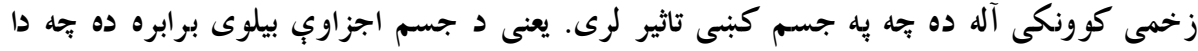

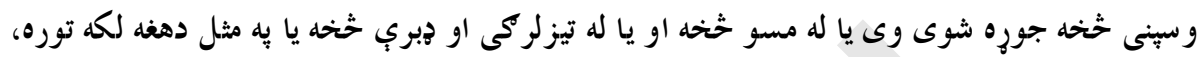

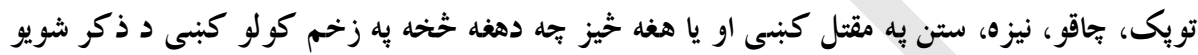

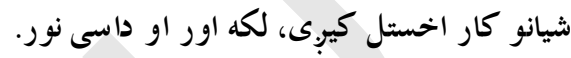

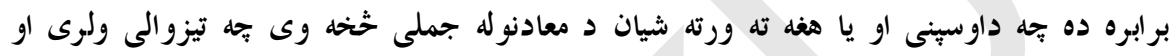

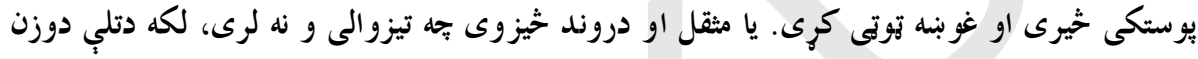
كانى، د تبرشا او هغه ته ورته شيان.

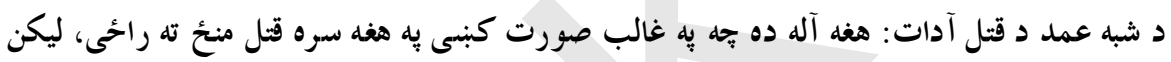

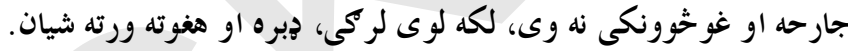

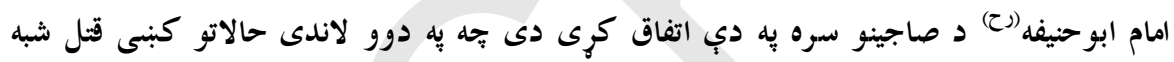

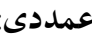

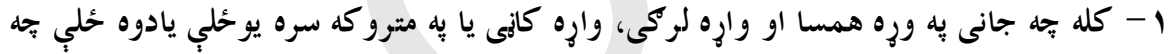

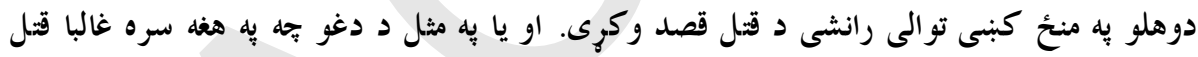

$$
\text { منحُ ته نه رائى. }
$$

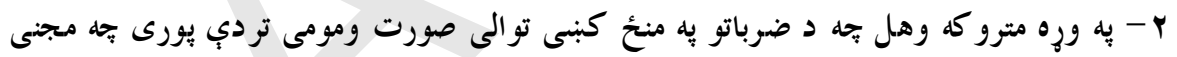

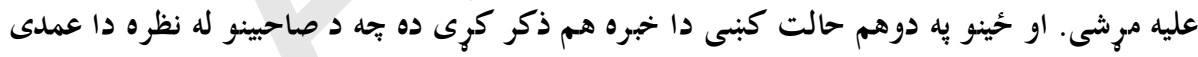
قتل دى.

$$
\text { امام ابوحنيفه(ح) او صاحبينو به دوونو روحالاتو كبنى اختلاف كرى دي دي. }
$$

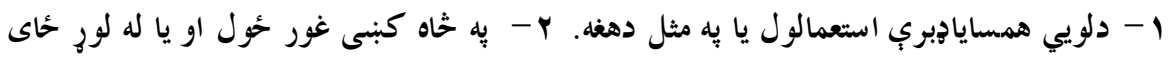

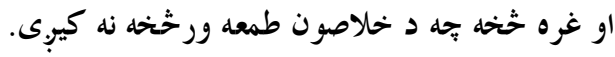

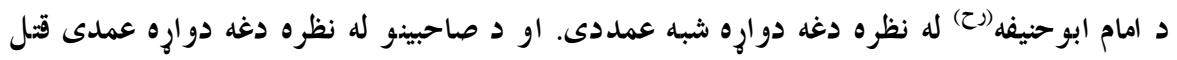

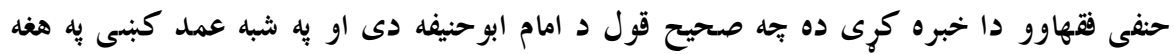

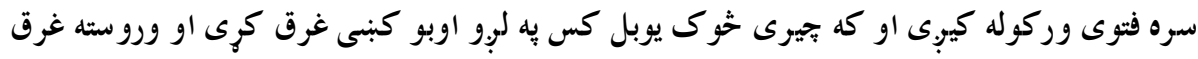

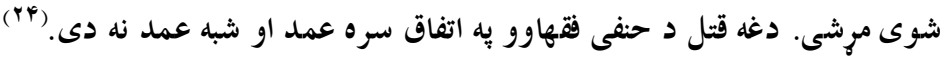




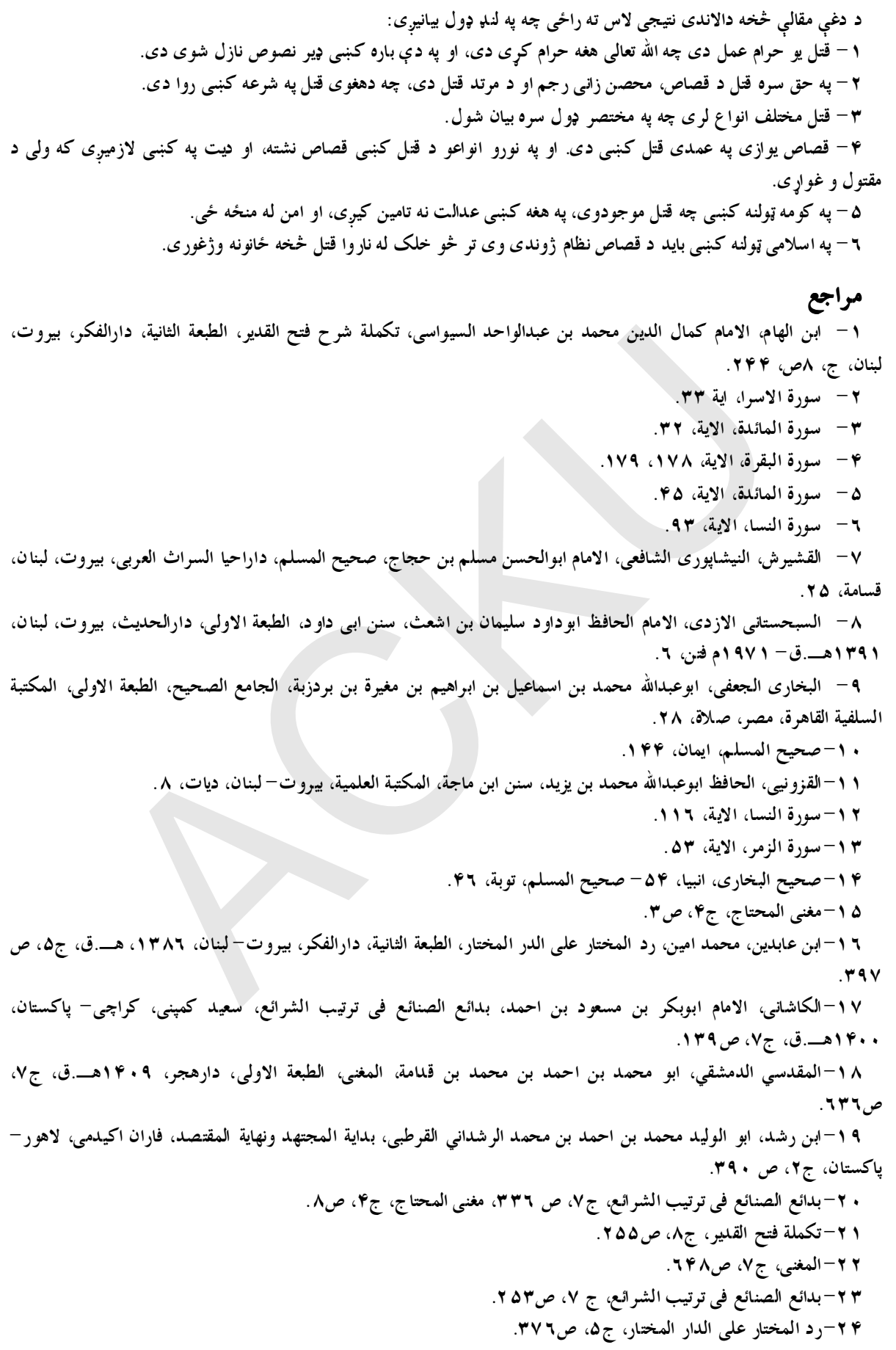




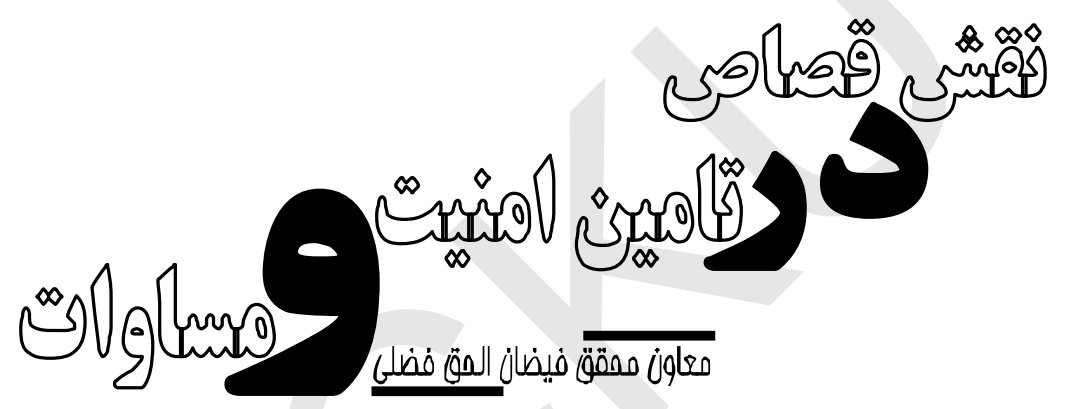

عقوبات (مجازات) كه قصاص بخشى از آن است در اسلام حلقهاى است از حلقههاى به هم

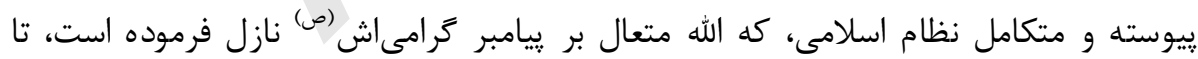

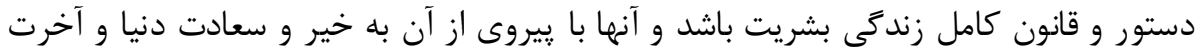

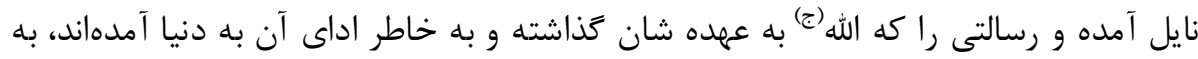
خوبى ادا نمايند.

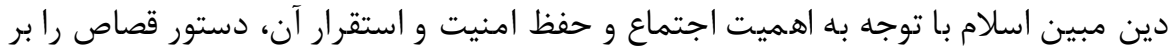

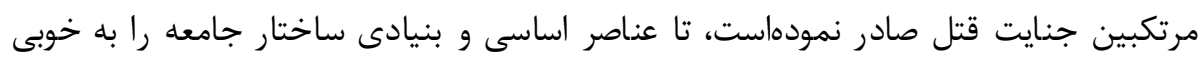

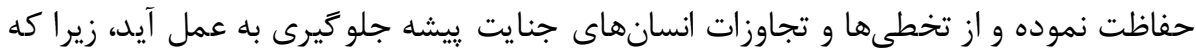

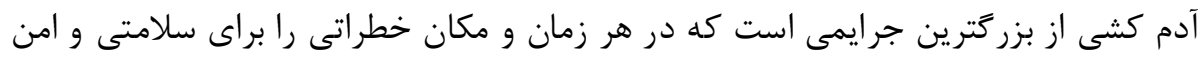
جامعه به بار مى آورد. 
به اين اساس لازم ديده مىشود تا نخست به طور فشرده از تعريف لغوى و اصطلاحى قصاص بحث نموده سيس به اصل اصل موضوع بر درديم.

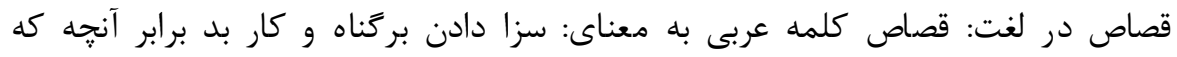

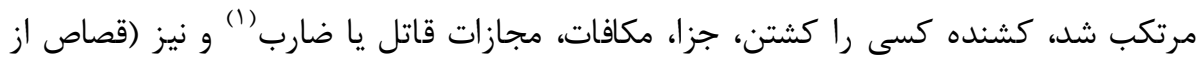

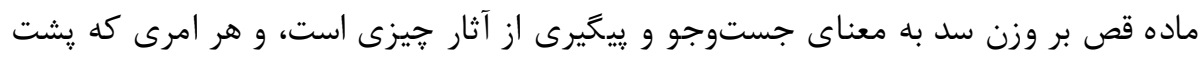

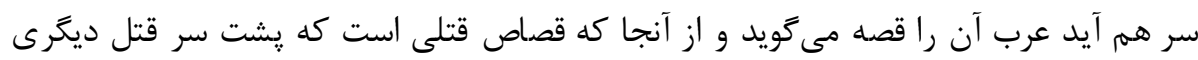

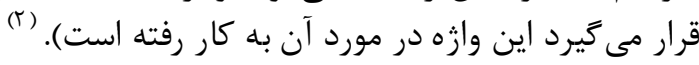

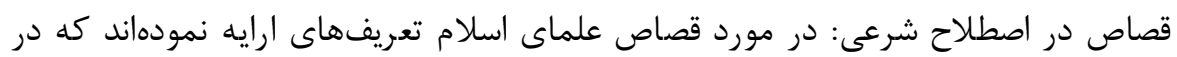

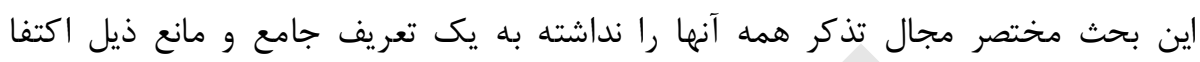

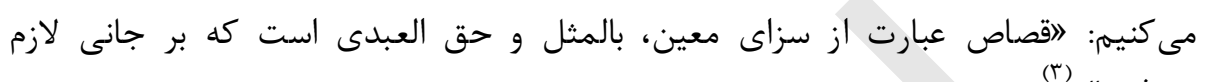

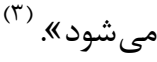

\section{شرح تعريف اصطلاحى سنى}

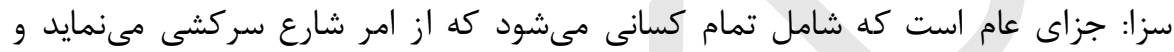

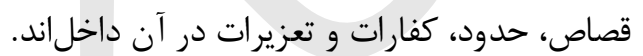

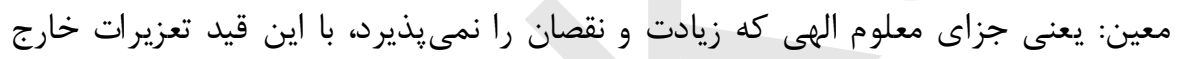

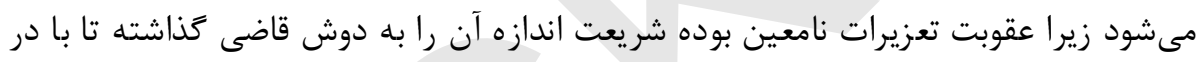

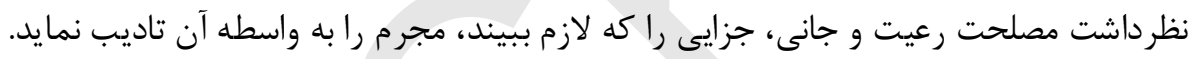

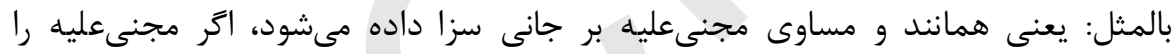

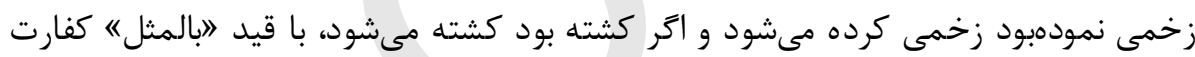

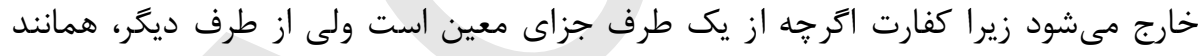

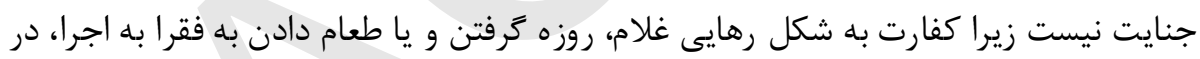
مى آيد. حقاً للعبد: اين قيد حدود را خارج مىسازد زيرا حدود تنها حق الله متعال مىباشد و بنده ران

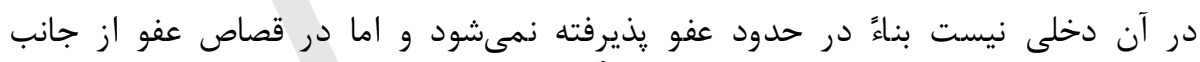

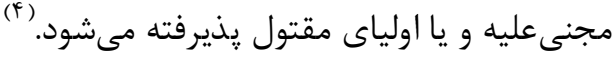

\section{نظر عمومى برجر مقتل و عقوبت شرعى آن (قصاص)}

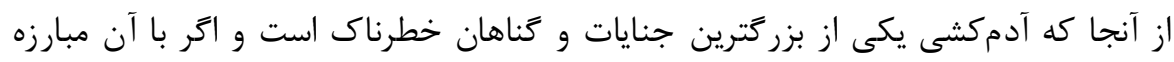

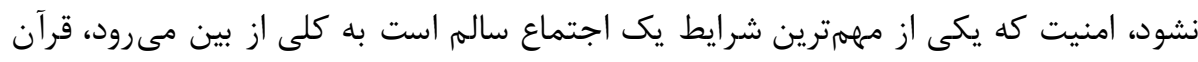

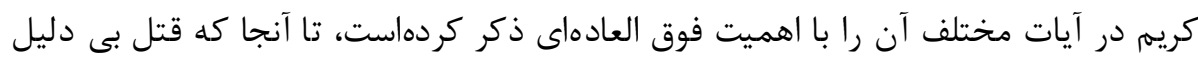

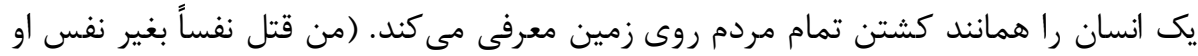

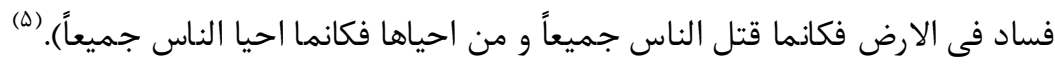


يعنى: آن كس كه انسانى را بدون اينكه قاتل باشد و يا در زمين فساد كند بكشد، كويا همه

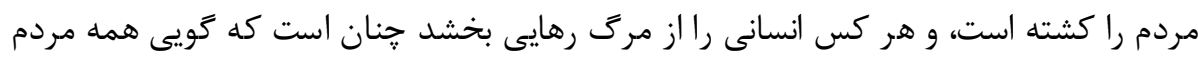
رازندا كردماست

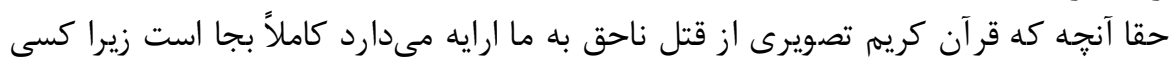

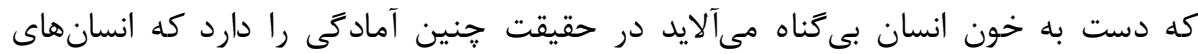

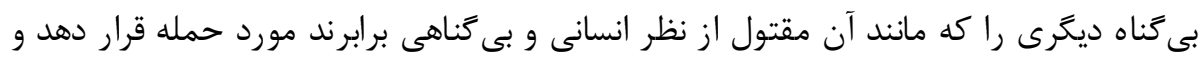

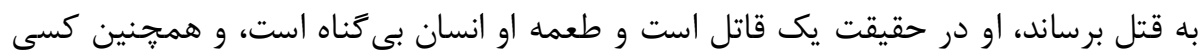

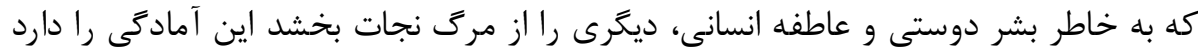

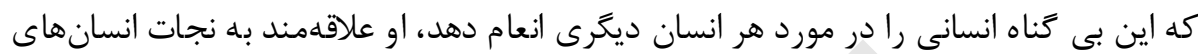

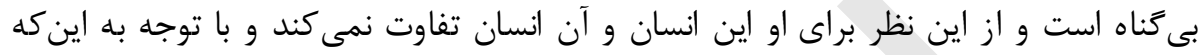

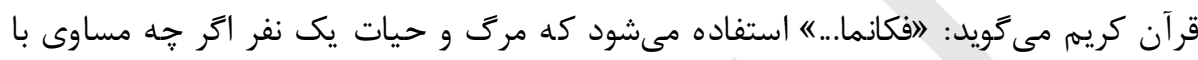

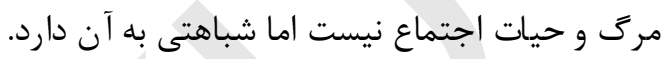

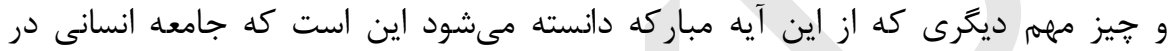

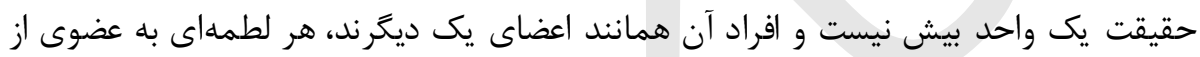

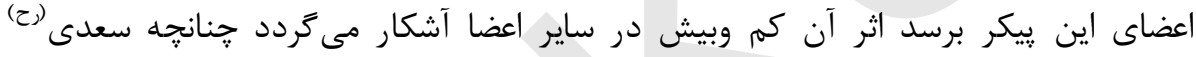

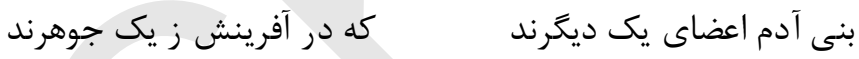

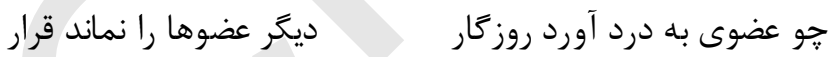

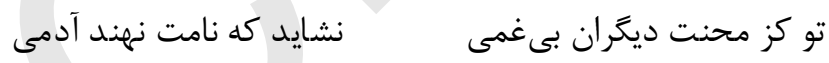

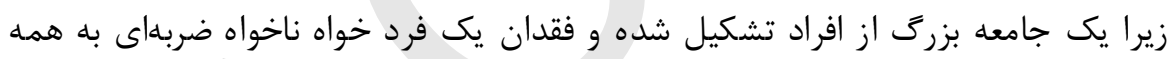

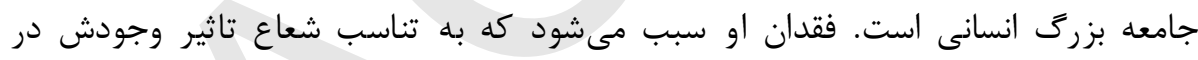

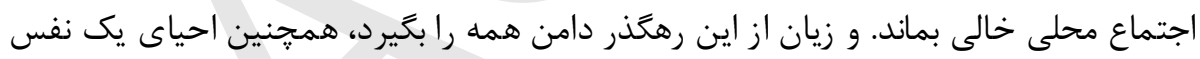

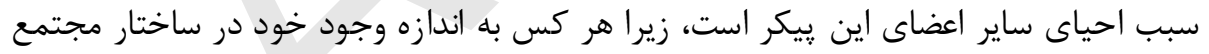

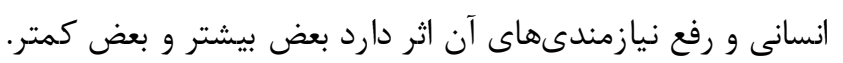

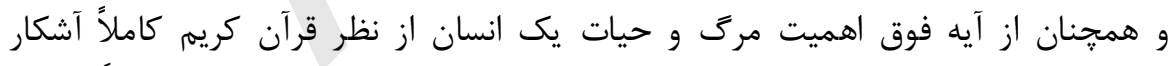

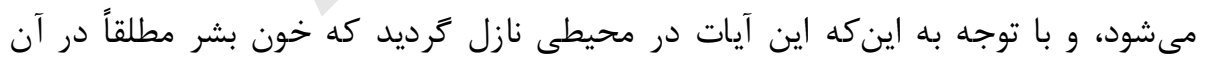
ارزشى نداشت عظمت آن آشكارتر مى كر دد.

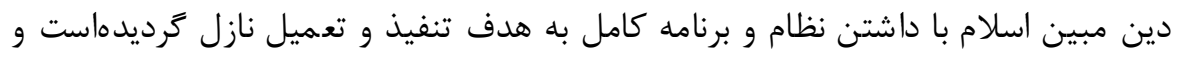

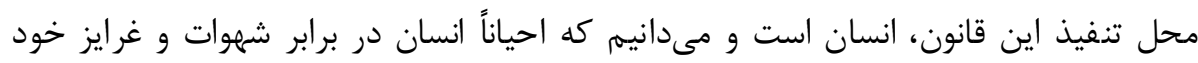

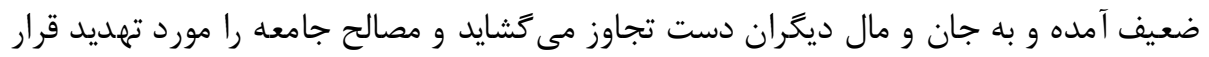

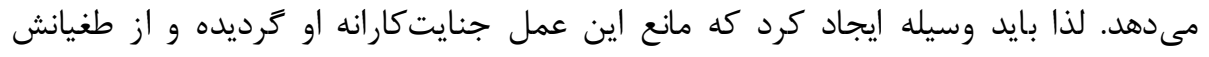

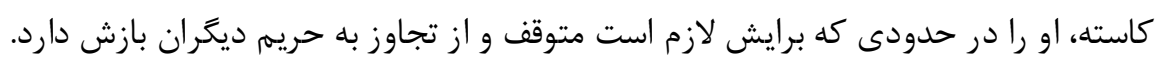


يس عقوبت قصاص يخانه عامل باز دارنده از آدمكشىها و وسيله خوبى جهت آوردن امنيت و

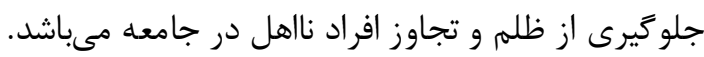

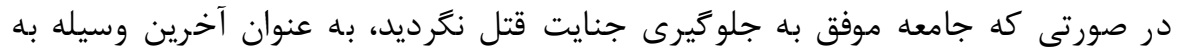

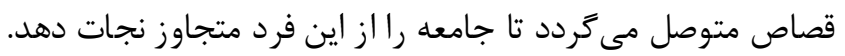

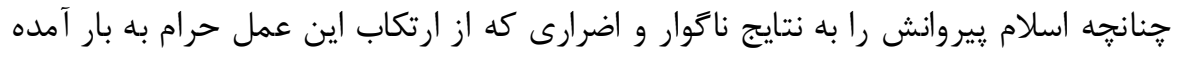

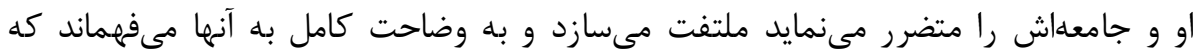

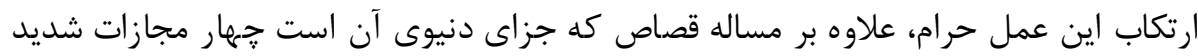

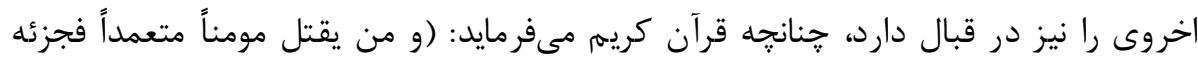

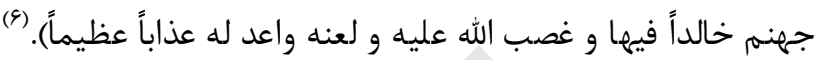

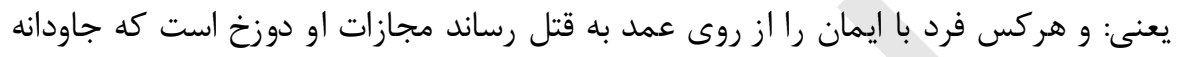

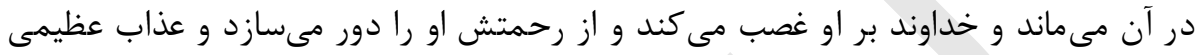
براى او آماده ساختهاست. و به اين ترتيب تطبيق قصاص و عقوبات در اسلام بر كسانى كه از اين همه حدود حدود تجاوز

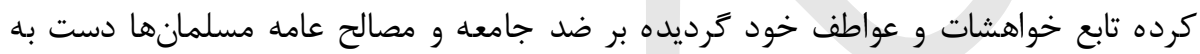

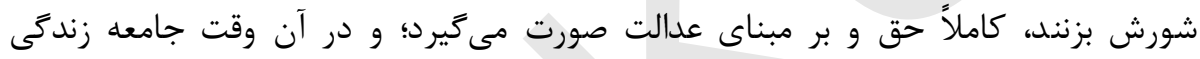

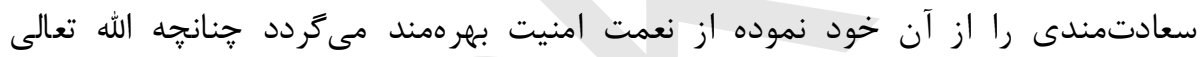

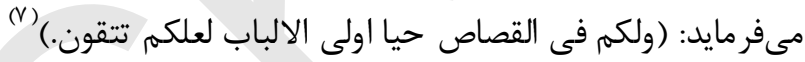

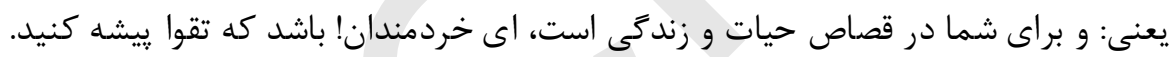

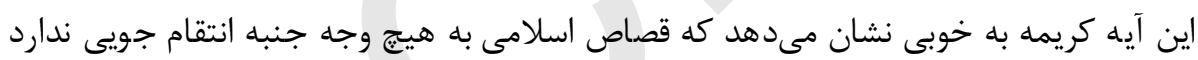

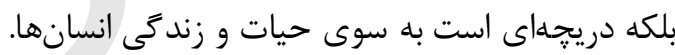

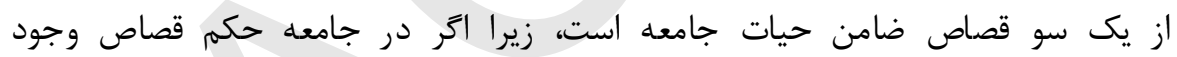

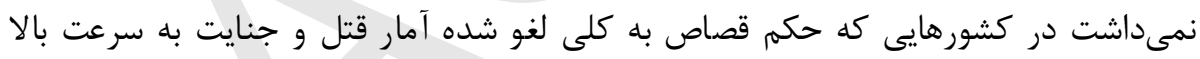

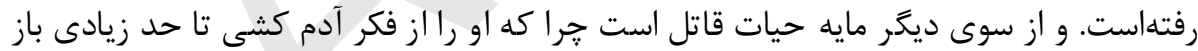

$$
\text { مى دارد و كنترول مى كند. }
$$

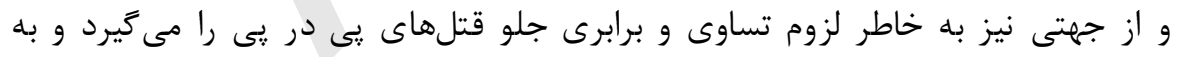

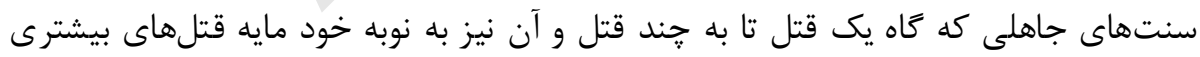

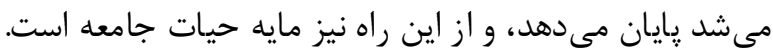

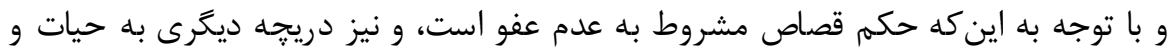

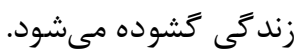

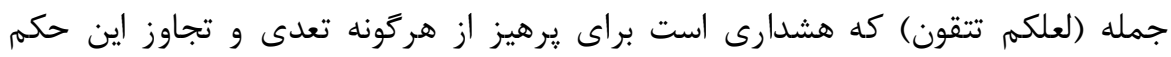

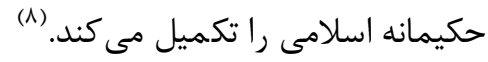

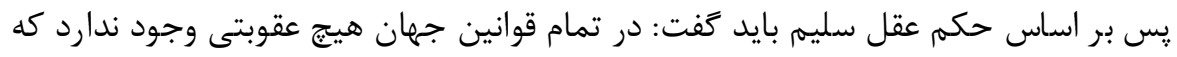

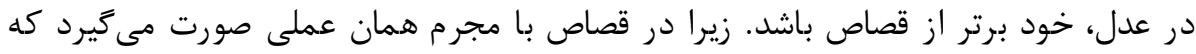


مرتكب شدهاست. و عاملى كه مجرم را به سوى جرم مى كشاند، اكثراً تنافع بقا و حب برترى و

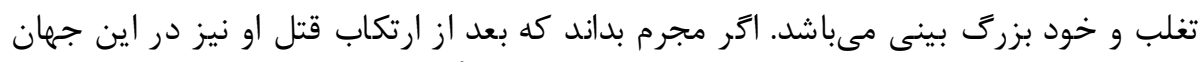

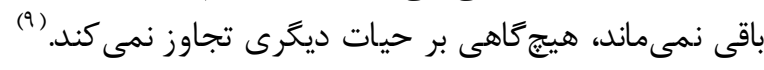

قصاص و عفو يك مجموعه عادلانه

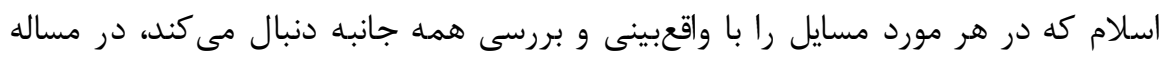

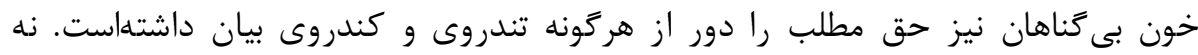

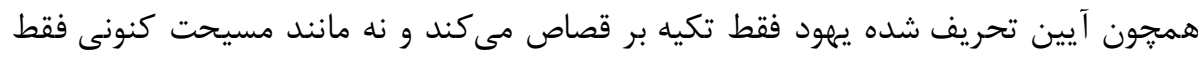

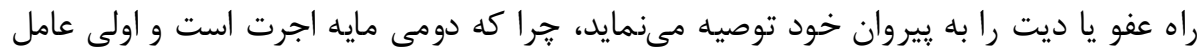

$$
\text { خشونت و انتقام جويى. }
$$

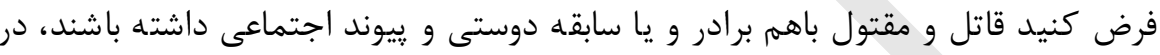

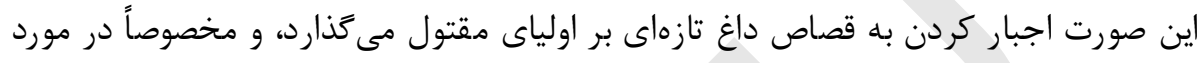

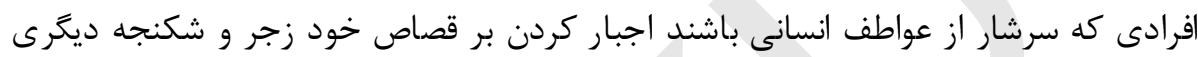

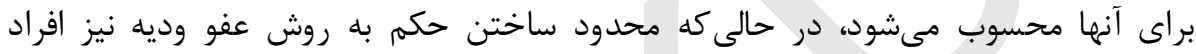

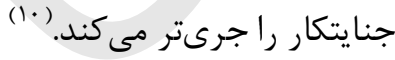

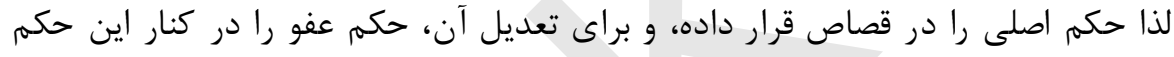

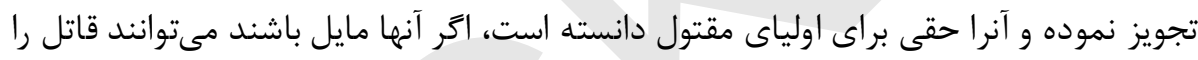

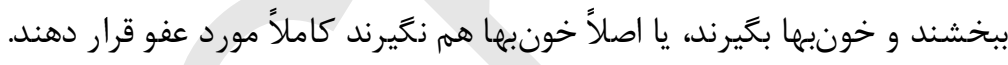

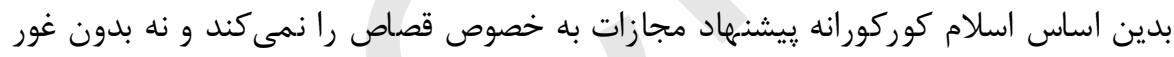

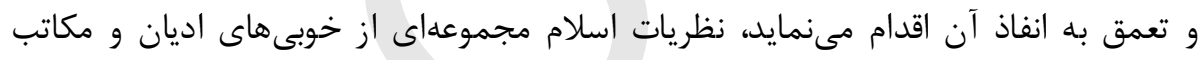

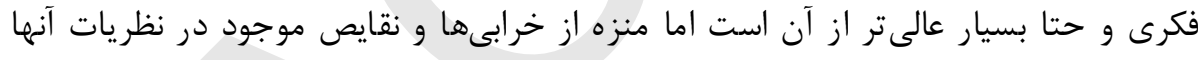

اسلام به مفهوم واقعى كلمه عدل را برقرار مىسازد، و قبل از انفاذ قصاص همه اوضاع، عوامل

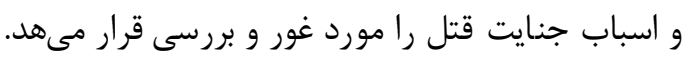

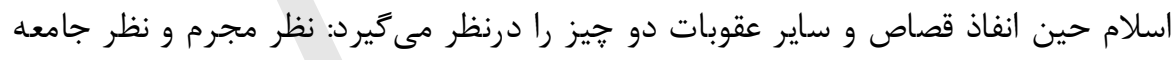

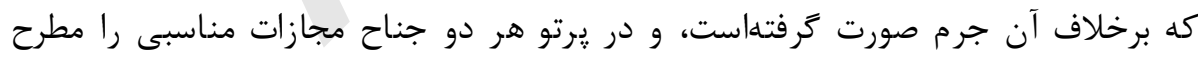

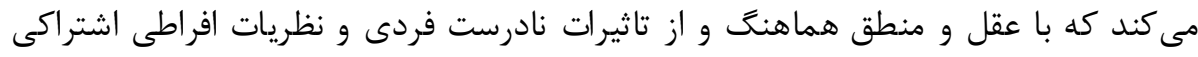
كاملاً برى مى باشد.

\section{اهداف تطبيق قصاص در اسلام}

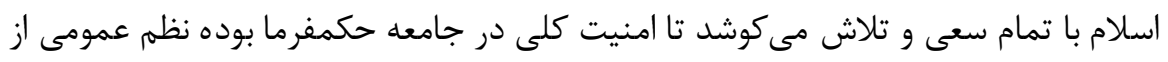

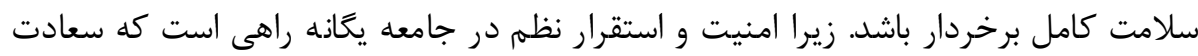

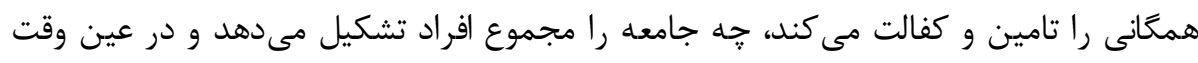

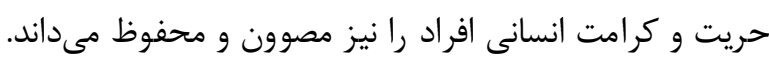




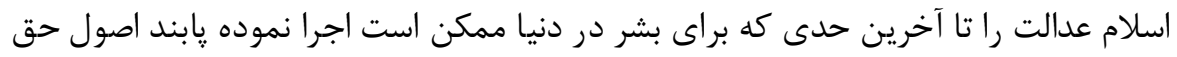

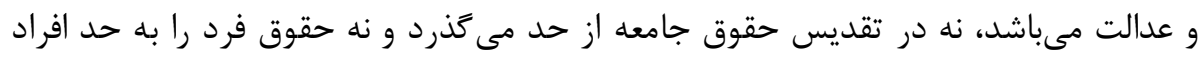

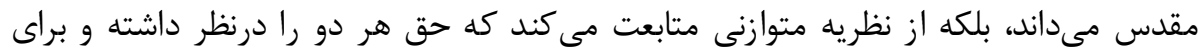

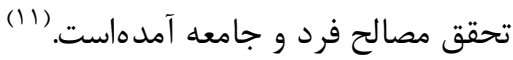

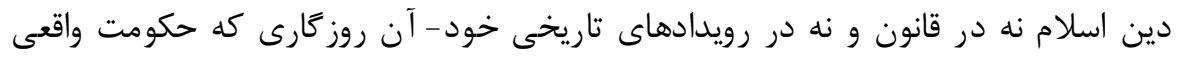

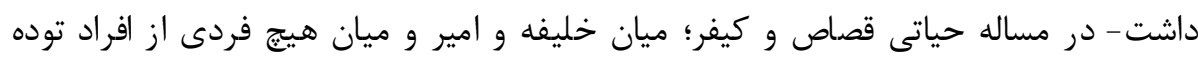

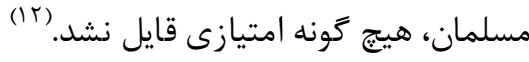

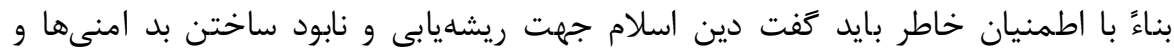

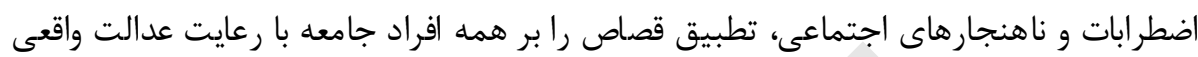

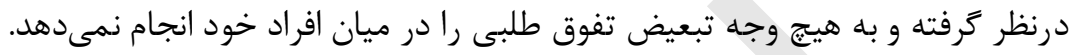

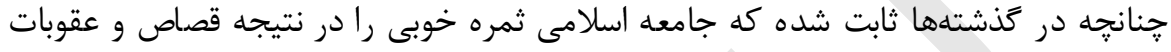

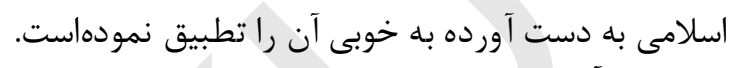

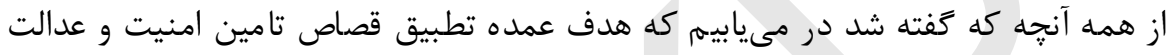

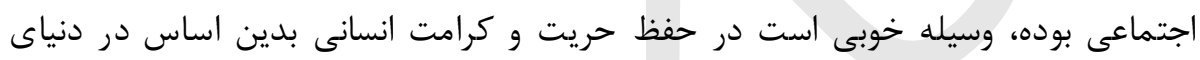

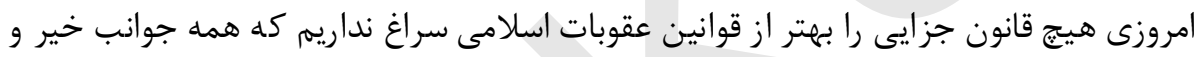

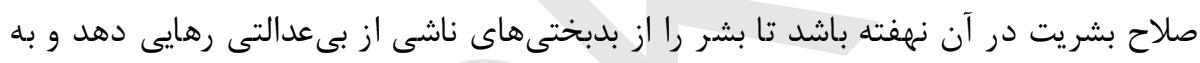
ساحل امنيت و آرامى داخل كند.

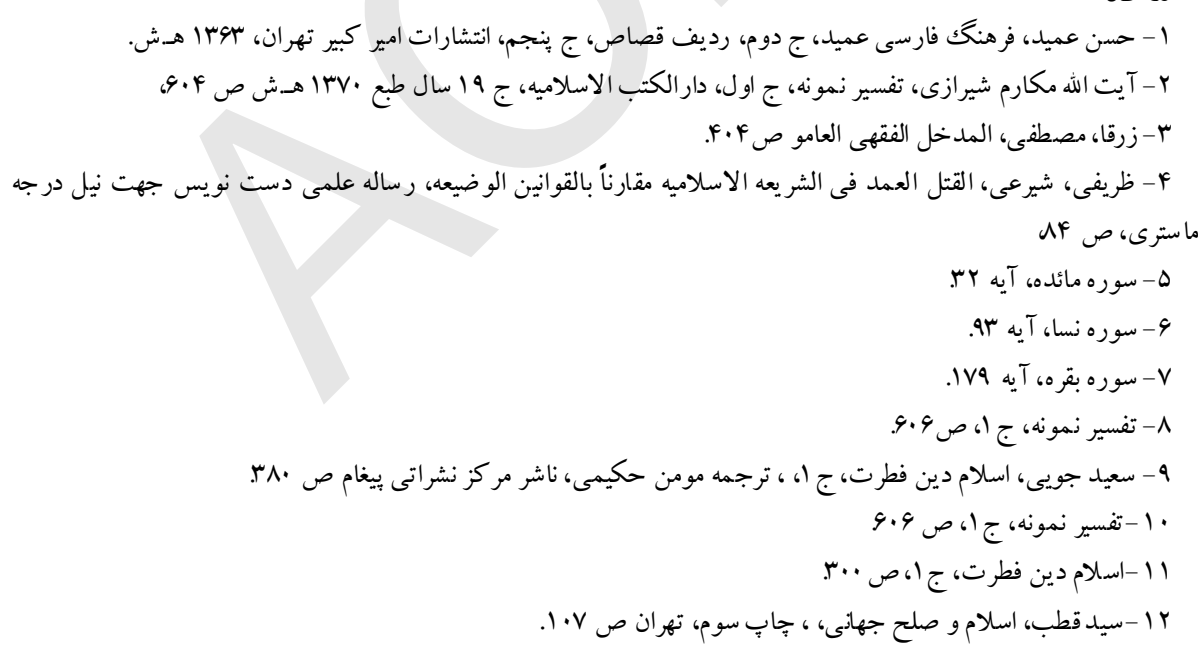

\section{ماخذ}




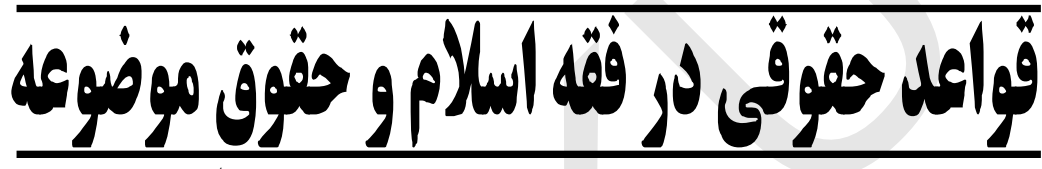

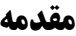

قواعد حقوقى، قواعدى است كه بر اعمال اشخاص از اين جهيت كه ده در اجتماع هستند،

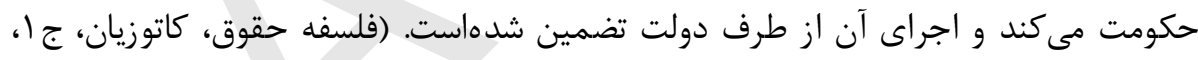

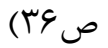

$$
\text { بر اساس تعريف فوق قاعدهى حقوقى عبارت است ازئ }
$$

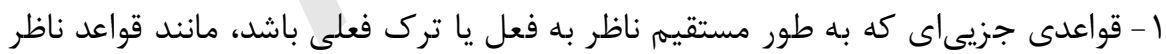

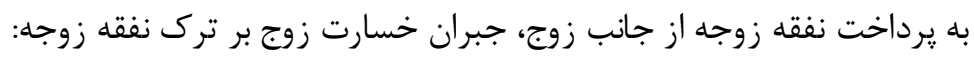

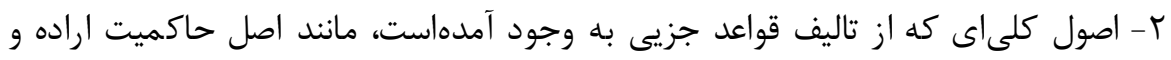

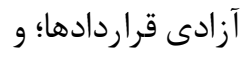

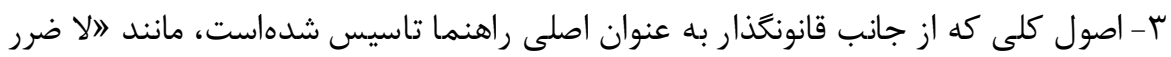

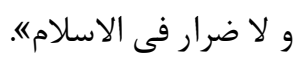

بر اساس تعريف فوق، قاعدهى حقوقى از دو عنصر تشكيل معى الإيابد:

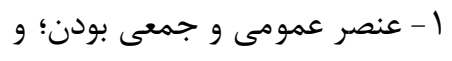

r- عنصر ضمانت اجراى قدرت عمومى و و حاكميت. 


\section{بخش اول - مشخصات قاعدهى حقوقى (خصايص القاعده القانونيه)}

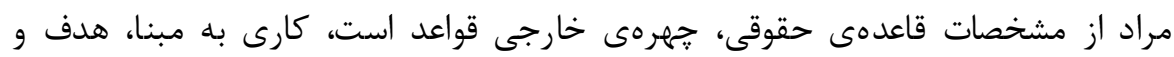

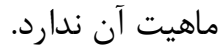
حقوقدانان براى قواعد حقوقى، اوصاف مختلفى بر شمردهاند، ولى دربارهى اساسى بودن هيج يكى از آنها اتفاق نظر وجود ندارداي

\section{1- عمومى (كلى) بودن: (القاعده القانونيه عامه و مجردها}

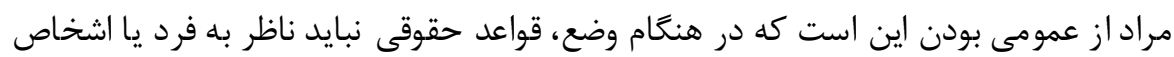

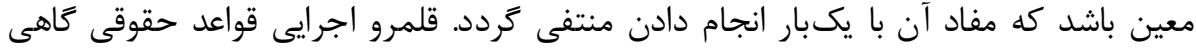

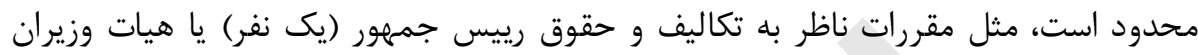

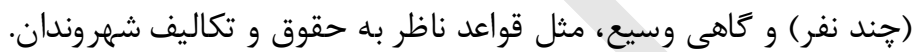

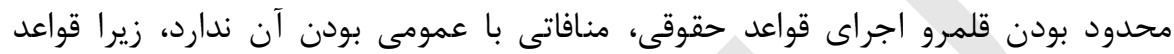

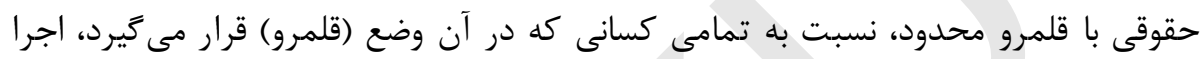

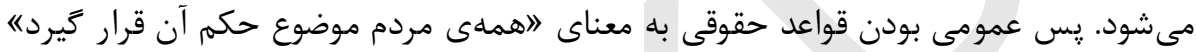
نيست. سنخ ديكرى از امر و نهى قانونى وجود دارد كه قدرتالزام قواعد حقوقى را دارد ولى قاعدهى

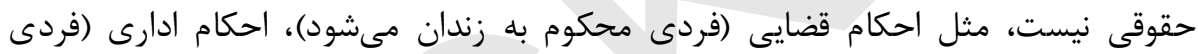

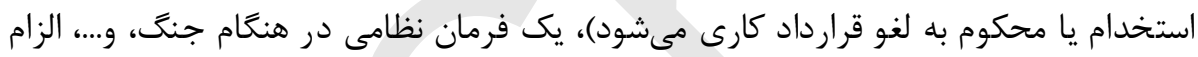

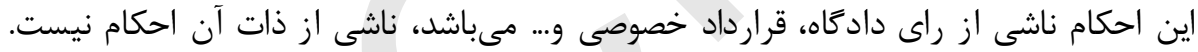

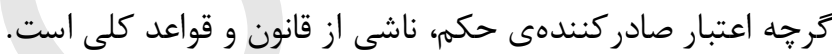

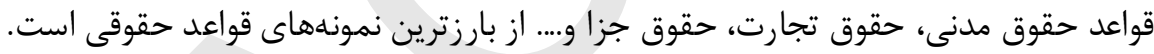

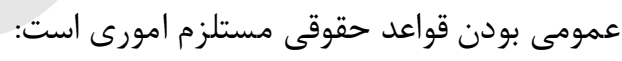

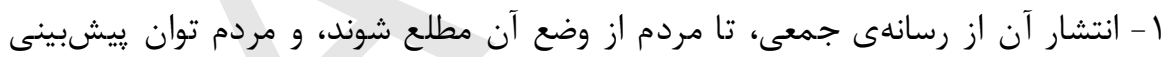

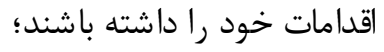

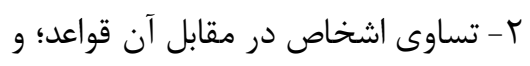

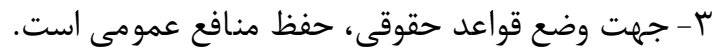

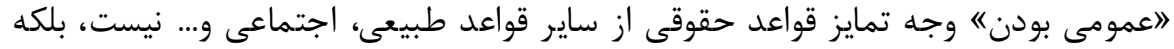

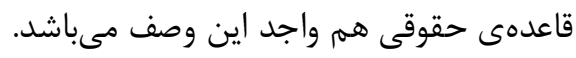

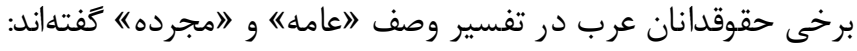

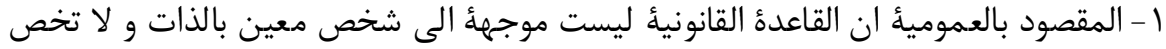

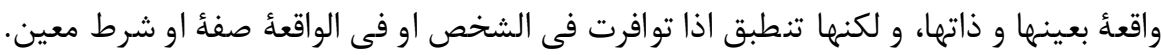

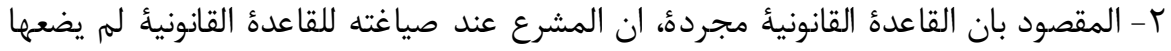

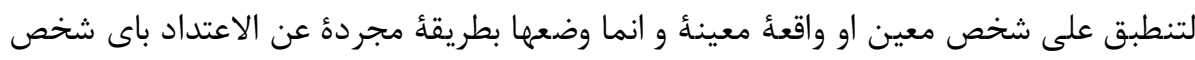

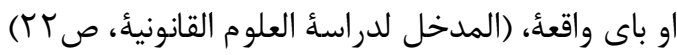


"دايمى بودن" از نتايج عمومى بودن قواعد حقوقى است. اكر قانون داراى وصف عمومى بود،

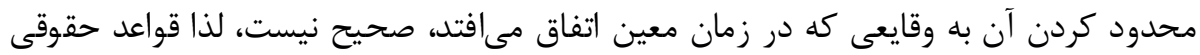

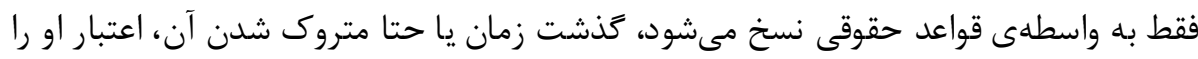
كم نمى كند.

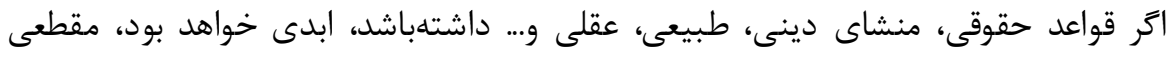

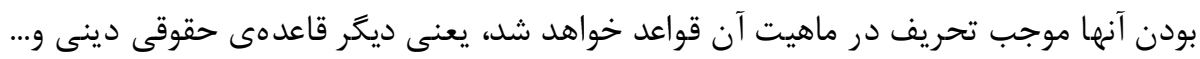

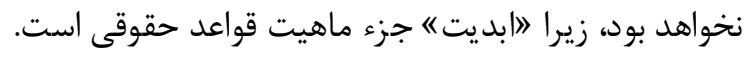

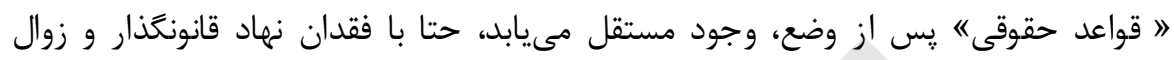

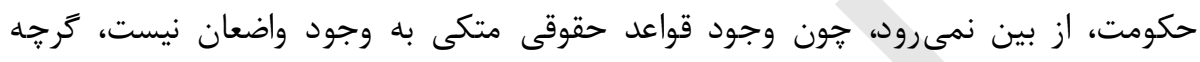

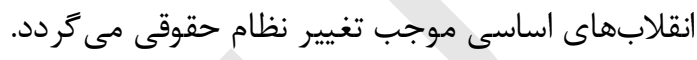

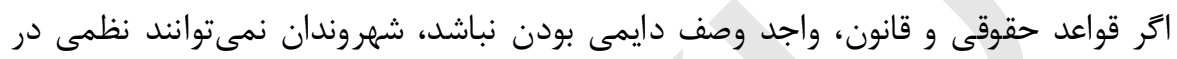

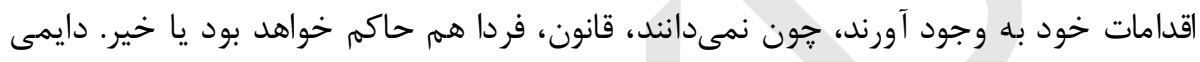

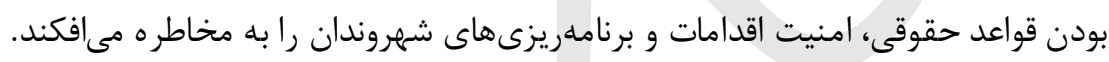

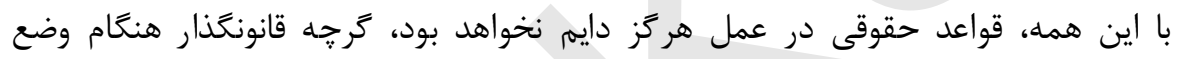

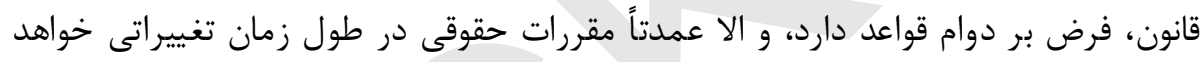

\section{r - اجتماعى بو دن (القاعده القاذونيه من القواعد الاجتماعيه)}

زندگى انسان دو جهرهى گَوناگون دارد:

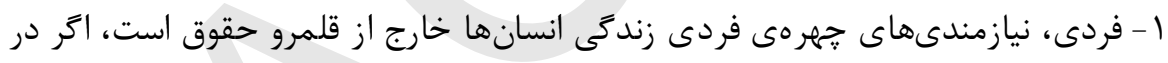

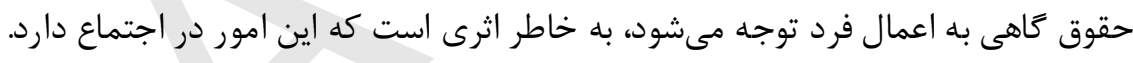

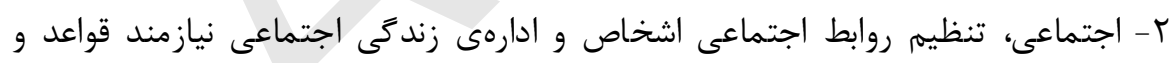

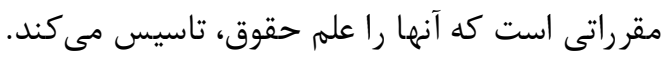

\section{F - F الزام آور بودن (القاعده القاذونيه قاعده ملزمه)}

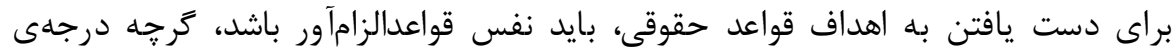
الزامآور بودن قواعد حقوقى يكسان نيست.

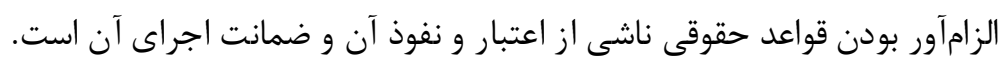

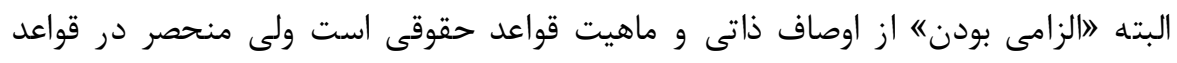
حقوقى، و از نشانهاى خاص آن نيست.

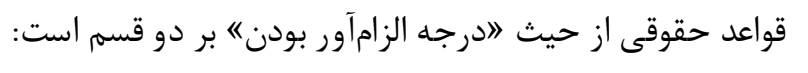




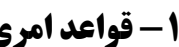

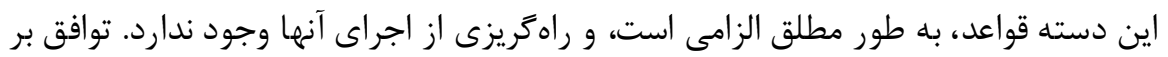

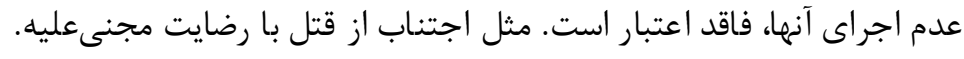

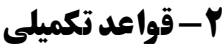

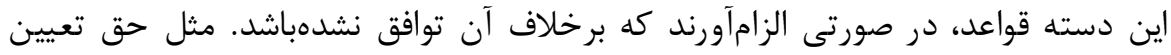

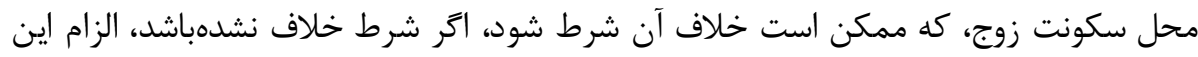
قاعده مثل قاعدهى امرى است

$$
\text { برخى مقررات حقوقى كه در ظاهر واجد وصف الالزامآور" بودن، نيست: }
$$

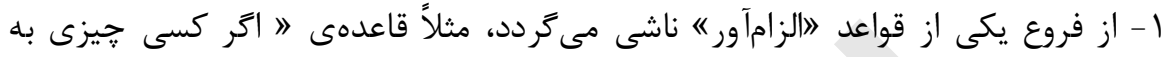

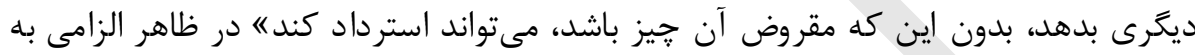

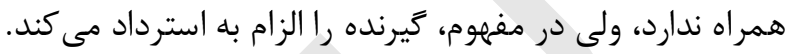

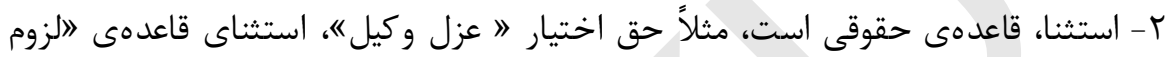

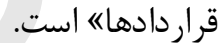

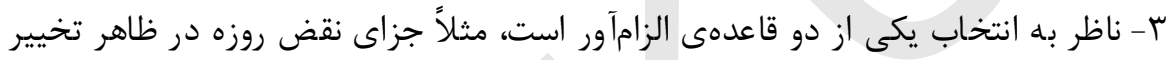

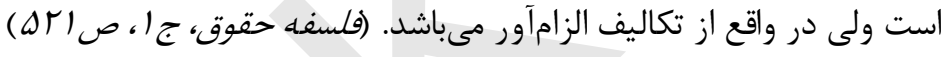

\section{ه- ضمانت اجرا داشتن (القاعده القاذونيه تقترق بالجزاء المادى)}

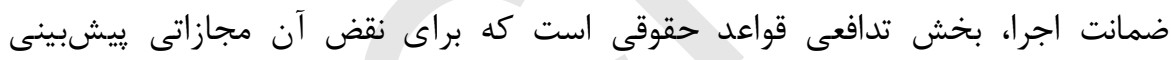

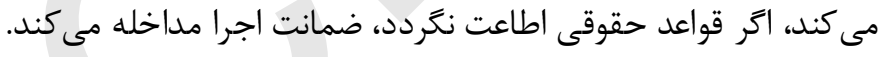

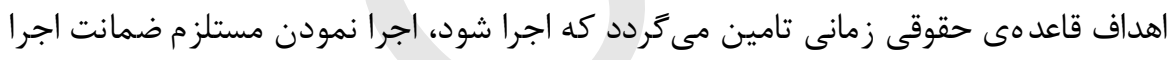

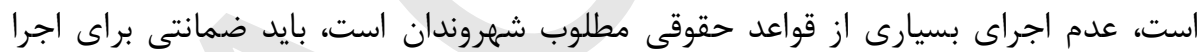

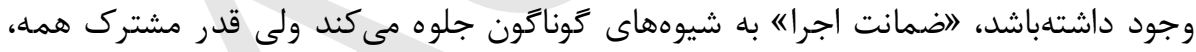

$$
\begin{aligned}
& \text { قواى صالح عمومى و حكومت است: } \\
& \text { 1 - مجازات: } \\
& \text { الف - مجازات بدنى، اعدام، شلاق و...، } \\
& \text { ب- مجازات مالى، مصادره اموال، جريمه و....، } \\
& \text { ج- زندان، }
\end{aligned}
$$

د- محروميت از برخى حقوق، محروميت از عضويت در مجلس، محروميت از استفاده از

Y- دخالت مستقيم قدرت عمومى مثل استرداد مال غصب شده از غاصب، r- بطلان اعمال انجام شده: ايقاى طلاق بدون شرايط صدات صحت،

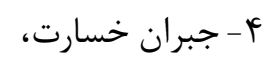


برخى حقوقدانان عرب اقسام ضمانت اجرا را را جنين بيان مى كنند:

$$
\text { 1 - الجزاء الجنائى (ضمانت اجرايى كيفرى): }
$$

و هو اشد صور الجزاء، و يكون عند الاعتداء على المجتمع كلهن.....و يتولى قانون العقوبات بيان

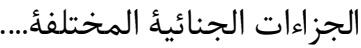

$$
\text { r- الجزاء المدنى (ضمانت اجراى مدنى الائي): }
$$

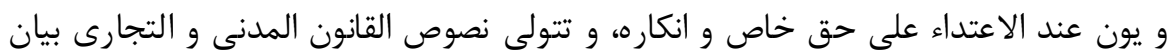

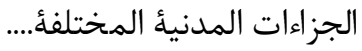

$$
\text { r- الجزاء الادارى( ضمانت اجراى ادارى): }
$$

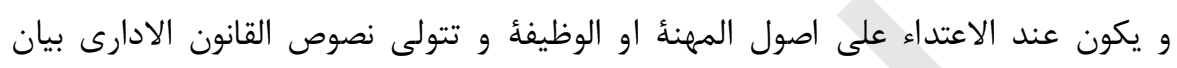

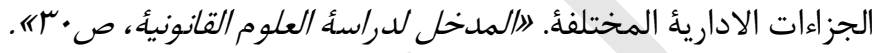

\section{بخش دوم - مبناى قواعد حقوقى}

"مبانى" جمع "امبناه است، "مبانى حقوق" در اصطلاح حقوقدانان عبارت است از از اصولى

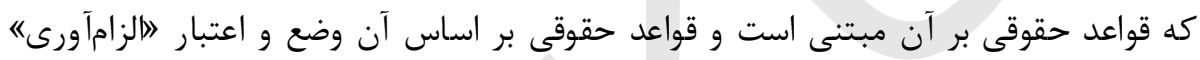

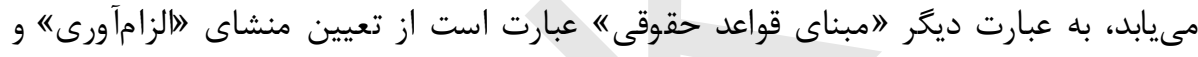

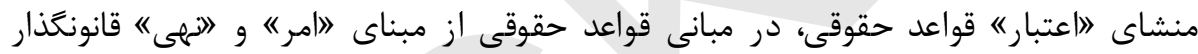

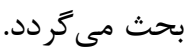

اختلاف در تعيين مبانى قواعد حقوقى موجب تاسيس مكاتب حقوقى شدهاست.

\section{1 - مكتب حقوق فطرى (طبيعى - آرمانى)}

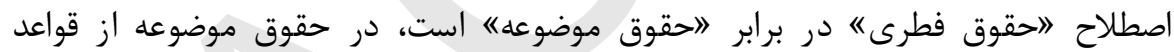

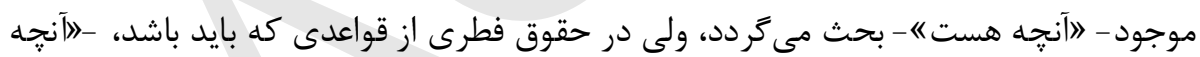

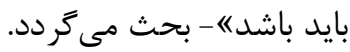

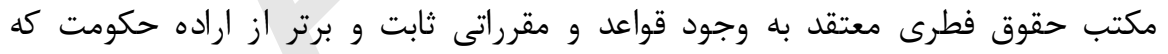

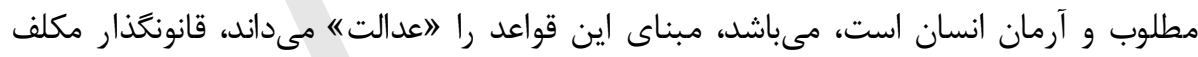

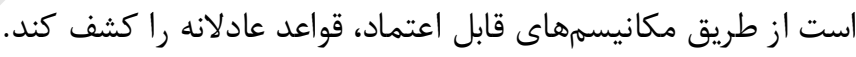

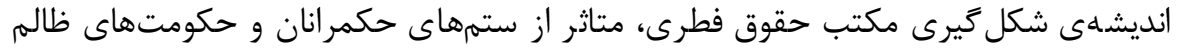

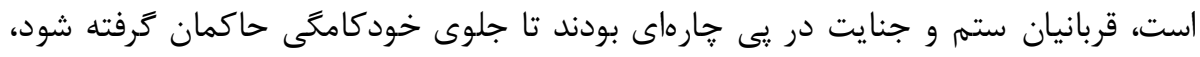

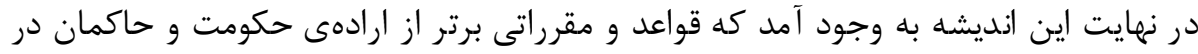

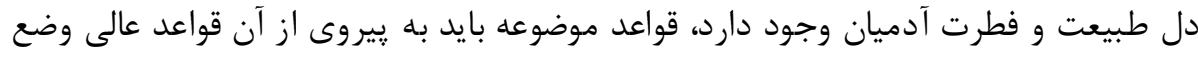

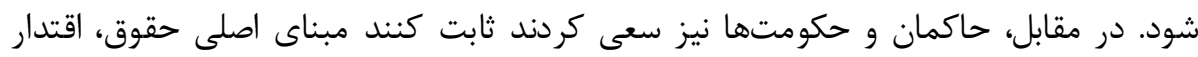

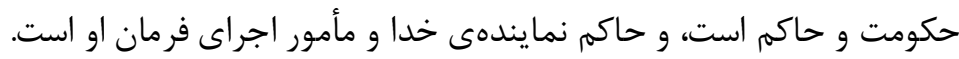




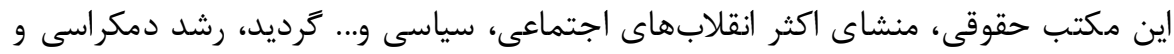

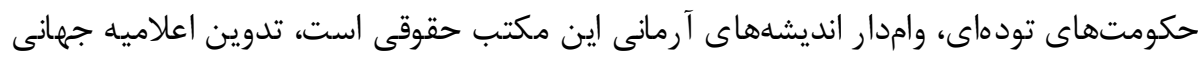

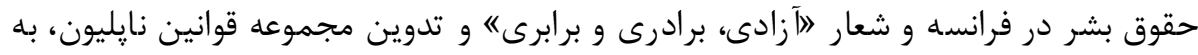

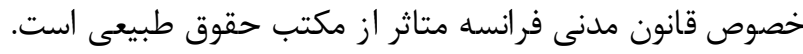

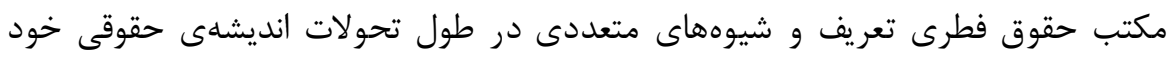
براى كشف قواعد عالى و عادلانه معرفى كر دهاند.

\section{الف) مكتب حقوق فطرى در عصر مذهبى (بيش از سده هفدهم)}

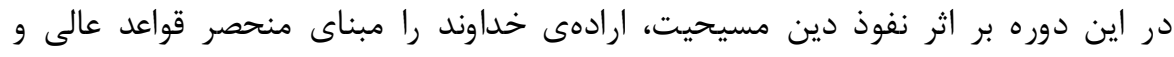

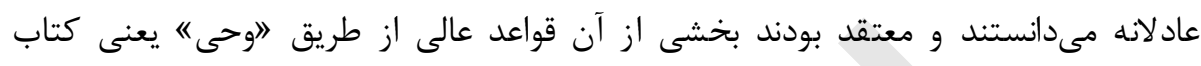

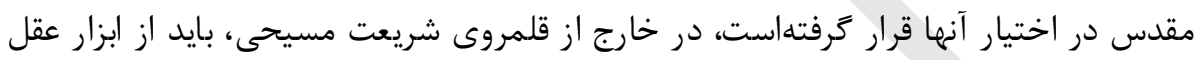
براى يافتن آن قواعد عالى بهره جست آنست "اسن توماس داكن" حكيم مذهبى قرن سيزدهمه، قوانين را به سه دسته دسته تقسيم مىكرد: الف) قوانين الهى

اين قواعد ناشى از ارادهى خداوند است، عقل بشر به آن آن دسترسى ندارد، خداوند با ارسال

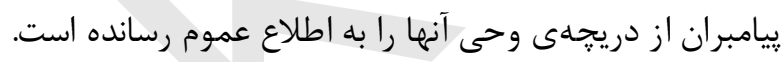

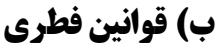

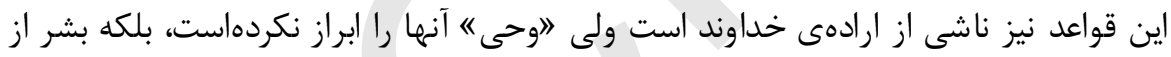

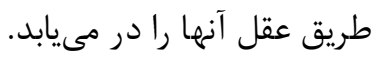

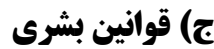

كه ناشى از ارادهى انسان است و به منظو منظور اجراى قوانين فوق، وضع شدهاست. (مقدمهى

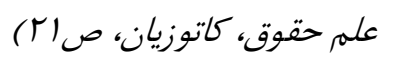

شايد مقر رات قسم سوم، همان، صان آيين دادرسى فعلى باشد.

\section{ب) مكتب حقوق فطرى در عصر خردترايى" قرنهاى هفدهم و هردهمه}

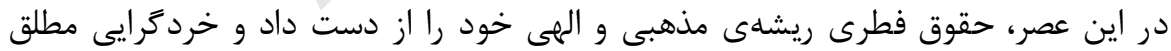
جايكزين "وحى" شد اين عصد، حقوق

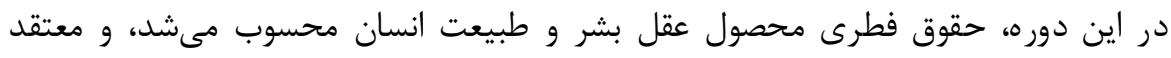

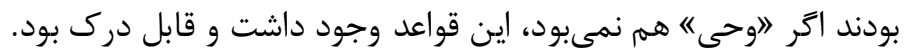

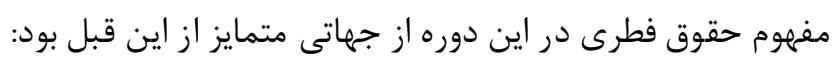

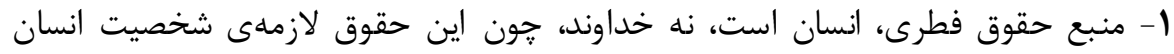

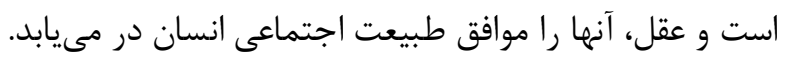


r- هدف حقوق فطرى، حمايت از حقوق فردى است، نه اجراى ارادهى يرورود أار و تأمين

$$
\text { اطاعت او. }
$$

نظريهى "قرارداد اجتماعى" حاصل اين دوره است، فلاسفهى حقوق در طول اين دوره

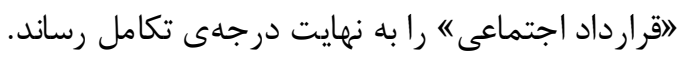

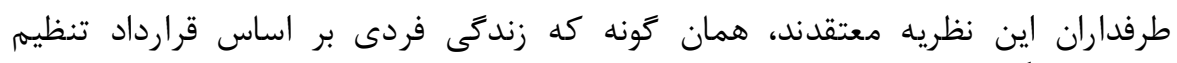

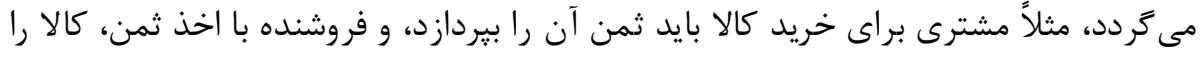

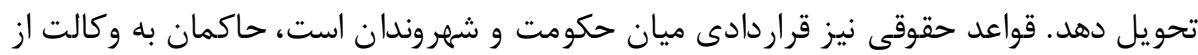

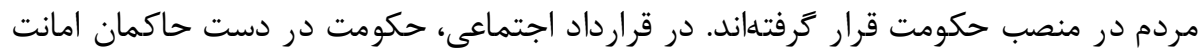

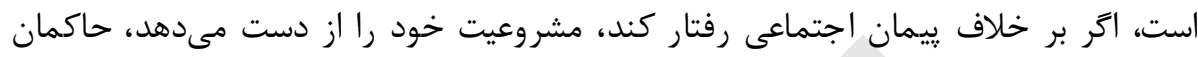

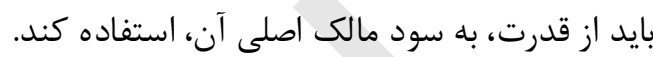

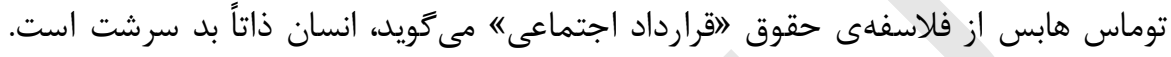

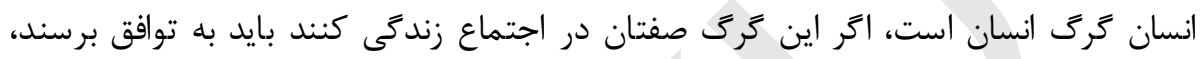

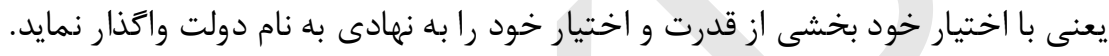

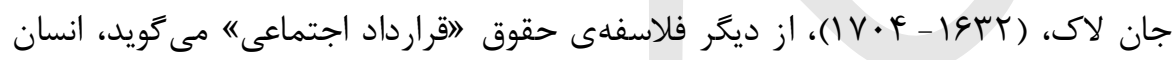

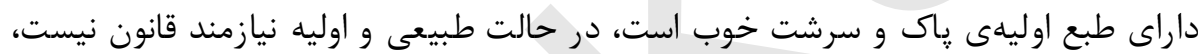

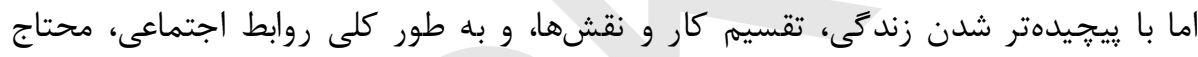

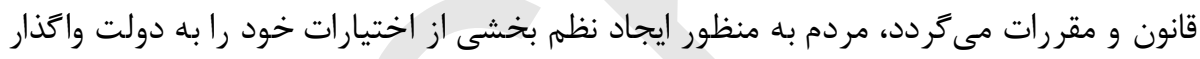
مى كند.

زان زاكى روسو از ديخر فلاسفهى حقوق اقرارداد اجتماعى" مى گويد: انسان يك ارادهى

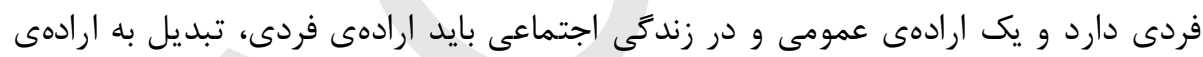

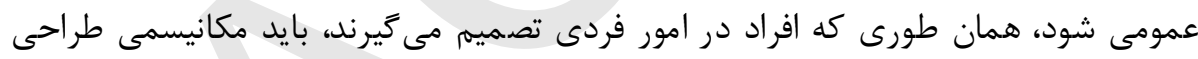

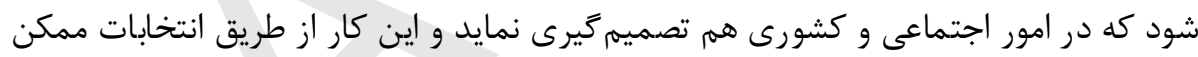

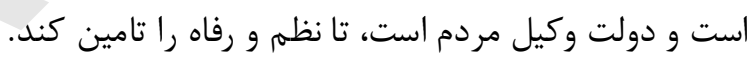

\section{ج) حقوق فطرى درعصر تجربه 》 قرون نوزدهم و بيستم "}

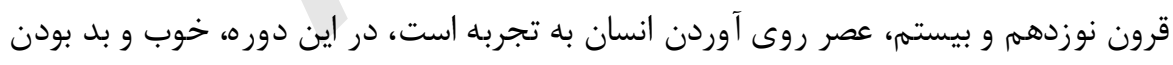

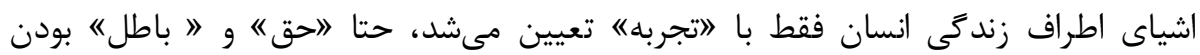
انديشهها. قواعد حقوقى نيز از اين رويكرد جديد دور نماند، اين رويكرد، تحول عظيمى در در حقوق

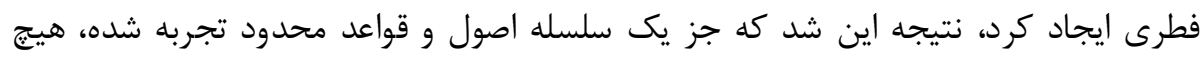

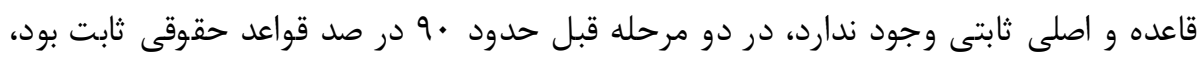

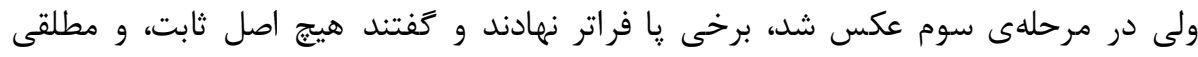

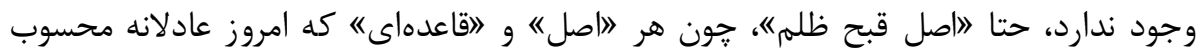

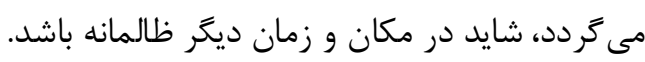


اين ديدكامها منجر به انقراض مكتب حقوقى فطرى مى شعد كه مكتب حقوق فطرى نوين،

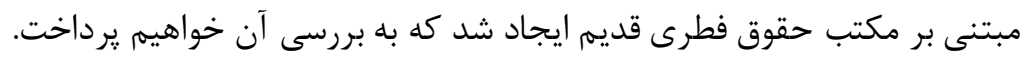

\section{Y - برر سى مكتب حقوق فطرى (طبيعى)}

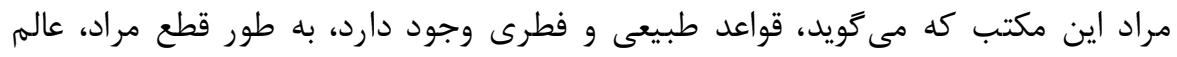

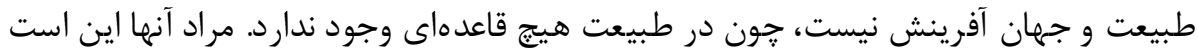

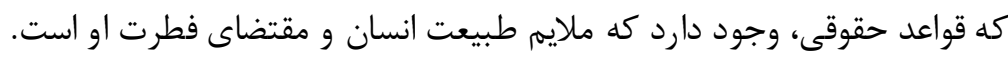

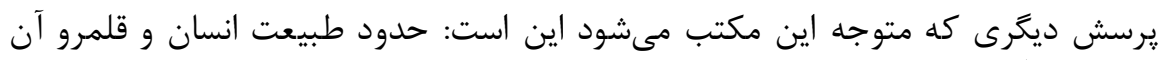

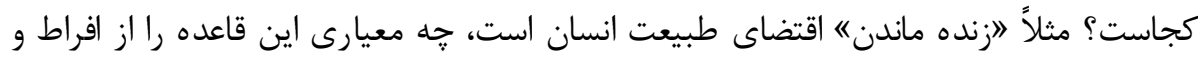

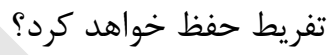
مقتضاى طبيعت انسان بايد به واسطه قانونى تعديل شود، و الا انسان براى زنده ماند اندن، به

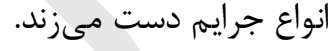

مكتب حقوق فطرى مى گَويد: اين معيار عدالت است، قواعد مقتضاى فطرت انسان بايد

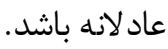

\section{الف) بر رسى مفهوم عدالت در حقوق فطرى}

1 - نخستين نقد مكتب حقوق فطرى اين است، عدالت به جه مفهوم و ماهيتى مبناى قواعد

$$
\text { حقوقى است؟ }
$$

$$
\text { عدالت به سه معنا تعريف شدهاست: }
$$

\section{1- اعطاء كل ذى حق حقه}

عدالت به معناى اعطاى حقى، بـ حقد صاحب حق، نمىتواند مبناى الزامآورى قواعدى حقوقى

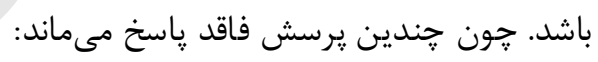

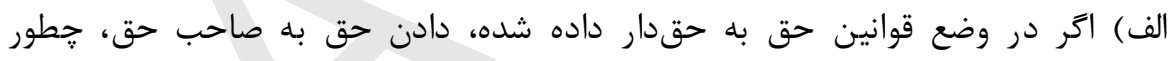

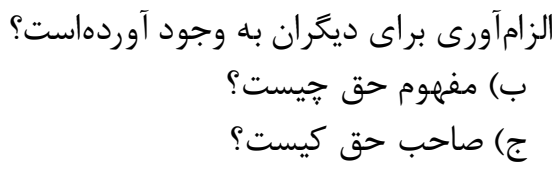

$$
\text { د) حكومت حق قانونگذارى را بر جاته مبنايى به دست آورده؟ }
$$

در اين فرض اجراى عدالت متوقف بر "حق شناسى" و "اصاحب حق" است، معلوم نيست

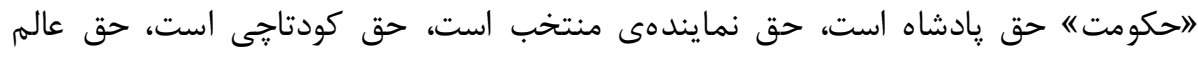

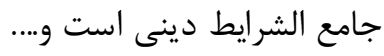

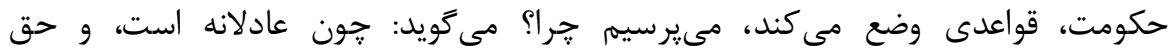

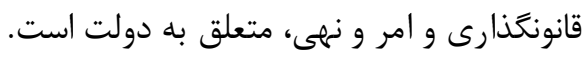

بر اساس اين تعريف عدالت، دليل مكتب حقوق فطرى عين مدعا است، به عبارت ديكر 
براين اساس بايد ابتدا مبناى 》الزامآور" بودن قواعد حقوق، تعيين شود، و "اعدالته به به

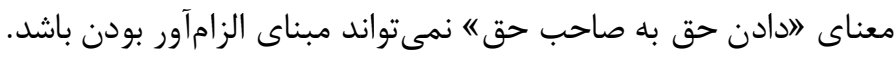

\section{Y - وضع الشيئ فى وضعه (قرار كرفتن هر جيزى در جايكًاه مناسب خود)}

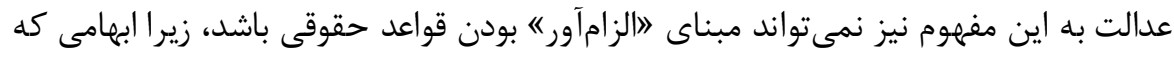

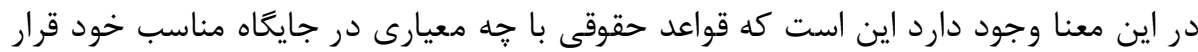

$$
\text { مى كيرد؟ در اين معنأ }
$$

جايخاه مناسب قواعد حقوقى، مناسبت و ملايمت آنها با حيات اجتماعى انسان است، عدالت

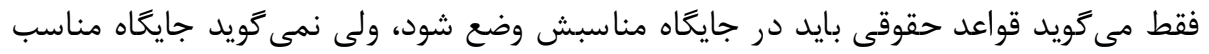

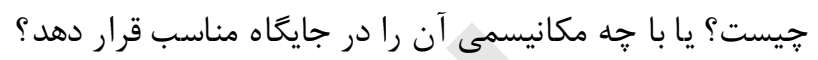

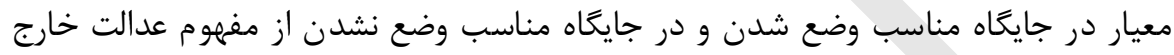

يكى از جيزهايى كه بايد در موضع خودش قرار كيرد، قانونگذارى است، حق قانونگذارى به

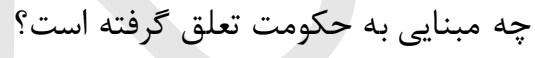

\section{ع بالت بالتوازن و التساوى}

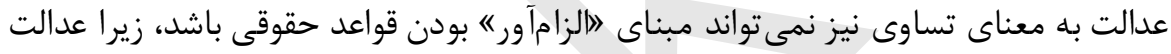

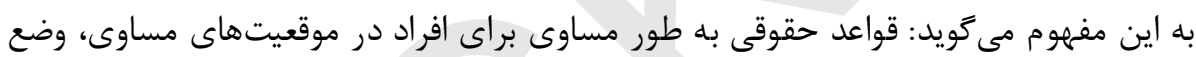

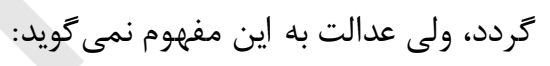

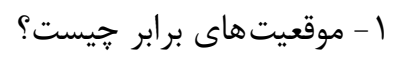

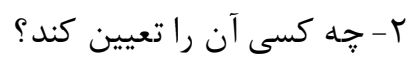

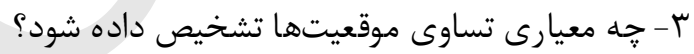

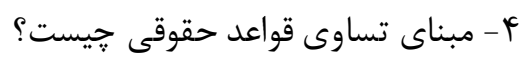

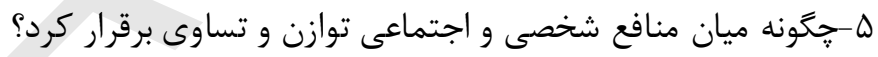

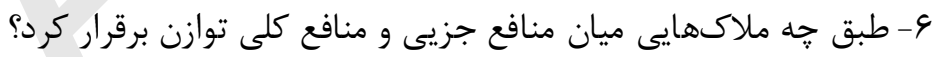

ب) برر سى تشخيصدهنده عدالت در مكتب حقوق فطرى داء

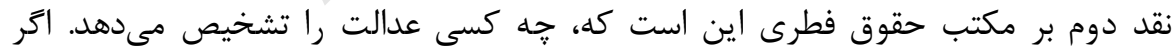

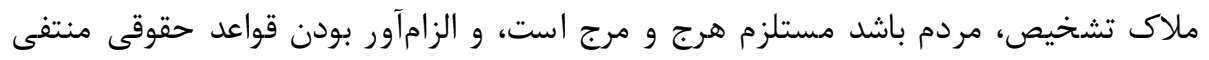

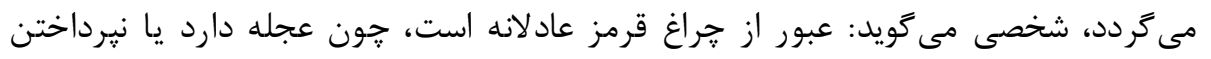
ماليات عادلانه است جونى شئ..........

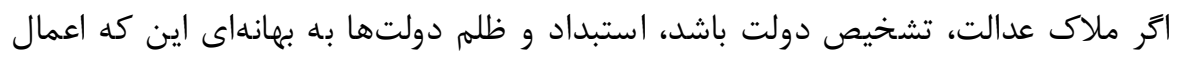

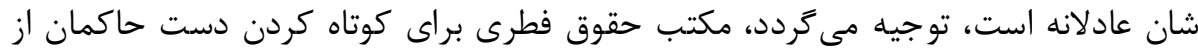

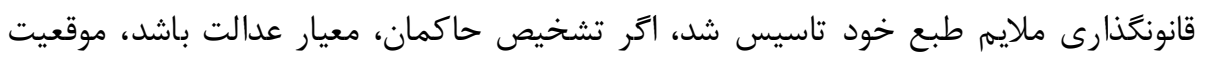

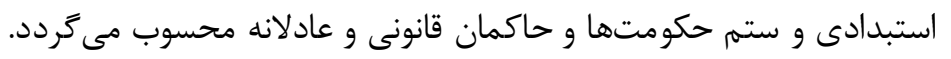




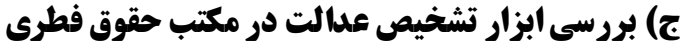

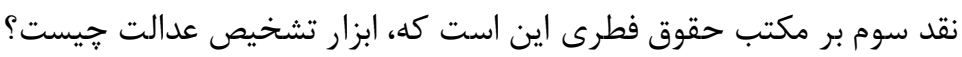 فلاسفهى حقوق سه ابزار براى تشخيص عدالت بيشبينى اينى كردهاند:}

-

در دورههايى كه "دين" حاكميت مطلق داشتهاست، در اين دوره معتقد بودند، هر حكمى و

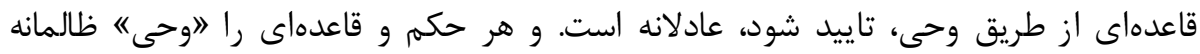
معرفى كند، ظالمانه است.

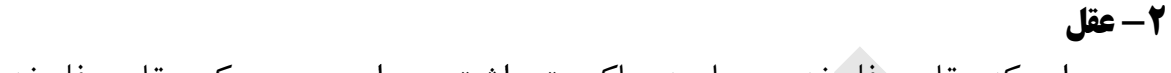
در دورهاى كه عقل و فلسفه، بر جامعه حاكميت داشت، در اين دوره حكم عقل و فلسفه

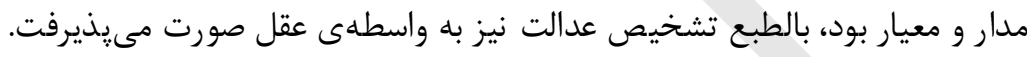

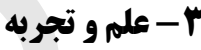

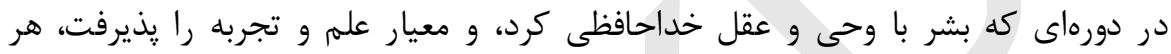

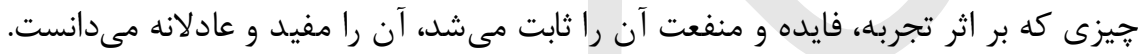

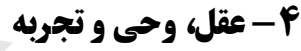

برخى معتقدند، همهى ابزارهاى وحى، عقل و تجربه، به به طور اجتماع مورد نياز بشر است،

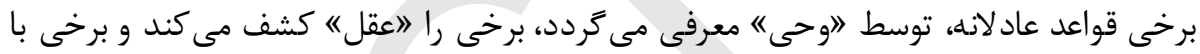

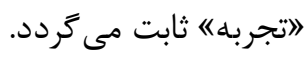

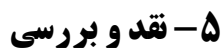

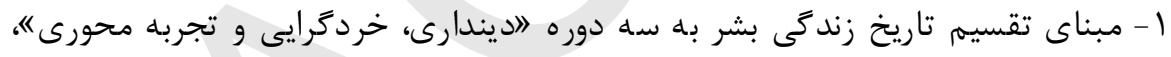

$$
\text { فاقد اعتبار تاريخى و علمى است. }
$$

تقسيم فوق مبتنى بر خرافى بودن و فاقد جنبلى حقيقى و عينى بودن لادينه است، اين

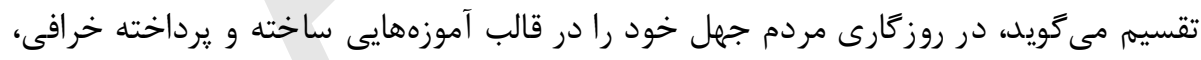

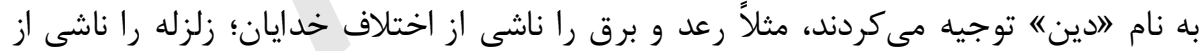

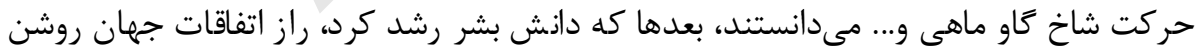

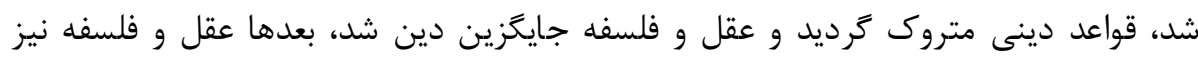

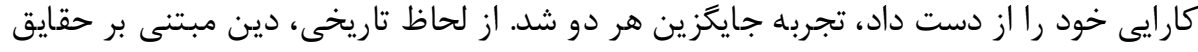

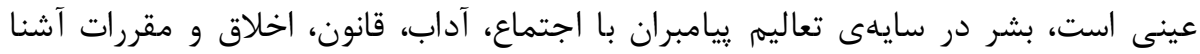

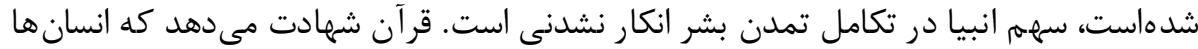

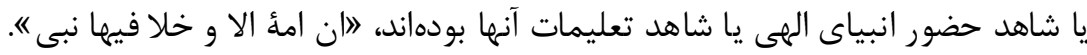

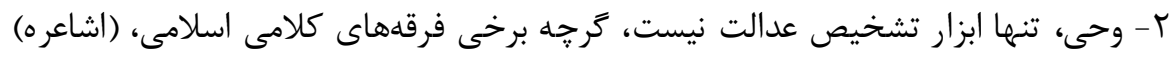

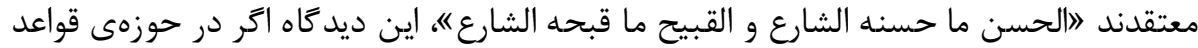


حقوقى راه ييدا كند، آثار بسيار مخربى دارد، جِون مستلزم از بين رفتن تمامى معيارهاى عقلى

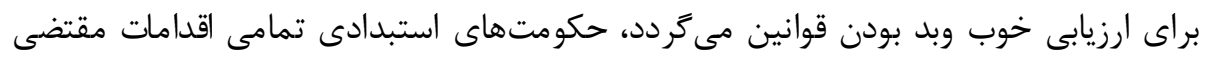

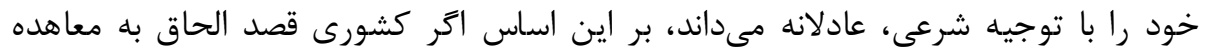

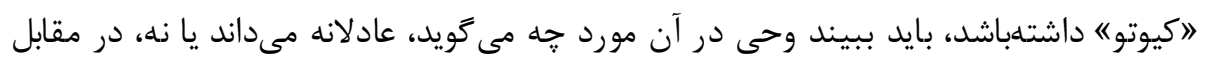

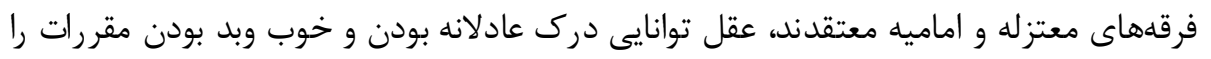

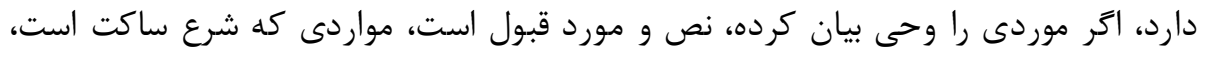

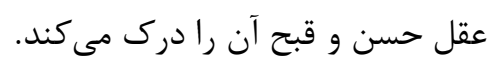

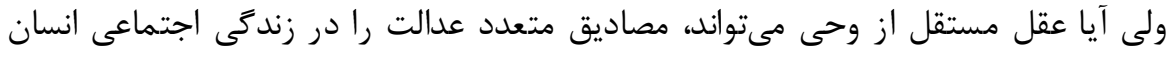

$$
\text { تشخيص دهد؟ }
$$

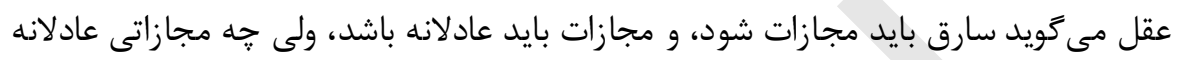

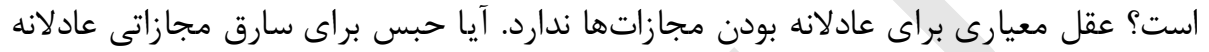

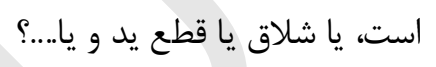

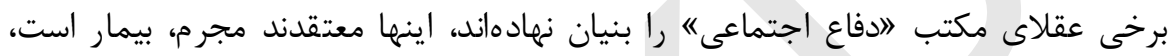

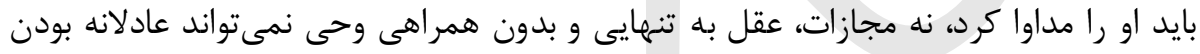

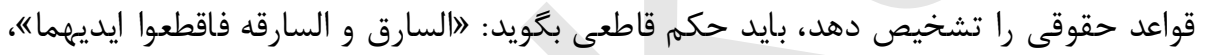

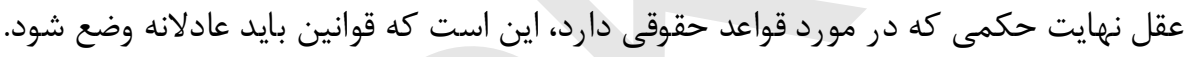

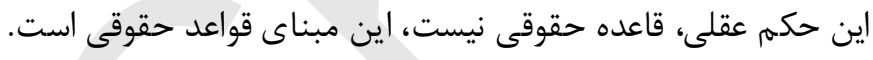

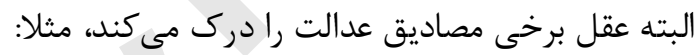

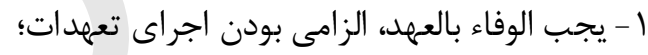

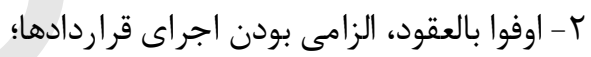

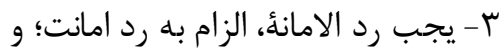
....- ${ }^{\uparrow}$

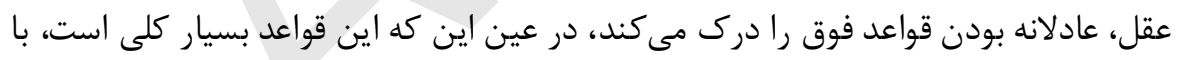

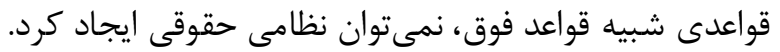

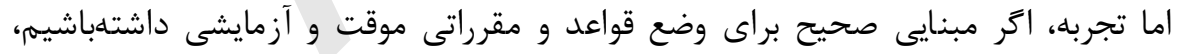

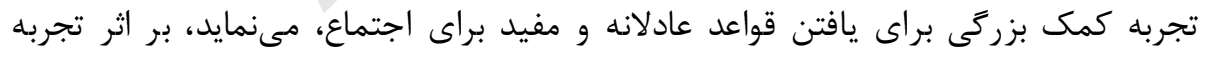

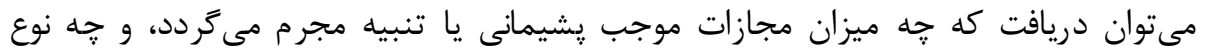

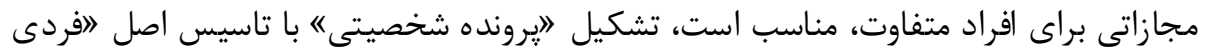

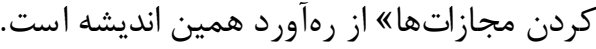

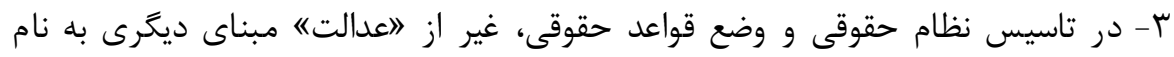

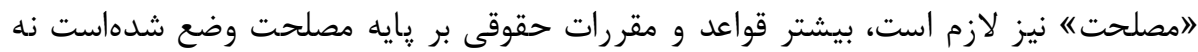

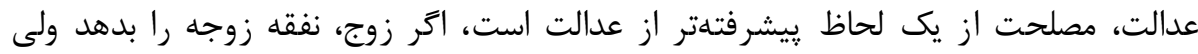

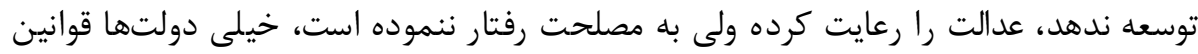

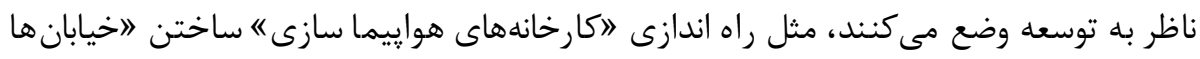




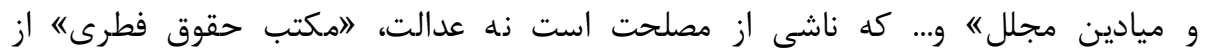
|"مصلحت "به عنوان مبناى دوم قواعد حقوقى نام نبر دماند.

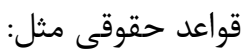

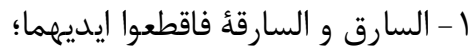

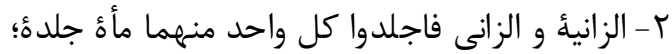

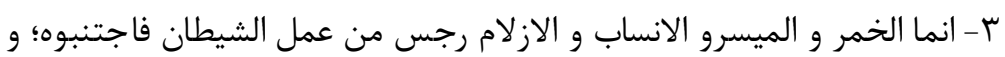

....- r

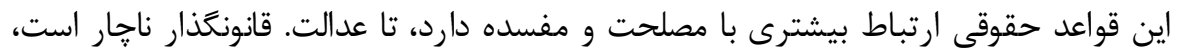

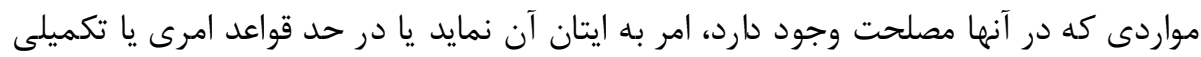

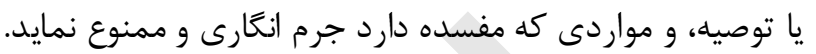

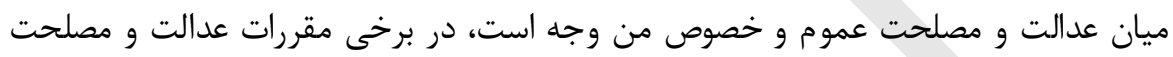
هر دو وجود دارد در برخى فقط يكى از آنها.

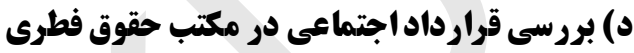

قرارداد اجتماعى با اشكالات فراوانى درانى رو به رو رواست

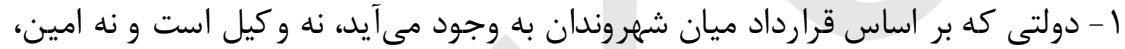

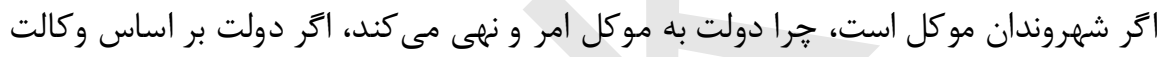

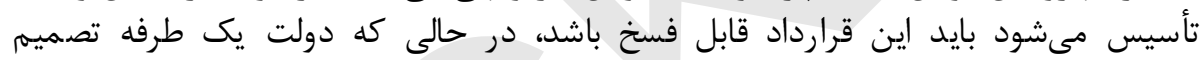

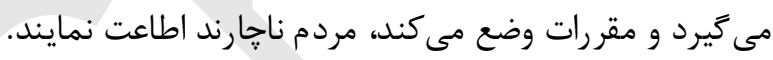

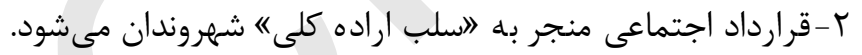

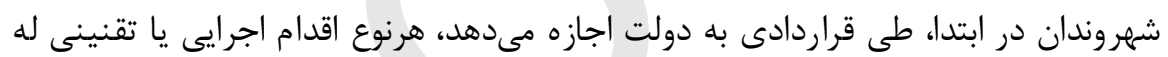

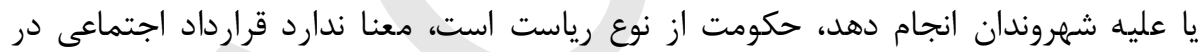

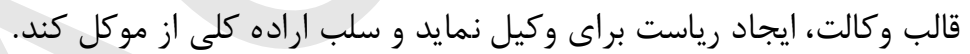

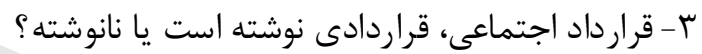

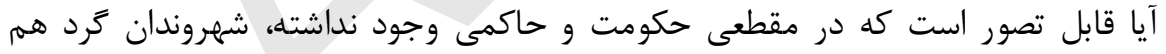

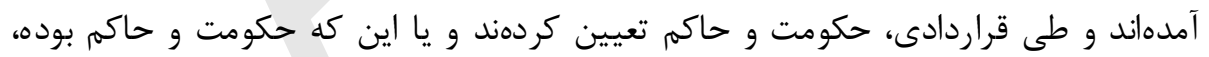

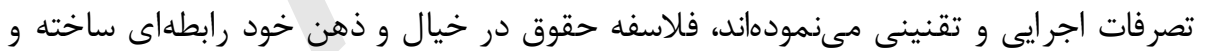

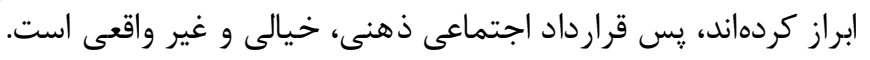

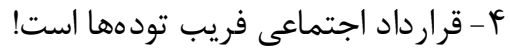

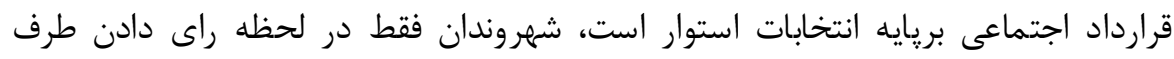

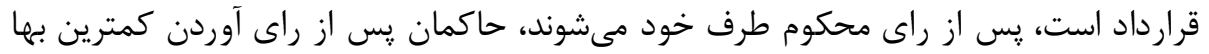
به موكلان خود نمى دهند. ادامه دارد 


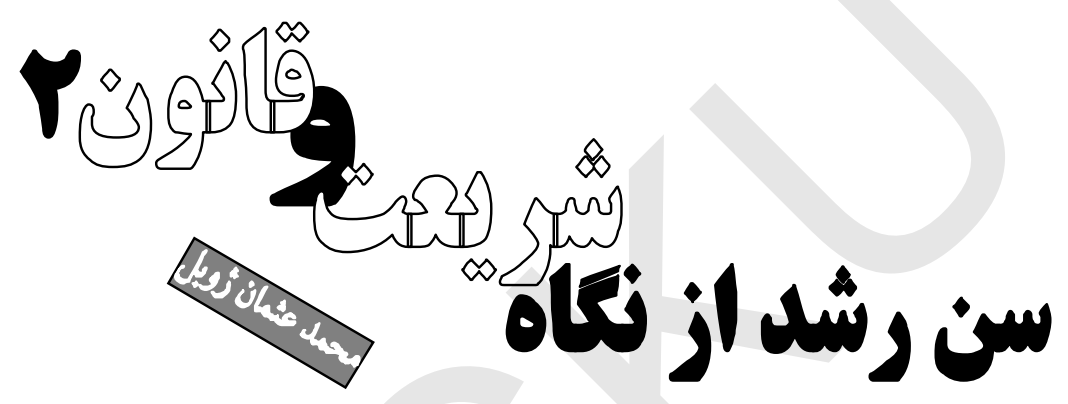

سير موضوع در اففانستان

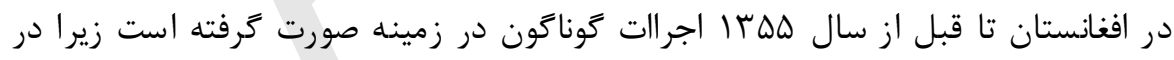

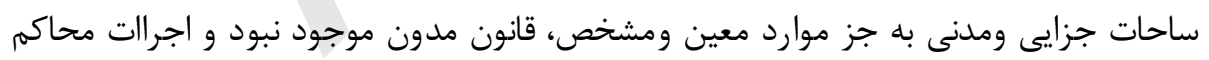

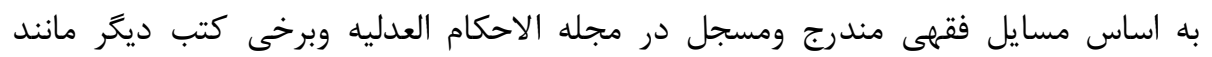

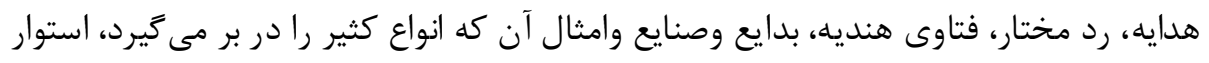
بود. بر طبق احكام شريعت تعيين سن رشد و سن بلوغ مفوض به راى راى قاضى بود و وبا علايم

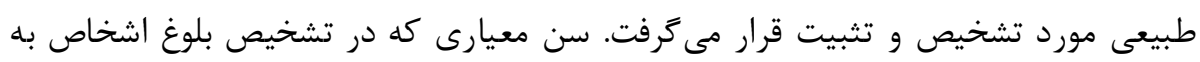

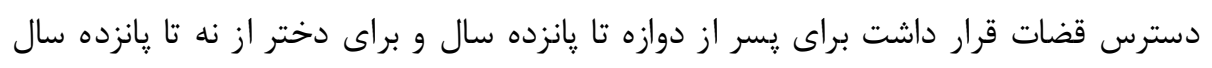
تخمين شدهبود. 
بدين منظور قواعد خاص فقهى در اختيار قاضى قرار داشت تا با رعايت آن شخص بالغ را از عدم آن و رشيد را از غير آن تفكيك نمايد.

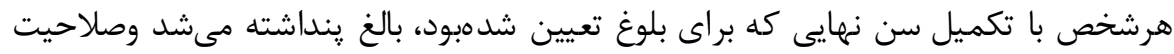

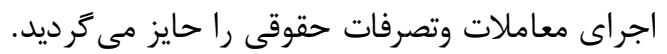

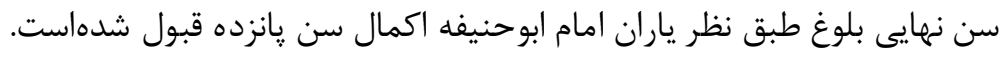

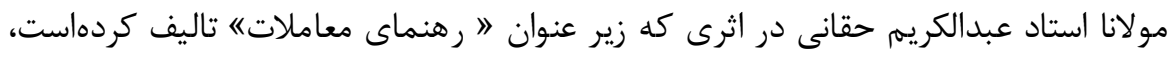
مراتب فوق را هنين دسته بندى نمودهاست: ا - هر كس مىتواند با داشتن اهليت حقوقى مالكيت اموال خود را به به ديگرى انتقال بدهد و

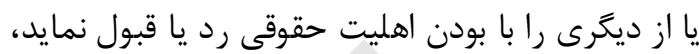

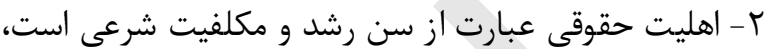

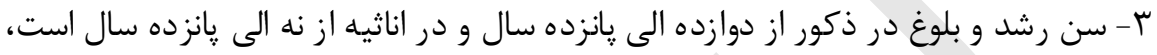

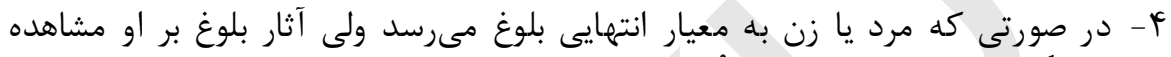

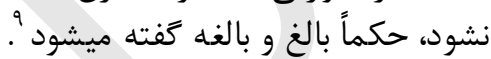

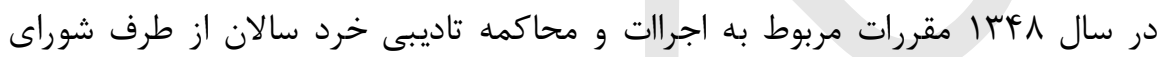

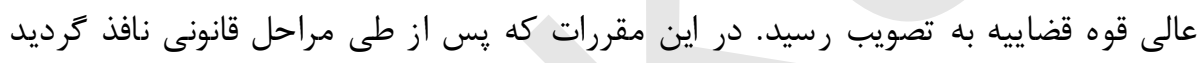

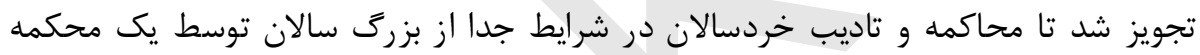
اختصاصى انجام يذيرد.

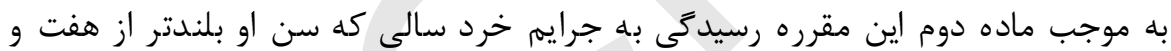

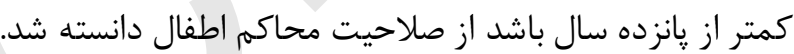

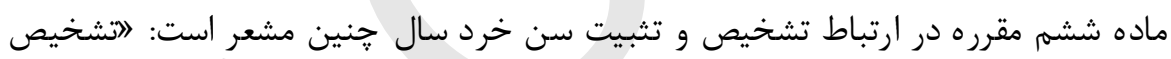

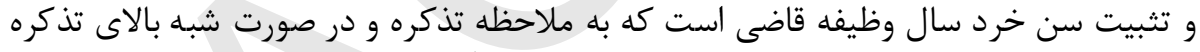

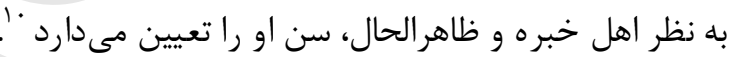

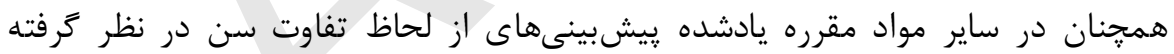
شدهاست كه به طور عمده عبارت اند ازئ

If ماده

اخرد سالان يانزده ساله و متجاوز از آن اتر مرتكب قباحت و يا جنحه كردند محكمه يكى از طرق ذيل را الختياز مينمايد:

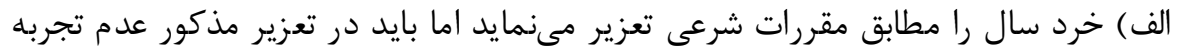

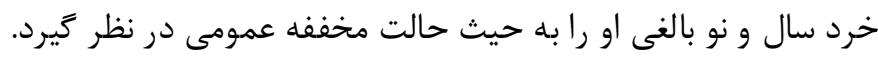
ب) خرد سال را به اشخاص مندرج ماده جهارم تسليم مى ردهد"

أ-موارد جهار كانه مأخوذ است از: رهنماى معاملات، تاليف: محمد عبدالكريم حقانى، كابل: انتشارات ستره محكمه، مطبعه

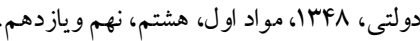

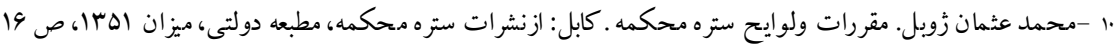




\section{Aosto}

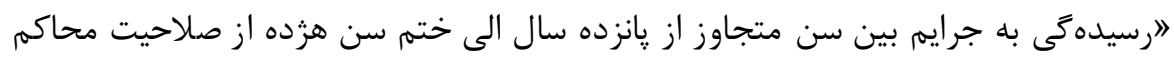

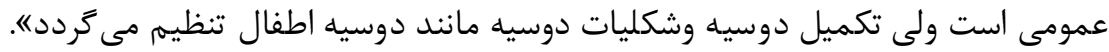

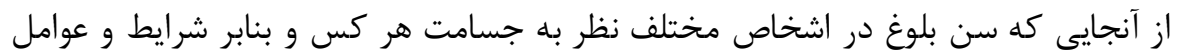

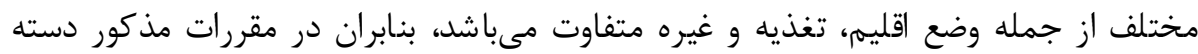

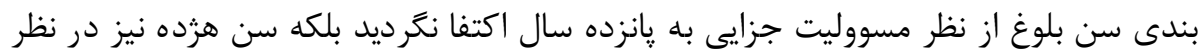

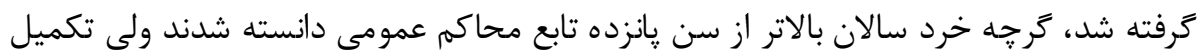

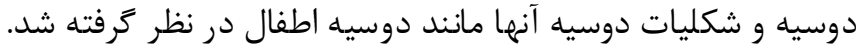

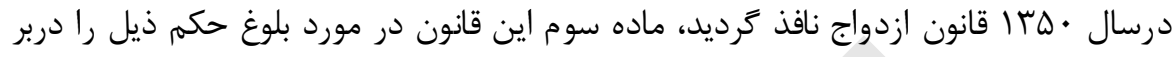
داشت:

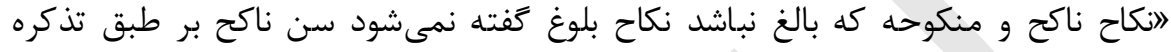

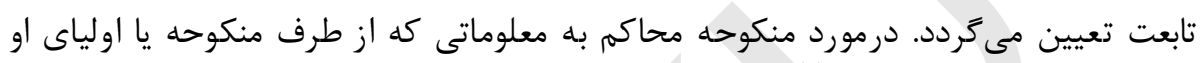

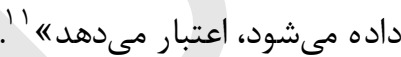

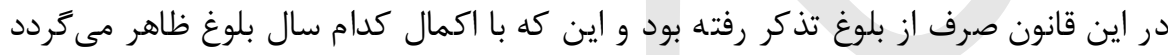

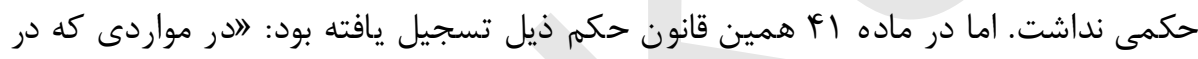

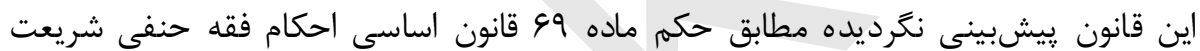

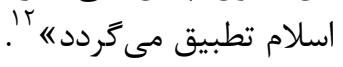

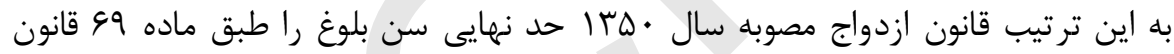

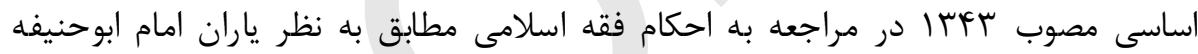

$$
\text { يانزده سال در نظر كرفته بود. }
$$

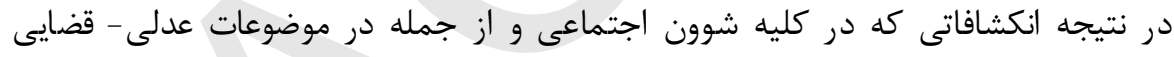

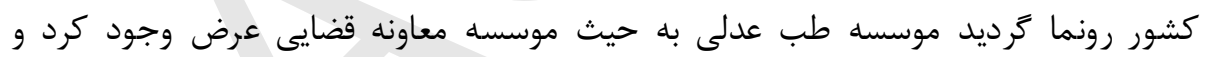

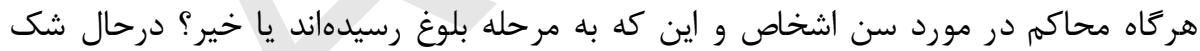

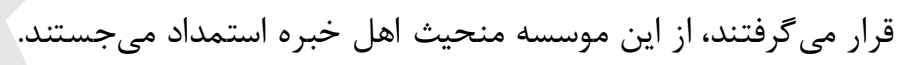

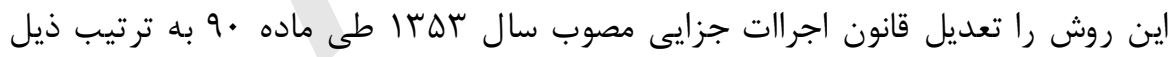
ييشبينى كرد:

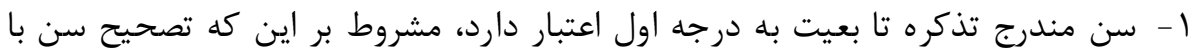

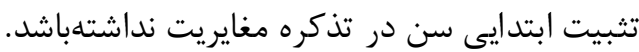

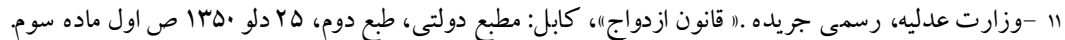

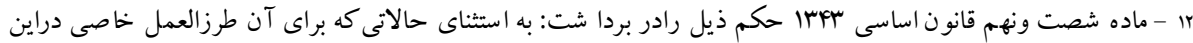

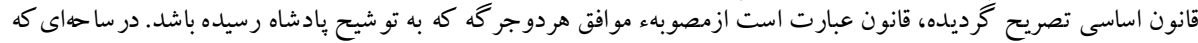

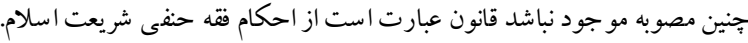


r- سنى كه از طرف طبيب عدلى و در صورت عدم موجوديت از طرف ساير اطبا تثبيت

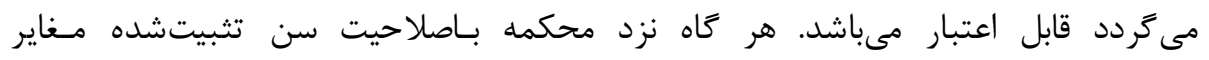

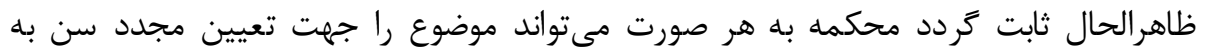

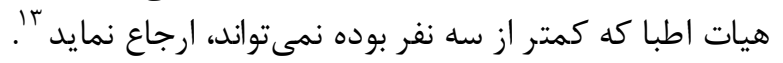

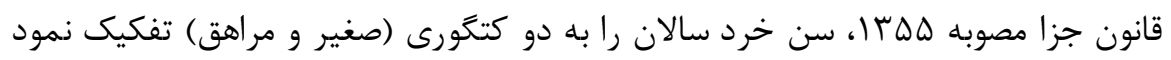

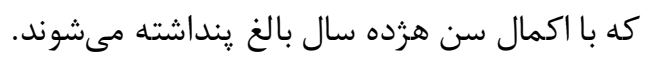

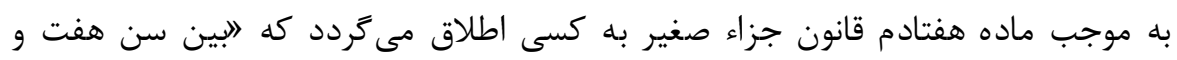

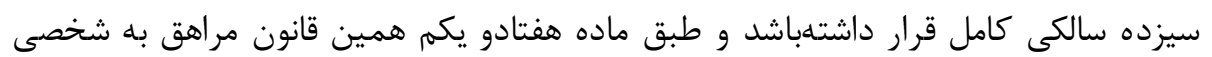

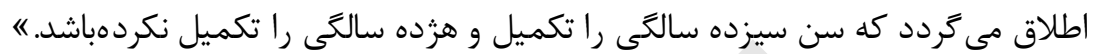

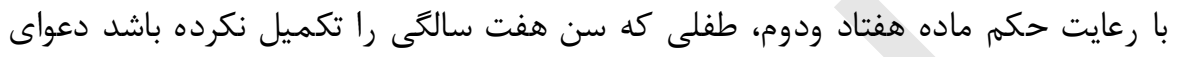

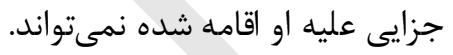

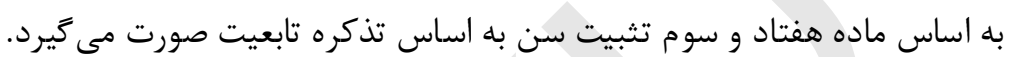

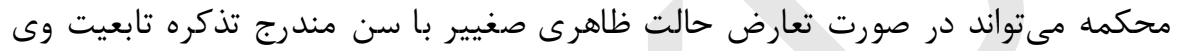

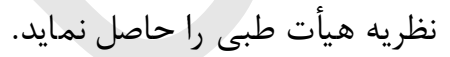

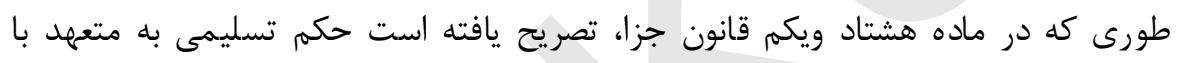

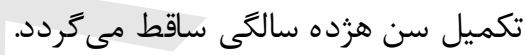

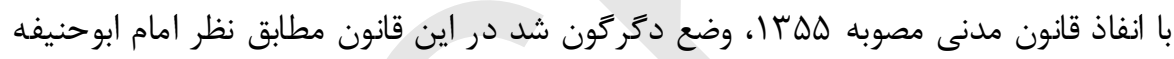

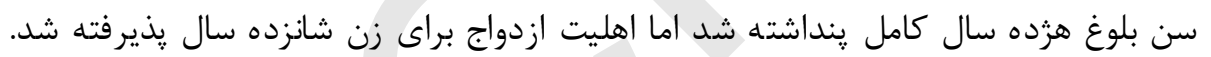

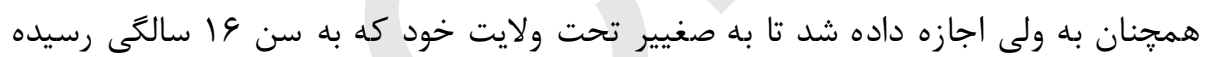

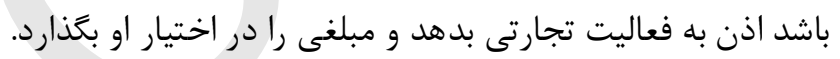

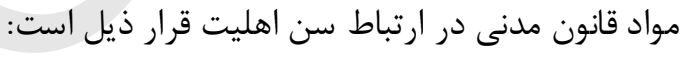

rqosis

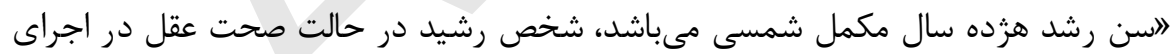

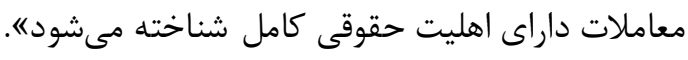

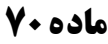

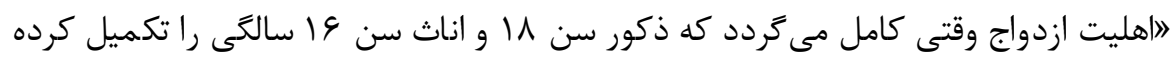
باشد《.

\section{(YYY) مادO)}

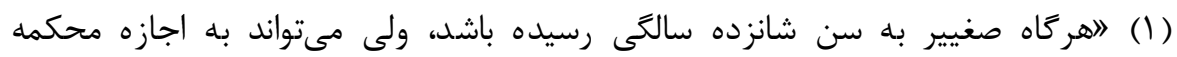

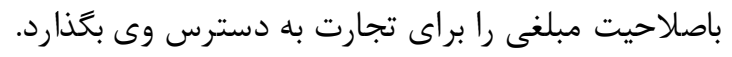


(T) اذن به تجارت خواه مطلق باشد يا مقيد با وفات يا عزل ولى از بين نمىروده.

(YYA) ماد (Y)

تصرفات ماذون در حدودى كه محكمه باصلاحيت در اموال وى مجاز قرار داده است به منزله

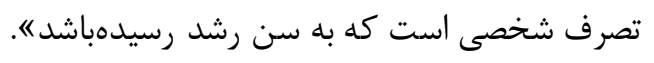

(YAT) ماد

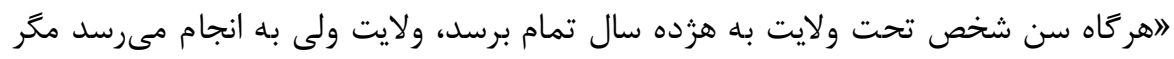

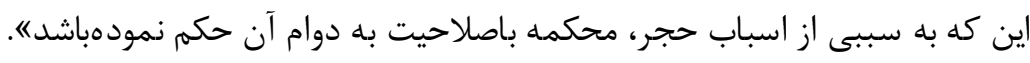

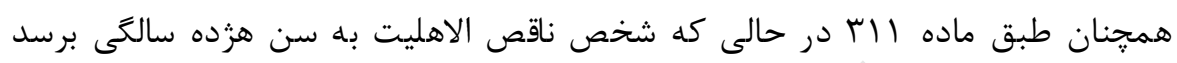

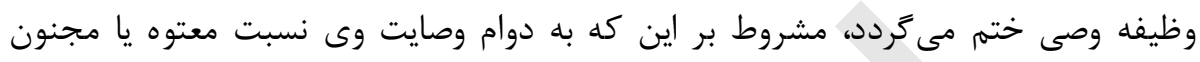
بودن شخص تحت وصايت امر نشدهباشد.

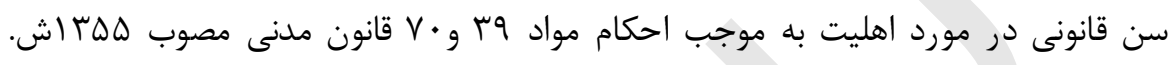

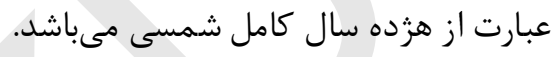

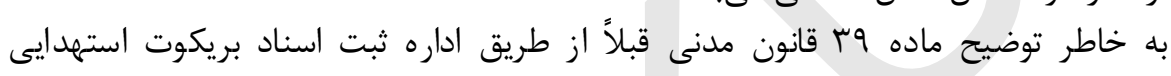

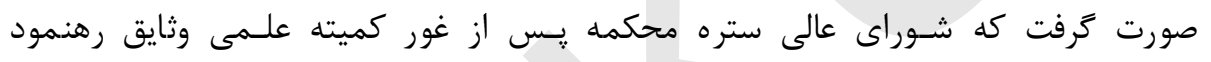

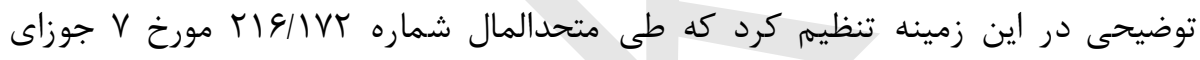

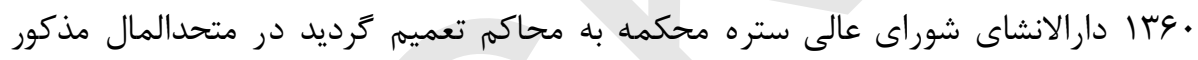

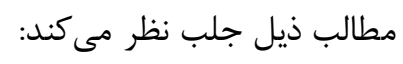

\section{متن استهداء}

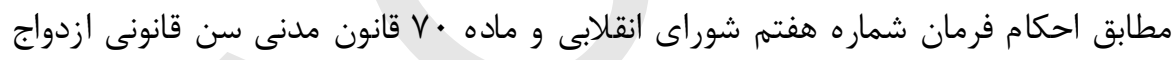

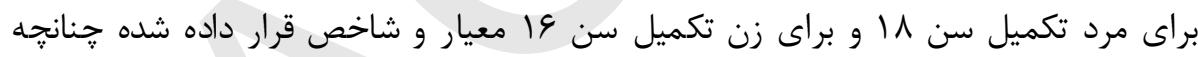

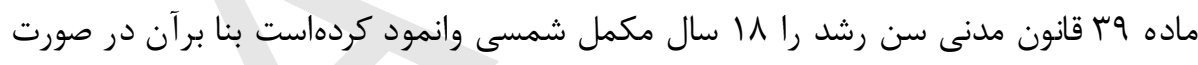

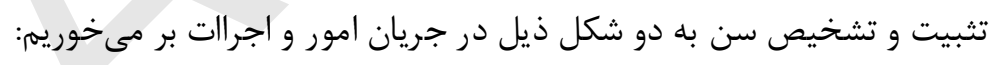

اول

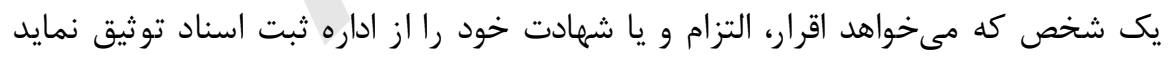

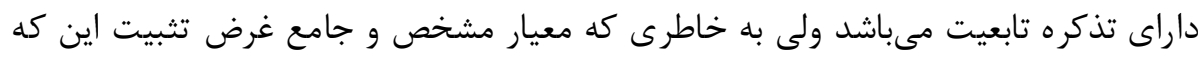

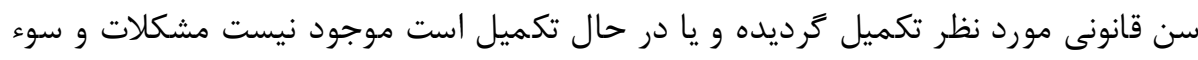

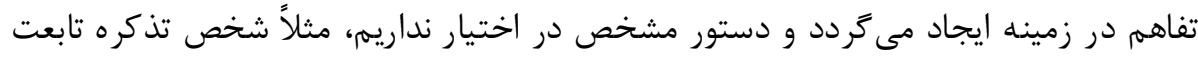

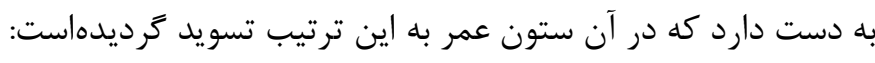

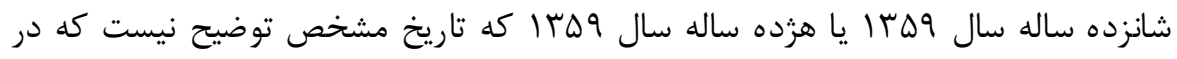

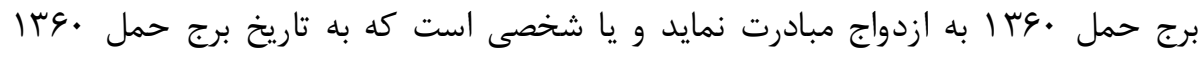

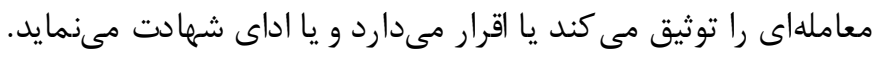
بنابران طور فشرده مواد آتى قابل يادآورى است مارد 


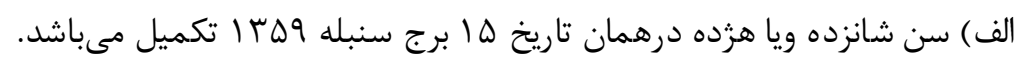

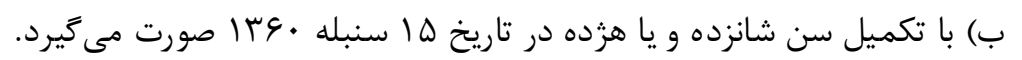

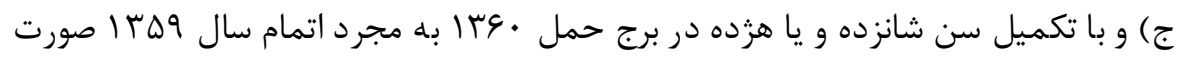
مى زيرد. لذا در زمينه طالب هدايت مىباشيمى تا به منظور استفاده از طريق واحد و معين و هماهنكى

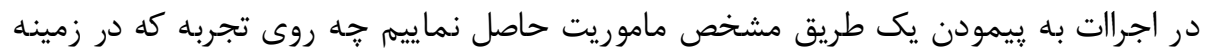

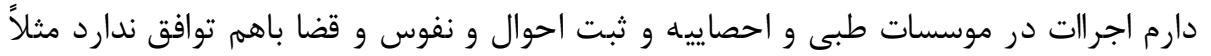

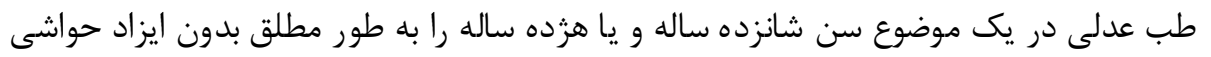

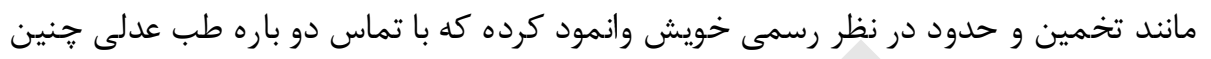

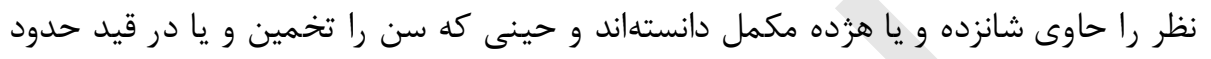

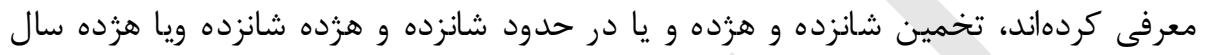

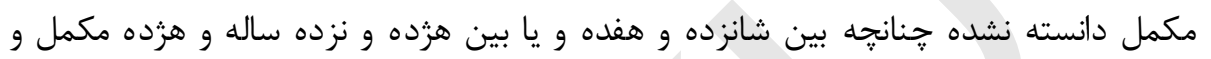

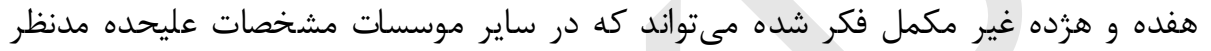
كرفته مىشود.

دوم

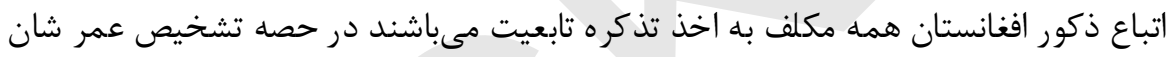

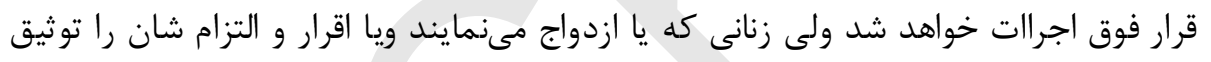

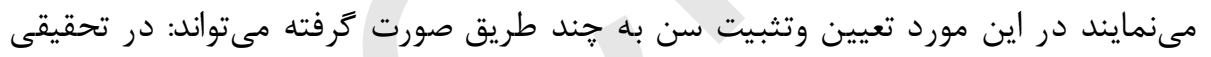

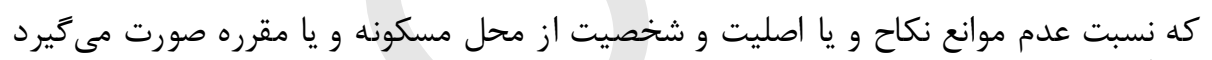

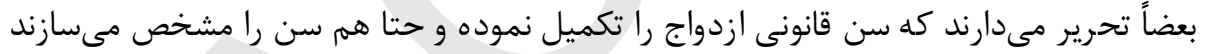

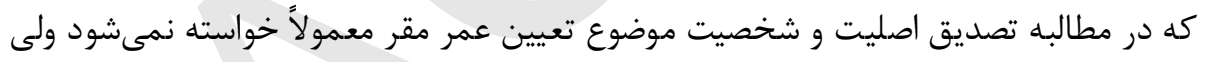

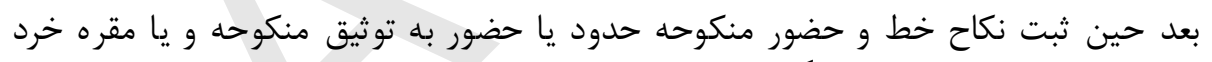

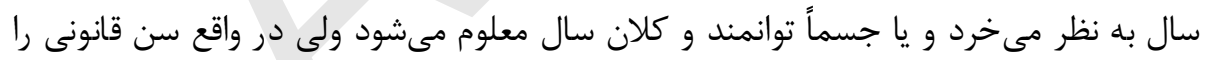

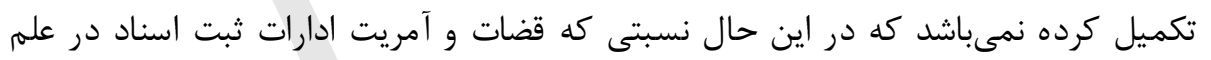

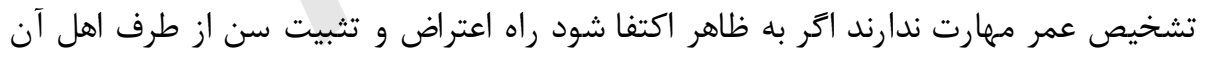

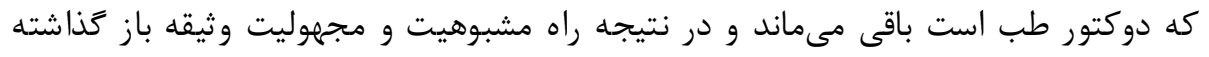

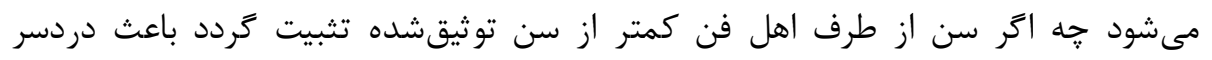

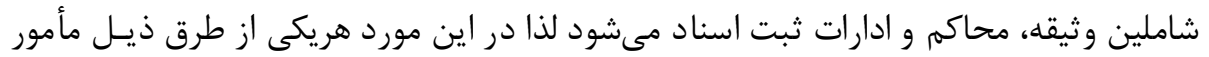

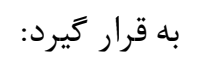

الف) تعيين و تشخيص سن در صورتئ كُ كه زن تذكره به دست نداشتهباشد از راه استحصال

$$
\text { نظر طبى صورت كيرد. }
$$




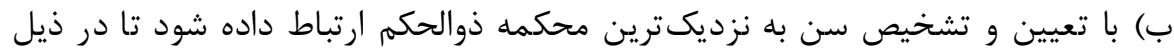

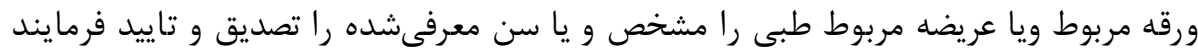

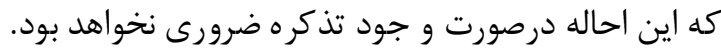

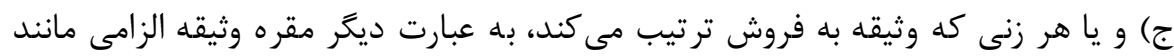

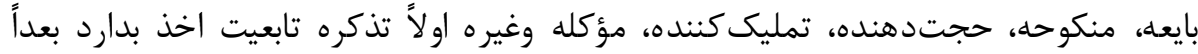
موضوع مورد نظر خود را توثيق نمايد.

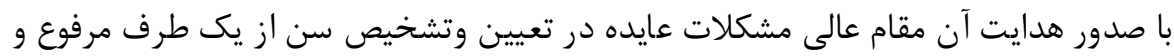

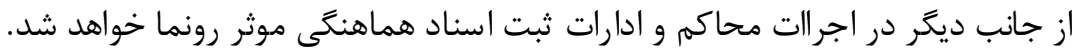

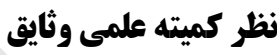

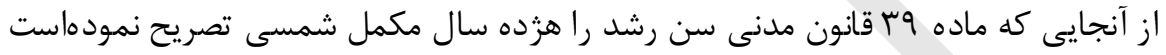

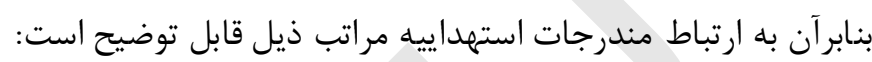

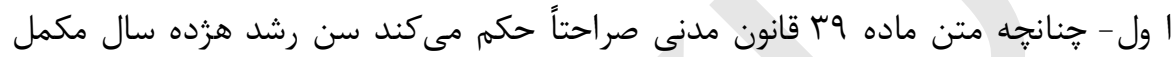

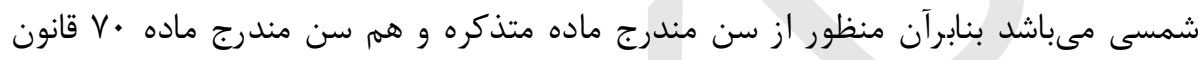

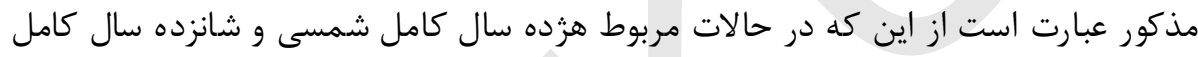
سبرى كرديده باشد.

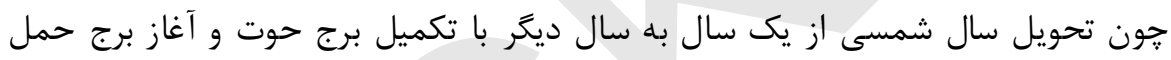

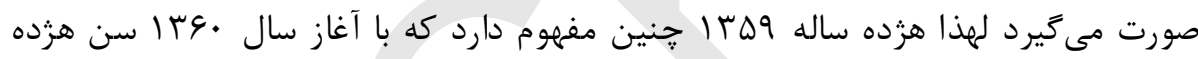
سالكى را تكميل نموده است. دوم - با رعايت حكم ماده •ه قانون مدنى و حكم مندرج ماده •9 تعديل قانون اجرات

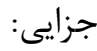

$$
\text { الف) در تعيين سن، تذكره تابعيت مدار اعتبار شناخته مىشود. }
$$

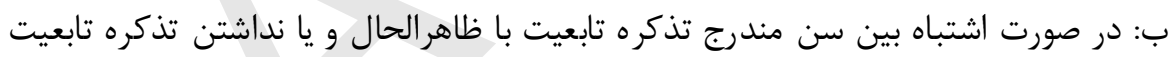

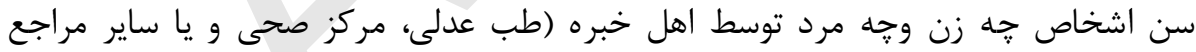

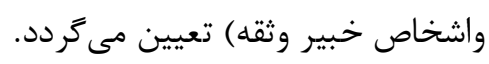

سوم) جواب توضيحى فوق بعد ملاحظه و تاييد شوراى عالى ستره محكمه تعميم كر دد.

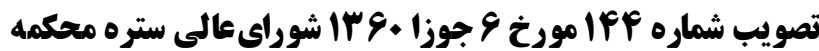

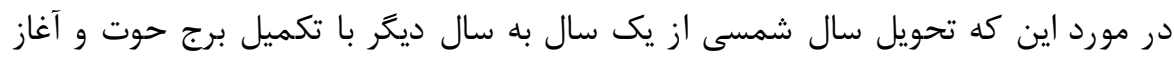

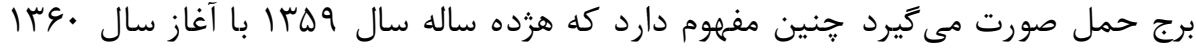

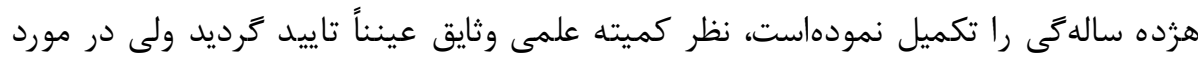

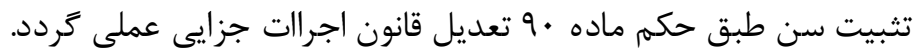
موضوع غرض آكاهى به عموم محاكم تعميم كر دد" أ. 


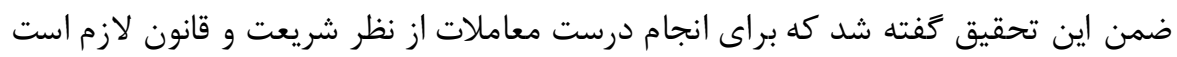

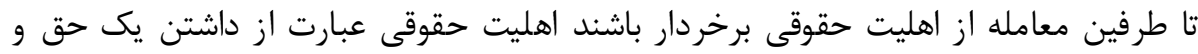

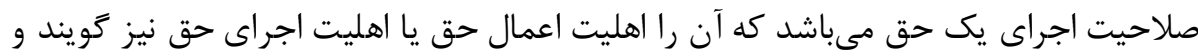

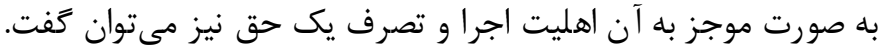

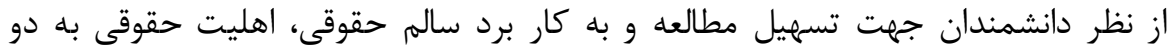

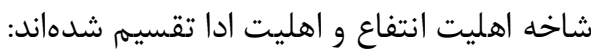

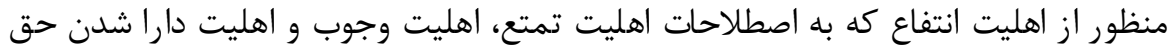

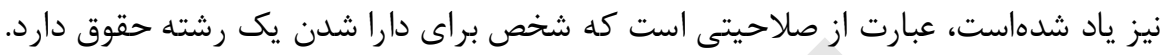

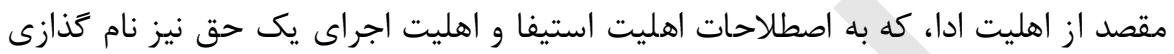
كرديدهاست صلاحيتى است كه شخص براى اعمال و اجراى يك حق قانونى دارد، مانند

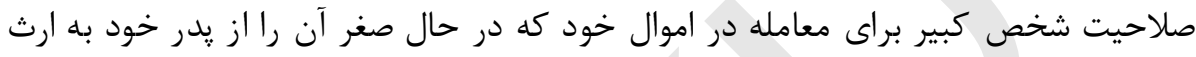
در مورد كتّورى اول يا اهليت انتفاع اصلًا مشكلى مطرح نيست زيرا انسان وقتى كه

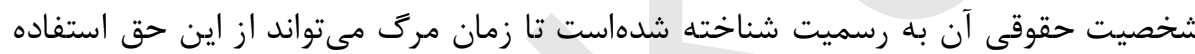
برد و حايز آن باشد.

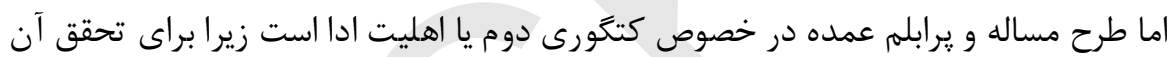
وجود يك سلسله اوصاف و شرايط لازم است و شخص عامل، طرفين معامله يا كسى كه دها

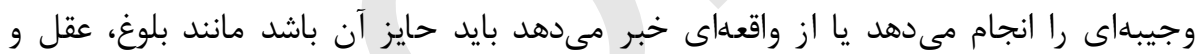
يكى از اركان عمده اهليت ادا را بلوغ تشكيل ميدهد كه شريعت و قانون به آنه آن تصريح

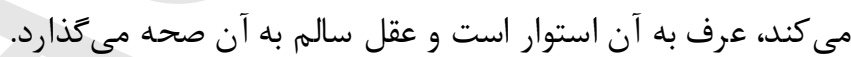

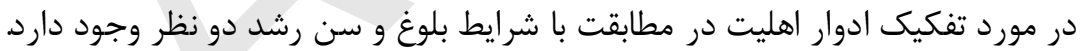

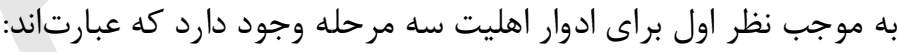

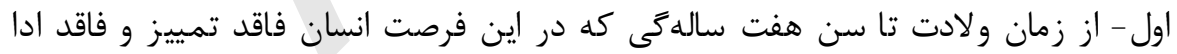

دوم - از سن هفت سالهى تا زمان بلوغ در اين مرحله انسان ناقص تمييز و ناقص اهليت اداء

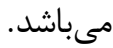
سوم - اكمال سن هزده سال تا آخرين مرحله حيات را تشكيل مى دهد. در اين دوره انسان

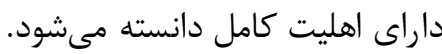
به اساس نظر دوم، دورههاى حيات انسان از حيث قبول اهليت ومكلفيت به ينج مرحله

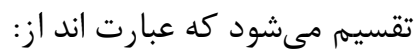
اول -دوران جنين: كه از موقع حمل آغاز وتا زمان تولد ادامه دارد دارد. 
دوم- دوران طفوليت وعدم تمييز: از زمان تولد آغاز وتا اكمال سن هفت سالهَى ادامه مى سيابد. سوم - دوران تميز: از اكمال سن هفت آغاز و تا زمان بلوغ دوام مى كند.

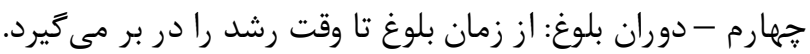

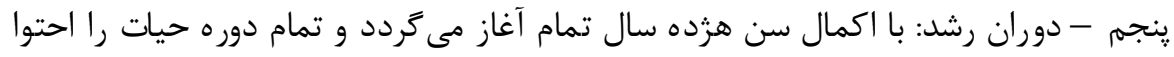
مىنمايد. حد رسيدن به ابلوغ " به نامهاى سن رشد، كبارت و سن قانونى نيز ياد شدهاست.

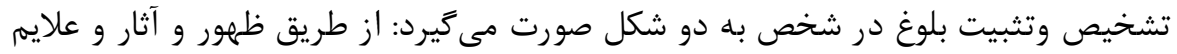

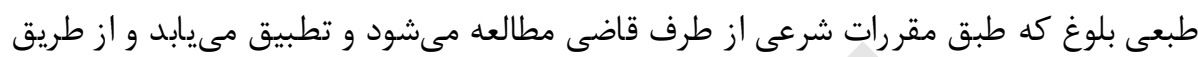
رسيدن به سن نهايى بلوغ.

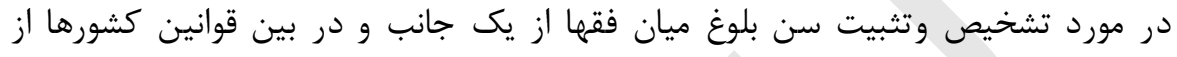

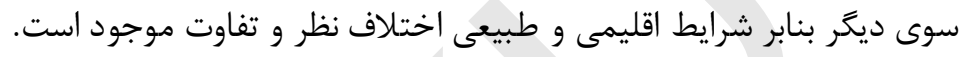

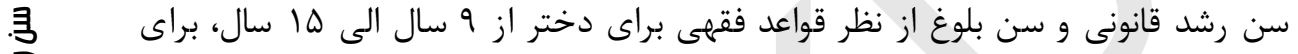

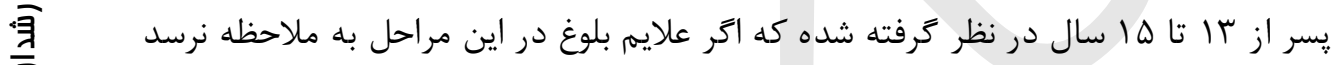

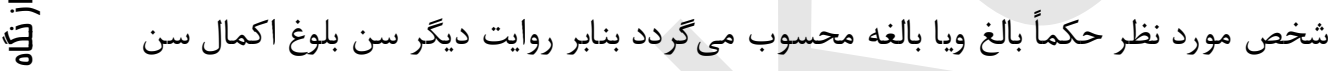
هزده سالهى قبول شئ شدهاست.

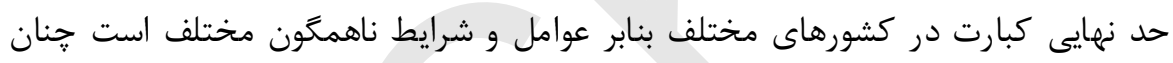

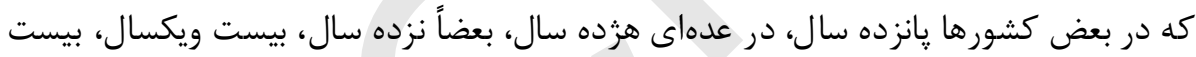

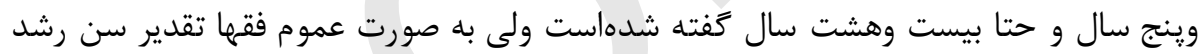
را به قاضى موكول مىنمايند.

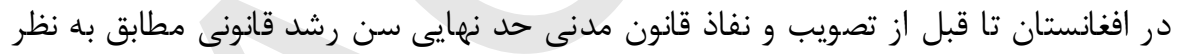

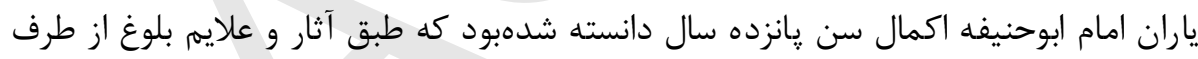

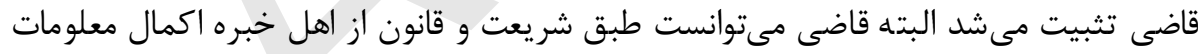

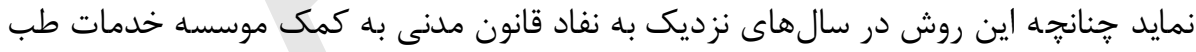

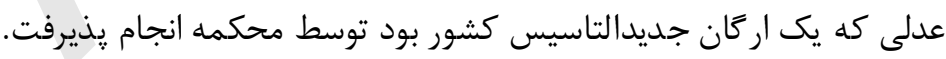

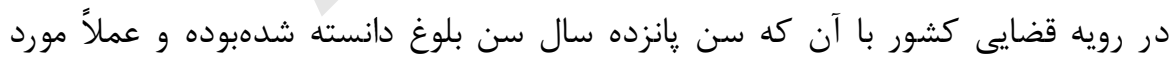

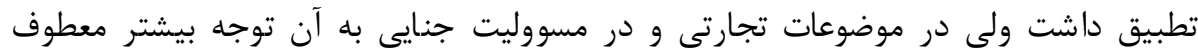

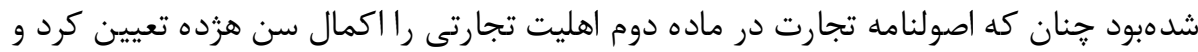

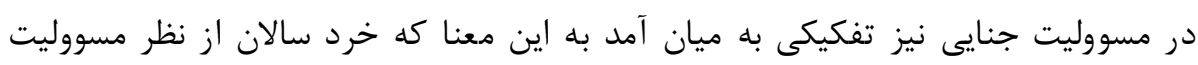

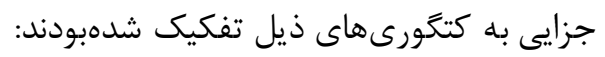

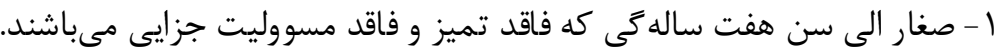

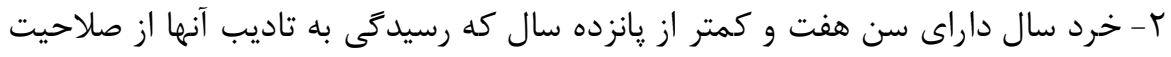
محاكم اطفال دانسته شد. 
ب- خرد سالان داراى سن پانزده تا هزده سال تمام كه اصطلاح مراهق در خصوص آنها قابل

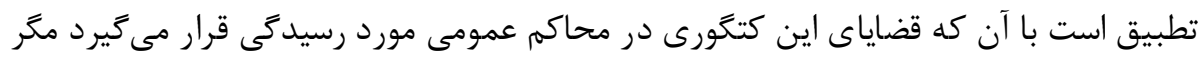

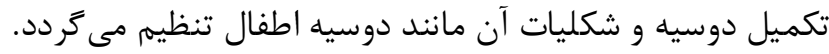

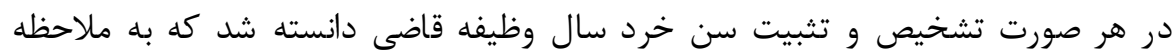

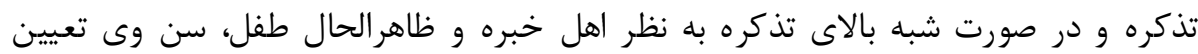

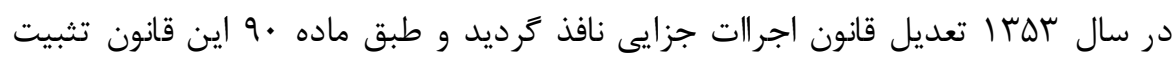

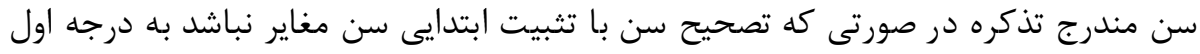

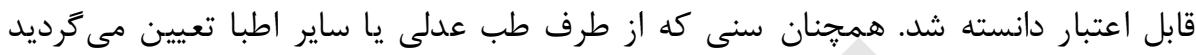

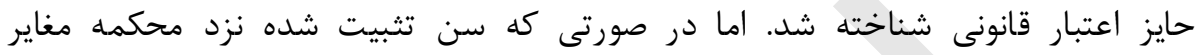

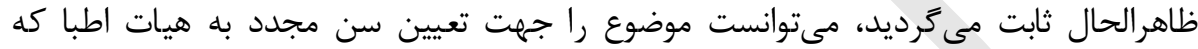

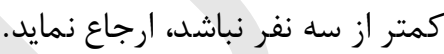

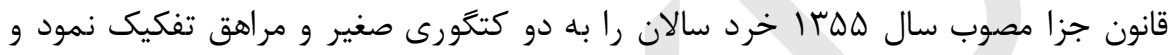

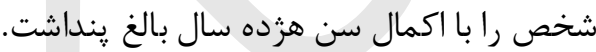

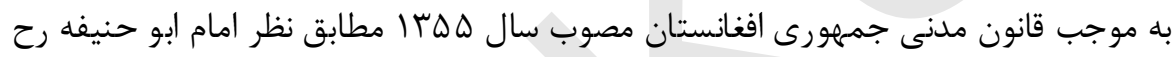

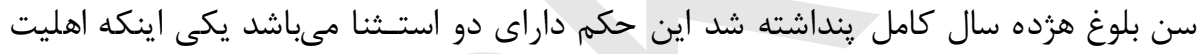

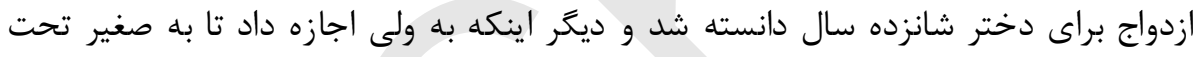

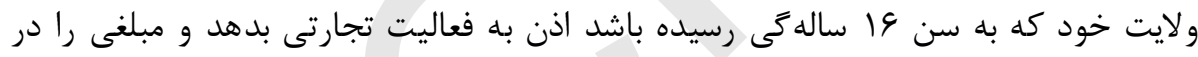

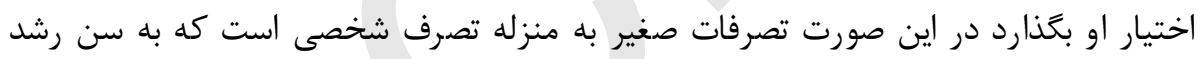
ريدهباشد. به اين ترتيب به اساس اسناد ودلايلى كه در متن تصريح شد سن رشد قانونى عبارت از

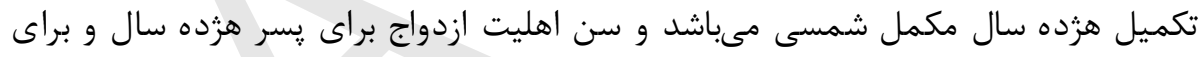
دختر اكمال سن شانزده سال يذيرفته شدهاست سترل

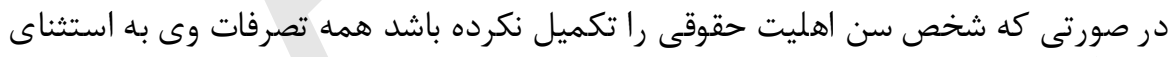

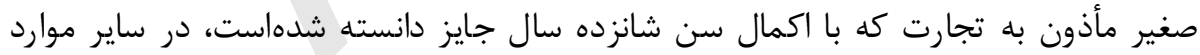

$$
\text { صحيح دانسته نمىشود. }
$$

تشخيص و تثبيت سن (رشد قانونى) از طرف محكمه با در نظر داشت شرايط ذيل صورت

$$
\text { مى الفيرد: در تعيين سن تذكره تابعيت مدار اعتبار است. }
$$

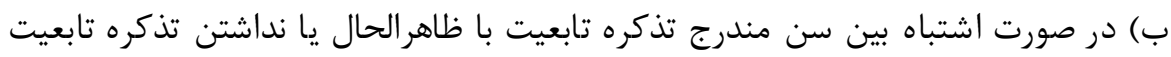

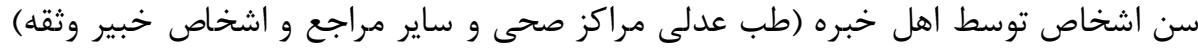
تعيين مى گردد. 
ج) هر كاه با اكمال حد نهايى سن بلوغ آثار و علايم بلوغ در شخص ديده نشود اين شخص

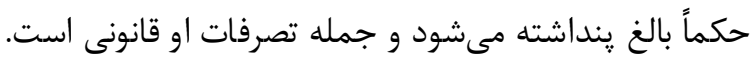

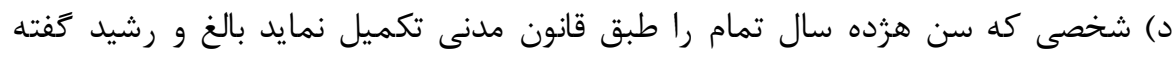

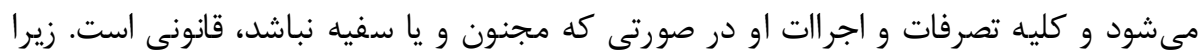

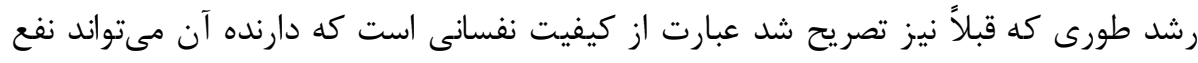

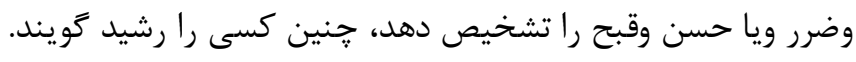

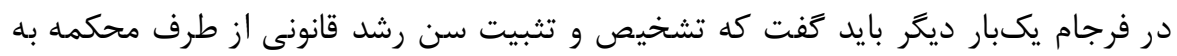

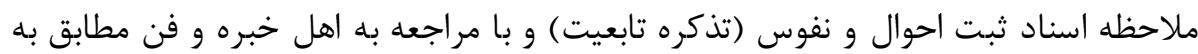

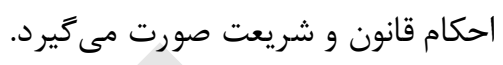

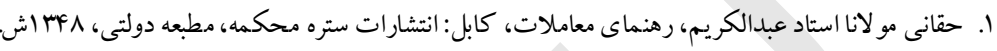

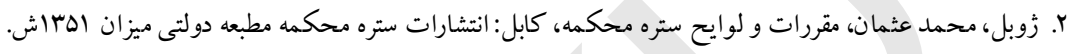

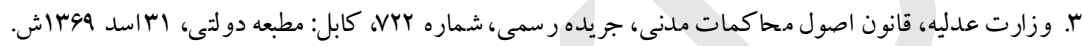

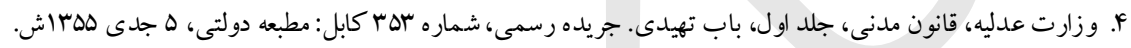

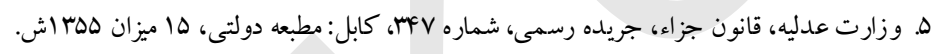

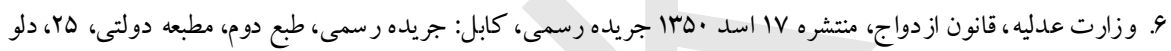




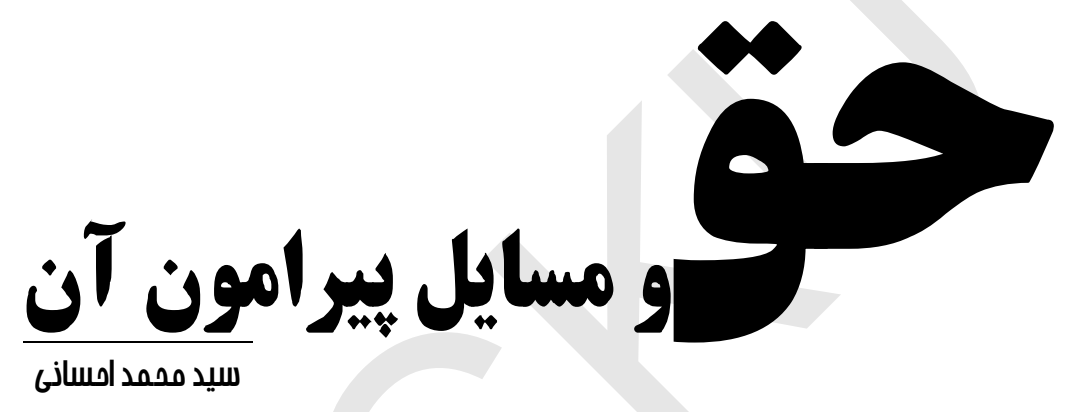

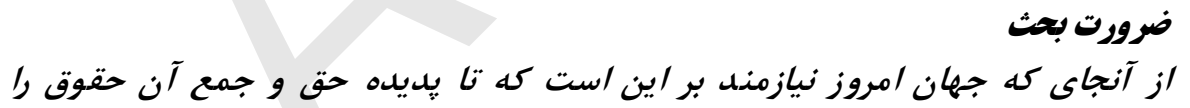

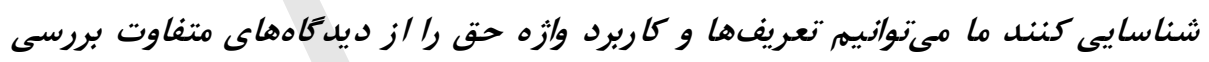

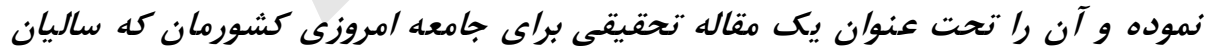

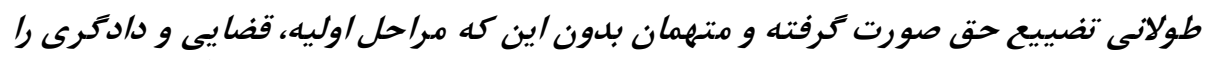

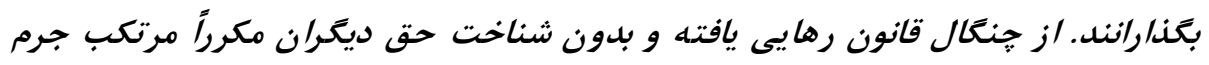
شدند.

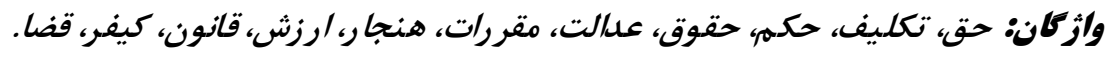

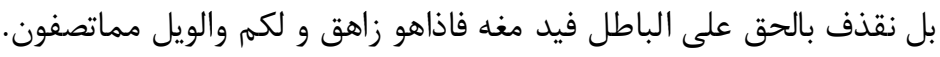

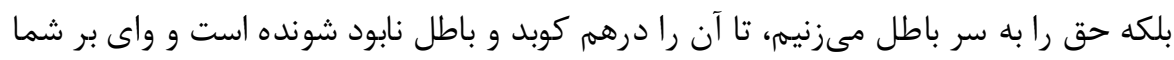
از آنجه به خدا نسبت مي بـدهيد. 


\section{حق و مسايل بيرامون آن}

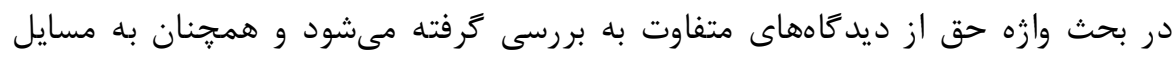

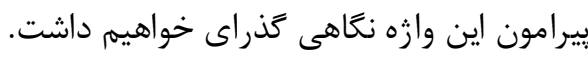

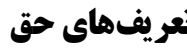

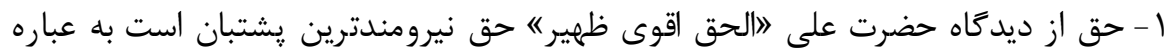

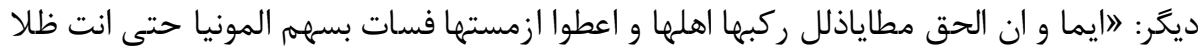

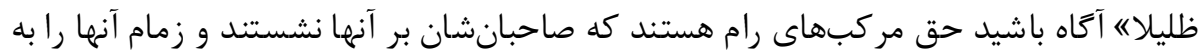

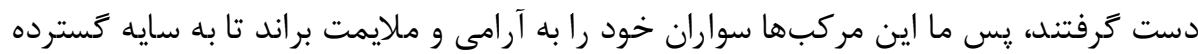

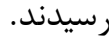

حضرت على فرموده، حق: ابه شخصيت ها شناخته نمىشود؛ خود حق را بشناس تا بيروان

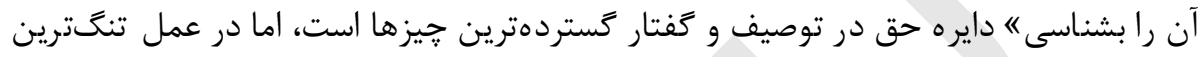

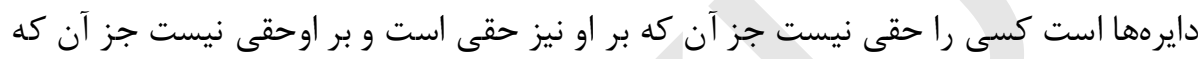

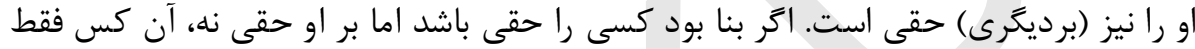

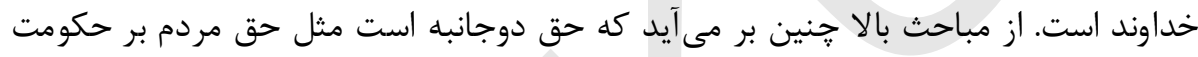

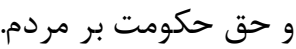

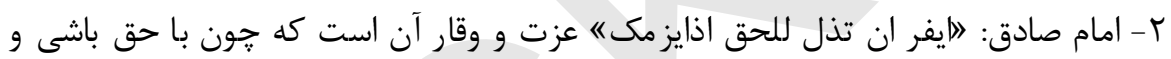
در برابر آن فروتنى كنى. - مان. r- حق در معناى عام خود عبارت است از الهلطهاى كه بر براى شخص بر شخص ديخر يا مال

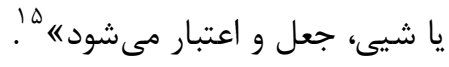

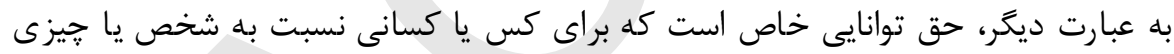

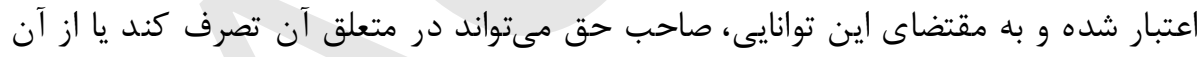

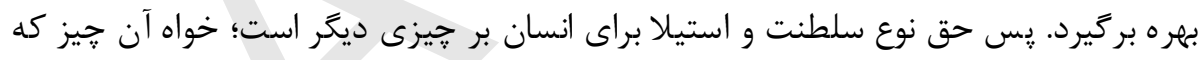

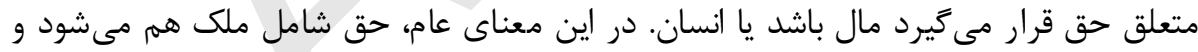

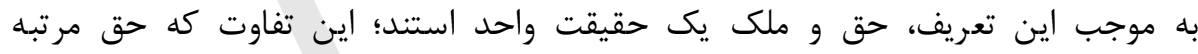

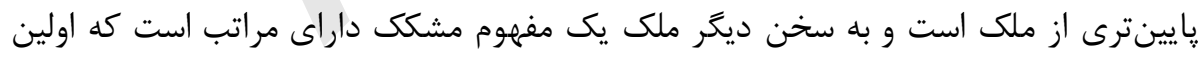

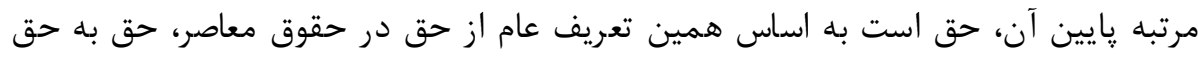

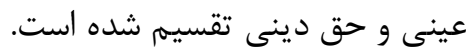

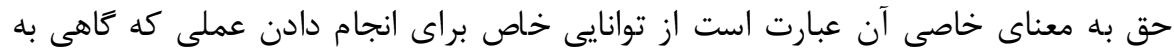

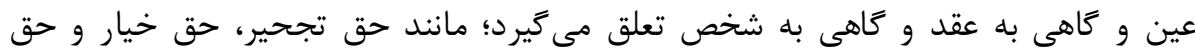
قصاص. 
† أ لغت شناسان، براى وازه حق معناى متعددى ذكر ميى كنند. از آن جمله اين معانى است:

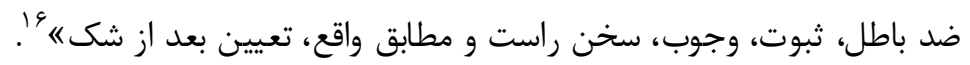

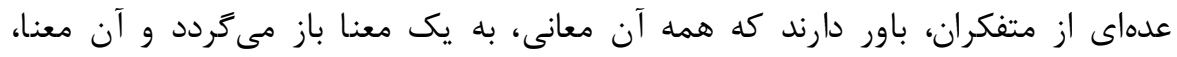

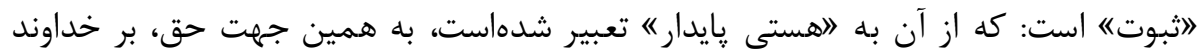

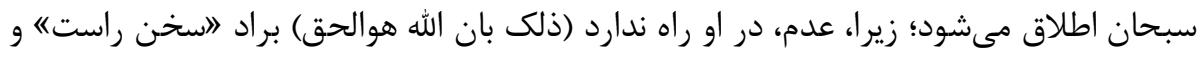

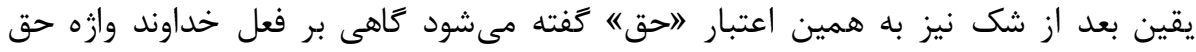

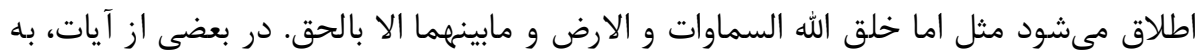

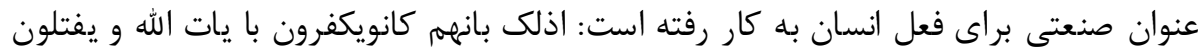
النبيين بغير الحق.

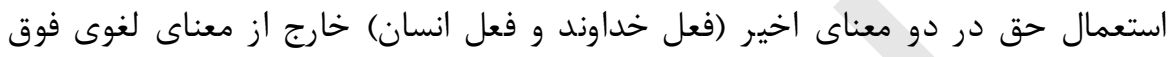

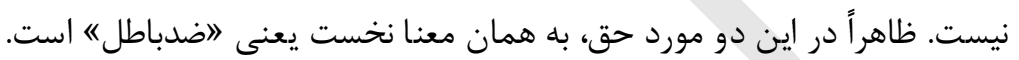

\section{ه- حق در اصطلاح}

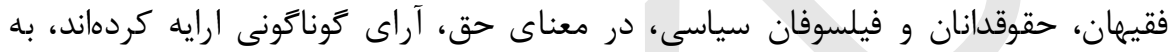

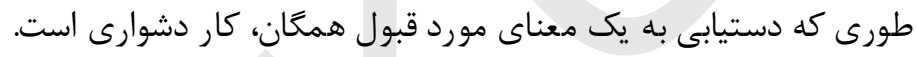

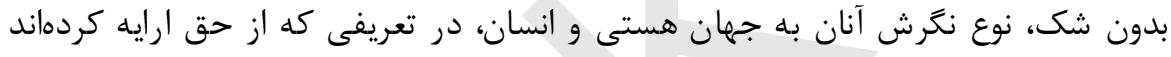

$$
\text { برخى از تعريفهاى حق جنين است: }
$$

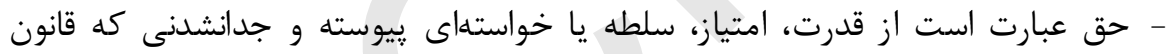

براى شخص مى شناسد.

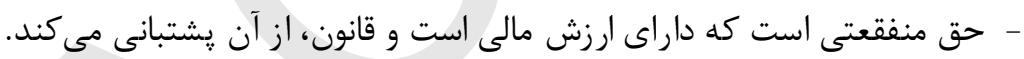

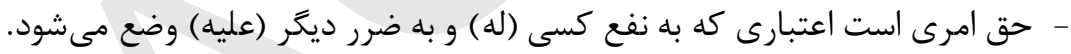

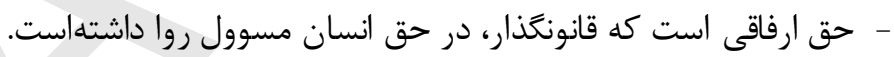

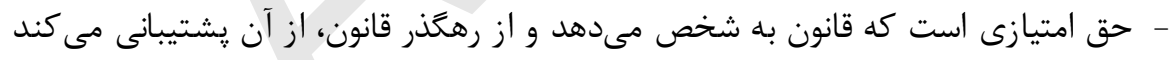

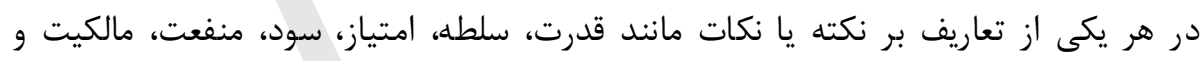

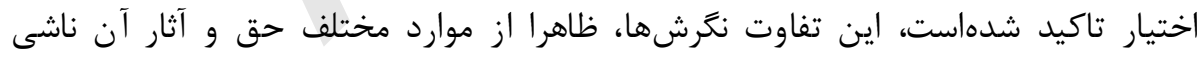


؟ أ حقوق قابل اسقاط و انتقال قهرى و در عين حال غير قابل نقل ادارى مانند حق خيار كه

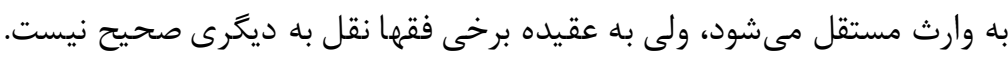

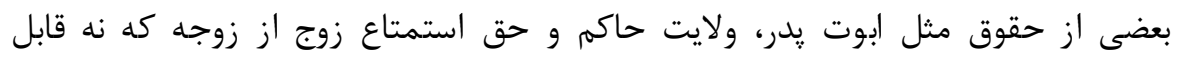

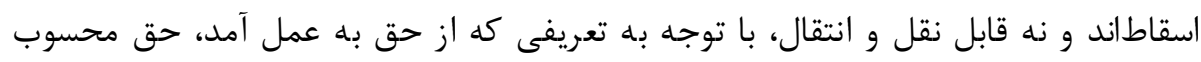

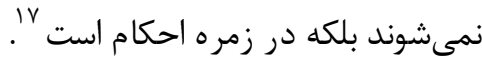

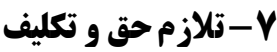

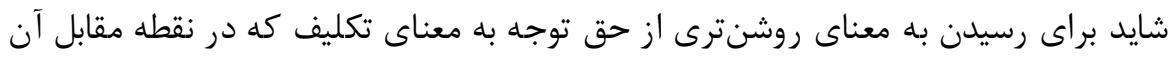

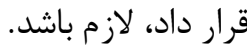

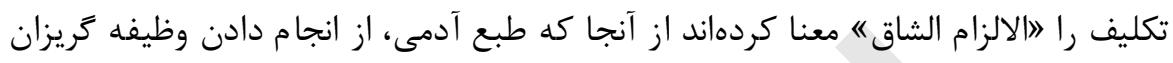

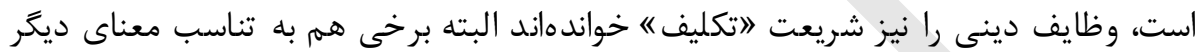

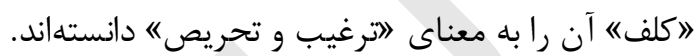

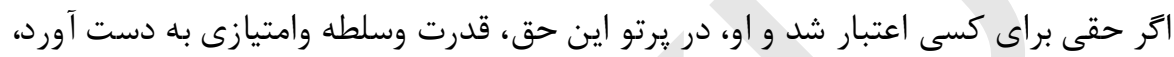

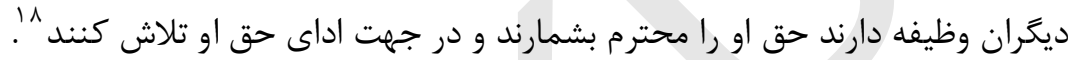

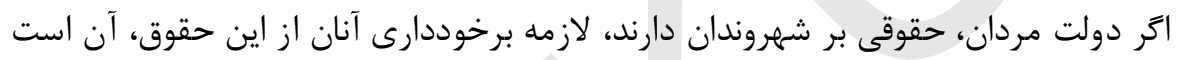

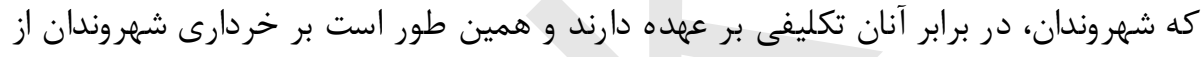
حقوق.

\section{ن إنكاه حكيمان و عارفان از افقى بالآر}

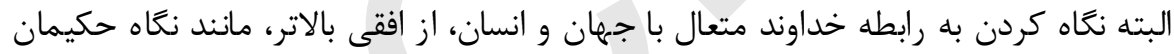

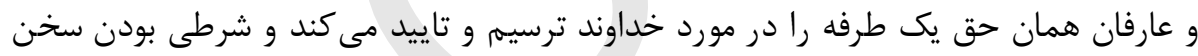

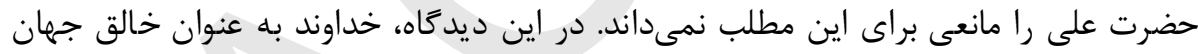

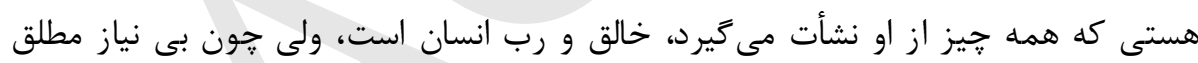

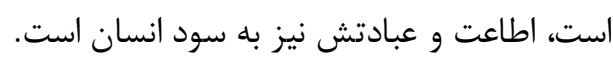

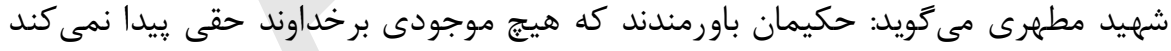

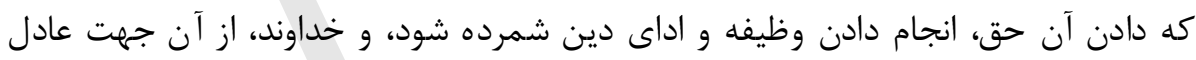

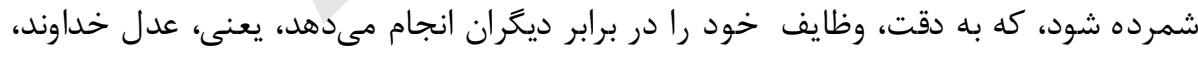

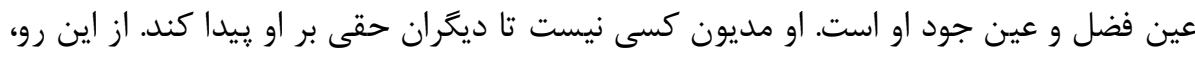

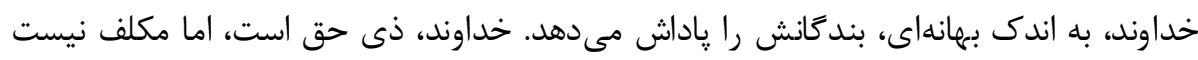

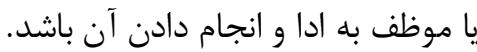

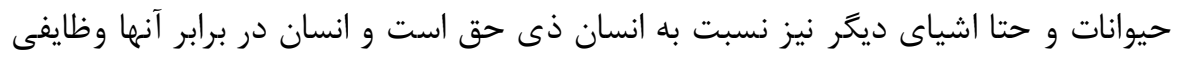

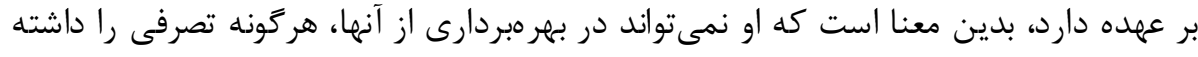




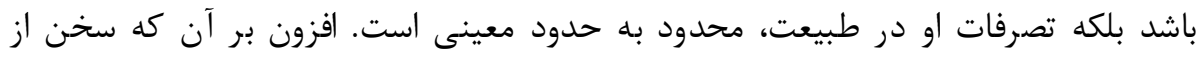

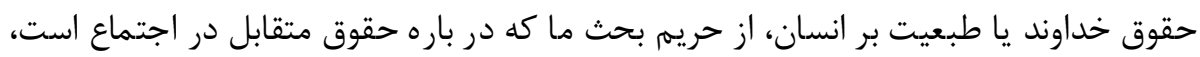

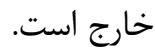

نكته ديكر آن كه اتر در معنا و مفهوم حق، نوع امتياز و بهرهمندى نهفته است، و شخص

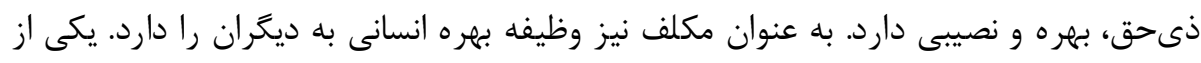

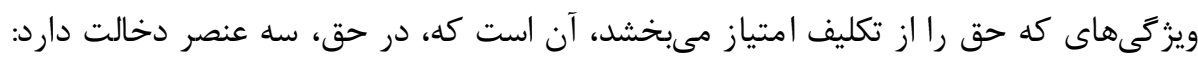

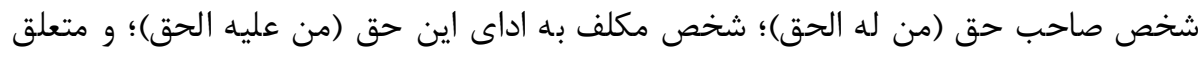
حق و تكليف دو عنصر اساسى در زندگى اجتماعى و فردى انسان است و هر انسان، همان

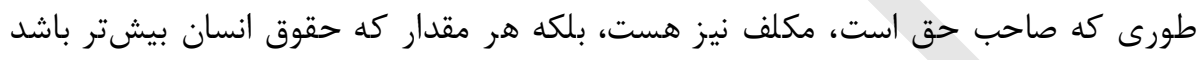

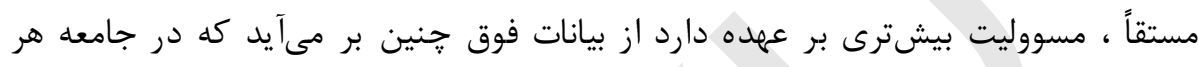

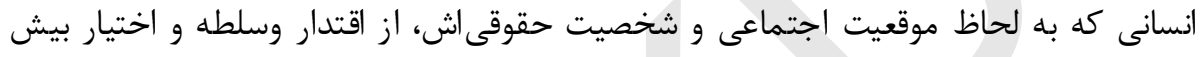

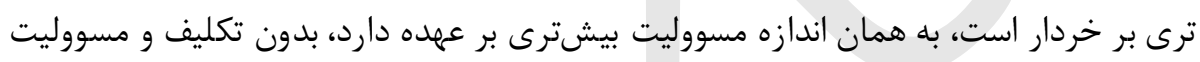

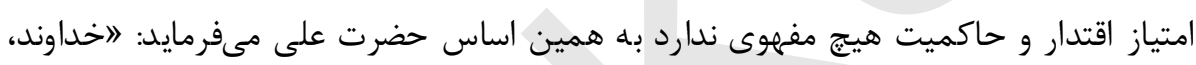

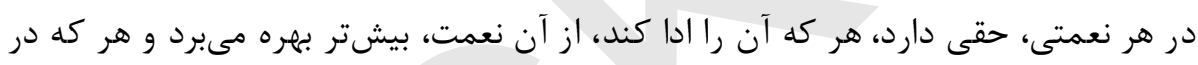

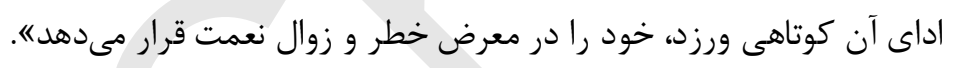

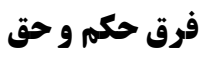

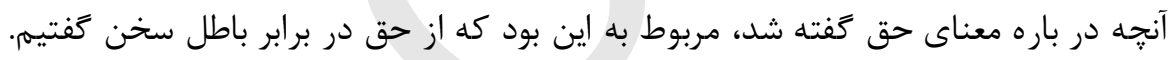

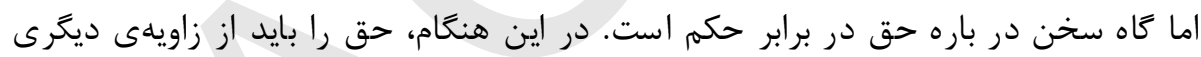
نكريست. اكر امرى صرفاً جنبهى قانونى داشته يا در حد وظيفه باشد و به اشيا بركر دد، حكمم ناميده

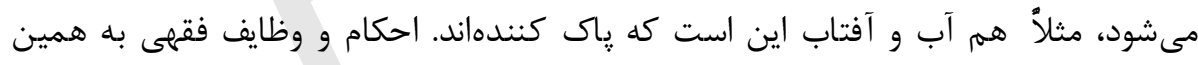

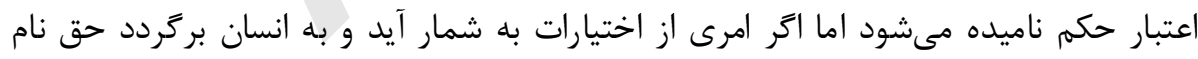

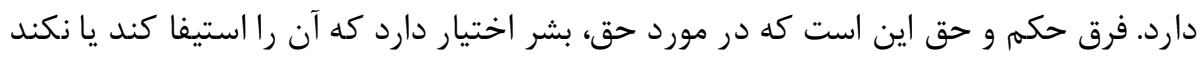

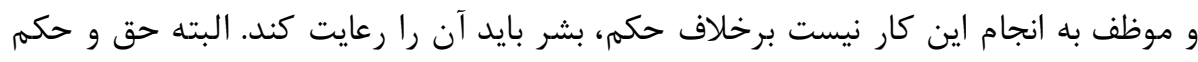

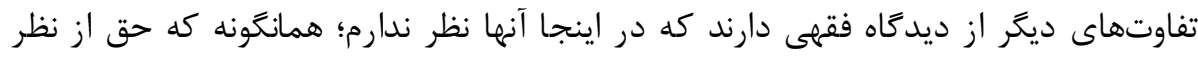

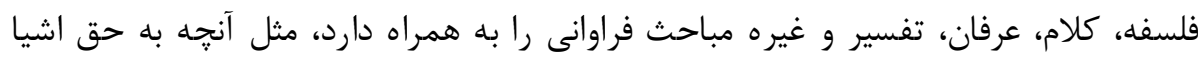

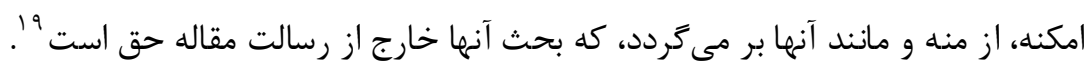


تعريف: ارايه تعريفى از حقوق ماندوق ماند، ديخر شاخههاى علوم اجتماعى كار آسانى نيست.

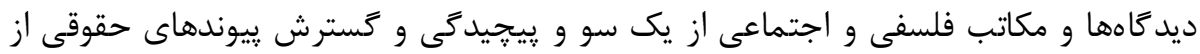

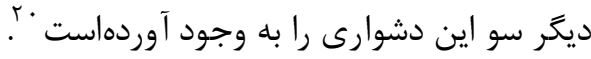

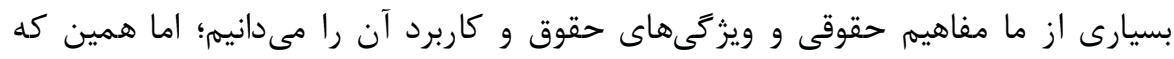

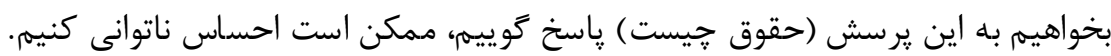

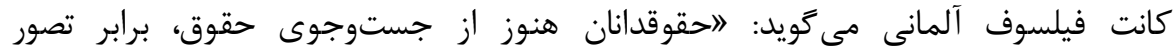

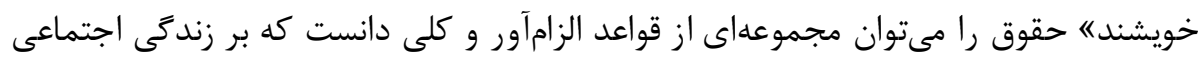

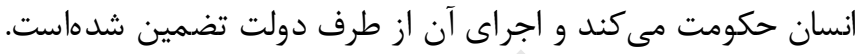

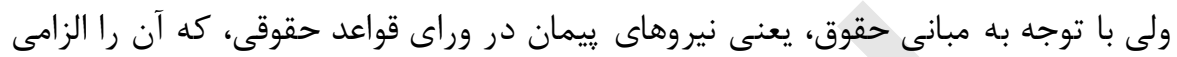

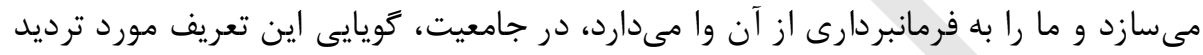

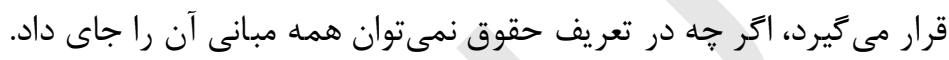

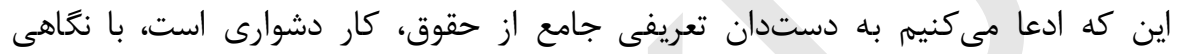

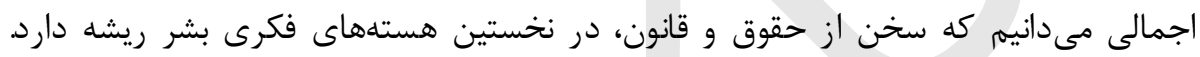

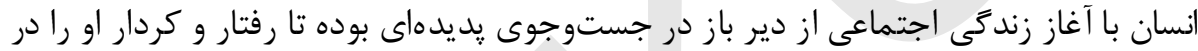

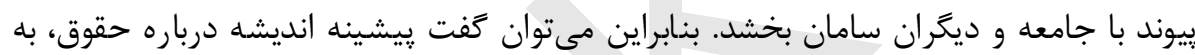

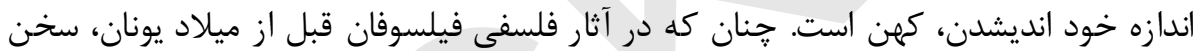

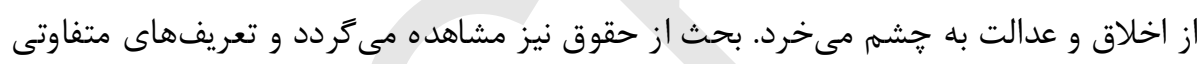

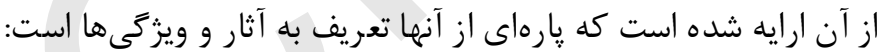

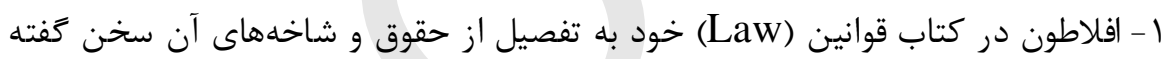

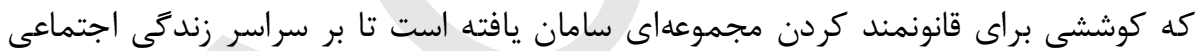

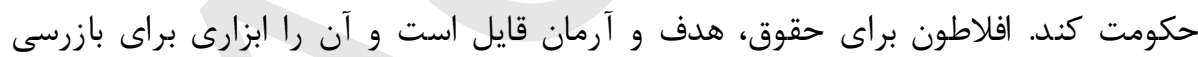

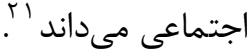

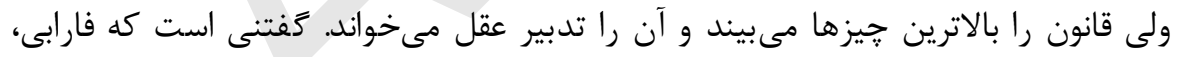

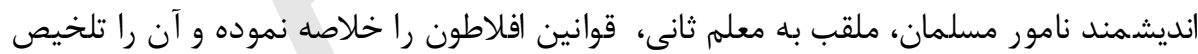
نواميس افلاطون ناميدهاست. ارسطو نيز در متون بسيارى از حقوق بحث كرده، اما تعريف رسمى أن از آن به به دست نداست ندادهاست

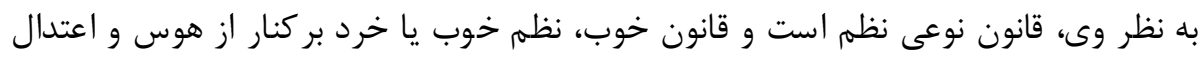

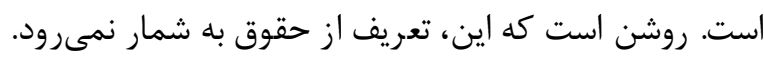

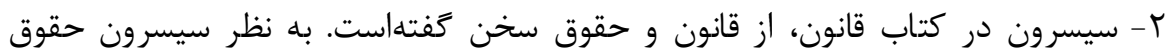

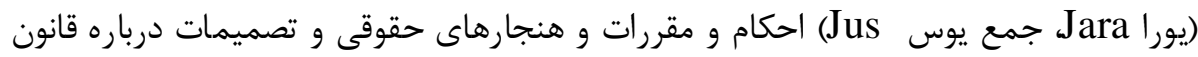

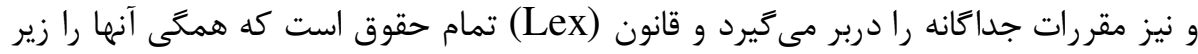




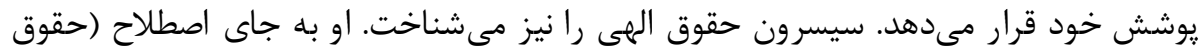

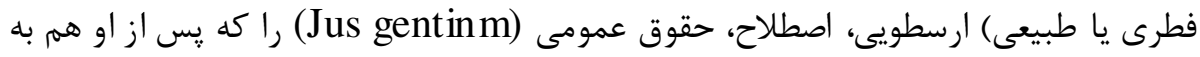

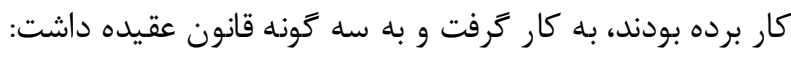

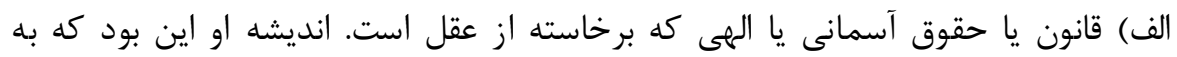

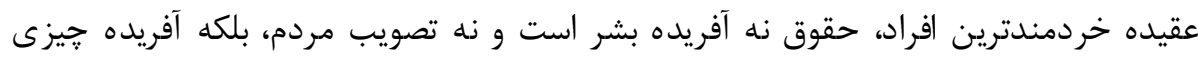

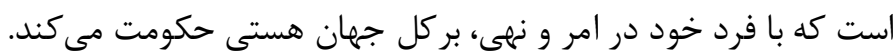

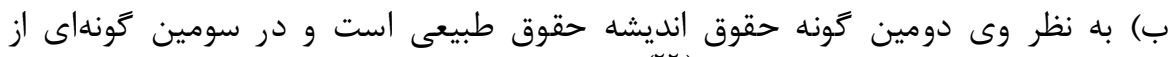

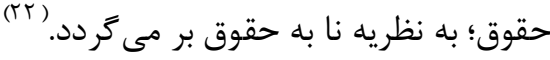

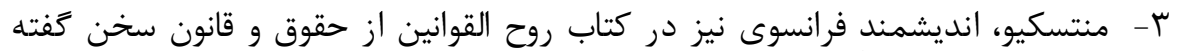

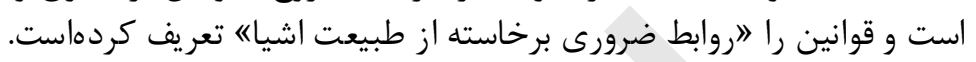
F

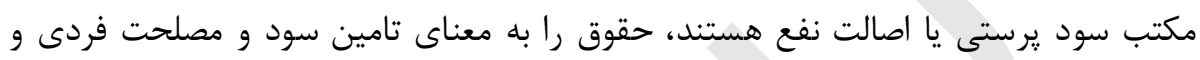
همعانى مىشناسند.

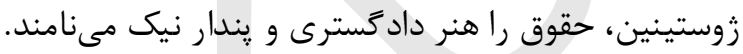

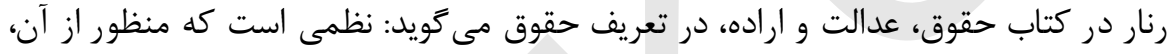

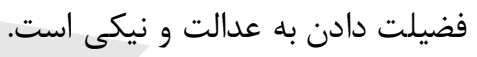

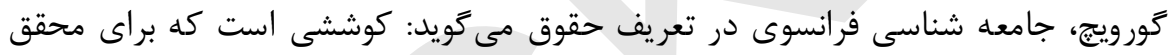
ساختن عدالت در جامعه معين انجام مى شعى شود.

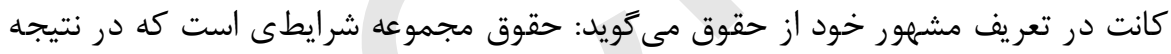

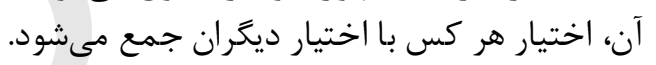

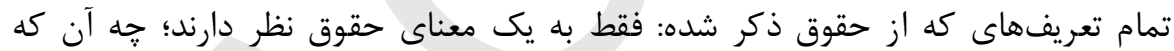

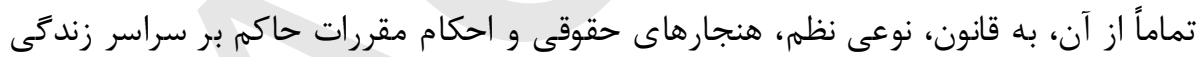

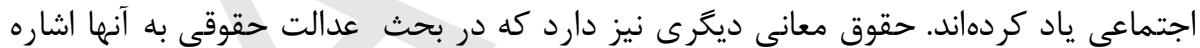

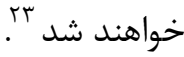
معانى حقوق به طور خلاصه جندين إن است:

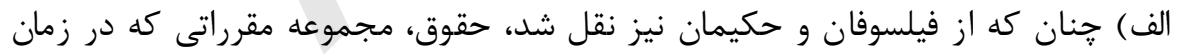

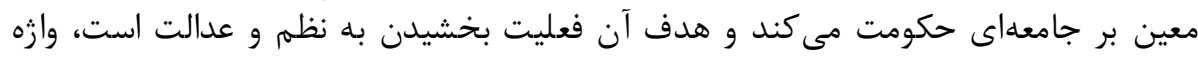

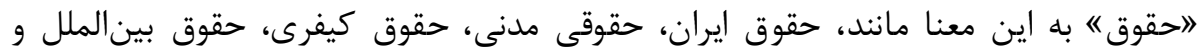

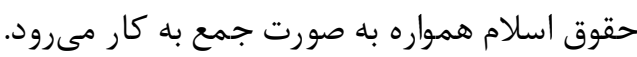

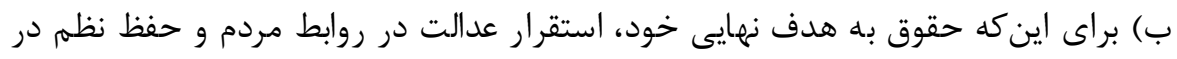

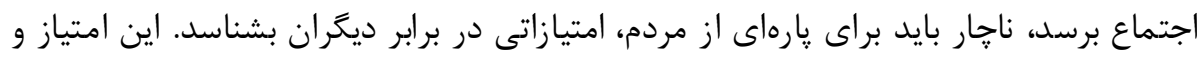

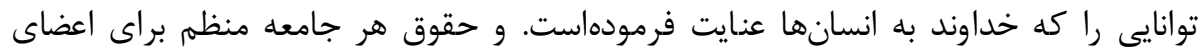


خود و نيز جامعه بينالمللى براى تمام انسانها به رسميت مى شناسد، حق مىنامند كه جمع آن حقوق است.

\section{عدالت حقوقى}

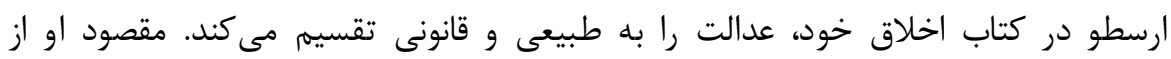

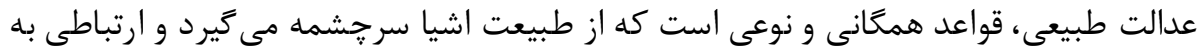

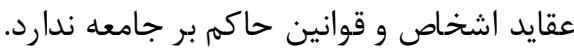

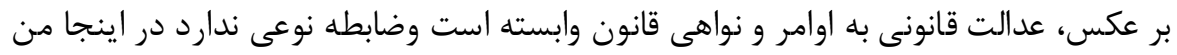

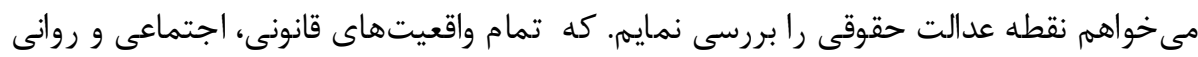

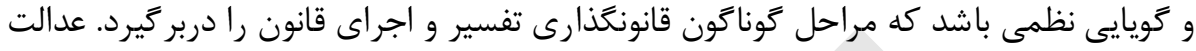

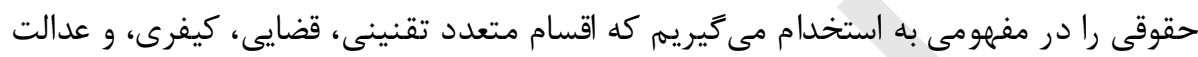

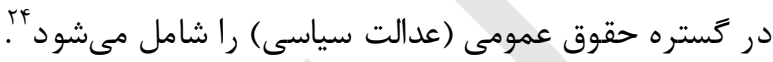

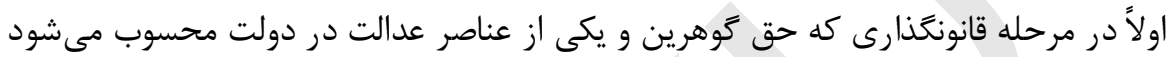

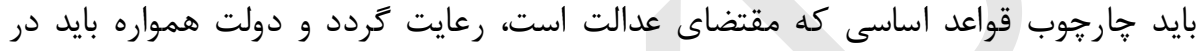

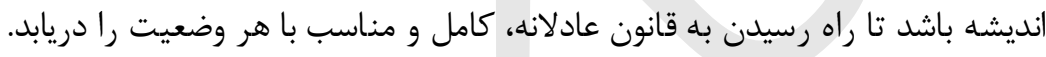

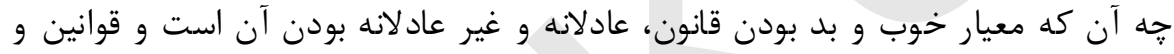

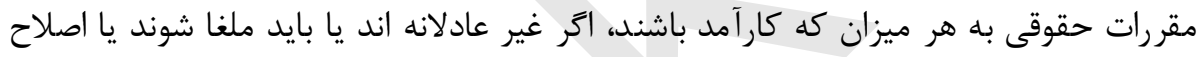

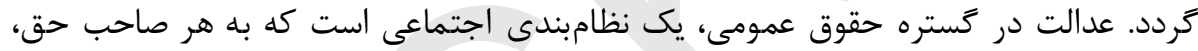

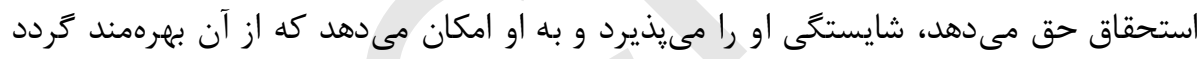

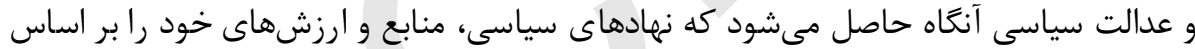

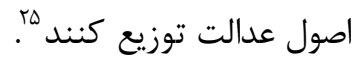

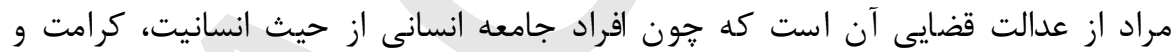

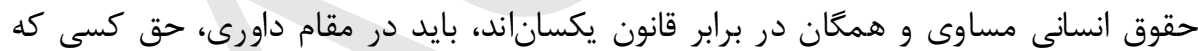

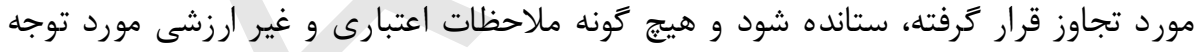

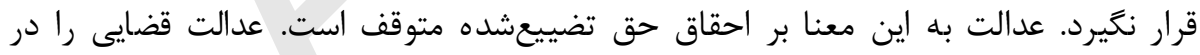

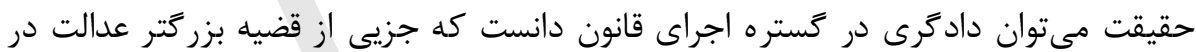

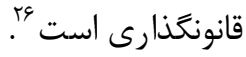

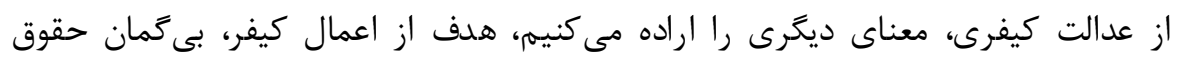

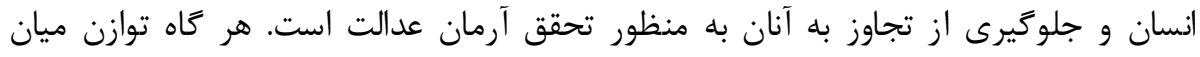

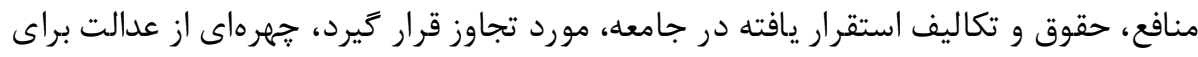

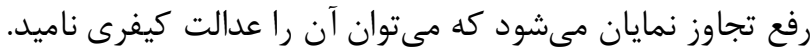




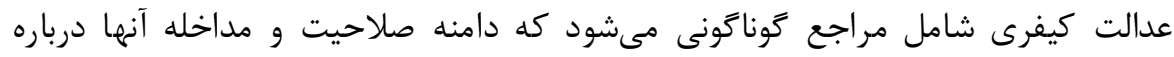

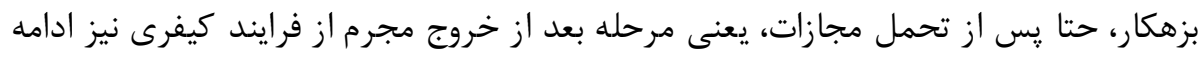

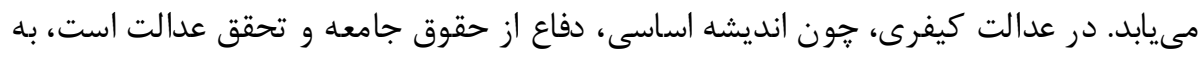

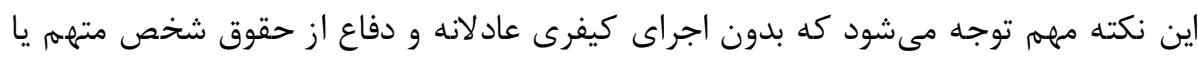

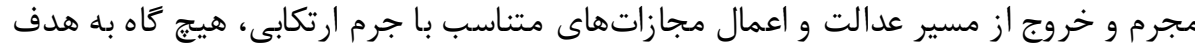

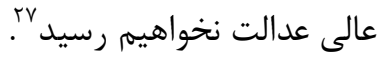

خلاصه

حق عبارت از نيرومندترين يشتيبان است، عزت و وقار انسانها آن است كه خون با حق

$$
\text { باشد و در برابر آن فروتنى كند. }
$$

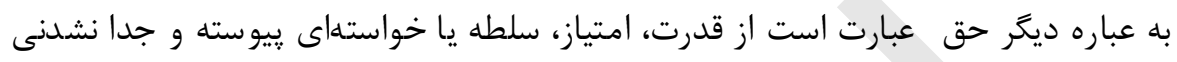

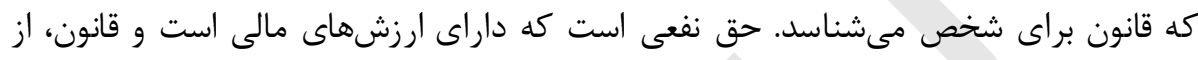

$$
\text { آن حمايت مى كند. }
$$

حق از ديدكاه نايينى به جهمار قسم است:

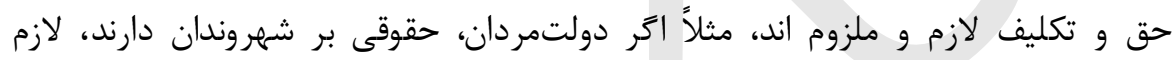

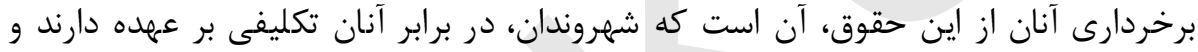

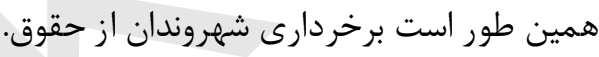

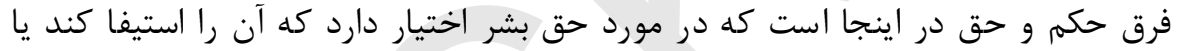

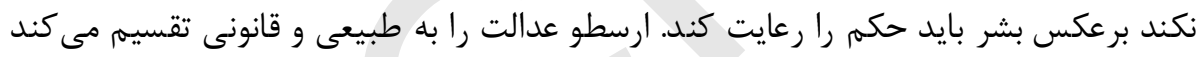

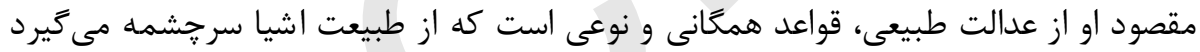

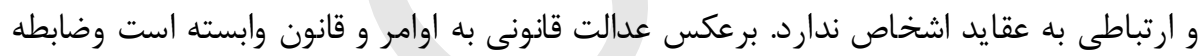

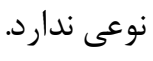

\section{منابع}

1-متيخب ميزانالحكمه، محمدى رى شهرى، حميد رضا شيخى، تلخيص سيد حميد حسينى، با اشراف سيد

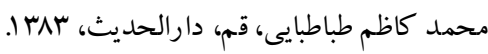

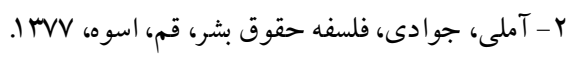

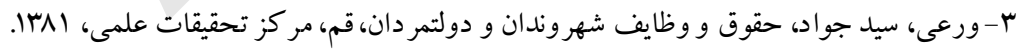

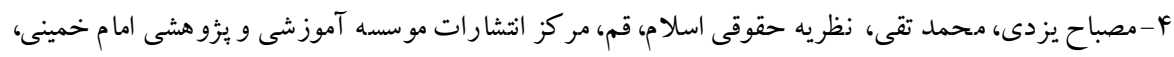

$.1 Y M r$

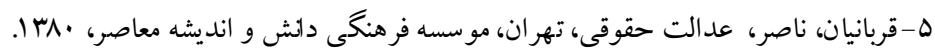

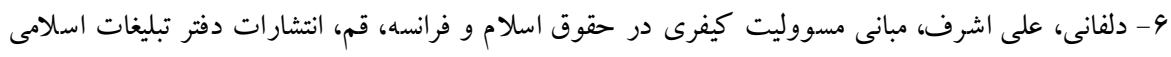

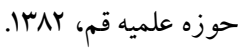




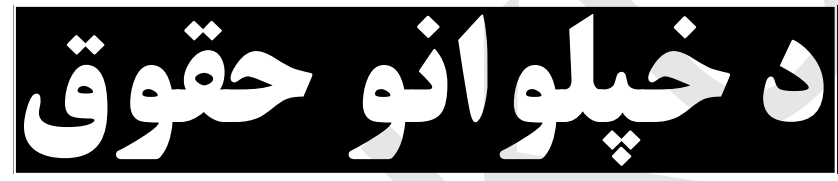

ابو صهيب فضلى

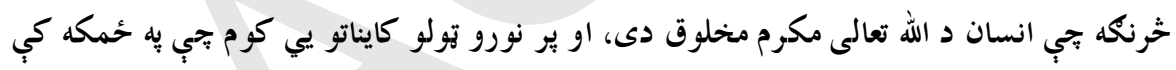

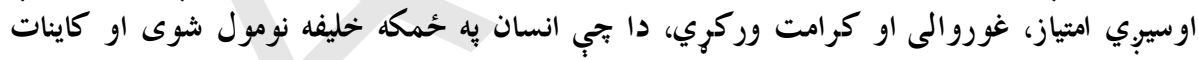

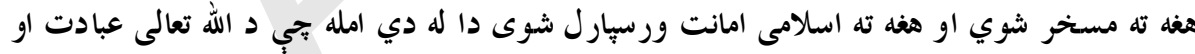

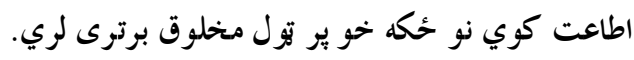

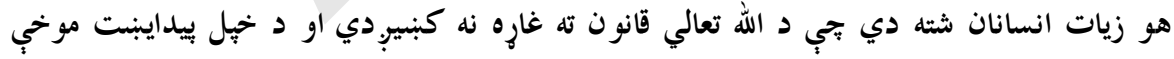

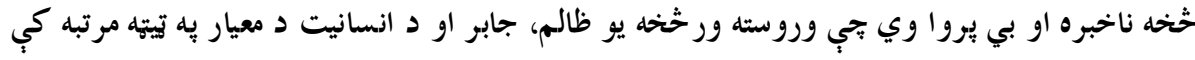

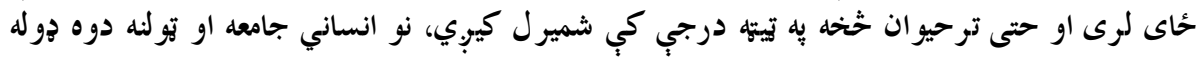

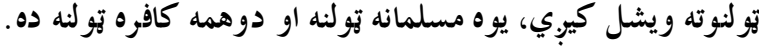

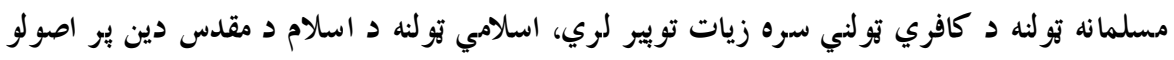

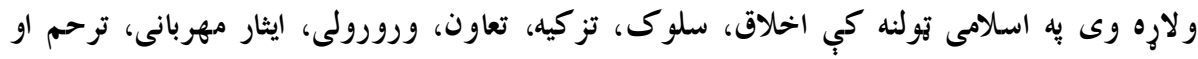

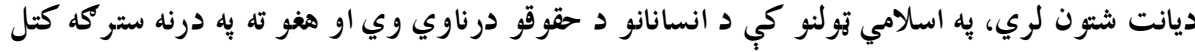
كيوب. 


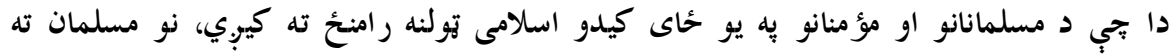

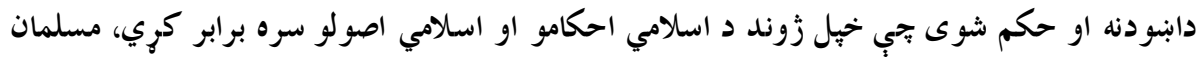

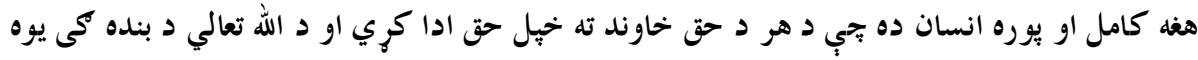

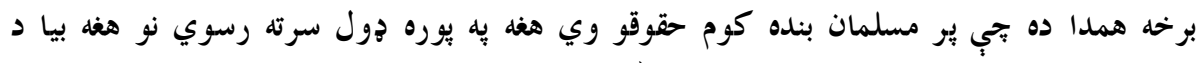

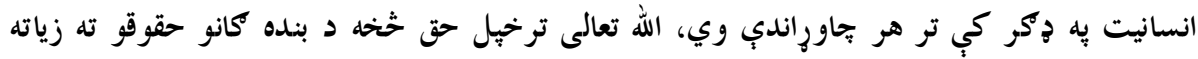

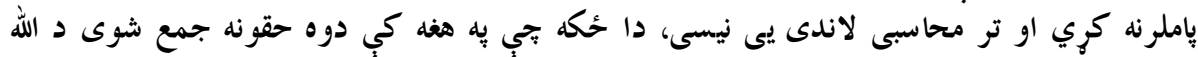

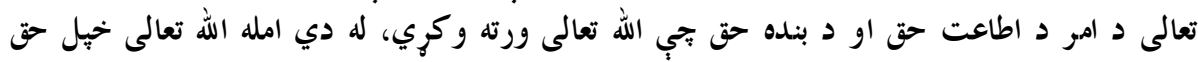

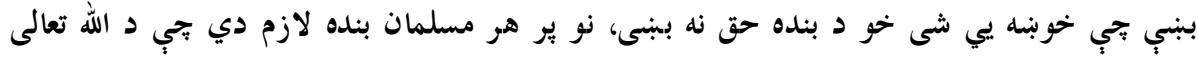

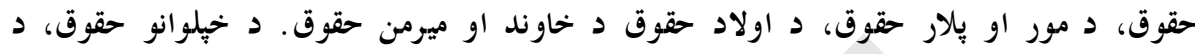

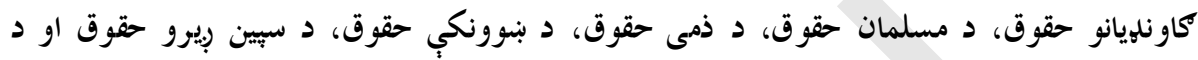

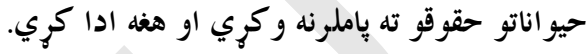

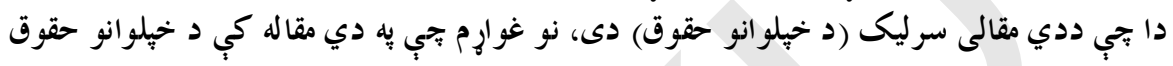

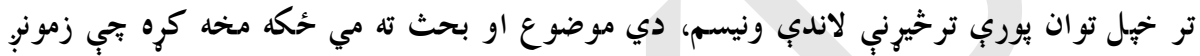

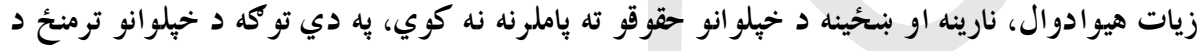

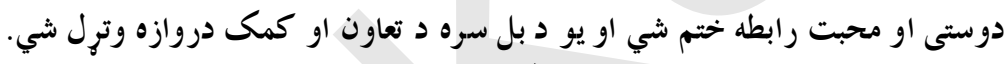

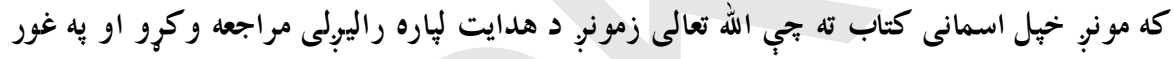

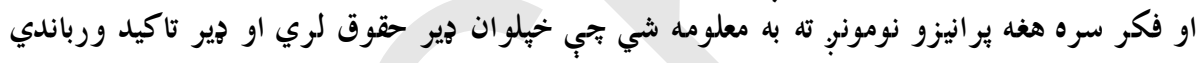

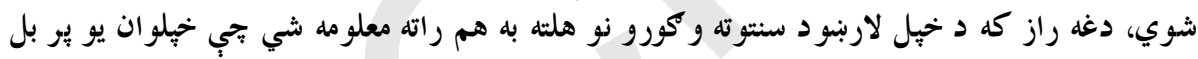

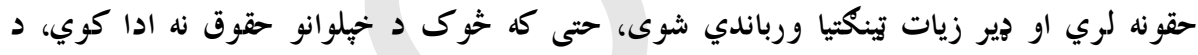

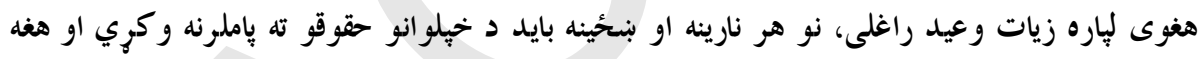

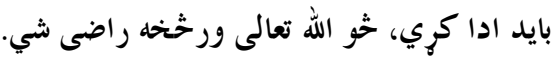

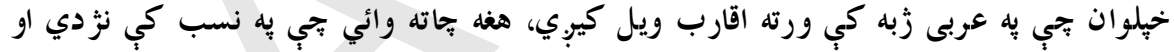

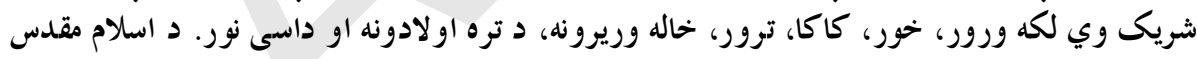

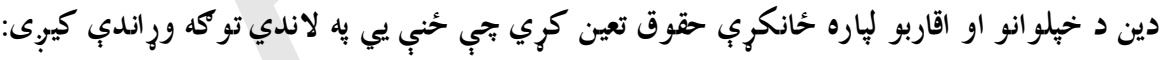

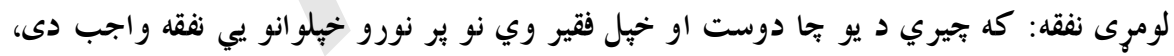

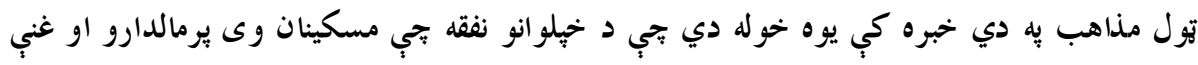

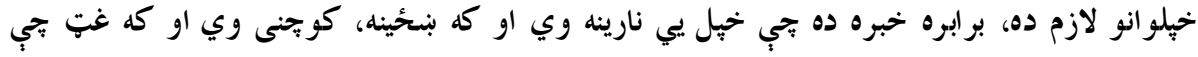

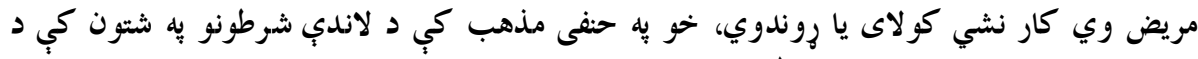

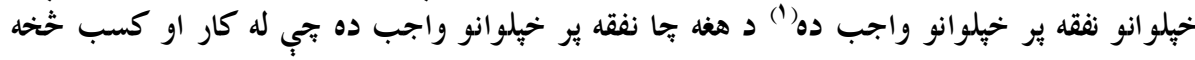

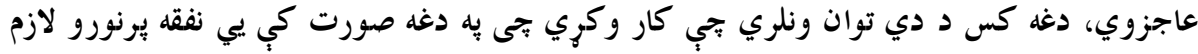

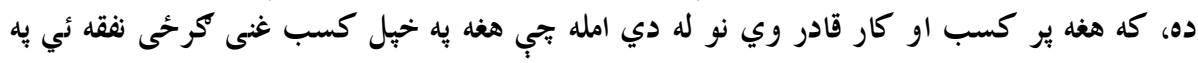

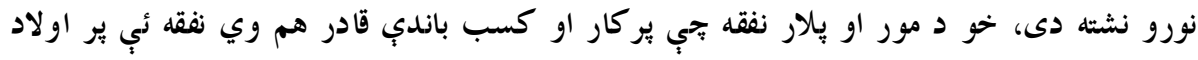

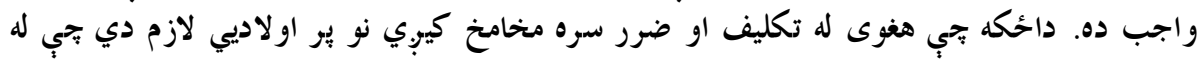


هغوى ثخه ضرر او تكليف دفع كري، نو د خبلو انو نفقه ددي حديث شريف به استناد واجب كنبل

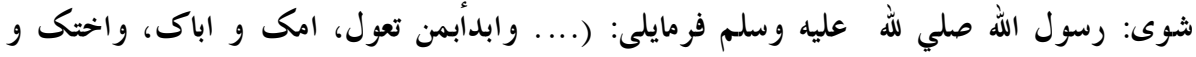

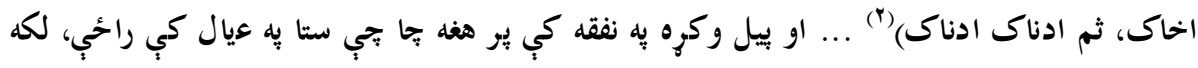

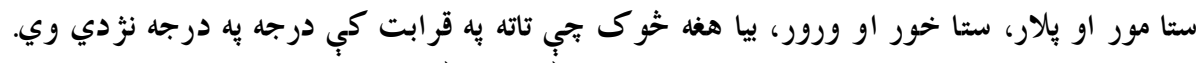

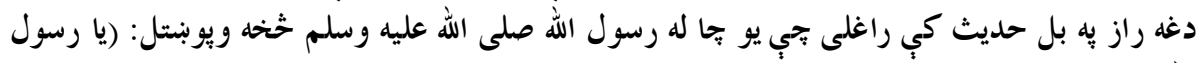

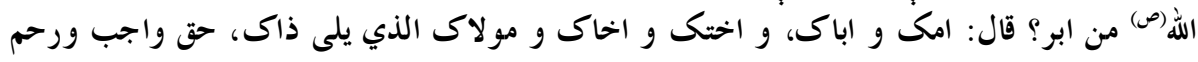

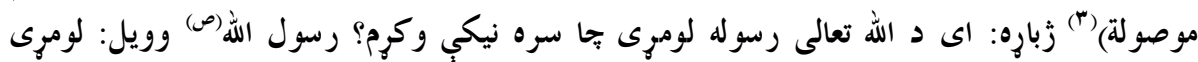

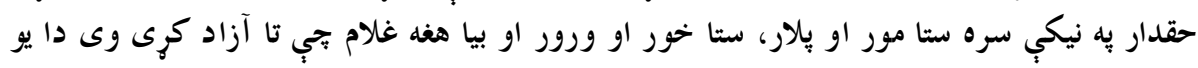

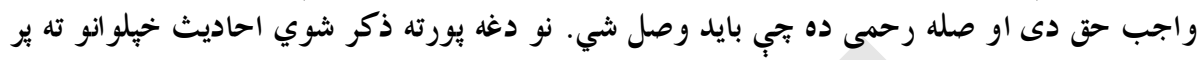
نفقى دليل كرحي.

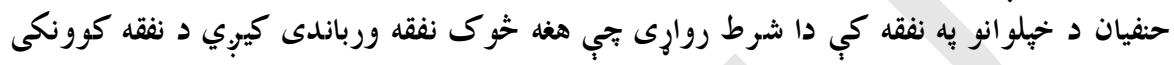

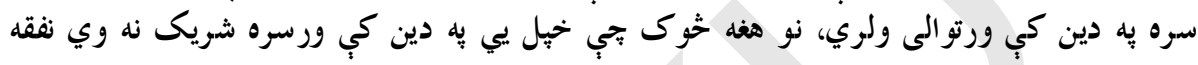

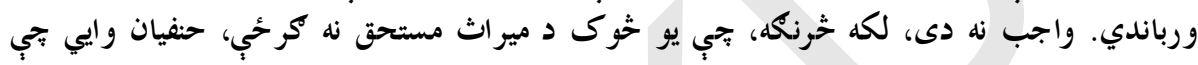

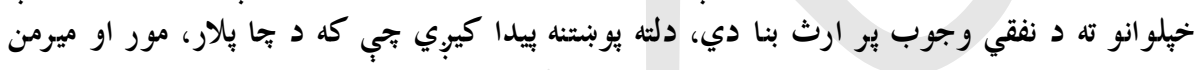

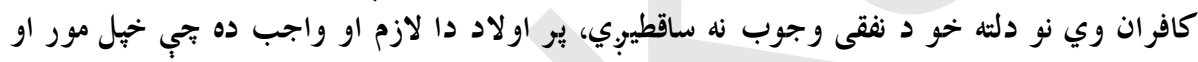

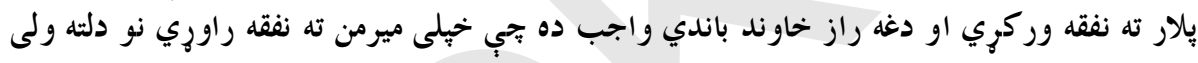

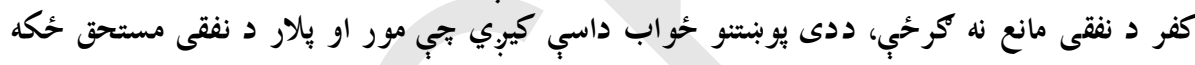

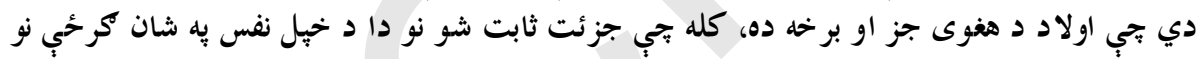

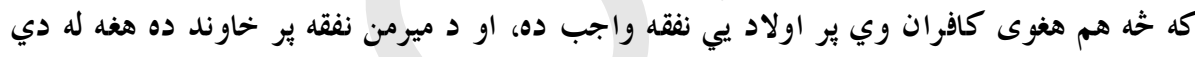

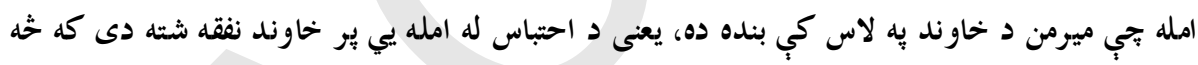

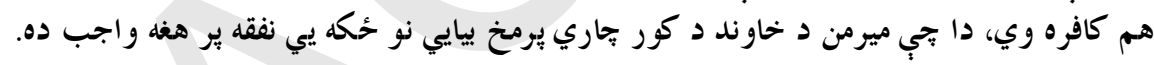

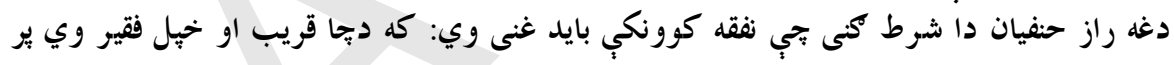

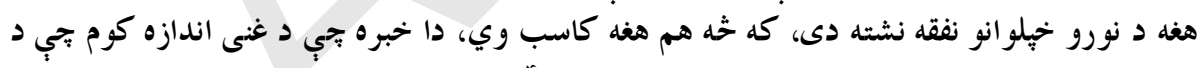

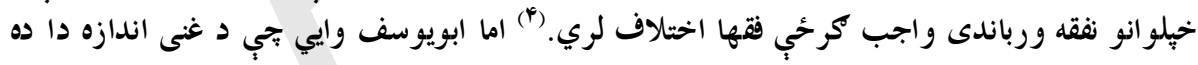

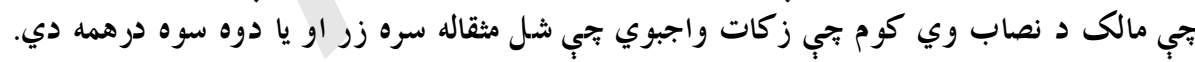

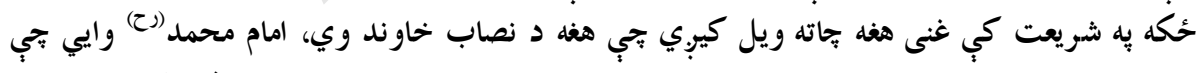

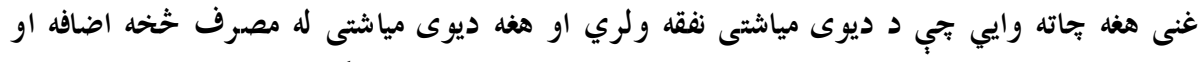

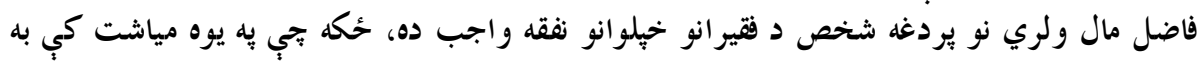

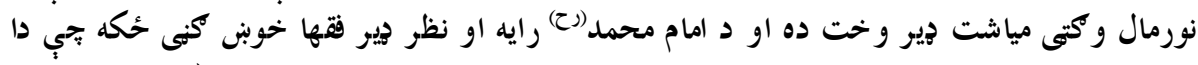

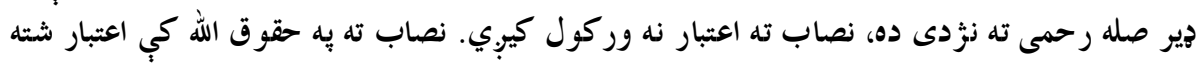

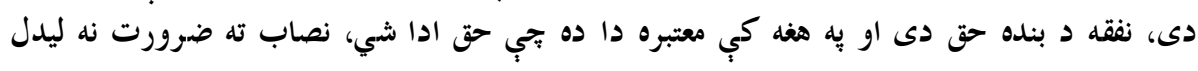




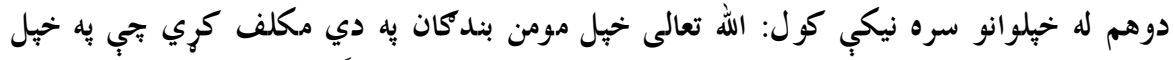

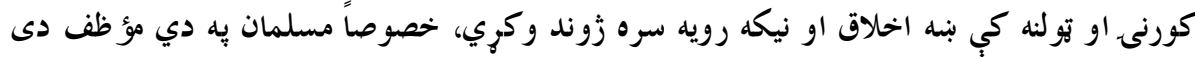

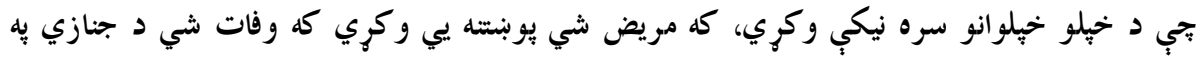

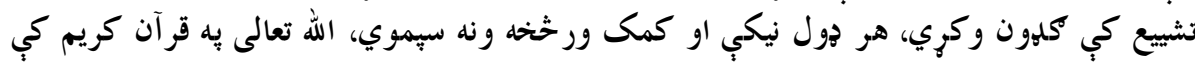

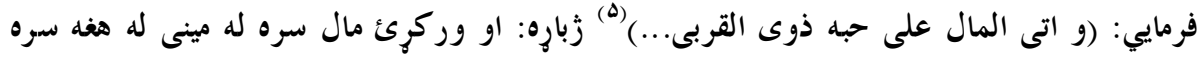

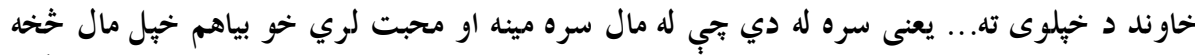

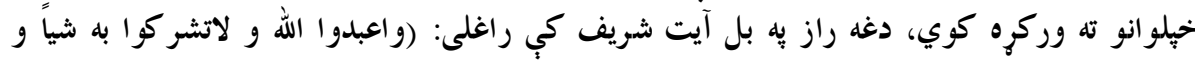

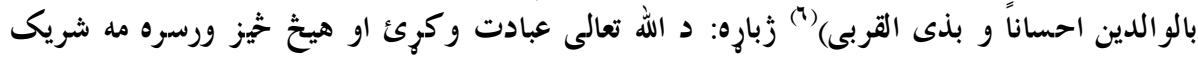

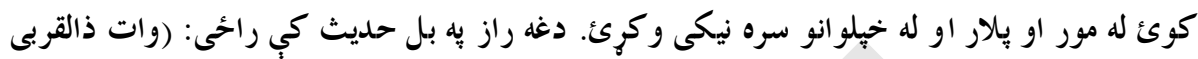

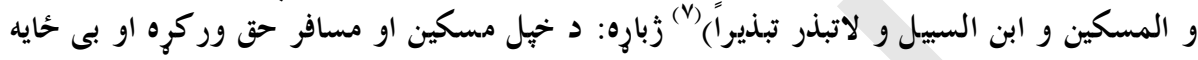

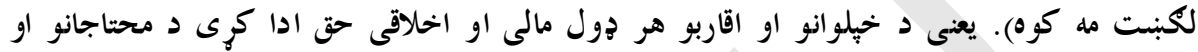

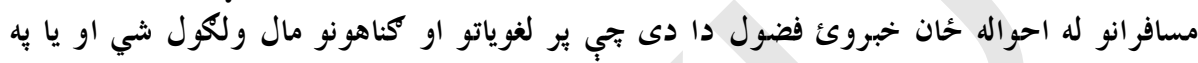

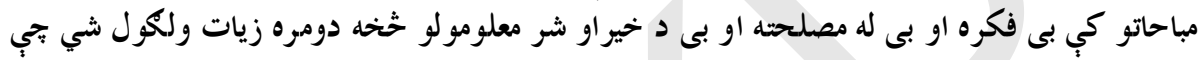

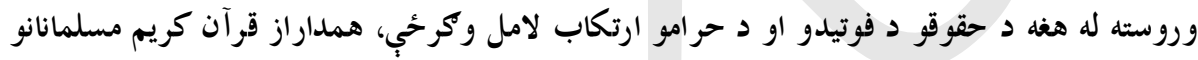

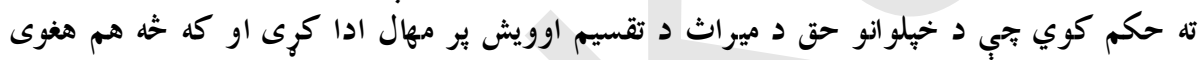

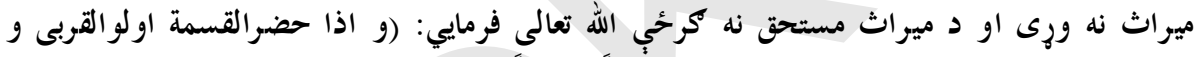

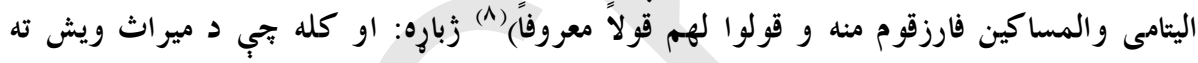

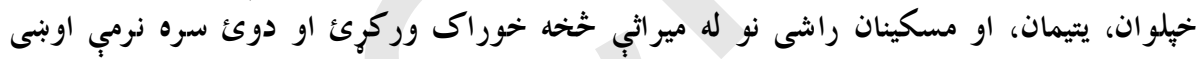

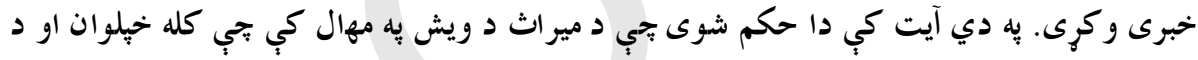

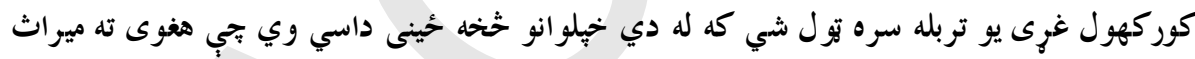

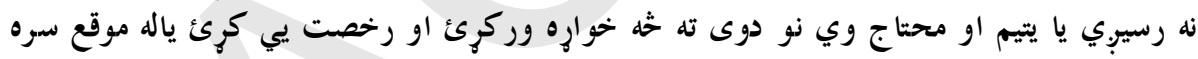

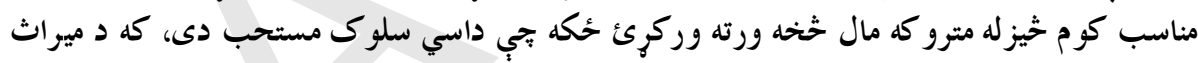

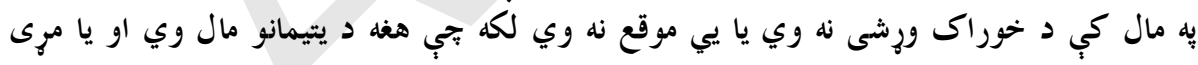

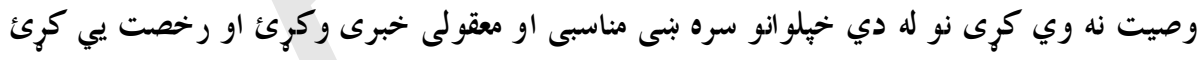

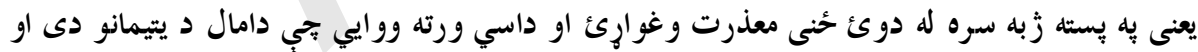

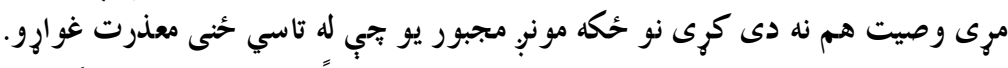

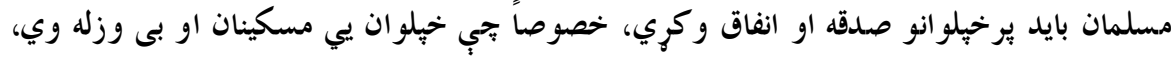

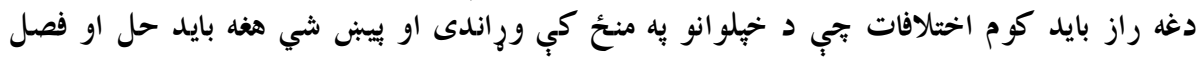

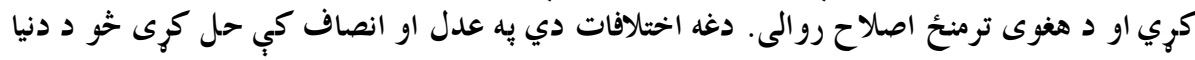

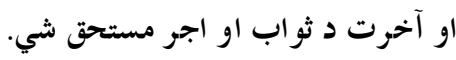

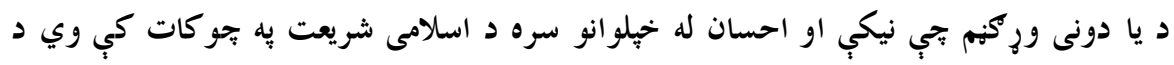

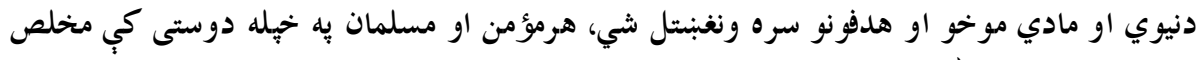

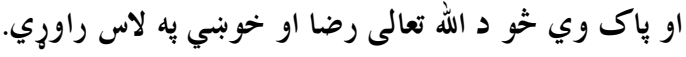




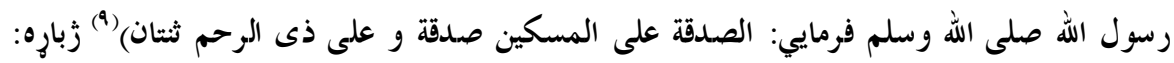

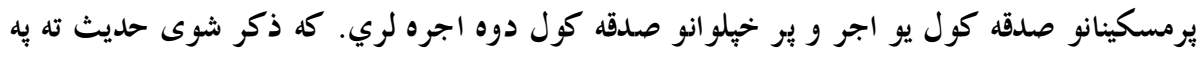

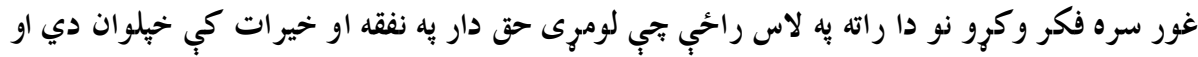

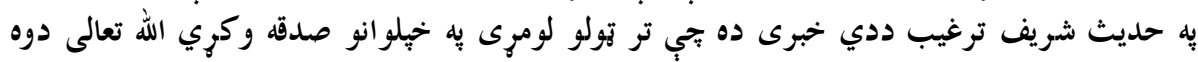

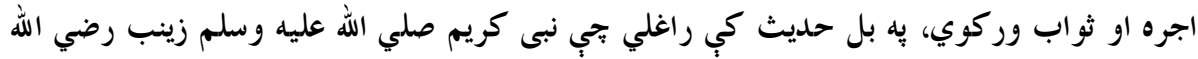

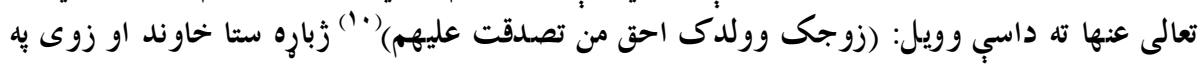

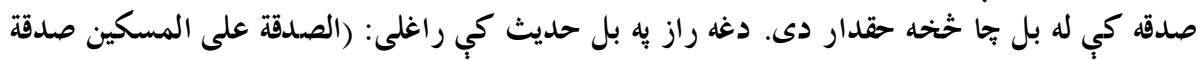

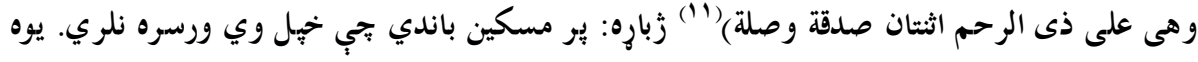

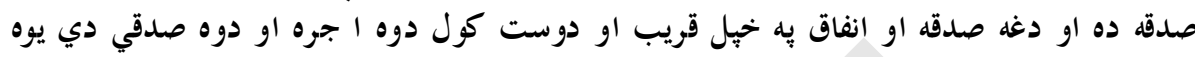

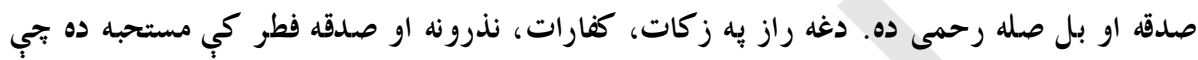

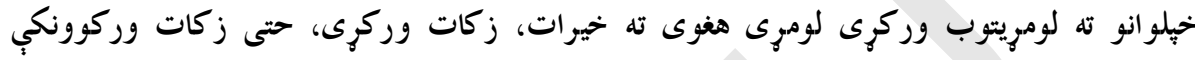

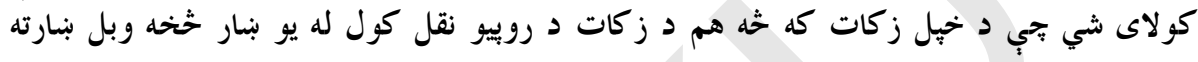

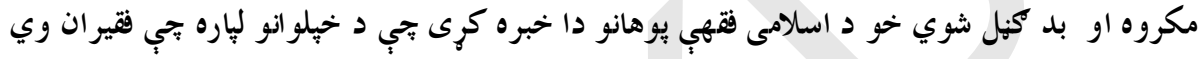

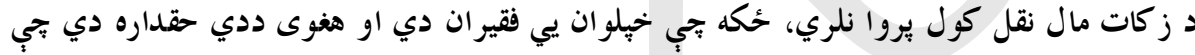

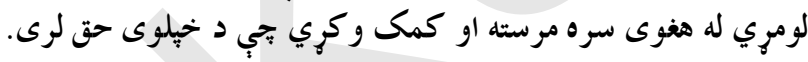

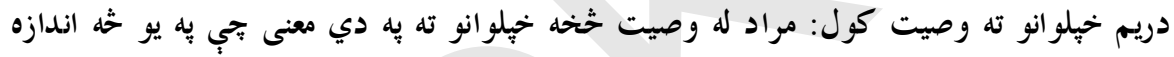

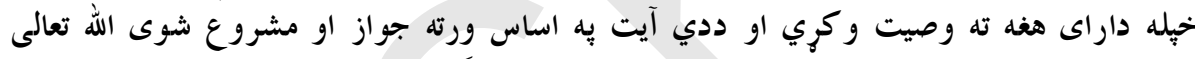

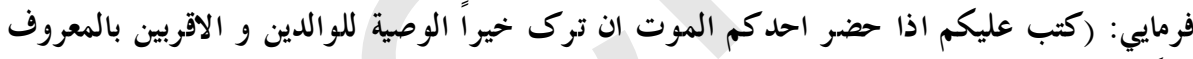

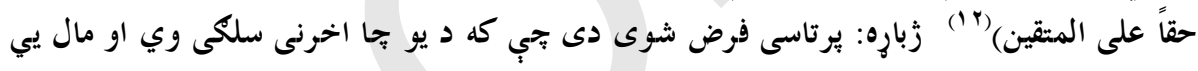

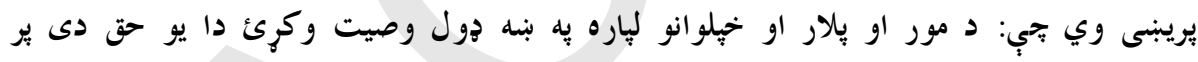

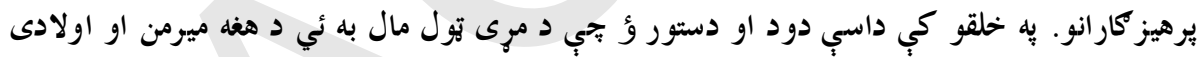

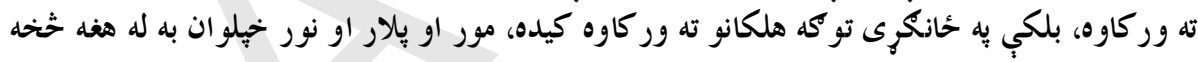

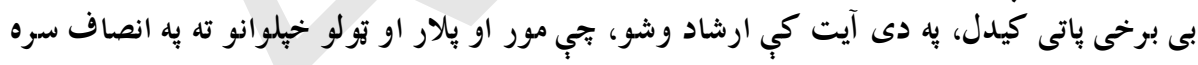

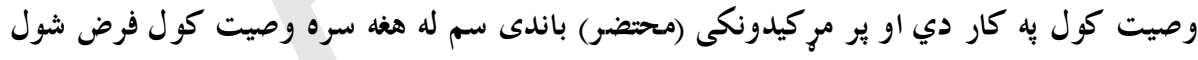

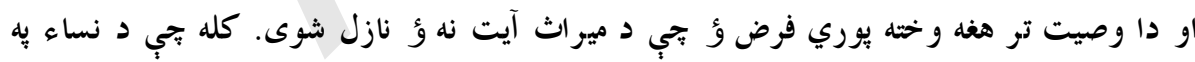

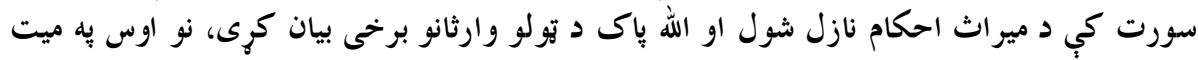

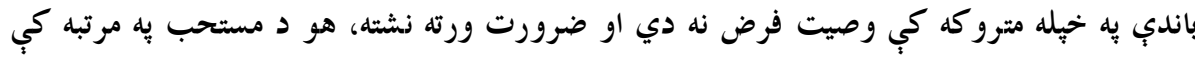

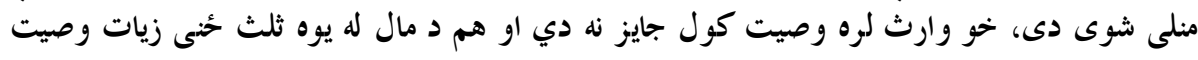

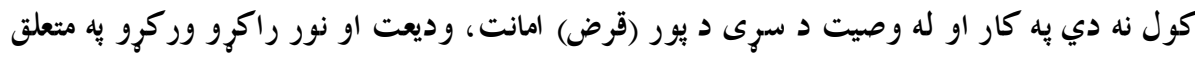

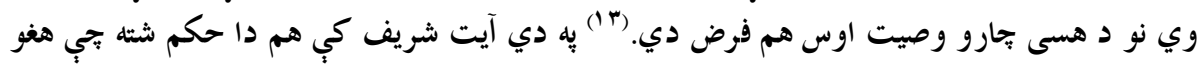

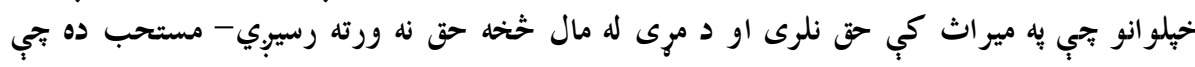

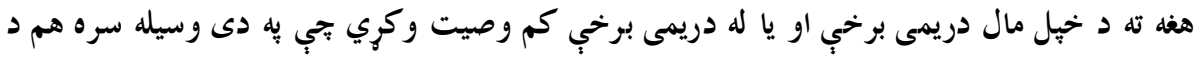

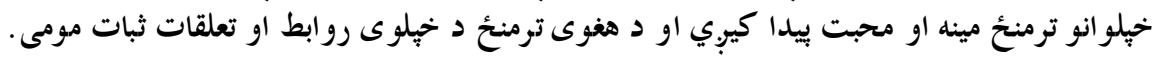


خلورم د خهلو انو سره محبت كول: مسلمان انسان فطرتاً او طبيعتاً نور مسلمانان خوبن او دوست

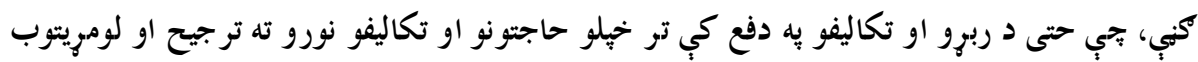

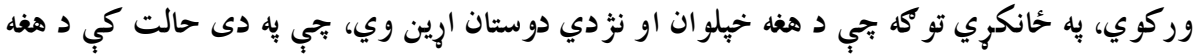

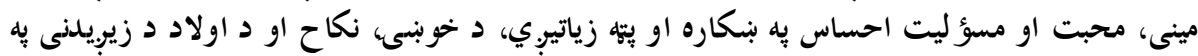

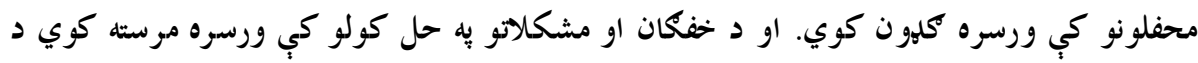

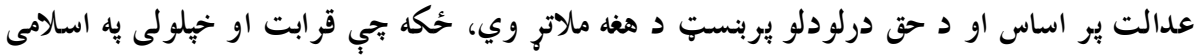

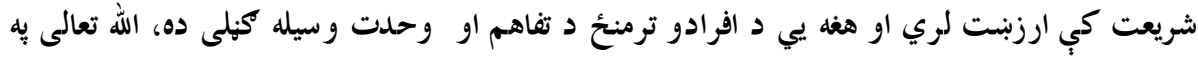

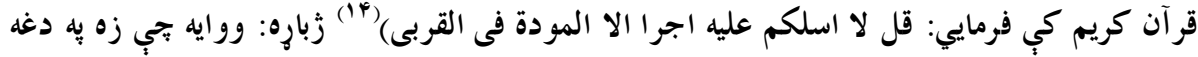

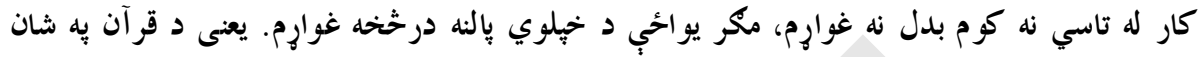

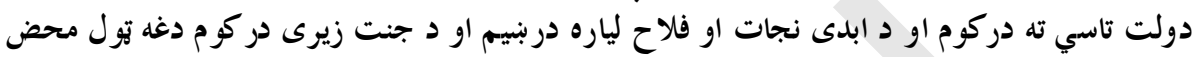

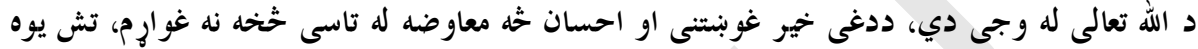

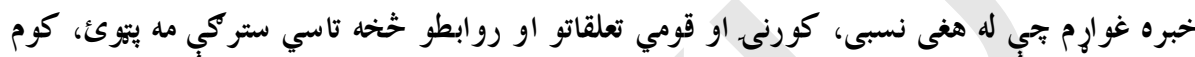

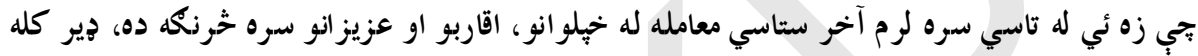

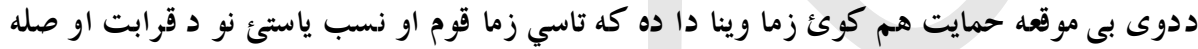

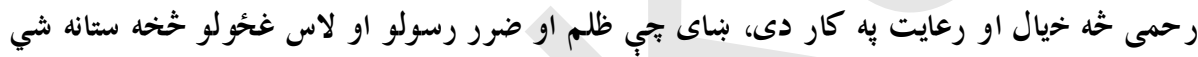

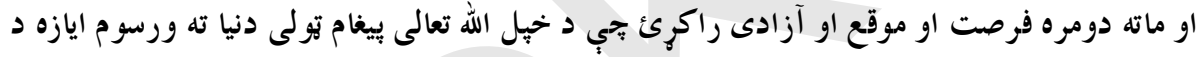

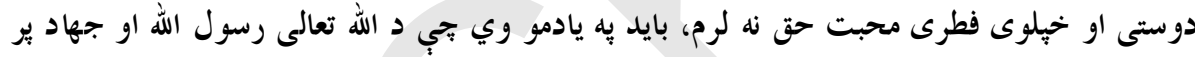

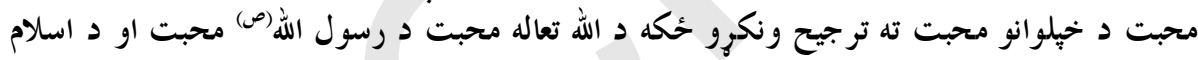

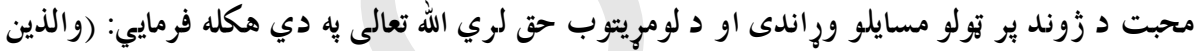

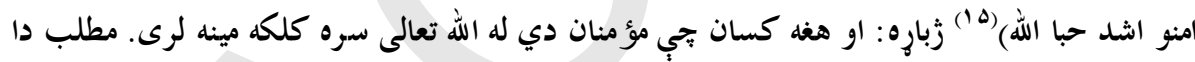

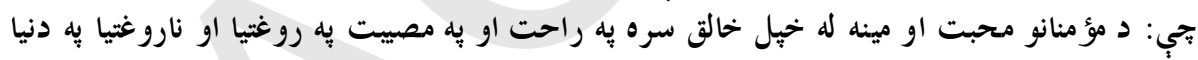

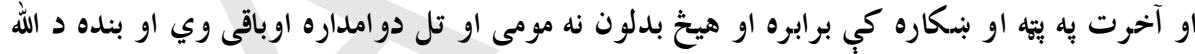

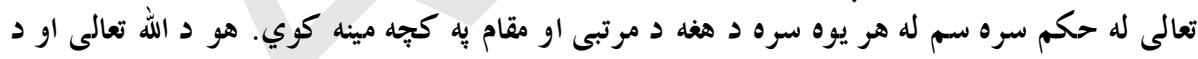

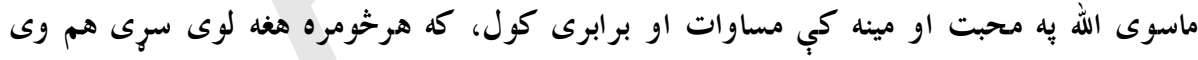
خالص شرك او د مشر كانو كار دى.

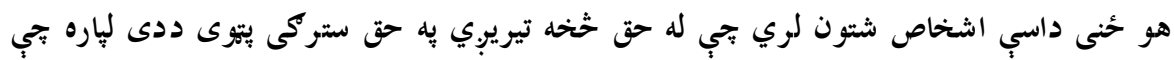

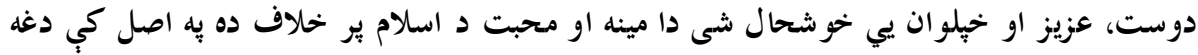

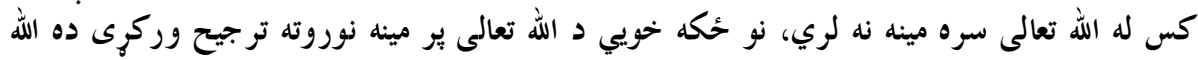

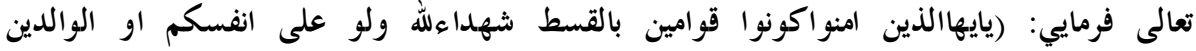

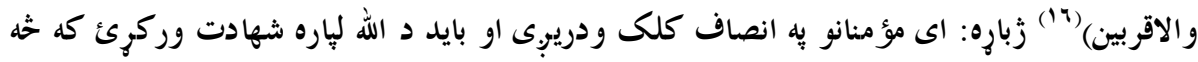

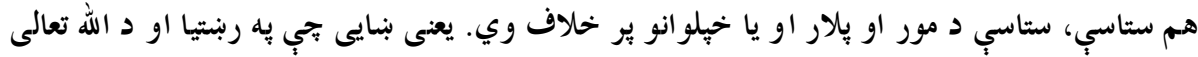

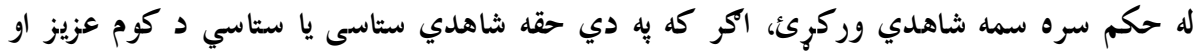


خيلوان زيان هم وي، هره هغه خبره بجي ربنتيا وى بنايى تجب به بنكاره دول سره اظهار كره شى او د د

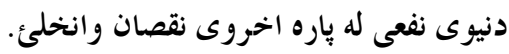

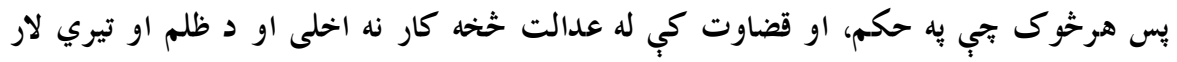

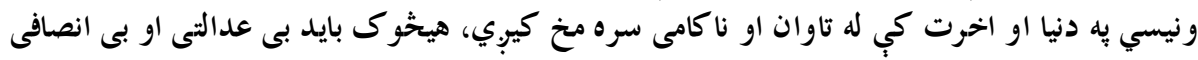

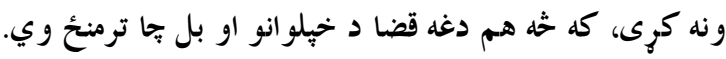

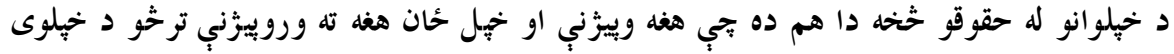

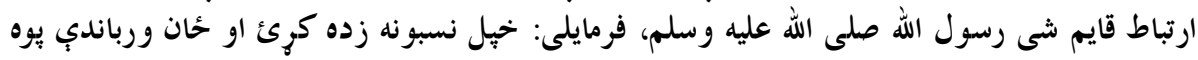

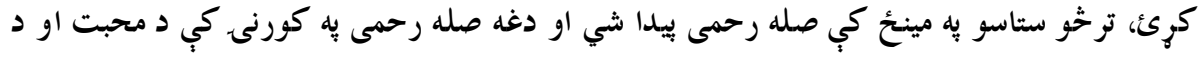

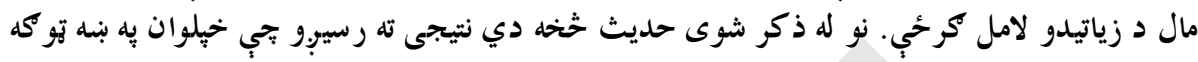

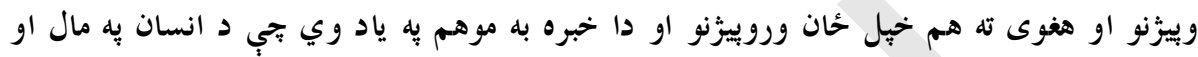

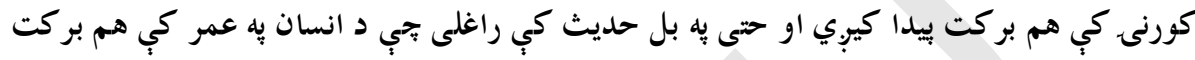

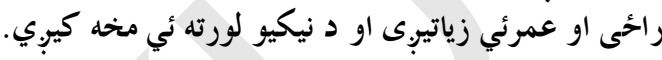

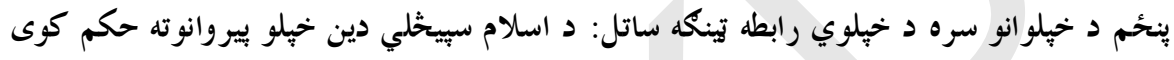

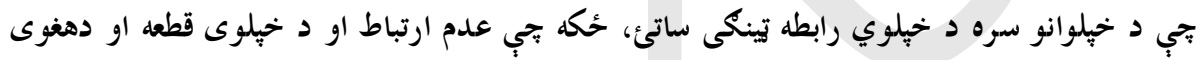

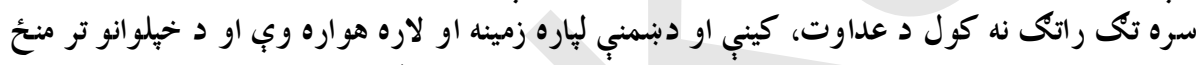

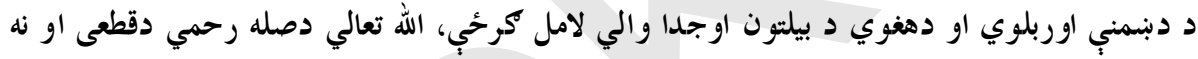

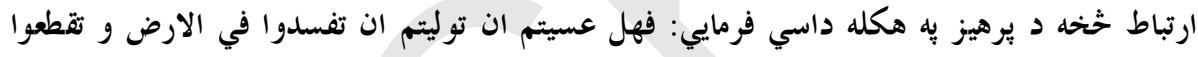

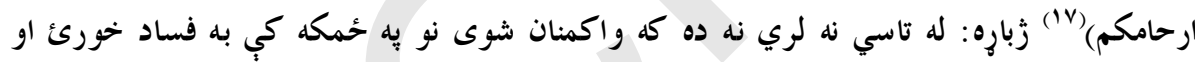

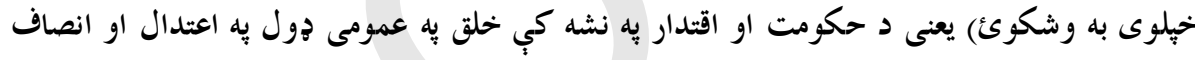

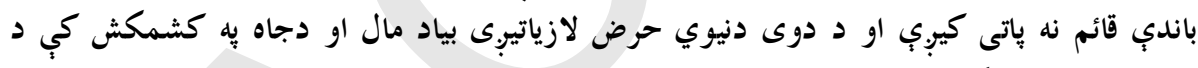

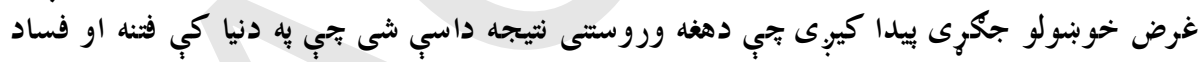

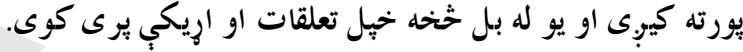

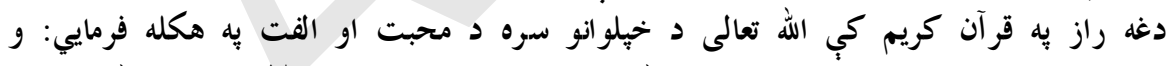

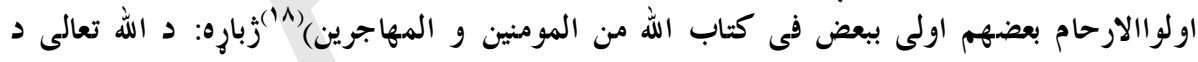

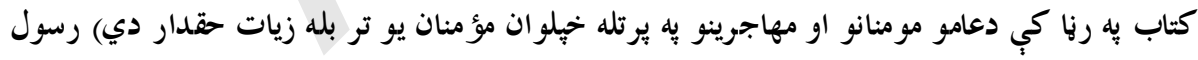

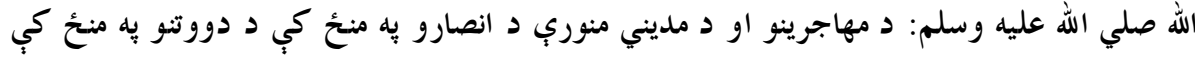

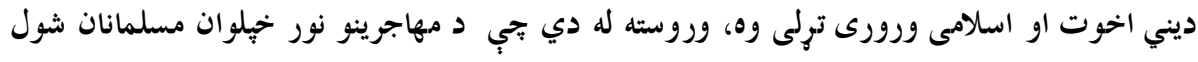

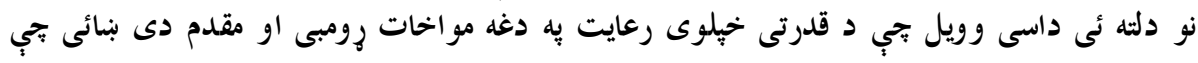

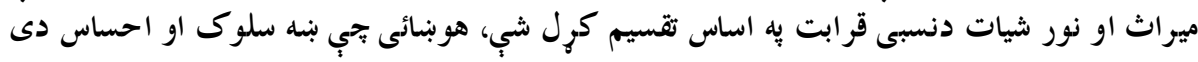

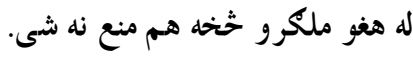

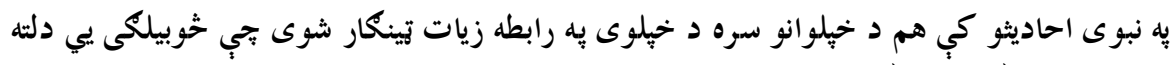

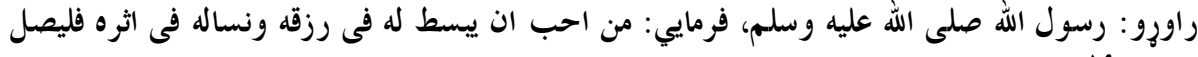

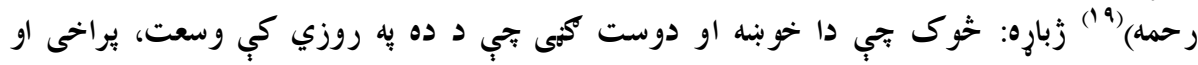




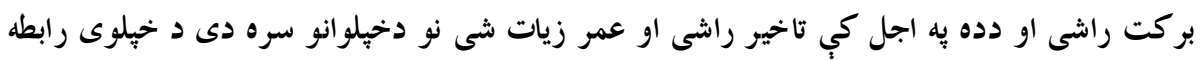

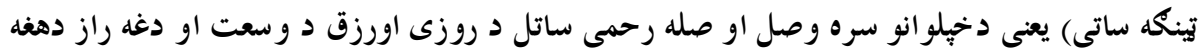

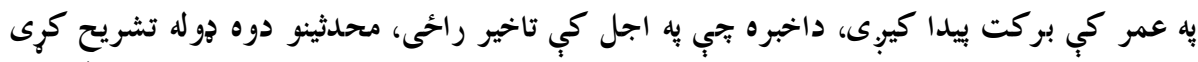

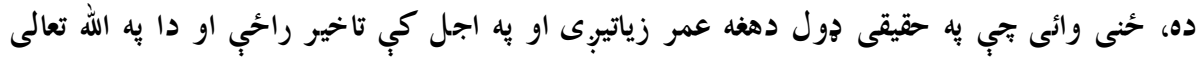

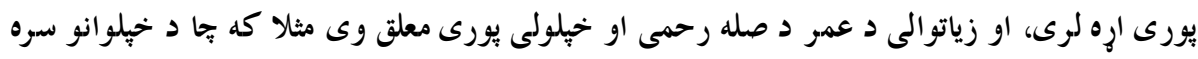

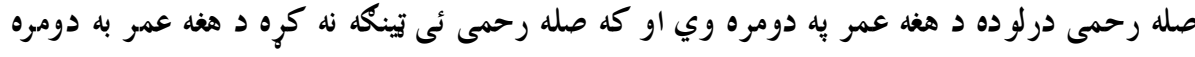

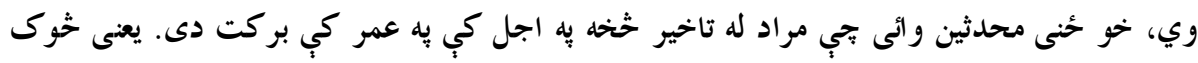

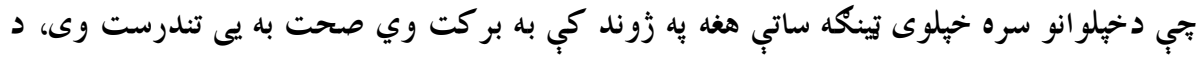

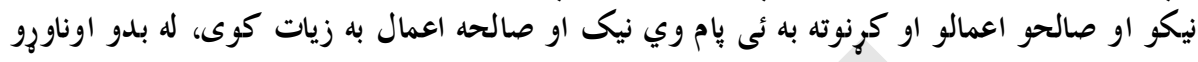

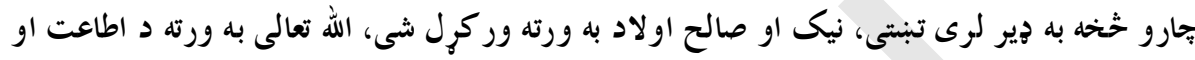

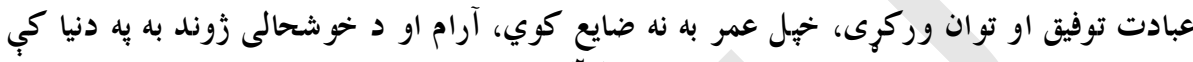

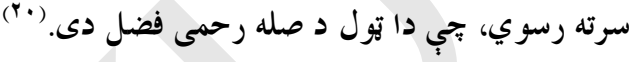

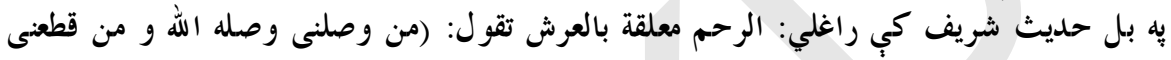

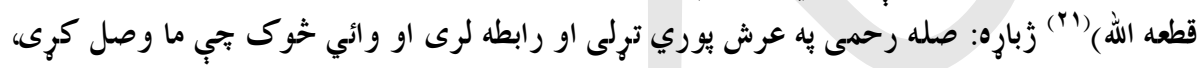

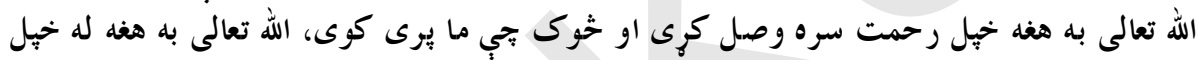

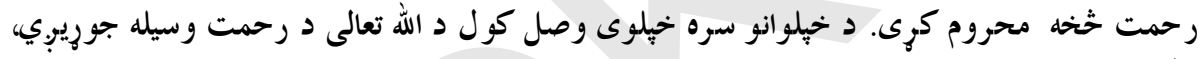

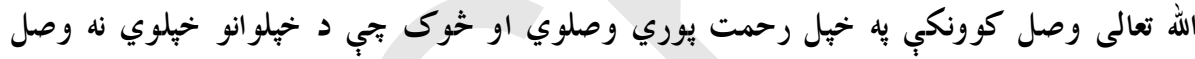

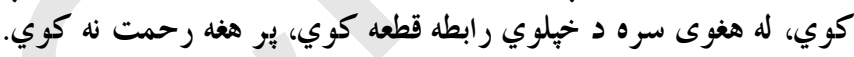

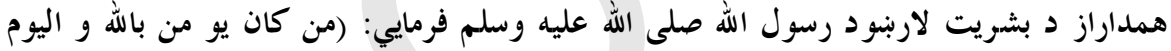

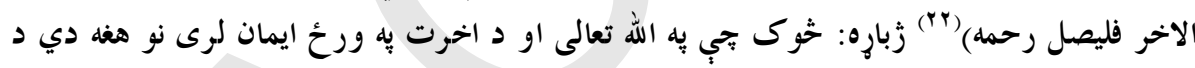

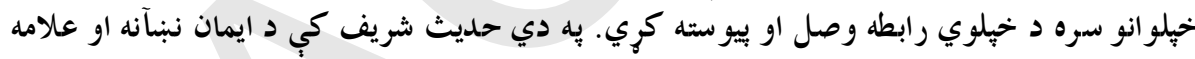

$$
\text { صله رحمى شميرل شوى ده. }
$$

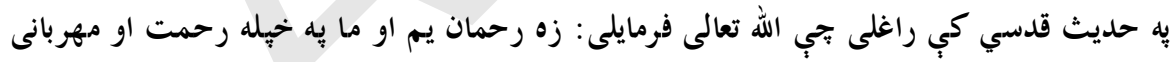

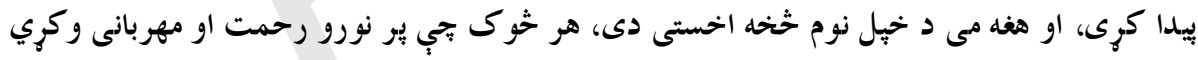

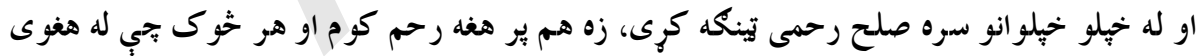

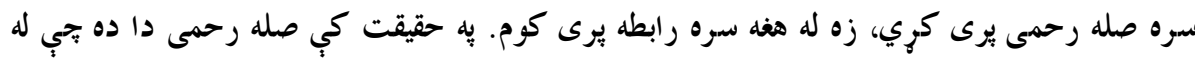

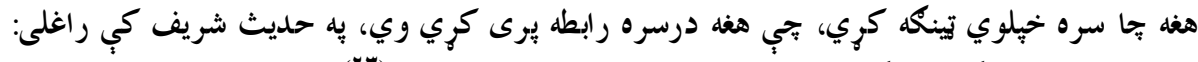

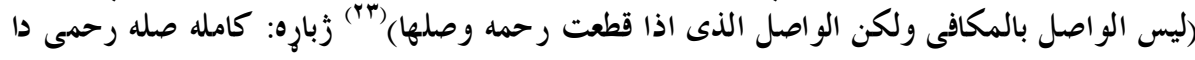

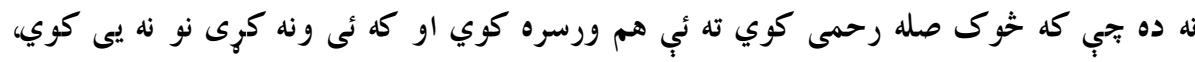

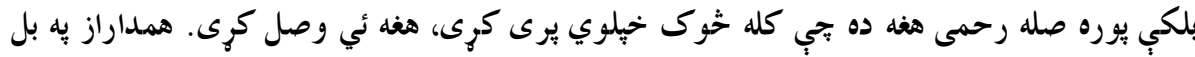

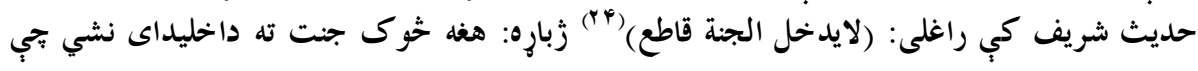

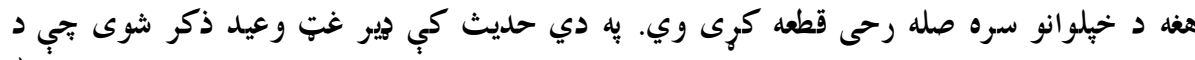

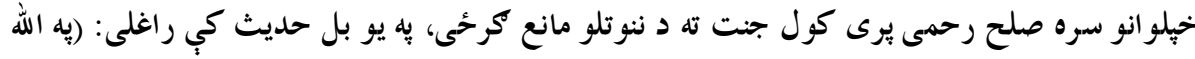




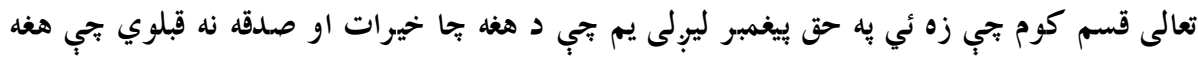

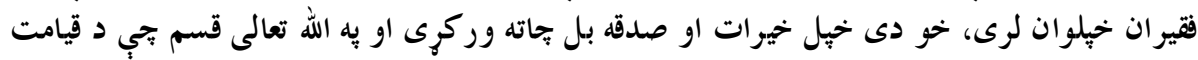

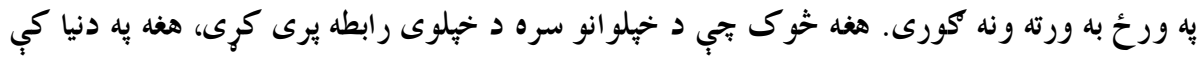

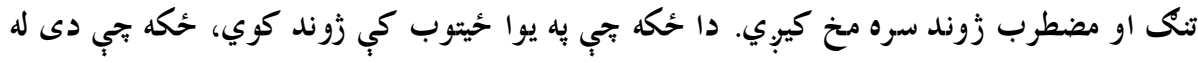

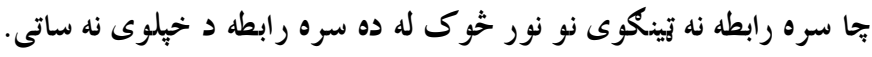

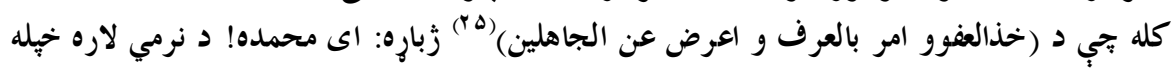

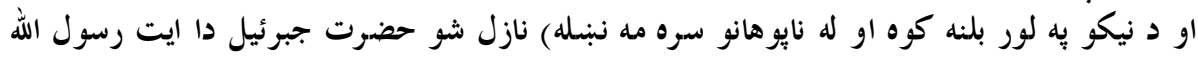

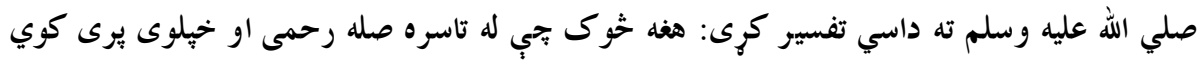

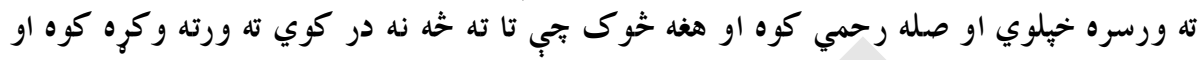

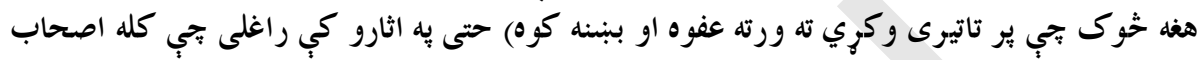

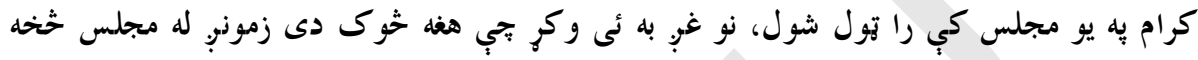

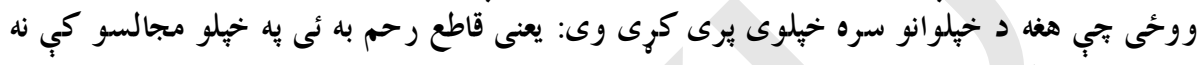

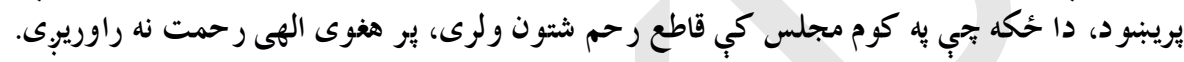

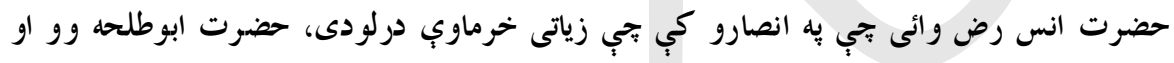

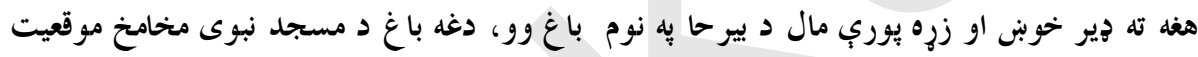

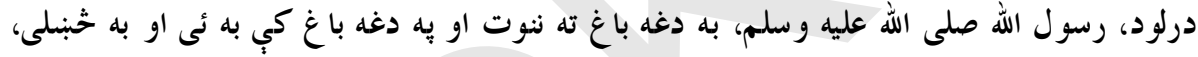

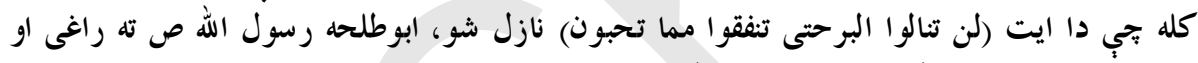

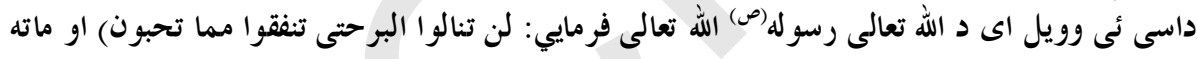

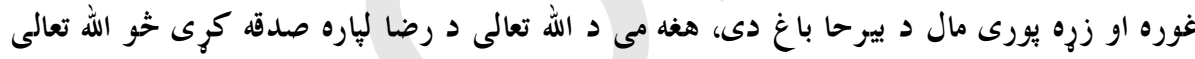

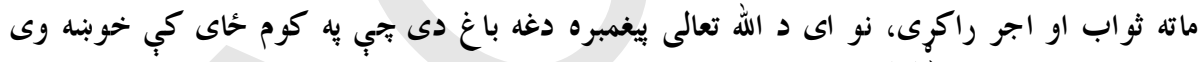

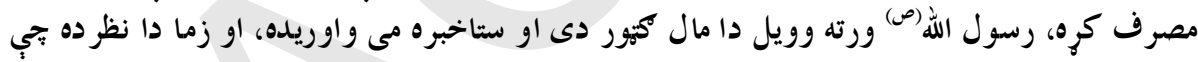

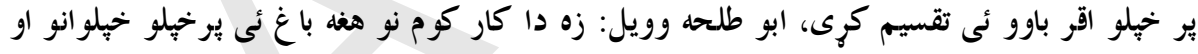

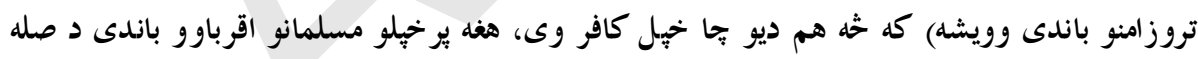

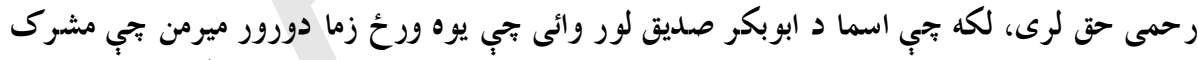

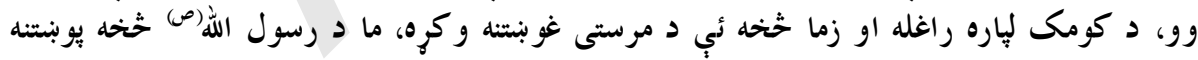

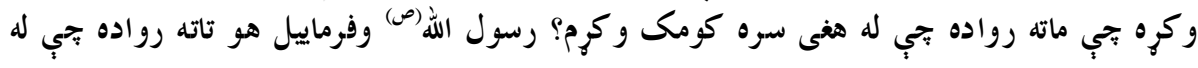

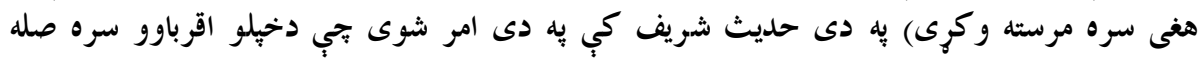

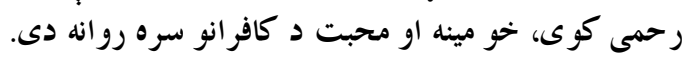

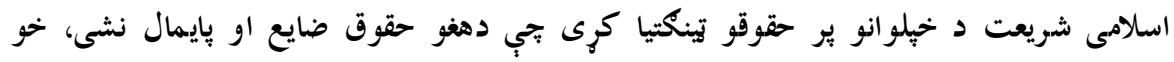

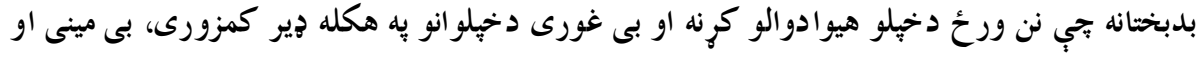

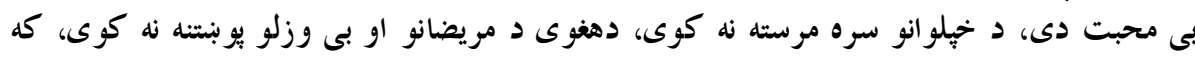

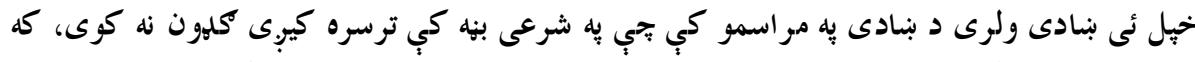

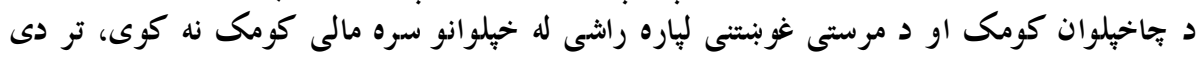




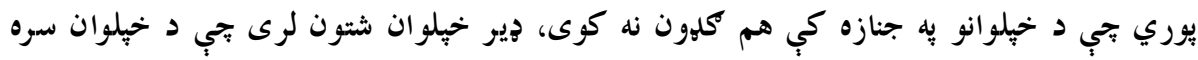

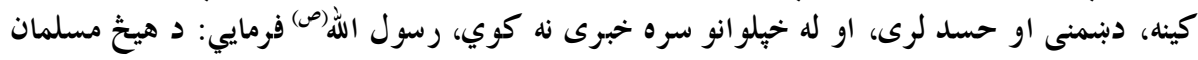

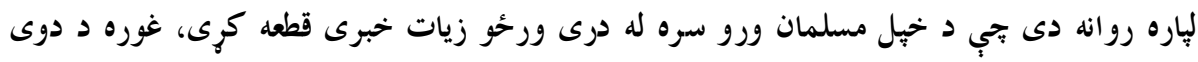

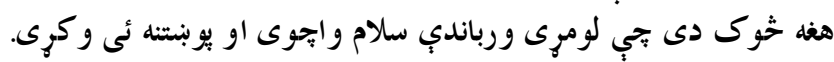

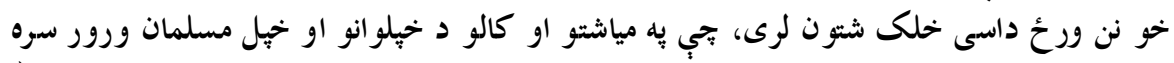

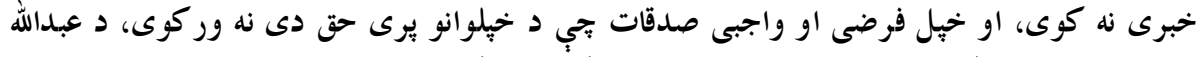

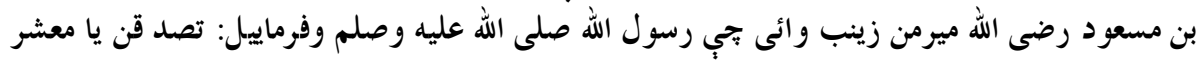

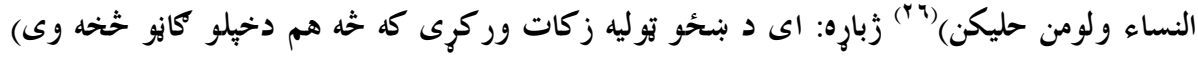

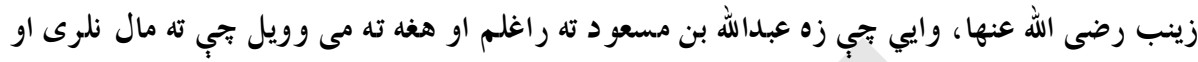

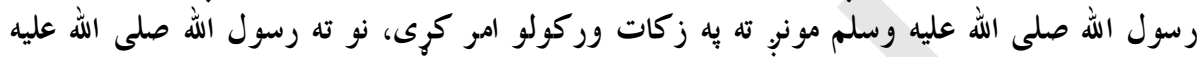

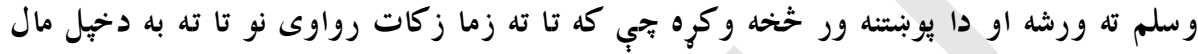

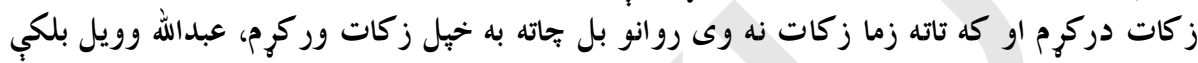

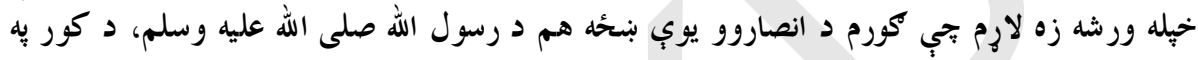

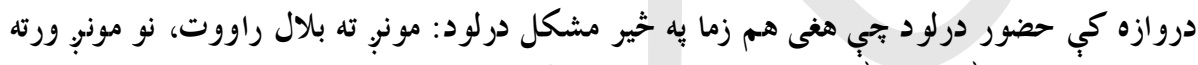

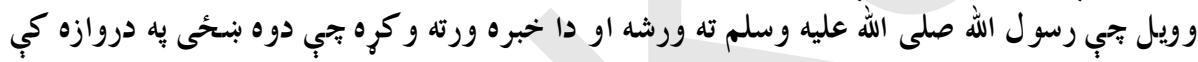

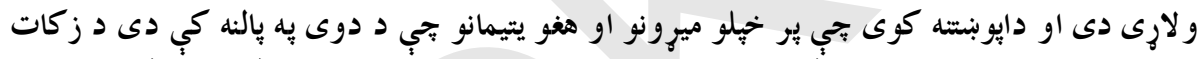

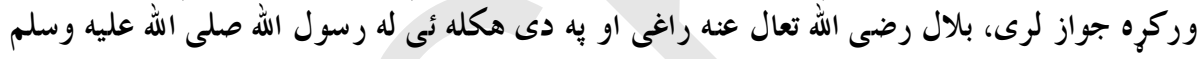

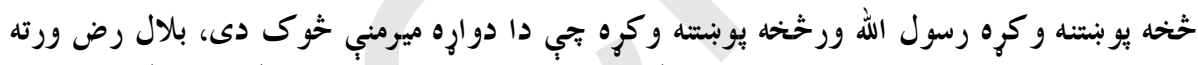

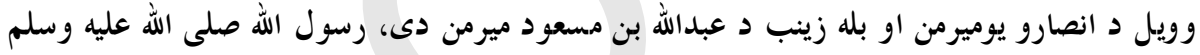

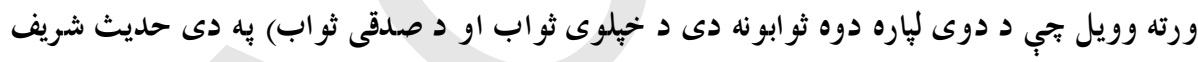

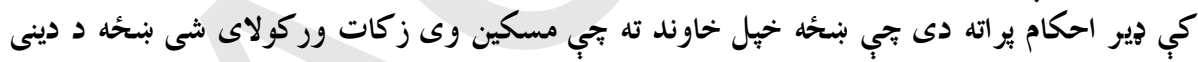

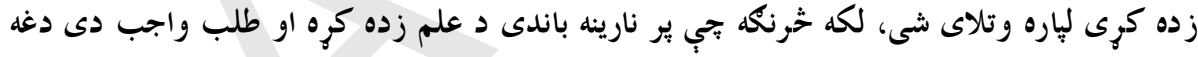

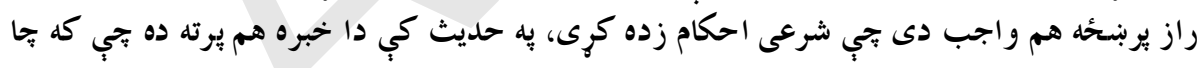

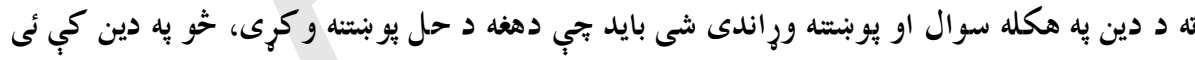

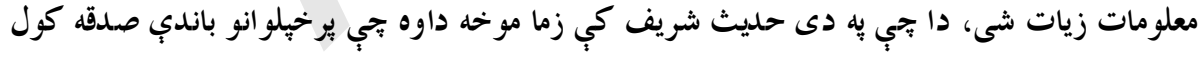

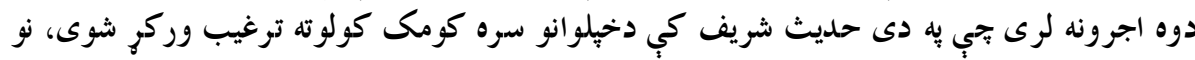

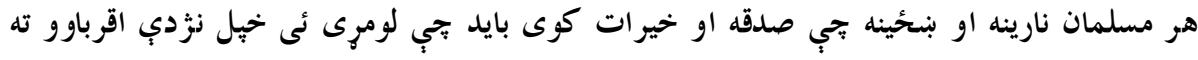

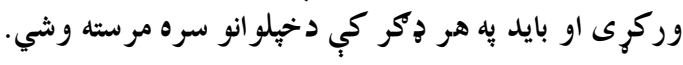

ماخذونه او مراجع

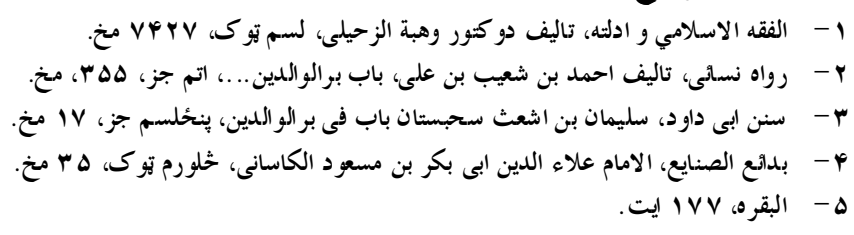




$$
\begin{aligned}
& \text { צ- - النسا م ايت. }
\end{aligned}
$$

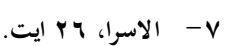

$$
\begin{aligned}
& \text { ^- - النسا، } 1 \text { ايت. }
\end{aligned}
$$

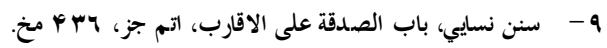

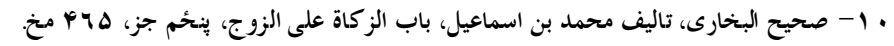

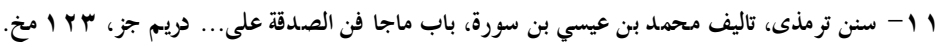

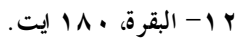

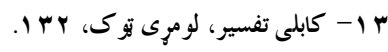

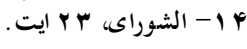

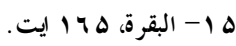

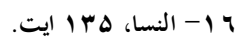

$$
\begin{aligned}
& \text { IV }
\end{aligned}
$$

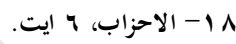

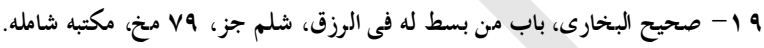

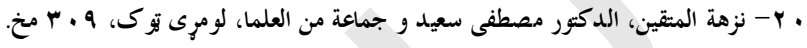

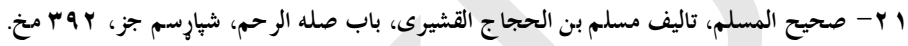

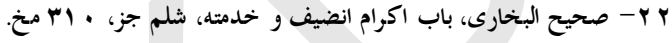

$$
\begin{aligned}
& \text { Pr }
\end{aligned}
$$

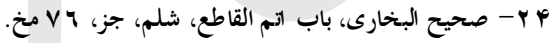

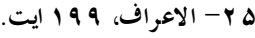

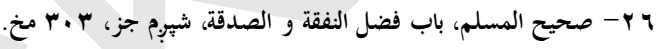




\section{كنفر انس كور ميور (مونت بلانك) در مورد جرايم سازمان يافته \\ در هنر هاى زيبا وآثار باستانى فيه \\ مع داكترمحمدقاسم هاشمزى}

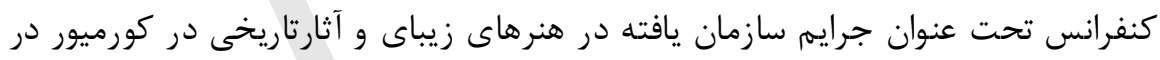

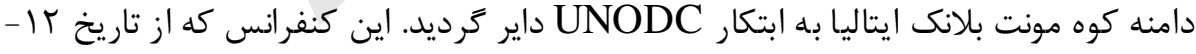

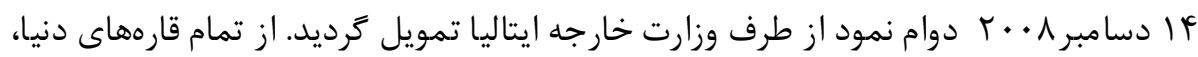

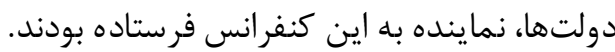

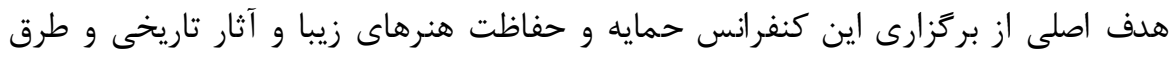

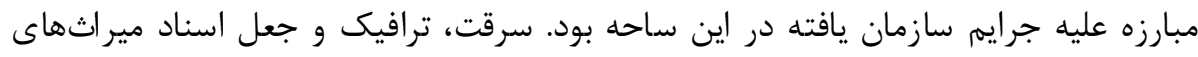

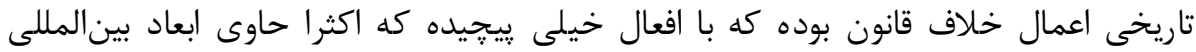

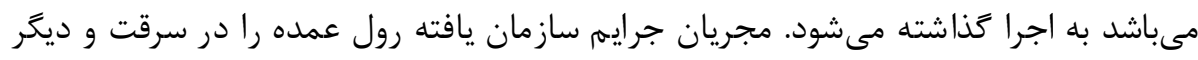

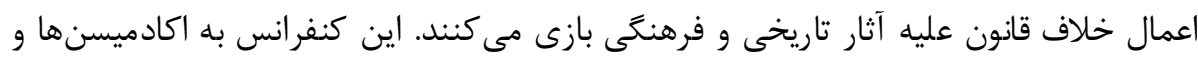


مجريان (محافل اجرايى موزيمها وانجمنها) موقع داد تا كرد هم يكجا شوند و تبادل افكار در

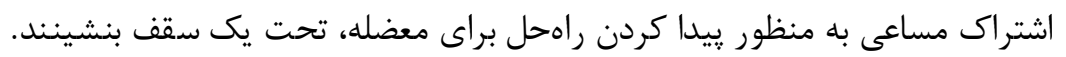

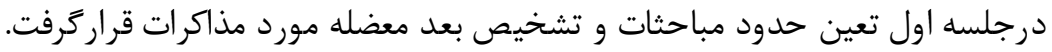

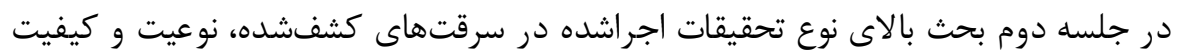

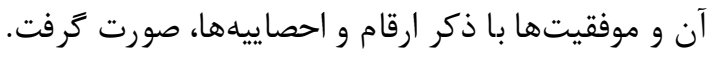

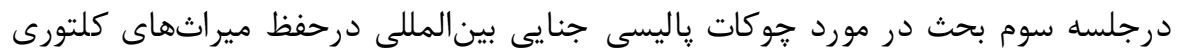

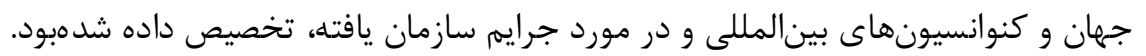

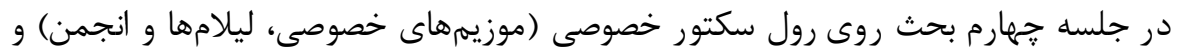

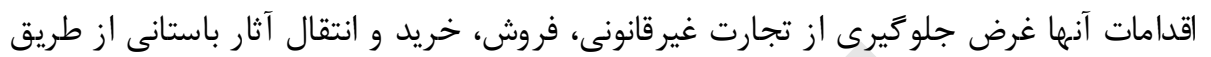

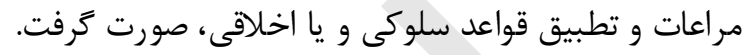

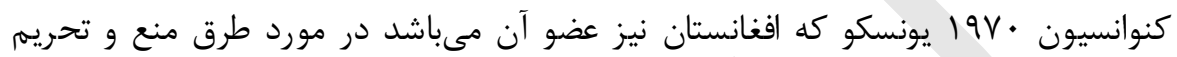

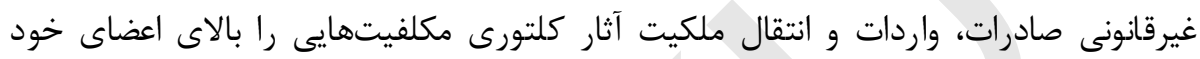

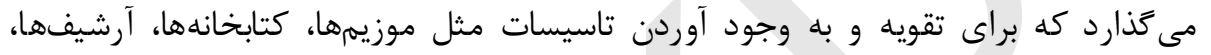

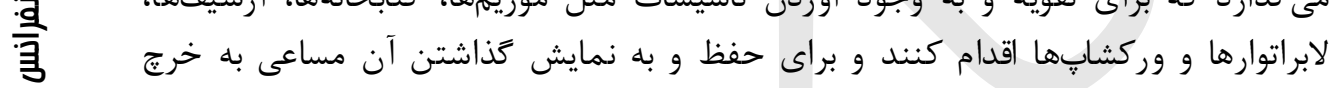

بد بلدئ.

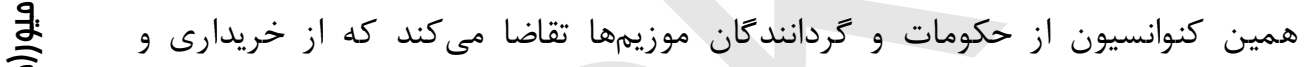

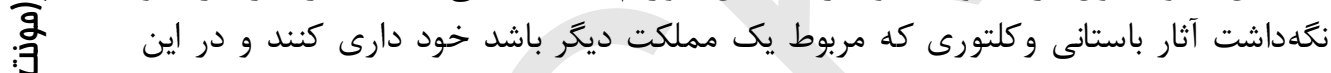

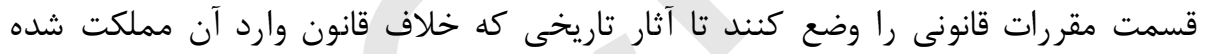

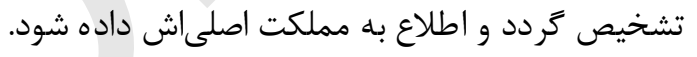

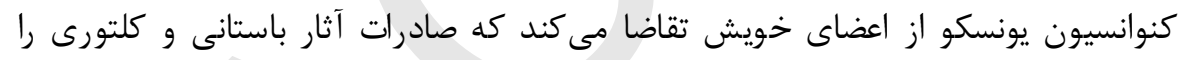

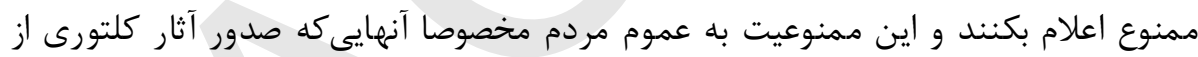
آنها متصور باشد تفهيم كر دد.

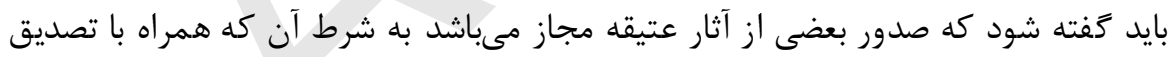

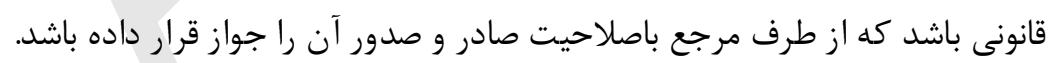

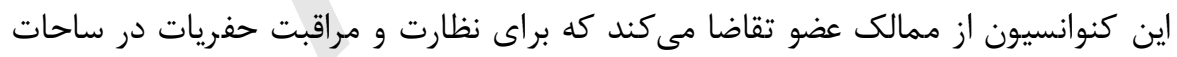

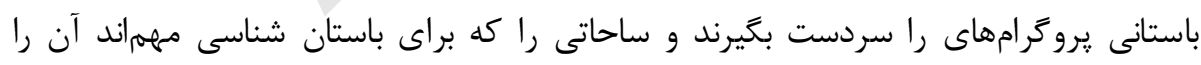

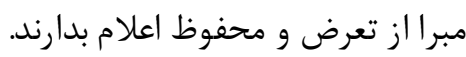

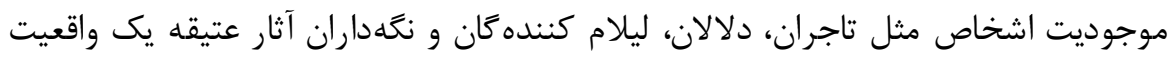

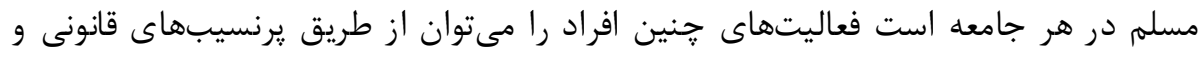

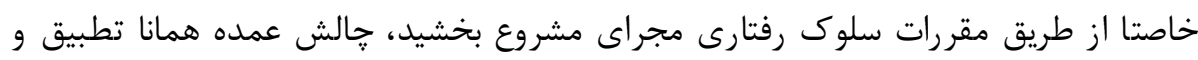

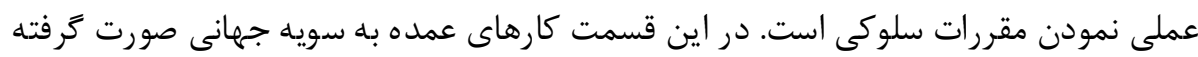

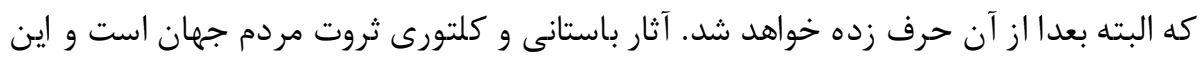

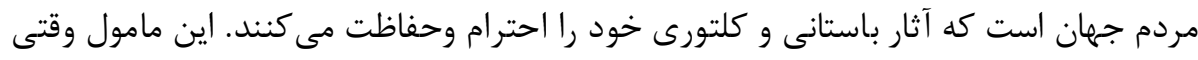


برآورده مىشود كه آنها مكلفيت خويش را بدانند و بياموزند. كنوانسيون يونسكو در ماده

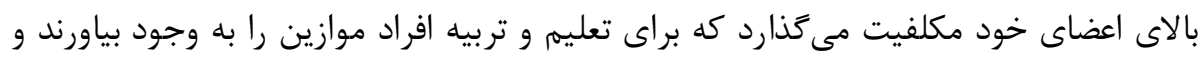

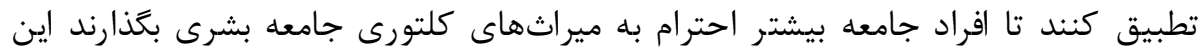

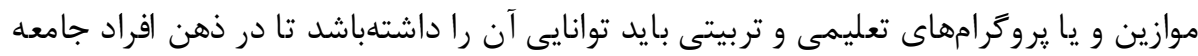

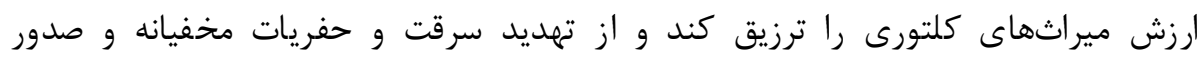

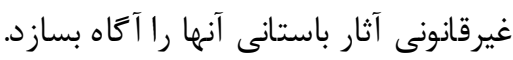

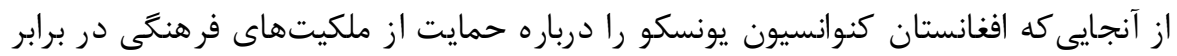

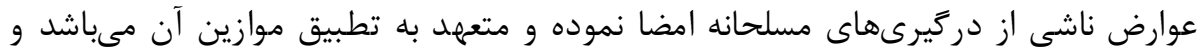

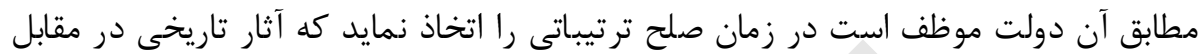

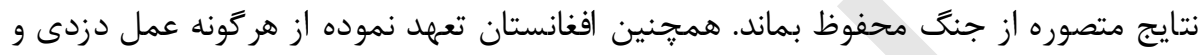

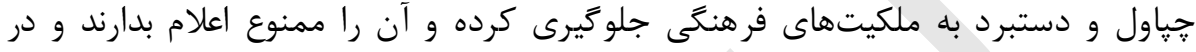

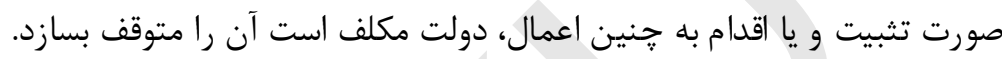

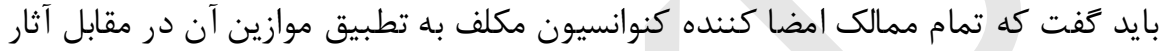

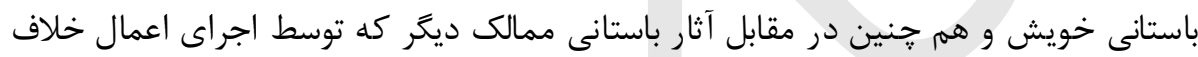

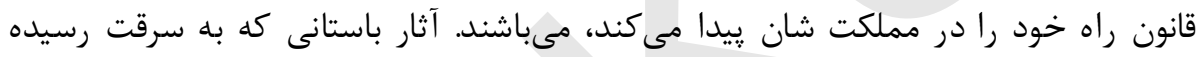

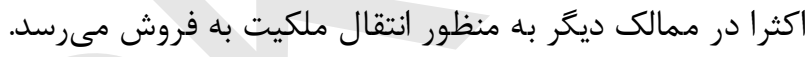

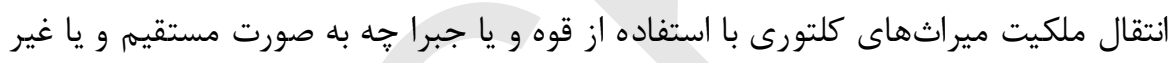

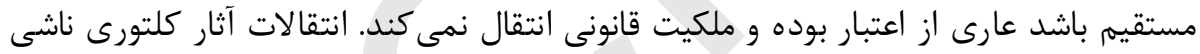

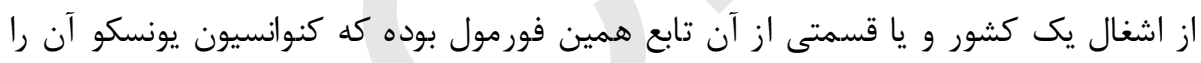

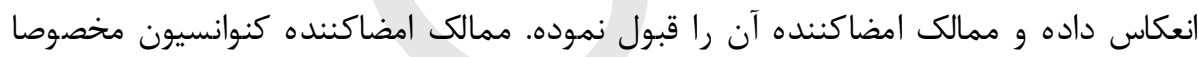

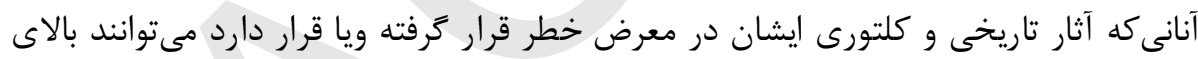

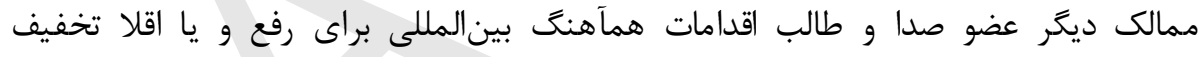
خطرشوند. ممالك مخاطب شده به اساس كنوانسيون يونسكو مكلف هستند تا اقدامات

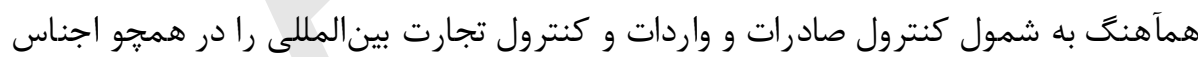

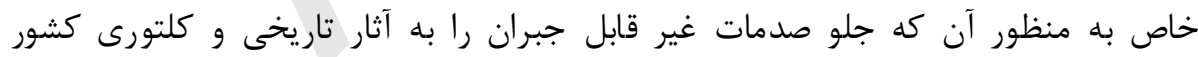
درخواست كننده، اتخاذ نمايند.

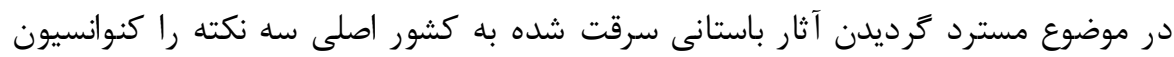

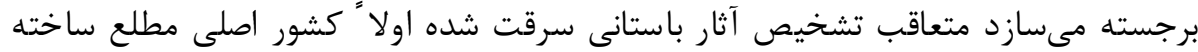

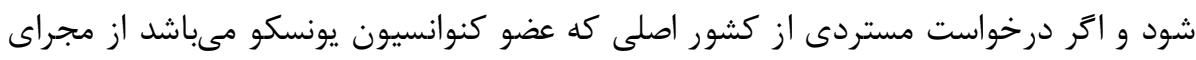

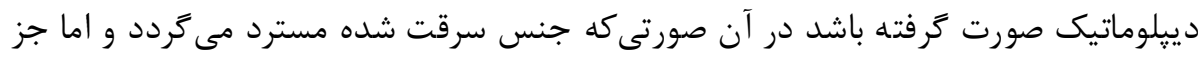

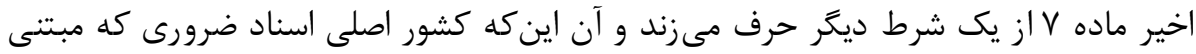

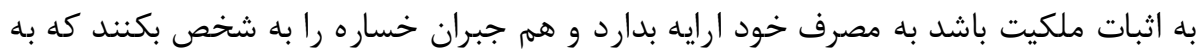

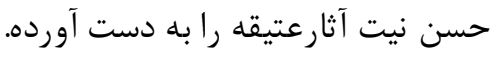


با آن كه كنوانسيون، مسترد شدن آثار را تابع هيج تكس و يا ماليه نمى داند موضوع يرداخت

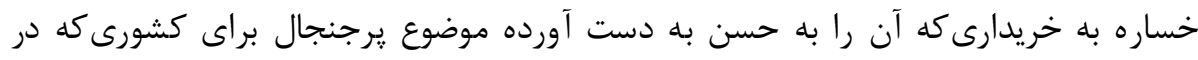

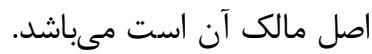

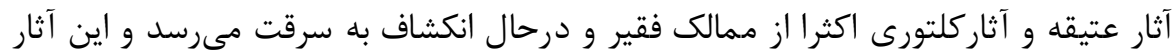

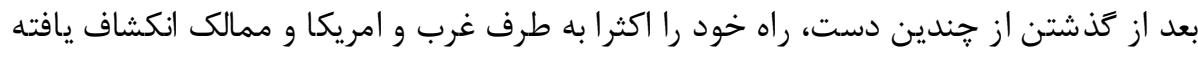

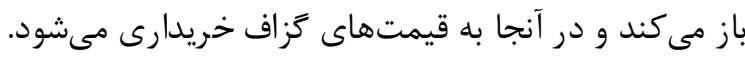

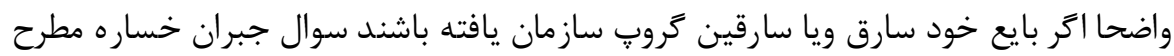

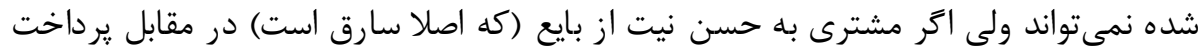

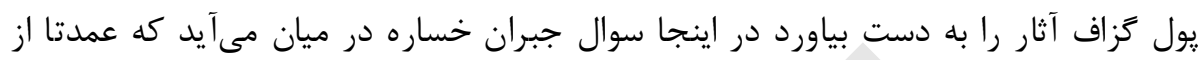

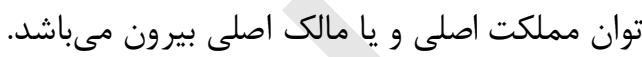

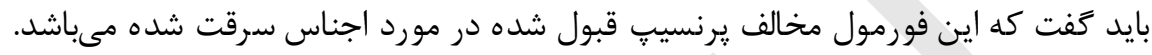

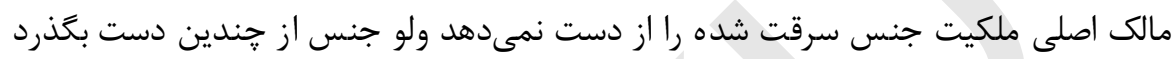

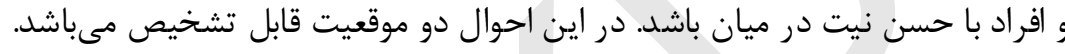

\section{اول تصرف و دوم تملك}

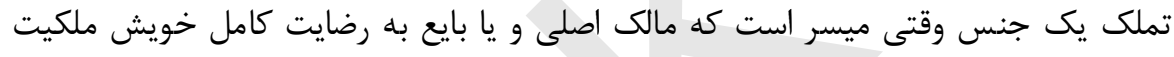

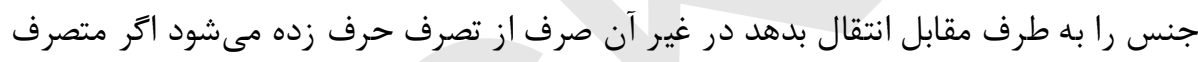

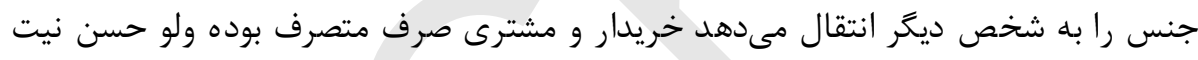

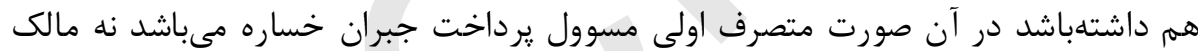

قاعده قبولشده موجود است كه مشترى حين خريدارى آثار باستانى ازكنج كاوى دأن دقيق ويا

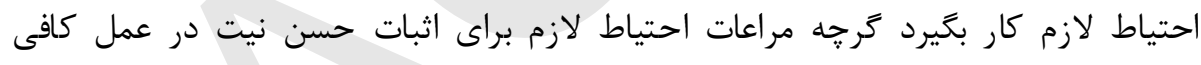

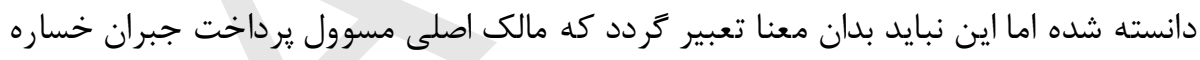
مىباشد نه سارق متصرف.

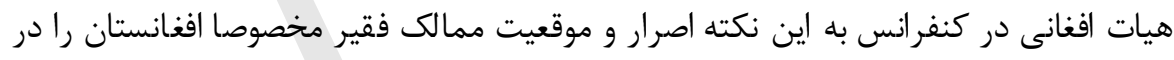

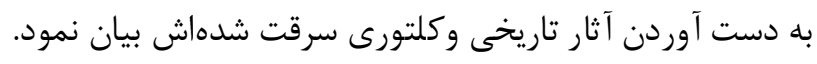

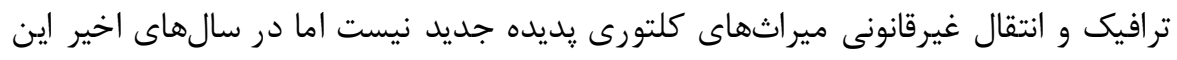

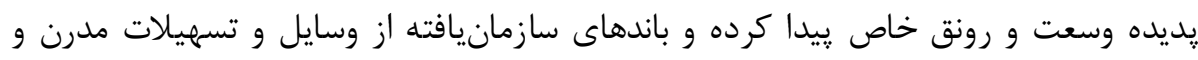

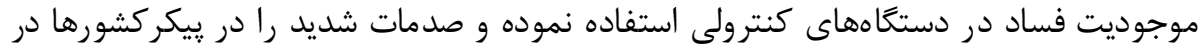

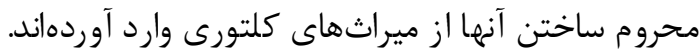

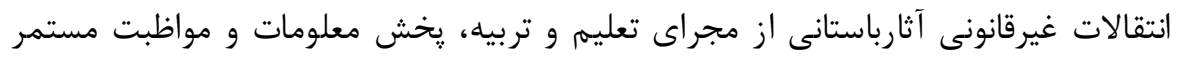

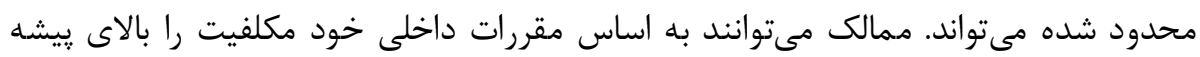

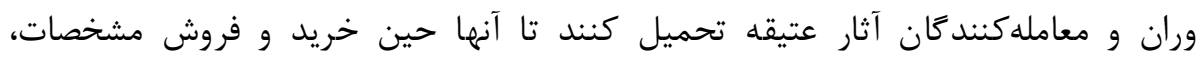


تاريخجه، قيمت فروش در هر معامله، اسم بايعان و فروشندگان با آدرس آنها و كشور اصلى دانى

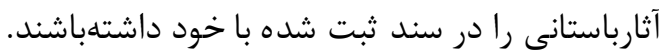

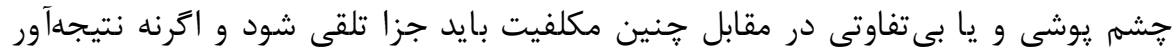

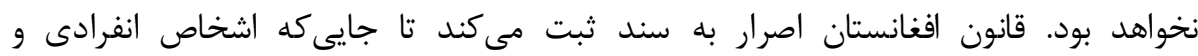

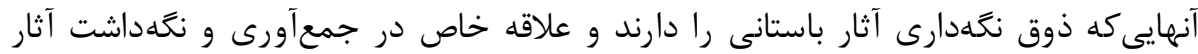

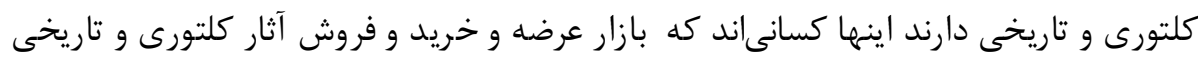

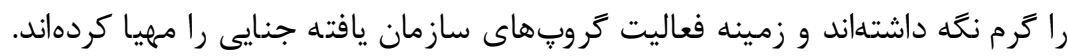

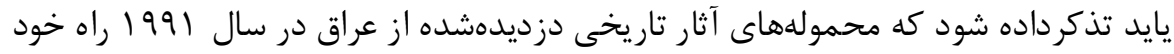

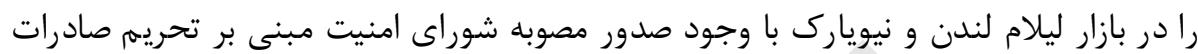

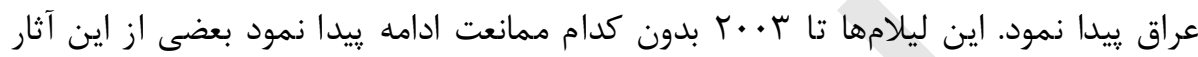

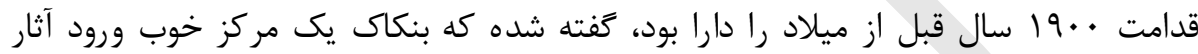

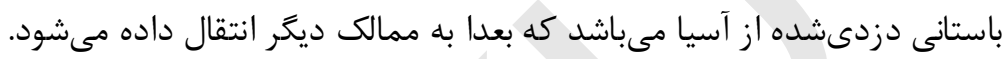

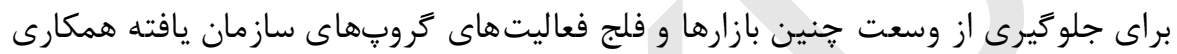

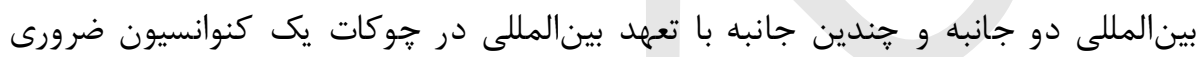

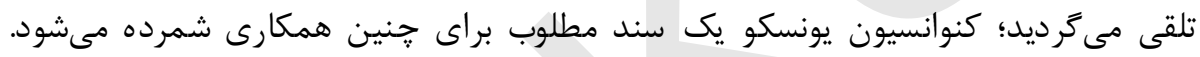

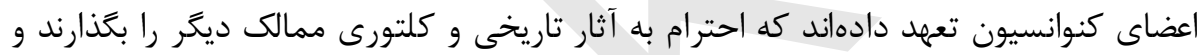

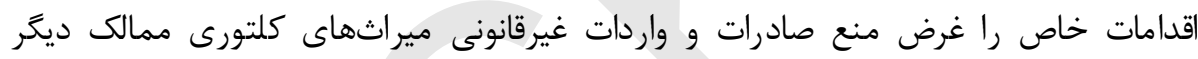

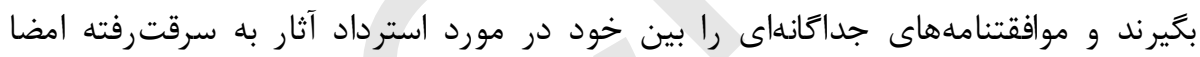

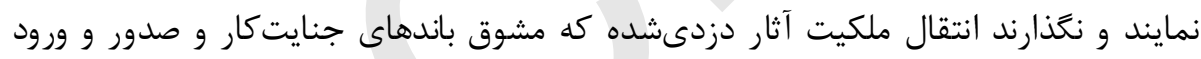

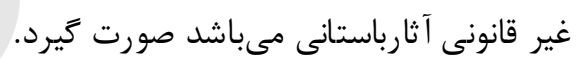

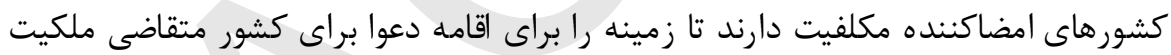

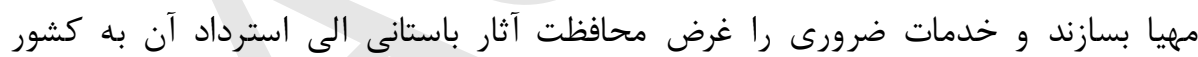

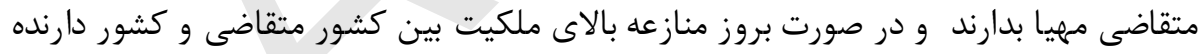

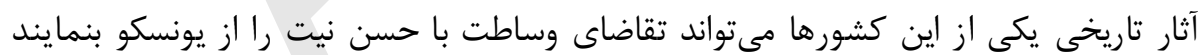

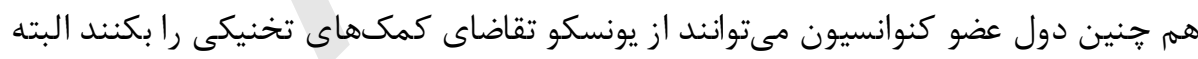

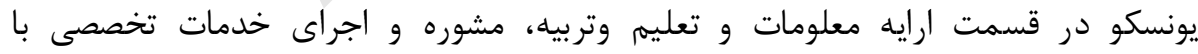

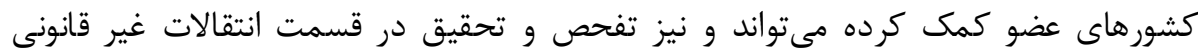

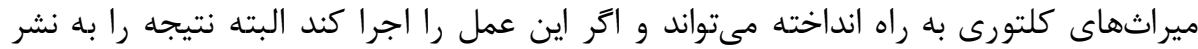

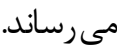

\section{جرايم سازمان يافته - همكارى بينالمللى}

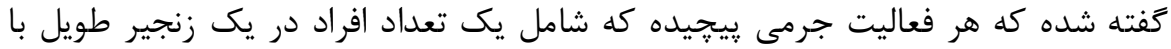

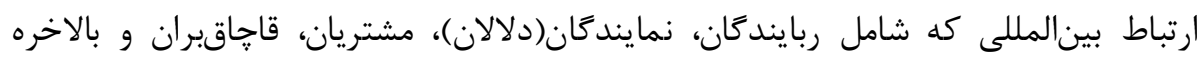


تاجران در بازار عرضه، با يك تشكيل، جه به شكل عنعنوى باشد و يا خير، گروٍ سازمانيافته جرمى ناميده مىشود.

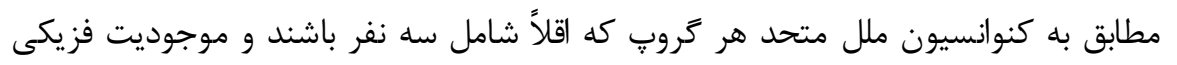

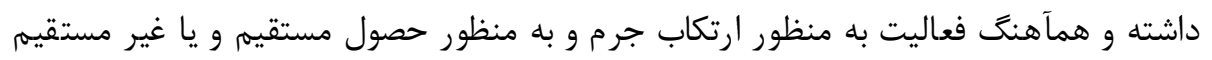

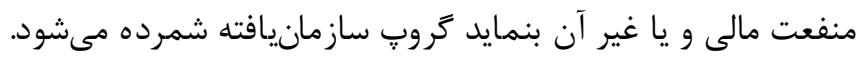

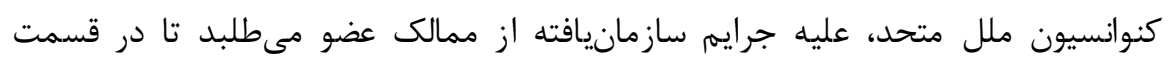

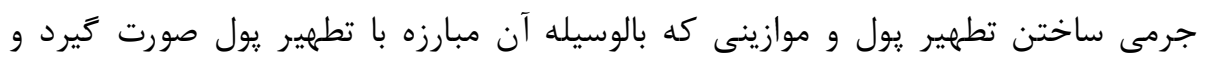

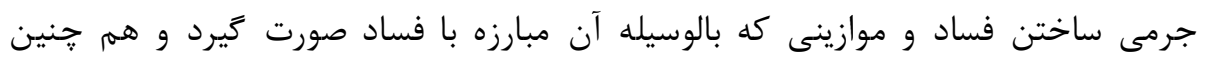

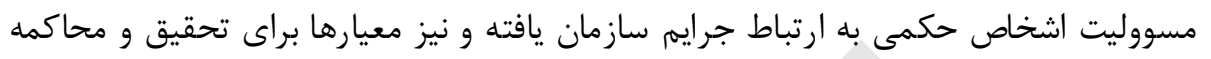

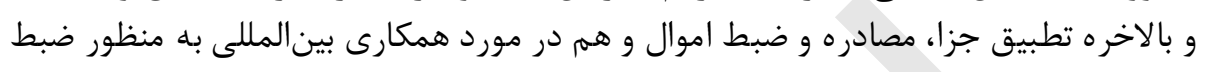

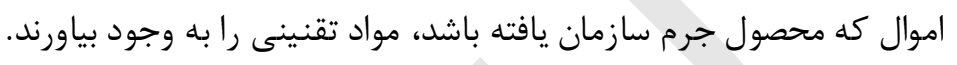

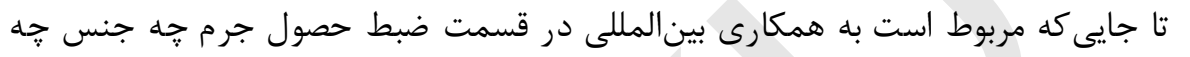

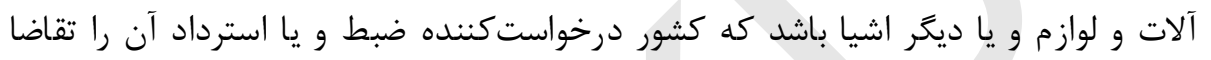

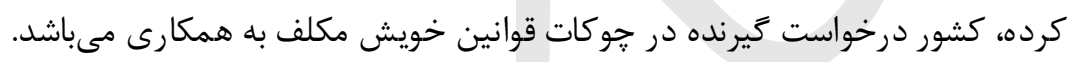

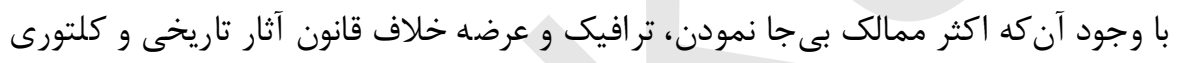

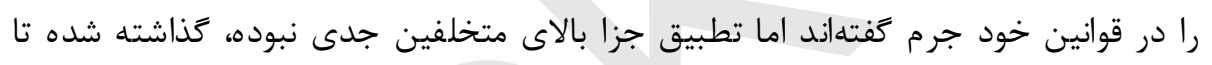
بازار تقاضا رونق ييدا كند.

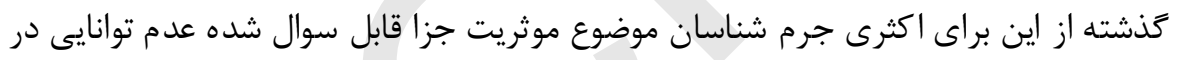

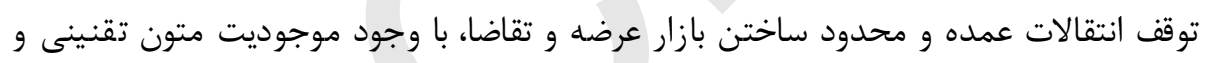

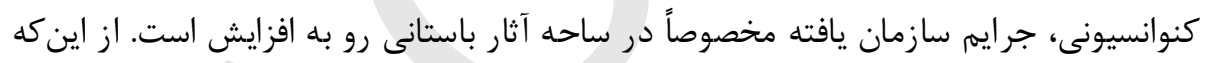

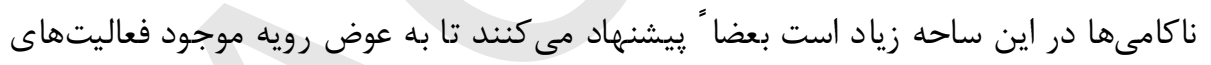

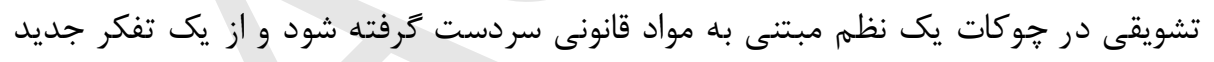

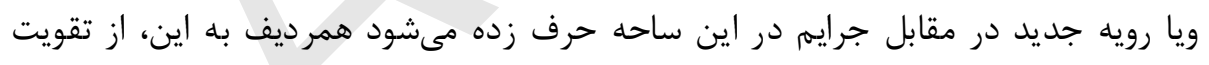

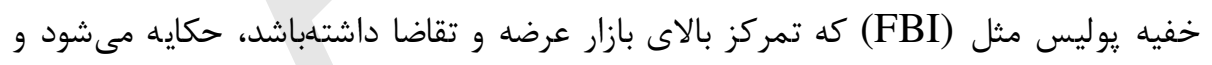

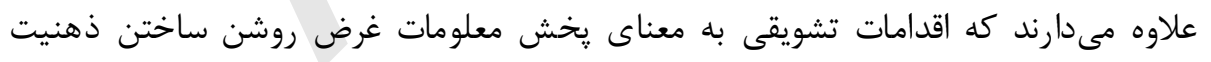

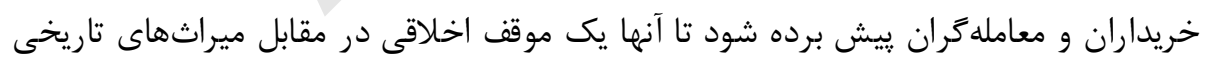

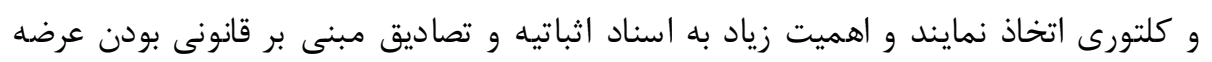

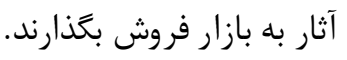

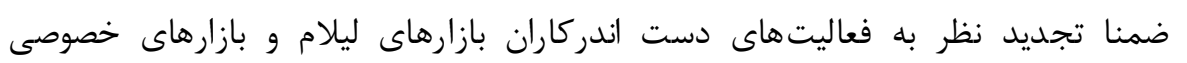

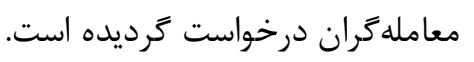

\section{اهميت اسناد وسوابق}

اسناد منضمه آثار تاريخى بايد حاوى نكات ذيل باش آند:

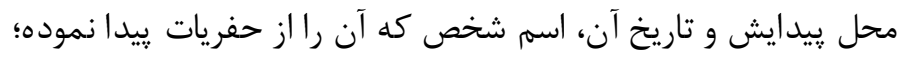


معلومات نشرشده در مورد آثار تاريخى و دخول آن به بازار؛ و و إندار

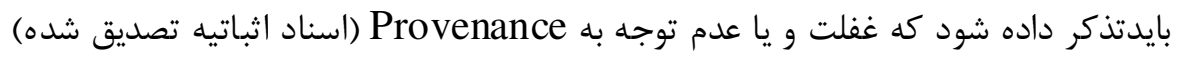

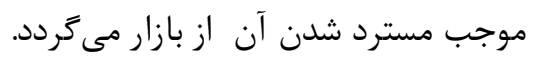

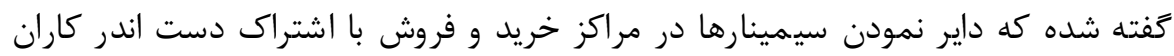

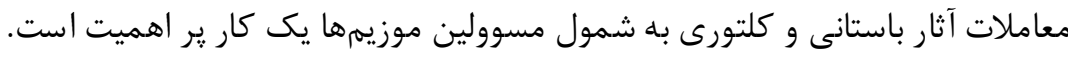

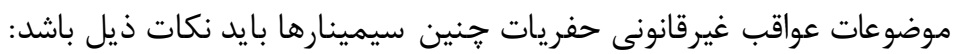

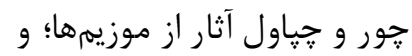

طرز شناخت آثار دزدى شده و اشتهار، امتهار وزئاع از خريدآن و يا تصاحب ولو به شكل تحفه هم

(متاسفانه موزيمها كمتر علاقه نشان دادهاند تا جنين موازين را مدنظر بخديرند وموزيمها

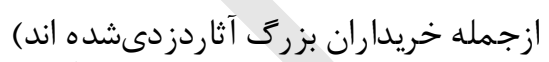

\section{آثارباستانى سرقت شده - همكارى بينالمللى}

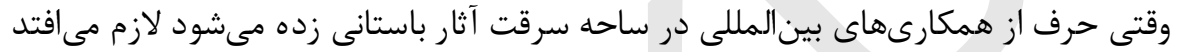

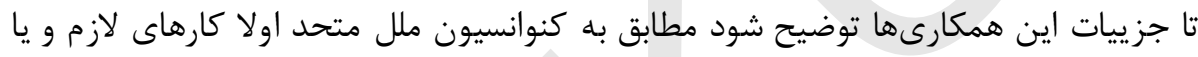

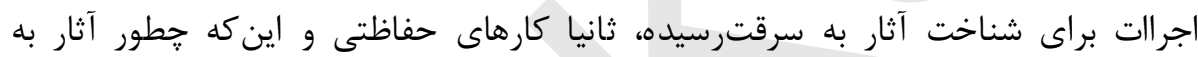

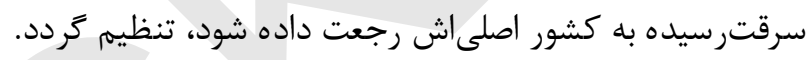

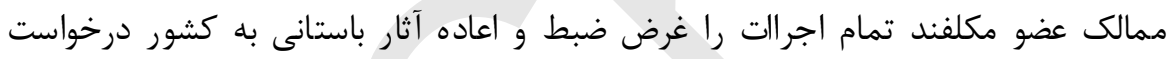

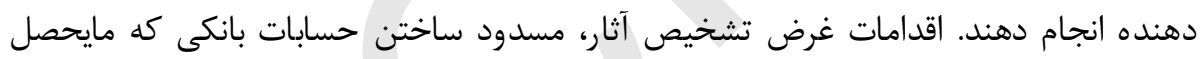

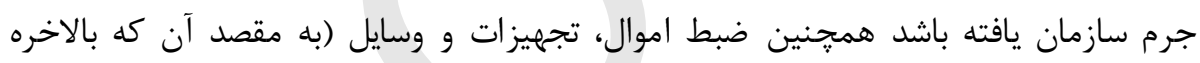

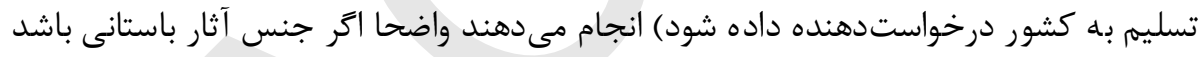

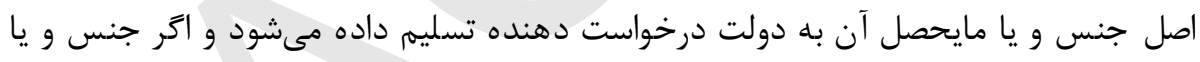

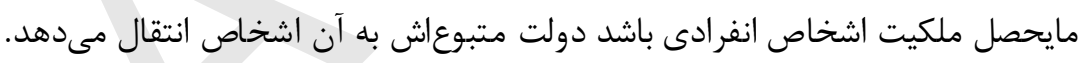

\section{استرداد - همكارى بينالمللى}

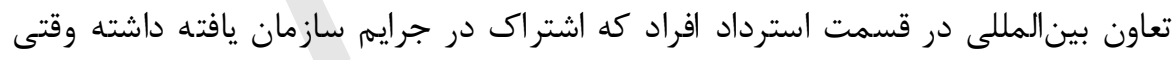

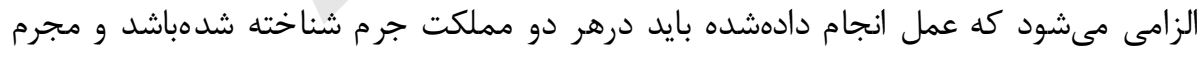

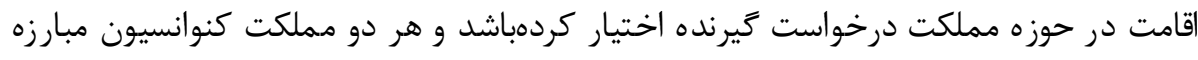

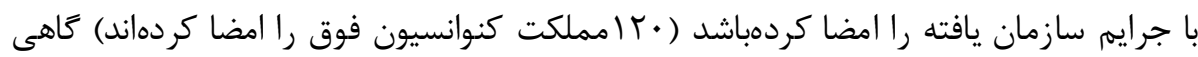

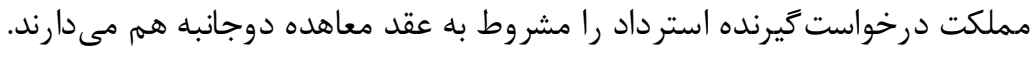

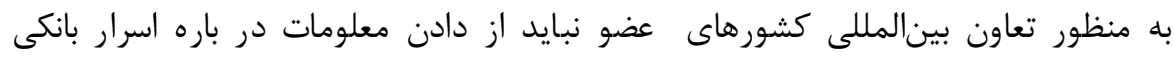

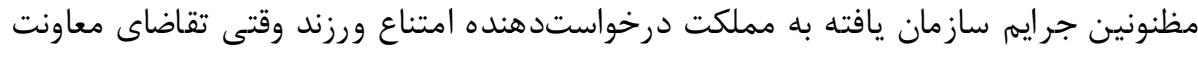

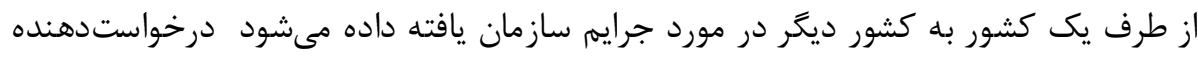
بايد مراتب ذيل را در نظر بخيرند، مثلا: 
خلاصه واقعيتهاى مندرج قضيه همنوا با تعريف جرم سازمان يافته، نوع همكارى تقاضا شدهاست. در صورت امكان هويت، آدرس، مليت كسانى كه در جرم شامل باشند.

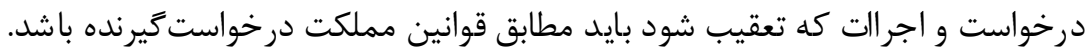

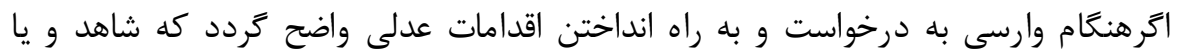

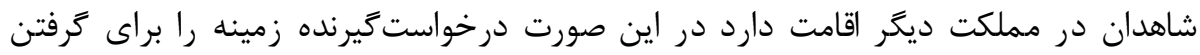
شهادت مهيا مىسازد.

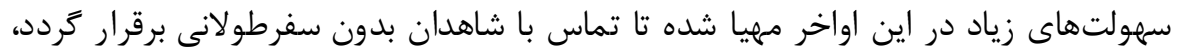

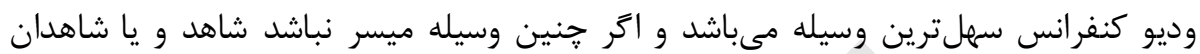

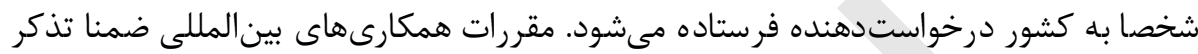

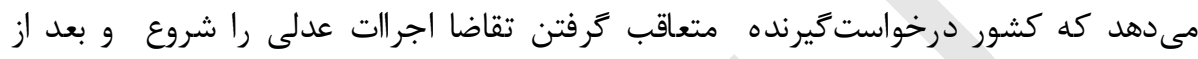

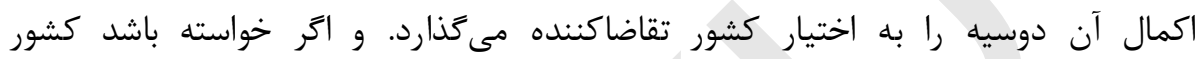
درخواست گيرنده مىتواند از مملكت درخواستدهنده تقاضا كند تا دوسيه ومعلومات آندات مندرجات آن را مخفى نخهدارد.

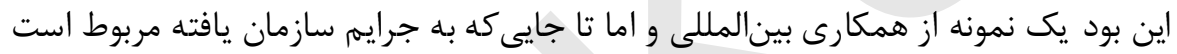

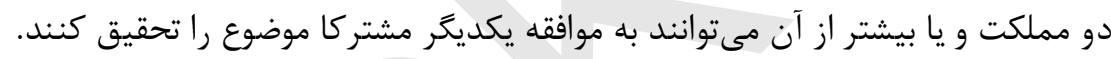

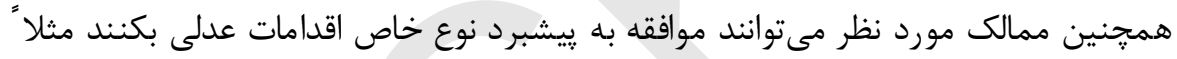
تحت نظر قراردادن مظنون توسط وسايل برقى و يا تعقيب توسط افراد خفيه يوليس.

\section{ليلام آثارباستانى}

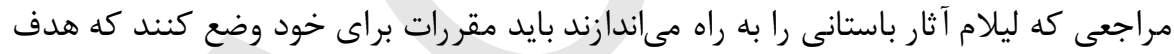

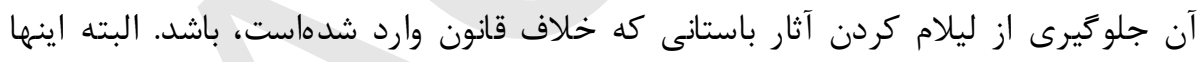

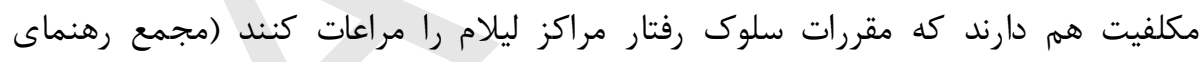

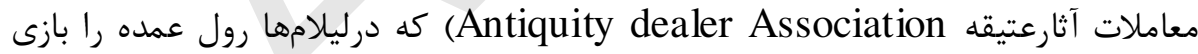

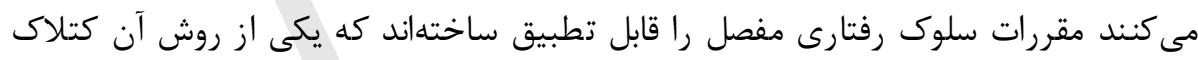

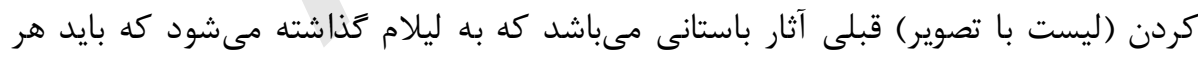

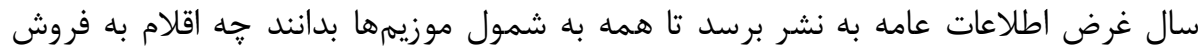

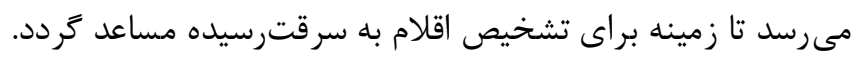

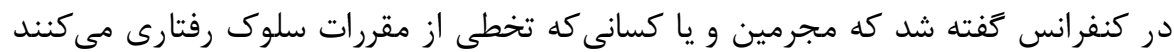

$$
\text { بايد اسماى آنها نشر شود. }
$$

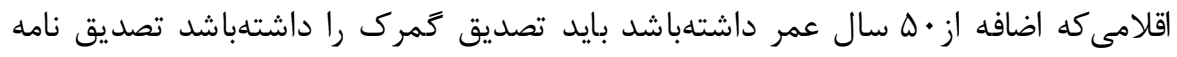

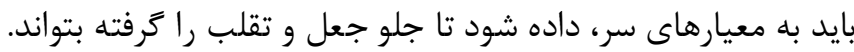

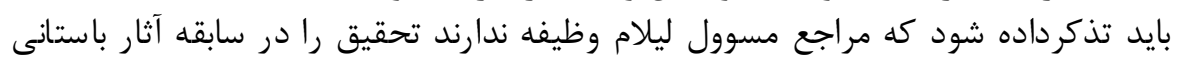




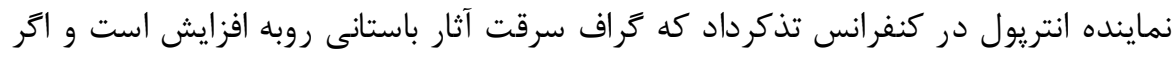

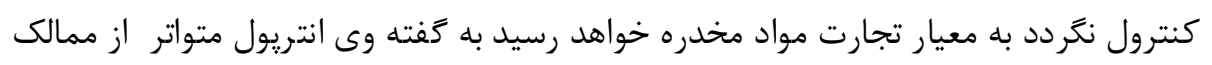

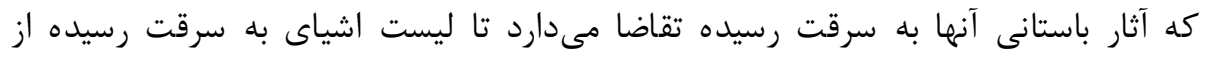

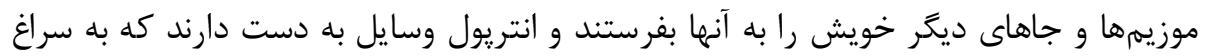

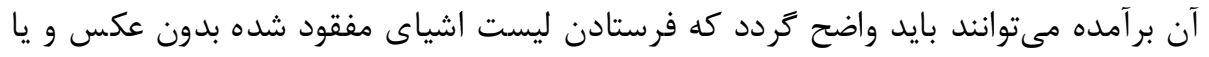

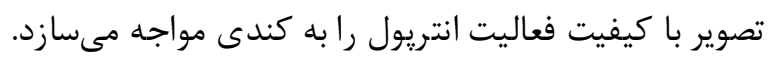

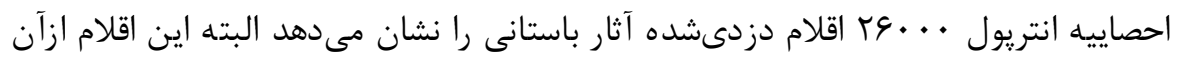

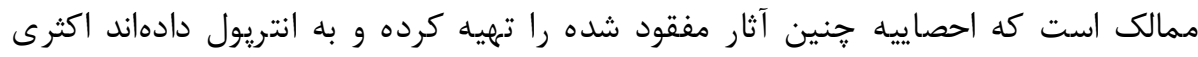

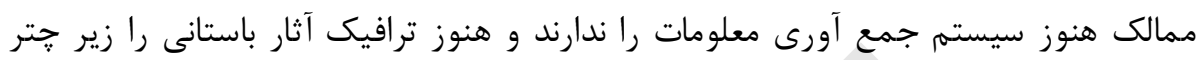
مراقبت خود قرارندادهاند.

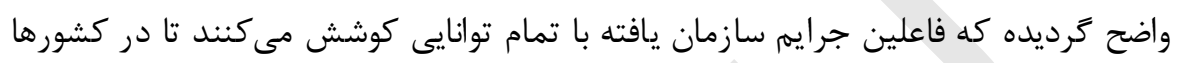

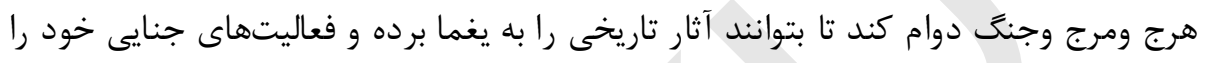
مفكوره جهانى شدن و آزادى مسافرتها مردمان را باهم بيشتر وصل مى كند و اين سبب مخفى نكهدارند.

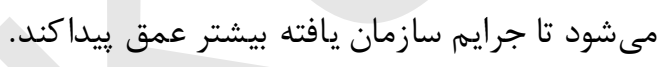

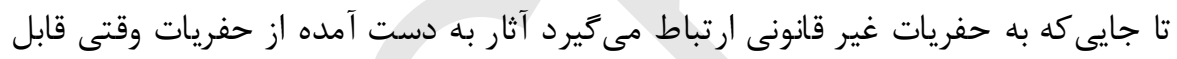

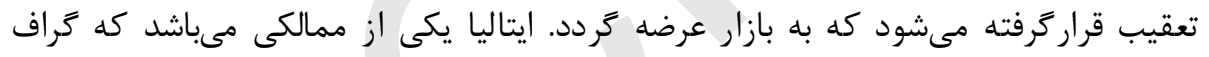

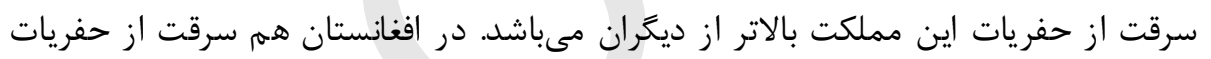

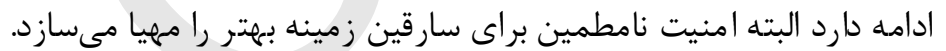

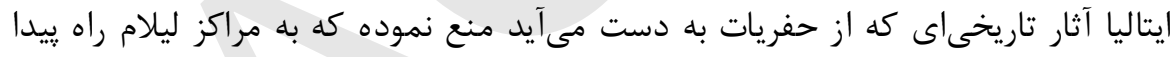

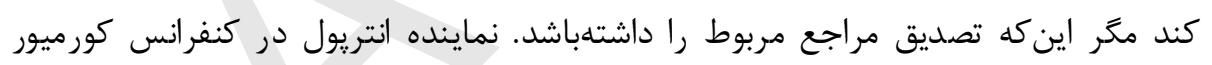

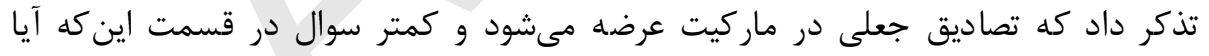

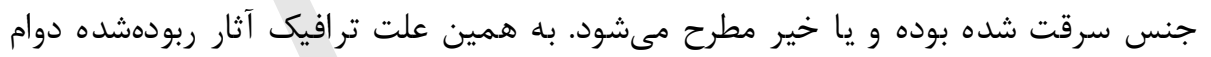

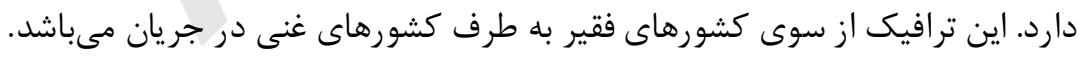

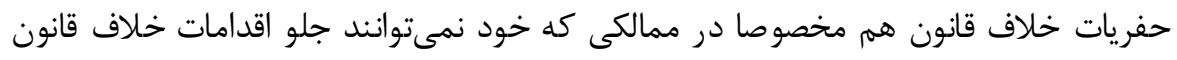

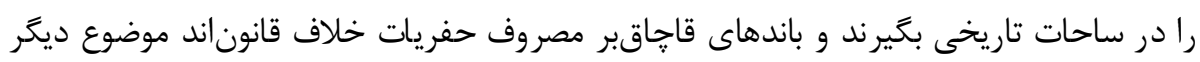

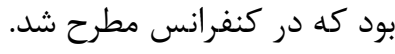

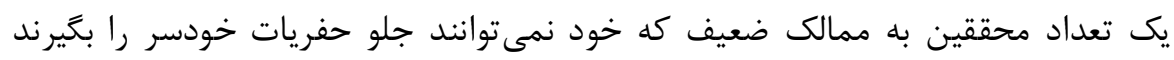

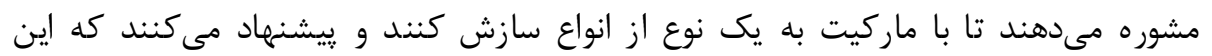

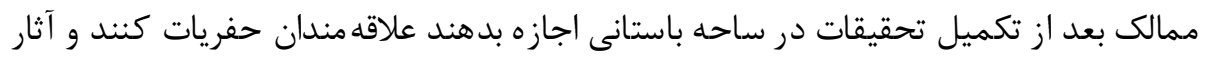

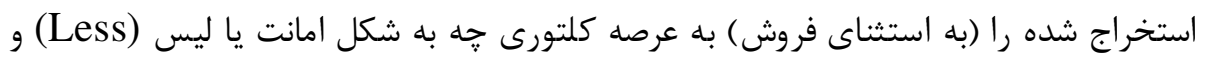


يا مالكيت مشترك باشد، بيش كنند و بحذارند حفريات را افراد و يا سكتور خصوصى به راه اندازند.

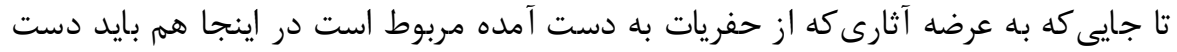

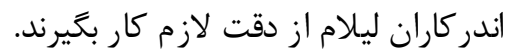

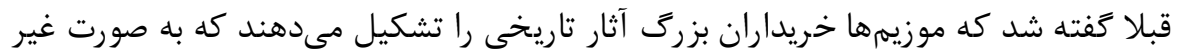

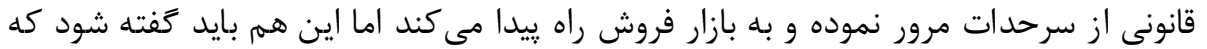

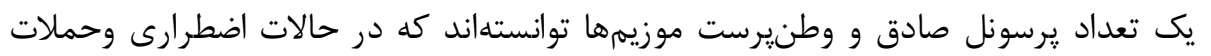
بالاى موزيمها آثار كرانبها را نجات بدهند.

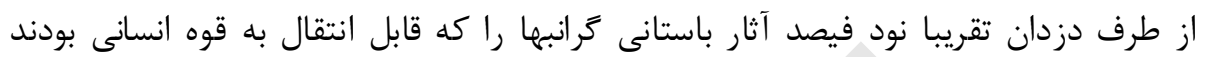
مخفى نمودند و از يغما نجات دادند.

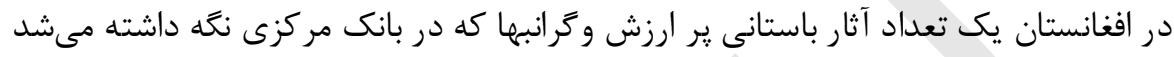

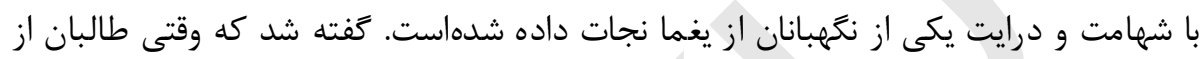

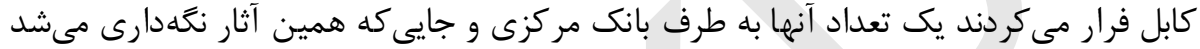

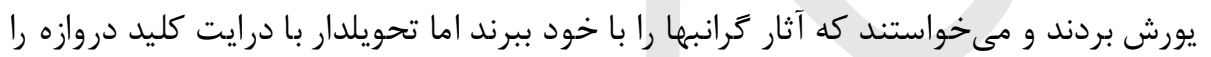

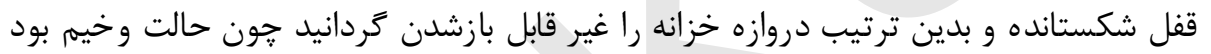

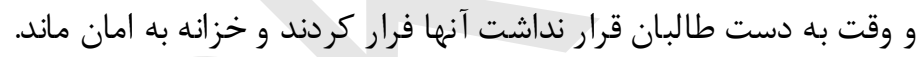

\section{كنفرانس كور ميور بعد از ختم جند روز مباحثه به نتايج ذيل ر سيد:}

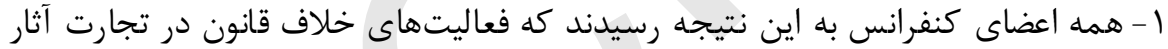

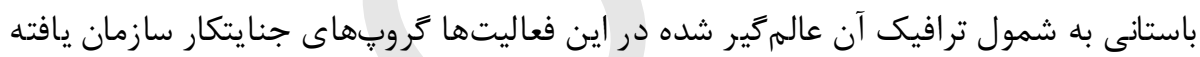

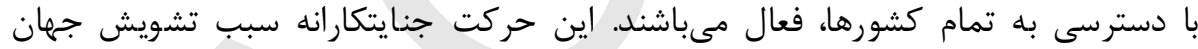

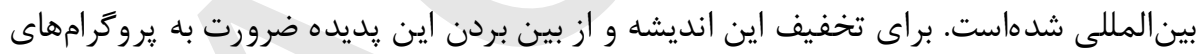

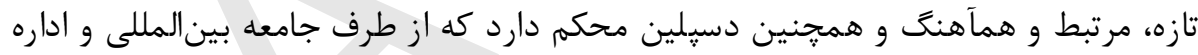
ملى بِيش برده شود.

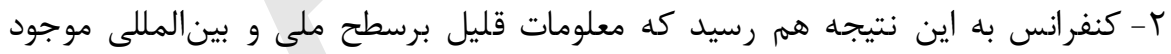

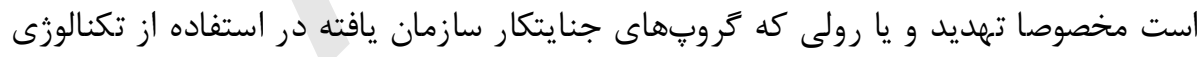

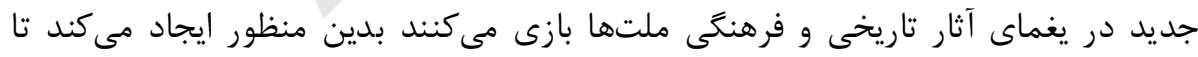

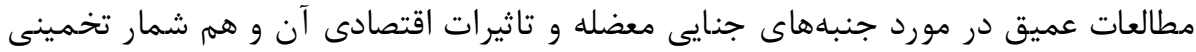

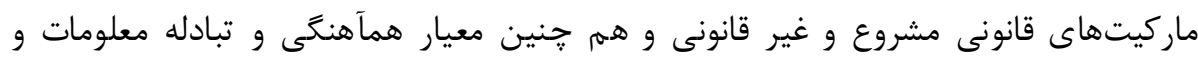

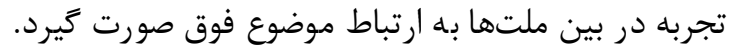

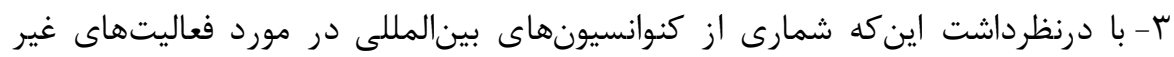

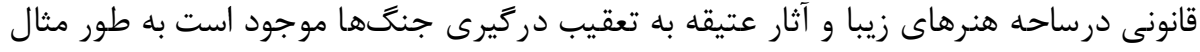

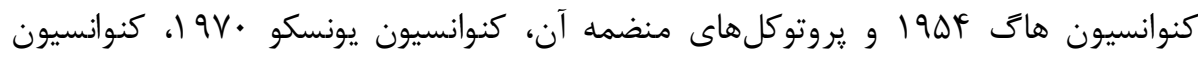
1990 UNIDROIT 
جنايى جديد باشد ضرورت است كه هدف آن يكى هم غيرقانونى ساختن ترافيك هنرهاى زيبا

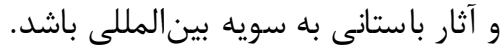

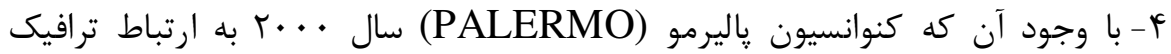

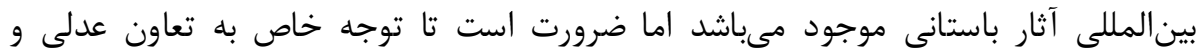

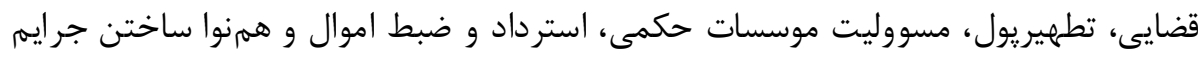

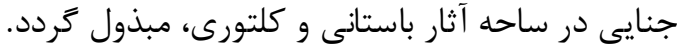

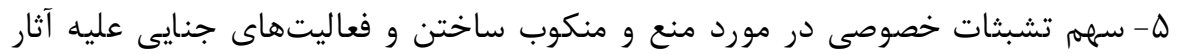

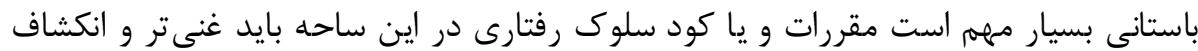

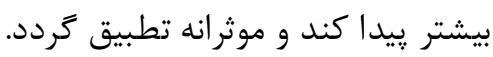

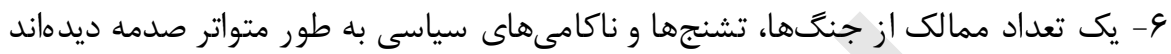

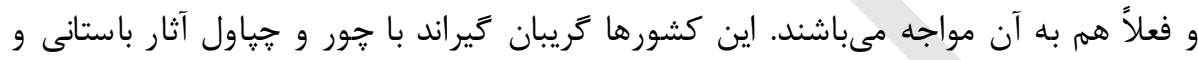

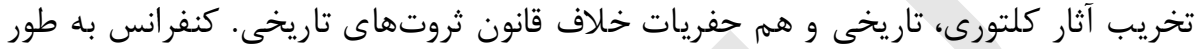

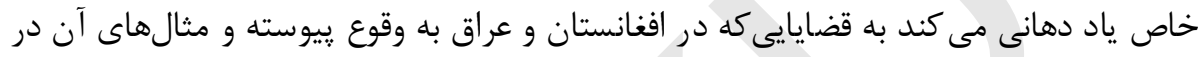

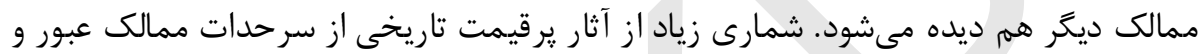

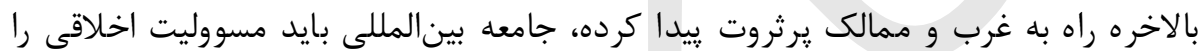

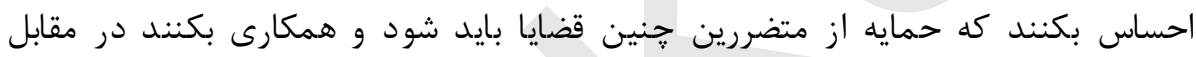

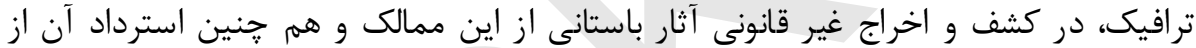

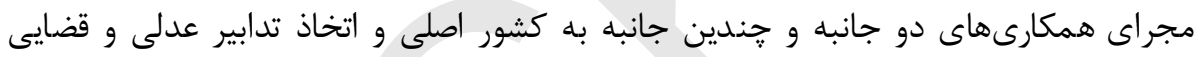

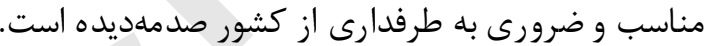

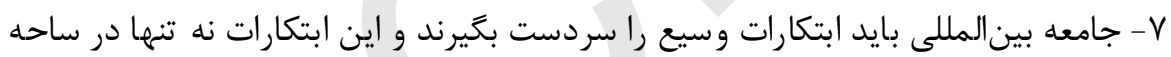

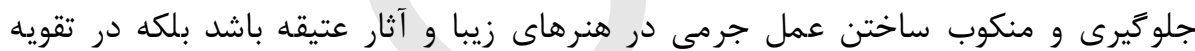

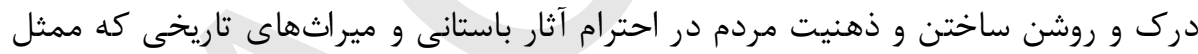

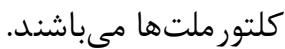

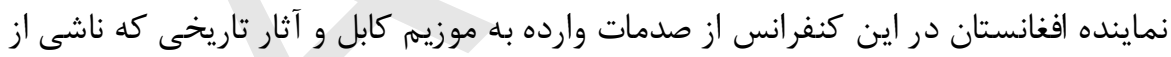

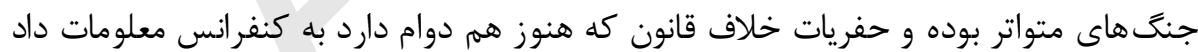

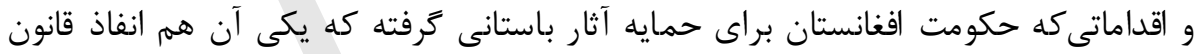

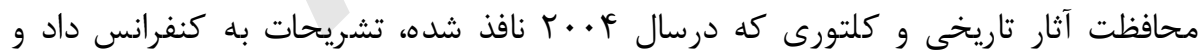

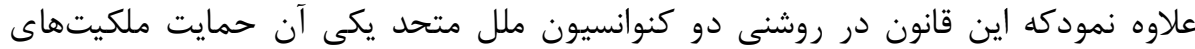

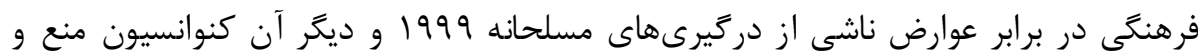

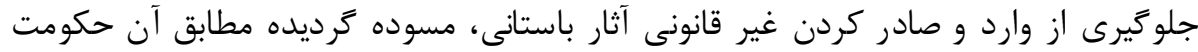

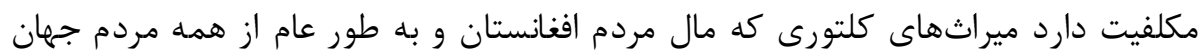

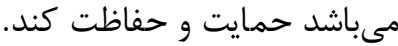

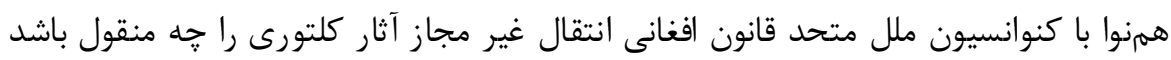
و يا غير منقول اعمم اينكه كشف شدهباشد و يا خير ممنوع اعلام نمودهاست. 


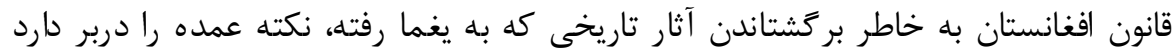

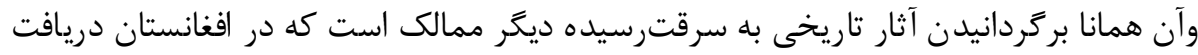

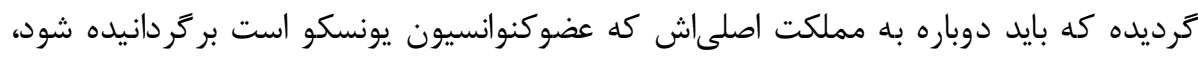

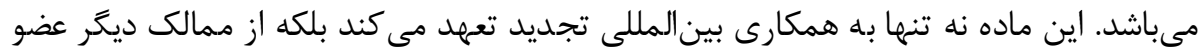

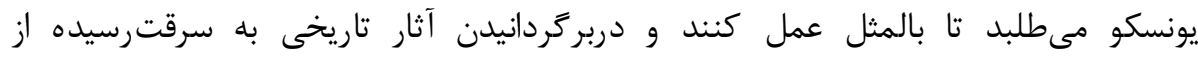

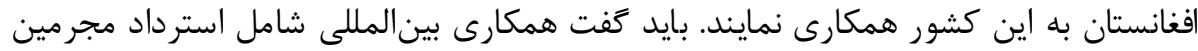

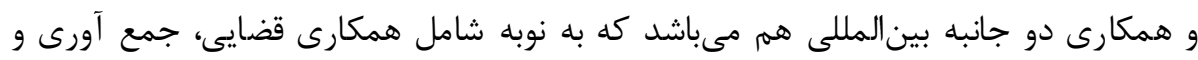

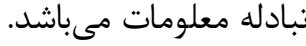

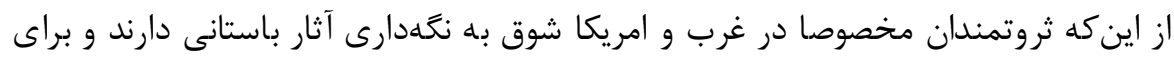

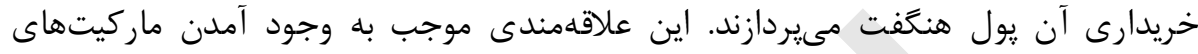

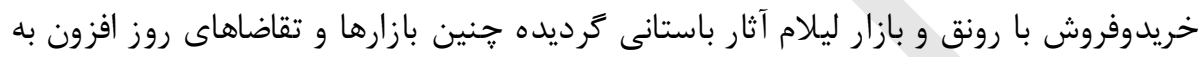

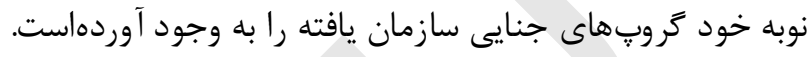

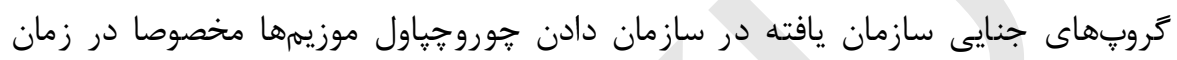

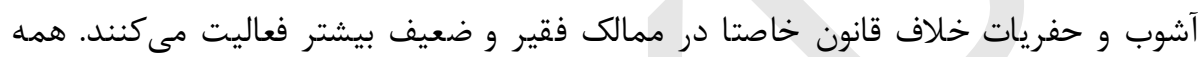

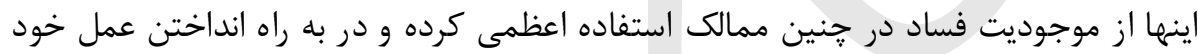

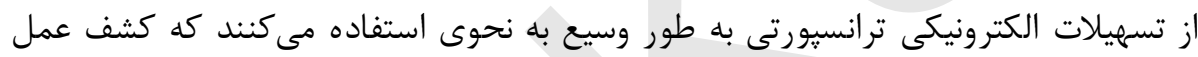

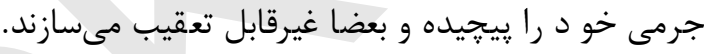

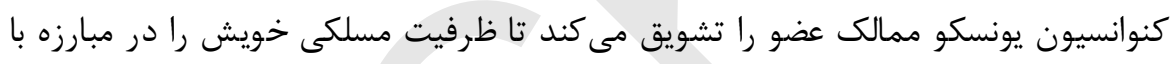
جرايم سازمان يافته بلند ببرند و وعده مى دهد تا همكارى تخنيكى با ممالك درخواست كنينده بكنند.

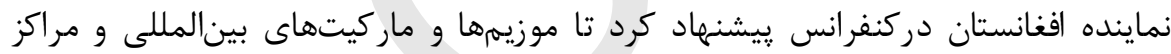

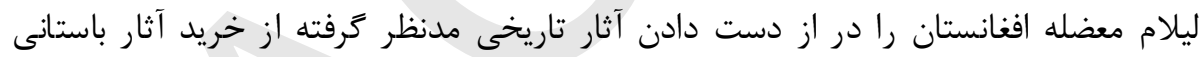

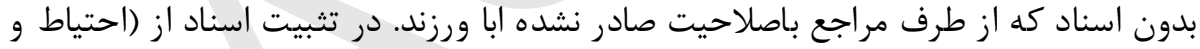

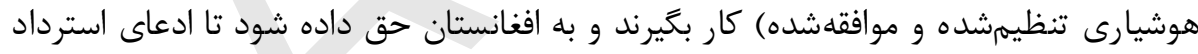

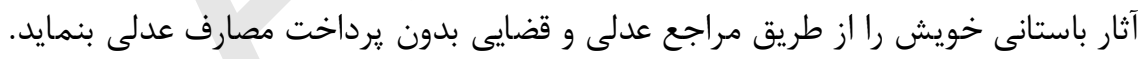

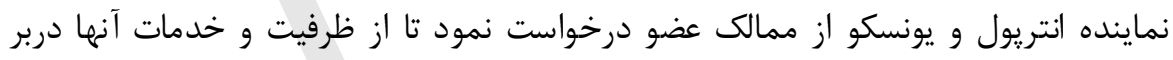

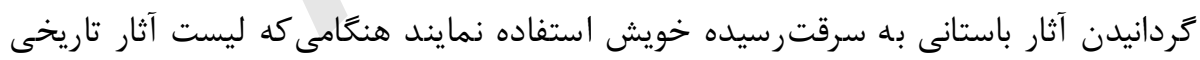

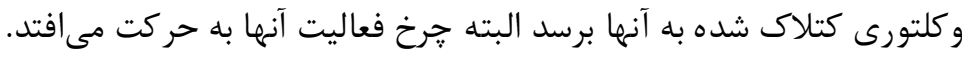

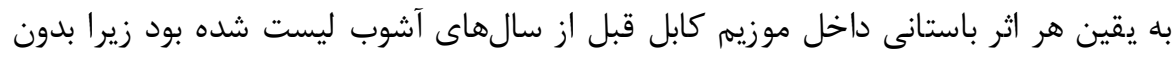

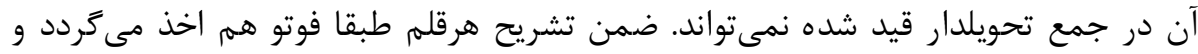

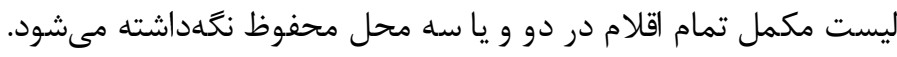

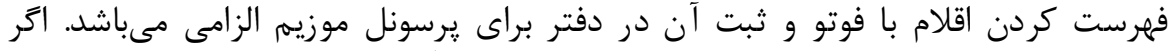

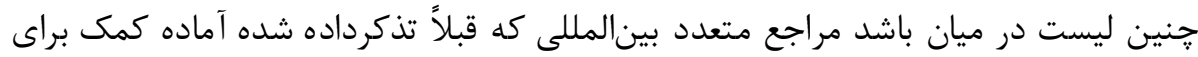

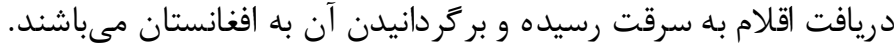




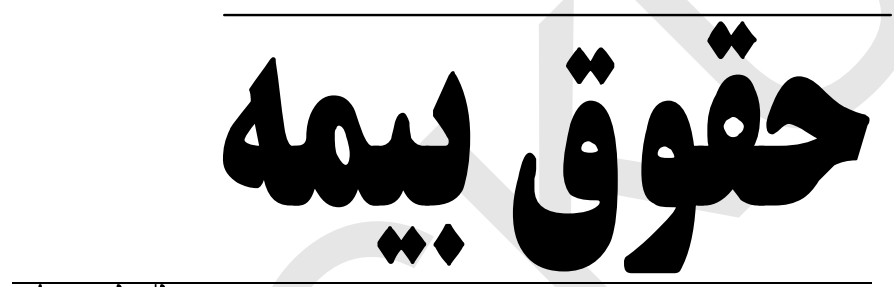

محمد ظريف حريف

زندگى، سلامت و دارايى انسان هميشه در معرض حوادث غير مترقبه (فورس مازور) و آفات

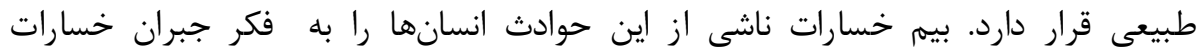

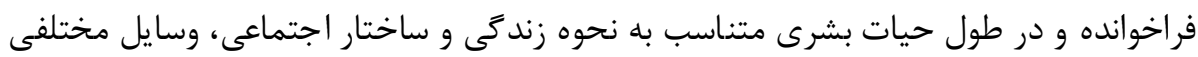
براى اين منظور به كار گرفته شدهاست

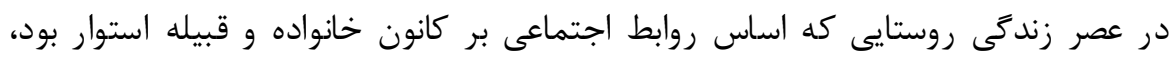

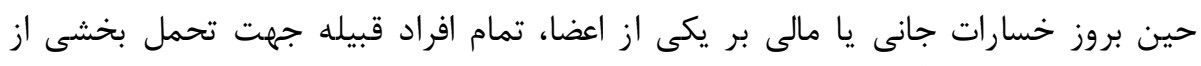

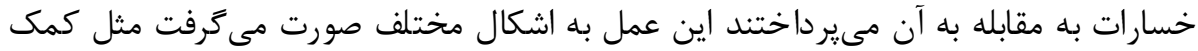

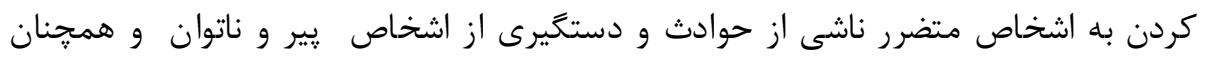
تكفل خانوادههاى بدون سريرست. 
از زمانى كه ساختار اجتماعى، زندگى روستايى به زندگى شهر نشينى تغيير يافت، خسارات

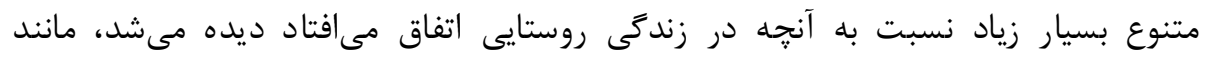

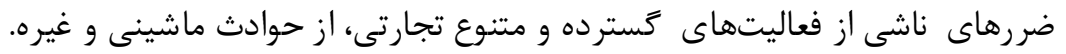

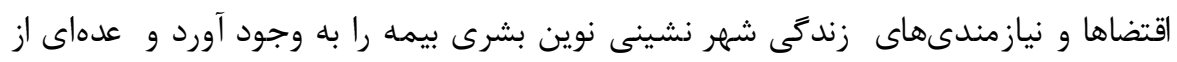

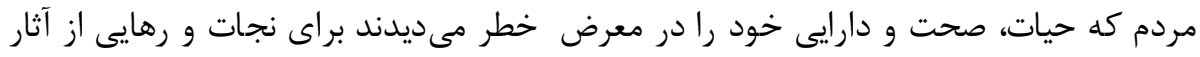

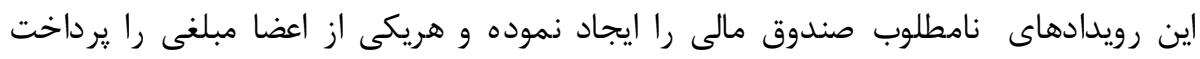

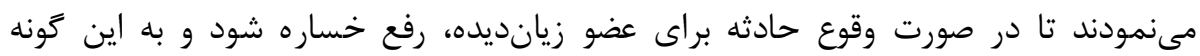

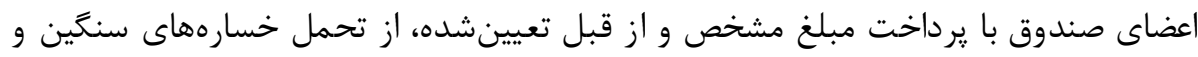

$$
\text { غير مترقبه رهايى مىيافتند. }
$$

تاريخجه بيمه

بيمه براى اولين بار در قرن يانزدهم ميلادى در زمينه حمل نقل درئه ديايى كالاها در كشورهاى

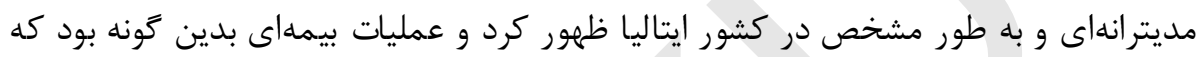

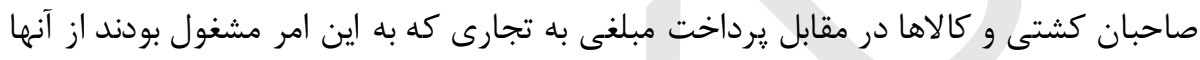

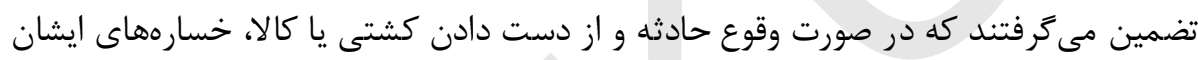

$$
\text { جبران شود. }
$$

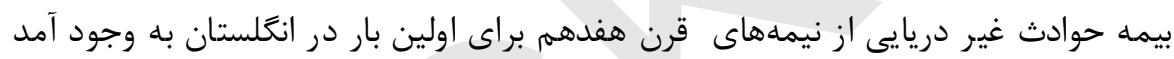

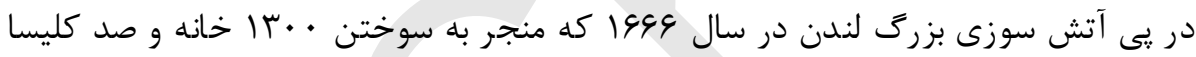

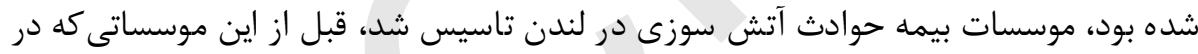

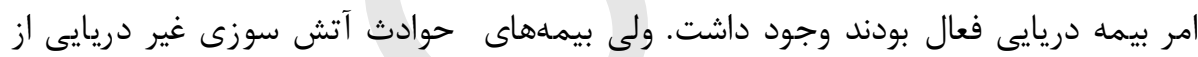

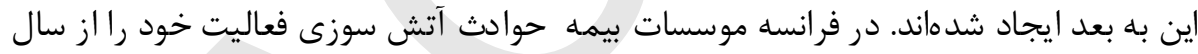
IVD. از اواخر قرن نزدهم به اين طرف از اثر توسعه ماشينيزم و فعاليتهاى اقتصادى خطر إئر ايجاد

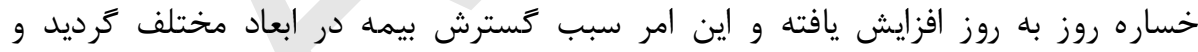

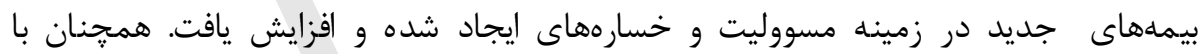
ييشرفت علم طب بيمههاى عمر اشخاص نيز توسعه يافتهاست. (1)

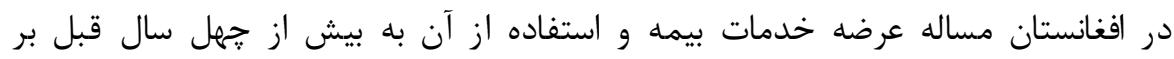

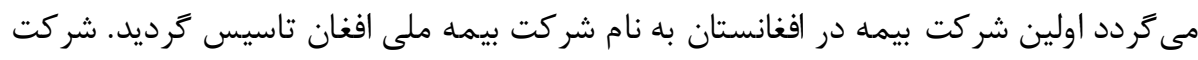

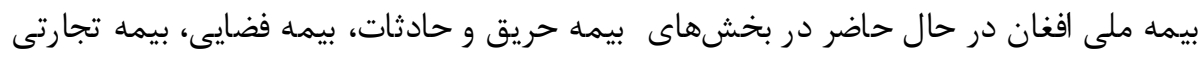

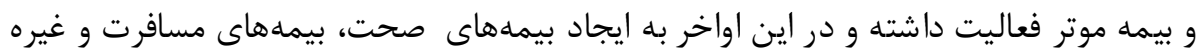

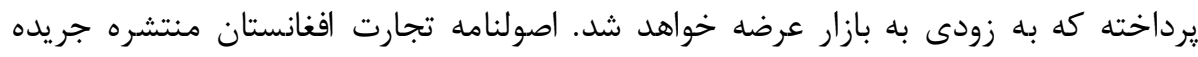

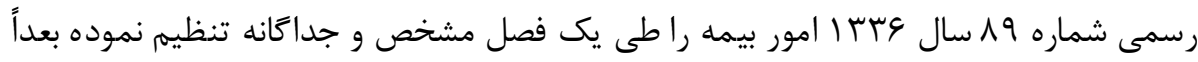

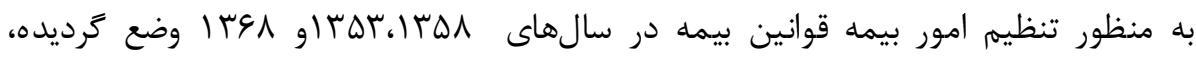

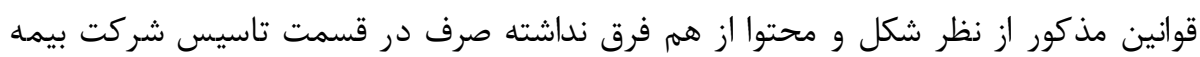




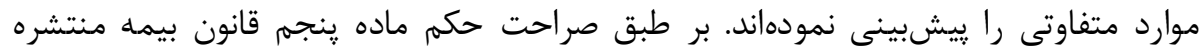

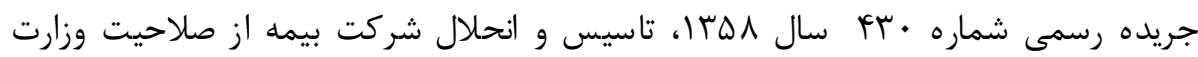

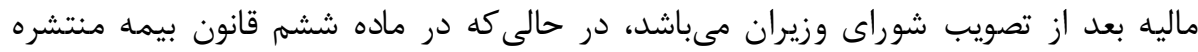

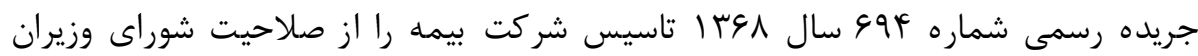

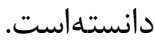

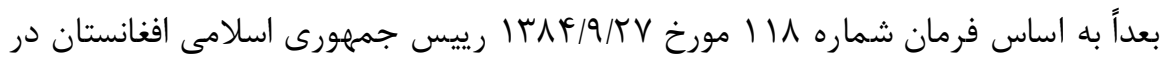

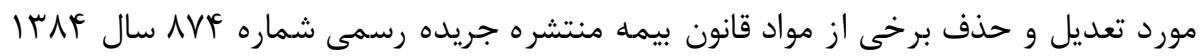

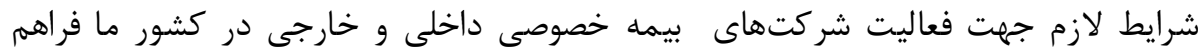

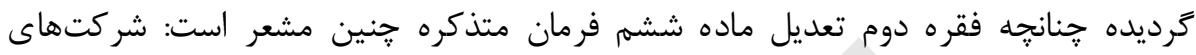

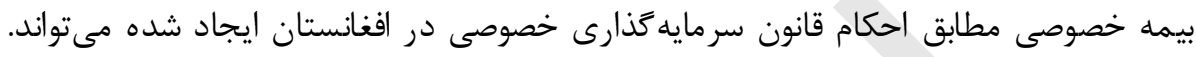

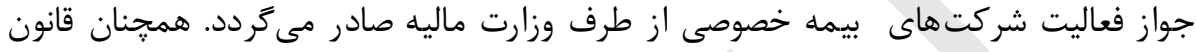

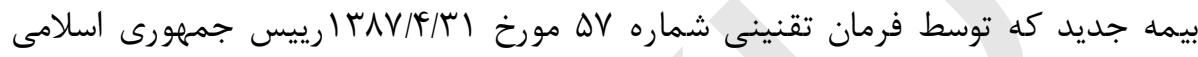

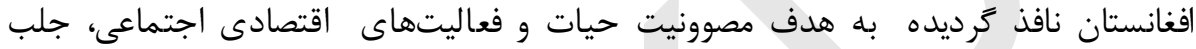

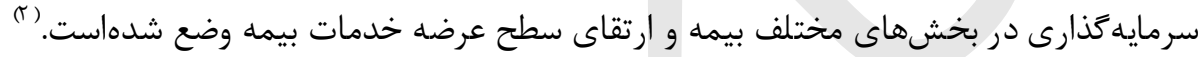

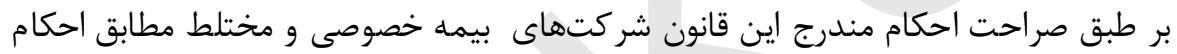

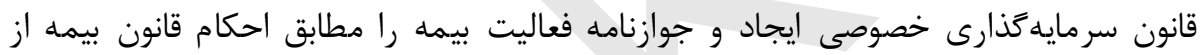

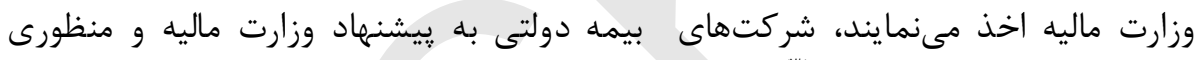
شوراى وزيران ايجاد مى كردند. (")

\section{تعر يف بيمه}

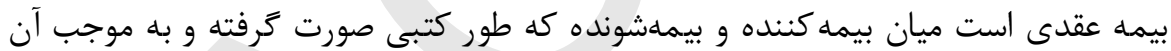

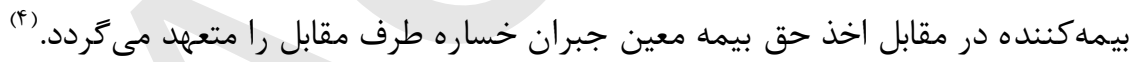

نقش بيمه

نقش اصلى بيمه ايجاد تامين مالى است. اين تامين به نوبه نوبه خود آثار روانى و اقتصادى

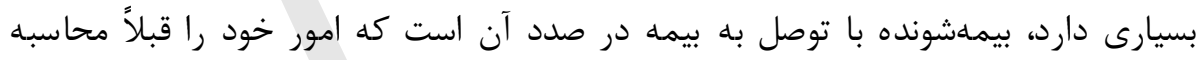

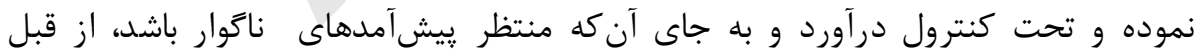

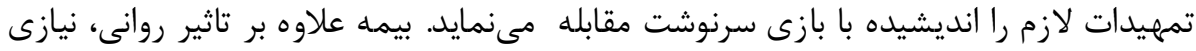

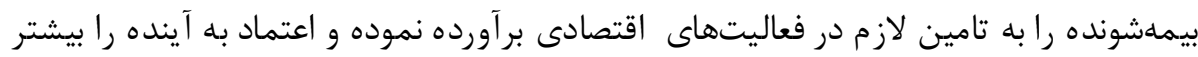

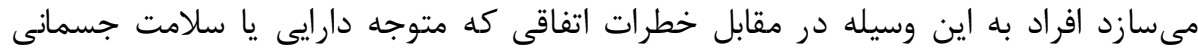

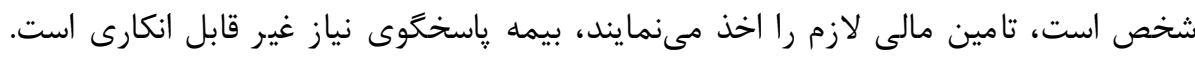

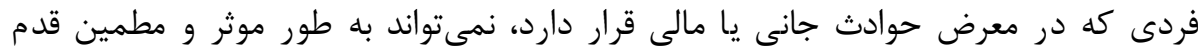

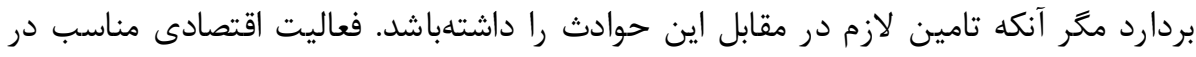

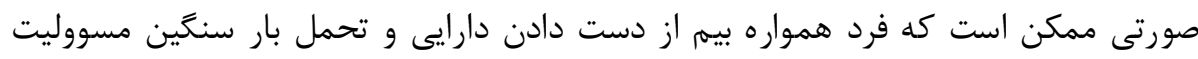


حوادث را نداشتهباشد و اين امر با يوشش بيمه تحقق مى يذيرد. اين مساله در مورد زندكى

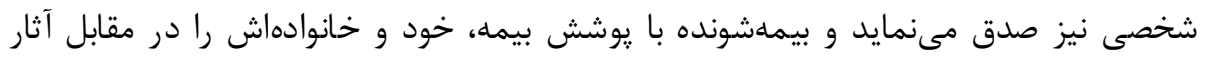

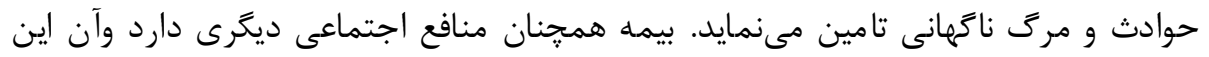

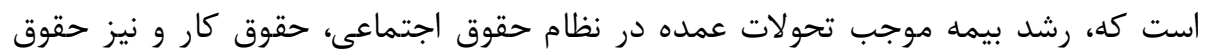

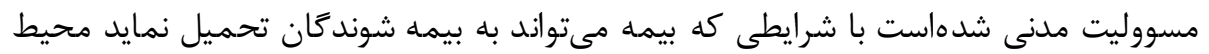

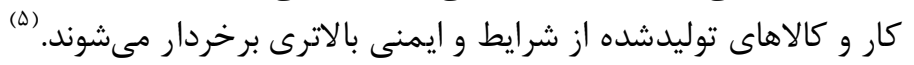

انواع بيمه

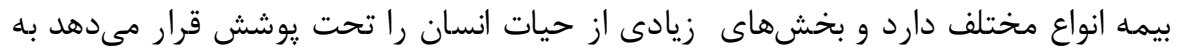

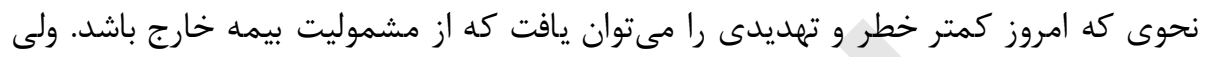

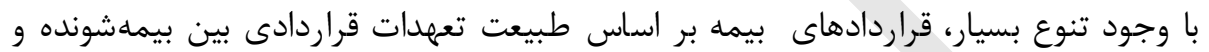

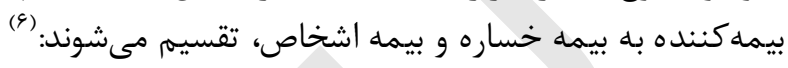

ا- بيمه خساره

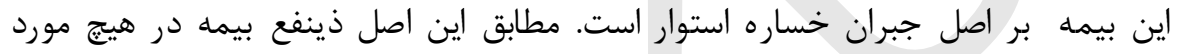

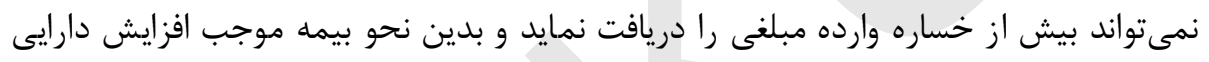

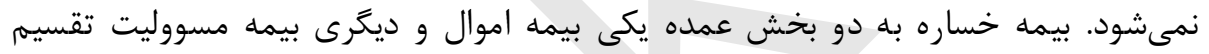

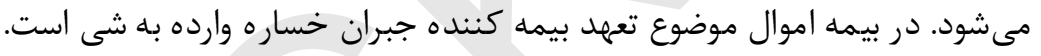

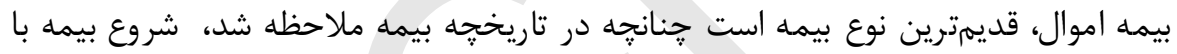

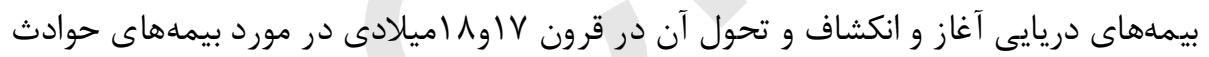

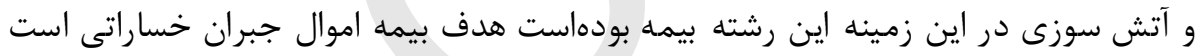

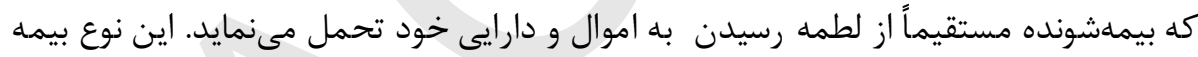

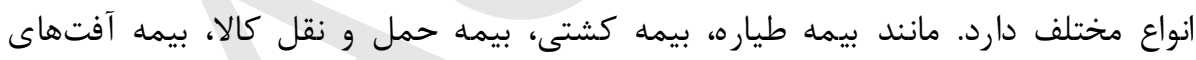

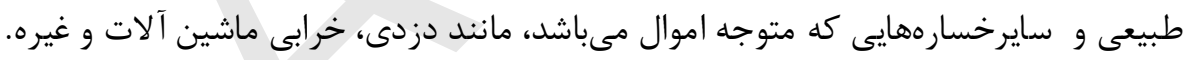

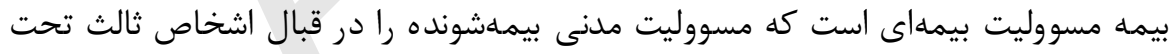

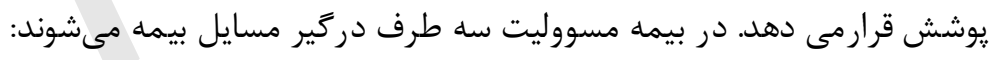

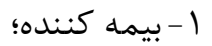

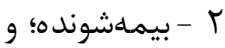

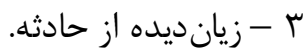
اين رشته بيمه نيز انواع مختلف دارده مارد مثلاً بيمه مسووليت موتر، طياره و كشتى، بيمه

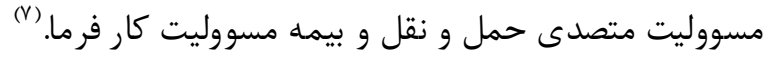

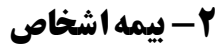
موضوع بيمه اشخاص تماميت جسمانى شخص بيمهشونده است زند إكى، مرك، خساره جانى،

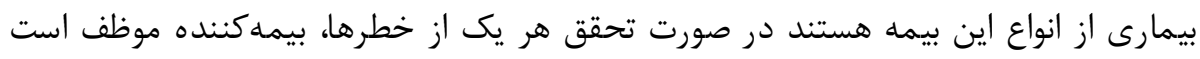




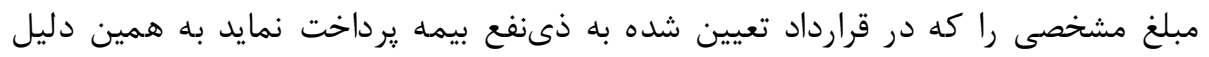

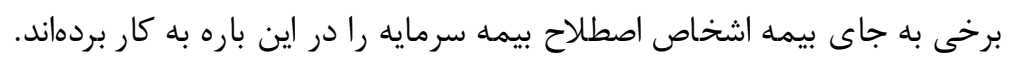

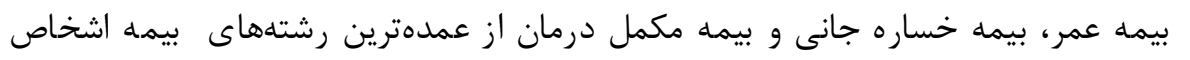

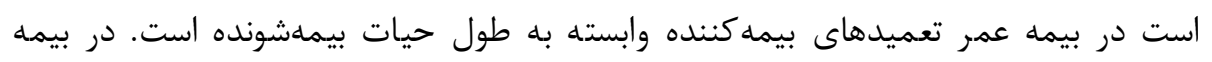

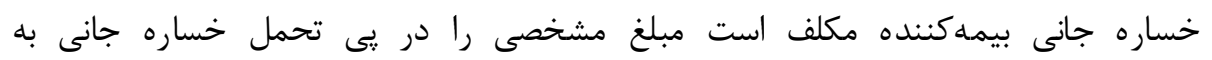

$$
\text { بيمهشونده بيردازد. }
$$

\section{ماهيت حقوقى عقد بيمه}

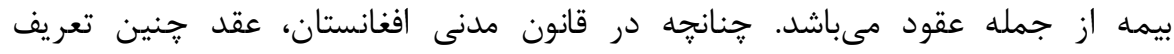

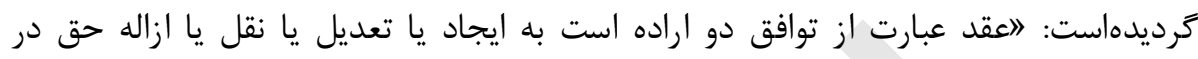

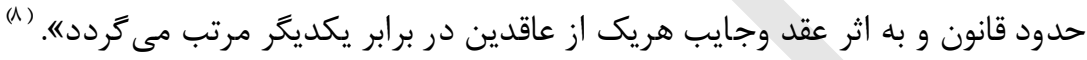

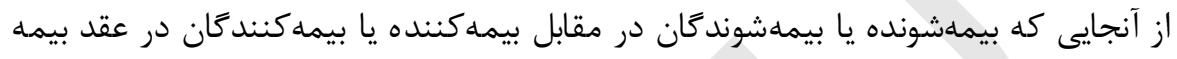

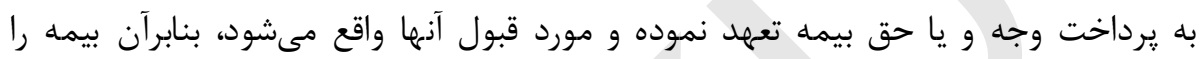

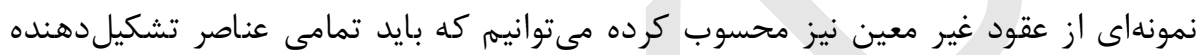
عقد را دارا باشد.

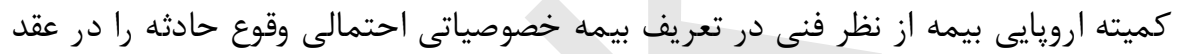

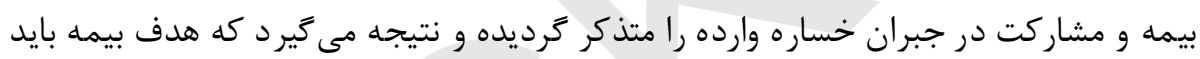
مطابق جبران خطر باشد.

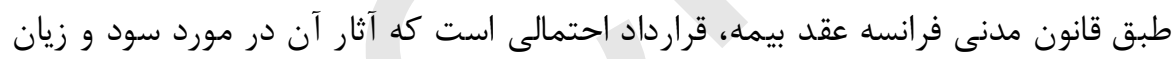

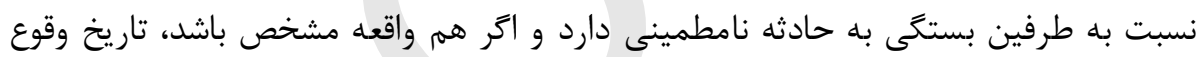

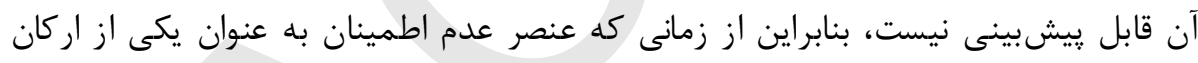

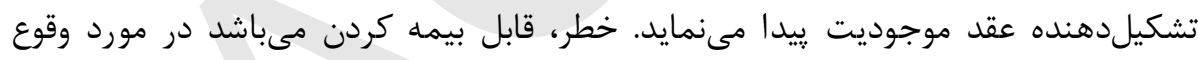

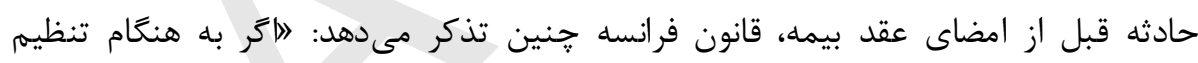

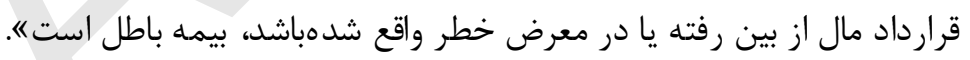

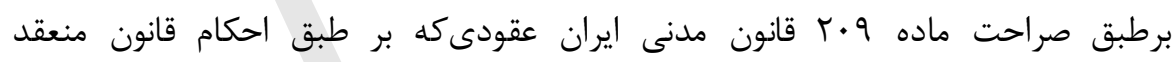

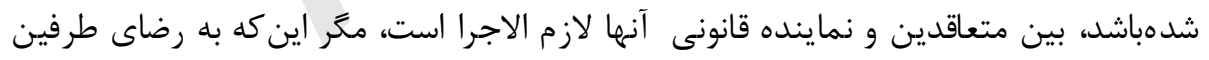

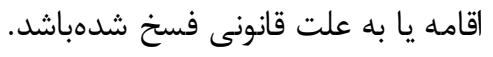

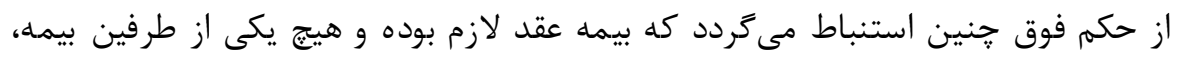

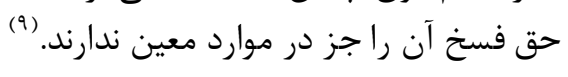

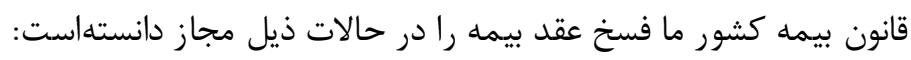

$$
\text { 1 - در صورت افلاس و انحلال بيمه كنيندا. }
$$

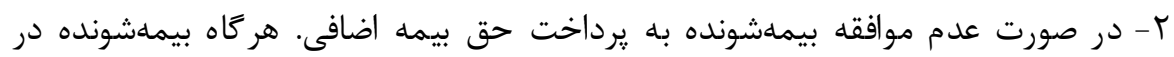

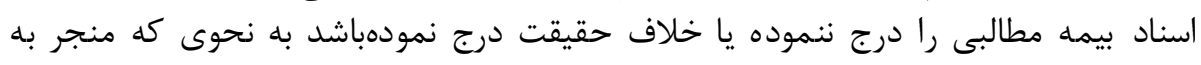

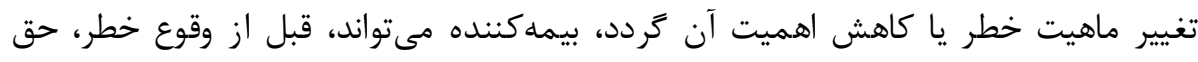


بيمه اضافى مطالبه نموده يا بيمهنامه را فسخ نمايد و حق بيمه اخذ شده را به بيمهشونده

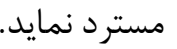

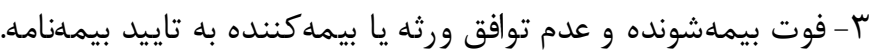
F شخص مذكور حاضر به ادامه بيمدنامه نغرددد.

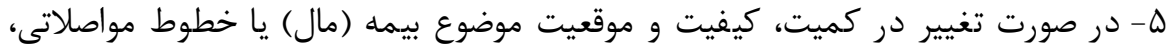

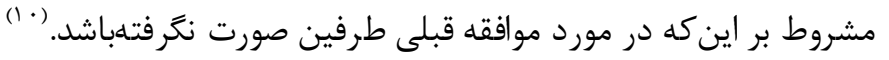

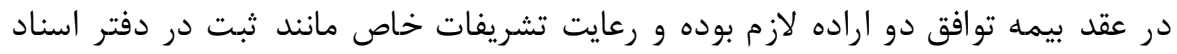

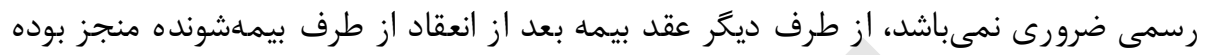

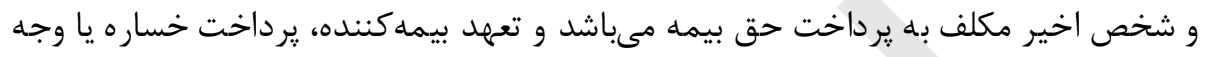

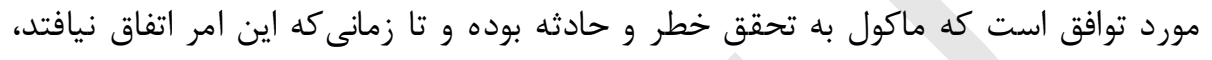

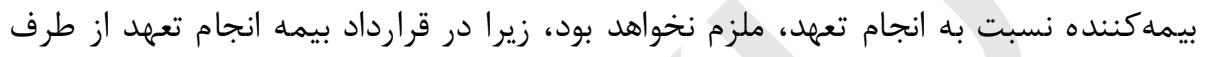

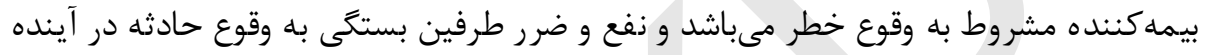

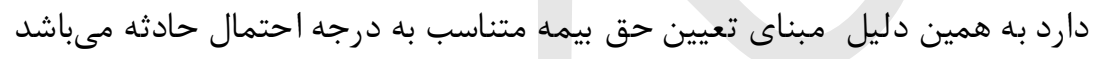

\section{اوصاف عقد بيمه}

بيمه از جمله عقود معين مىباشد به اين معنا كه علاوه بر اصول كلى قراردادها داراى احكام

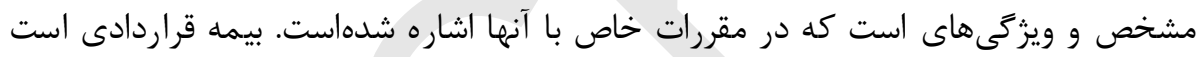

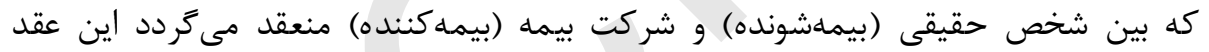
داراى اوصافى ذيل مىباشد:

$$
\begin{aligned}
& 1 \text { - بيمه عقدى است رضايى (قصدى)؛ } \\
& \text { r - بيمه عقدى است لازم؛ } \\
& \text { ץ- بيمه عقدى است معوض؛ بيمه عقدئ } \\
& \text { |f ب بيمه عقدى است غير مجانى؛ } \\
& \text { ه- بيمه عقدى است استمرارى؛ } \\
& \text { צ- بيمه عقدى است اتفاقى؛ }
\end{aligned}
$$

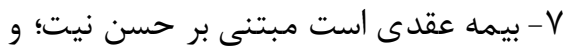

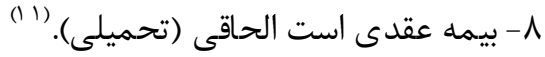

انعقاد عقد بيمه

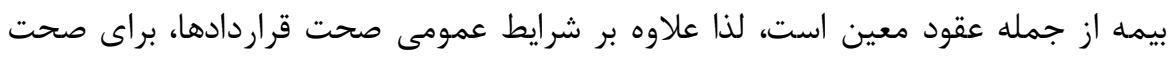
عقد ممكن است شرايط خاصى نيز وجود داشتهباشد. 
جهت انعقاد عقد بيمه، شر ايط خاصى در رابطه به اهليت انعقاد عقد وجود دارد. در واقع براى

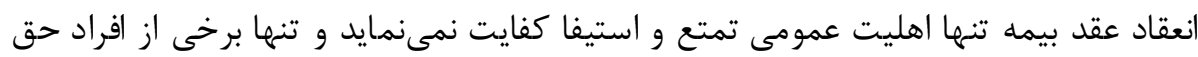

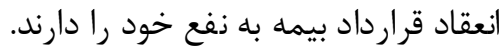

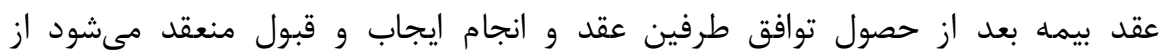

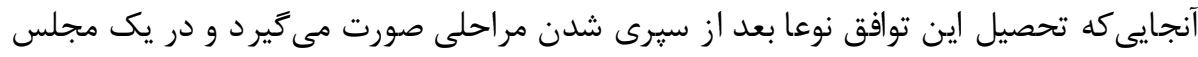

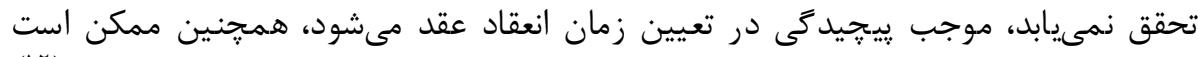

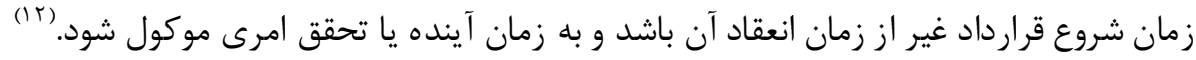

\section{حقوق و تعهلات طرفين}

در انعقاد قرارداد بيمه هر يكى از طرفين طرفين در مقابل طرف ديگر تعهد بر انجام امر يا امورى مىنمايند:

\section{1- حقوق و تعهدات بيمه شونده}

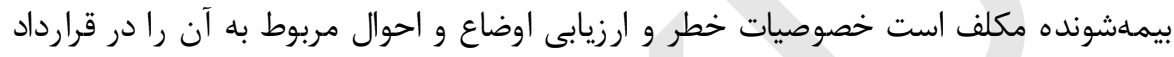

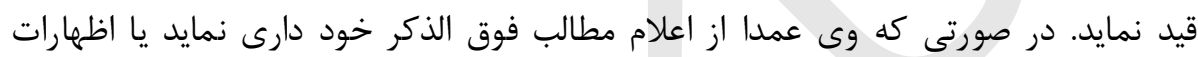

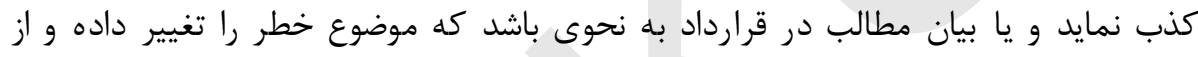

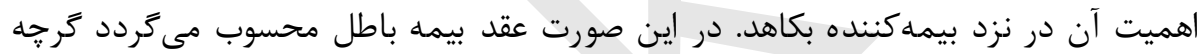

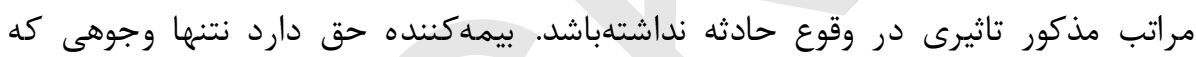

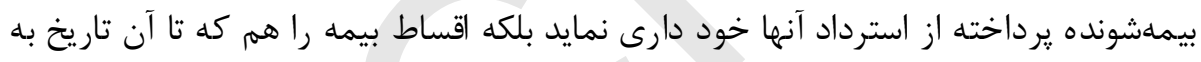
تاخير افتاده از بيمهشونده مطالبه نمايد.

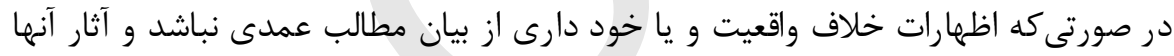

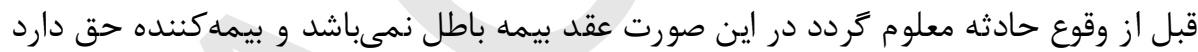

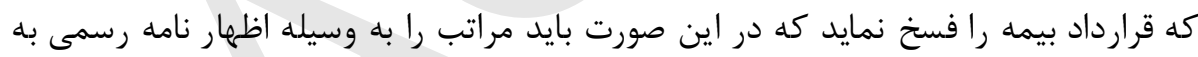

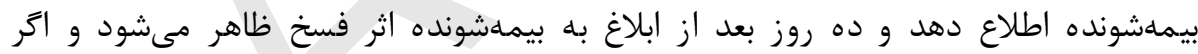

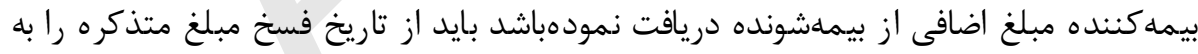
بيمهشونده مسترد نمايد.

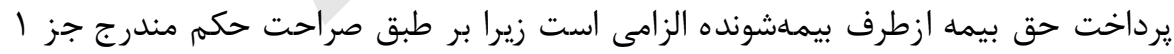

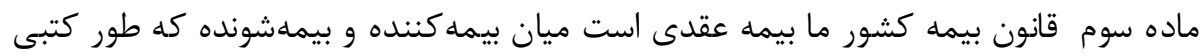

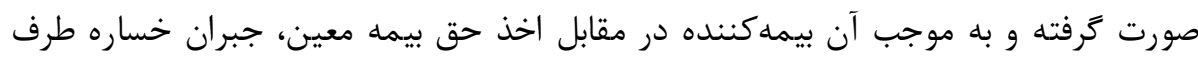

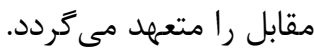

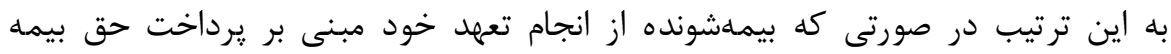

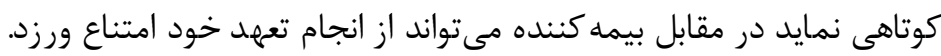

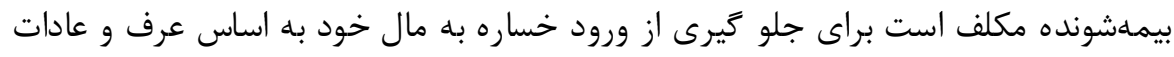

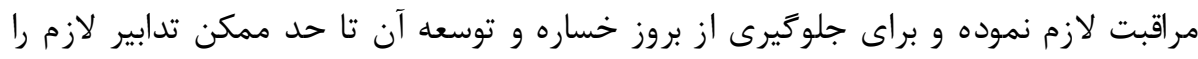


اتخاذ نمايد و حد اكثر در ظرف ينج روز از تاريخ اطلاع وقوع حادثه، بيمه كننده را مطلع نمايد

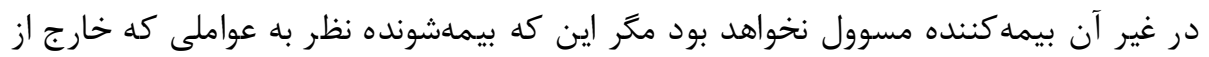

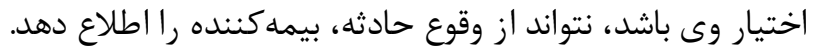

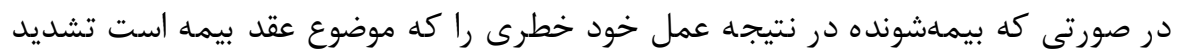

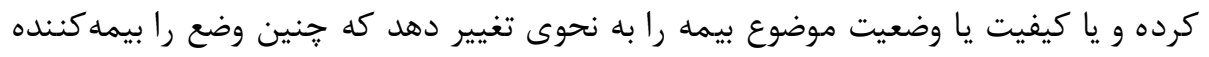

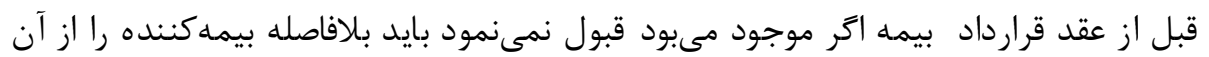

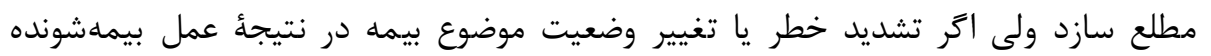

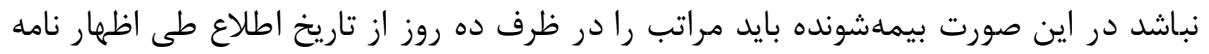

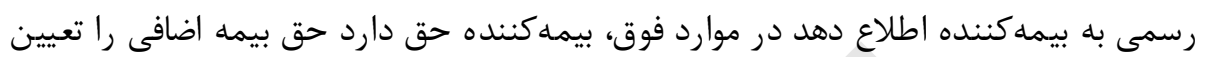

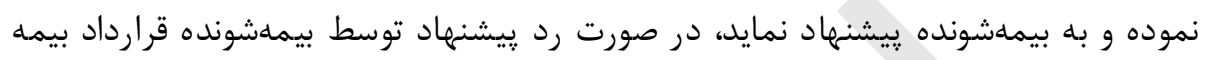
قابل فسخ مىباشد.

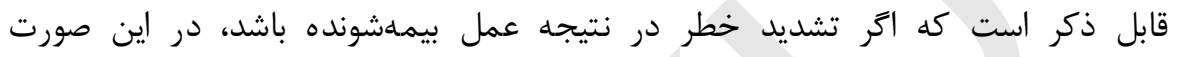

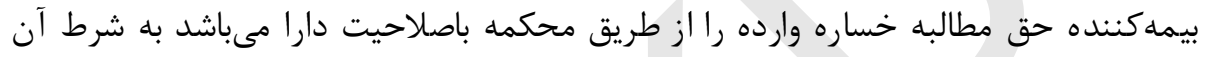

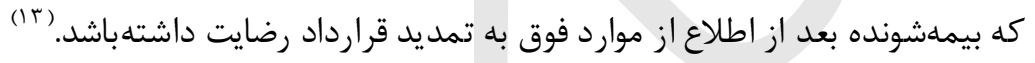

\section{r - حقوق و تعهدات بيمه كننده}

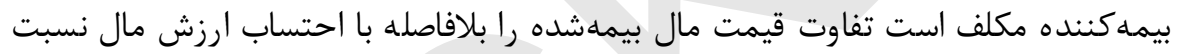

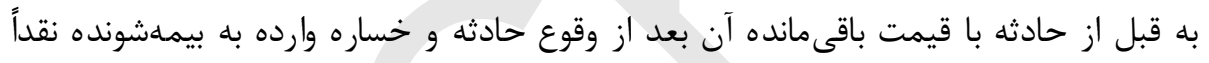

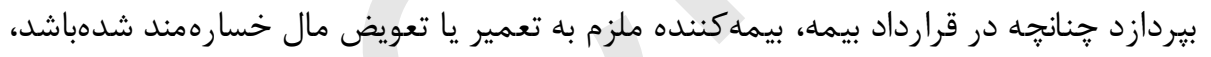

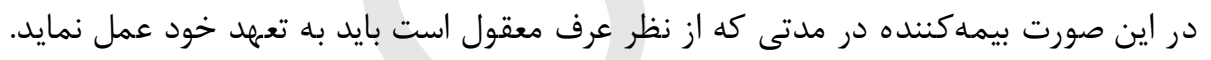

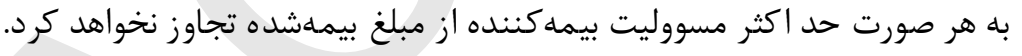

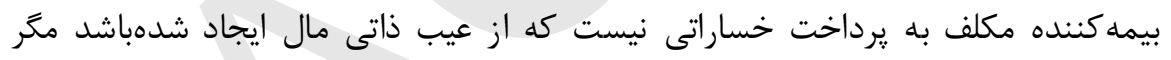

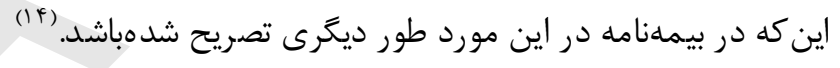

\section{بيمهنامه}

عقد بيمه و شرايط آن در سند كتبى تحرير مى مَردد كه سند مذكور به نام بيمهنامه ياد

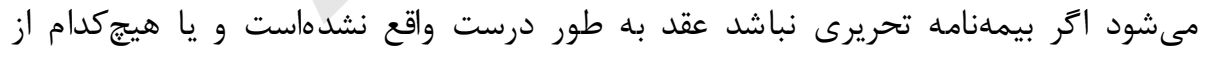

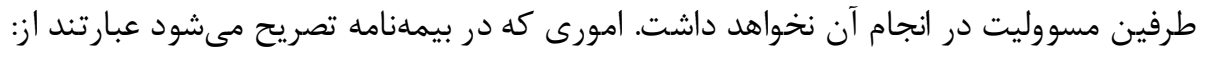

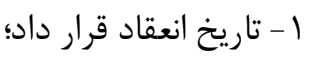

$$
\begin{aligned}
& \text { r- اسم بيمهشونده و بيمه كنتنده } \\
& \text { r- r - موضوع بيمه؛ }
\end{aligned}
$$

ץ أ- حادثه يا خطرى كه عقد بيمه به منه مناسبت آن به عمل آمدهاست؛

$$
\begin{aligned}
& \text { ه- ابتدا و انتهاى بيمه؛ }
\end{aligned}
$$

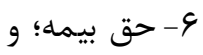




$$
\begin{aligned}
& \text { V - ميزان تعهد بيمه كننده در صورت وقوع حادثه. (1ه) } \\
& \text { رايج ترين انواع بيمهنامه عبارتاند ازئ تعنده دين صورت }
\end{aligned}
$$

\section{ا - بيمهنامه حاوى ارزش موضوع بيمه يا فاقد ارزش موضوع بيمه}

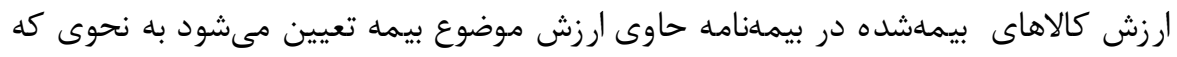

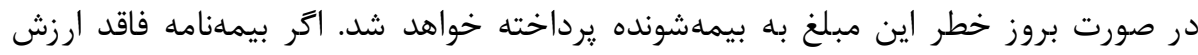

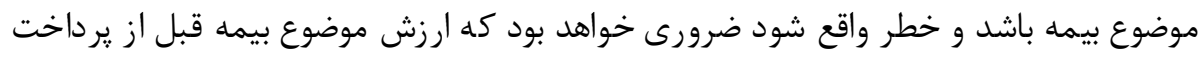

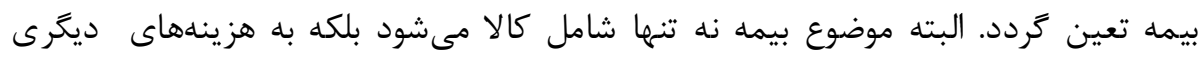

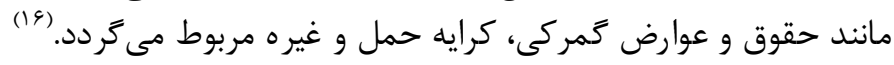

\section{Pاد - بيمهنامه شناور يا با بوشش باز}

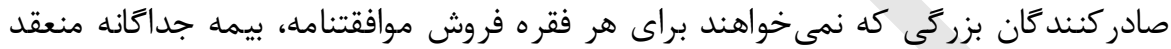

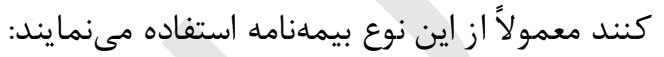

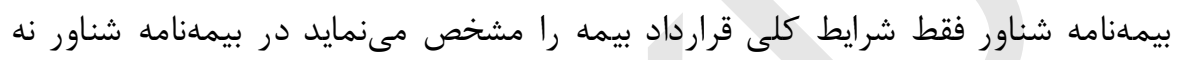

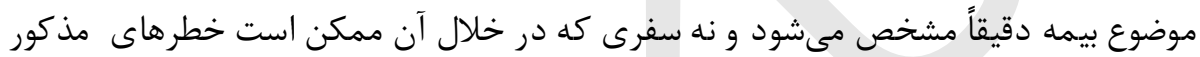

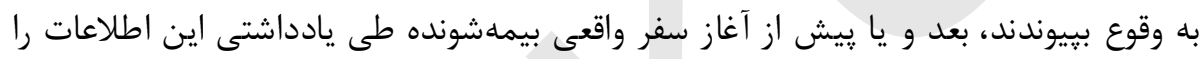
براى بيمه كننده ارسال مى دارد. بيمهنامه با يوشش باز از اين جهت با بيمهنامه شناور شباهت دارد كه تنها حاوى عبارات آدات و

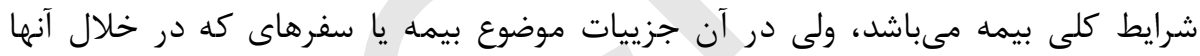

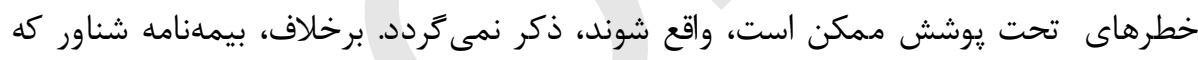

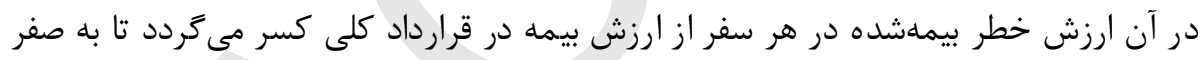

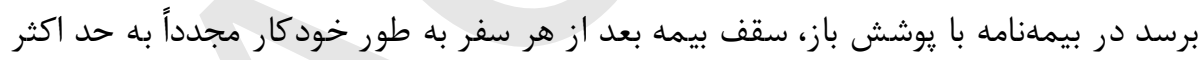

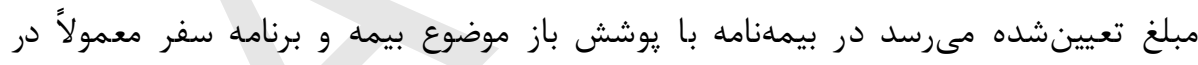

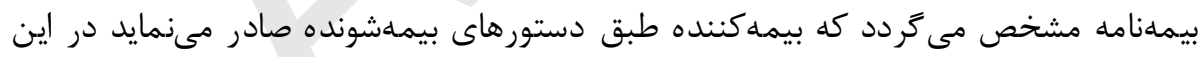

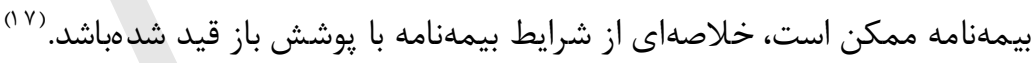

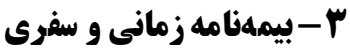

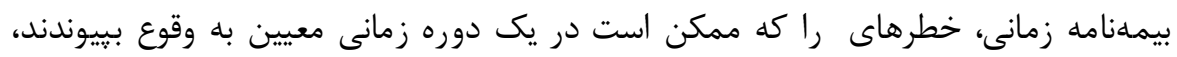

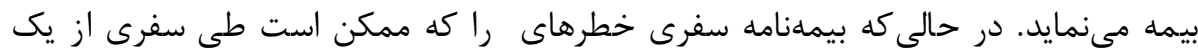

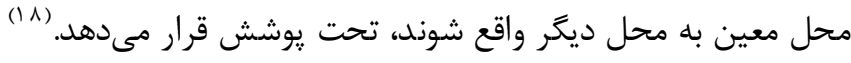
خاتمه قرارداد بيمه

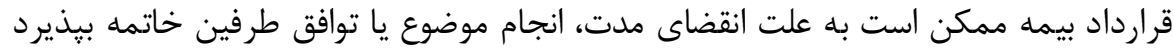

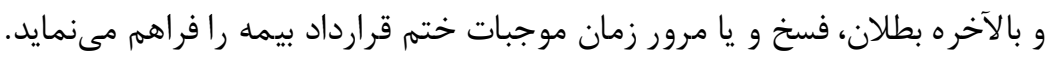


الف) انقضاى مدت انجام موضوع بيمه

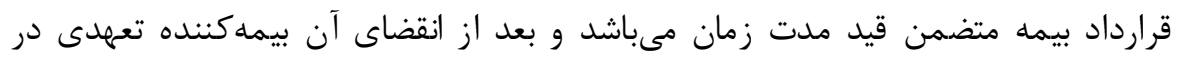

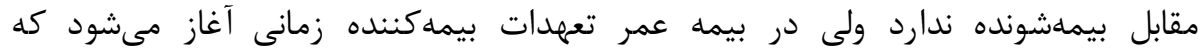

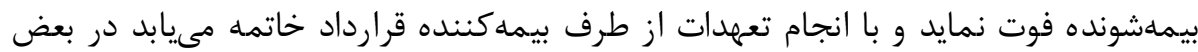

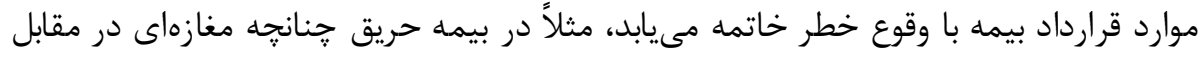

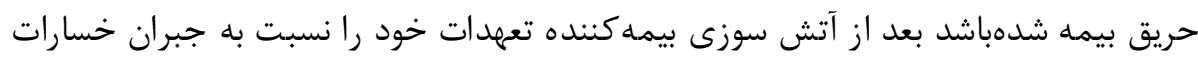

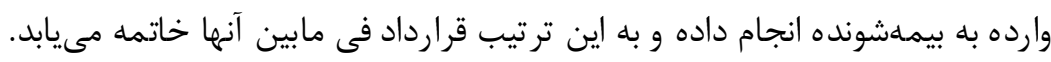

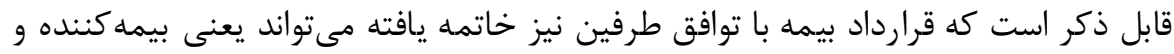

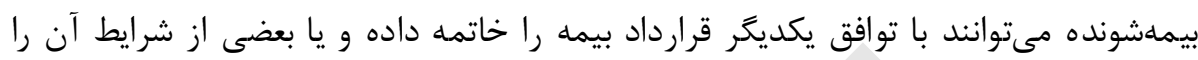
حذف نمايند. (19)

\section{ب) بطلان، فسخ و مرور زمان}

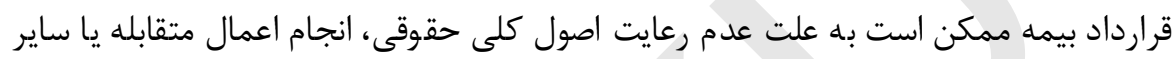

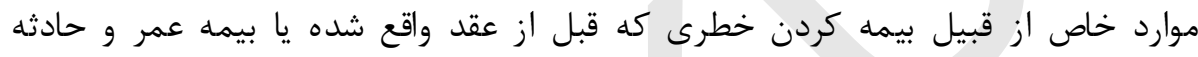

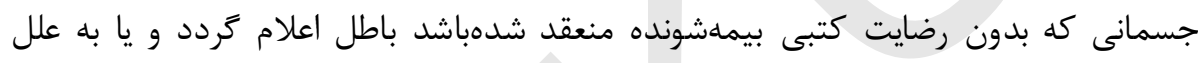

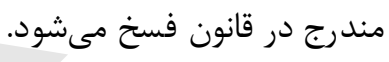

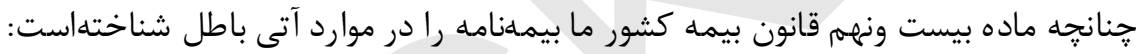

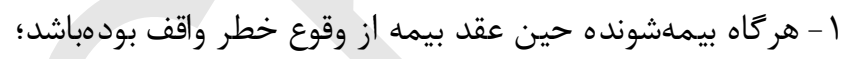

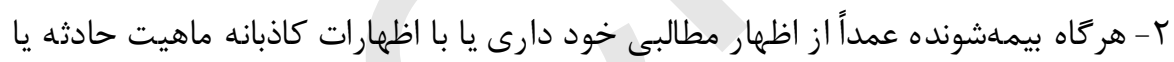

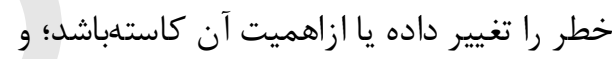

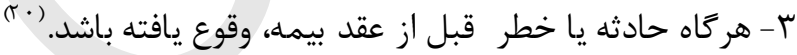

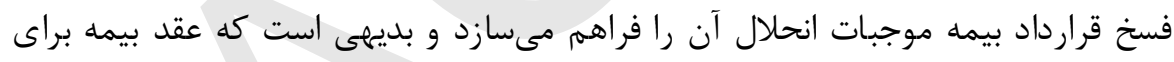

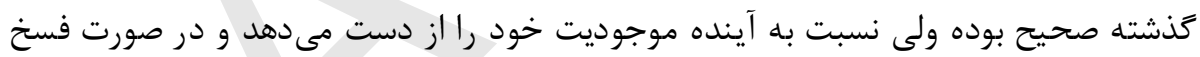

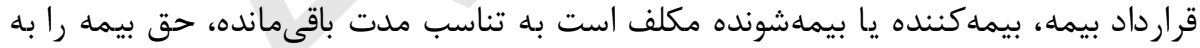

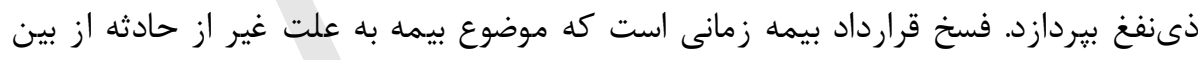

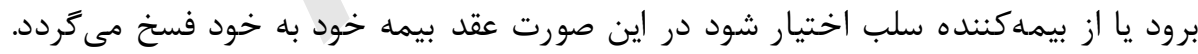

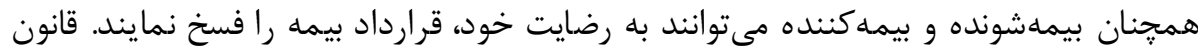

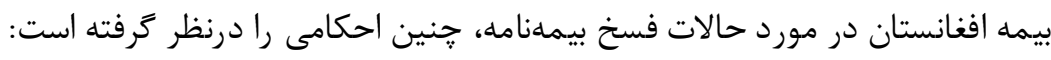
1 - درصورت افلاس يا انحلال بيمه كنينده؛

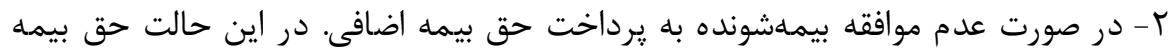

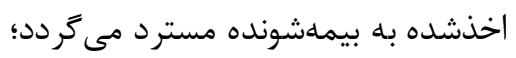

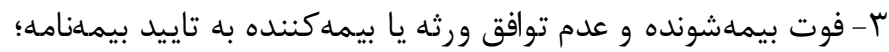

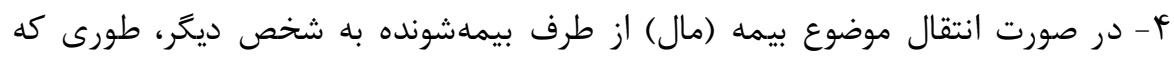
شخص مذكور حاضر به ادامه بيمهنامه نكردد؛ و و 
ه- درصورت تغيير در كيفيت، كميت و موقعيت موضوع بيمه (مال) يا خطوط مواصلاتى،

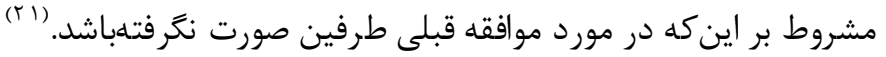

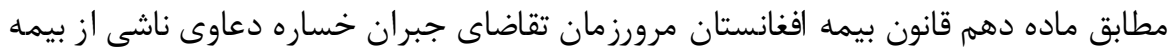

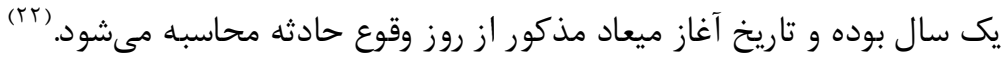

\section{منابع و ماخذ}

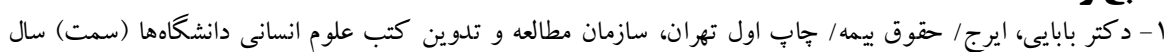

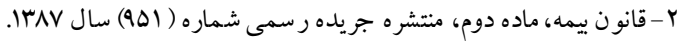

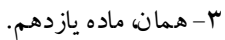

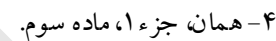

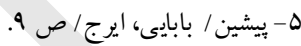

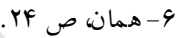

ro

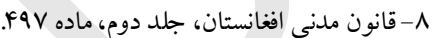

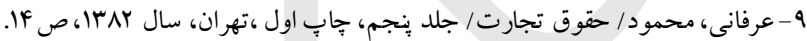

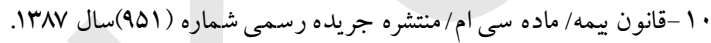

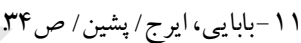

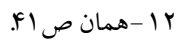

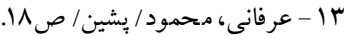

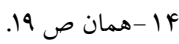

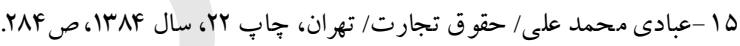

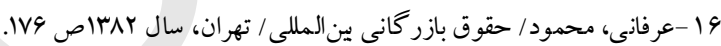

IVV IV - IV - IV - IV

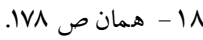

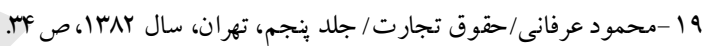

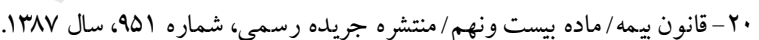

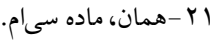

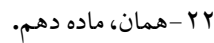




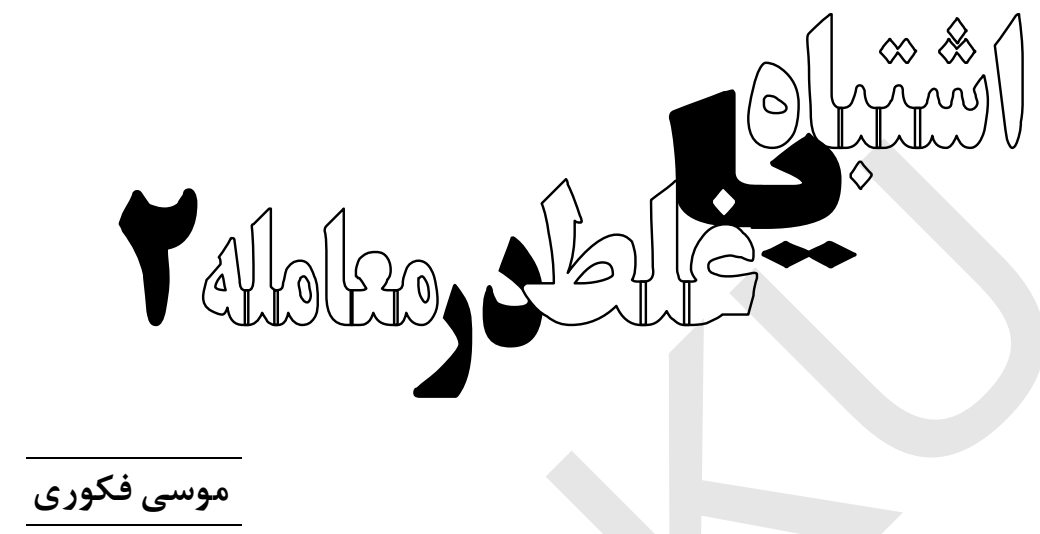

احكام اشتباه در موضوع عقد

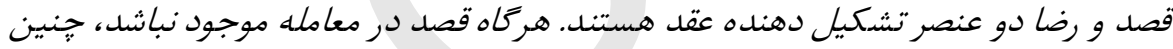

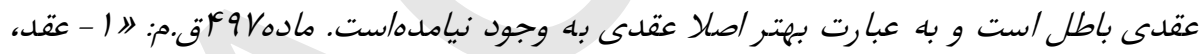

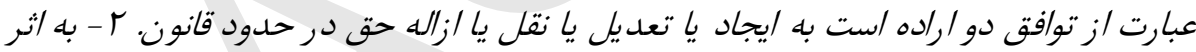

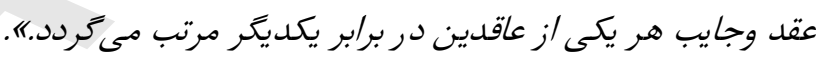

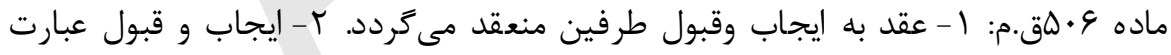

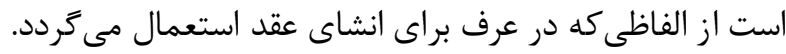

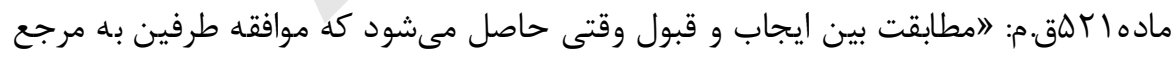

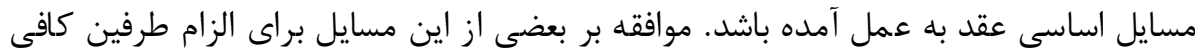
نمىباشد.《. 
د در متون فقهى دو راه حل براىاشتباه در موضوع عقد، بيش بينى شدهاست:

بطلان: بطلان در لغت "خلاف حق " است و در مقابل صحت قرار دارد و اصولا عملى حقوقى

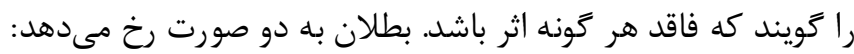

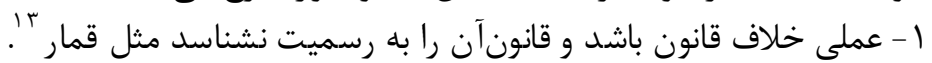

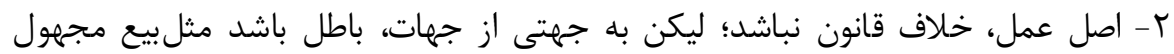
الثمن

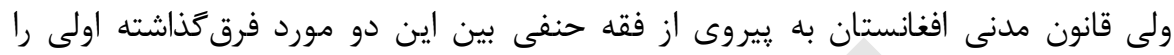

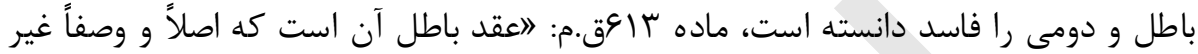

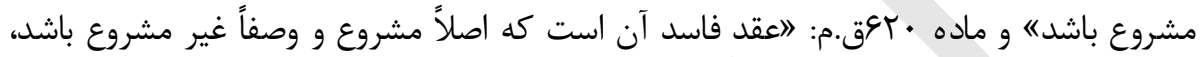

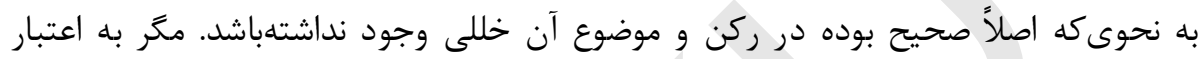

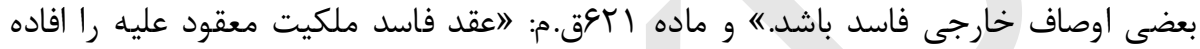

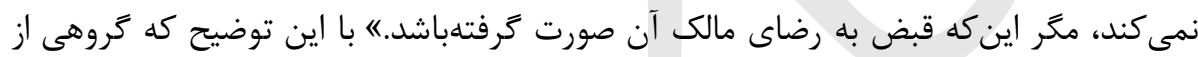

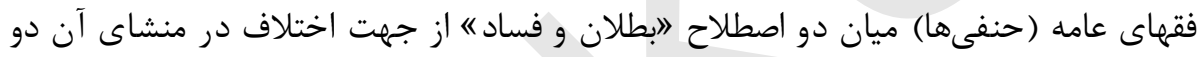

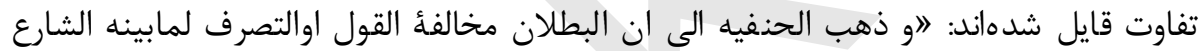

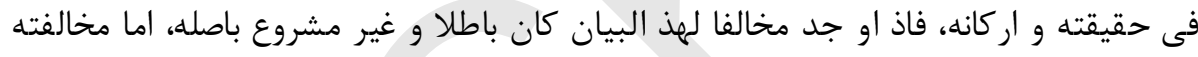

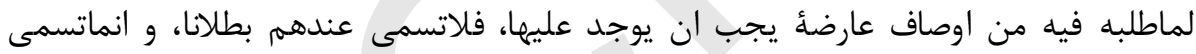

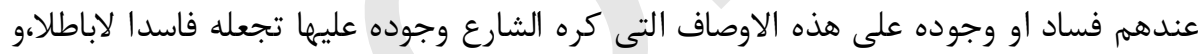

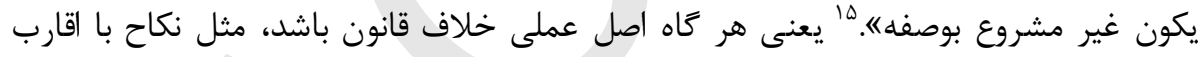

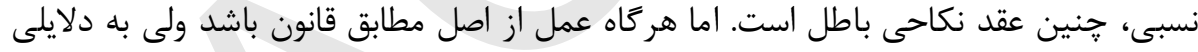

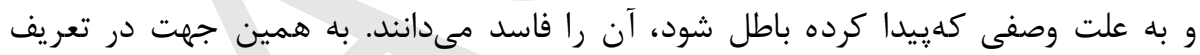

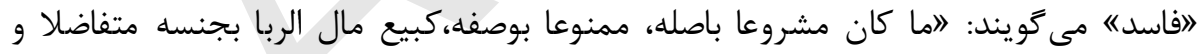

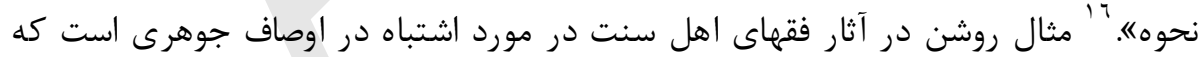

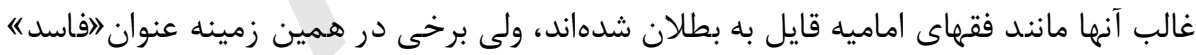

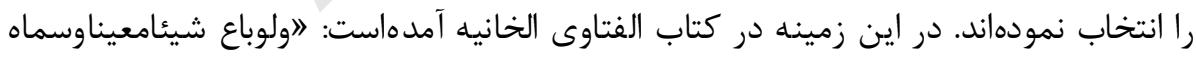

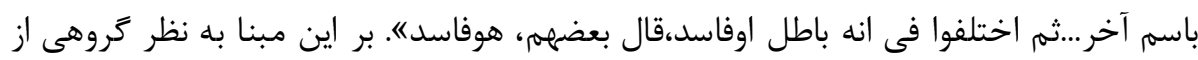

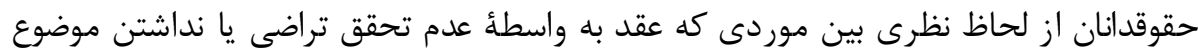

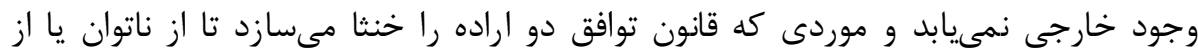

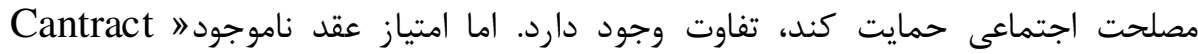
《inexistant

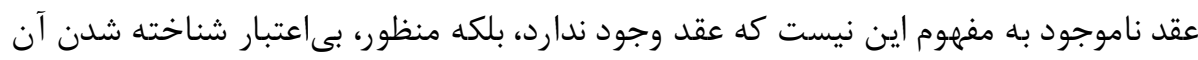

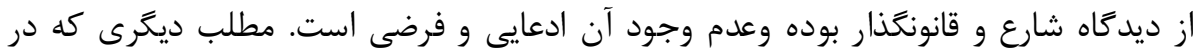


تمايز ميان بطلان و فساد به نظر مىرسد و مويد آن است، اين است كه تقابل ميان صحت و

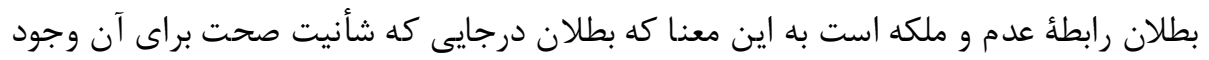

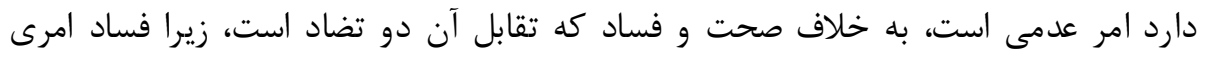
وجودى است مانند ميوه فاسدكه سوال مى شود كجاى آن آن فاسد است؟؟ا.

\section{موارد بطلان معامله در اثر اشتباه}

اشتباه در موضوع عقد در موارد زير موجب بطلان معامله مى معردد:

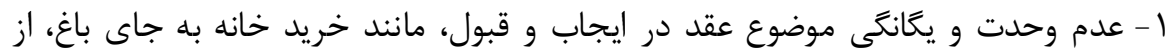

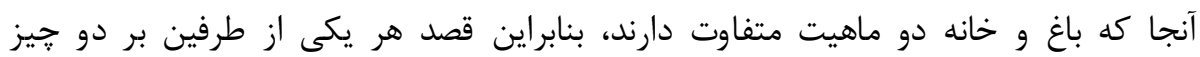

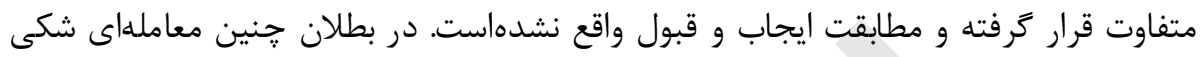

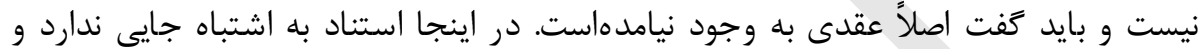

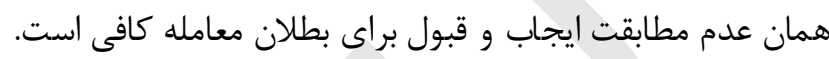

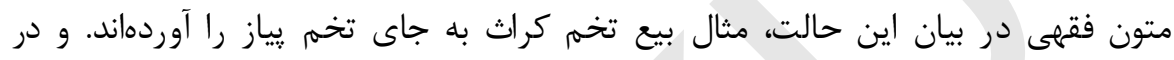

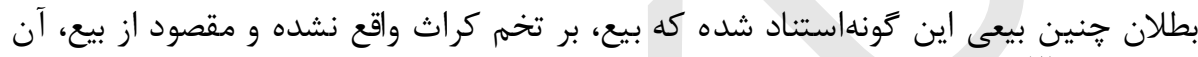
نبودهاست. نبلان جنين اشتباه طرفين عقد در جنس موضوع عقد؛ يكى ديكر از مواردى كه اشتباه در آن سبب

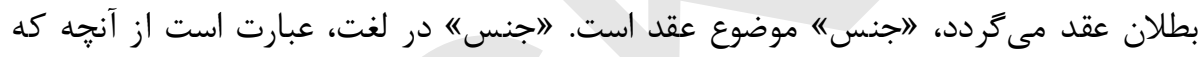

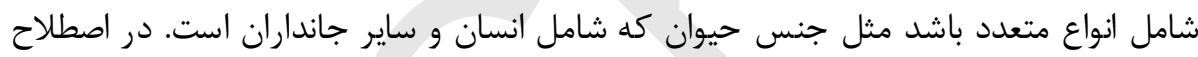

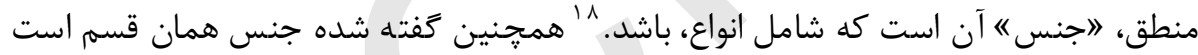

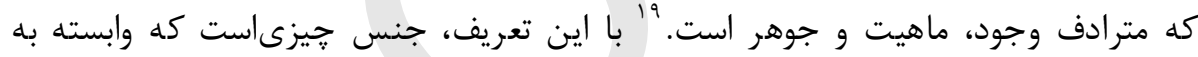

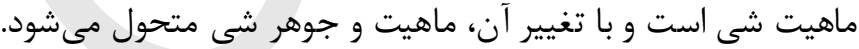

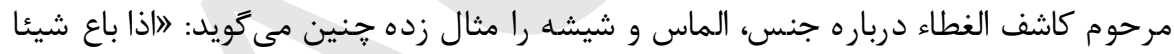

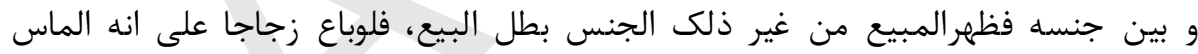

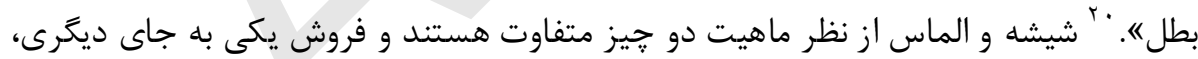

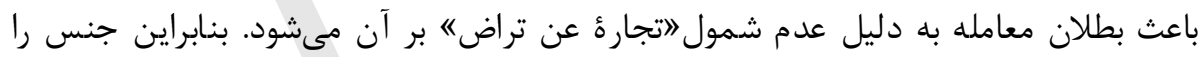

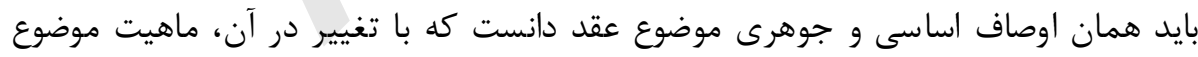
عقد دخر كون مىشود.

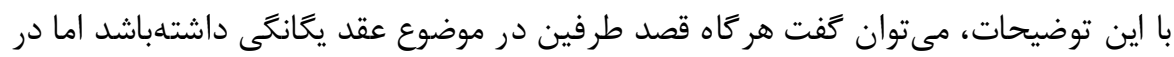
اوصاف وخصوصيتهاى مورد معامله اشتباه صورت

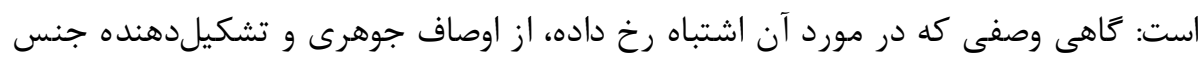

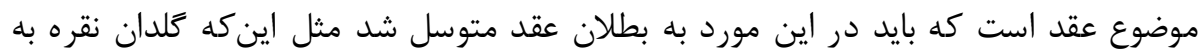

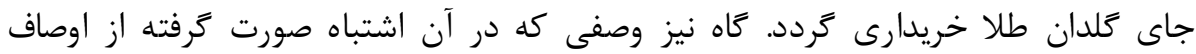

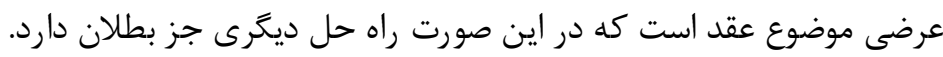
خيار: خيار در لغت، اسم مصدر از اختيار بوده داراى دو معنا است: 


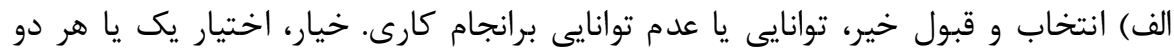

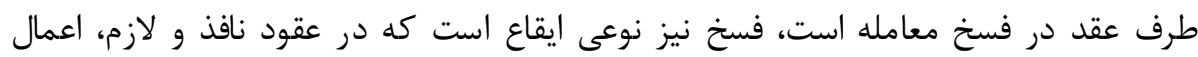

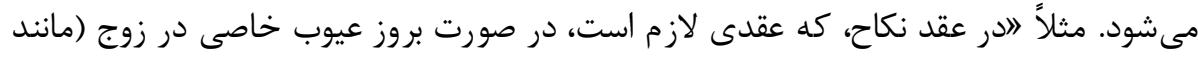

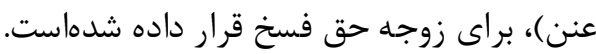

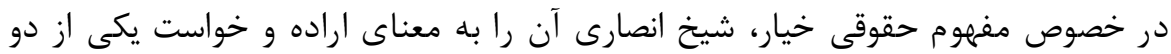

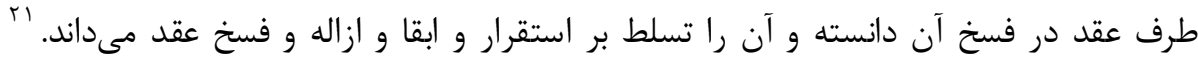

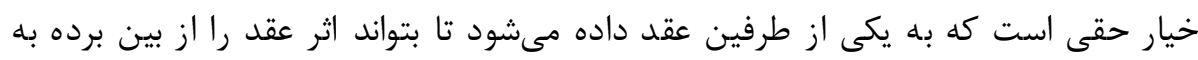
حالت اول بركرداند.

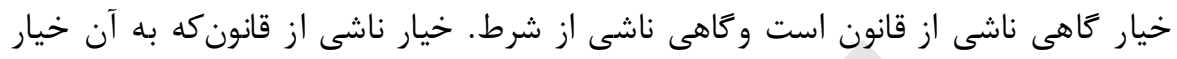

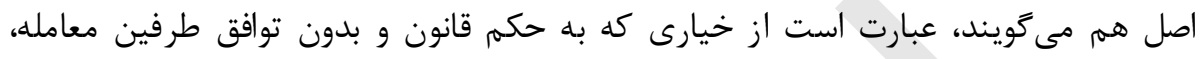

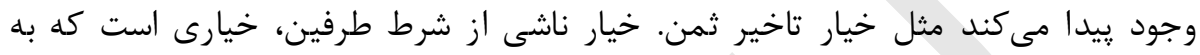

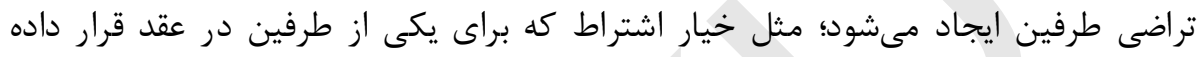

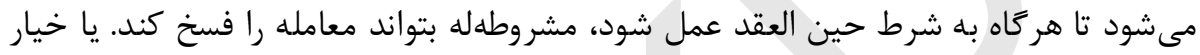

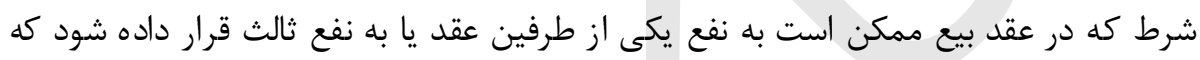

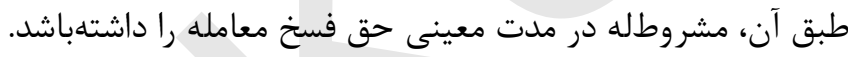

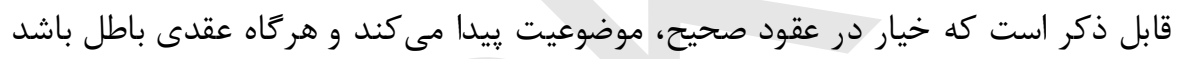

$$
\text { در نظر كرفتن خيار براىطرفين، كارى بيهوده است است. }
$$

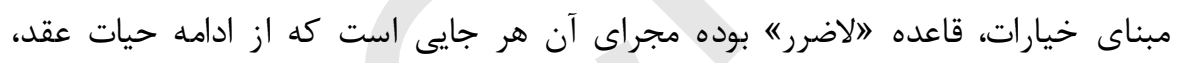

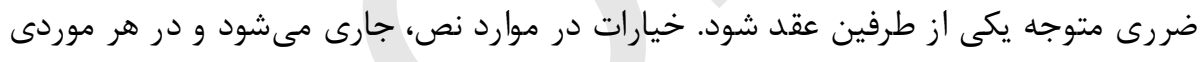

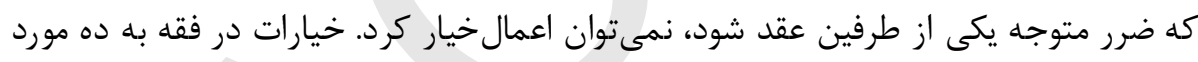

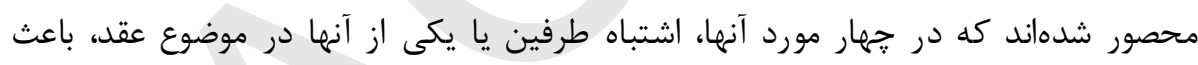

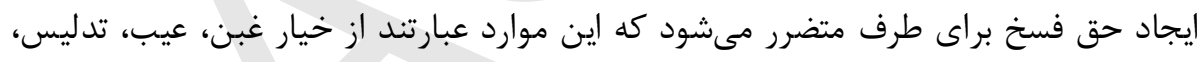

$$
\text { رويت و تخلف وصف. }
$$

\section{تفاوت بطلان و خيار}

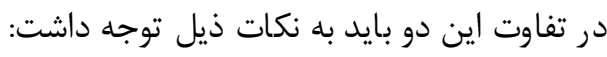

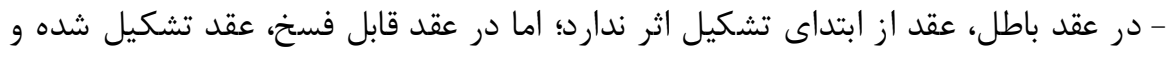

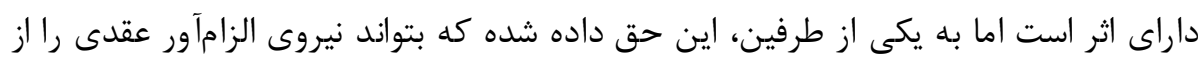

$$
\text { بين ببرد. }
$$

- بطلان عقد در مورد عقود جايز و لازم، قابل تصور است مثل عقد وكالت كه از عقود جايز

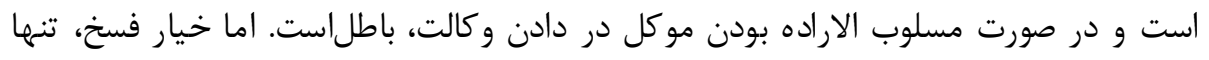

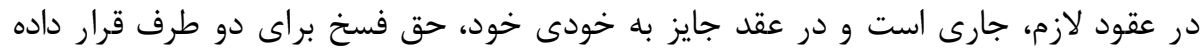

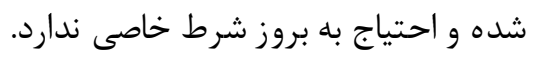

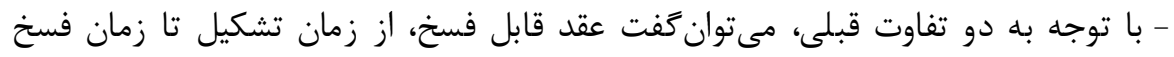




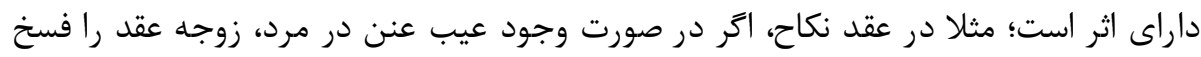

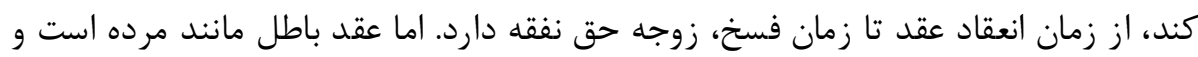

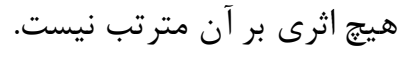

\section{قانون موضوعه}

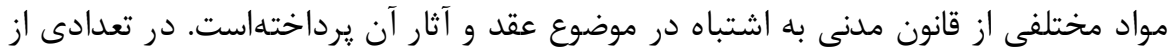

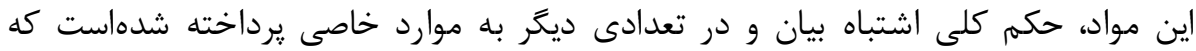

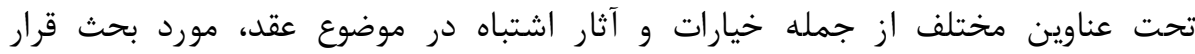
كرفتهاست.

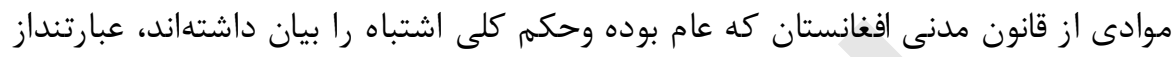

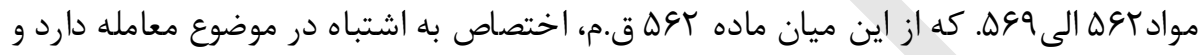

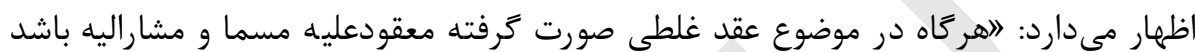

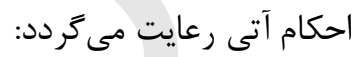

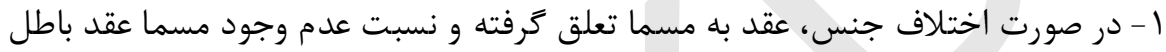
شناخته مىشود. ץ- در صورت اتحاد جنس و اختلاف وصف، عقد به مشاراليه تعلق كرفته و نسبت موجود

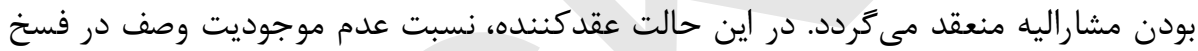

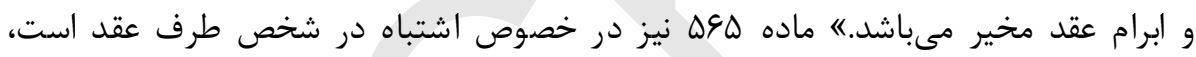

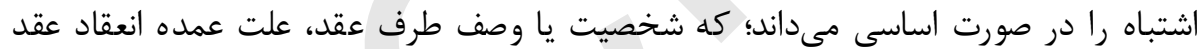

با توجه به اين مواد، مشخص مى كردد راه حلى كه قانون مدنى افغانستان به طور كلى درد در

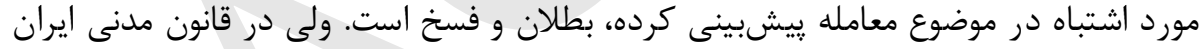

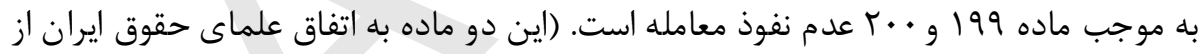

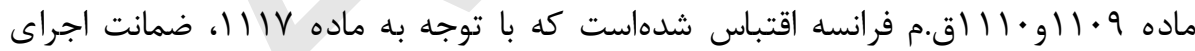

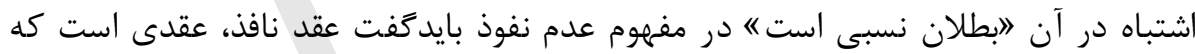

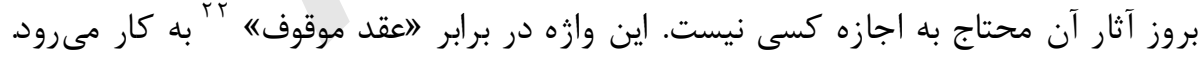

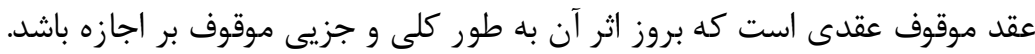

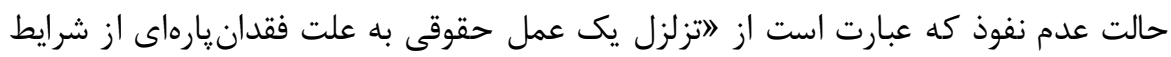

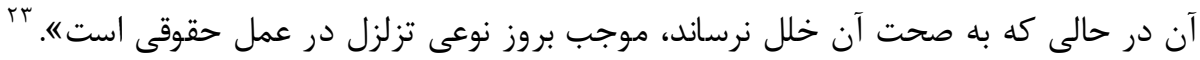

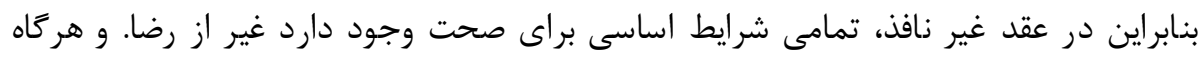

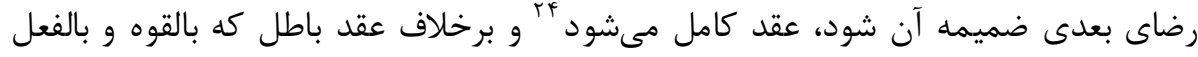

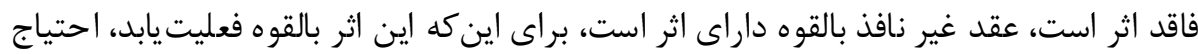
به اجازه است. در تفاوت عدم نفوذ و خيار فسخ بايدَّفت: تفاوت اصلى عقد غير نافذ و خيارى، در تاثير 


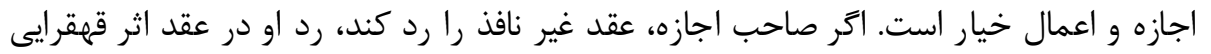

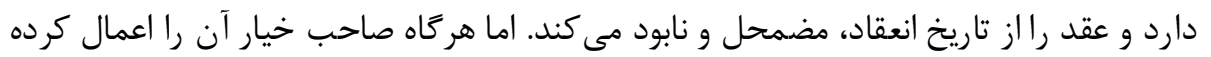

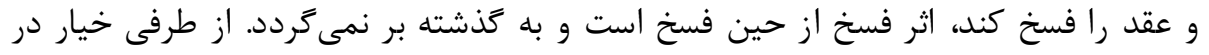

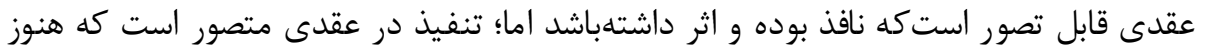

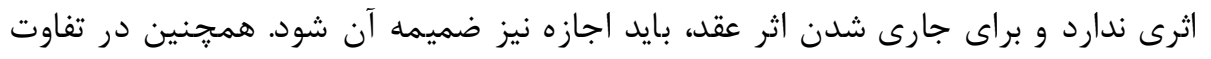

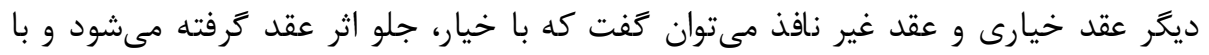

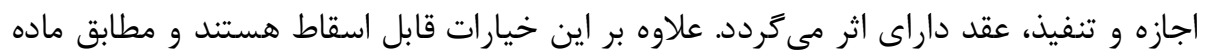

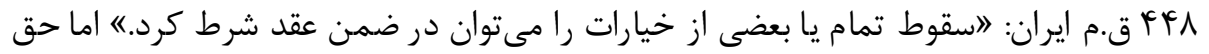

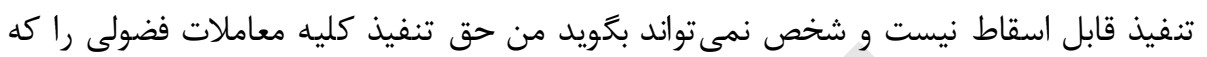

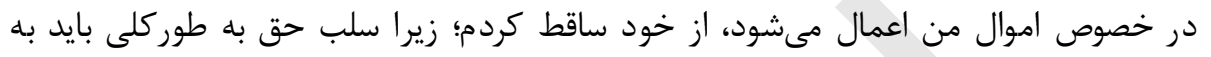

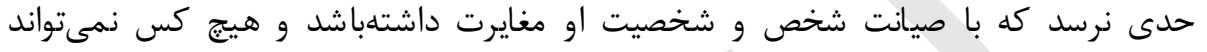

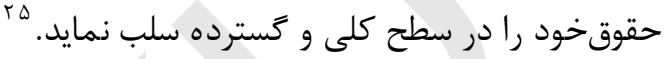

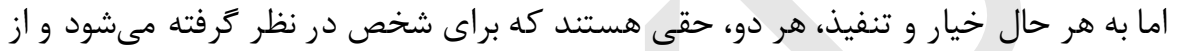

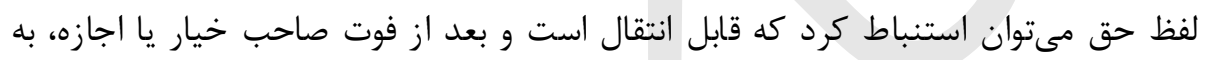

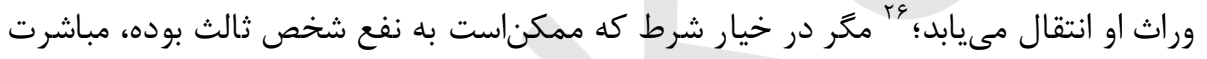

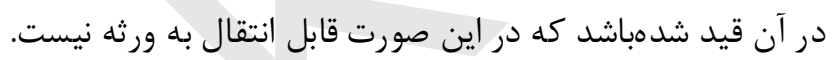

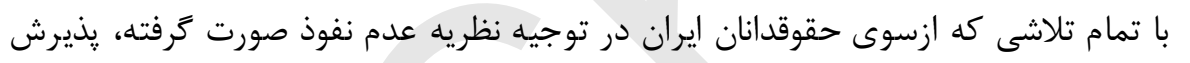

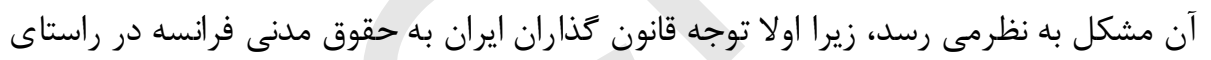

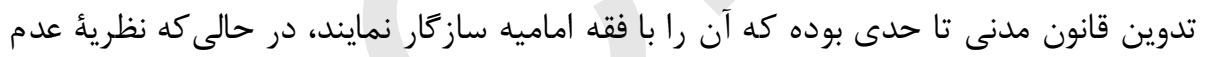

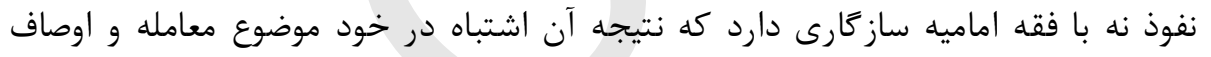

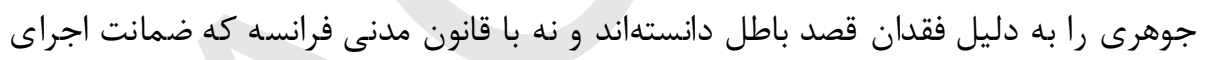

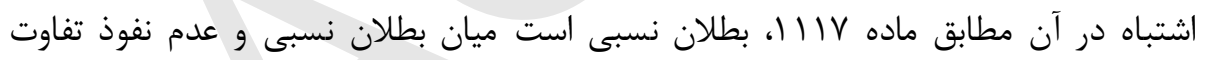

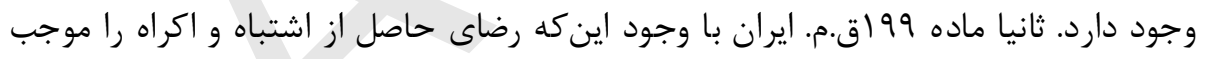

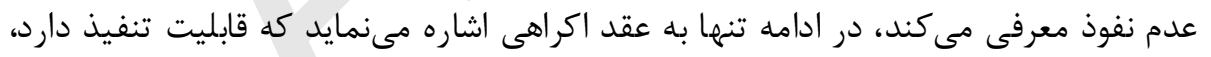

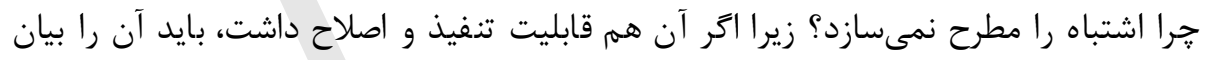

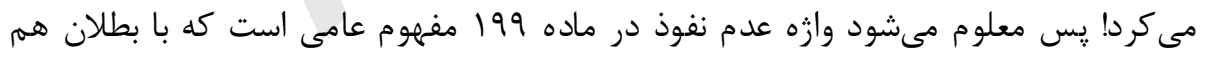
ساز كار است.

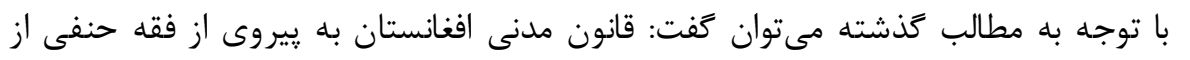

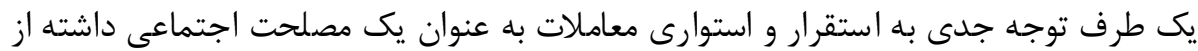

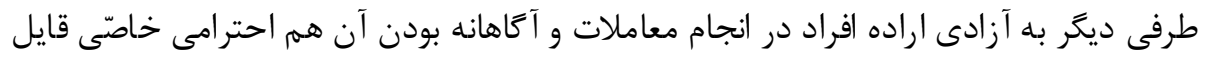

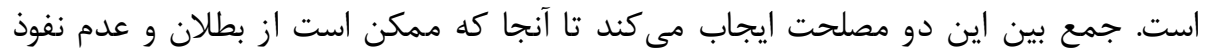

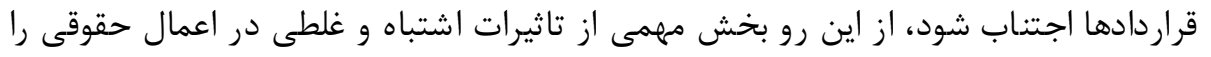

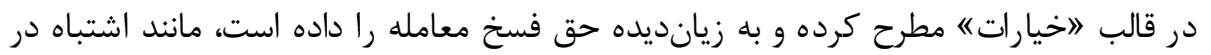

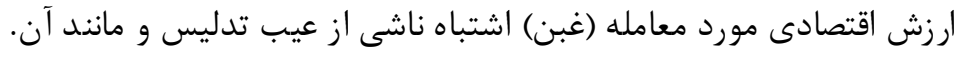


ديدكاه قوانين مدنى و حقوقى برخى از كشور هاى عربى

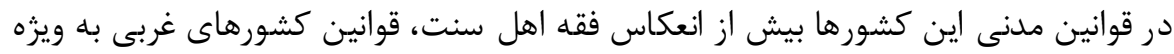

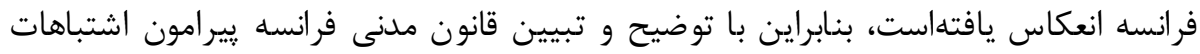

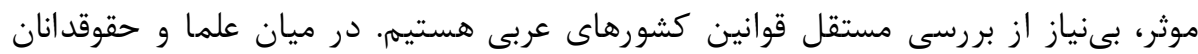

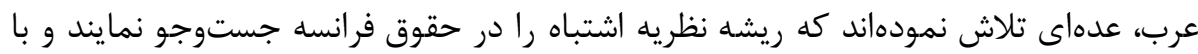

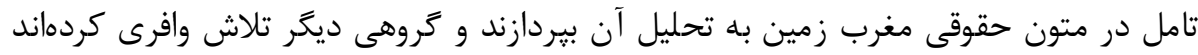

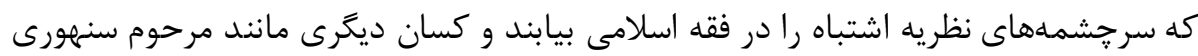

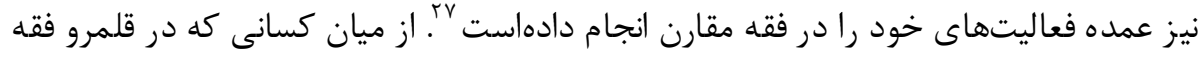

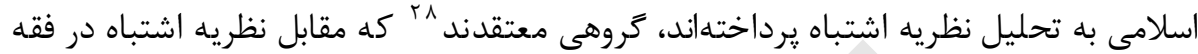

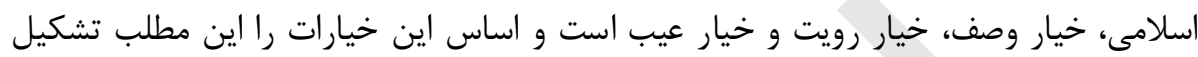

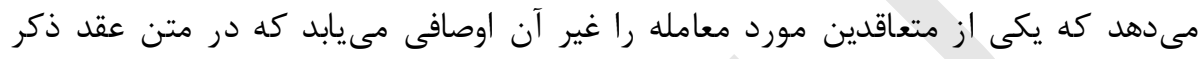

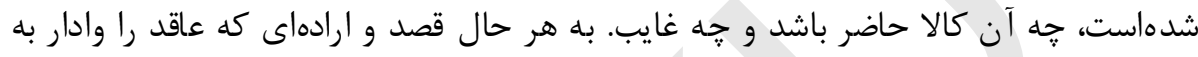

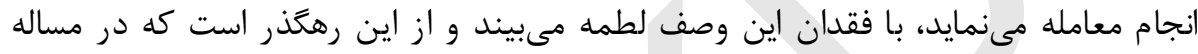

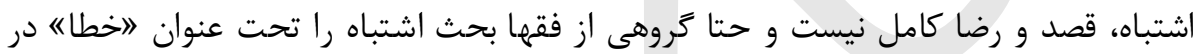

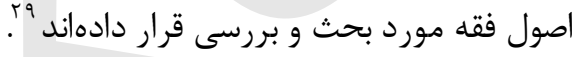

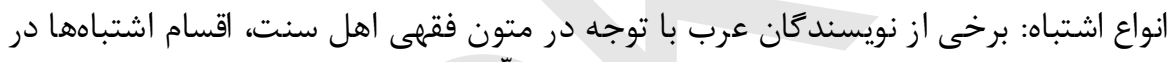

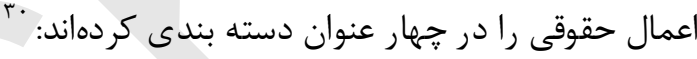

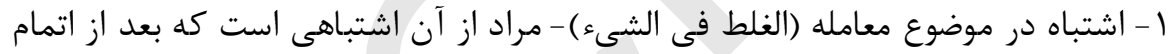

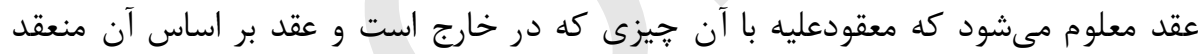

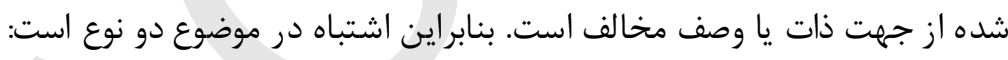

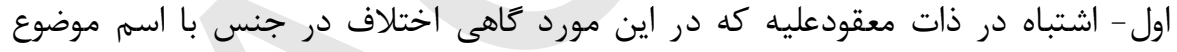

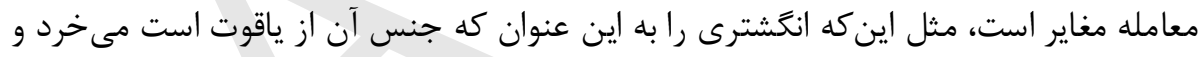

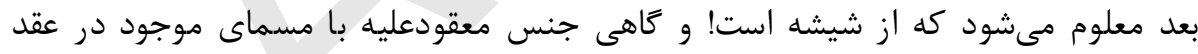

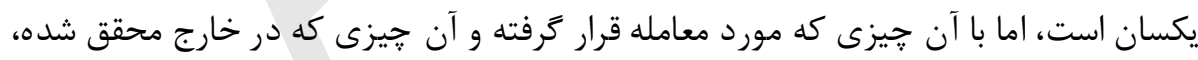

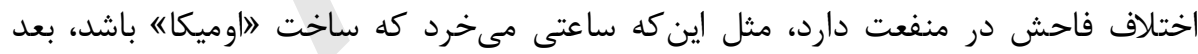

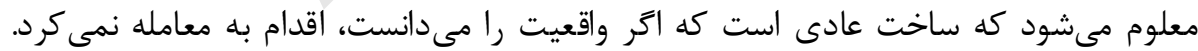

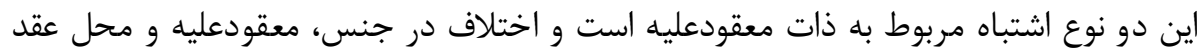

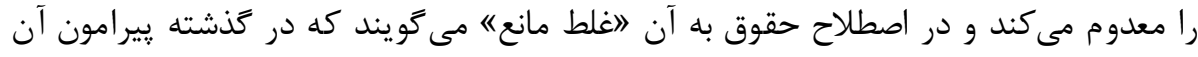

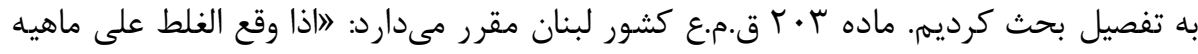

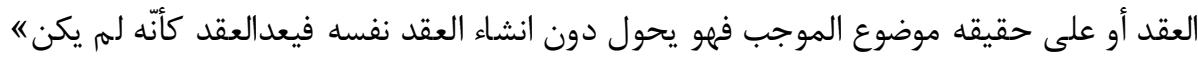

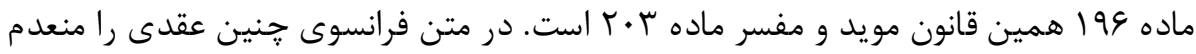

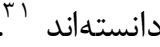
در ماده لا | اق.م عراق نيز آمدهاست \| - اذا وقع غلط فى محل العقد و كان مسمى و مشاراً 


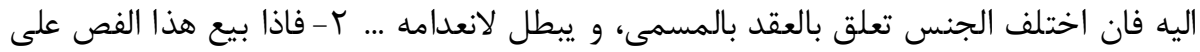

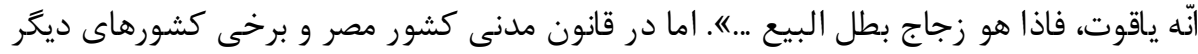
به اين نوع اشتباه اشارهاى نشدهاست.

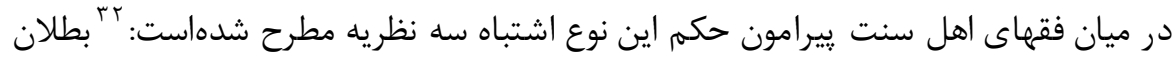

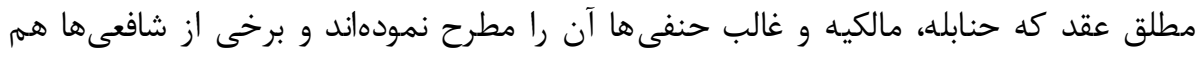

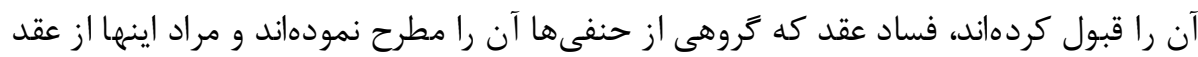

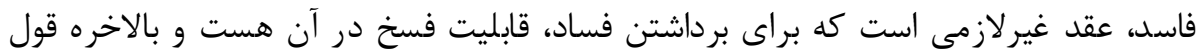

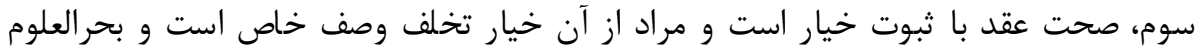

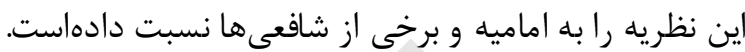

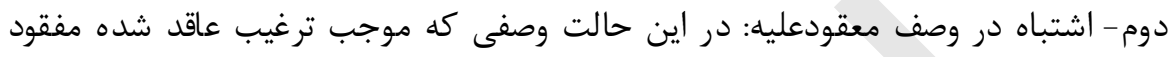

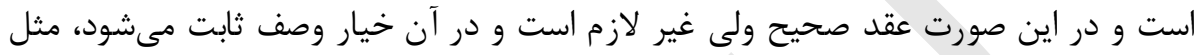

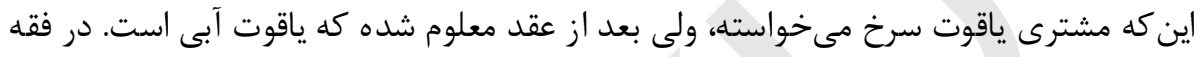

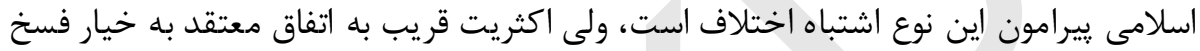

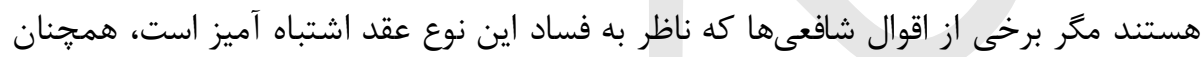

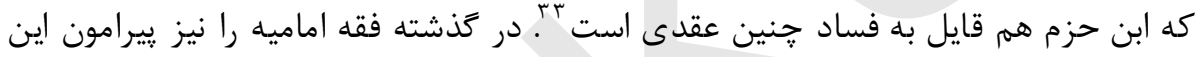

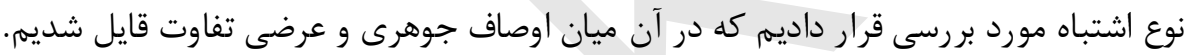

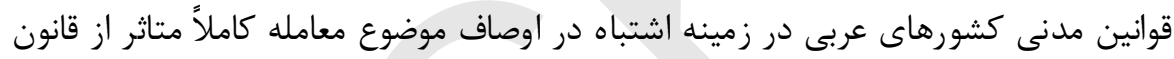

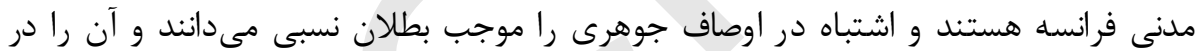

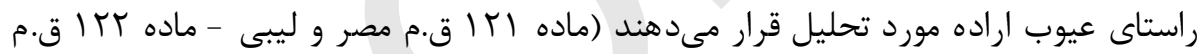

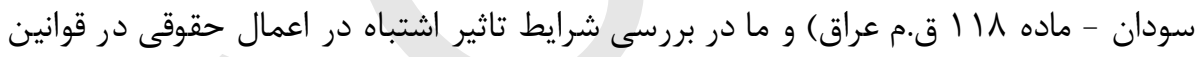

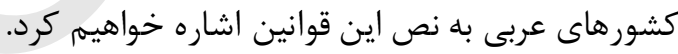

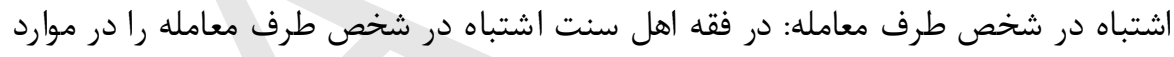

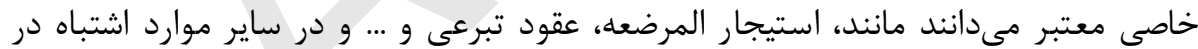

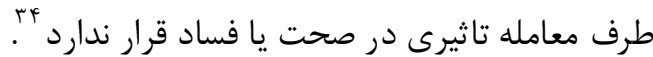

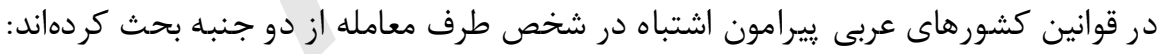

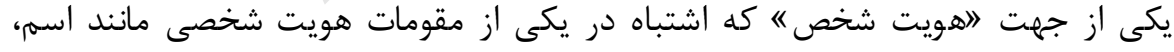

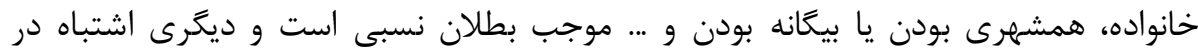

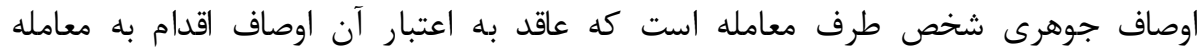

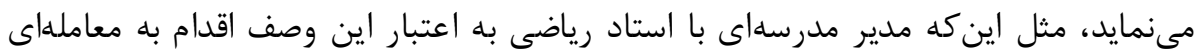

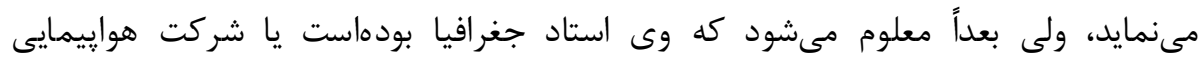

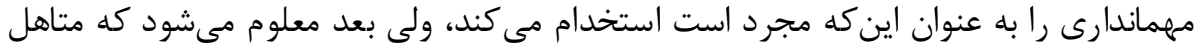

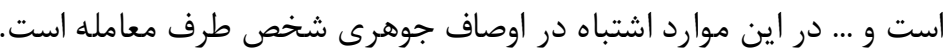

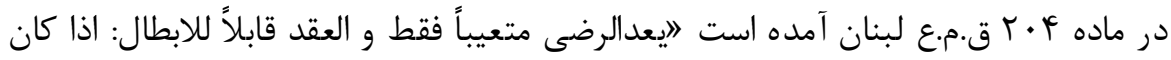


الغلط يتناول هويه الشخص او صفاته الجوهريه فى العقود المنظور فى أنشائها الى شخص العاقد...《.

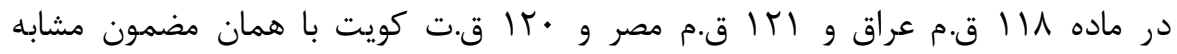

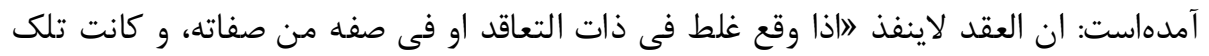

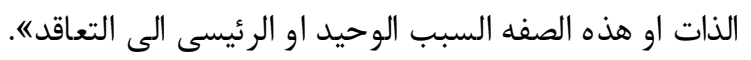

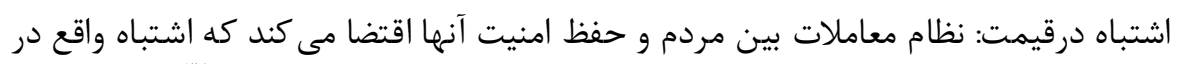

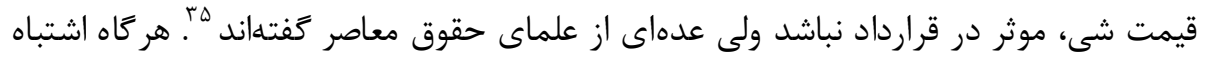

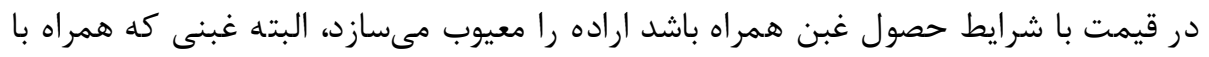

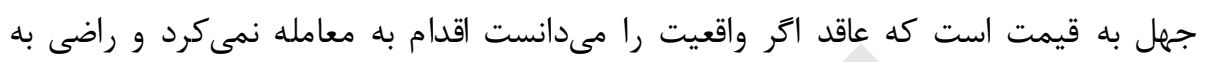
جنين غبنى نمى توند. در برخى از متون حقوقى ميان دو نوع غبن تفاوت قايل شدهاند: بَّ غبن شخصى كه مربوط

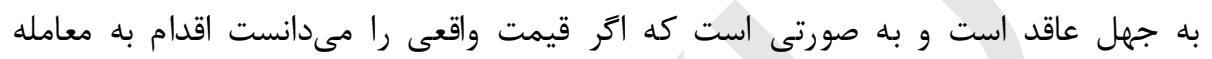

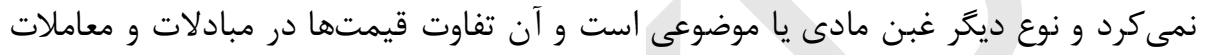

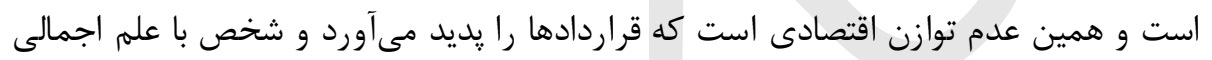

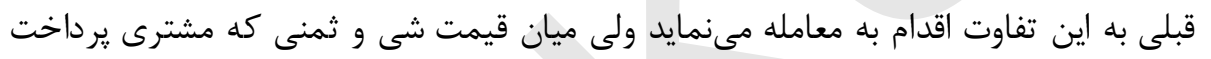

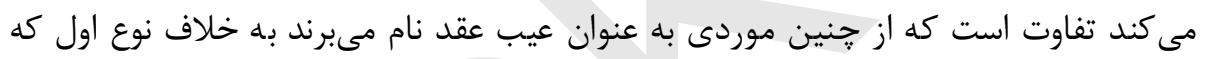

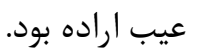

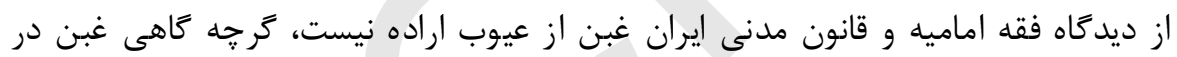

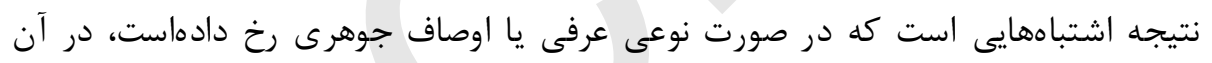

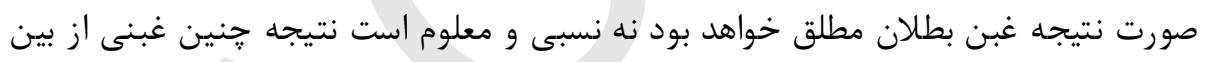
رفتن توافق دو اراده است.

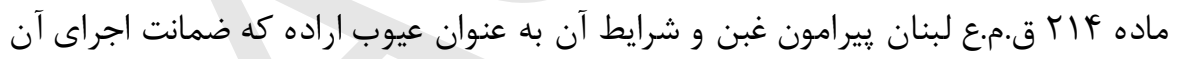

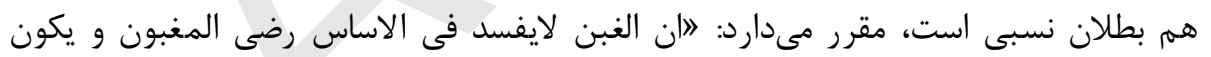

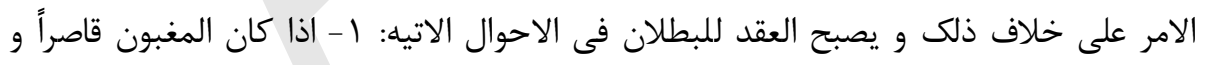

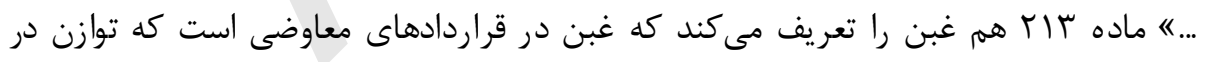

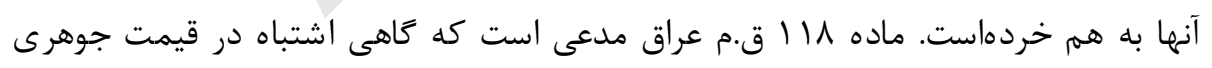

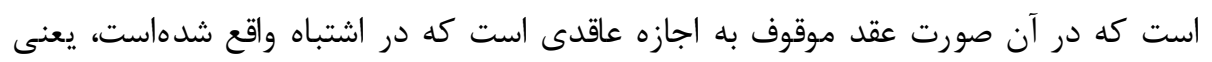

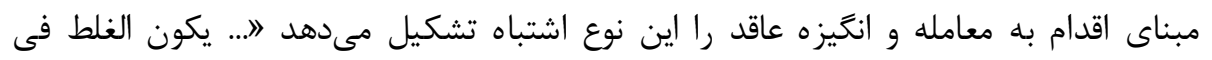

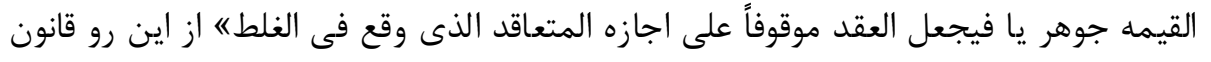

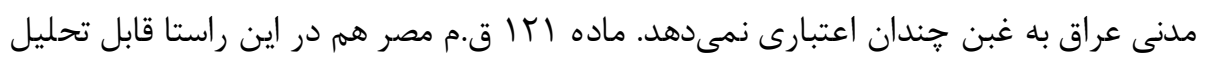

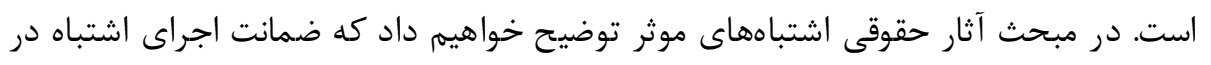

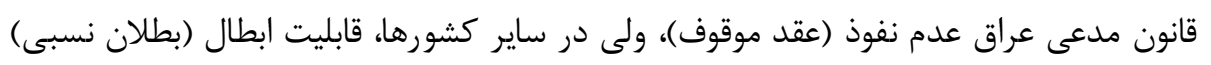


اشتباه در قانون: عنوان اشتباه در قانون در كلمات علماى حقوق به كار رفتهاست و در بيان

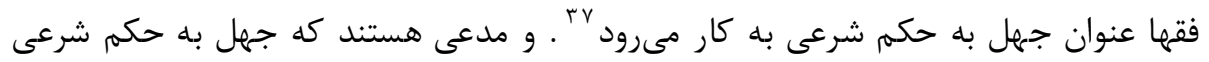

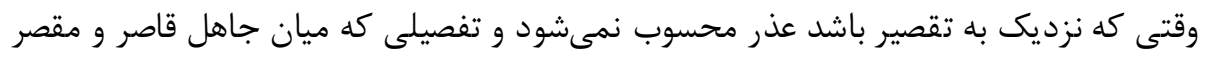

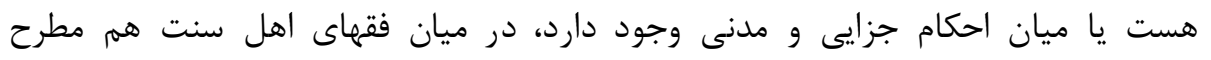

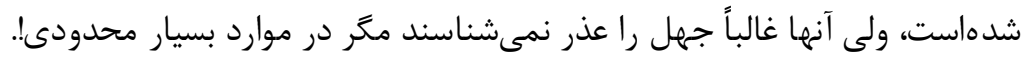

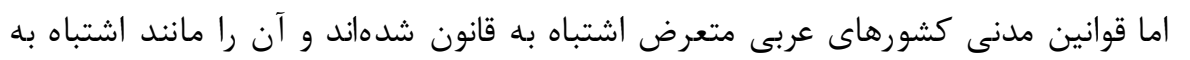

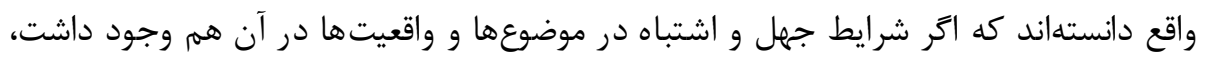

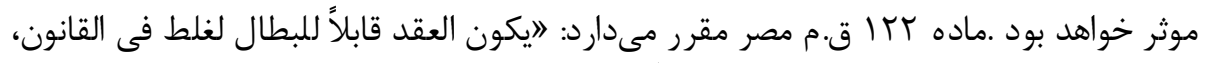

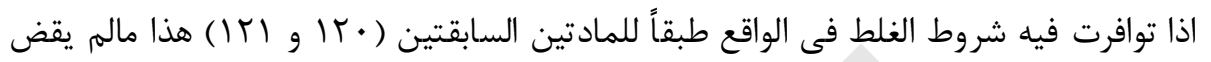
القانون بغيره

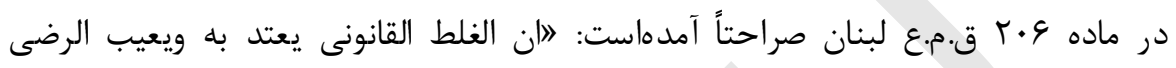

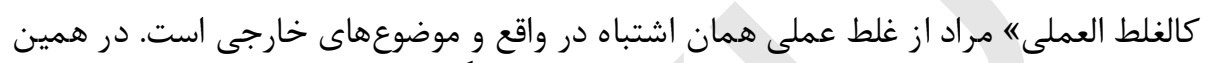

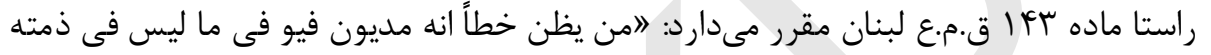

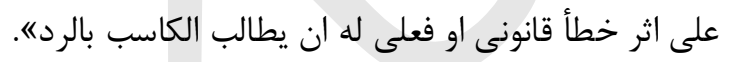

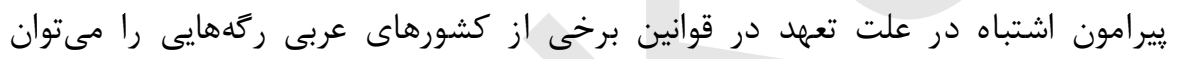

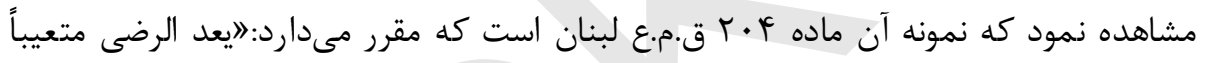

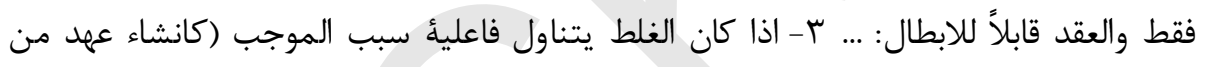

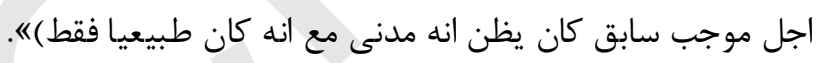

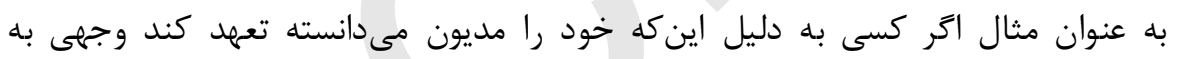

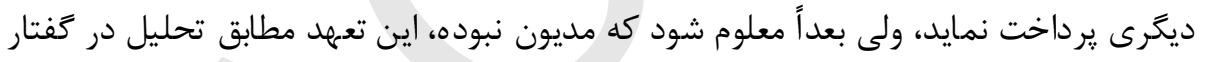

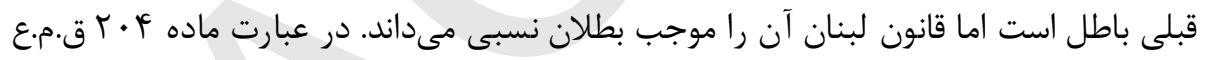

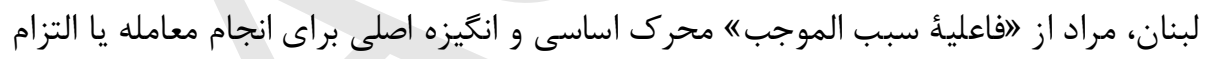

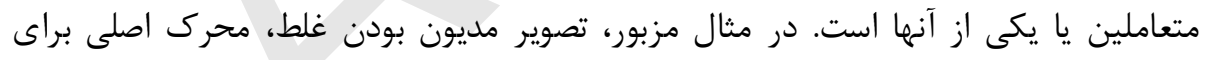

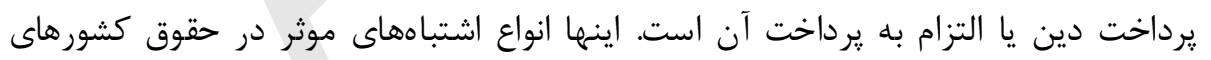
عربى بود . شرايط تاثير اشتباه: بعد از اين كه انواع اشتباههاى موثر در قوانين و متون حقوقى كشورهاى

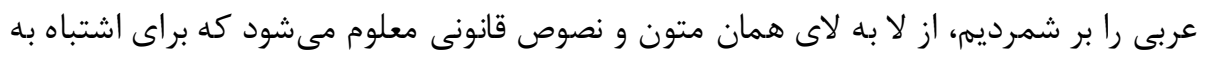

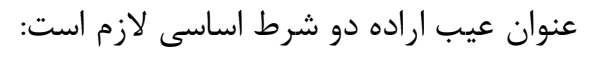
1 - اشتباه بايد جوهرى باشد.

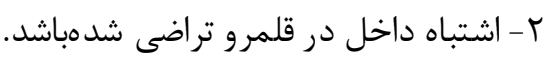

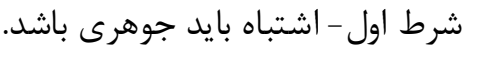

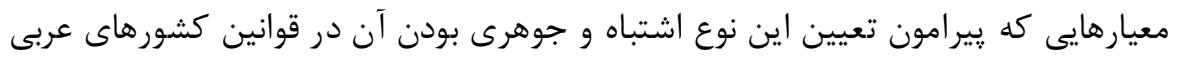

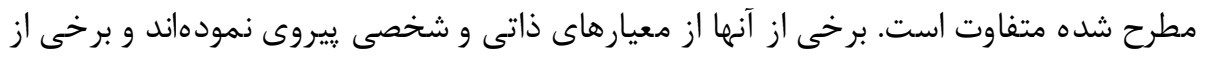


مكاتب مادى و موضوعى تعديلشده كه در حد ززارش مختصر به نصوص مواد قانونى در اين

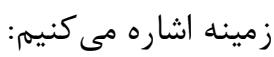

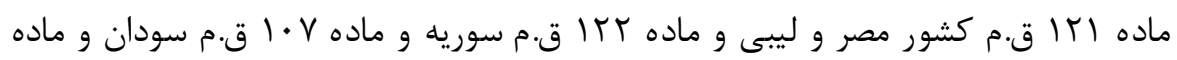

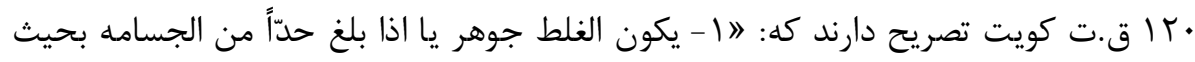

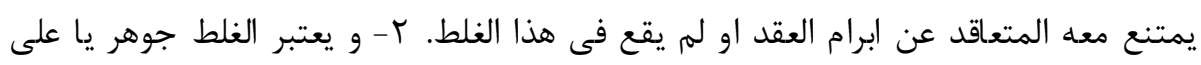

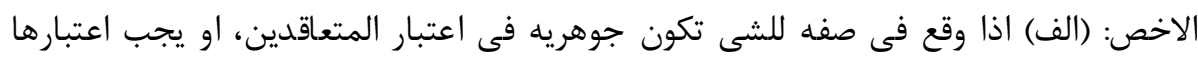

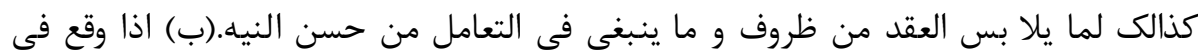

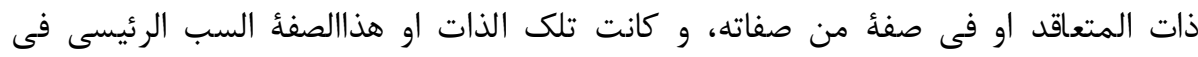

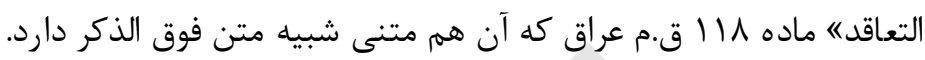

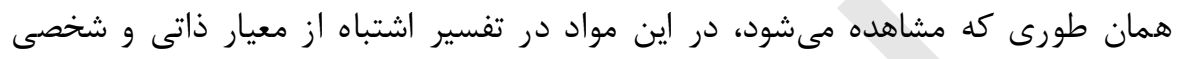

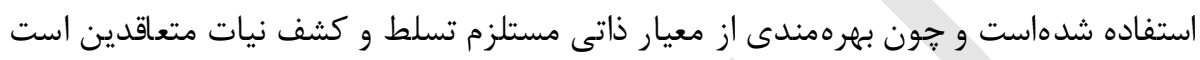

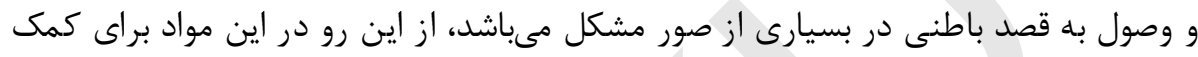

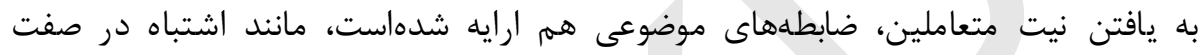

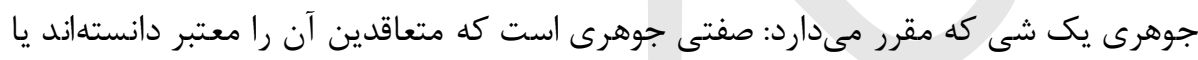

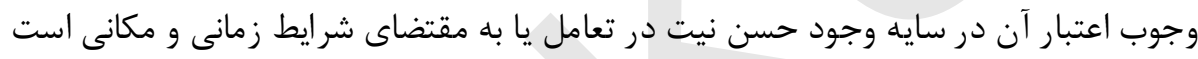

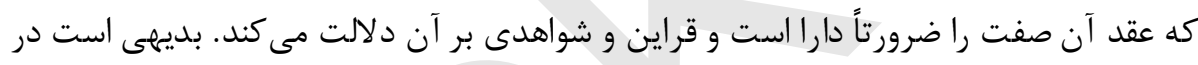

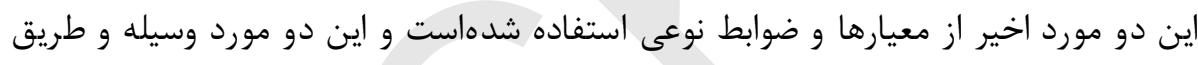

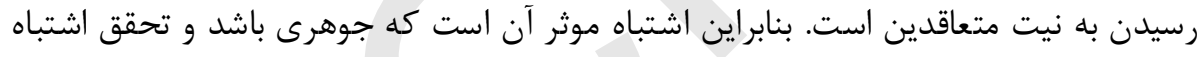

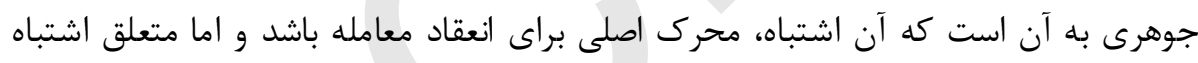

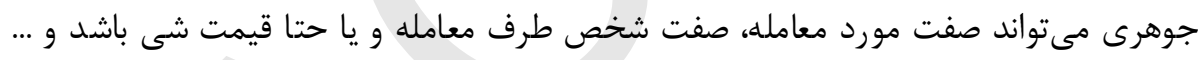

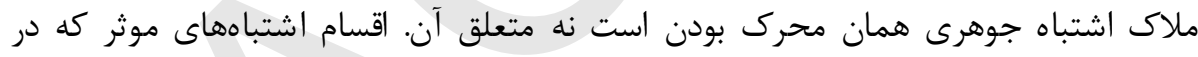

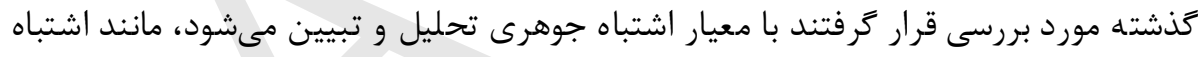

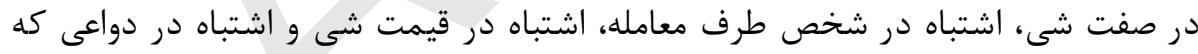

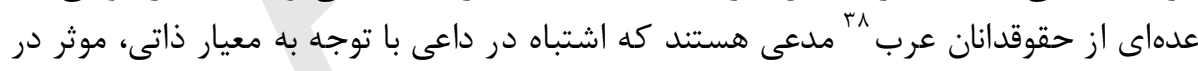

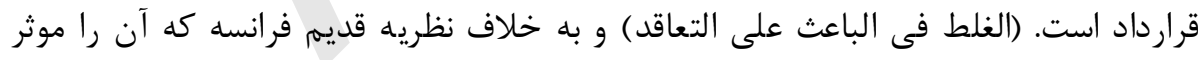

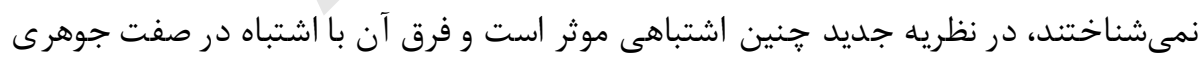

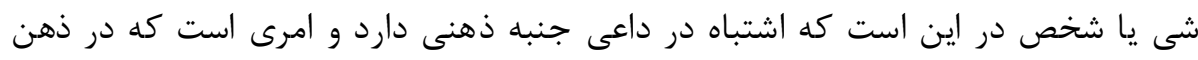

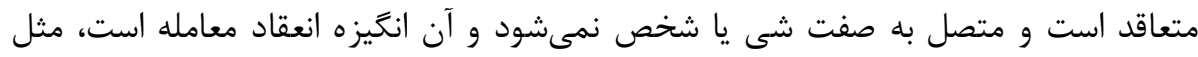

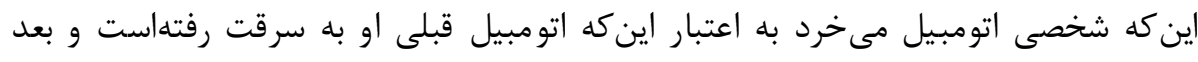

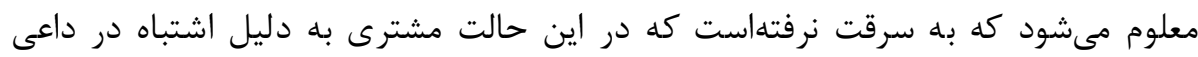

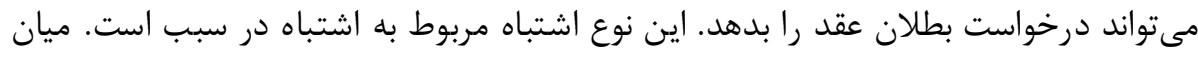

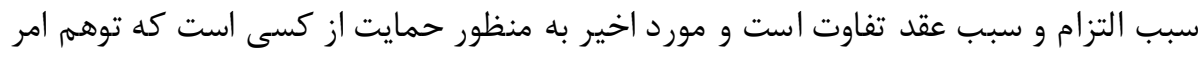

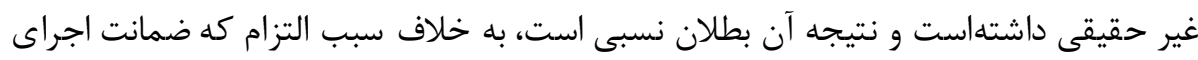


آن بطلان مطلق است.

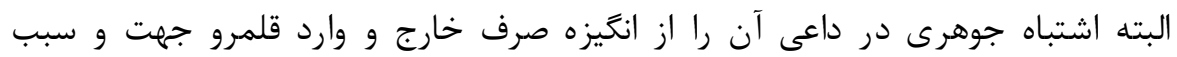

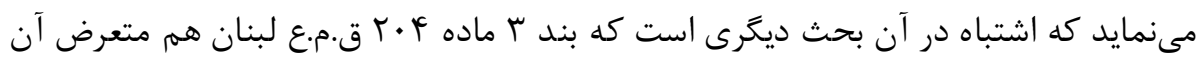

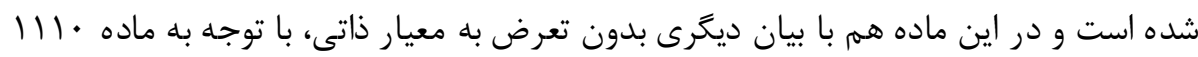

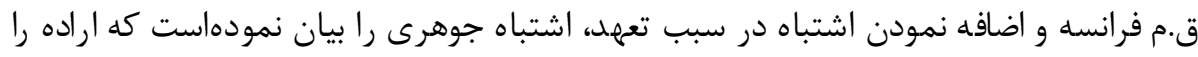

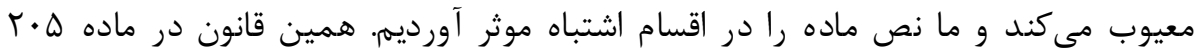

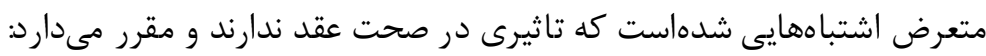

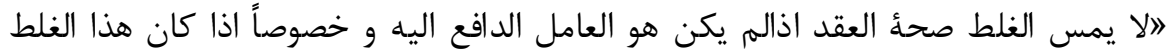

$$
\text { يتناول: }
$$

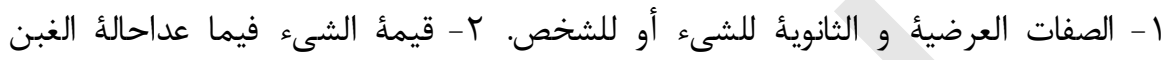

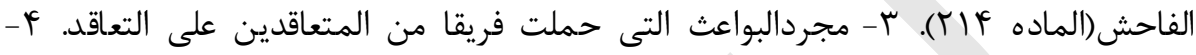

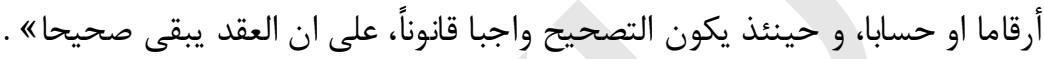
شرط دوم - اشتباه بايد داخل در قلمرو تراضى باشد.

(يجب ان يكون الغلط داخلاً فى نطاق التعاقد).

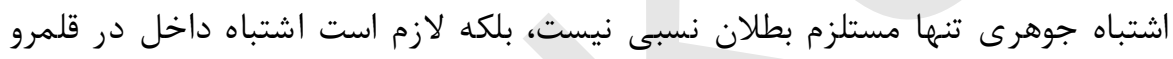

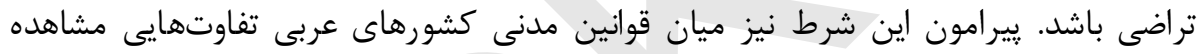

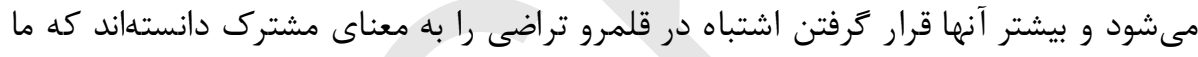

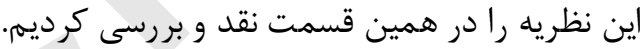

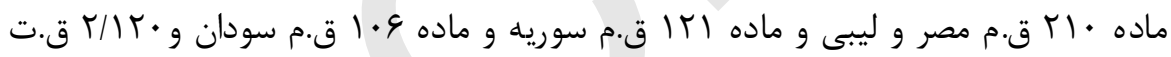

$$
\text { كويت مقر رمى مدارد: }
$$

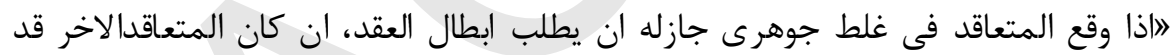

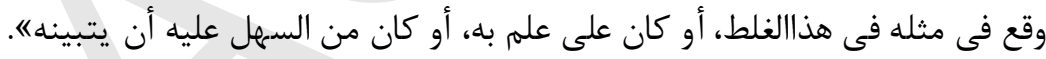

$$
\begin{aligned}
& \text { ماده } 119 \text { ق.م عراق مقر مر مى دارد: }
\end{aligned}
$$

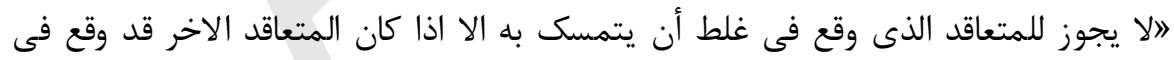

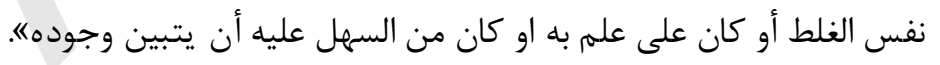

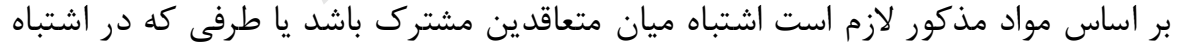

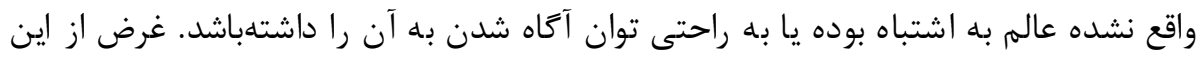

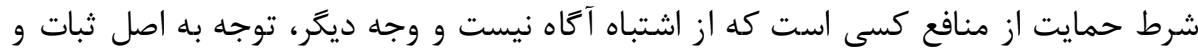

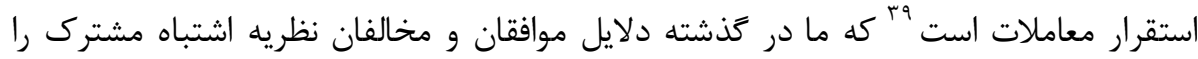

$$
\text { مورد بررسى قرار داديمه. }
$$

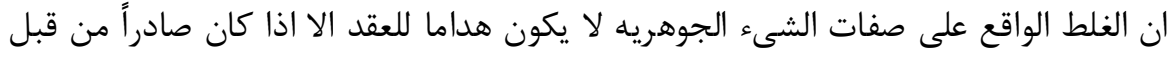

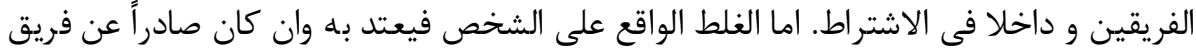




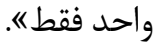

همان طورى كه ملاحظه مىشود، در ماده مذكور ميان اشتباه در صفت جوهرى و شخص

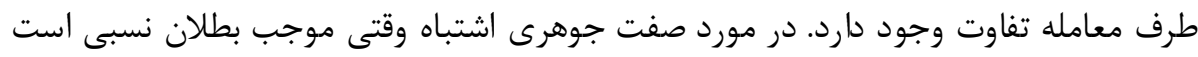

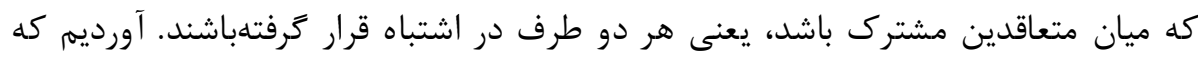

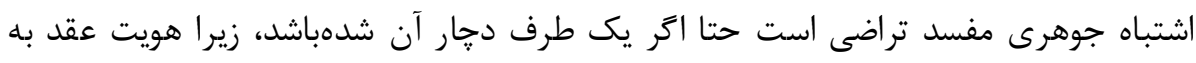

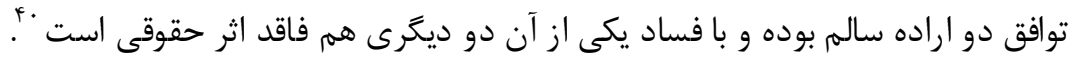

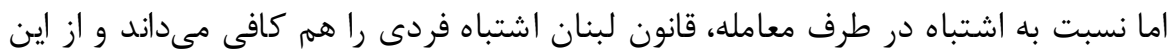
جهت با قوانين مدنى ساير كشورهاى عربى تفاوت دارد. در باره اشتباه در علت تعهد و مشترك

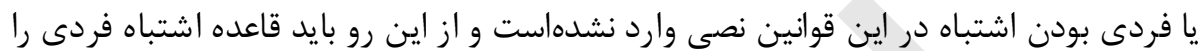
در آنها كافى دانست. با اين گزارش مختصر معلوم گرديد كه متون حقوقى كشورهاى عربى به طور عمده متاثر از

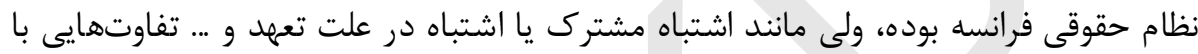

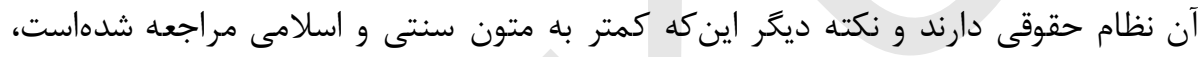

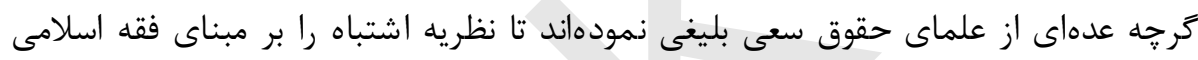

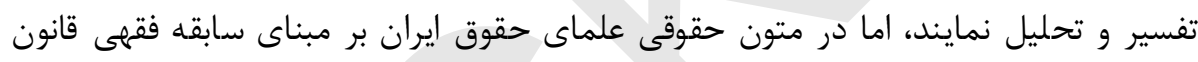

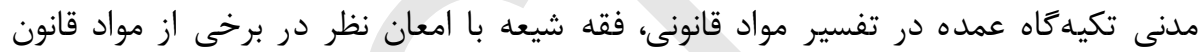

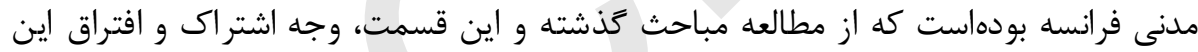
دو ديدگاه كاملاً معلوم مى گرددد.

\section{آثار حقوقى اشتباه در قوانين مدنى كشور هاى عربى}

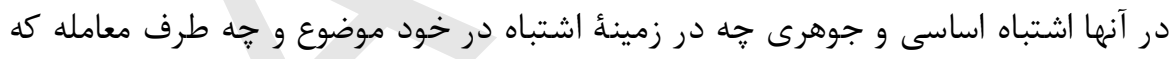

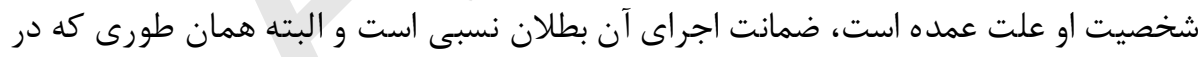

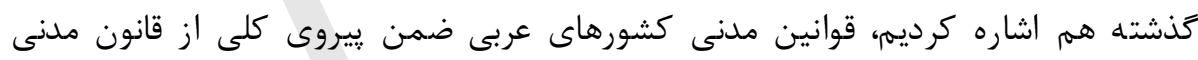

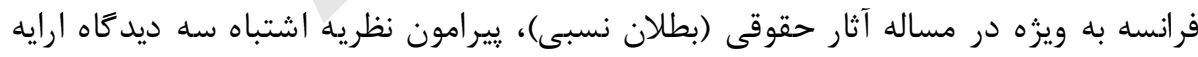

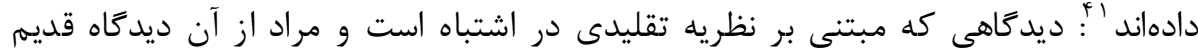

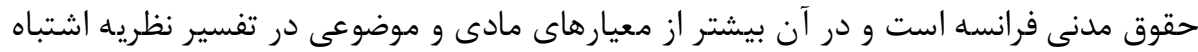

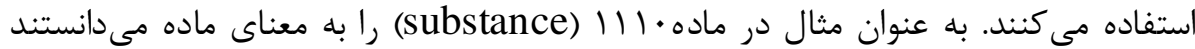

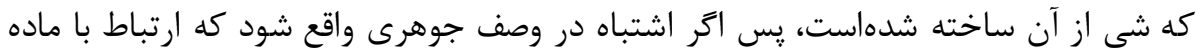

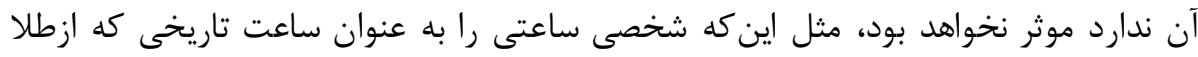

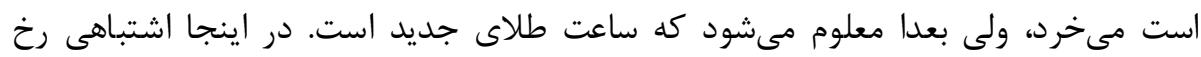

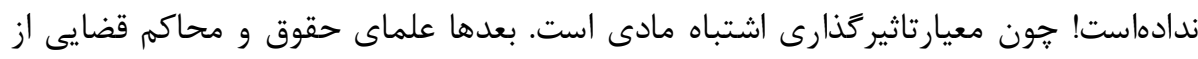


آن تفسير عدول كرده، مراد از اشتباه در (Substace) را به اوصاف جوهرى هه تعميم دادند و معيار تفسير آن هم ذاتى يا شخصى شد يا در طرف معامله (Qualites Substantielles)

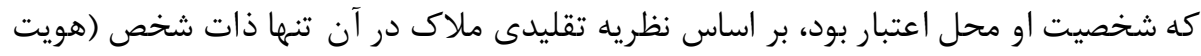

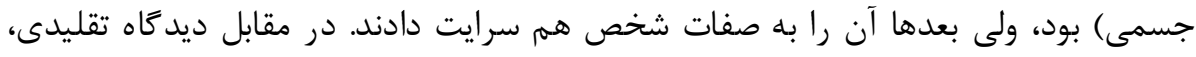

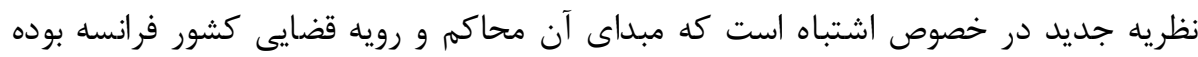

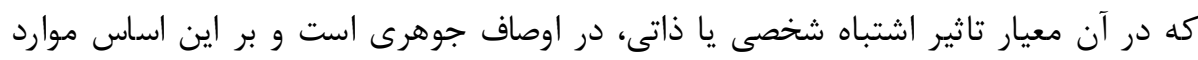

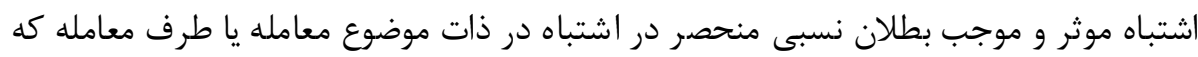

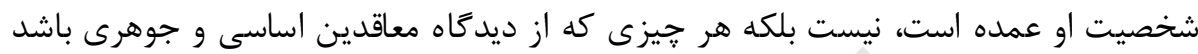

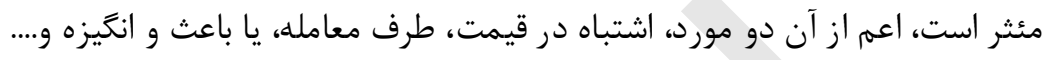

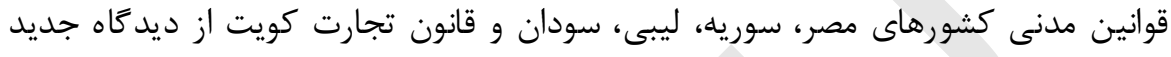

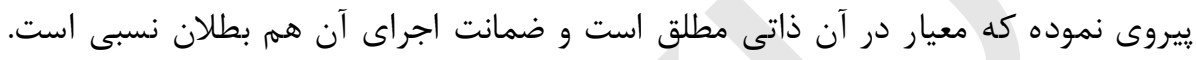

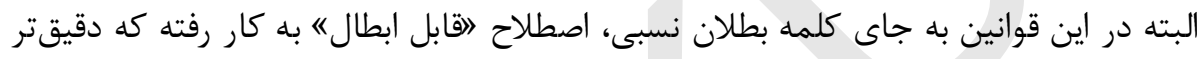

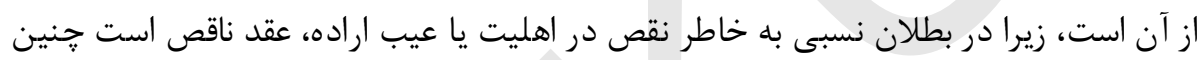

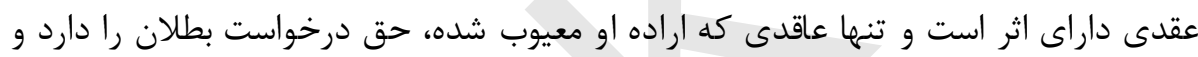

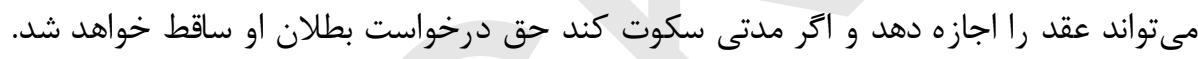

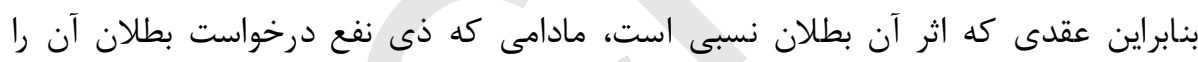

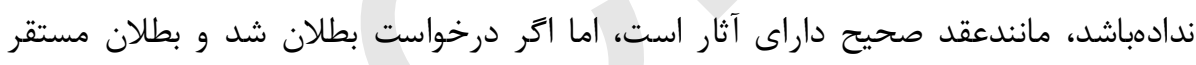

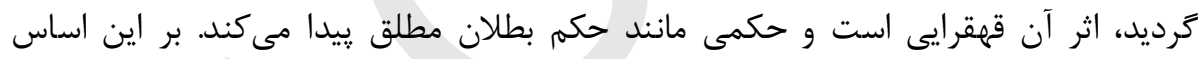

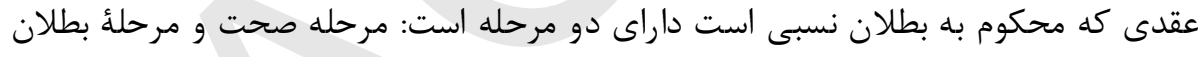

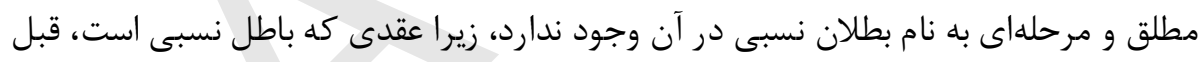

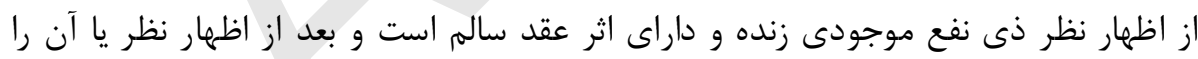

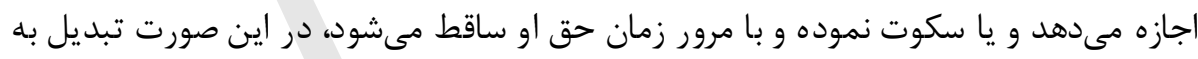

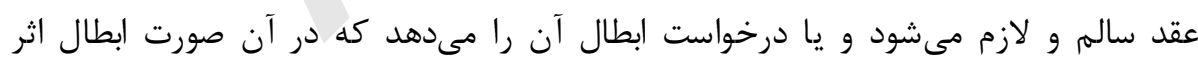

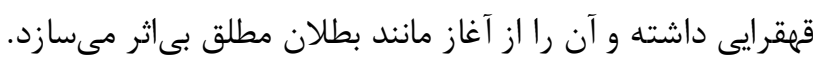

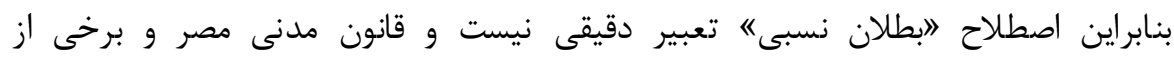

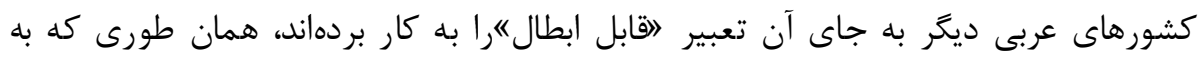

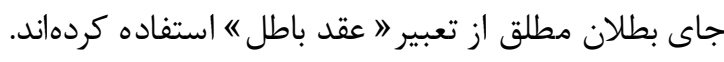

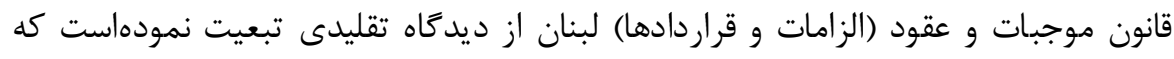

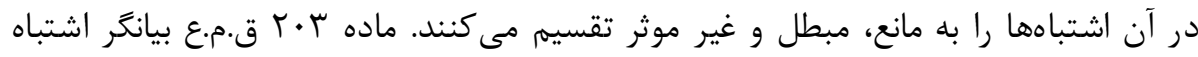

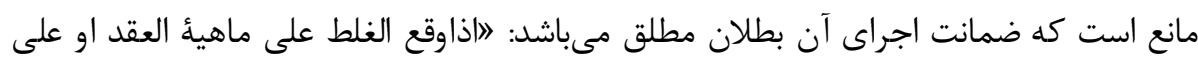


حقيقةُ موضوع الموجب، فانْه يحول دون انشاء العقد نفسه، فيعد العقد كأن لم يكنه.

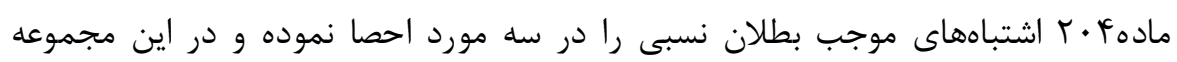

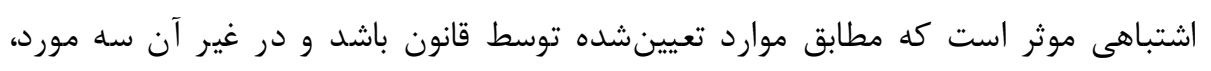

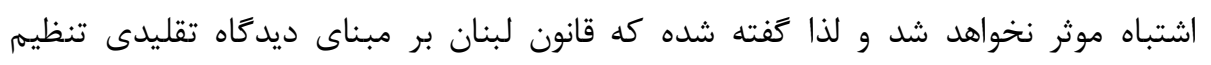
شدهاست.

و بالاخره كروه سوم قانون مدنى عراق است كه در آن معيار ذاتى و ديد كاه جديد همراه با

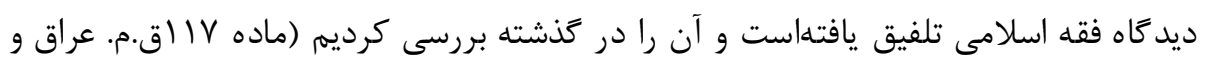

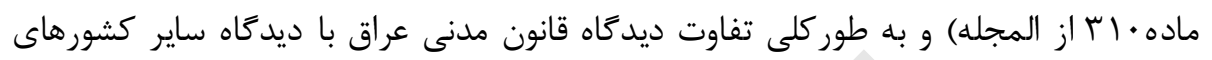

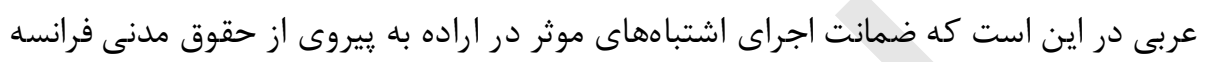

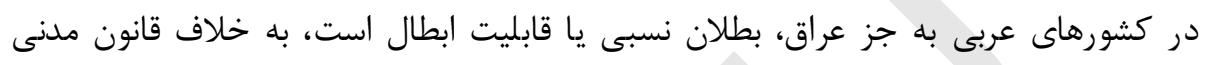

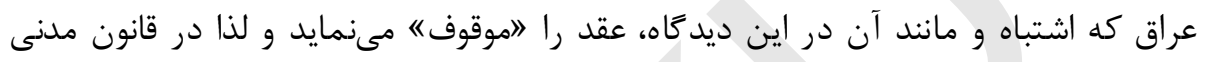

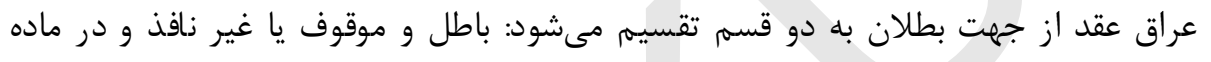

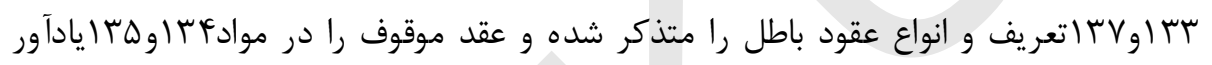

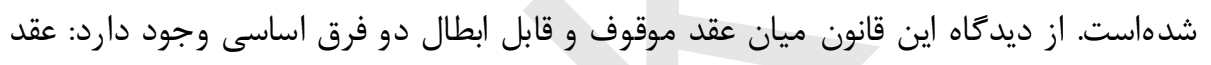

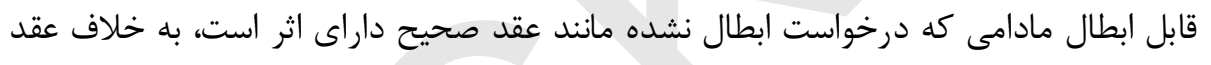

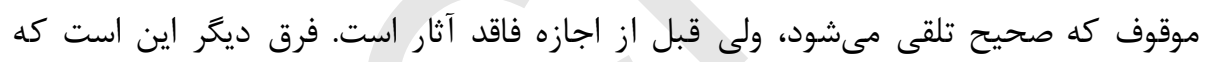

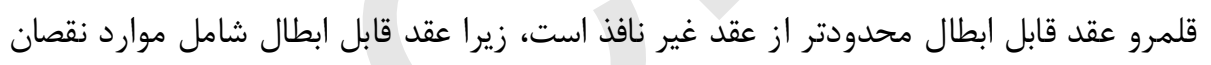

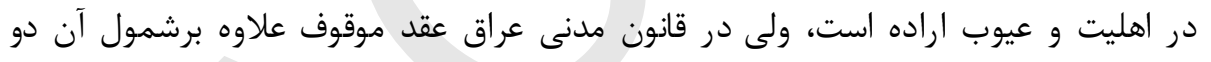

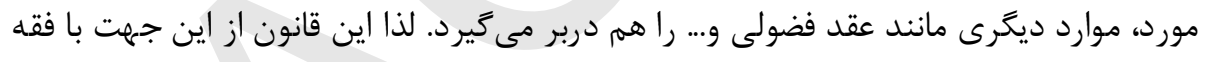
اسلامى هماهنگ است.

\section{بهنوشتها}

$$
\begin{aligned}
& \text { با ( ) و منه القمار بلاخلاف اجده فيه، بل الاجماع ... فيهاما يقتضى كونه من الباطل، الذى نهى الله عن اكل المـالبه" (جواهر }
\end{aligned}
$$

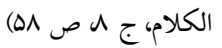

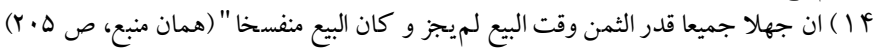

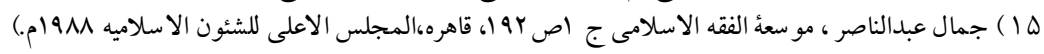

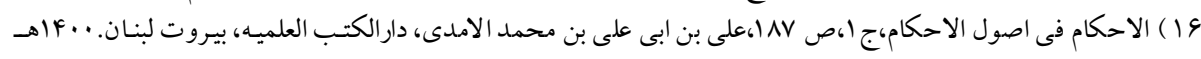

$$
\begin{aligned}
& \text { (.) }
\end{aligned}
$$

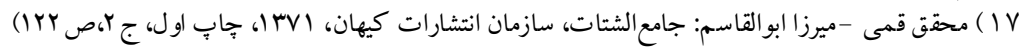

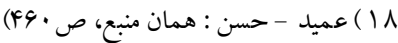

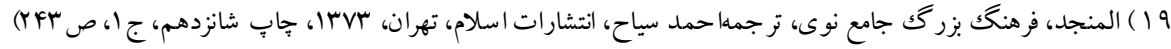

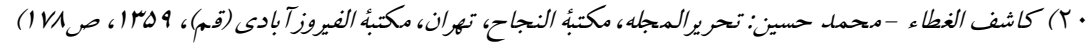

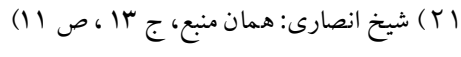




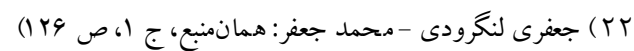

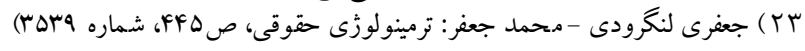

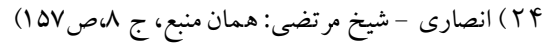

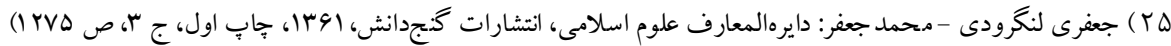

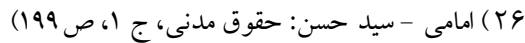

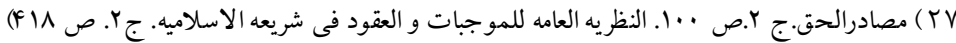

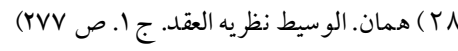

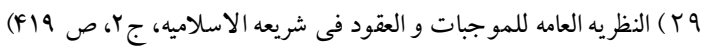

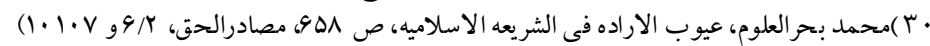

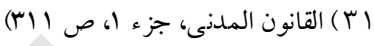

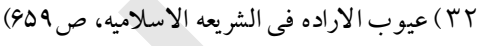

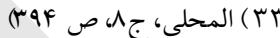

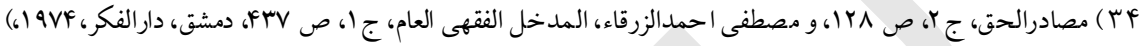

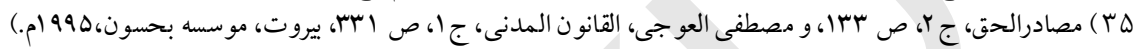

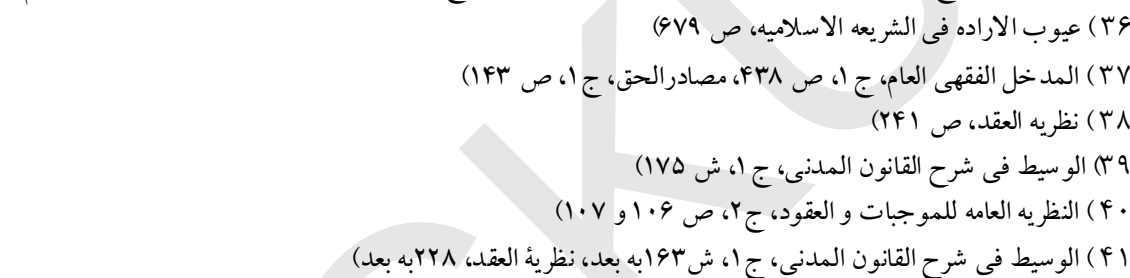

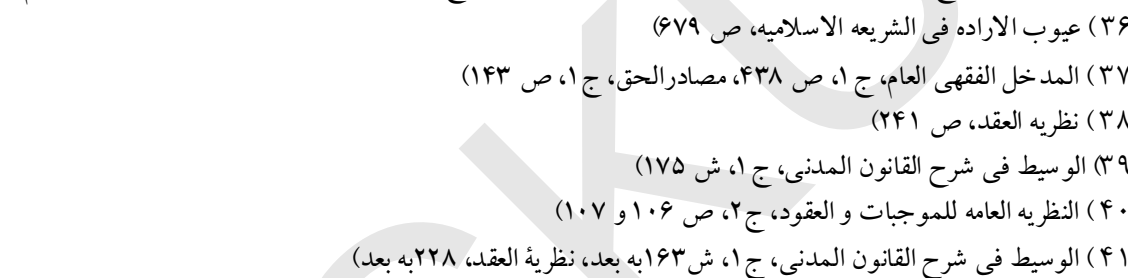

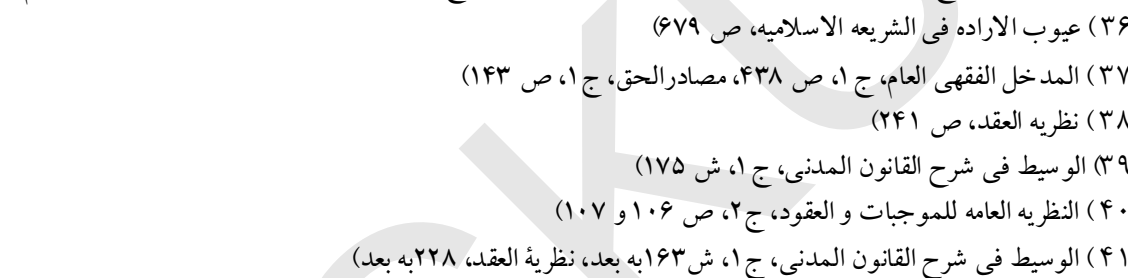

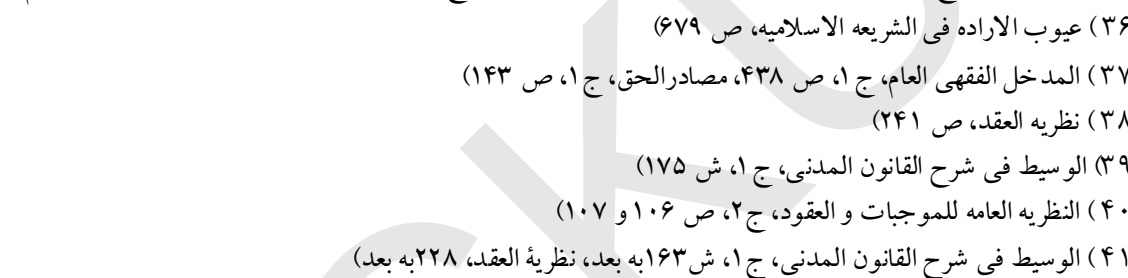

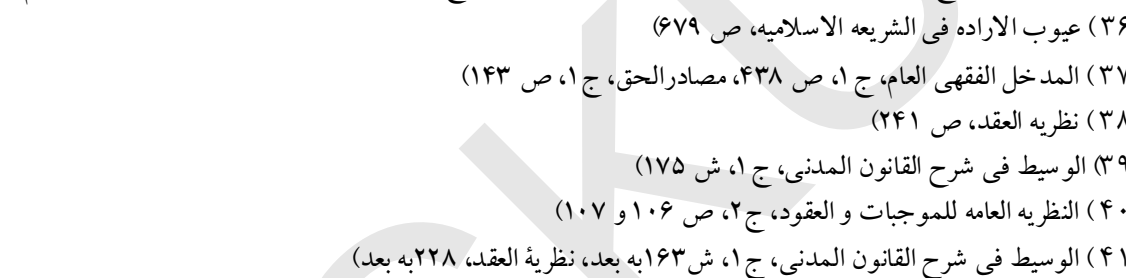

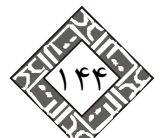




\section{د احاديثو قانونى مرجعيت}

عبدالبارى غيرت

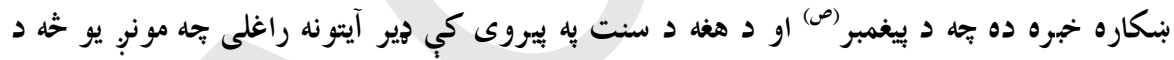

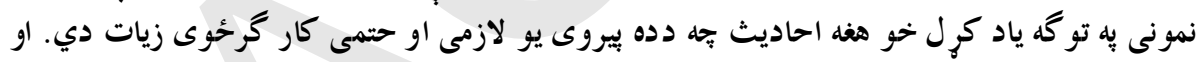

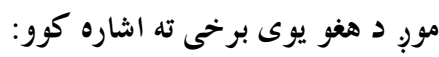

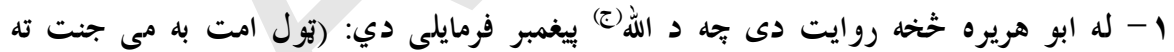

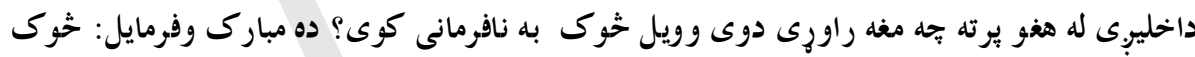

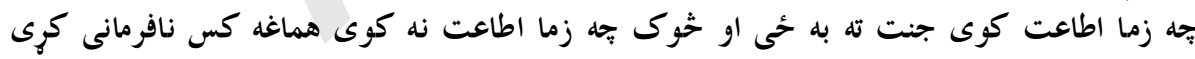

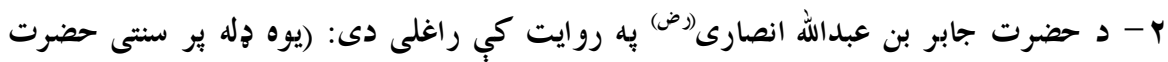

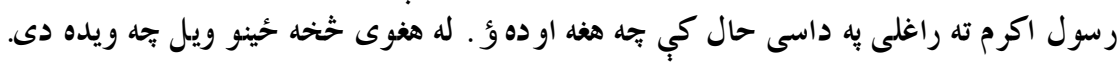

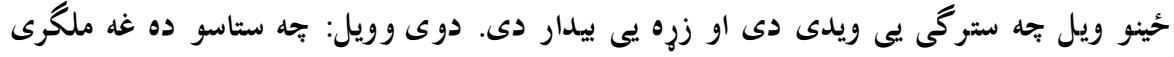

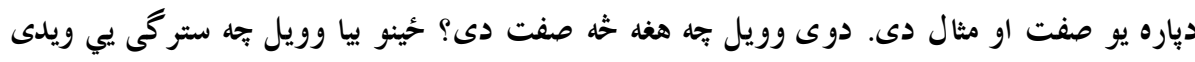

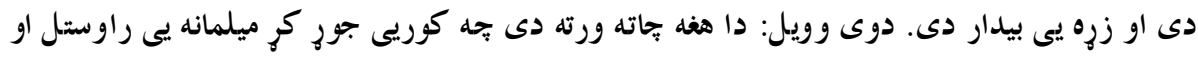

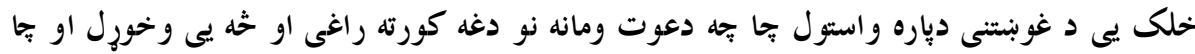

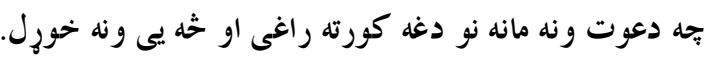




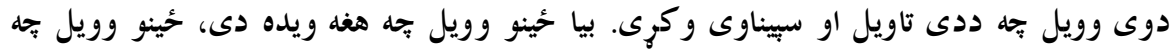

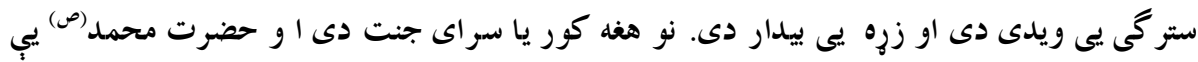

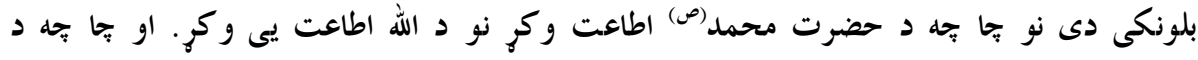

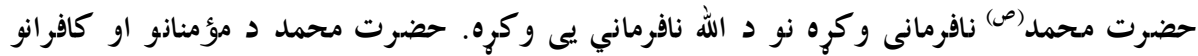

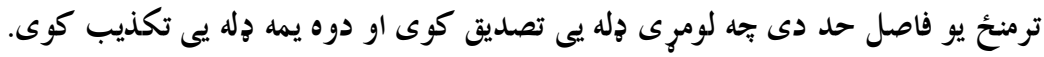

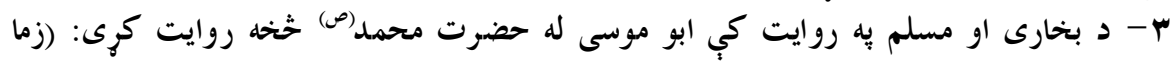

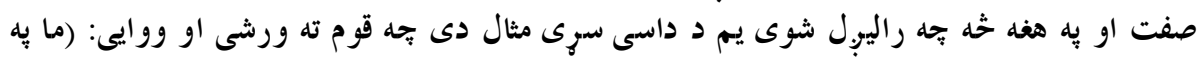

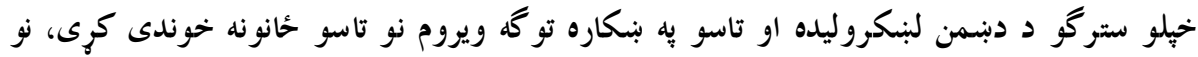

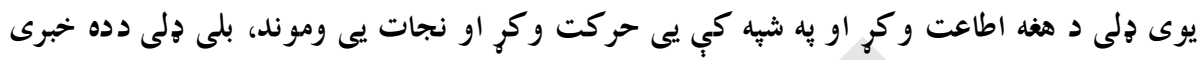

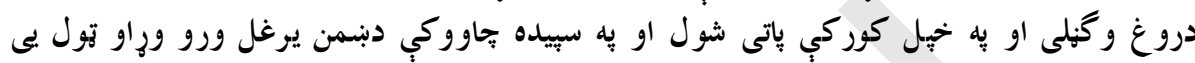

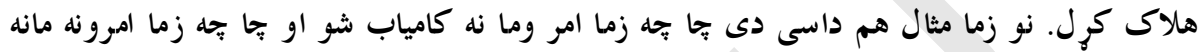

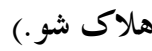

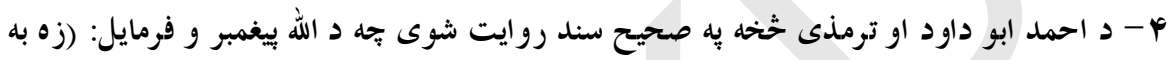

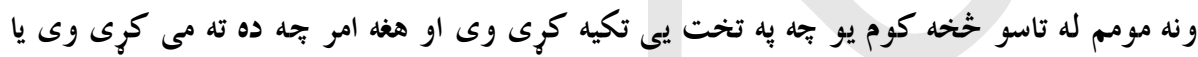

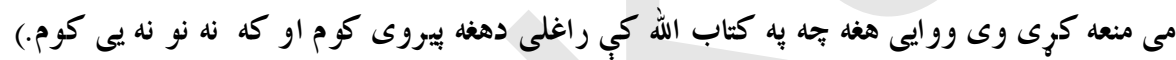

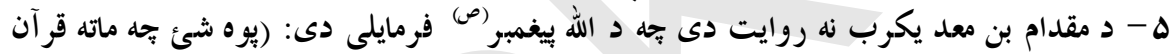

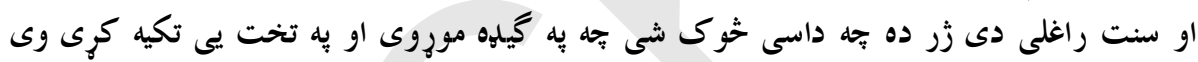

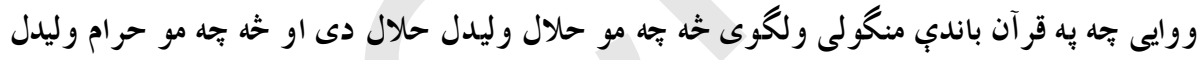

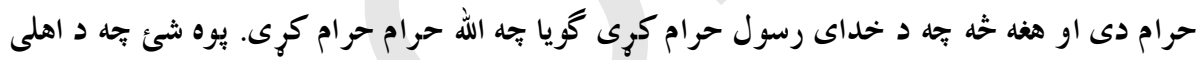

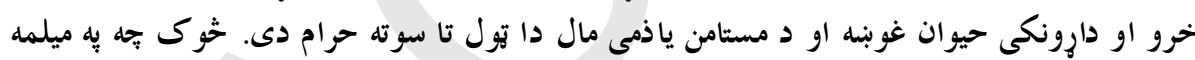

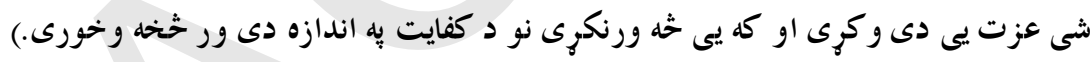

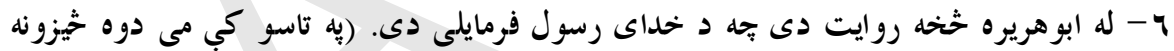

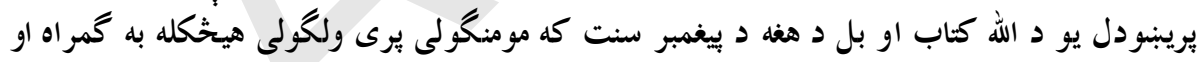

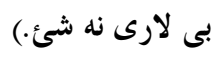

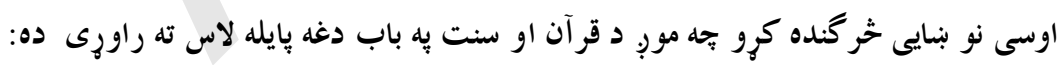

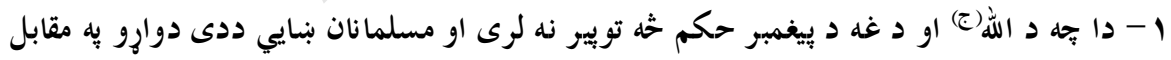

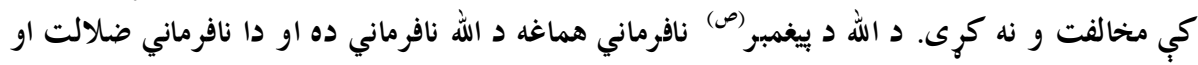

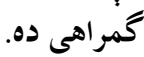

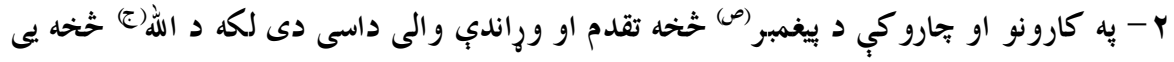

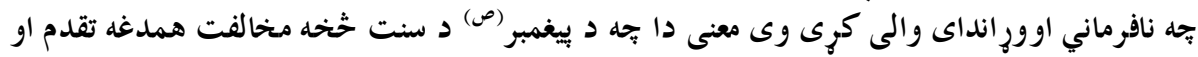

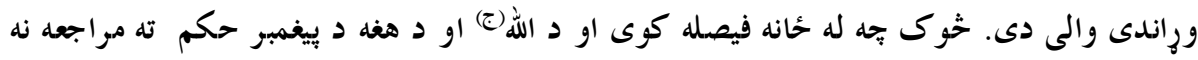

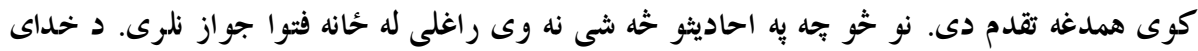


رسول جهه امر نه وى كرى امر مه كوىئيه يوه كار كي تصميم مه نيسى خو تجه د خداى د بيغمبر (ص)

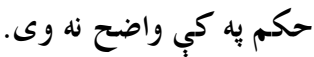

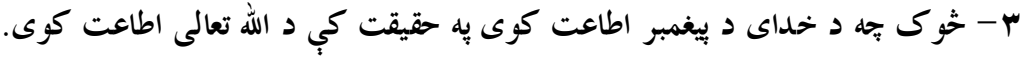

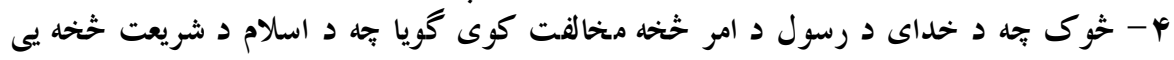

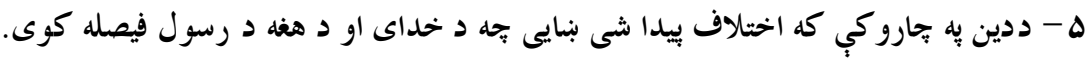

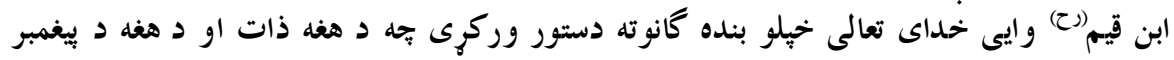

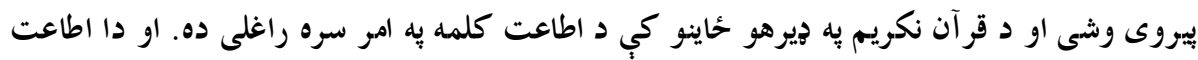

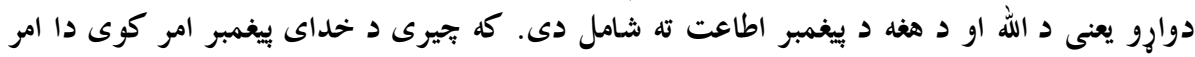

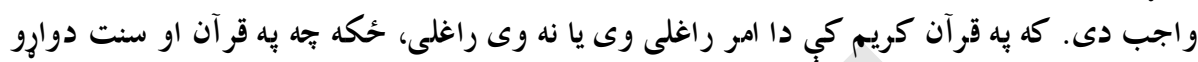

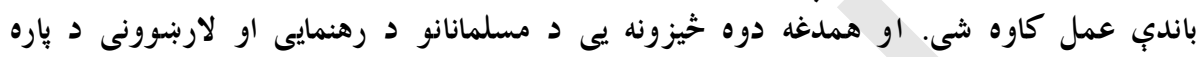

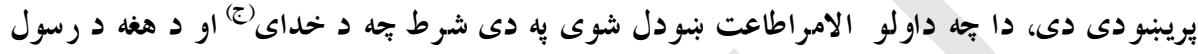

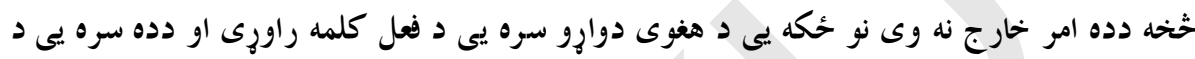

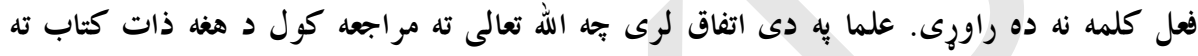

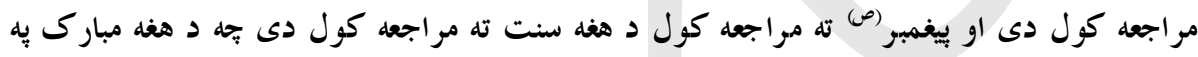

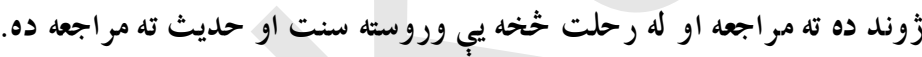

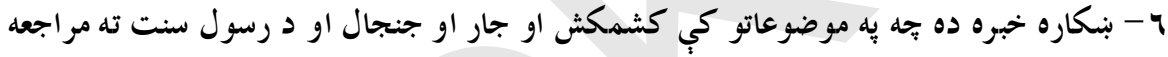

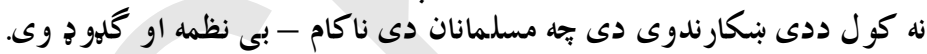

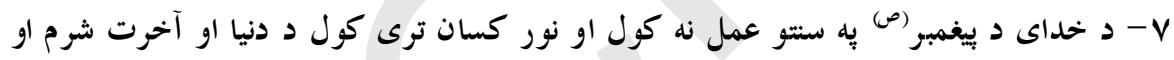

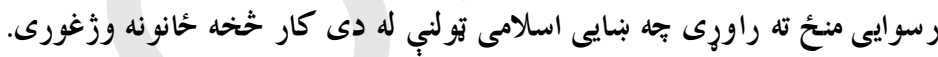

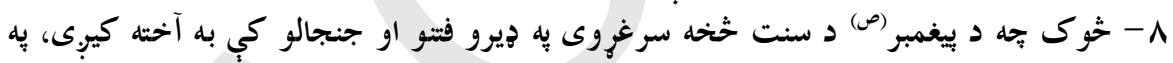

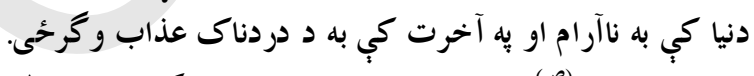

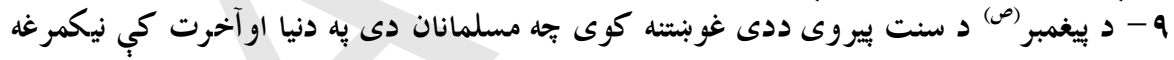

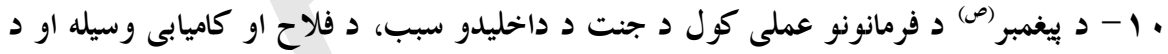

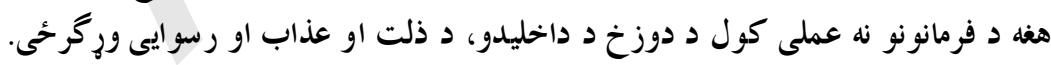

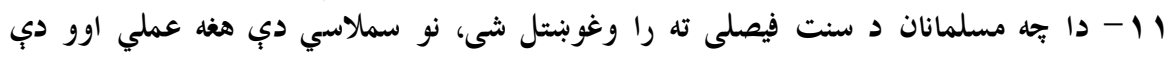

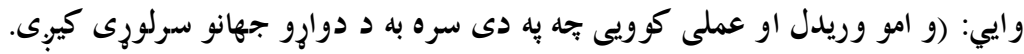

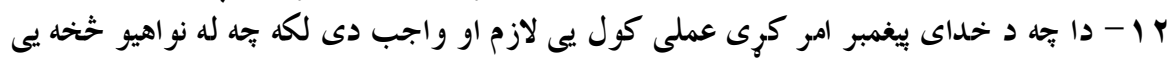

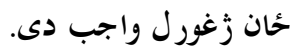

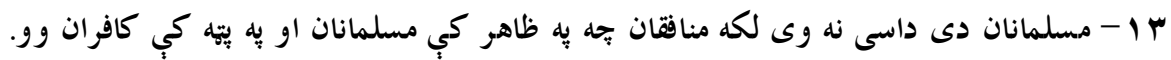

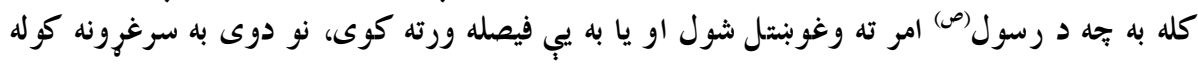
او د هغه د فرمان خخه دهل يب متخ ارواوه. 


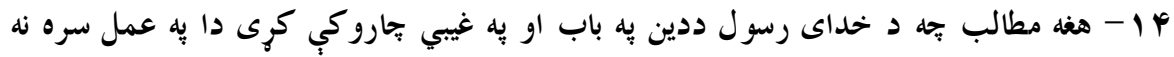

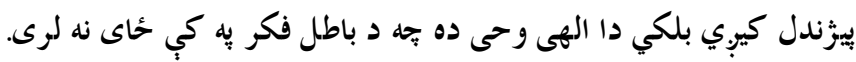

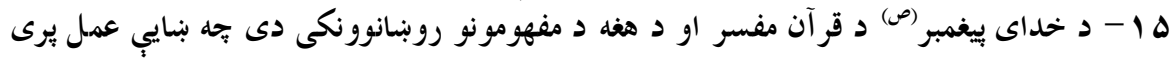
و شى. 19 واجب دى. او خوك تحه يوازى قرآن كافى بولى او سنت ته ارتيا نه وينى د رسول اكرم د لارى خخه بـ مخا لفت كرى دى دئ

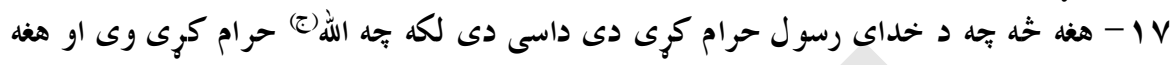

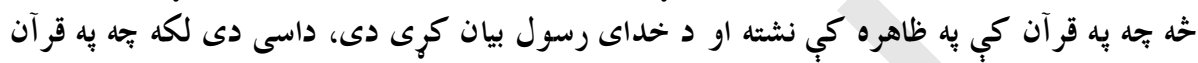

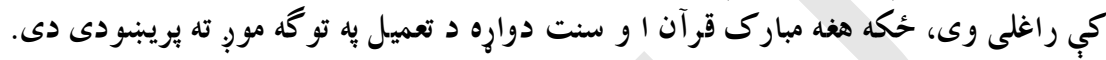

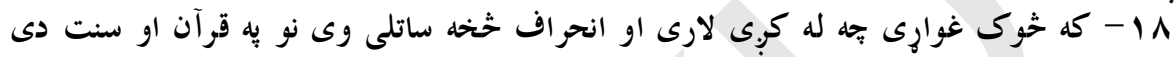

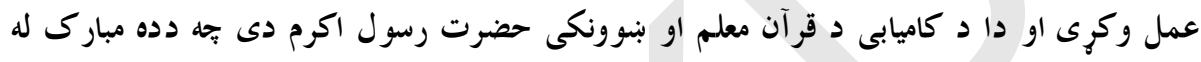

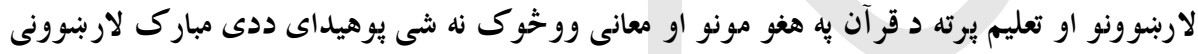

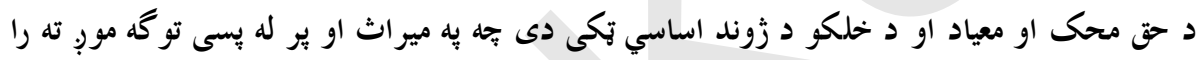

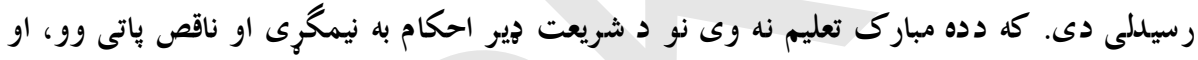

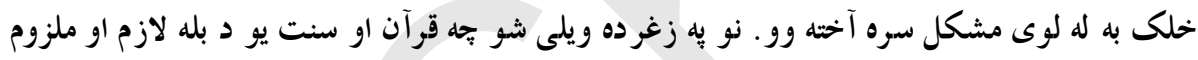

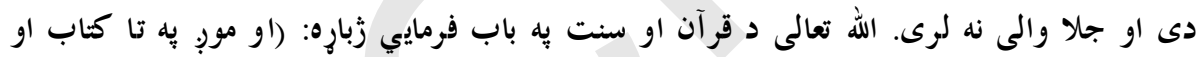

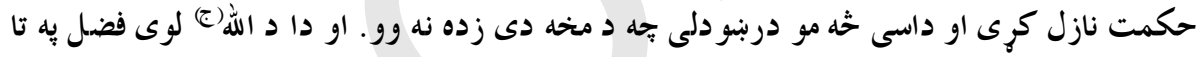

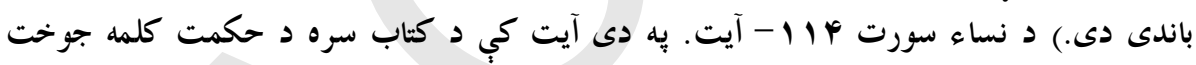

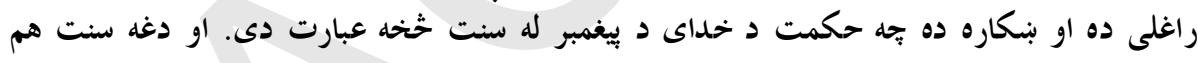

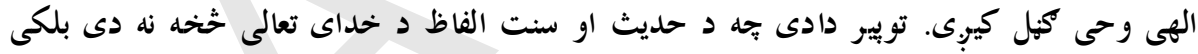

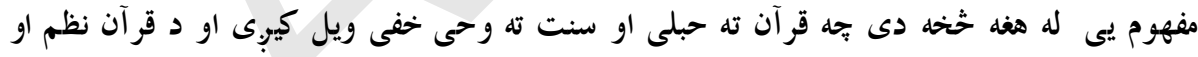

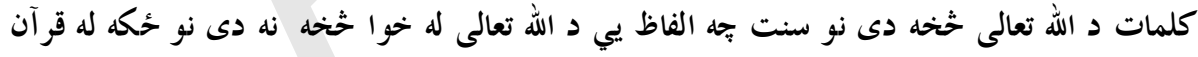

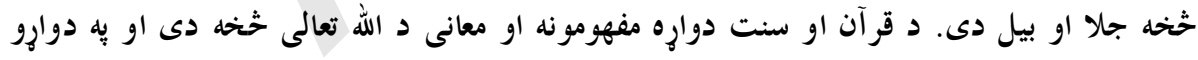

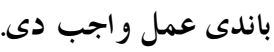

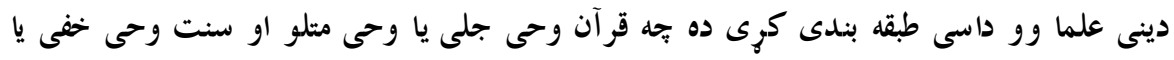

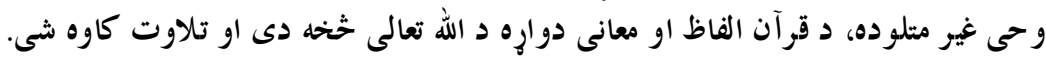

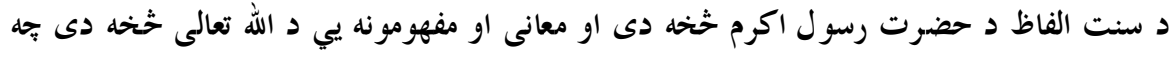

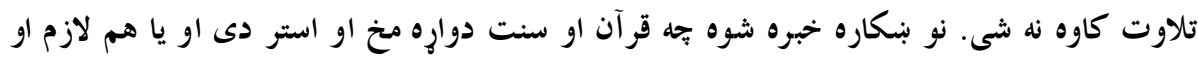

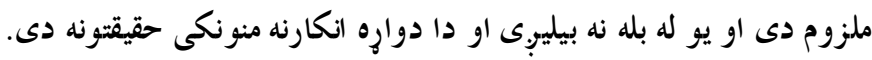




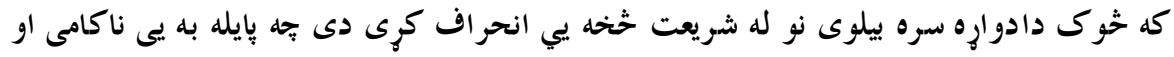

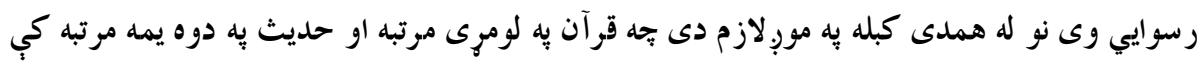

قر آن متن او احاديث شر حه وبولو او بنايي به دى عقيده او سوتج دو ويجه داد واره د د اسلامى قو انينو

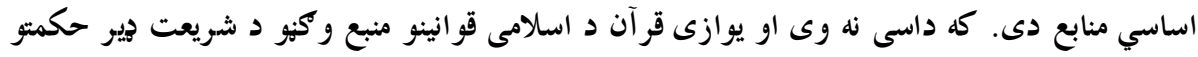

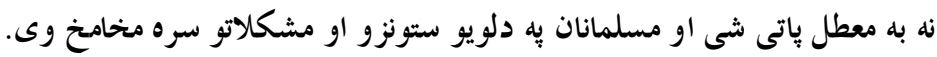

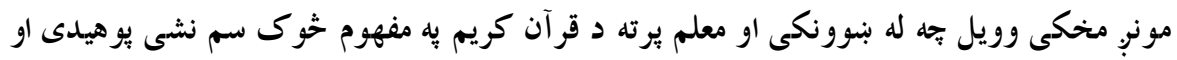

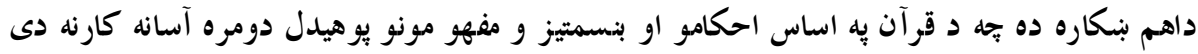

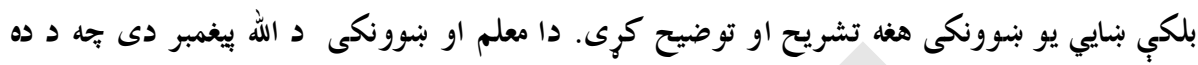

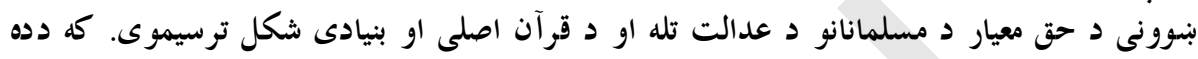

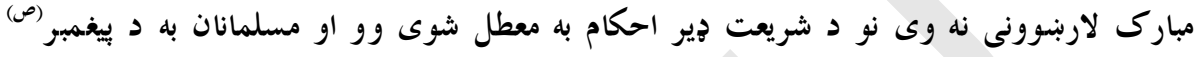

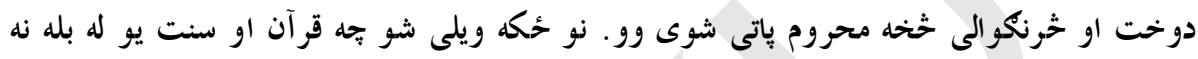

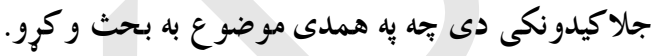

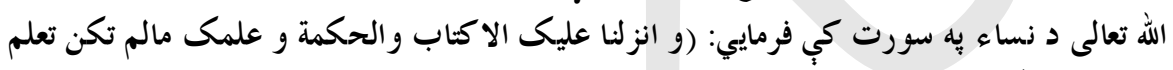

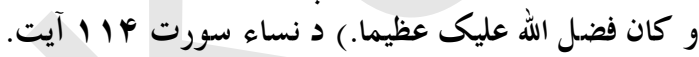

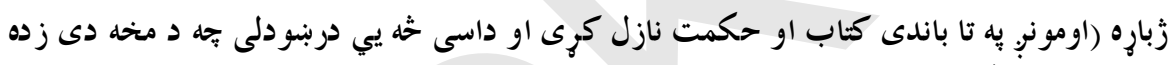

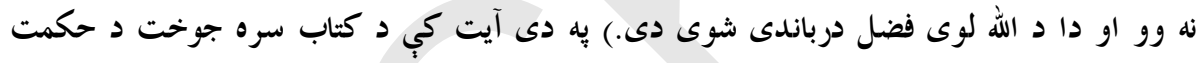

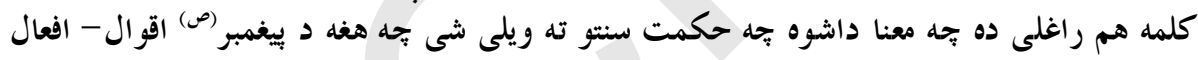

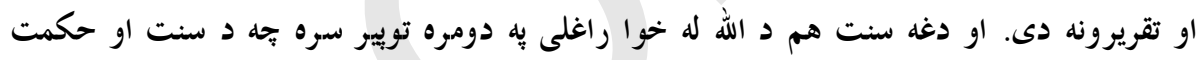

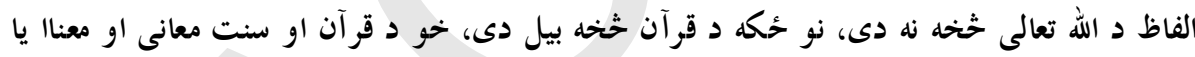

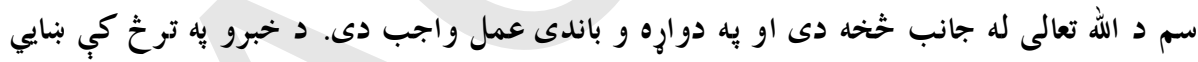

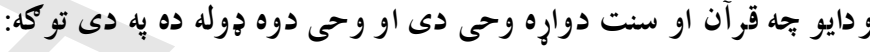

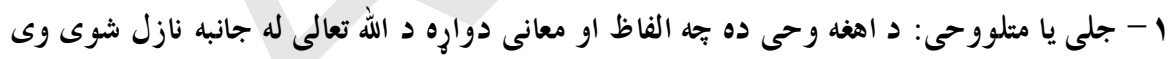

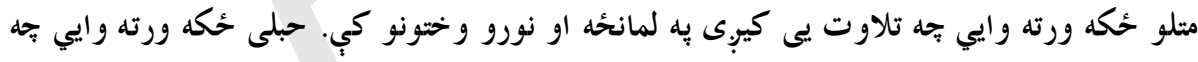

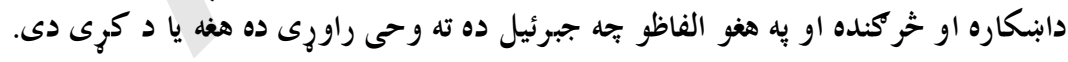

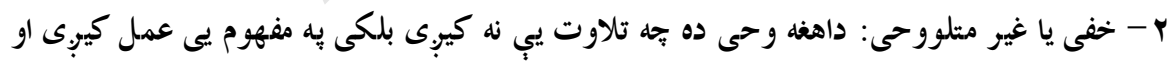

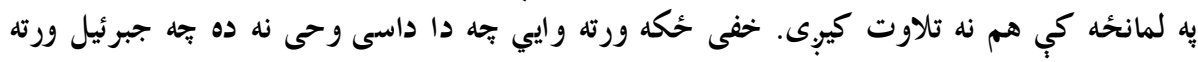

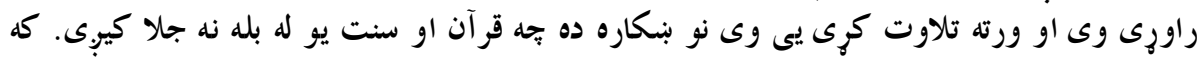

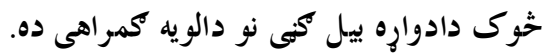

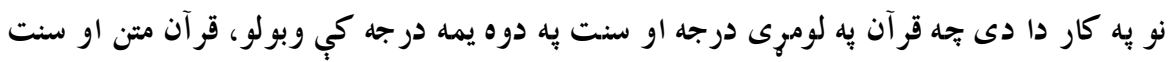

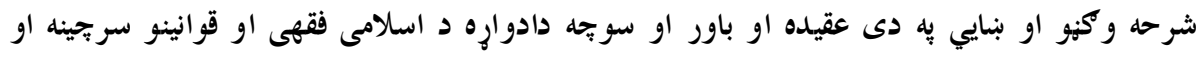

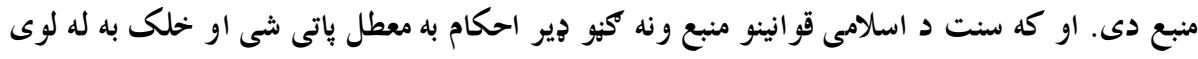

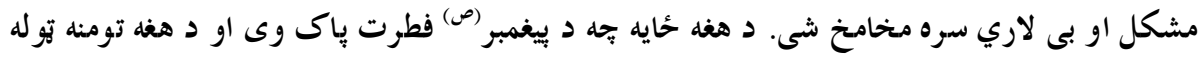


له شرف غيرت باكى او صفائى خخه جوره شوى وى او دده تول كره وره به به حق او نيكى بنا وى او

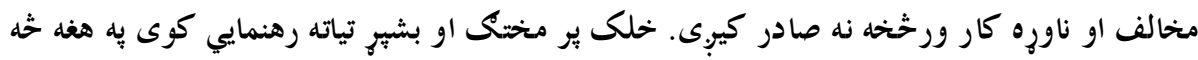

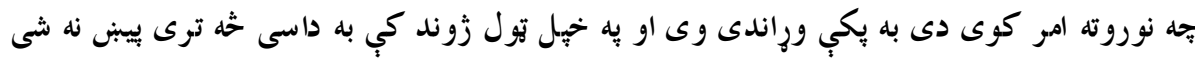

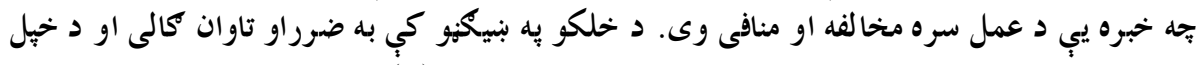

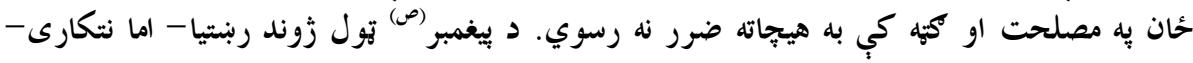

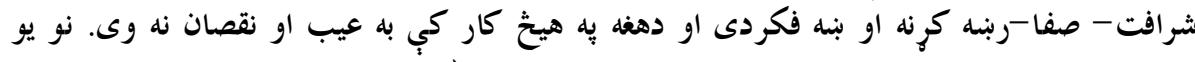

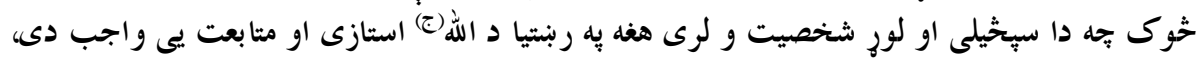

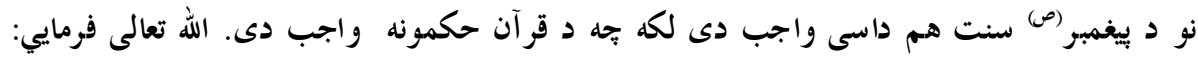

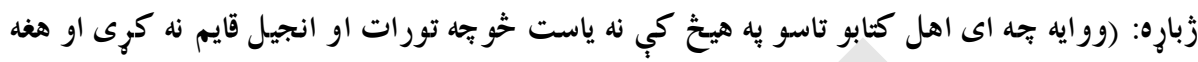

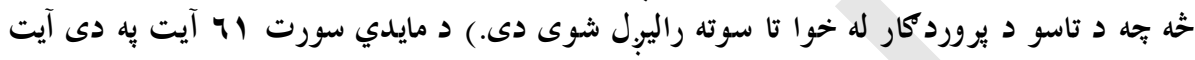

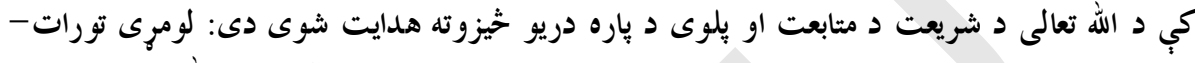

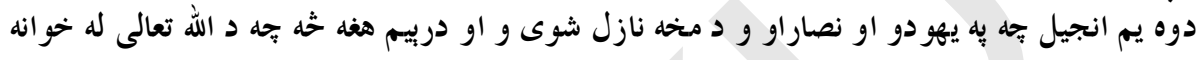

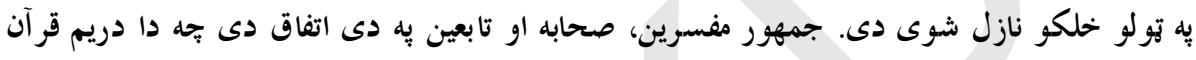

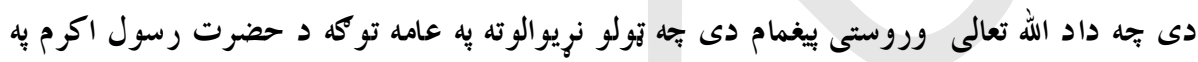

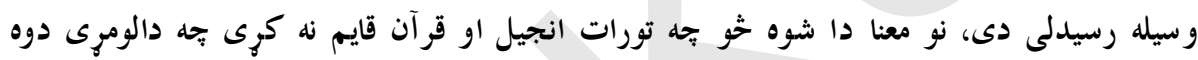

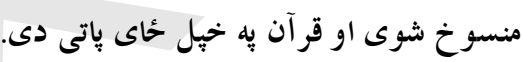

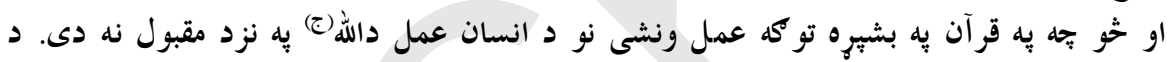

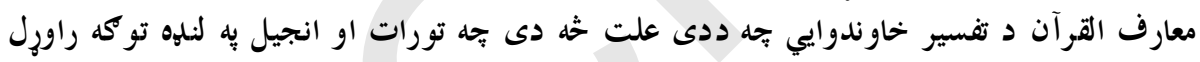

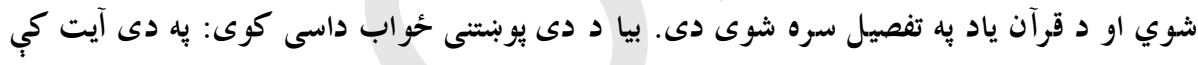

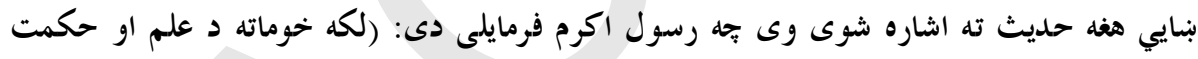

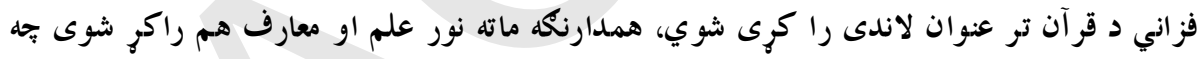

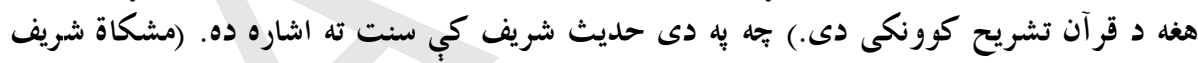

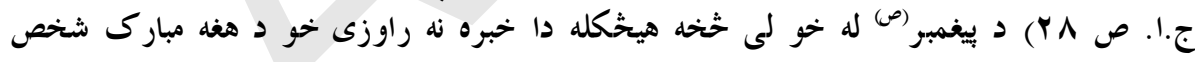

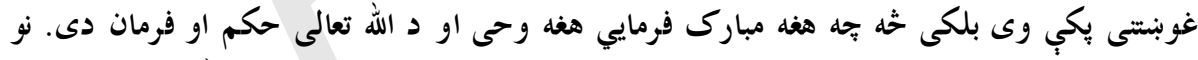

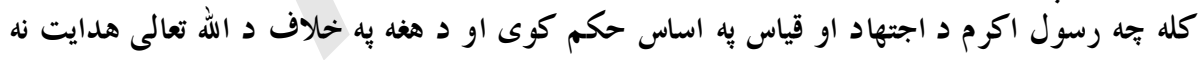

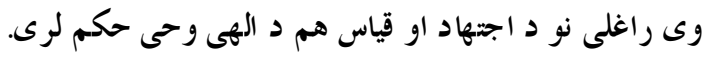




\section{ديدار هيات عالى رتبه حكومت شاهى ناروى}

\section{با وزير عدليه جمهورى اسلامى افغانستان}

آلموند جانسون، (معيين وزارت خارجه حكومت شاهى ناروى)، ترج مولاند يِيدرسون (معيين

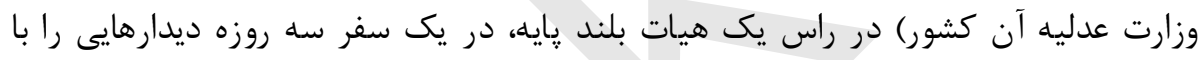

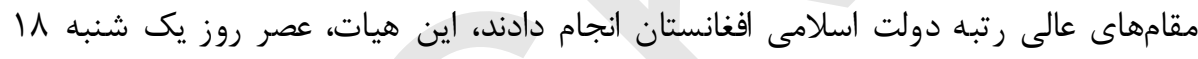

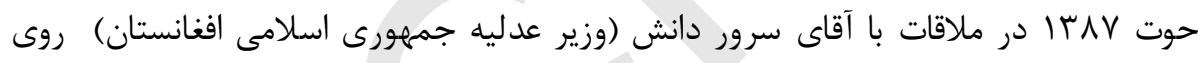

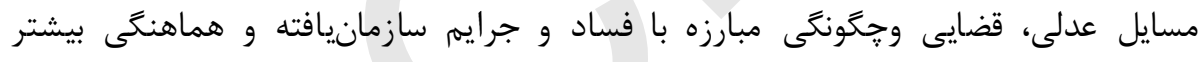

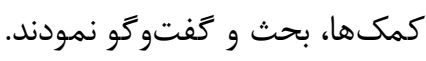

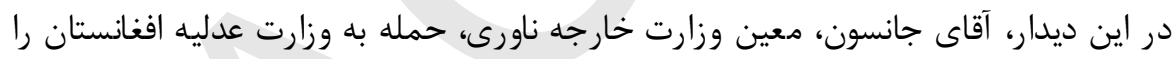

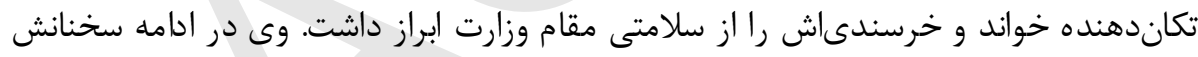

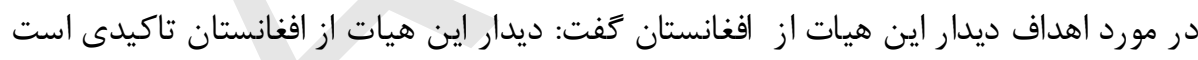

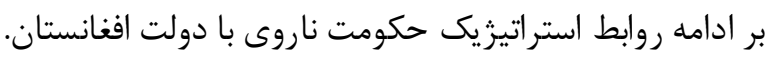

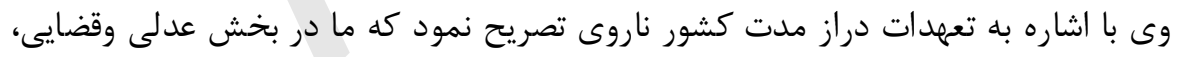

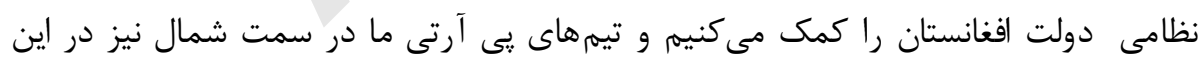

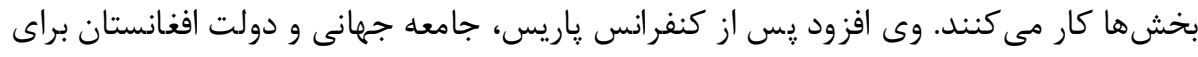

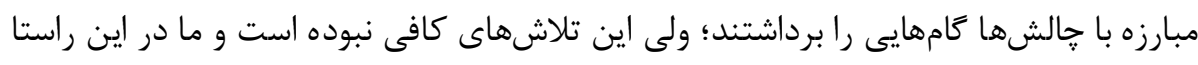
با خالشهاى زياد مواجه هستيه.

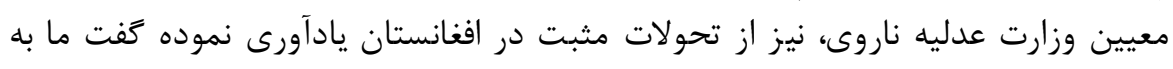

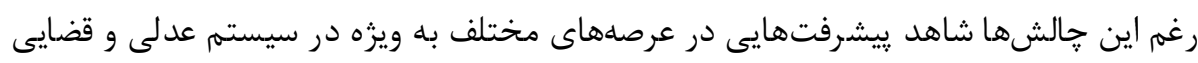

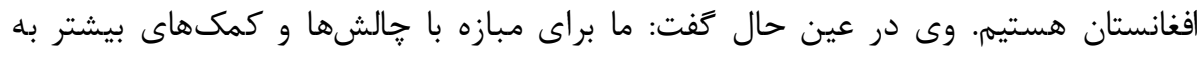

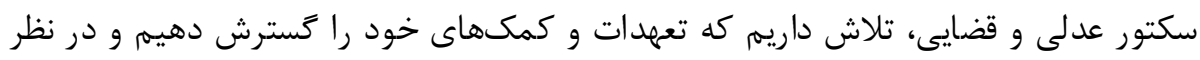


داريم كه بَّ تن از مشاروين يوليس عدلى را براى مشورهدهى در سكتور عدلى و قضايى به

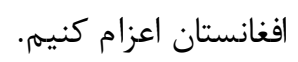

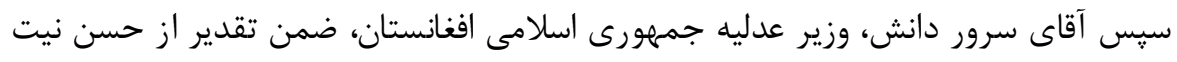

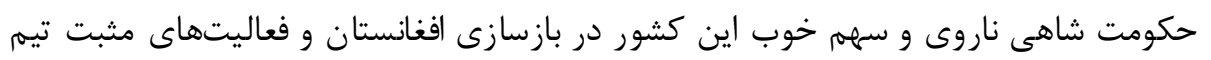

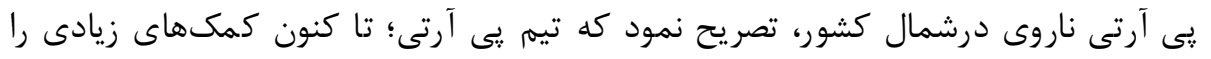

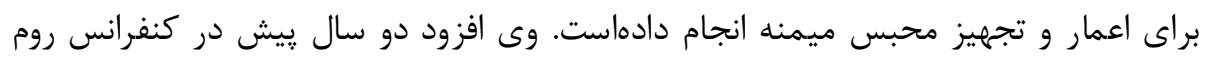

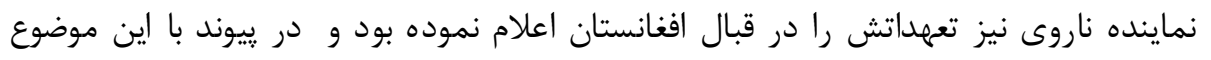

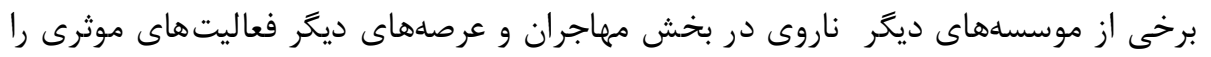

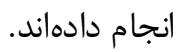

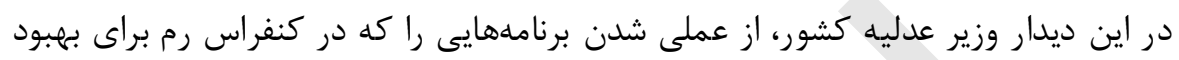

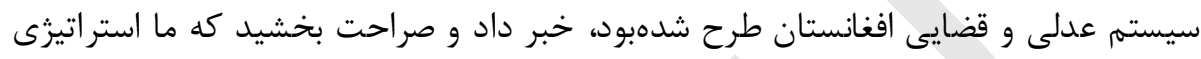

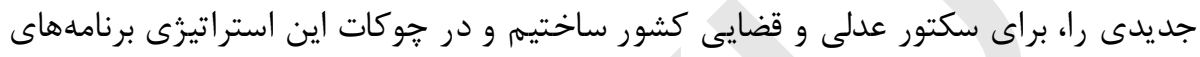

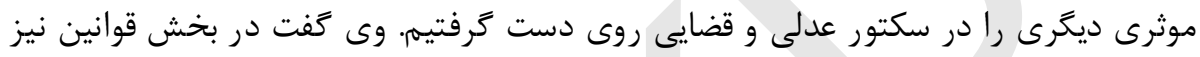

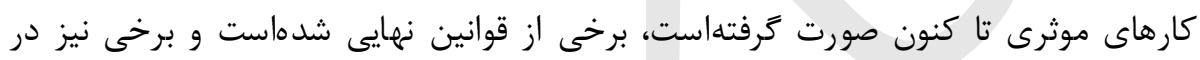

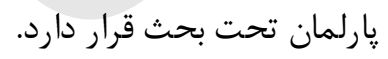

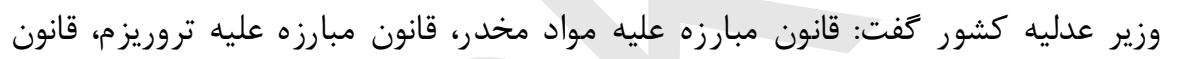

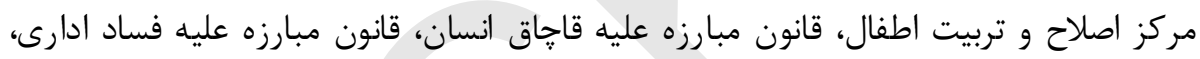

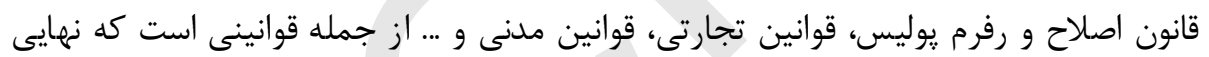
شدهاست. وزير عدليه كشور، در مورد قانون اجرات جزائ جايى كشور كفت: روى تدوين اين قانون در

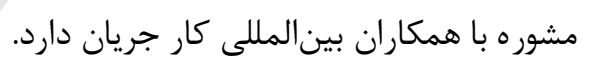

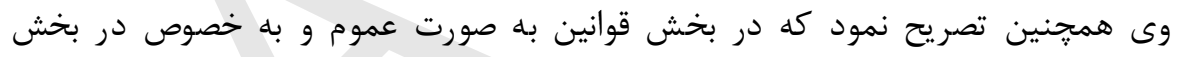
اصلاحات جزايى بيشرفت هاى خوبى نصائ داشتيم.

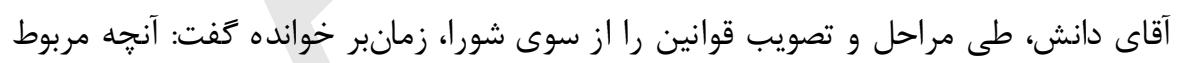

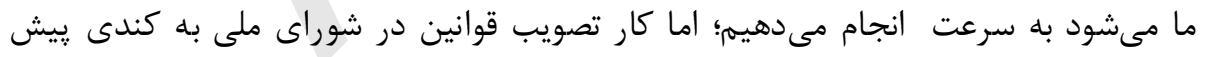

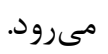

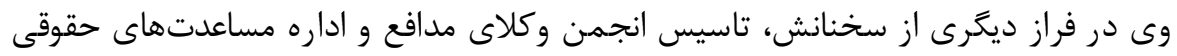

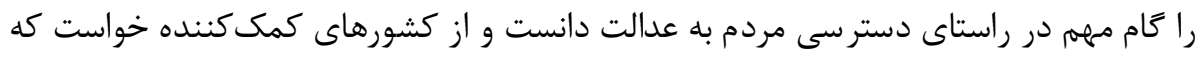

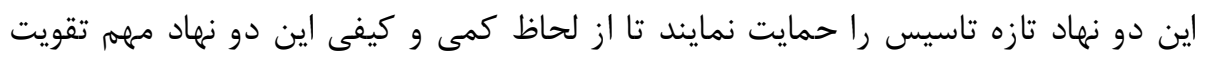
كردد.

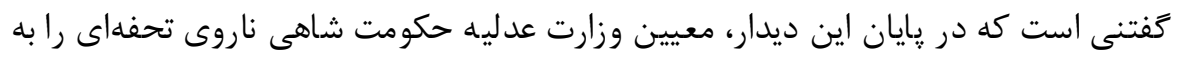

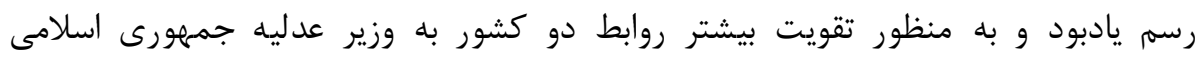

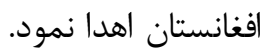




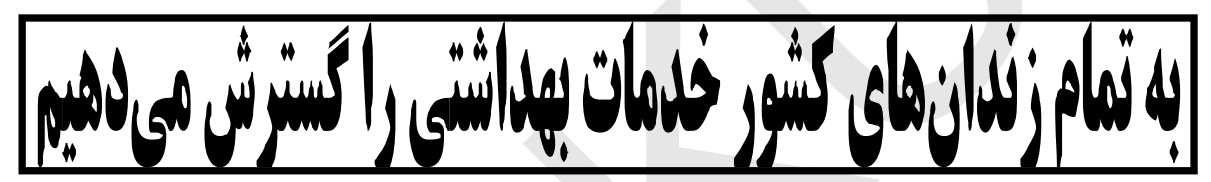

وزارت عدليه، وزارت صحت عامه و نيروهاى بينالمللى كمك به امنه امنيت(آيساف)، روز دوشنبه

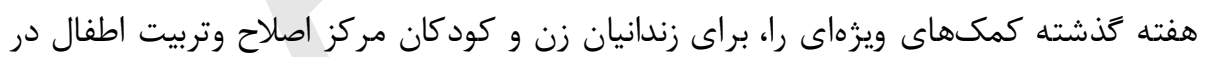
ناحيه بادام باغ كابل توزيع كرد.

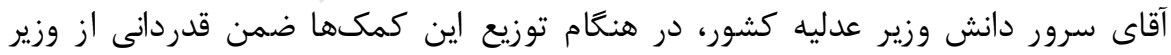

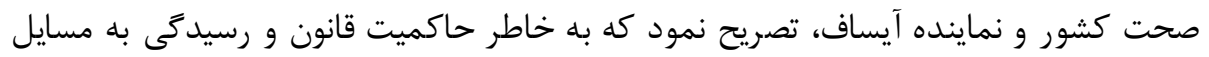

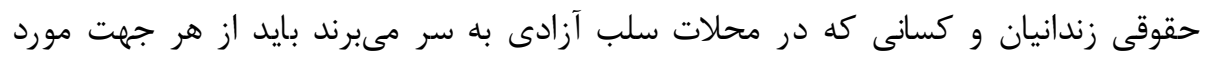
توجه قرار بخيرند.

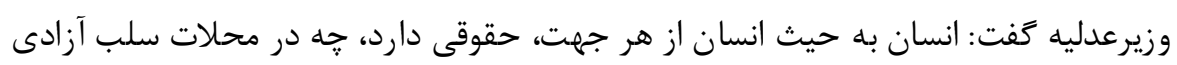

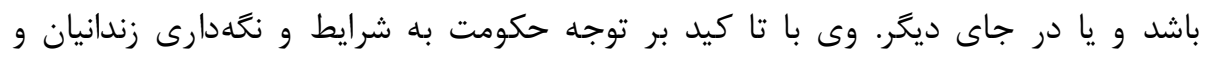

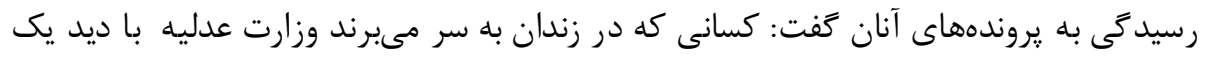

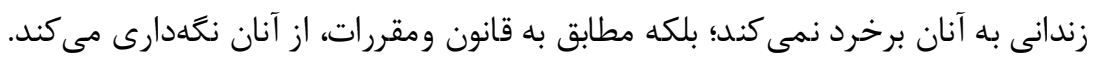




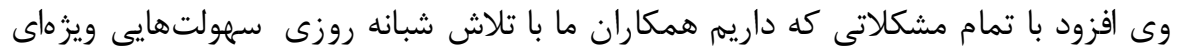

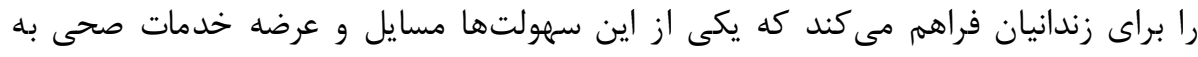

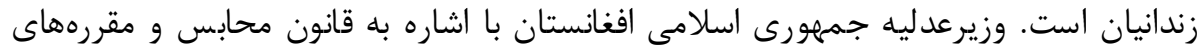

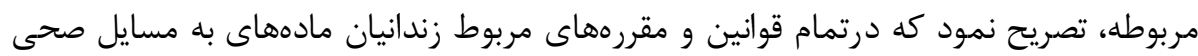

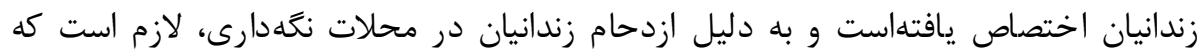

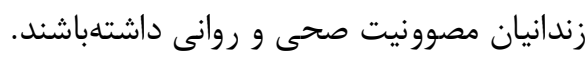

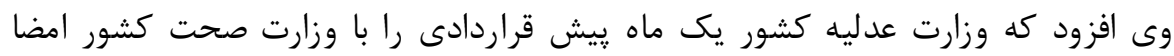

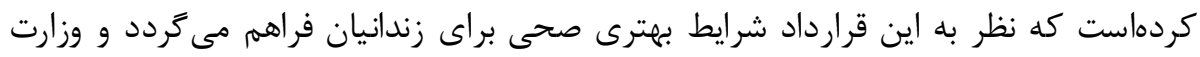

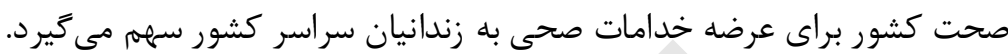

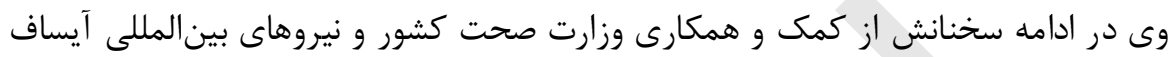

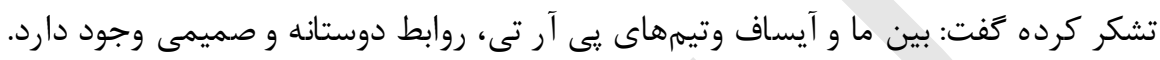

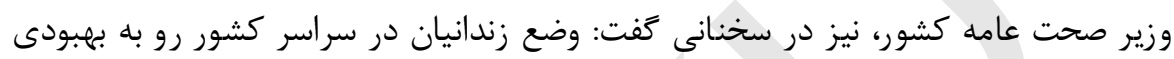

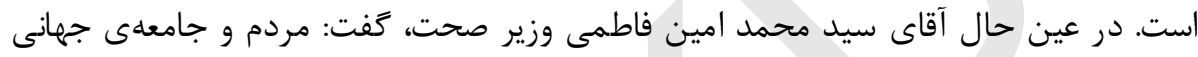

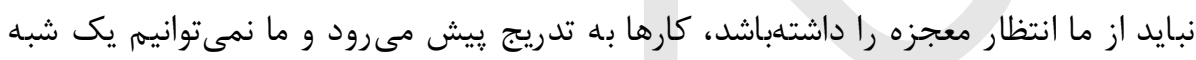

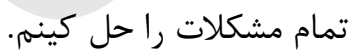

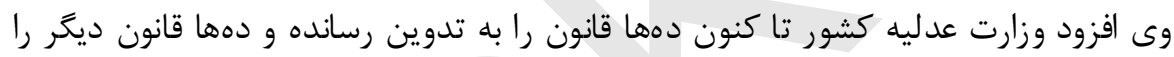

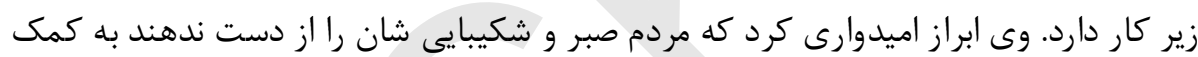

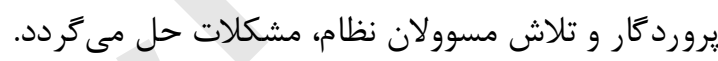

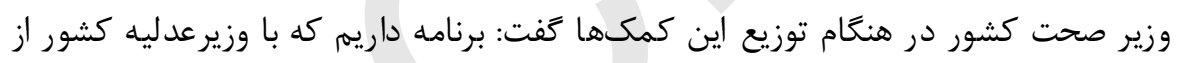

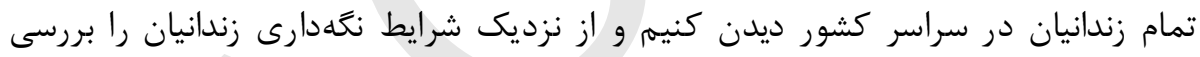

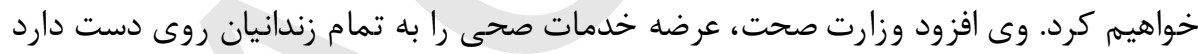

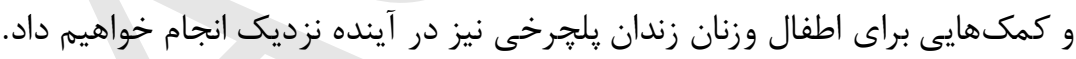

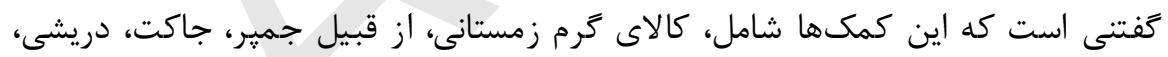

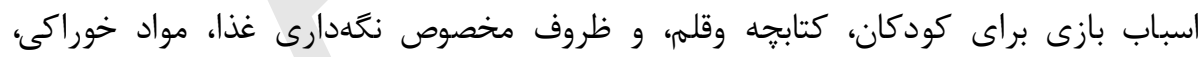

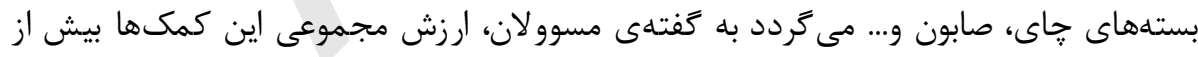

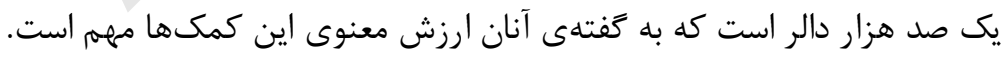




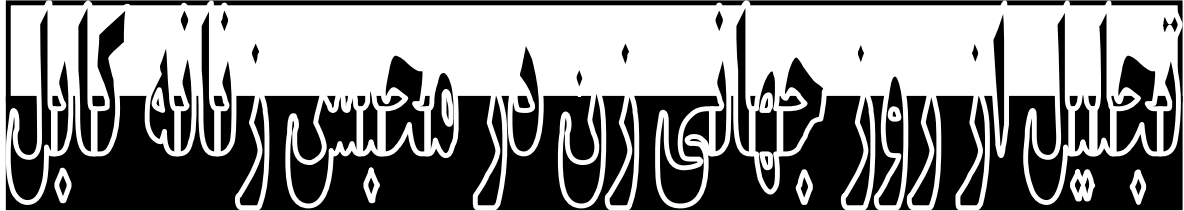

از هشتم مارج (روز همبستكى زنان جهان)، روز شنبه IV حوت IVAV إ در محبس زنانه كابل

كرامى داشت به عمل آمد. (آهد.

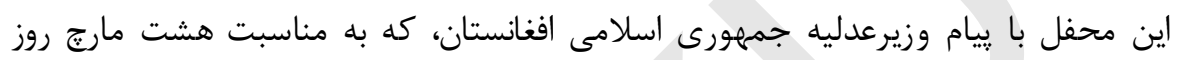

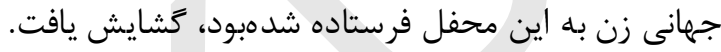

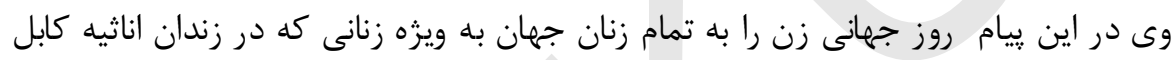

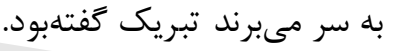

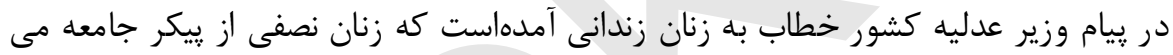

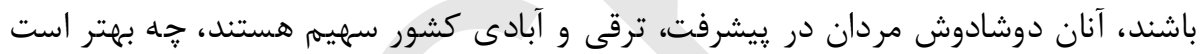

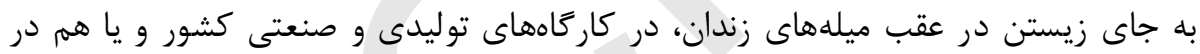

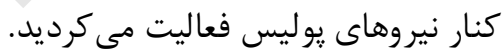

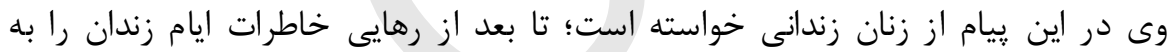

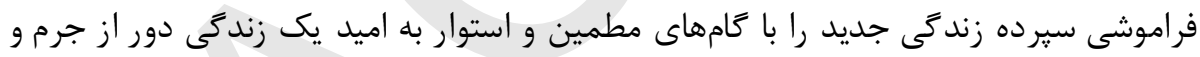
جنايت آغاز نمايند.

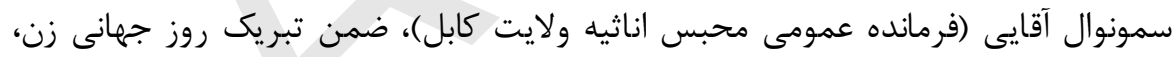

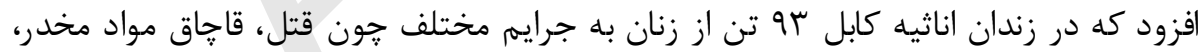

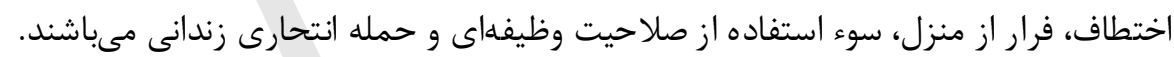

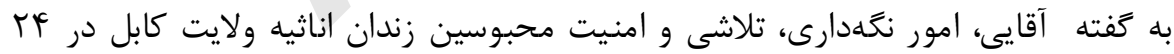

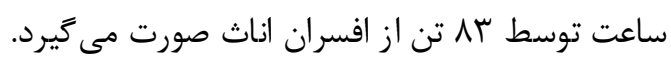

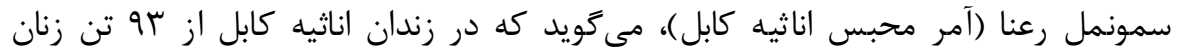

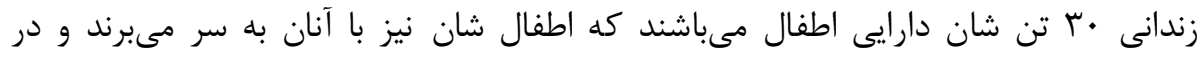
محبس نكَهدارى مىشوند.

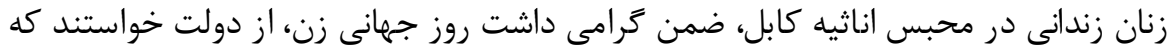

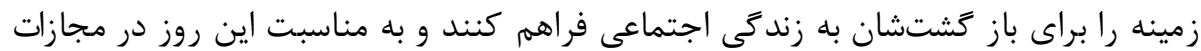

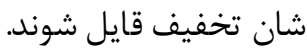




\section{صنايع دستى زنان زنفانى در ولايت هرات به زمايش كناشته شل}

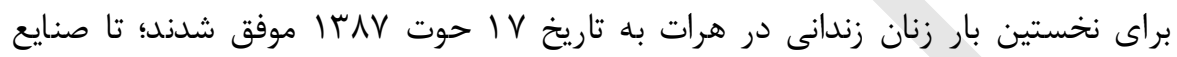

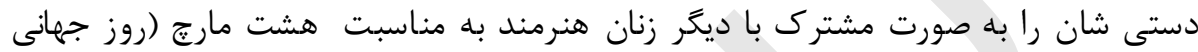

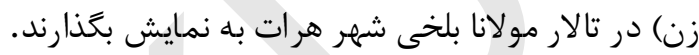

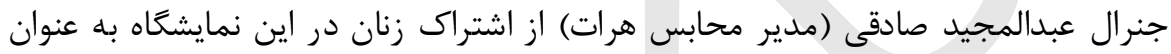

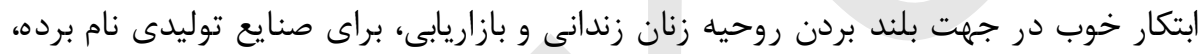

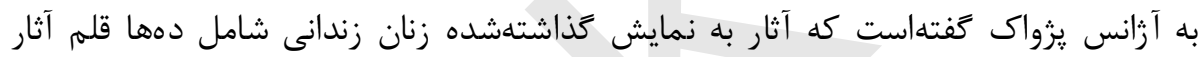

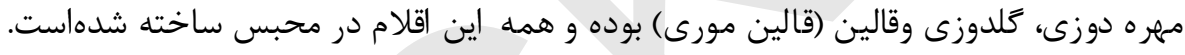

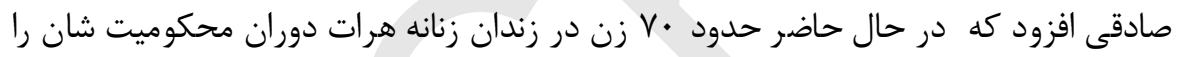

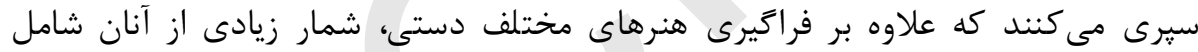
صنوف سوادآموزى نيز مى كباشند.

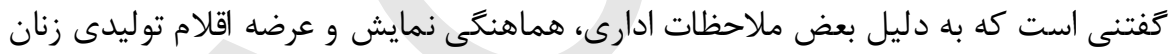

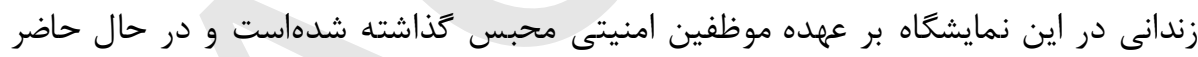

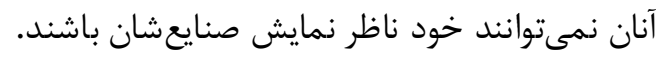

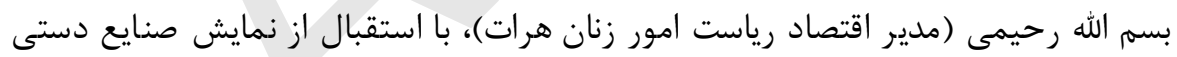

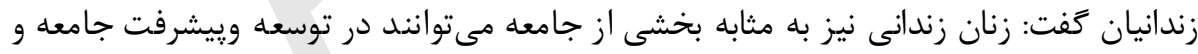
خانواده شان نقش موثر ايفا نمايند.

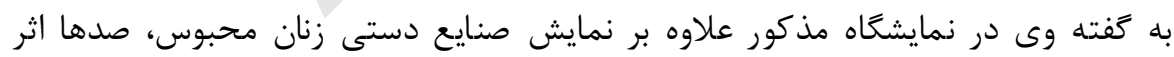

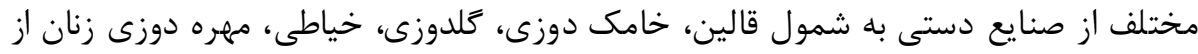

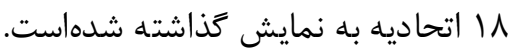

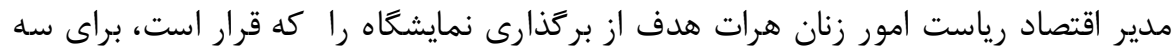

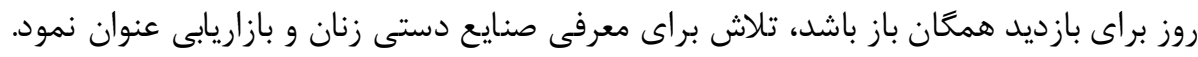

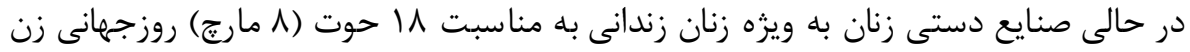

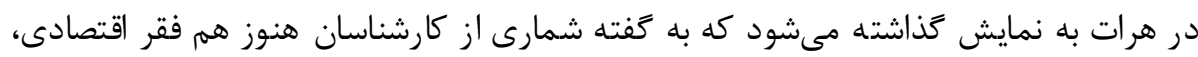

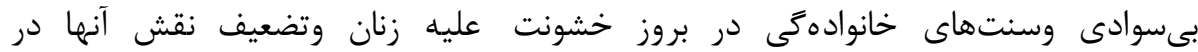
فعاليتهاى اجتماعى به قوت خود باقى است. 


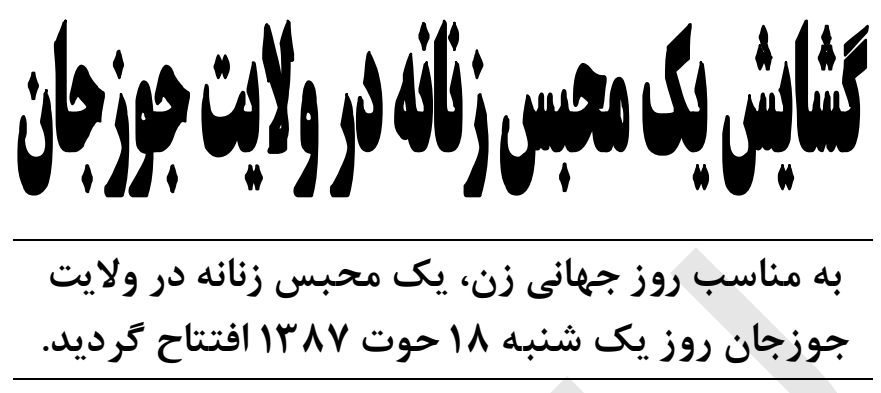

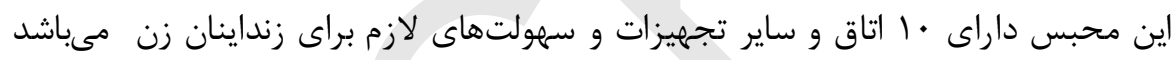

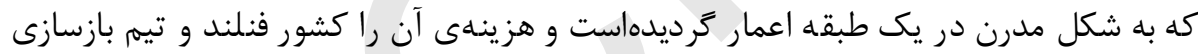
ولايتى مستقر در ولايت بلخ يرداختهاست.

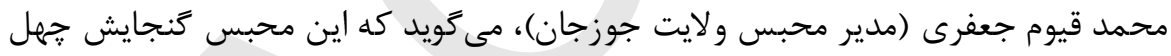

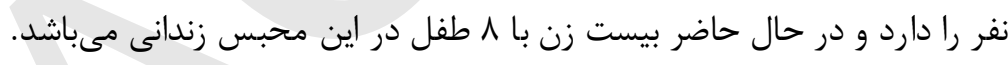

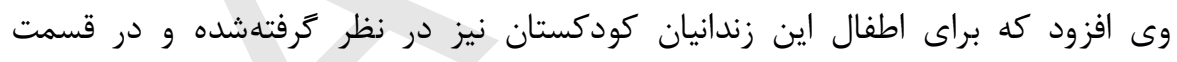

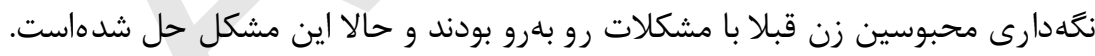

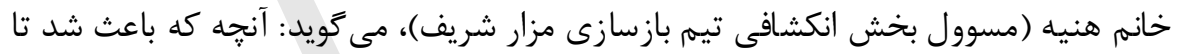

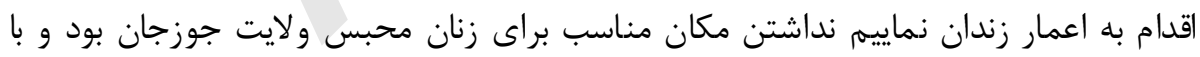

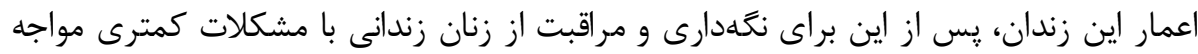
خواهيم شد. تعمير اين محبس در ساحه يك جريب زمين در محوطه زندان قبلى ولايت جوزجان اعمار كرديدهاست.

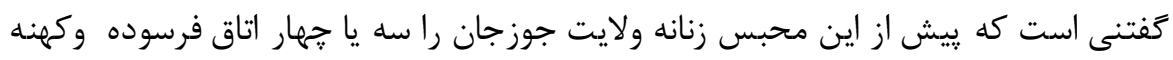

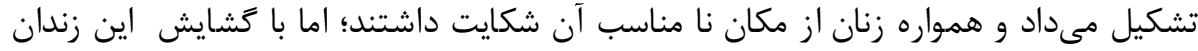

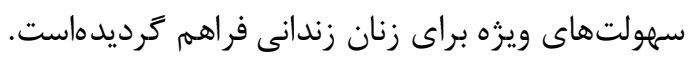




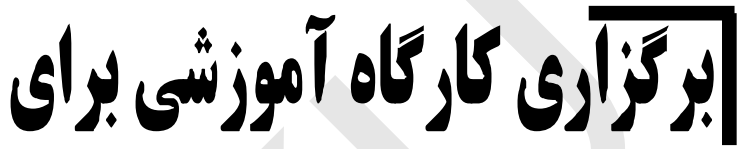

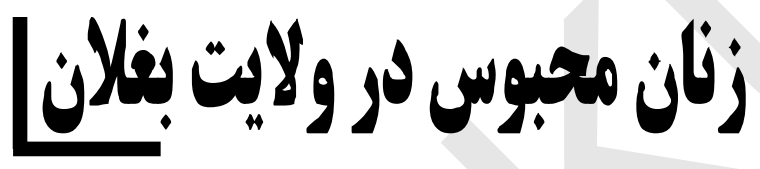

كار كاه آموزشى زير عنوان "ادرمانهاى اجتماعى و روانى" براى سه روز از سوى رياست امور

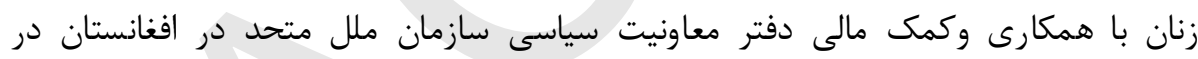

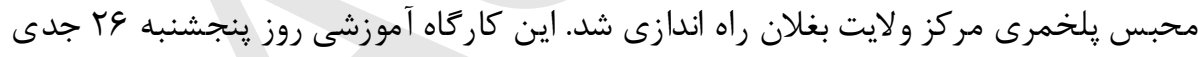

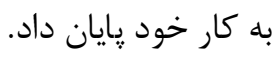

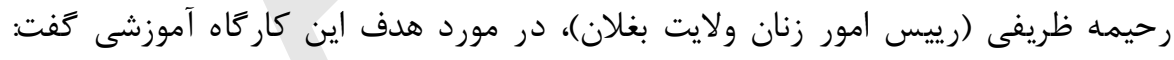

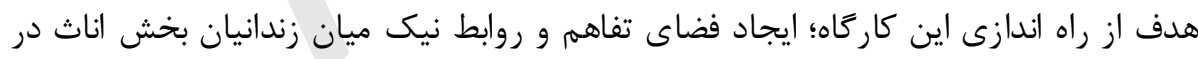

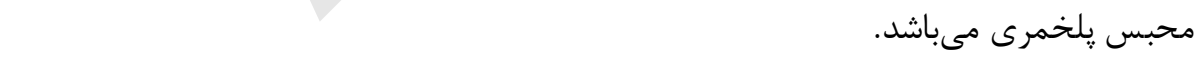

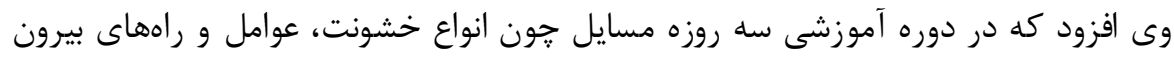

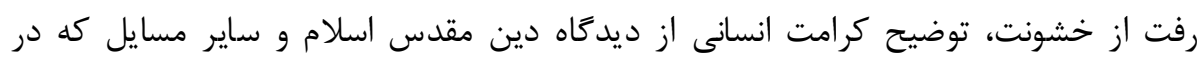

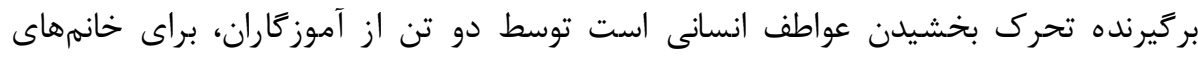

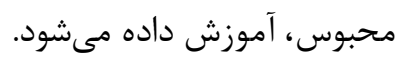

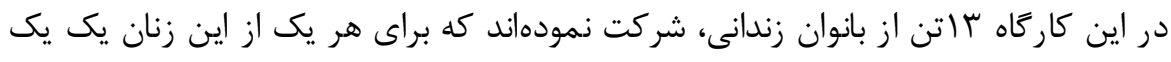

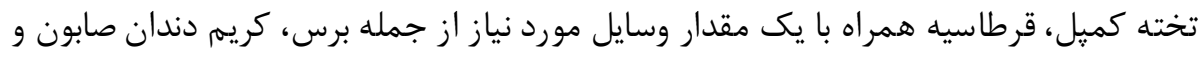
روى ياك از جانب رياست امور زنان توزيع كرديد. 


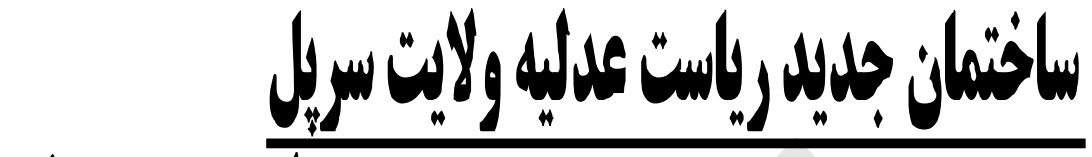

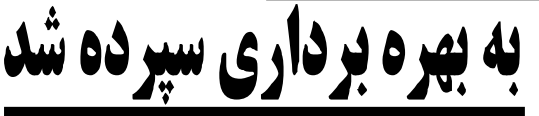

تعمير جديد رياست عدليه ولايت سريل، روز سه شنبه بF جدى افتتاح و به بهره بردارى سيرده شد. كار اعمار اين تعمير هشت ماه يِيش آغاز شدهبود.

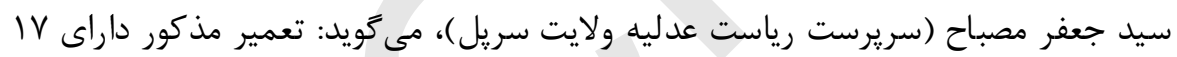

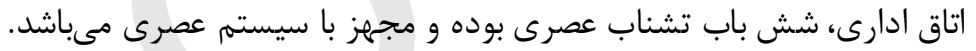

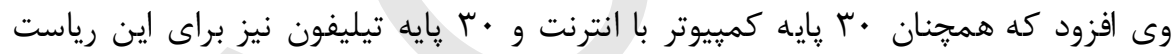
تهيه شدهاست.

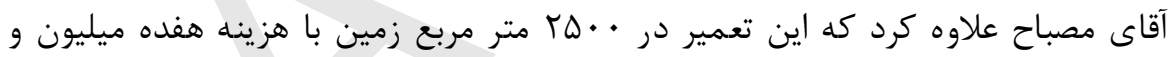

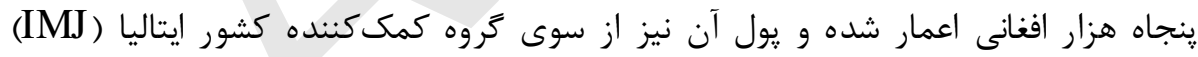

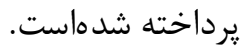

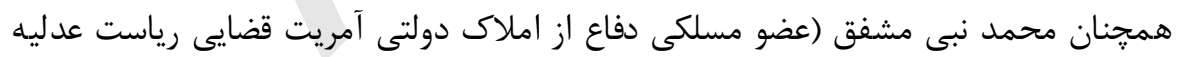

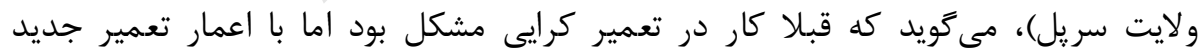

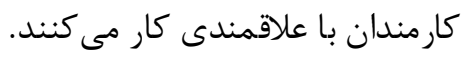

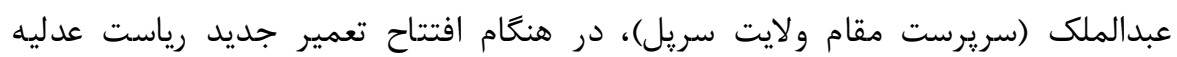

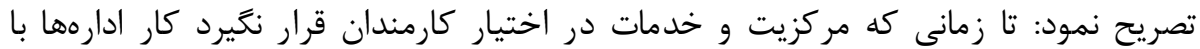

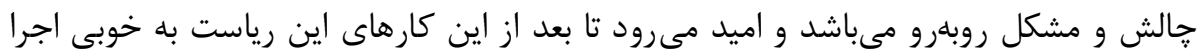
شود. قابل يادآور است كه روز دوشنبه سب جدى نيز تعمير رياست عدليه ولايت جوزجان به كمك

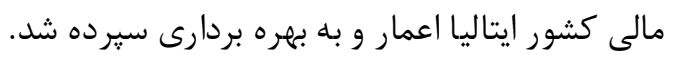




\section{امول و فنون ميانجيَّرى در حل و فصل منازعات زيلير جإِ يافت}

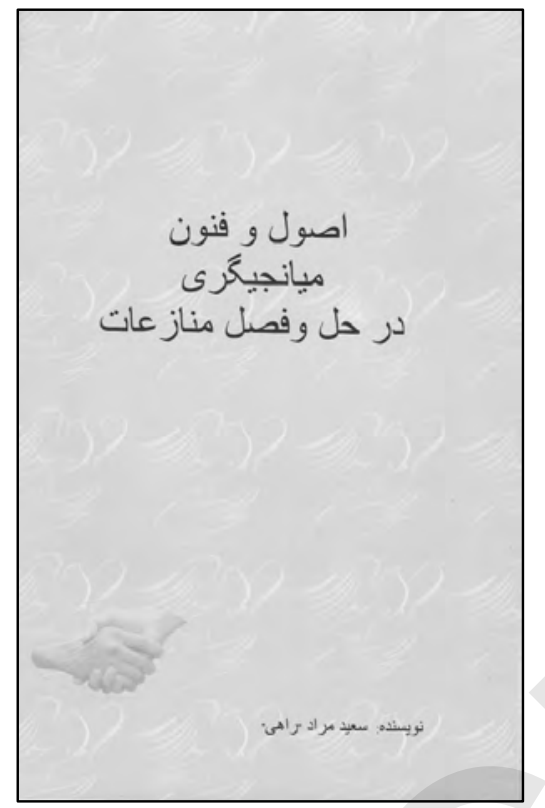

اصول و فنون ميانجيكرى در حل و فصل منازعات كه توسط سعيد مراد راهى تاليف گر ديده

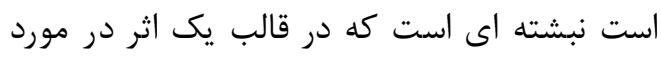

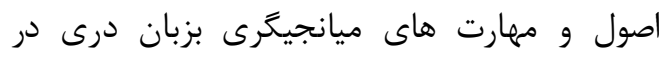

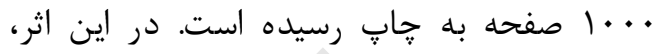

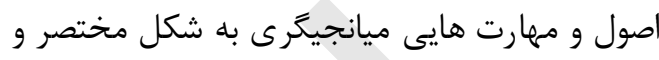
بزبان ساده توضيح گرديده است.

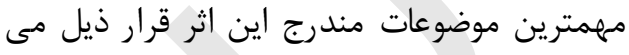

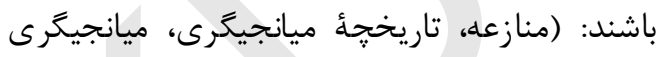

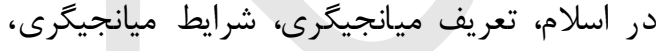

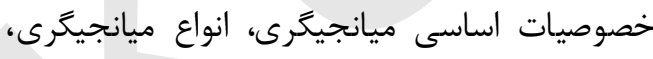

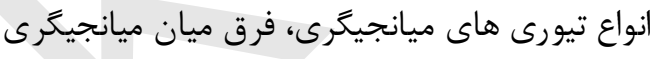

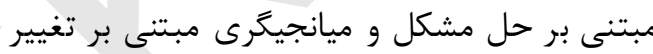

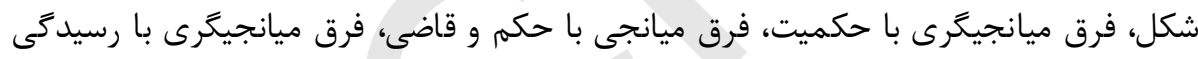

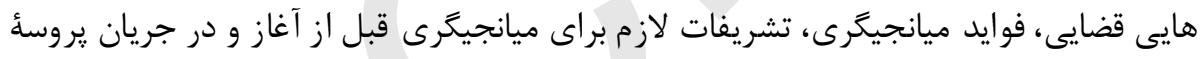

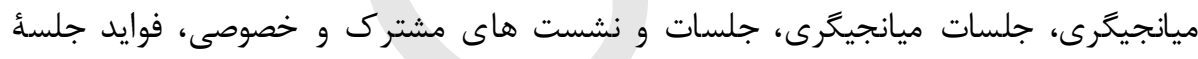

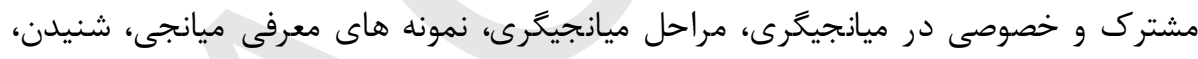

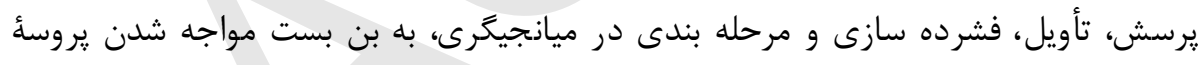

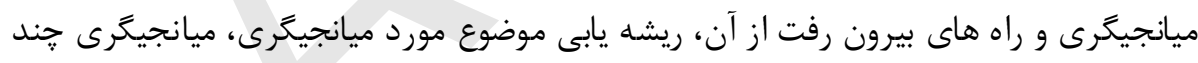

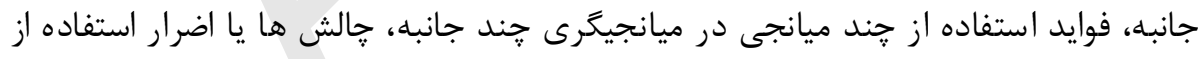

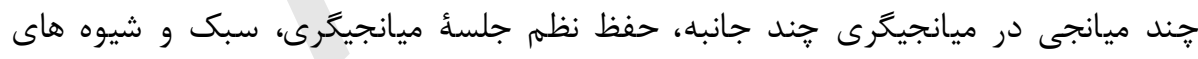

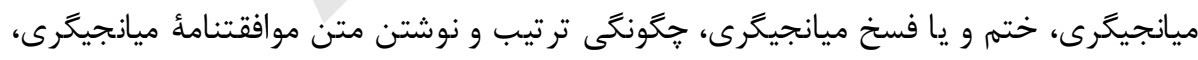

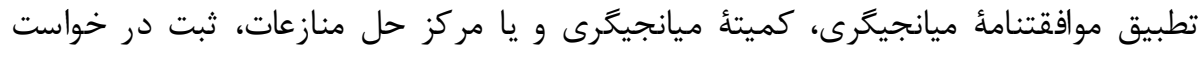

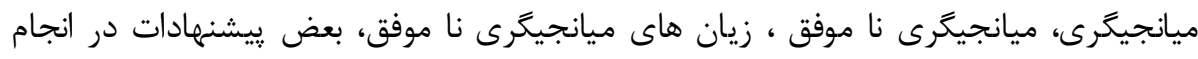

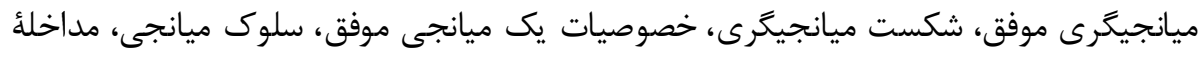

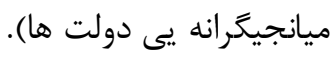

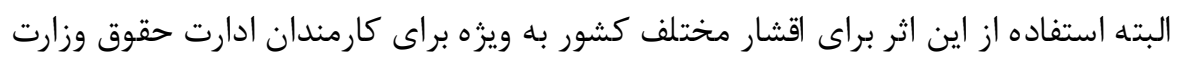

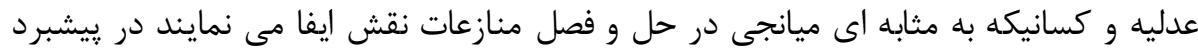

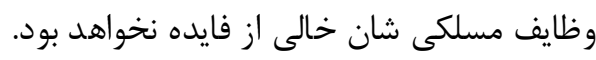




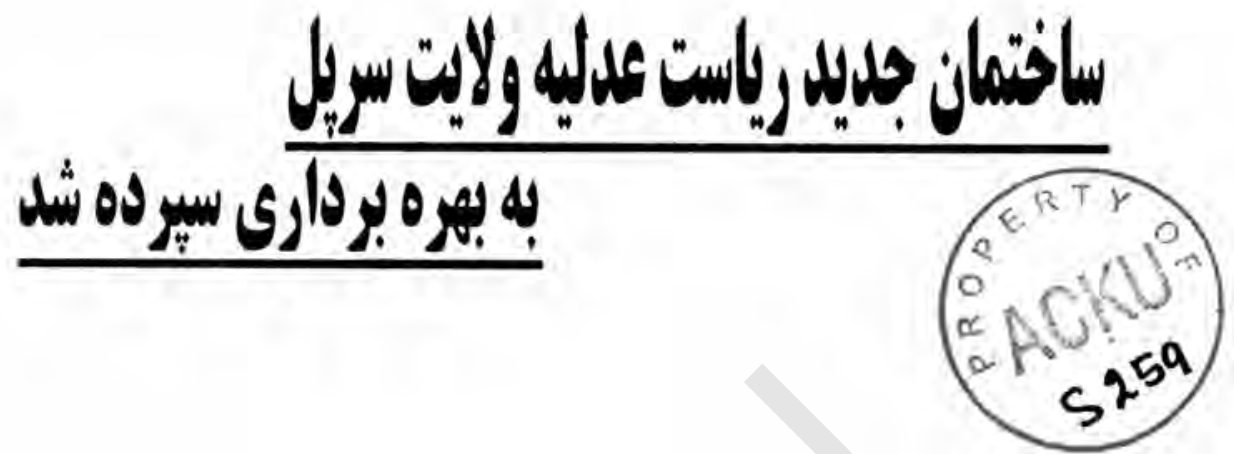

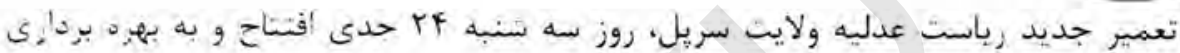

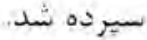

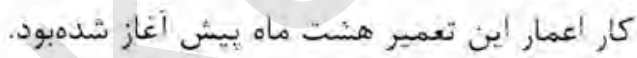

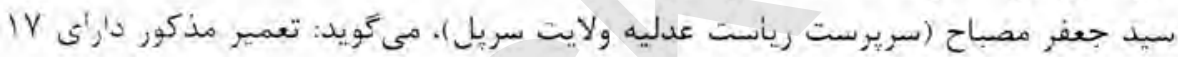

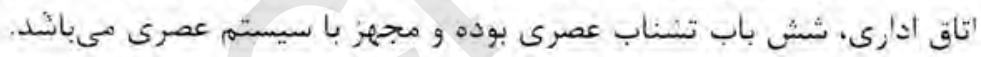

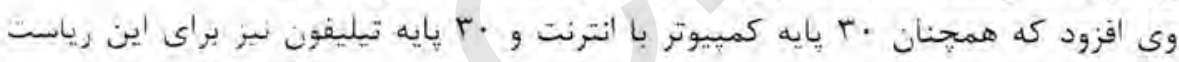
تهيه شدمالست.

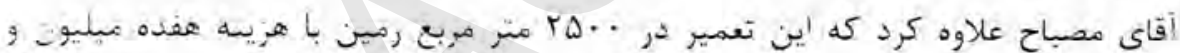

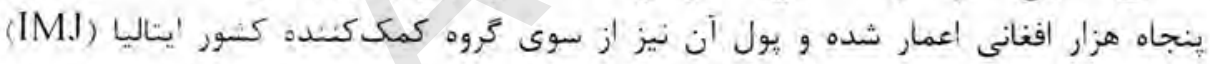
يرداختيه شدهاست هنت

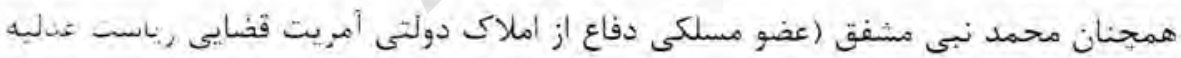

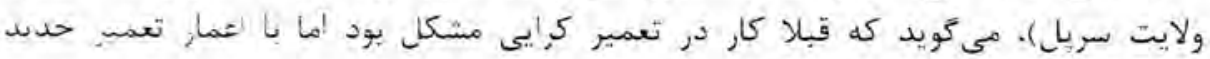

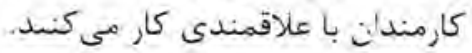
عبدالملك (سريرست مقام ولايت سريل)، در هنغام افتثاح تعمير حديد رباست عدليه

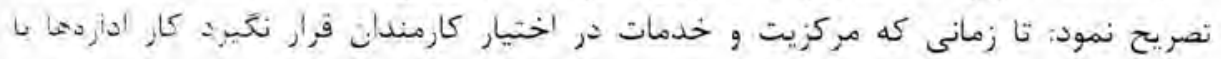

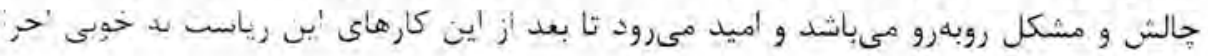
شود

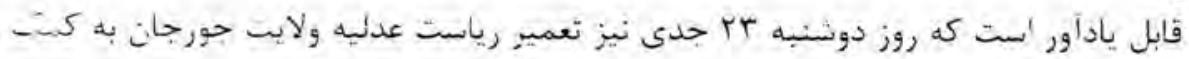

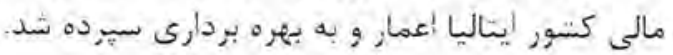



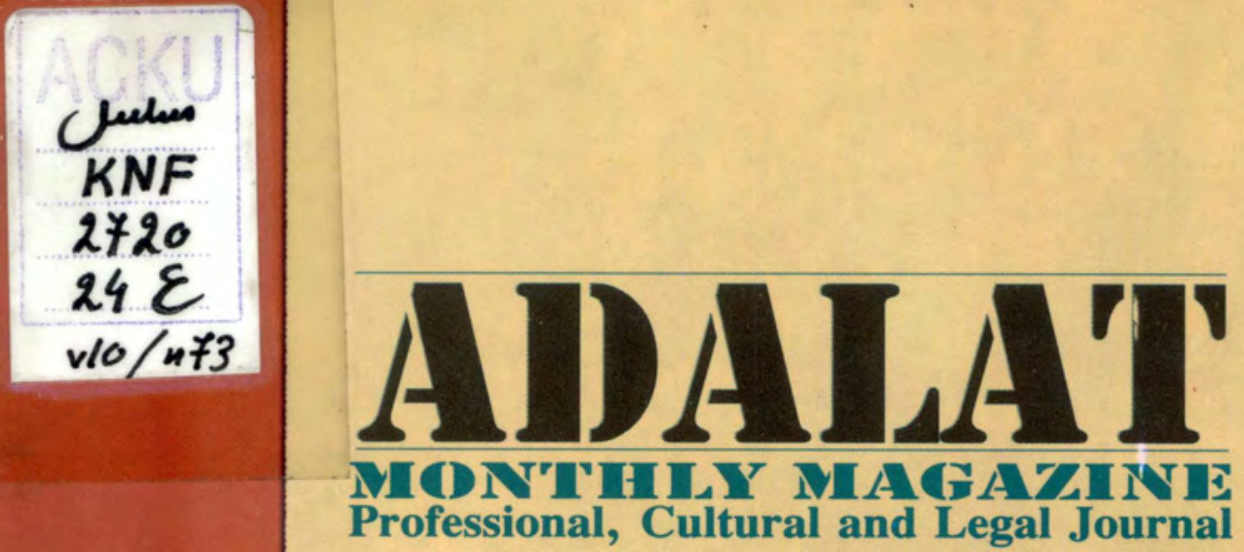

$\checkmark$ The Role of parliament in Promotion and Guarantee of Humanitarian Law.

$\square \quad$ The Role of Religion in the Decreasing of Crimes.

$\checkmark$ International Legal Instruments on the Prevention of War Crimes.

$\square$ Does the Addiction remove the Criminal Responsibility?

$\checkmark$ Legal Rules in Islamic Jurisprudence and Statute Law.

$\checkmark$ The Maturity from Sharia and Law Viewpoint.

$\checkmark$ The Legal Reference of Ahadiths (Islamic Narrations).

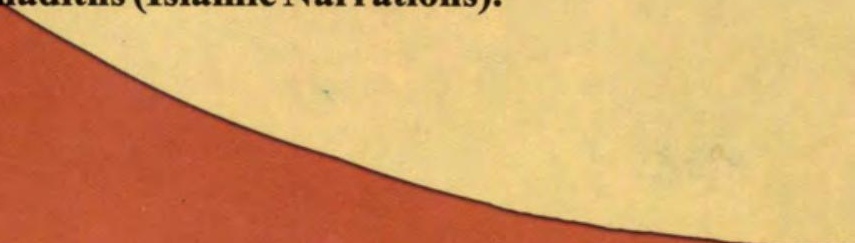

